\title{
DEMOCRACIAS POSIBLES: CRISIS Y RESIGNIFICACIÓN. SUR DE MÉXICO Y CENTROAMÉRICA
}




\title{
DEMOCRACIAS POSIBLES: CRISIS Y RESIGNIFICACIÓN. SUR DE MÉXICO Y CENTROAMÉRICA
}

\author{
María del Carmen García Aguilar \\ Jesús Solís Cruz \\ Pablo Uc
}

Coordinadores
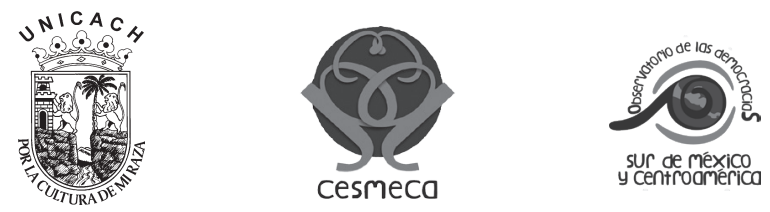

Universidad de Ciencias y Artes de Chiapas

Centro de Estudios Superiores de México y Centroamérica Observatorio de las Democracias: Sur de México y Centroamérica 
324.204

D44

Democracias posibles: crisis y resignificación. Sur de México y Centroamérica / Coordinadores María del Carmen García Aguilar, Jesús Solís Cruz, Pablo Uc.-- la. Ed.-- Tuxtla Gutiérrez, Chiapas, UNICACH, 2016.

366 p. : $23 \mathrm{~cm}$.

ISBN: 978-607-8410-66-8

1. Democracia - política - Sur de México. 2. Democracia - crisis - Centroamérica. 3. Democracia política - poder.

I.García Aguilar, María del Carmen, coord. II. Solís Cruz, Jesús, coord. III. Uc, Pablo, coord.

Primera edición: Septiembre de 2016

ISBN: 978-607-8410-66-8



D.R. ๑ 2016 Universidad de Ciencias y Artes de Chiapas

la Av. Sur Poniente 1460, Tuxtla Gutiérrez, Chiapas, México, 29000

www.unicach.edu.mx

editorial@unicach.mx

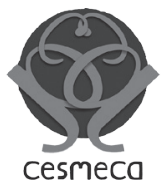

Centro de Estudios Superiores de México y Centroamérica

Calle Bugambilia 30, fracc. La Buena Esperanza

San Cristóbal de Las Casas, Chiapas, México, 29243

Tel. y Fax: 01 (967) 67869 21, ext. 106

www.cesmeca.unicach.mx

Observatorio de las Democracias: Sur de México y Centroamérica

Centro de Estudios Superiores de México y Centroamérica

Calle Bugambilia 30, fracc. La Buena Esperanza

San Cristóbal de Las Casas, Chiapas, México, 29243

Diseño de portada y fotografías de interior: Ayün Mutsábiri

Impreso en México 
A la memoria de Berta Cáceres y Carlos Sojo 


\section{INDICE}

Presentación

Jorge Rovira Mas

9

Introducción

15

Primera parte. Debate teórico

Debate teórico en torno a la democracia: del concepto hegemónico a las otras democracias

Laura Álvarez Garro

Pensamiento y realidad de la democracia liberal en tiempos de globalización neoliberal. A propósito de México y Centroamérica María del Carmen García Aguilar

Perspectivas contrahegemónicas de la democracia: discursos y prácticas otras de lo político y lo democrático

PabloUc

Segunda parte. Centroamérica y México

El Triángulo Norte de Centroamérica: dilemas de la democracia en una subregión conflictiva

Daniel Villafuerte Solís

Guatemala, ihacia un nuevo paradigma de construcción de ciudadanía? Jahir Dabroy

Democracia desde arriba, democracia desde abajo: elecciones, poder y conflicto en la Honduras post-golpe de Estado Andrés León 
Mesianismo político en El Salvador: análisis de discurso de los candidatos de ARENA y el FMLN en las campañas electorales presidenciales de 2004 y 2009

Carlos Mauricio Hernández

¿Extracciones y consultas? La minería y los derechos de los pueblos indígenas como un mentís de la democracia en Guatemala

Manuel Ignacio Martínez Espinoza

Democracia, confianza y ciudadanía en México

Juan Mora Heredia y Margarita Jiménez Badillo

Chiapas, la democracia que no fue

Jesús Solís Cruz

Yucatán y el alcance estabilizador de las elecciones convergentes de 2015

Efrain Eric Poot Capetillo

Tercera parte. Democracias otras

Profundizaciones en torno a la demoeleuthería

Carlos Alonso Reynoso y Jorge Alonso Sánchez

Las guerras, la otra política y los medios indígenas en movimiento

Xochitl Leyva Solano y Axel Köhler

Desde abajo, por la izquierda y con la Tierra: la diferencia de Abya Yala/ Afro/Latino/América

Arturo Escobar

Mirar los horizontes. Reflexiones finales 


\title{
Presentación
}

\author{
Jorge Rovira Mas
}

Este libro es producto de dos generaciones de centroamericanos y mexicanos, investigadores a quienes toca vivir una realidad política que se ha venido configurando en esta área mesoamericana en el último cuarto de siglo (1990-2015), cuya comprensión exige el diálogo historizado, abierto y crítico. Su marco académico, con el apoyo de otras instituciones académicas y organizaciones de la sociedad civil, es el Observatorio de las Democracias: sur de México y Centroamérica, dentro del Centro de Estudios Superiores de México y Centroamérica (CESMECA) de la Universidad de Ciencias y Artes de Chiapas (UNICAH). Valga decir, una iniciativa institucionalizada que recientemente también ha cumplido un par de décadas aportando una mirada novedosa y convocante sobre una subregión hasta entonces y aún ahora pobremente visibilizada y valorada.

Han transcurrido ya dos décadas desde que a finales de 1996 se firmaron en la ciudad de Guatemala los Acuerdos de Pazentreel Gobiernodeesepaísyla Unidad Revolucionaria Nacional Guatemalteca (URNG). Cuatro años antes, en 1992, se había producido otro tanto en Chapultepec (Ciudad de México), entre la administración salvadoreña de Alfredo Cristiani, del partido de derecha Alianza Republicana Nacionalista (ARENA), y el Frente Farabundo Martí para la Liberación Nacional (FMLN).

Estos acuerdos constituyeron una "resultante histórica" de una compleja trama de actoresenconflicto, nacionaleseinternacionales, y de procesos políticosmuy prolongados. La lucha armada en ambas sociedades y el ejercicio sistemático del terror de Estado, particularmente en Guatemala, en donde la confrontación interna se extendió entre 1960 y 1996, con saldo de centenas de miles de muertos, desaparecidos y desplazados, sólo es comparable en este continente, en la magnitud y horror de estas consecuencias, a lo ocurrido en Colombia en la segunda mitad del siglo XX, circunstancias las nuestras apenas conocidas en el resto de América Latina, sobre todo en el Cono Sur.

El anhelo por la democracia brotado inmediatamente después de concluida la II Guerra Mundial en 1945 fue abortado una y otra vez, con la excepción de Costa Rica, en el resto de los países de la región. Con el golpe de Estado que el ejército y la Agencia Central de Inteligencia - la CIA —, con el beneplácito y la participación de los sectores sociales más conservadores de la sociedad, le dieron al gobierno de Jacobo Arbenz Guzmán en 1954, tras apenas cumplirse diez años del inicio de aquella primavera 
democrática que fue la Revolución de Octubre de Guatemala (1944), se malogró la experiencia progresista insignia que por entonces vivía la región. E igualmente se enviaron señales inequívocas de contención en el clima político que se fue construyendo durante la Guerra Fría con la irrefrenable injerencia de las administraciones de Estados Unidos.

La crisis del orden oligárquico en Centroamérica —en las interpretaciones fundamentadas de manera prolija por Edelberto Torres Rivas en sus trabajos-, tras la caída de los regímenes autoritarios personalistas de Ubico en Guatemala (1944), Hernández Martínez en El Salvador (1944) y Carías Andino en Honduras (1948), con la supervivencia de aquel de los Somoza en Nicaragua desde 1937 cuando menos hasta 1979, dicha crisis no se pudo resolver en las décadas posteriores al inicio de la segunda mitad del siglo XX. Ese orden sociopolítico, de perfil oligárquico por la hegemonía de clase que lo sustentaba, pero también por las características estructurales adquiridas en el ejercicio del poder, se prolongó manu militari ya no bajo la tutela de caudillos salidos del ejército, sino por medio directo de la propia institución armada y los diversos recursos políticos a los cuales apeló. Fue en El Salvador, en Honduras y en Guatemala en donde se experimentaron sus manifestaciones, primordialmente entre 1954 y 1979 , con variantes temporales según estas distintas sociedades, pues el de Nicaragua estuvo anclado en un régimen persistentemente autoritario, aunque dinástico por largas cuatro décadas.

La crisis definitiva del orden oligárquico sobrevino cuando dos procesos diferentes fueron creando las condiciones políticas para su quiebra definitiva. Por un lado, con los reiteradamente fallidos empeños de distintos sectores moderados por abrir la arena de la competencia partidaria por el poder del Estado y brindar legitimidad a ésta por medio de elecciones con resultados no fraudulentos que dieran oportunidad a la alternancia. Por otro, con la irrupción nuevamente — desde la década de los años treinta del siglo pasado no se había observado nada semejante con tanto ímpetu- de los sectores populares liderados por organizaciones de izquierda inspiradas ahora en la Revolución cubana principalmente, que cuestionaban de raíz las estructuras sociales vigentes y aspiraban a un cambio social profundo.

En este contexto de vectores políticos, la democracia representativa nunca fue la preferencia de los principales y más influyentes contendientes en Centroamérica que arribaron a los Acuerdos de Paz de los años noventa: la derecha oligárquica y la izquierda revolucionaria. Tampoco lo había sido para el Frente Sandinista de Liberación Nacional (FSLN) triunfante en Nicaragua en 1979. No obstante, lo cierto es que ella fue adquiriendo carta de ciudadanía y de paulatino reconocimiento, ni con igual validación ni con idéntico entusiasmo entre las partes confrontadas, durante las negociaciones que procuraron solución al prolongado y sangriento contencioso acaecido en las décadas finales del siglo XX. 
Advertido lo anterior, es fundamental reconocer igualmente que la democracia real que emergió en Centroamérica desde los años ochenta en medio del conflicto armado en el seno de las sociedades de la región, si bien entonces con una inclusión limitada de sectores políticos que sólo se amplió en la última década del siglo XX tras los Acuerdos de Paz, estaba signada por cuatro conjuntos de factores.

El primero de ellos fue la aspiración a dejar atrás, sin retorno, la larguísima noche de los regímenes políticos autoritarios, prácticamente el único factor experimentado en sus diversas variantes por la inmensa mayoría de la población a lo largo y ancho de la historia centroamericana. Se trataba de un bono de legitimidad que sólo el grado de eficacia en el funcionamiento de la democracia representativa podía hacerlo crecer o desperdiciar.

El segundo fue que, a pesar de la producción desplegada en la región de nuevas y renovadas constituciones en todos los países - con la excepción de Costa Rica que mantuvo vigente la de 1948 con sus reformas-, y junto a las instituciones salidas de ellas —el sistema de partidos, la subordinación del ejército a las autoridades civiles electas y sobre todo la cultura política-, estaban aún muy condicionadas por la historia reciente y el pasado autoritario.

El tercer factor fue el peso y la influencia política que preservaron las clases sociales dominantes tradicionales, algunas de las cuales se fueron reconvirtiendo en términos de áreas de negocios, en las cuales se adentraron, y de ideología política, siendo el caso de El Salvador quizás el más sobresaliente.

Como último factor, si bien en modo alguno el de menor importancia, se encuentran las consecuencias que trajo consigo la crisis económica en Centroamérica. Se trató de la cancelación del estilo de crecimiento propio de la post Segunda Guerra Mundial, viable y vigente durante el periodo 1950-1979, cuyas vicisitudes provinieron tanto de causas de origen interno a estas formaciones sociales, como del perfil de la regionalización, en el marco condicionante establecido por al menos dos crisis económicas internacionales entre finales de los años setenta e inicios de los ochenta. Este estilo se había edificado a partir del aumento de los volúmenes exportados y la diversificación de los productos de agroexportación tradicionales —café, banano, azúcar, carne de ganado vacuno y algodón-, a lo cual se agregó la industrialización sustitutiva de importaciones al amparo del Mercado Común Centroamericano (1960) y una expansión estatal moderada, con niveles de pobreza muy extendidos en la población y una desigualdad evidente, si bien en aquellos años con mediciones fiables casi inexistentes. Pero la modernización neoliberal globalizada que se ha puesto en marcha en todas las sociedades y economías de la región desde finales de los años ochenta, cada una con sus especificidades, ha ido generando lo siguiente: la variación y el ensanchamiento de las exportaciones no tradicionales hacia terceros mercados; un florecimiento de los servicios financieros, del comercio y, en algunos países, del turismo; y la pérdida de importancia relativa de las actividades agrícolas, acompañada del 
desplazamiento/emigración de la población hacia el extranjero. Los niveles de pobreza se han mantenido sumamente elevados, siendo Costa Rica — donde alrededor del 20\% de la población total se encuentra en dicha situación- y El Salvador - con un porcentaje superior al 40\%-, en donde la cuestión es menos acuciante no obstante su magnitud, pues en los restantes países es de una gravedad extrema, muy por encima del $50 \%$. Y la desigualdad, de la misma manera, se ha mantenido muy alta, por encima del 0.5 en el índice de Gini; Costa Rica, con su deterioro de la última década, muy cerca ya de este valor.

El caso de México, desde luego, ofrece variantes que se comentan en este libro y sobre lo cual no conviene aquí extenderse. Han resultado de mucha importancia las sucesivas reformas políticas y electorales a partir de la de 1977 prohijada por Reyes Heroles, secretario de Gobernación del entonces presidente José López Portillo (1976-1982), pero sobre todo los factores políticos que incidieron en la transformación del sistema de partidos. Éste cambió de ser hegemónico sin alternación, a otro de índole de pluralismo limitado e ideológicamente moderado con alternancia a partir del año 2000. Pero por encima de cualquier otra circunstancia o conjunto de ellas, lo que llama la atención de manera notable en la experiencia histórica reciente de México es la extraordinaria emergencia del zapatismo y todo lo que con él se cuestiona y se propone. Y la manera como lo hace: desde el principio de la autonomía hacia fuera y hacia dentro de la propia colectividad, y con una visión que reivindica a la democracia como una "forma de sociedad", de ser-en-comunidad.

En suma, la democracia representativa real operante en la región y en México, en este caso en el contexto de las transformaciones económicas generadas tras el Tratado de Libre Comercio de Norteamérica vigente desde 1994, cuyas derivaciones en diversos aspectos económicos se empatan con las ocurridas en Centroamérica durante las últimas dos décadas, ha producido y reproducido un piso social extremadamente precario para el ejercicio de los valores y las prácticas de la democracia, no obstante los progresos habidos en algunos ámbitos.

A lo largo de las tres últimas décadas, en consonancia con las numerosas transiciones a la democracia representativa en América Latina y su generalización en el continente, el paradigma dominante que ha llegado a prevalecer para su estudio — transición a la democracia y factores de consolidación/crisis de ella, por algunos denominado como "transitología" - se encuentra anclado en la teoría "pluralista competitiva de élites", en una tradición teórica asentada en autores como Schumpeter, Dahl y Sartori entre muchos otros.

Uno de los postulados fundamentales de esta tradición es el planteamiento de que la democracia es un "régimen político" y no una "forma de sociedad". Dicha teoría ha experimentado en las últimas décadas, en el contexto de la llamada "tercera ola democratizadora"(Huntington), unconsiderabledesarrollo. Haprovenidoparticularmente 
de las academias de las sociedades centrales. La investigación tanto sobre la crisis de la representación política en dichos espacios, como también sobre los procesos de transición democrática desde regímenes autoritarios en las sociedades del sur global, ha reforzado el interés, los estudios, la financiación del quehacer académico y la producción de literatura sobre múltiples temas al amparo de este enfoque.

Desde el centro - hay que consignarlo también-y mediante los procesos de circulación del conocimiento a escala global, incluidas en ello las dinámicas de socialización científica que conllevan los estudios de postgrado de los jóvenes del sur en universidades de los países del norte, el planteamiento se ha diseminado considerablemente. Más aún cuando incluso las mismas universidades de excelencia de la periferia científica acogen, a veces sin suficiente ejercicio crítico, este enfoque, lo aprovechan y lo relanzan mediante sus programas de estudio.

No se trata así tan sólo de realidades políticas - la democracia electoral-y de las miradas con las cuales las observamos y analizamos, sino también de la forma como se torna en principal una determinada corriente teórica y los mecanismos mediante los cuales cobra fuerza y se reproduce de manera ampliada. Pero igualmente hay que hacer notar sus consecuencias: el ignorar o desvalorizar otras modalidades de experimentar, concebir y estudiar la democracia.

Ya hemos indicado al inicio de este prólogo un rasgo fundamental de esta obra: constituye un producto de calidad de estudiosos centroamericanos y mexicanos, en su gran mayoría que analizan la realidad política de la democracia real existente y reflexionan críticamente sobre ella. Una realidad que forma parte casi coextensa de sus biografías, una realidad como es la de Centroamérica y México en el transcurso de las últimas tres décadas, cuando en el inicio de este periodo se despertaron tantas ilusiones y expectativas para dejar atrás el pasado político y construir un futuro cualitativamente muy distinto por producir, y en donde hoy las "resultantes históricas" que demandan explicación obligan a ser cautos, si no es que pesimistas, al evaluarse los cambios generados.

Es un libro en el cual la reflexión teórica en la primera parte de la obra, pero también en su tercera y última, se compromete con la crítica rigurosa de la democracia que prevalece, funcional a la nueva dinámica del capitalismo global, que procura incorporar, subordinar y expoliar múltiples recursos hasta ahora no alcanzados por el ímpetu envolvente de este modo de producción. Pero mediante esa reflexión teórica, y al mismo tiempo en ella, se plantean de manera muy inspiradora los horizontes de las "democracias otras", a partir de un riquísimo pensamiento crítico latinoamericano de cuya gran fertilidad no reparamos por la obnubilación que nos genera el pensamiento hegemónico. Esta apertura y destaque de las "democracias otras" no se realiza con la pretensión de concretar un ejercicio simplista de negación de lo presente y de postulación de un cierto futuro de praxis democrática unificado o bien homogéneo como alternativa, sino 
haciéndose eco del ethos zapatista: un principio de abordaje y exploración de la realidad abierto y respetuoso, desde el cual se ausculte "un mundo en donde quepan muchos mundos".

Por medio de este libro, con los varios artículos que componen su segunda parte, es posible aproximarse analíticamente a una visión de conjunto sobre el funcionamiento reciente de las democracias de Guatemala, Honduras y El Salvador en momentos críticos, así como también a las tendencias contrastantes en dos estados del sureste de México: Chiapas y Yucatán.

El origen y sustento de este empeño, el balance conseguido, la crítica inspiradora y éticamente comprometida con el develamiento de las injusticias y limitaciones que la democracia actual no ha conseguido reparar, antes bien que en algunos casos ha coadyuvado a mantener o a incrementar, en medio, eso sí, de una mayor conciencia colectiva y activación de los grupos subalternos de estas sociedades, y los horizontes de emergencia institucional y de nuevas prácticas democráticas que aquí se describen, hacen de este libro un bien logrado, honesto, interesante, oportuno y muy recomendable producto que convoca a su lectura. 


\section{Introducción}

La democracia liberal como pensamiento y práctica pareciera definirse por una paradoja: por un lado, el número de países a ésta adscrita y la creciente demanda y exigencia de su institución o de su "retorno"; por otro, el registro, en la realidad concreta, de una crisis que devela no sólo las aporías consustanciales a su naturaleza como modelo político, sino también la decisión deliberada de someterla a las exigencias de una sociedad autorregulada bajo el timón del mercado, que le es incompatible. Lo nuevo no es la paradoja en sí, sino el sentido de perplejidad que provoca el tránsito continuo entre una posición y otra y lo imprevisible de sus desenlaces, situación que exige, como aconseja Muguerza, no pronunciarse por alguna, sino asumir las tensiones que abarcan a ambas por igual, encarando sus consecuencias y optando, frente a la sinrazón, por un racionalismo "templado en la perplejidad", nunca "excesivamente seguro de sí mismo" (1999: 661-662).

Ello implica recuperar el estado actual de los derroteros siempre inestables de la paradoja primaria que lo hace posible, esto es, las tensiones relacionales entre la tradición democrática y la tradición liberal, y su crisis, manifiesta en el triunfo omnímodo del liberalismoeconómico, hoydefinidocomoneoliberalismo, cuyosentidodeautorregulación visibiliza el rompimiento de la democracia liberal como proyecto y experiencia política histórica, esto es, el quiebre de la idea misma de una relación de "contaminación" que, sin superar la oposición, posibilita formas de pluralismo que la definen como modelo político dominante (Mouffe, 2003).

En paralelo a la dimensión del daño sufrido por la democracia liberal, está la necesidad de recuperar "los otros juegos políticos", esto es, los proyectos y experiencias que nacen desde lo social como desafíos al despliegue de una política cuyo poder no sólo cruza la frontera del pensamiento que la hace posible, sino que incluso hoy la niega; se trata de formas plurales que inventan prácticas de subsistencia y de vida, que escapan, resisten, alteran y desafían a una política instituida que reclama la legalidad, el orden, el monopolio de la fuerza, y amenaza a todo aquello que sea su opuesto.

Desprovistas del sentido finalista, homogeneizante, fastuoso y espectacular, constituyen experiencias plurales, creativas, exitosas y erráticas, portadoras de luces intermitentes en un contexto de oscuridad política que las condena, pero cuyo sentido colectivo, deliberado e intersubjetivo, resignifica la política y la democracia. Esto es, 
desplaza, así sea esporádicamente, el paradigma político teórico y normativo hegemónico — que no legítimo-, y en su multiplicidad le sustituye. Como lo hace la teoría crítica del sur, intuimos también que estamos ante experiencias que modulan un nuevo paradigma político, el de las "democracias otras" que, en tanto la política y lo político, se conciben articuladas a la sociedad, su acción y su praxis. Ello trae consigo el replanteamiento radical de la democracia liberal y la exigencia de definir aquéllas como experiencias y prácticas políticas "situadas".

Este sentido de perplejidad y su doble confrontación crítica sustenta el libro que hoy presentamos. Es producto del primer Seminario sobre la Democracia Liberal y las Democracias "Otras", que se realizó a fines de 2014, y de los Foros Sociales (2015 y 2016) que convocan diálogos y debates entre los actores y protagonistas sociales y la academia, ambas actividades organizadas por el Observatorio de las Democracias: Sur de México y Centroamérica. La valía de las colaboraciones, por sus abordajes de orden conceptual, temático y plural, llevó de manera natural a su compilación como materiales de trabajo para iniciaroreiniciarlareflexión sobrelasrealidades políticasdel surde MéxicoyCentroamérica, encuyasunidadespolíticas seinstauraron democraciasen condiciones socialesyeconómicas que de antemano la inhabilitaron para responder a las demandas sociales y ciudadanas, degradándolas en simple maquinaria de consecución de votos por partidos y elites locales. En paralelo, las realidades de esta porción del sur registran imaginarios comunitarios que hoy se visibilizan en una abierta lucha contra el capital transnacional que acomete la acumulación por "desposesión", con la anuencia de los gobiernos nacionales que instauran el autoritarismo sin alterar su imagen de gobierno democrático.

La y los coordinadores del volumen organizaron las contribuciones en tres partes, sostenidas por el reconocimiento analítico de "las democracias", en plural, situadas en tiempo y espacio, jugando con dos grandes interrogantes, en las que los materiales ofrecidos, sin alcanzar respuestas finales, orientan el sentido de las respuestas: ipuede la democracia liberal seguir sosteniéndose con procesos electorales disociados de una sociedad que vive la cotidianidad de la pobreza, la violencia y las grandes desigualdades en ingreso y estatus, como expresiones fácticas de incompatibilidad entre democracia y capitalismo?, ipueden los proyectos y experiencias políticas "otras" en nombre del derecho a la vida constituirse en el campo político de subjetivaciones capaces de sustraerse del paradigma liberal-democrático y de instituir desde su multiplicidad, heterogeneidad e intemporalidad, un nuevo paradigma democrático?

La primera parte conjuga las dimensiones conceptuales desde sus respectivos modelos interpretativos y sus despliegues, abiertos e inciertos, con las realidades políticas y sociales concretas que se intentan explicar y comprender. La segunda parte del libro abre la mirada a entidades del sur de México y a países de Centroamérica con trabajos precisos sobre los contextos nacionales, la democracia política y los procesos electorales recientes. Tiene de suyo la recuperación analítica del destrozo deliberado de instituciones, reglas y 
normas constitucionales que han terminado por hacer de la democracia un bien de mercado reducido a procesos electorales anómalos. La tercera parte recupera las experiencias de las "democracias otras", experiencias que dibujan en los territorios del sur un mapa amplio de proyectos y experiencias sociales y comunitarias abocados a la construcción de medios de vida alternativos y contrahegemónicos, que enfrentan la guerra cotidiana del capitalismo global y lo desafían. Son textos analíticos acompañados de una reflexión situada desde las vivencias y su sentido fenomenológico político que impugna y trasciende la democracia liberal para sostener la política y lo político desde el campo social.

Partidaria de un pensar en el que teoría y práctica son elementos esenciales del debate y la reflexión científica, y de una definición de la democracia que supera tanto la definición hegemónica de la democracia mínima y de la democracia liberal-procedimental, como el sentido empírico y anecdótico de ésta, Laura Álvarez Garro abre la primera parte del libro con un texto que privilegia el carácter hipotético y de aproximación a la verdad de la teoría, que tiene tras de sí lo que Bachelard (1984) definiera como la "filosofía del no", que niega el pensamiento único de la vieja tradición. La autora nos provee de un marco de explicación que recupera, para su discusión, los fundamentos ontológicos dela democracia contemporánea para luego recuperar los marcos políticos y sociales de nuestra región de estudio. Diserta sobre el pensamiento político "posfundacionalista" que privilegia lo político como una forma de lazo social, no supeditado sólo al ejercicio de la administración del Estado - política - ni tampoco a su pertenencia a priori a sujetos esenciales de la política. Se trata de una forma de sociedad, que exige cuestionar los fundamentos mismos de ésta y de sus actores, los sujetos. Con estos materiales críticos en mano, Álvarez Garro realiza una lectura sobre los déficits de los abordajes hegemónicos de las ciencias sociales y, en paralelo, enmarca con solidez el debate acerca de la democracia y cómo ésta ha sido abordada en nuestra región.

El texto de María del Carmen García Aguilar, "Pensamiento y realidad de la democracia liberal en tiempos de globalización neoliberal. A propósito de México y Centroamérica”, constituye una reflexión analítica sobre el proyecto y la experiencia de la democracia liberal en los países de estudio. Los tres apartados del capítulo tratan sobre la historicidad situada de la democracia política que explica la reducción de su campo a los procesos electorales, pese a los esfuerzos académicos por hacer de la "transición" y "consolidación" campos de análisis propositivos con sólidos sustentos conceptuales y metodológicos. Bordan también, desde distintos ángulos, las tensiones entre el diseño normativo y sus hacedores, para recuperar la naturaleza de los poderes que están detrás de la crisis democrática y su máscara, esto es, los festines democráticos de masas deliberadamente diseñados y operados por los medios de comunicación y los dueños del dinero. Desde el reconocimiento de la crisis de la política, y con ella la de la democracia liberal, la autora reflexiona sobre la urgencia de trabajar con los nuevos materiales de realidad y subjetividad 
política y social producidos en más de cuatro décadas de un neoliberalismo global desbocado que impone, pero al que también se confronta o se resiste.

Finaliza esta primera parte del libro con el texto de Pablo Uc, "Perspectivas contrahegemónicas de la democracia: discursos y prácticas otras de lo político y lo democrático". El autor planea desbordar el umbral del debate teórico sobre la democracia como "insuficiencia política" - reducida al ejercicio de gobierno y estatalidad - para desarrollar algunos enfoques contrahegemónicos conceptualizados como democracias otras, situadas desde lo marginal y autónomo de lo político. Se trata de un pensamiento que tiene tras de sí, como indica Uc, una impugnación al modelo homogéneo y cerrado que disuelve la potencia de lo diverso para resignificar la producción de lo común y la construcción de formas heterogéneas de gobierno y sociedad, es decir, la demo-diversidad democrática.

La segunda parte del libro la abre el trabajo de Daniel Villafuerte Solís, "El Triángulo Norte de Centroamérica: dilemas de la democracia en una subregión conflictiva". Configurada esta subregión por Guatemala, El Salvador y Honduras, el autor reconstruye en cada uno de estos países los cambios políticos surgidos a partir de las transformaciones que se vienen operando en el programa económico, en el Estado y en las estrategias geopolíticas que Estados Unidos implementa aduciendo riesgos a la seguridad interna, regional y hemisférica. Es un ejercicio analítico que permite a su autor sostener que son estos vectores - programa económico, Estado e injerencia estadounidense- los que han propiciado que las sociedades de los tres países registren el mayor índice de violencia en el mundo, altos niveles de pobreza, exclusión social y crecientes flujos migratorios a Estados Unidos. En suma, no puede haber democracia en países profundamente desiguales y excluyentes, en cuyo territorio transita el $80 \%$ de la droga que se consume en Estados Unidos. "Un país que expulsa a su población, en lugar de protegerla, no puede caracterizarse como democrático; un país donde las minorías toman las decisiones y donde los representantes en los congresos no consultan a sus electores, tampoco puede llamarse democrático".

El capítulo de Jahir Dabroy, "Guatemala, ¿hacia un nuevo paradigma de construcción ciudadana?", ofrece una lectura precisa sobre la reciente coyuntura política en el país, que devela la naturaleza estructural de la crisis del sistema político guatemalteco. Frente a una de las mayores movilizaciones sociales contra la corrupción política, que devino en el retiro de inmunidad y en las subsecuentes órdenes de arraigo y arresto en prisión de la vicepresidenta y del presidente Otto Pérez Molina, el autor se interroga si Guatemala transita hacia un nuevo paradigma de ciudadanía. Su respuesta crítica deshoja el entrecruzamiento de intereses internos y externos que posibilitaron dichos resultados, ofreciendo una lectura sobre los límites de la democracia política, producto de un Estado reducido en sus funciones y diseñado para que funcione mal. Con ello, no resulta extraño que los resultados de una segunda vuelta dieran el triunfo a una figura televisiva que asume el poder presidencial en un ficticio horizonte de "normalidad democrática". 
El texto de Andrés León, "Democracia desde arriba; democracia desde abajo: elecciones, poder y conflicto en la Honduras post-golpe de Estado", en oposición a una lectura oficial, ofrece un análisis crítico sobre las condiciones del golpe de Estado de 2009 y la situación actual del país, "explorando tanto el proceso histórico de producción de una cierta formación estatal hacia fines de los setenta”, como el proceso de producción y disputa de la hegemonía, en la línea de las luchas ciudadanas y de las disputas territoriales, horizontal la primera y vertical la segunda. La distinción entre democracia "desde arriba" y democracia "desde abajo" permite a León reconstruir la historia política hondureña, cuyos puntos de inflexión se acomodan para fortalecer un régimen "desde arriba" en el que se conjugan el poder del Ejército y un sistema bipartidista, para caracterizar así a la modernización del Estado como un proceso pasivo y revolucionario.

El texto de Carlos Mauricio Hernández, "Mesianismo político en El Salvador: análisis de discurso de los candidatos de ARENA y el FMLN en las campañas electorales presidenciales de 2004 y 2009", es un fresco sobre el mesianismo político activado en las campañas electorales, pero también, en tanto vector de un imaginario social que es constitutivo de la cultura política en otros países de América Latina. Desde el discurso de las campañas, Hernández deshoja los cinco arquetipos míticos de carácter religioso contenidos, explícita o implícitamente, en los discursos de ambos candidatos: bestia, peste, horizonte utópico, mesías y pueblo, cuyo fondo religioso se conecta con el protagonismo de la figura presidencial. Recuperando el estado de la cuestión, registra la relación discursiva entre religión y política y, con ella, el juego mediático de las creencias de fe por parte de los partidos políticos. Se trata de una relación fuerte que exige su comprensión analítica en tanto que, aparentemente excluido de una cultura política democrática moderna, define y modula resultados electorales presidenciales.

El texto de Manuel Martínez Espinoza, “iExtracciones y consultas? La minería y los derechos de los pueblos indígenas como un mentís de la democracia en Guatemala", ofrece una lectura crítica sobre la experiencia de la democracia liberal, en la que destaca la tensión entre modelo político y realidad, sostenida por el "enfrentamiento constante e irresuelto entre actores, instituciones y procesos contradictorios que se efectúa en el marco de un Estado que preserva su núcleo fundacional". Posteriormente, continúa con un ejercicio analítico de esta tensión, abordando el caso de la minería y de los derechos de los pueblos indígenas, que invita a la reflexión sobre los límites del Convenio 169 sobre Pueblos Indígenas y Tribales de la OIT y del Acuerdo sobre Identidad y Derechos de los Pueblos Indígenas, firmados en común en los Acuerdos de Paz e incorporados en la Carta Constitucional. El capital transnacional minero, como la expresión de una "acumulación por desposesión", o "reprimarización" que trasgrede y violenta todo principio de soberanía, configura un Estado que reprime toda expresión social de defensa de los derechos humanos afectados. 
Por su parte, el texto de Juan Mora Heredia y Margarita Jiménez Badillo, "Democracia, confianza y ciudadanía en México", se centra en la miseria en la que se debate la democracia en México, alejada del ideal republicano abierto por la democracia política y en la búsqueda de su rehabilitación a través del ejercicio ciudadano. Privilegiando el campo simbólico y cultural —construcción de identidades políticas y formas de intervención social que organizan la vida pública mexicana-, los autores analizan e interpretan las Encuestas de Cultura Política (2001, 2003, 2005, 2008, 2012) y revisan el sentido ambivalente de los ciudadanos respecto a la democracia, esto es, frente a su frágil vocación asociacionista, su rechazo mayoritario hacia las entidades y los actores vinculados al circuito institucional, así como al ideal de la democracia como forma de gobierno.

Por su parte, Jesús Solís Cruz, en su contribución "Chiapas, la democracia que no fue", plantea un análisis a contrapelo de las lecturas festivas de un creciente desarrollo democrático electoral en Chiapas, asentadas en el supuesto de las alternancias, el multipartidismo y la competencia electoral. Tomando como referente empírico las elecciones locales de 2015, y como axioma de trabajo la acentuación de un modelo utilitario de la política y la regresión a formas políticas predemocráticas en la entidad, el autor sitúa el proceso histórico reciente de la democracia procedimental en Chiapas, para mostrar cómo del contexto de dominio unipartidista, vigente hasta principios de la década de 1990, se pasó a un campo político de mayor complejidad que posibilitó la primera transición en el gobierno estatal. El análisis registra la reinstauración de prácticas políticas centradas en la figura del gobernante que derivaron en la negación misma de las instituciones liberal-parlamentarias que habían posibilitado la complejización del campo político. Esta práctica autonegada de la democracia asesta un golpe certero al sistema político representativo mismo y deriva en un vaciamiento de la legitimidad democrática.

El trabajo de Efraín Poot, "Yucatán y el alcance estabilizador de las elecciones convergentes de 2015", ofrece un análisis de los procesos electorales federal y local, bajo la tesis de que, en el caso de Yucatán, "el sistema de representación política es el reflejo de la escasa diferenciación o diversificación de la estructura social", por lo que los procesos electorales son el principal mecanismo estabilizador de las disputas por el control político estatal. El centro de análisis, bajo la perspectiva de la "medición de la calidad de la democracia", es el municipio de Mérida, desde donde deshebra el tejido político que hace de la entidad una sociedad "democráticamente correcta”, visible en su apego a la nueva reforma político-electoral y en un bipartidismo cuyas dirigencias locales son también sustentadas por la iniciativa privada local, promotora ésta de la participación ciudadana en la elección de sus autoridades. No obstante, indica el autor, amén de las tensiones propias en toda disputa por el poder parlamentario y gubernativo, el índice de marginación de Yucatán lo coloca en el undécimo lugar a nivel nacional. 
Los textos que conforman la tercera sección del libro: "Democracias otras", son trabajos en los que se conjugan el diagnóstico crítico, el reconocimiento político de las ausencias y la potencia de las experiencias alternativas de lo democrático. Su recuperación abre un campo conceptual y político que exige una estimación crítica y propositiva por parte de las ciencias sociales. Los tres textos se sustentan en una valoración crítica del modelo de la democracia política para, recordando a Hugo Zemelman, "nombrar lo no nombrado"

El primer texto, "Profundizaciones en torno a la demoeleuthería", de Carlos Alonso y Jorge Alonso, es un ejercicio que conjuga pensamiento y práctica. Frente a una democracia electoral que nos aturde y desarma, por su recurrente circularidad sombría y sin fin, el trabajo conceptual y reflexivo de los autores sobre el concepto de demoeleuthería no puede ser más oportuno. Se trata de una noción que define "la libertad de los de abajo", ajena a la conjunción de los términos demos y kratos, en el que el demos de abajo sufre la dominación. Los autores nos aportan una lectura que, de cara a la experiencia zapatista, cuyo centro de acción gira en torno a la autonomía, define los contenidos y la riqueza analítica del concepto demoeleuthería. Para ello recurren a precisiones pedagógicas y conceptuales claves - contraposición, ser y tener (Macel); egoísmo y altruismo (From); colonización y liberación (Fanon) - y definen qué es la idea del ser, que es ser-en-libertad, lo que abre paso a un campo semántico que culmina en la autonomía, en abierta contraposición con la violencia discursiva de la democracia liberal y la expoliación práctica del capitalismo neoliberal neocolonial.

La demoeleuthería sería entonces el concepto cuyo contenido refiere a la lucha por conservar el sustento que es condición para el ser, por ende, su implicación en "todo proceso de descolonización y en la lucha contra toda clase de colonialismo". El texto nos lleva a la experiencia zapatista, a sus prácticas y procesos vividos socialmente, tan ilegibles en el pensamiento y la teoría política hegemónica hoy dominante. Nos acerca a un pensamiento que enfrenta a la democracia liberal y la ignora en tanto sustento político de un capitalismo global agresivo y desbordado en su afán de ganancias y de progreso.

El segundo texto de esta tercera parte, "Las guerras, la otra política y los medios indígenas en movimiento", de Leyva y Köhler, recupera los proyectos y experiencias de comunicadores comunitarios mayas de Chiapas en un contexto de violencia política, y sostienen que la video auto-representación "es un arma de lucha al emerger de la necesidad vital y política de hacerse escuchar, de autodocumentar y de contrainformar, así como de acompañar desde adentro las movilizaciones de los pueblos, las luchas de resistencias autonómicas por la vida y contra la muerte que propaga hoy el capitalismo, la colonialidad y el sistema patriarcal". Sustentado en una autolectura histórica y política de los sujetos indígenas, que visibiliza la violencia de la "lógica del mundo mercado" y sus tensiones con una lógica de mundo "propio", el ejercicio analítico de los autores está orientado no sólo a esclarecer el concepto mismo de "guerra", o mejor, de "guerras" contemporáneas, que 
bien pueden sintetizarse en los conceptos de "biopolítica" y "necropolítica", de matriz colonial (Foucault, 2007; Mbembe, 2011), sino también a visibilizar las "otras democracias" en las que dispositivos y estrategias, como la tecnología de la comunicación y sus saberes, articulados al autoconocimiento de lo propio, producen chispas o luces capaces de irrumpir en una política que entraña una agresiva pulsión de muerte.

Concluimos esta última parte del libro con el texto "Desde abajo, por la izquierda y con la Tierra: la diferencia de Abya Yala/Afro/Latinoamérica", una aportación generosa de Arturo Escobar, que oxigena las ciencias sociales de América Latina, en un contexto donde las fuerzas de los poderosos destrozan por igual el sustento de la democracia liberal que les ha legitimado, que las luchas sociales por la vida, la naturaleza y las sociabilidades de población mayoritaria asentada en miles de comunidades y localidades. A la sinrazón del desmedido y desquiciante poder de las derechas, del centro, e incluso de las izquierdas ortodoxas, Escobar recupera una vertiente de realidad que por su sentido intermitente y múltiple tendemos a ignorar. Se trata del pensamiento de las comunidades e intelectualidades indígenas y afrodescendientes, y los movimientos sociales y de los pueblos, para desde ahí interrogarse sobre el papel del pensamiento crítico en proyectos y experiencias sociales.

En tal sentido, el autor dibuja el mapa de retos que esta tarea conlleva: aprender a leer con sentido analítico y propositivo un mundo de muchos mundos, cuya problematización nos hace "tartamudear, cuando con tanta naturalidad invocamos a 'América Latina", referente geohistórico insuficiente para este nuevo pensamiento crítico, por lo que nos propone leer e interpretar desde: Abya Yala/Afro/Latino-América. Comparte con Emir Sader la urgencia de rescatar "la articulación entre pensamiento crítico y lucha de superación del neoliberalismo, entre teoría y práctica, entre intelectualidad y compromiso político". Esta exigencia está modulada por una tesis central: salir del pensamiento y la práctica de la modernidad fincada en la visión del progreso, para construir esa esfera de lo político que, desmarcada del sistema, del Estado y su democracia parlamentaria, resignifica prácticas colectivas, construye y reconstruye esas prácticas sociales que por ser sociales son plurales; son cuerpos colectivos subjetivables, a sabiendas de que no hay pueblo ni sujeto elegido de la verdad.

Los materiales de este libro pretenden modestamente abrir un debate crítico sobre la democracia liberal y las democracias "otras", así como ser un punto de partida para leer y pensar la política y las democracias en una porción significativa del sur global, Centroamérica y sur de México, y abonar, con ello, un terreno que hoy se escabulle, el del pensamiento crítico, que pretendemos sea el que sustente y justifique nuestro Observatorio. 
INTRODUCCIÓN

\section{Referencias bibliográficas}

Bachelard, Gastón (1984). La filosofía del no: ensayo de una filosofía del nuevo espíritu científico. Buenos Aires: Amorrortu.

Foucault, Michel (2007). Nacimiento de la biopolitica. Buenos Aires: FCE.

Mbembe, Achille (2011). Necropolítica. España: Mesulina.

Mouffe, Chantal (2003). La paradoja democrática. Barcelona: Gedisa.

Muguerza, Javier (1996). Desde la perplejidad. Ensayo sobre la ética, la razón y el diálogo. México: FCE.

María del Carmen García Aguilar

Jesús Solis Cruz

Pablo Uc 


\section{Primera parte. Debate teórico}






\title{
Debate teórico en torno a la democracia: del concepto hegemónico a las otras democracias
}

\author{
Laura Álvarez Garro
}

\section{Prolegómenos teóricos}

Plantear la cuestión de la democracia nunca ha sido una tarea sencilla. A lo largo de la historia numerosas aproximaciones han pretendido dar cuenta de la misma, ya sea pensándola como una forma de gobierno, como un tipo de régimen o como una "forma" de lazo social. Además, la tarea se complejiza cuando se introducen dentro del análisis las variantes devenidas de "formas de sociedad" distintas, que se caracterizan por poseer marcos culturales y económicos heterogéneos y siempre en disputa. Frente a este escenario, se ha tratado de brindar respuestas, que transitan desde el establecimiento de definiciones mínimas conceptuales de la democracia que puedan ser aplicadas a Occidente de manera universal, hasta aquellas que con el afán de introducir la complejidad dejan de lado la discusión conceptual y avanzan a una descripción particular, situada en un espacio y tiempo, pero que tiene como principal limitante su singularidad.

Es en esa tensión donde se ubica nuestro trabajo. Por un lado, se debate contra las definiciones cristalizadas de la democracia liberal-procedimental que se han mostrado ineficientes para comprender los conflictos en la región; pero, por otro lado, nos resistimos a generar una mirada particularizante, descriptiva y anecdótica de nuestras democracias. En otras palabras, consideramos necesario un marco de explicación teórica, en la que se discuta cuáles son los fundamentos ontológicos de la democracia liberal-procedimental contemporánea que permitan comprender por qué ésta se ha petrificado como el "único modelo posible" de organización de lo político, para así avanzar hacia el análisis de los marcos particulares de nuestros respectivos Estadosnación, comunidades y movimientos sociales. Lo anterior se desprende de contemplar lo político como una forma particular de lazo social, que no estaría supeditado sólo al ejercicio de la administración del Estado — política — ni pertenecería a priori a sujetos 
esenciales $^{1}$ de la política, tal como las derivas del marxismo clásico, el anarquismo o algunos movimientos sociales sugieren.

De lo que se trata es de la "forma de sociedad", de la pregunta por la comprensión de los fundamentos que actúan como supuestos de una determinada forma de ver el mundo, aquellos que se oscurecen en la experiencia cotidiana, que no se discuten cuando se piensa que todo siempre ha sido así. Tal como lo plantea Claude Lefort $(1988,1990)$, las corrientes mainstream de la ciencia política o de la sociología política analizan la sociedad como si fuera posible delimitar los hechos políticos de los hechos sociales o de los hechos económicos. Lo que se olvida, lo que no se discute, es que esta diferencia en sistemas proviene de una mirada particular que está anclada previamente. En otras palabras, lo que hay que preguntarse es qué hace que nosotros tendamos a subdividir a la sociedad en subsistemas, qué operación ontológica y epistemológica hace posible pensar sus límites de manera rígida, estable en el tiempo y a través de las culturas. Poder dar cuenta de lo anterior implica reconocer que en nuestras democracias coexisten fundamentos filosóficos no problematizados, nociones de ser humano y sociedad que subyacen a la manera en que administramos el Estado, el vínculo entre éste y la sociedad, en una red conceptual que les otorga el lugar de sentido común.

Esta resistencia al trabajo conceptual, a cuestionar los universalismos y los esencialismos ${ }^{2}$ subyacentes a algunas interpretaciones en las ciencias sociales, tiene como consecuencia el desarrollo de narrativas que llegan a nudos problemáticos que no pueden desembrollar. Esta imposibilidad se desprende de no detenerse a cuestionar los fundamentos filosóficos con los que definen a los seres humanos y a la sociedad, con lo cual terminan repitiendo formas anquilosadas de pensar estos conceptos, que al final son herencia de planteamientos históricos que no pueden ni quieren problematizar. Terminan asimilando formas de pensar sin ninguna distancia crítica, sin preguntarse si efectivamente puede contribuir no sólo a la comprensión de nuestras democracias sino a su transformación. Preguntas tales como: iqué universales se juegan en nuestras

\footnotetext{
${ }^{1}$ Se entiende esto en línea con lo que plantean Laclau y Mouffe (Laclau, 1986; Laclau y Mouffe, 1987). Se sostiene que no existirían sujetos esenciales de la política que preexistirían el conflicto y que deberían de cumplir con una serie de propiedades para ser calificados como verdaderos. Por lo tanto, categorías que pretendan nombrar a un sujeto transformador que tendría la tarea histórica de la emancipación - proletariado, campesinos, pobres, indígenas, etcétera - se observan como cristalizaciones de posiciones que no contribuyen a la comprensión de la contingencia del conflicto político. La transformación política requiere de procesos de subjetivación que no están definidos a priori ni corresponden a un destino establecido.

${ }_{2}^{2}$ Para mayor información acerca de estos planteamientos, remitirse a: Álvarez Garro (2013), Arditi (1991), Butler (1992), Deleuze (1989), Deleuze y Guattari (2002), Derrida ([1967]1989, 1971, 1998), Fink (1989), Foucault (1968, 1988, 1992), Laclau (2005), Laclau y Mouffe (1987), Marchart (2009), Nietzsche ([1886]2005, 2008) y Rancière (2007), entre otros.
} 
democracias del sur de México y Centroamérica?, ipodemos aplicar exactamente los mismos marcos de comprensión correspondientes a países o naciones "centro" a nuestras realidades? o ¿son las propuestas de otras democracias capaces de ser modelo para la solución de conflictos en otras latitudes?, son preguntas que han quedado relegadas a una condición de marginalidad o rechazadas a priori por ser consideradas interrogantes no pertinentes o adecuadas.

Para ejemplificar lo anterior, podemos analizar brevemente cuáles han sido las vías de abordaje por parte de las ciencias políticas y la sociología política dominante destinadas a responder el porqué de la situación cambiante de la política en América Latina durante las últimas tres décadas, específicamente dos preguntas que se consideran centrales para el abordaje del tema: "1) icuáles son las condiciones para una transición de alguna forma de autoritarismo a la democracia? y 2) icuáles son los factores que explican la durabilidad de la democracia?" (Munck, 2010: 578).

En su artículo "Los orígenes y la durabilidad de la democracia en América Latina: avances y retos de una agenda de investigación", el autor arriba citado plantea que alrededor de estas preguntas se pueden distinguir cinco grandes líneas discernibles de investigación teórica y empírica: "i) la tesis de la modernización económica, ii) las teorías culturales, iii) las teorías sobre el desarrollo capitalista y las clases sociales, iv) los modelos de coyuntura crítica, y v) las teorías político-institucionales" (Munck, 2010: 578).

Si bien cada una de estas líneas de investigación adquiere su propio nivel de complejidad, en las cinco aparecen fundamentos metafísicos inamovibles, que se relacionan con una definición mínima de democracia y con una concepción de sujeto que se desprende del pensamiento moderno. Sin embargo, sobre esto regresaremos más adelante, una vez que hayamos analizado brevemente las principales aporías internas a las que arriban cada una de estas líneas de investigación.

La primera de éstas relaciona la estabilidad de la democracia con la modernización económica. El planteamiento, que tuvo por principal representante a Seymour Martin Lipset (1992), se resume de la siguiente manera: ante un mayor desarrollo económico aumento de ingresos en un país-, aumenta la probabilidad de una transición a la democracia y las probabilidades de su duración (Munck, 2010: 578). ¿Qué problemas se desprenden de este planteamiento? Más allá de los señalados por el propio Munck (2010: 579) acerca de la inadecuación de este planteamiento a la experiencia histórica de América Latina, en la cual aparecen ejemplos de países en donde coexistieron momentos de amplio desarrollo económico con regímenes dictatoriales o autoritarios, el problema fundamental estriba en la ausencia de análisis de fundamentos. No se cuestiona en qué momento se estableció la asociación entre democracia y liberalismo económico, ni cómo esto tiene un anclaje en el liberalismo político, sino que esto aparece como algo establecido. Tampoco se discute si este desarrollo económico contribuye a un mejor desarrollo social: su indicador de éxito es el aumento de ingresos en un país, sin contemplar si éstos se 
distribuyen o se quedan en unas pocas manos. Finalmente, no se discute acerca de qué definición de democracia se habla, pues se da por sentado que es aquella democracia que cumple con los criterios liberales y procedimentales necesarios para sostener elecciones periódicas.

La segunda línea de investigación se sustenta principalmente en los trabajos generados bajo la influencia del estudio de Almond y Verba (1963), en el cual sostienen que un país transita a la democracia y perdura en ésta en la medida en que sus habitantes tienen actitudes democráticas y apoyan un conjunto de valores que se consideran consistentes con el funcionamiento de la democracia. Si bien Munck (2010: 580-583), al igual que en el caso anterior, logra señalar dos grandes dificultades: diferencias culturales entre los países donde se realizó el estudio y Latinoamérica, y el problema de discriminar si esos valores funcionan como condición de posibilidad de la democracia o es la democracia la que produce esos valores, hay una notable ausencia de discusión conceptual. Por ejemplo: ¿qué se entiende por valores? ¿Qué se entiende por democracia? ¿Por creencia? ¿Son estos valores producto de una determinada "forma de sociedad" o están instalados en la naturaleza humana? iSon valores que pueden ser aplicados de forma universal o adquieren connotaciones distintas de acuerdo con la diversidad de comunidades humanas en el espacio y en el tiempo?

La tercera línea de investigación puede ser objeto de las mismas críticas que la primera, pero se le puede incluir una pregunta central: ipor qué se ubica el modo de producción capitalista como el único que puede garantizar una democracia? ¿Por qué dar condición de verdad a un modo de organización económica que puede no ser compartido por otras sociedades? La respuesta que los autores ubicados en esta línea pretenden brindar (Johnson, 1958; Touraine, 1989) es que una sociedad capitalista puede ofrecer mejores condiciones de desarrollo para las distintas clases sociales, con la ventaja adicional de fortalecer una clase media que puede actuar como mediadora entre las clases altas y bajas, dotando de mayor estabilidad al régimen. Sin embargo, aparece aquí la pregunta por los sujetos esenciales de lo político: ise puede sostener que la clase media tenderá al equilibrio y no apostará por derivas autoritarias, dictatoriales o totalitarias? Es evidente que la experiencia histórica muestra lo contrario, pero aun frente a la evidencia, este tipo de planteamientos son asumidos por algunos sectores como condición de verdad, ignorando la contingencia de los conflictos políticos y sociales, las condiciones de subjetivación e inclusive el oportunismo de los diferentes actores que están inmersos en el conflicto.

Por su parte, se puede considerar la cuarta línea de investigación como la menos problemática de todas, ya que busca anclar su reflexión sobre la base de procesos históricos de larga duración. Al ser su característica distintiva la generación de un modelo de coyuntura crítica que permita explicar los desarrollos políticos, abre su abanico explicativo de forma más amplia que las anteriores tres líneas de investigación, con lo cual reduce la aparición de aporías. En palabras de Munck (2010: 585): “[...] introduce una ruptura significativa con respecto a las tres líneas de investigación 
discutidas anteriormente y ofrece una alternativa a las teorías societales a través de su énfasis en explicaciones históricas y políticas". Sin embargo, al igual que en las otras líneas, convendría preguntarse si estas investigaciones incluyen en su debate las transformaciones y permanencias de conceptos políticos en el tiempo; si logran problematizar las diferencias de sentido que se otorgan a eventos y conceptos dependiendo de los sujetos de enunciación y si pueden reconocer la existencia de otros marcos de comprensión para los fenómenos democráticos que desborden el fundamento liberal-procedimental.

Finalmente, la quinta línea de investigación pretende dar cuenta de los procesos de democratización a través del análisis de los actores que participan en actividades políticas y toman decisiones en este campo, en conjunto con las instituciones políticas diseñadas por los mismos, que pueden facilitar o constreñir la acción política cotidiana (Munck, 2010: 586). Sus principales representantes incluyen a Linz (2009), quien desarrolló una tipología de los regímenes políticos del siglo XX, planteando como hipótesis que la dinámica política de cada régimen afecta las perspectivas de una transición a la democracia; o los modelos de transición a la democracia de O’Donnell y Schmitter (1994). Si bien esta perspectiva, al igual que la anterior, pone acento en la autonomía de la política, analizando la dinámica de la esfera política propiamente dicha y sus élites, corre el riesgo de crear una relación de identidad entre lo político y la administración política, ya que no ingresa a la discusión conceptual que permita deslindar lo político del Estado.

En suma, si bien se pueden rescatar aportes importantes desde estas líneas de investigación, su poca o nula discusión y rigurosidad conceptual tiene por consecuencia que se asuman supuestos ontológicos y epistemológicos no problematizados acerca de los sujetos y las sociedades que cristalizan el pensamiento e impiden el surgimiento de nuevas formas de comprensión de fenómenos políticos y sociales. Plantear una crítica hacia este posicionamiento teórico-conceptual no sólo implica asumir un ejercicio conceptual complejo, sino además asumir como principio que los conceptos políticos están en constante movimiento y que poseen por sí mismos la capacidad de vincularse con la práctica política y social cotidiana. ${ }^{3}$

Por esta razón, para entender la democracia en nuestra región y en otras partes del mundo se debe incorporar al análisis el contexto de enunciación histórico-social. Sin embargo, esto no quiere decir que se puedan trazar fronteras radicales entre los lugares, las épocas o entre los contenidos de los conceptos. Las distintas maneras en que ha sido conceptualizada la democracia generaron efectos a largo plazo, huellas que persisten dentro del contenido del concepto. Otras se han diluido con el cambio de épocas,

\footnotetext{
${ }^{3}$ El encuadre teórico-conceptual que se desarrolla en adelante y en la próxima sección recupera algunos de los planteamientos ya expuestos en mi tesis doctoral. Ver Álvarez Garro (2013).
} 
quedando como formas ajenas o como puntos de comparación. Otras están en emergencia, reconstituyéndose frente a los retos contemporáneos.

Esta presunción se basa en dos supuestos. El primero, postulado por Schmitt ([1932]1991: 60), indica que todos los conceptos, ideas y palabras poseen un sentido "polémico"; son formulados con miras a un antagonismo, y están vinculados a una situación que puede tener como consecuencia última una agrupación de amigos y enemigos. En otras palabras, la forma en cómo un colectivo o un individuo defina la democracia posee un carácter performativo: amplía o limita el espacio de ejecución de una praxis política.

Este carácter polémico de los conceptos se complementa con el segundo supuesto, que incorpora la reflexión de Michel Foucault acerca del saber. Para Foucault (1992: 17-21) existe una voluntad de saber que emerge en los siglos XVI y XVII, para instalar una cierta forma de mirar, una cierta posición y una cierta función; una forma de observar, de medir y de clasificar. Esto tuvo por principal consecuencia prescribir un nivel técnico bajo el cual se medirían los conocimientos que podían ser verificables y útiles.

Por lo tanto, si tomamos en cuenta ambos supuestos, podemos dar un primer paso en el propósito de enmarcar el debate acerca de la democracia y cómo ésta ha sido estudiada en nuestra región. Se encuentra que el concepto de democracia no sólo está en disputa, sino que sus contenidos responden a una voluntad de saber. De esta manera, se puede plantear que la forma en cómo la ciencia política y la sociología política mainstream han abordado estas problemáticas responde de entrada a una determinada voluntad de saber que cierra el juego de las diferencias y pretende cancelar su carácter polémico, afirmando en todo momento que su definición de democracia es la "correcta".

Esta operación teórico-conceptual tiene por consecuencia una determinada "repartición de lo sensible", expresión acuñada por Jacques Rancière (2007: 25, 31) para referirse a la forma en que se establece el orden social, que dicta quiénes pueden ser vistos y escuchados, quiénes son invisibles y quiénes son ruido. Esto no sólo tiene implicaciones en la extensión que pueda tener un determinado debate conceptual, sino también en las posibilidades de transformación política y social. Ahora bien, para que esta operación tenga éxito, tiene que pasar desapercibida. Como se planteará más adelante, esta repartición de lo sensible proviene de una determinada configuración de lo político, de una "forma de sociedad" que impone una "forma de sentido" y una "forma de escena". Estos factores en conjunto permitirían brindar una aproximación a la respuesta de por qué las teorías de la democracia liberal-procedimental no pueden cuestionar sus fundamentos, ya que se satisfacen con generar un conocimiento técnico con base en un corpus conceptual inamovible y cristalizado, sin discutirlo en lo interno. Esta falta, lejos de ser azarosa, representa un síntoma, expresa un control interno que limita la discusión de la democracia a sus procedimientos técnicos, descartando del análisis aquello que se 
escapa a su control, aquel exceso que no puede ser controlado, previsto o tramitado por un marco de procedimiento jurídico. Por otro lado, aquellos énfasis que privilegian la particularidad, la diferencia y la descripción de procesos políticos sin dar una discusión conceptual, bajo estos supuestos, igual estarían reproduciendo definiciones ontológicas y epistemológicas del ser humano y la sociedad de forma implícita, lo cual tiene por consecuencia inmediata que se le puedan aplicar las mismas críticas que se han realizado a los modelos de la democracia liberal-procedimental.

Por esta razón, antes de proponer "otras" democracias, es urgente señalar cuáles son los fundamentos que sostienen el discurso de la democracia liberal-procedimental, aquellos que operan de forma implícita, que son huellas de otros momentos históricos, de otras formas de pensar lo político. Éstos establecen un marco que instala qué puede ser válido o legítimo dentro de la discusión del concepto, marcando de antemano qué puntos pueden ser objeto de debate y cuáles no. Poder distinguir estas huellas nos permitiría reconocer cuáles de ellas siguen operando de forma subrepticia en nuestras reflexiones, ya que buena parte del debate contemporáneo gira alrededor de esta noción hegemónica de democracia, sea para defenderla - modelos de democratización del espacio social que se alimentan de la tradición liberal-procedimental — o para oponerse a ella, dibujando una democracia cuasiperfecta, idealizada, romantizada, en la cual haya una superación absoluta del antagonismo. Esto es crucial ya que, como veremos más adelante, estas dos tendencias son caras de la misma moneda, ambas despolitizan, ponen en riesgo la construcción de lo político entendido como una forma específica de lazo social.

\section{Los fundamentos de la democracia liberal-procedimental}

Con el propósito de precisar cuál es la racionalidad política subyacente a las corrientes de pensamiento que defienden una noción de democracia liberal-procedimental, es necesario detenerse primero en las propuestas de Carl Schmitt y Claude Lefort, para así establecer un marco teórico-crítico mínimo. En su texto El concepto de lo político, Schmitt establece que el criterio de lo político supone una relación que es a su vez constitutiva y polémica. Constitutiva porque permite definir los límites de la comunidad, el adentro y el afuera, el nosotros y el ellos de forma pública: "Pues bien, la distinción política específica, aquella a la que pueden reconducirse todas las acciones y motivos políticos, es la distinción de amigo y enemigo" (Schmitt, [1932]1991: 56). Polémica en tanto esta definición se encuentra en construcción, porque las definiciones no son absolutas o eternas, sino que responden a esta misma distinción característica de lo político. Los agrupamientos actúan como cierres parciales de sentido, que responden a su vez a determinadas coyunturas y pueden ser modificados constantemente: un amigo puede ser enemigo o viceversa: "En realidad no existe ninguna ‘sociedad' o ‘asociación' política; lo que hay es sólo una unidad política, una 'comunidad' política. La posibilidad real de agruparse como amigos y enemigos basta 
para crear una unidad que marca la pauta, más allá de lo meramente social-asociativo, una unidad que es específicamente diferente y que frente a las demás asociaciones tiene un carácter decisivo" (Schmitt, [1932]1991: 74).

Lefort retoma este planteamiento y lo profundiza. Para este autor, existen momentos en los cuales, como producto de la resolución de un determinado conflicto o antagonismo político, se gesta una determinada forma de sociedad, con lo cual la pregunta acerca del espacio social y la relación entre los distintos actores que lo pueblan se revela en el doble movimiento de institución de lo político. De esta manera, lo político no se revela en la actividad política, sino en el doble movimiento por el cual el modo de institución de la sociedad aparece y se oculta (Lefort, 1988: 218-219). Parafraseando a Derrida (1998: 147), lo político encarna una doble dimensión: es un estrato particular y fundado pero a su vez invade todo el estrato fundamental o fundador de la existencia, individual o comunitaria. Esta forma de entender lo político permite comprenderlo como aquello que posee un carácter instituyente o constituyente en la sociedad, pero que a su vez es contingente:

Por un lado, lo político, en tanto momento instituyente de la sociedad, opera como fundamento suplementario para la dimensión infundable ${ }^{4}$ de la sociedad; pero, por el otro, este fundamento suplementario se retira en el 'momento' mismo en que instituye lo social. Como resultado de ello, la sociedad siempre estará en busca de un fundamento último, aunque lo máximo que puede lograr es un fundar efímero y contingente por medio de la política (una pluralidad de elementos parciales) (Derrida, 1998: 22-23).

De esta manera, lo político es a la vez un estrato regional, una capa particular, aunque sea fundadora; y la determinación suplementaria o sobredeterminante que atraviesa cualquier otra región del mundo humano o de la comunidad simbólica-cultural (Derrida, 1998: 147).

\footnotetext{
${ }^{4}$ La dimensión "infundable" de la sociedad se desprende de concebir a la misma como resultado de la contingencia del conflicto político, con lo cual no habría ningún fundamento metafísico o trascendental que le otorgue coherencia a priori. Esta forma de entender a la sociedad aparece como parte de nuestra racionalidad contemporánea a través de lo que Lefort (1990: 188) denominó la "disolución de los indicadores tradicionales de certeza". En las sociedades premodernas, el orden adquiría consistencia apelando a la divinidad o a la naturaleza como los fundamentos de las relaciones sociales, condición que se transforma cuando en el ingreso a la modernidad se critica de forma extensa esta racionalidad y la pregunta por el sentido deviene central. En la reflexión de Lefort (1990: 190), la pérdida por estos fundamentos produjo una mutación en el orden simbólico, una transformación crucial en la forma de sociedad. A partir de ese momento, la legitimidad se tendrá que buscar en la propia sociedad, no ya en un referente externo — dios o la naturaleza, o ambas—; lo que tendrá por efecto la "polemización" constante de los fundamentos.
} 
Esta dimensión configurante, que extrae su lógica del antagonismo odel desacuerdo, ${ }^{5}$ otorga una forma a la sociedad (mise en forme), dentro de la cual se configuran la noción de sentido (mise en sens) que se le otorga a las relaciones sociales y la forma en cómo se ponen en escena (mise en scéne). En otras palabras, el advenimiento de una sociedad capaz de organizar relaciones sociales sólo puede ser posible si instituye las condiciones de su propia inteligibilidad, si puede usar una multiplicidad de signos para lograr una cuasi-representación de sí misma. En este sentido, trazar una discriminación entre lo social y lo no-social o entre diversos subsistemas es un efecto de ficción, en tanto la conceptualización de lo político presupone la organización de la experiencia de coexistencia, misma que no está separada de nuestra existencia con el mundo, de lo que se define como visible o como invisible (Lefort, 1988: 218-219).

Por lo tanto, el espacio denominado sociedad no puede ser concebido como un sistema de relaciones a priori, no importa qué tan complejo se pueda imaginar a este sistema. Al contrario, es a partir del modo particular en que se instituyó o configuró la sociedad la que hace posible conceptualizar — sea en el pasado o en el presente- la articulación entre sus dimensiones, las relaciones entre los grupos e individuos, prácticas, creencias y representaciones. Si no se toma en cuenta esta referencia primordial a la institución de la sociedad como el lugar donde se generan principios que gobiernan la configuración espacial y temporal de la sociedad, se cae en una ficción positivista: se adopta el concepto de una sociedad pre-social (Lefort, 1988: 217-218).

Por lo tanto, de lo que se trata es de avanzar y cuestionar esta forma de comprensión que pretende observar en la sociedad elementos ya determinados y dispuestos a ser analizados con base en una teoría mínima o reduccionista de la democracia. Ahora bien, es necesario realizaruna aclaración antes de proseguir. Sibien losmomentos deinstitución oconstitución políticos tienen por efecto la aparición de una determinada forma de sociedad, no se quiere decir con esto que la transformación marque un antes y un después radicalmente distinto,

\footnotetext{
${ }^{5}$ Rancière entiende el desacuerdo (mésentente) como un tipo determinado de situación de habla en la cual uno de los interlocutores entiende y a la vez no entiende lo que dice el otro. Por lo tanto, el desacuerdo no es simplemente que un interlocutor diga blanco y el otro diga negro, sino que ambos al decir blanco tienen una definición diferente de blancura. Sin embargo, esto no quiere decir que sea por desconocimiento, no es el efecto de una simple ignorancia o de una ilusión constitutiva ni tampoco es efecto de un malentendido (Rancière, 2007: 8). El desacuerdo se produce en los casos donde la discusión sobre lo que se quiere hablar constituye la racionalidad misma de la situación de habla. En estos casos, los interlocutores entienden y no entienden lo mismo con las mismas palabras: "Hay toda una clase de motivos para que un X entienda y a la vez no entienda a un Y: porque al mismo tiempo que entiende claramente lo que le dice el otro, no ve al objeto del que el otro le habla; o aun, porque entiende y debe entender, ve y quiere hacer ver otro objeto bajo la misma palabra, otra razón en el mismo argumento" (Rancière, 2007: 9). Esta racionalidad del desacuerdo tendrá como efecto una forma de plantear el orden social que consiste en una repartición de lo sensible, que dicta quiénes pueden ser vistos y escuchados, quiénes son ruido y quiénes son invisibles.
} 
una frontera que se ha dejado atrás y que a partir de ese momento el significado pasado de las relaciones sociales queda enterrado. No, lo que sucede es que la forma anterior muta, se desplaza, se transforma. Algunos significados persisten en el tiempo, otros van a ser excluidos o marginalizados. Parafraseando una famosa frase de Freud, ${ }^{6}$ nuestra sociedad contiene la historia de las relaciones pasadas, de otras racionalidades políticas que han dejado huella, permanencia, que han sobrevivido en el tiempo justamente porque no se han cuestionado, porque se han elevado al estatus del sentido común. Por esta razón, aunque estemos de acuerdo en que cada forma de sociedad adquiere manifestaciones distintas de acuerdo con las regiones, localidades o culturas en las que se encarna, podemos suponer que, al menos en Occidente, el concepto de democracia hegemónico —-democracia liberalprocedimental - arrastra una serie de supuestos metafísicos enarbolados en otros periodos históricos, que no se han problematizado y que corresponden a esta forma particular de dotar de sentido y de escenificar nuestra forma de sociedad. En palabras del reconocido historiador conceptual Reinhart Koselleck: "Todo concepto fundamental contiene elementos de significados pasados en estratos situados a distintaprofundidadyexpectativas de futuro de distinta importancia" (Koselleck, 2012: 37).

Estos supuestos metafísicos que aparecieron en otros momentos de la historia, bajo otras formas de racionalidad política, de una u otra manera han logrado permanecer como parte de un discurso hegemónico que no se cuestiona: en palabras de Gramsci (1970: 9-10), adquieren una dimensión de sentido común. En esa misma tónica, Butler (1992: 7) plantea que cada teoría actúa incesantemente estableciendo fundamentos, asumiendo compromisos metafísicos implícitos, los cuales se posicionan como lo incuestionable. Esos fundamentos son aquellos que aunque reclaman ser universales, trazan las fronteras entre la inclusión y la exclusión, distinguiendo con esto qué temas, conceptos o preguntas pueden ser incluidos o no.

En el caso que nos ocupa, si bien pueden analizarse numerosos supuestos "oscurecidos" detrás de las teorías de la democracia liberal-procedimental que pueden ser resumidos en tres categorías: la importancia del orden, la razón como principio moral y la libertad como condición de posibilidad de la democracia?

La importancia del orden en la configuración de una "buena" sociedad, el desprecio del disenso o cualquier forma de expresión que altere el "buen orden de las formas" aparece en la literatura desde épocas tempranas. Si retomamos los debates producidos en la Grecia Antigua acerca de las distintas formas de gobierno, es evidente que la democracia

\footnotetext{
6 "[...] Como quiere que fuese, es este un proceso muy frecuente, sobre todo en fases tempranas del desarrollo, y puede dar lugar a esta concepción: el carácter del yo es la sedimentación de las investiduras de objeto resignadas, contiene la historia de las relaciones de objeto" (Freud, 1992: 31).

${ }^{7}$ Otro autor que ha analizado en extenso la centralidad que se le otorga a la libertad para definir a la democracia es Derrida (2003/2005), en su ensayo La razón del más fuerte (iHay Estados canalla?). Más adelante se retomarán algunos de sus planteamientos.
} 
era percibida como una forma considerada aberrante. Basta con observar la forma en que Platón (La República) o Aristóteles (La Política) pensaban la democracia: una forma de gobierno corrupta, defectuosa, degradada, que tenía el potencial de introducir la anarquía en todas las relaciones sociales. Si bien ambos autores difieren en algunos puntos de su crítica, concuerdan en que la democracia representa un peligro para lo que consideraban un objetivo fundamental de la polis: el establecimiento de un "buen orden".

En aras de comprender lo anterior, es necesario clarificar cómo los autores interpretaban la tensión entre las distintas formas de gobierno y cómo éstas se transformaban. En el caso de Platón (LaRepública, 544e), existían cinco formas de gobierno que correspondían a otras tantas modalidades del alma, ordenadas en una jerarquía: monarquía, aristocracia, democracia, oligarquía y tiranía; corrupciones cada una de éstas de lo que consideraba la forma perfecta: la República, una combinación entre monarquía y aristocracia. Si bien no interesa mostrar aquí en detalle cada una de las formas de gobierno, sí nos interesa detenernos en las razones por las cuales una forma de gobierno degradaba en otra. Para Platón (La República, 545c-545d) el pasaje de una forma de gobierno superior a otra inferior era producido por el disenso o la discordia, con lo cual toda oposición o resistencia a la forma de gobierno imperante se percibía como potencialmente disruptiva. En el caso de la democracia, a diferencia de las otras formas donde la extensión de la libertad estaba más reducida, este riesgo estaba aumentado. Esto es reflejo de una tensión que permanecerá como tema de discusión a lo largo de los siglos: ¿cómo conciliar una propuesta de orden con la libertad? ¿Cómo definir libertad? ¿Existen límites al disenso? ¿Se puede restringir la libertad en aras de evitar la discordia?

Esta tensión entre orden y libertad es clara en el planteamiento platónico, ya que por un lado observaba en la libertad la condición de posibilidad de la democracia, pero a la vez su condición de caída (La República, 557b). El escándalo democrático era que posibilitaba la aparición del disenso y la discordia, ya que no existía ningún orden preestablecido y cualquier persona podía participar de la polis. A diferencia de la monarquía o de la aristocracia, que eran gobiernos de los mejores, la democracia era una forma de gobierno aberrante en tanto cualquiera podía participar: "Es el estado de excepción donde no funciona ningún par de opuestos, ningún principio de repartición de roles" (Las Leyes, 690e). Además de lo anterior, el exceso de libertad posibilitaba la introducción de la anarquía en las relaciones sociales, ya que Platón observaba una consecuencia radicalmente negativa: la introducción de la igualdad en cosas que son naturalmente desiguales (La República, 558c).

Por su parte, Aristóteles difiere de su maestro en la categorización de las formas de gobierno, dividiendo éstas en buenas y malas. Las formas buenas se dedicaban a gobernar por el bien común - monarquía, aristocracia y república-, mientras que las malas se caracterizan por gobernar para el interés particular — democracia, oligarquía, tiranía. En el caso específico de la democracia, el juicio del estagirita era menos severo que el platónico: 
aquélla era la menos desviada de las formas malas de gobierno. Sin embargo, esto no quiere decir que no haya observado en ésta una amenaza al orden. La democracia presentaba un peligro al otorgar libertad a aquellos que no sabían qué hacer con ella -los pobres-, aquellos que no poseían la virtud suficiente para participar en la vida pública (La Política, 1317b). A pesar de que Aristóteles reconocía cuatro tipos distintos de democracia ( $\mathrm{La}$ Política, 1291b, 1292a, 1292b), de las cuales algunas recibían un juicio más severo, el problema central era la imposibilidad de conjugar un gobierno inteligente con un poder popular.

En resumen, Platón y Aristóteles sospechaban de la democracia por su condición popular, por su apertura a partes de la población que no tenían la virtud suficiente para saber qué hacer con la libertad; con lo cual el gobierno era imprudente y desordenado. Este recelo seguirá operando de forma permanente en la evaluación histórica que se hace de la democracia. Aun cuando a finales del siglo XIX esta percepción cambia y la democracia se ubicó como la mejor forma de gobierno posible, sigue conservando la sospecha y el rechazo a una mayor apertura ${ }^{8}$, que se expresa en el cierre o en la mayor dificultad que poseen ciertos estratos de población - minorías étnicas, sociales, sexuales - de participar en la toma de decisiones públicas. El pueblo se reduce a su condición de "elector", ya que de otra manera se corre el riesgo de caer en la anarquía, en el desorden.

Esta centralidad otorgada al orden como virtud de un buen gobierno permanecerá dentro del debate filosófico; sin embargo, si en la época antigua el orden estaba asociado a una ética propia de la comunidad política, es en la modernidad que el orden comienza a ser asociado con una razón, instalándose como un fundamento metafísico inamovible. En otras palabras, si en la Grecia Antigua el conocimiento era la vía para solventar los conflictos entre los seres humanos y entre las distintas partes del alma; en la Modernidad se le suma al debate el concepto de razón y de quién puede detentarla, quién o quiénes pueden asumir el gobierno en aras de conseguir los objetivos del Estado.

\footnotetext{
${ }^{8}$ No es difícil observar en estos argumentos similitudes con los sostenidos por los defensores de las teorías elitistas de la democracia; por ejemplo, la definición de democracia que brinda Schumpeter (1971: 343): "Así, pues, la elección de los representantes se considera como el fin que se subordina al fin primario del sistema democrático, que consiste en invertir al electorado del poder de decidir controversias políticas. Supongamos que invertimos el orden de estos dos elementos y ponemos en segundo lugar la decisión de las controversias por el electorado, y, en primer lugar, la elección de los hombres que han de efectuar la decisión. Para expresarlo de otra manera ahora adoptamos el criterio de que el papel del pueblo es crear un gobierno o algún otro organismo intermediario, el cual crearía, a su vez, un ejecutivo nacional o gobierno. Entonces lo definiremos así: método democrático es aquel sistema institucional, para llegar a las decisiones políticas, en el que los individuos adquieren el poder de decidir por medio de una lucha de competencia por el voto del pueblo". Esta definición se sustenta en el criterio de que Schumpeter (1971: 335) consideraba al ciudadano normal como uno que desciende al nivel inferior de prestación mental cuando ingresa en el campo de la política, argumentando y analizando de forma infantil y primitiva.
} 
Esta asociación se puede encontrar en Hobbes ([1651]2011) y en Locke ([1690]2008). En el caso de Hobbes, la solución a los problemas de seguridad de la época — guerras de religión y la amenaza de los otros Estados emergentes- solamente podía ser asumida por la figura de un Absoluto, aquel que podía encarnar en sí mismo el gobierno, en aras de brindar seguridad a la población. El Leviatán se ubica entonces como la máxima autoridad del Estado, al cual se le debe obediencia en aras de mantener el buen orden, ya que al igual que sus predecesores, Hobbes observaba en la libertad y en el conflicto las principales amenazas a éste. Esta estructura implicaba el ejercicio de consentimiento, el cual fue argumentado por Hobbes con base en la razón: en aras de sobrevivir, la razón dicta que se debe restringir la libertad con el objetivo de garantizar la propia conservación (Hobbes, [1651]2011: 137-138).

Koselleck (1988: 33) plantea que para que este esquema sea lógicamente concluyente, la razón tiene que hacer coincidir moralidad y política. La ruta crítica se construye de esta manera: la razón invita a los seres humanos a someterse a un soberano, el soberano le pone fin a la guerra civil, de esta manera su calificación moral — si es bueno o malo- se desprende de su función política: lograr y mantener el orden. La lógica del intercambio se establece: en aras de obtener seguridad, la razón dicta que se debe obedecer al Estado, ya que esto otorga más beneficios que pérdidas. Tal como lo plantea Koselleck (1988: 31), frente a las doctrinas tradicionales de la moral, él opone aquella cuyo eje es la razón política, en tanto las leyes de la moralidad están cumplidas en el establecimiento del Estado. Elénfasis que Hobbes otorga a la razón y su expresión en la obediencia al soberano instala una asociación que permanecerá vigente hasta nuestra época contemporánea: la obediencia es racional, mientras que la desobediencia es irracional.

Locke ([1690]2008: 38), al igual que Hobbes, comparte la idea y la necesidad de un poder soberano, pero con un desplazamiento crucial. Si en Hobbes el poder estaba inscrito en un Absoluto, en Locke ([1690]2008: 23) este poder estaba representado por las leyes, las que debían ser consentidas bajo un criterio de mayoría. Así, la racionalidad política se desplaza de pensar a un soberano que rige absolutamente, a un conjunto de leyes que provienen del interior de la conciencia humana, que se basan en la moralidad propia de cada individuo. Este principio, uno de los pilares fundamentales de la democracia liberal, se construye sobre la presunción de un ciudadano que racionalmente acepta la obediencia como condición de virtud moral, sea al soberano absoluto o a las leyes; con lo que a contrario sensu tiene por consecuencia que se asocie el disenso, la desobediencia y el conflicto con la irracionalidad. En otras palabras, esto introduce, no solamente el concepto de razón como aquel que guía o encauza el establecimiento del lazo social, sino que se establece que el consenso o consentimiento es producto de la razón; por lo tanto, se comienza a asociar el disenso como algo irracional, que atenta contra la conservación del sí mismo y de la comunidad. Sólo puede existir un orden estatal si la pluralidad de partes se reconoce/identifica con una moralidad que acepta la necesidad moral de un gobernante y de un orden político (Koselleck, 1988: 31). 
Con el tiempo, la concepción de una razón moral como aquella que nos llevará a seguir el gobierno de las leyes se sostendrá y figurará como uno de los fundamentos de la democracia liberal-procedimental. Si con los antiguos griegos la racionalidad política se caracterizaba por la búsqueda de un orden trascendental, ajeno al paso del tiempo y de la historia -idea del bien o la igualdad geométrica-, en el caso de Hobbes y Locke, en tanto precursores del liberalismo político, se instala una racionalidad política que, además del orden como principio normativo, se sostiene en una concepción de la razón moral como aquella que impulsaría al ser humano a buscar el consenso. Si bien difieren las soluciones al problema del conflicto político en Hobbes y en Locke, ambas concuerdan en la necesidad de apelar a la razón para imponer límites a la libertad natural del individuo.

Finalmente, como producto de la aparición del liberalismo político y económico, la discusión acerca del orden y de la razón adquirirá un matiz que explicará el porqué de la asociación cristalizada entre democracia y libertad. De acuerdo con los planteamientos de Foucault (2007: 61), durante los siglos XVII y XVIII hubo una serie de factores ${ }^{9}$ que tuvieron por consecuencia que el concepto de libertad se desdoblara: por un lado, en una concepción jurídica de la libertad, la cual estaría sustentada por los planteamientos del liberalismo político y su defensa de los límites del Estado; y por otro lado, la libertad que emerge de la relación entre gobernantes y gobernados. Por tanto, frente a la presión que tenía el Estado desde diferentes sectores para garantizar sus libertades - libertad de mercado, libertad del vendedor y el comprador, libre ejercicio de la propiedad, la libertad de discusión y posteriormente la libertad de expresión-, se hizo necesario que la nueva razón gubernamental produjera esa libertad que tenía necesidad de consumir (Foucault, 2007: 84). Entonces se crea todo un cuerpo jurídico de procedimientos destinados a producirla, organizarla y garantizarla. El Estado se convierte en el administrador de la libertad, ya que tiene que lograr un punto de equilibrio entre los límites externos y las regulaciones internas que el Estado debe respetar; por lo tanto, esa administración no resultará en un imperativo "sé libre", sino en un marco regulatorio de producción de libertad para los seres humanos. Así, se implementa una solución al tan temido exceso de libertad.

\footnotetext{
${ }^{9}$ Se podrían trazar tres grandes procesos coyunturales que aceleraron la búsqueda de un refinamiento en los procedimientos o reglas que debían de seguirse para mantener un orden político. Primero, el consenso alrededor de la necesidad de un gobierno de leyes generó como efecto que se instalara dentro de la racionalidad política a la ley como un espacio racional que tendría la capacidad de ser "neutral", de garantizar la igualdad y, por ende, resolver los conflictos. En segundo lugar, la introducción del ser humano en tanto sujeto cognoscente y a la vez objeto de conocimiento presiona para que se contemple a éste como parte de la planificación y el control a futuro, como parte de la toma de decisiones (Polizeiwissenschaft) (Foucault, 1968: 334-335). En tercer lugar, el desarrollo de la economía política generó que se demandaran garantías por parte del espacio gubernamental para que sus objetivos estuvieran protegidos de amenazas externas o internas (Foucault, 2007: 30-31).
} 
En consecuencia, el Estado debe enfrentarse a dos grandes problemas de seguridad. El primero estriba en proteger el interés colectivo frente a los intereses individuales (Foucault, 2007: 85), pero además proteger los intereses individuales contra lo que pudiera parecer una intrusión procedente del interés colectivo (Foucault, 2007: 86); y el segundo consiste en evitar que la libertad de los procesos económicos represente un peligro para las empresas o para los trabajadores y que la libertad de los trabajadores represente un problema para la empresa y la producción. Esto trae como resultado que se tenga que prevenir y regular los accidentes individuales, las enfermedades, la vejez, para que los individuos puedan contribuir a la sociedad y no ser un peligro (Foucault, 2007: 86). Por consiguiente, el Estado no sólo garantiza la libertad, sino que debe crear como contraparte toda una serie de procedimientos de control, coacción y coerción que serán la contrapartida y el contrapeso de las libertades (Foucault, 2007: 87). Esta tensión entre libertad y seguridad puede ser regulada de una mejor manera en un gobierno democrático, con lo cual su asociación quedó petrificada, asumiéndose como una condición necesaria para cualquier democracia occidental.

En conclusión, el desarrollo de la democracia liberal-procedimental no sólo fue resultado de la suma de huellas de otras racionalidades políticas que dejaron su impronta en los conceptos del orden, la razón y la libertad; sino que también fue una reacción a una serie de acontecimientos políticos, económicos y sociales que presionaron a los Estados a adoptar una forma de gobierno que se adaptara mejor a estos requerimientos. Esta serie de procesos contingentes configuraron el paso de caracterizar a la democracia como una forma despreciable de gobierno a una forma de gobierno que posee en sí misma la capacidad de satisfacer los requerimientos del liberalismo político y del liberalismo económico. Sin embargo, esto no quiere decir que se haya modificado radicalmente la percepción hacia esta forma de gobierno, sino que más bien algunas de las críticas enfiladas hacia ella fueron canalizadas a través de procedimientos y mecanismos de sujeción, con el objetivo de controlar su capacidad de inducir el disenso.

El recelo hacia lo popular todavía se expresa en los diversos mecanismos que reducen la participación política al desarrollo de partidos políticos y al ejercicio del voto, ya que a lo largo de la vigencia de este modelo se encuentran élites políticas que se mantienen en el ejercicio de los altos puestos de poder. Si a esto se le suma una asociación lógica de que el conflicto político o el disenso ponen en riesgo la estabilidad de la comunidad, no sólo en términos de conservación, sino en términos morales, se termina asociando al consenso como algo moralmente bueno, mientras que el disenso es algo moralmente malo. Esto disminuye sustancialmente las posibilidades de disenso y de aceptación de éste por parte de la opinión pública, lo que condena las críticas a la democracia a ser consideradas como ataques a la razón y a la moral.

Estoincide en laconcepción de sujeto que manejala democracialiberal-procedimental, el cual es percibido como un ser humano en una única dimensión: racional. A esta 
racionalidad moral, heredera del pensamiento contractualista, se le sumó la racionalidad científica, ${ }^{10}$ esa que le permitió al ser humano plantearse el conocimiento de una forma objetiva. Por consiguiente, la democracia liberal-procedimental contempla que el ser humano toma sus decisiones como ciudadano basado en una racionalidad que contempla las dos vertientes: la moral y la científica. Por la primera de ellas, aquél buscará el consenso - lo bueno- antes que el conflicto - lo malo-; si no cumple con esta prerrogativa normativa, no estará cumpliendo con su deber moral de buscar la autoconservación de sí mismo y de la sociedad; y por la vertiente científica, se basará en la suposición de ser un ciudadano con capacidades plenas de información y conocimiento para tomar una decisión objetiva. Por lo tanto, el criterio de mayoría se sostiene sobre este concepto de ser humano que no puede ser cuestionable, ya que si son puestos en cuestión los procedimientos o la institucionalidad democrática se está poniendo en entredicho la racionalidad que lo sustenta, acto que de acuerdo con este esquema de pensamiento es juzgado de irracional. Por consiguiente, a pesar del desarrollo de los humanismos y la incorporación del ser humano como objeto de estudio, éste sigue observándose en la teoría y práctica política del pensamiento liberal-procedimental como un ser fracturado, dejando de lado los afectos, el contexto y las numerosas situaciones que pueden afectar su acción política.

Esto tiene por efecto que se confunda lo político con la administración política, aquello que Rancière (2006: 70-71; 2007: 71) conceptualiza como policía: un reparto de lo sensible que está caracterizado por la ausencia de vacío y de suplemento, en el cual la sociedad estaría compuesta de grupos dedicados a modos de hacer específicos, en lugares donde se ejercen las ocupaciones, en modos de ser correspondientes a estas ocupaciones y lugares. Lo social se observa como un sistema, como algo que ya estaría dado de antemano, sin cuestionar su momento de institución ni cómo éste afecta en la forma en cómo se interpreta. La distribución de posiciones, las formas de hacer, ver y decir, responden a esta lógica de administración. El lugar del pueblo en la democracia liberalprocedimental se reduce a su condición de elector, sujeto a las artimañas de las distintas élites políticas y económicas -que sí poseen "virtud" para gobernar-, que constantemente lo interpelan desde un lugar moral. Si el pueblo decide o manifiesta descontento, disenso o discordia frente a esta noción hegemónica, sele acusa de irracional, malo, incivilizado, bárbaro: aparecen los procedimientos de control, coacción y coerción. De ahí que la democracia liberal-procedimental se blinda a sí misma frente a posibles críticas: al instalarse desde el pedestal de la razón, mira con desprecio cualquier intento de reformarla, de reconfigurarla. Su defensa magistral es ubicarse como el mejor modelo posible, descalificando las críticas ad portas. No es casualidad que dentro de este esquema

\footnotetext{
${ }^{10}$ Este movimiento teórico-conceptual fue trabajado por Foucault (1968) en su texto Las palabras y las cosas.
} 
de pensamiento, la voluntad de saber deseche otros abordajes, otras formas de democracia como potencialmente válidas, ya que no pertenecen a esta red conceptual. No son válidas: son "ruido".

Frente a eso, nuestra propuesta es comprender la democracia como una forma de poder político que organiza lo social. Implica reconocer su dimensión fundamentalmente conflictiva, su carácter precario y abierto. Sólo así podremos avanzar en el juego de diferencias y lograr generar miradas críticas, transformadoras y novedosas al tramitar nuestros conflictos. De otra manera, seguiremos imponiendo un marco que enfatiza un deber ser construido sobre la repetición de conceptos no problematizados y, por ende, con poca efectividad para atender la complejidad de las demandas políticas y sociales que enmarcan a nuestra región.

\section{"Democracia por-venir"}

Pensar la democracia como una forma de poder conflictiva, precaria y abierta requiere como condición mínima ampliar el horizonte de análisis. Para ello, retomaremos como excusa para nuestra reflexión final el conocido aforismo derridiano acerca de la "democracia por-venir". Si bien esta reflexión ha formado parte de numerosos escritos del autor, es en su ensayo La razón del más fuerte (iHay Estados canalla?), donde recupera extensamente las diversas aristas sobre las cuales avanzó sobre este tema a lo largo de su vida.

Uno de los temas centrales que desarrolla este autor en el citado texto gira alrededor de la indeterminación propia del vocablo democracia. Derrida (2005: 25) apunta que esta condición ha estado presente a lo largo de la historia, propia de un concepto que en sí mismo contiene diversas aporías. En otras palabras, si la democracia es un concepto indeterminado, está siempre sujeto a la espera de ser llenado, de ser dotado de contenido."

\footnotetext{
Il "A fin de cuentas, si intentamos retornar al origen, no sabemos todavía lo que habrá querido decir democracia, ni lo que es la democracia. Pues la democracia no se presenta, no se ha presentado todavía, pero va a venir. Mientras tanto, no renunciemos a utilizar una palabra cuya herencia es innegable pero cuyo sentido todavía es oscuro, obstinado, reservado. Ni la palabra ni la cosa 'democracia' son todavía presentables. Todavía no sabemos qué hemos heredado, legatarios como somos de esta palabra así llamada griega y de lo que nos asigna, nos prescribe, nos lega y nos delega. Somos innegablemente legatarios, incluso delegados de dicha palabra, y decimos 'nosotros', aquí, en tanto que legatarios o delegados de esta palabra que nos fue enviada, dirigida desde hace siglos y que siempre dejamos para más adelante. Naturalmente, que hay alegatos de democracia por doquier, entre 'nosotros'; pero nosotros mismos seguimos sin saber el sentido de este legado, la misión o la emisión o la comisión de dicha palabra o la legitimidad de dicho alegato. El legado y el alegato, así como la lectura de la leyenda (juguemos aquí entre legare y legere), no hacen sino remitir a más adelante o a otro lugar. Este remitir no hace señas hacia el pasado de una herencia si no es quedando por venir. (Se cierran los paréntesis,
} 
En esa misma línea, en otro trabajo señalé que la democracia es un significante vacío (Álvarez Garro, 2013: 116), que actúa como punto nodal cuando es asociado con otros significantes, otorgando sentido y coherencia a una determinada red conceptual. Esto es fundamental en aras de dar el debate acerca de otras democracias ${ }^{12}$. Ahora bien, idónde podemos ubicar esta indeterminación?

En primer lugar, la indeterminación proviene del propio origen etimológico de la palabra. La disputa acerca de definir a quién nombra el demos, si significa todo el cuerpo ciudadano, o si corresponde sólo a la plebe, la muchedumbre, las órdenes inferiores o el vulgo, se combina además con la disputa acerca del significado de kratos: poder o gobierno (Arblaster, 1991: 25; Finley, 1980: 21). Esto implica una disputa siempre abierta acerca de quién o quiénes pueden detentar el ejercicio del gobierno y para quién se gobierna; o de quiénes pueden detentar el poder y sobre quién se ejerce; además de esclarecer si gobierno o poder significan lo mismo. En esa misma línea, Rosanvallon (2003: 22) nos señala que en la democracia se conjugan la historia de un desencanto y la historia de una indeterminación. Por un lado, existe una indeterminación acerca del sujeto mismo de la democracia, ya que el pueblo - al no ser un sujeto esencial encarnado en una clase, etnia o población particular- solamente puede ser aprehendido a través de aproximaciones sucesivas de sí mismo. La dimensión del "nosotros" está siempre en disputa, en-construcción. Eso tiene por consecuencia radical el establecimiento de relaciones de frontera, la exclusión de partes de la población que pueden ser conceptualizadas como amenazas a la democracia - los enemigos - Por otro lado, aparece la dimensión del poder: se pretende crear un poder que abarque de forma igualitaria a toda la población, pero que por otro lado brinde respuesta a las demandas particulares desprendidas de esta noción precaria del "nosotros", la cual instala una jerarquía de valores que establecería criterios diferenciales de atención con respecto a "ellos", a los "otros". Finalmente, surge la incertidumbre acerca de cuáles son las formas adecuadas de "poder" social, que superen las tensiones generadas entre el deseo de autonomía y un proyecto de participación social (Rosanvallon, 2003: 22-24).

En segundo lugar, la indeterminación aparece cuando se reconoce que la democracia es la única forma de gobierno o régimen que permite el cuestionamiento de sus propios límites. Es decir, es la única organización de lo político que permite que por sus propios mecanismos se pueda discutir acerca de su abolición. En este sentido, Derrida (2005: 2627) nos hace un llamado fundamental a reconocer que la democracia requiere de un ejercicio de violencia para detener lo que de otra manera puede llevar a su propia destrucción:

fin de la confesión.)" (Derrida, 2005: 26).

${ }^{12}$ Es claro que el trabajo de análisis histórico conceptual presentado en la sección anterior pretende reconstruir una narrativa histórica que da cuenta de cómo se instaló esta forma hegemónica de comprensión del concepto. 
[...] La aporía de forma general, [...], se debe a la libertad misma, a la libertad de juego en el concepto de democracia: idebe una democracia dejar en libertad y en posición de ejercer el poder a aquellos que bien podrían atentar contra las libertades democráticas y poner fin a la libertad democrática en nombre de la democracia y de la mayoría, que, en efecto, éstos bien podrían reunir? ¿Quién puede considerarse autorizado a qué para hablar entonces, a un lado y otro de ese frente, de la democracia misma, de la democracia auténtica y propiamente dicha, cuando precisamente el concepto de la democracia misma, en su sentido unívoco y propio, brilla por su ausencia en el presente y para siempre? Cuando tienen la garantía de la mayoría aritmética, los peores enemigos de la libertad democrática pueden, al menos en virtud de un simulacro retórico verosímil (y los islamistas más fanáticos, llegado el caso, pueden hacerlo), presentarse como los más demócratas de todos (Derrida, 2005: 53).

Frente a este escenario, la pregunta por las "otras democracias" pareciera adquirir un tono pesimista. Sin embargo, esa aparente debilidad constituye más bien la fortaleza de la democracia: cualquier intento de solventar esta fatalidad autoinmunitaria — palabras de Derrida (2005: 56) - puede llevar a la destrucción del propio experimento democrático. De lo que se trata es de aceptar que la democracia contiene en sí misma promesas y amenazas:

El 'por venir' no significa sólo la promesa sino también que la democracia no existirá nunca, en el sentido de la existencia presente: no porque será diferida sino porque seguirá siendo siempre aporética en su estructura (fuerza sin fuerza, singularidad incalculable e igualdad calculable, conmensurabilidad e inconmensurabilidad, heteronomía y autonomía, soberanía indivisible y divisible o compartible, nombre vacío, mesianicidad desesperada o desesperante, etcétera) (Derrida, 2005: 111).

De esta manera, ya queda claro que de lo que se habla en este punto no es de pesimismo o de imposibilidades, sino de un análisis realista que permita posicionarnos con respecto a las expectativas que puede causar la apelación a otras democracias que pretenden ubicarse como contrapropuestas a la democracia liberal-procedimental: cuasi-perfectas, idealizadas, romantizadas; que ubican en el centro de su debate la posibilidad de la superación del antagonismo y, por ende, la aspiración o el horizonte de una sociedad pacificada en sí misma que abrace los principios democráticos - icuáles? - como la máxima aspiración ética universal.

En primer lugar, cualquier defensa de una democracia sobre otra implica la generación de un efecto de frontera: ubicar fuera del campo del "nosotros" a aquellos que se consideran sus enemigos. Tal como lo plantea Derrida (2005: 55), esto se ha manifestado de múltiples maneras: alejándolos del ejercicio del sufragio, expulsándolos de la comunidad nacional, 
reenviarlos a "casa" - la condición de los migrantes es clara en ese sentido—, la aplicación de medidas represivas, entre otros. Pero la pregunta que emerge es: iqué sucede con estos mecanismos de exclusión, propios de la constitución de las comunidades políticas, cuando el movimiento de lo político instala en el ejercicio de gobierno o de poder a sectores históricamente rechazados, que van a transformar política y económicamente el orden con el objetivo de garantizar condiciones de vida dignas a la población? Por ejemplo, podemos imaginar un escenario en el cual, en un determinado país de la región, se gesta un movimiento de emancipación en el que la disputa por quién es el pueblo ha sido contestada por la unión de movimientos sociales que reivindican la incorporación de todasy todos en el ejercicio de la ciudadanía, que tenga como efecto material la distribución equitativa de riqueza y oportunidades. Sin embargo, es crucial reconocer que esta aspiración siempre va a generar mecanismos de exclusión: sean aquellos que no comulgan con la idea de una sociedad equitativa e igualitaria, o aquellos que se cuestionan sobre quiénes son los beneficiarios de estas políticas. En el horizonte de la democracia — cual sea el contenido asociado a ella - la cuestión se reduce a "quiénes pueden vivir juntos", "iqué es un semejante?", "isemejante como ciudadano, como ser humano, como congénere, como prójimo?”, etcétera (Derrida, 2005: 28).

Esta dificultad, que habla acerca de la distribución de posiciones y la generación de un determinado orden, al ser propia de un modelo que permite en todo momento su cuestión, es insuperable. Por ende, la solución será siempre conflictiva. Cualquier persona puede impugnar el orden basado en una concepción diferente del mundo, la cual puede ser criticada política o moralmente, pero no por ello invisibilizada. De otra manera, la aspiración de esta alteridad democrática se cancela de antemano. No podemos suponer que la otra democracia se imponga sobre nuevas propuestas simplemente porque la consideramos correcta.

Esto nos lleva a un segundo supuesto. Implementar una determinada forma de democracia requiere como condición necesaria un ejercicio de violencia: la detención de un significado que pueda argumentarse como unívoco: “[...] Para hablar democráticamente de la democracia, sería preciso, con algún performativo circular y con la violencia política de una retórica armada, de una fuerza de ley, imponer un sentido a la palabra 'democrático' y producir así un consenso que fingimos, ficticiamente, suponer como algo dado - $\mathrm{O}$, como poco, posible y necesario: en el horizonte" (Derrida, 2005: 95). Esto implica reconocer e incorporar en todo momento la dimensión del poder, la sujeción y la autoridad. Una sociedad que pretenda estar más allá del poder y la sujeción es una sociedad que ha instalado una onto-teología.

Esto nos señala un reto, ya que no podemos negar que la forma hegemónica de democracia contemporánea produce sufrimiento masivo a las poblaciones, pero tampoco podemos pretender superar esa condición instalando formas de democracia que pretendan convertirse en totalidades en sí mismas, que pretendan imponerse como la 
forma única, auténtica y correcta de la democracia. Si retomamos el ejemplo anterior y lo ubicamos como experiencia histórica, podemos observar que es el caso de Venezuela, Bolivia, Argentina, Ecuador, entre otros. Estos países, que en algún momento formaron partedeloque se denominó "giroalaizquierda" — con todas las dificultades terminológicas asociadas - están atravesando en este momento una intensificación del antagonismo resultante de la disputa acerca de quién debe gobernar y para quién. La incapacidad de estos gobiernos para atender las demandas de otros sectores de la población ${ }^{13}$ está generando una reactivación de mecanismos represivos - persecución de opositores políticos, reducción de espacios de litigio público y permanencia de élites en el poder, entre otros- que ponen en riesgo un proyecto político pensado en superar las asimetrías estructurales producidas por la imposición de la democracia liberal-procedimental en conjunción con el neoliberalismo.

En consecuencia, una "democracia por-venir" que pretenda aparecer en el aquí y el ahora no debe responder a una única forma, sino que debe estar fundamentalmente abierta. Debe ser capaz de reinventarse, cuestionarse, revolverse sobre sus propios cimientos sin perder con esto su fortaleza. Al hacer eco del planteamiento derridiano, queremos proponer una democracia que se mire desde su carácter histórico-social, abierta a nuevas formas de organización pero sin anquilosar ninguna de éstas. Debe reconocer que su ejercicio es conflictivo, sujeto al poder y a la violencia. Reconocer que estos elementos no son moralmente malos, sino que constituyen las condiciones de posibilidad para la superación de las aporías actuales, sin que esto signifique una superación absoluta. En este sentido, las otras democracias deben evitar caer en la tentación totalitaria, deben navegar en la tensión siempre presente entre la defensa de la democracia de sus enemigos y la incorporación de los otros en tanto sujetos válidos de la emancipación. Debe asumir y reconocer en todo momento su condición de consenso precario, su inestabilidad y su doble condición de promesa y amenaza:

La democracia es el único sistema, el único paradigma constitucional en el que, en principio, se tiene o se arroga uno el derecho a criticarlo todo públicamente, incluida la idea de la democracia, su concepto, su historia y su nombre. Incluidas la idea del paradigma constitucional y la autoridad absoluta del derecho. Es, por lo tanto, el único que es universalizable, y de ahí derivan su oportunidad y su fragilidad. Pero para que dicha historicidad —única entre los demás sistemas políticos- sea total, es preciso sustraerla no sólo a la Idea en el sentido kantiano sino a toda teleología, a toda onto-teo-teleología (Derrida, 2005: 111).

\footnotetext{
${ }^{13}$ Si bien se reconoce que algunas de estas partes responden a intereses geopolíticos y económicos fuera de la región; en un escenario democrático, al menos se debe permitir la emergencia del disenso y la apertura de un litigio público acerca del escenario común bajo el cual se ordena a la sociedad.
} 


\section{Referencias bibliográficas}

Almond, G. y S. Verba (1970). La cultura cívica. Estudio sobre la participación política democrática en cinco naciones. Madrid: Fundación FOESSA.

Álvarez Garro, L. (2013). La democracia liberal-procedimental. Un análisis del concepto desde la teoría posfundacional. Tesis de doctorado en Humanidades con énfasis en Filosofía Moral y Política. México: Universidad Autónoma Metropolitana.

Arblaster, A. (1991). Democracia. México: Nueva Imagen.

Arditti, B. (1991). Conceptos, ensayos sobre teoría política, democracia y filosofía. Paraguay: Centro de Documentación y Estudios. RP Ediciones.

Aristóteles (2008). Política. España: Gredos.

Butler,J.(1992). “Contingentfoundations: Feminismand thequestion of "postmodernism”". En J. Butler y J.W. Scott (comps). Feminists Theorize the Political. Nueva York y Londres: Routledge.

Deleuze, G. (1989). Lógica del sentido. Barcelona: Paidós.

Deleuze, G. y F. Guattari (2002). Mil mesetas. Capitalismo y esquizofrenia. España: Pre-textos. Derrida, J. ([1967]1989). La escrituray la diferencia. Barcelona: Anthropos.

Derrida, J. (1971). "Firma, acontecimiento, contexto". En J. Derrida, J. (2008). Márgenes de la filosofía. Madrid: Cátedra.

Derrida, J. (1998). Políticas de la amistad. Madrid: Trotta.

Derrida, J. (2005). Canallas. Dos ensayos sobre la razón. Madrid: Trotta.

Fink, E. (1979). La filosofía de Nietzsche. Madrid: Alianza Editorial.

Finley, M. (1980). Vieja y nueva democracia. Barcelona: Ariel.

Foucault, M. (1968). Las palabrasy las cosas. Argentina: Siglo XXI.

Foucault, M. (1988). "El sujeto y el poder". En Revista Mexicana de Sociología. 50(3), 3-20.

Foucault, M. (1992). El orden del discurso. Buenos Aires: Tusquets.

Foucault, M. (2007). Nacimiento de la biopolítica: curso en el Collége de France (1978-1979). Argentina: FCE.

Freud, S. (1992). "El yo y el ello". En S. Freud, Obras completas, t. XIX. Buenos Aires: Amorrortu, pp. 13-59.

Gramsci, A. (1970). Introducción a la filosofía de la praxis. Barcelona: Península.

Hobbes, T. ([1651]2011). Leviatán o la materia, forma y poder de un estado eclesiástico y civil. Madrid: Alianza Editorial.

Johnson, J. (1958). Political Change in Latin America: The Emergence of the MiddleSectors. Stanford: Stanford University Press.

Koselleck, R. (1988). Critique and Crisis. Enlightenment and the Pathogenesis of Modern Society. Cambridge: The MIT Press.

Koselleck, R. (2012). Historias de conceptos. Estudios sobre semántica y pragmática del lenguaje político y social. Madrid: Trotta. 
Laclau, E. (1986). Política e ideología en la teoría marxista. Capitalismo, fascismo, populismo. Madrid: Siglo XXI.

Laclau, E. (2005). La razón populista. Argentina: Fondo de Cultura Económica.

Laclau, E. y C. Mouffe (1987). Hegemonía y estrategia socialista. Hacia una radicalización de la democracia. Madrid: Siglo XXI Editores.

Lefort, C. (1988). Democracy and Political Theory. Great Britain: Polity Press.

Lefort, C. (1990). La invención democrática. Buenos Aires: Nueva Visión.

Linz, J.J. (2009). "Regímenes totalitarios y autoritarios". En J.J. Liz, Obras escogidas 3. Sistemas totalitarios y regímenes autoritarios. Madrid: Centro de Estudios Políticos y Constitucionales.

Lipset, S. (1992). "Algunos requisitos sociales de la democracia: desarrollo económico y legitimidad política”. En A. Batlle, Dieztextos básicos de ciencia política. Madrid: Ariel.

Locke, J. ([1690]2008). Segundo tratado sobre el Gobierno Civil. Un ensayo acerca del verdadero origen, alcance y fin del Gobierno Civil. Madrid: Alianza Editorial.

Marchart, O. (2009). El pensamiento político posfundacional. La diferencia política en Nancy, Lefort, Badiouy Laclau. Argentina: Fondo de Cultura Económica.

Munck, G. (2010). "Los orígenes y la durabilidad de la democracia en América Latina: Avances y retos de una agenda de investigación”. Revista de Ciencia Política, vol. 30, núm. 3, pp. 573-597.

Nietzsche, F. ([1886]2005). Más allá del bieny del mal. Madrid: Alianza Editorial.

Nietzsche, F. (2008). Fragmentos póstumos. Volumen IV. (1885-1889). España: Tecnos.

O'Donnell, G. y P. Schmitter (1994). Transiciones desde un gobierno autoritario. Conclusiones tentativas sobre las democracias inciertas. Buenos Aires: Paidós.

Platón (2006). Diálogos IV. República. Madrid: Gredos.

Platón (1999). Diálogos VIII. Las leyes. Madrid: Gredos.

Rancière, J. (2006). Política, policía, democracia. Chile: Editorial LOM.

Rancière, J. (2007). El desacuerdo. Política y filosofía. Argentina: Nueva Visión.

Rosanvallon, P. (2003). Por una historia conceptual de lo político. Buenos Aires. FCE.

Schmitt, C. ([1932]1991). El concepto de lo político. España: Alianza Editorial.

Schumpeter, J. (1971). Capitalismo, socialismo y democracia. Madrid: Aguilar.

Touraine, A. (1989). América Latina: política y sociedad. Madrid: Espasa-Calpe. 


\title{
Pensamiento y realidad de la democracia liberal en tiempos de globalización neoliberal. A propósito de México y Centroamérica
}

\author{
María del Carmen García Aguilar
}

\section{Democracia y democracias situadas}

Un ejercicio de revisión conceptual sobre la democracia liberal en América Latina, orientado a explicar las razones de su crisis presente, exige recuperar la "conciencia de cambio político" que, durante las últimas dos décadas del siglo pasado, afianzados en un entorno mundial de profundas transformaciones, marcó las directrices del pensamiento político de la región (Farfán, 1996). ${ }^{1}$ La pretendida hegemonía sistémica alcanzada por la democracia, antelas experiencias incipientes de creación o instauración de gobiernos democráticos, fue aclamada por intelectuales y analistas políticos que, con distintos tonos, aducen la inevitabilidad de su "universalización" como "forma final y única de gobierno" (Fukuyama, 1990; Huntington, 1994). No es un hecho menor que en la Conferencia Regional del Consejo Latinoamericano de Ciencias Sociales se colocara la democracia como el nuevo eje del debate intelectual y político, con el propósito explícito de irrumpir el destrozo social de regímenes militares y autoritarios (Lechner, 1992).

Una vertiente importante de las ciencias sociales de América Latina, en particular de la ciencia política, hizo suya la producción conceptual y categorial de la democracia liberal. La apuesta, como expresión del cambio político, explica no sólo la exclusión de un pensamiento político crítico de Occidente que desde décadas atrás registra tensiones conceptuales e históricas en la construcción y desarrollo de la democracia (Schumpeter, 1984; Michels, 1912; Weber, 1964 y 1967), sino también el encubrimiento de tensiones estructurales y contextuales concretas que inhiben la forma democrática de gobierno, tales como los enclaves autoritarios, las correlaciones de fuerzas que se gestan en el

\footnotetext{
${ }^{1}$ Texto realizado en el marco del año sabático de la autora en el Instituto de Ciencias Sociales y Humanidades “Alfonso Vélez Pliego", de la Benemérita Universidad Autónoma de Puebla.
} 
marco del cambio geopolítico con el fin de la Guerra Fría, y los numerosos déficit políticos, societarios y de liderazgos en la instrumentalización y despliegue de la democracia representativa (Garretón,1995 y 1999; Torres-Rivas, 2004).

La investigación política dominante se va a circunscribir a los estudios pormenorizados del rigorismo procedimental de las reglas y normativas de la representación, sostenida por los procesos de la "transición" y la "consolidación". La posibilidad de la democracia liberal está dada por el logro de su institucionalización, que formalmente abre, como indica Cansino (2000 y 2005), una amplia agenda de investigaciones sobre las transiciones, esto es, sobre la construcción del entramado constitucional y normativo propio de la nueva realidad política y, en paralelo, la construcción y fortalecimiento de la ciudadanía a través de la activación de los paradigmas de la acción racional y del individualismo metodológico.

No obstante, desde el inicio de su instrumentalización y puesta en práctica, las tensiones entre realidad y modelo democrático liberal resultan inocultables, lo que lleva al desarrollo de vertientes teóricas que modulan las particularidades de la transición y consolidación. Sartori sugiere que el análisis de la democracia es situado, estableciendo, con fines analíticos, que los países de Europa del Este y Central se definen como países de "instauración democrática" sin "consolidación democrática", y los países de América Latina, como países de "instauración democrática" con "consolidación casi siempre precaria" (Sartori, 1993: 17). O’Donnell (1994) tipificará las democracias latinoamericanas como "democracias delegativas", las que, si bien cumplen con los criterios poliárquicos, no son representativas; no son consolidadas pero pueden ser duraderas; su posibilidad de existir deviene de la interacción entre la crisis material que los nuevos gobiernos heredan y las concepciones de gobierno que enfatizan el poder omnímodo y personalista de quien gana, con las únicas restricciones del tiempo constitucional para gobernar y la coyuntura o correlación de fuerzas en la que gobierna. ${ }^{2}$

Ya desde los años noventa, la profundidad de las tensiones registradas entre teoría y realidad, que se intensifica y generaliza en los años que van del siglo XXI, derivó en la asunción de una democracia minimalista o pragmática, es decir, reducida a un procedimiento de elección de la autoridad política (Dahl, 1994; Sartori, 1993). En el campo teórico, sin el triunfalismo inicial, pero con fines de incidencia real en el proceso electivo de los representantes, persisten los debates sobre las tensiones de las transiciones y las consolidaciones a la luz de la existencia cada vez más inocultable de estructuras paralelas

\footnotetext{
2 "El presidente es considerado como la encarnación del país, principal custodio de sus intereses. Las políticas de su gobierno no necesitan guardar ninguna semejanza con las promesas de su campaña [...]. Los candidatos presidenciales ganadores se sitúan a sí mismos tanto sobre los partidos políticos como sobre los intereses organizados [...] otras instituciones — por ejemplo, los tribunales de justicia y el poder legislativo-constituyen estorbos que acompañan a las ventajas a nivel nacional e internacional de ser un presidente democráticamente elegido [...] es más democrática, pero menos liberal que la democracia representativa [...] es fuertemente mayoritaria" (O`Donnell, 1994).
} 
institucionalizadas informalmente que, como el "particularismo", conviven en "una delicada relación de tensión con las reglas e instituciones formales [...] de la poliarquía" (O’Donnell, 2002: 312). Sin obviar la reflexión de las tesis primarias de la democracia, la preocupación conceptual se va a desplazar también hacia las esferas del ejercicio de gobierno, con propuestas de reformas e innovaciones institucionales de las que se espera que su despliegue real logre la relación virtuosa entre gobernantes y gobernados propia de una gobernanza democrática.

En un esfuerzo más articulado por superar el dominio de un pensamiento instrumental y funcional, una nueva mirada conceptual y analítica refrenda como problema acuciante los rasgos institucionales del gobierno democrático y de su ejercicio, nucleados por la relación entre representación y participación, que permite recuperar el deber ser de la democracia. Se trata del modelo analítico de la "calidad de la democracia", que intenta superar la definición procedimental y el trayecto difuso de la transición y la consolidación, para explorar el sentido normativo de sus valores, recuperando vectores como gobierno de ley, rendición de cuentas, reciprocidad, libertad e igualdad, entre otros (Morlino, 2005; O’Donnell, 2005; Schmiter, 2005; Prowel Jr., 2005; Cansino, 2013). Afianzado en el reconocimiento de la crisis del pensamiento de la política de corte estadounidense (Sartori, 2004), el modelo analítico de medición de la calidad de la democracia tiene un fin propositivo y normativo que deriva en la instrumentalización de mecanismos concretos que incorpora la razón pública de los actores políticos y sociales en la tarea de transparentar las responsabilidades que les competen.

Prima la idea de que la crisis no deriva del principio de legitimidad de la democracia sino de su calidad, en las formas de hacer política (Lechner, 2002: 274). Así, bajo el sustento de las tesis primarias, en las que se recuperan valores y principios de la democracia, se tiene una producción conceptual y metodológica que deriva en propuestas de reformas e innovaciones institucionales con fines de incidencia real tanto en el proceso electivo de los gobernantes, como en el ejercicio de gobierno democrático.

Sin embargo, los análisis e investigaciones empíricas sobre el proyecto y la experiencia democrática en el siglo XXI siguen registrando no sólo profundas tensiones entre pensamiento y realidad, sino la generalización de éstas en las sociedades occidentales, que devienen en el reconocimiento sistémico de la crisis de la democracia liberal (Della Porta y Mény, 1987). Esta extensión sistémica de la crisis irrumpe el sentido "situado" de su análisis y se corre el riesgo de generalizar la naturaleza y carácter de la crisis y, por ende, las formas de salida de ésta. Hipotéticamente se podría proyectar que, aunque bajo un contexto distinto, nos encontramos en una situación similar a la de los años ochenta y noventa, cuando se anunció la inevitabilidad de la democracia como forma de Estado y de gobierno, y con ello una conciencia de cambio político con igual direccionalidad. Todo apunta a que la direccionalidad del cambio político, de la que habrá que tomar conciencia, tiene ya una ruta y un fin establecido en el paradigma de la seguridad, cuyos impactos son 
sin duda el destrozo mismo de la democracia liberal, la que décadas atrás se definió como sistema político "único y último".

En este escenario crítico, y en el seno de la filosofía posfundacional, emerge la democracia radical, que recupera la centralidad de la articulación de la democracia y lo político, lugar donde se conjugan las relaciones de poder, de hegemonía y de antagonismo. Su aporte es tanto el registro de las aporías y paradojas de la democracia liberal, desvelando los modos en que el neoliberalismo global los encubre, como el de privilegiar la indeterminación nucleada por una redefinición de los sentidos de la política desde lo social (Marchart, 2009).

En esta vertiente, la analítica de las relaciones ocultas y mediadas entre democracia liberal y economía global/neoliberal ha permitido recuperar el pensamiento político de Schmitt, quien, bajo otras preocupaciones, registra las tensiones irresolubles del liberalismo y la democracia, esto es, las tensiones entre un liberalismo que sostiene la "igualdad para la humanidad" y una democracia que, para ser tal, exige la heterogeneidad; un liberalismo que es portador de una igualdad "no política", y una democracia en la que la igualdad sólo es posible en el seno de su unidad política -el Pueblo o el Estadonación - del que emana la figura del ciudadano (Mouffe, 1999; Agapito, 2006; Fernández, 2007; Agamben, 2010).

\section{Pensamiento y realidad de la democracia liberal en Centroamérica y México}

Como indicamos, en las dos últimas décadas del siglo pasado el pensamiento político y su despliegue analítico en la región centroamericana y en México, al igual que en otros países de América Latina, hizo del paradigma de la transición el concepto que resume los "contenidos y rasgos esenciales que concentra [...] la conciencia de cambio" (Farfán, 1996: 15). La importancia vital de la transición es su responsabilidad en la construcción de las instituciones que configurarán la estructura básica y de intermediación de los ordenamientos democráticos, tareas imprescindibles para la consolidación democrática como forma de gobierno (Cansino, 2000).

Sin embargo, desde la construcción misma de la democracia liberal centroamericana, la confluencia de factores internos y externos en los planos de las estructuras y de las coyunturas gestaron dinámicas contradictorias que tienen que ver no sólo con los acoplamientos del modelo democrático a realidades abiertamente antidemocráticas, sino también con el peso que implica el fin de la Guerra Fría y el inicio de un nuevo ciclo geopolítico, con la entrada del neoliberalismo global, que exigirá la reorganización del conjunto de la sociedad y de la política. No es nada extraño entonces que el recurso de las tipologías y sus productos, dadas las diferencias, altere la lógica del modelo político en cuestión. 
En contraste con los países del Cono Sur, en donde después de la experiencia de regímenes militares la democracia política se torna en el eje de estudios precisos sobre las tensiones entre modernización y autoritarismo (O`Donnell, 1994; Lechner, 1985), en los países de Centroamérica, salvo Costa Rica, el debate sobre la democracia y su importancia en las ciencias centroamericanas se dio indirectamente en el marco de las negociaciones que decantaron en los Acuerdos de Paz, por lo que su despliegue se registró apresurado, sin posibilidades de debate analítico y deliberativo sobre los términos de transición y consolidación.

La bibliografía registrada en los años ochenta sobre la democracia y sus posibilidades en la región es, prácticamente, inexistente; en los noventa es aún restringida en comparación con los temas de la geopolítica, la revolución y el autoritarismo. No obstante, ocupan un lugar importante los temas de los procesos de paz y de los derechos humanos, supuestamente sustentados ambos en la democracia política. Entre 1988 y 1996, Lánder (1996) registra una decena de textos que hacen visibles las tensiones entre el modelo de análisis político y la realidad, de los que destacan los artículos de Torres-Rivas titulados "Centroamérica: democracia de baja intensidad" (1988), "La recomposición del orden: elecciones en Centroamérica" (1990) y "Centroamérica: la transición autoritaria hacia la democracia" (1991), que, junto con el artículo de Carlos Vilas, "Después de la revolución: democratización y cambio social en Centroamérica" (1992), constituyen esfuerzos seminales para, con el instrumental de las ciencias políticas, tensar o inhabilitar conceptos construidos para realidades propias de las sociedades de Occidente que contrastan con las sociedades de la región. ${ }^{3}$

Tras una prolífica producción editorial, Edelberto Torres-Rivas sostendrá que en el último cuarto del siglo XX las modalidades de construcción y de funcionamiento de las democracias en Centroamérica deben situarse en una perspectiva conceptual y analítica que difiere de las fases contempladas en su sentido clásico. Aquí se estaría viviendo, en esos años, "[...] la experiencia del régimen político que en su proceso de cambio deja de ser una dictadura militar sin ser aún una democracia" (2006: 156), esto es, un momento provisional que el autor define como una "situación (pre) democrática" que, no obstante, es la base o condición para que opere el otrofactor, la "implantación democrática”. En la región, sostiene, al igual que otros autores, que este proceso es tardío, sólo sucede a partir de los años ochenta, cuando las posibilidades del fin de la Guerra Fría marcan la necesidad de una nueva estrategia geopolítica; se trata entonces de una "instauración de lo nuevo", adaptable a "una

\footnotetext{
${ }^{3}$ En la bibliografía construida por Lánder destacan también, entre otros, los artículos de Goodman, Leogrande et al. "Political Parties and Democracy in Central American" (1992); el artículo de David Held titulado "Democracy: Past, Present and Possible Futures" (1993), y el texto de Domínguez y Lindenberg: "Democratic Transitions in Central American and Panamá" (1994).
} 
nueva realidad que no los rechaza", y no de una "restauración de prácticas olvidadas"4 (Torres-Rivas, 2004: 152).

En esta perspectiva, lo que en el marco de Esquipulas I y II se anuncia como la decisión expresa de los cinco presidentes centroamericanos de arribar a la democracia liberal representativa, como el compromiso nodal para la restauración del orden, ${ }^{5}$ constituye en realidad lo que Torres-Rivas define como la fase "(pre) democrática”. Aún más, para la experiencia de Guatemala, El Salvador y Honduras, registra que la instrumentalización de dicha fase ocurre bajo la responsabilidad de gobiernos autoritarios — si bien civiles-, definidos por su rechazo a toda oposición, incluyendo las mínimas demandas de la democracia en su gradiente minimalista. En el caso de Nicaragua, la distensión EsteOeste propició el declive revolucionario ante la exigencia de la democracia representativa.

Es innegable que en la región centroamericana los cambios institucionales formales fueron en la dirección correcta: se reforman o promulgan nuevas constituciones, se impulsan los sistemas de partidos y los sistemas electorales, que garantizan el pluralismo y, con ello, la democracia representativa y participativa. Más aún, Honduras, Guatemala, El Salvador y Nicaragua tuvieron procesos electorales con presencia y vigilancia internacional, que terminaron por legitimar el logro formal de las transiciones a fines de la década de los ochenta y en los mismos noventa del siglo XX, para arribar a la consolidación democrática, según los actores políticos, o a la instauración democrática en la línea de Torres-Rivas. La urgencia de decretar la normalidad del orden político vía los acuerdos, y de ahí obviar las condiciones de posibilidad real de la democracia como forma de gobierno, se ejemplifica en el caso de El Salvador, cuando la ONU da por concluido el Acuerdo de Paz, y posteriormente con el mismo instrumento en el caso de Guatemala (Páez, 1998).

En México, pese a la existencia de una Constitución que define un Estado de derecho liberal-democrático, la democracia como forma real de gobierno fue tardía y limitada (Hartlyn y Valenzuela, s/f). Hasta los años ochenta el pensamiento político democrático es minusvalorado, en tanto que el proyecto de la revolución como eje del cambio social fue hegemónico. Las protestas y el movimiento estudiantil de 1968 devinieron en la demanda del derecho de la soberanía popular, se concretaron en el proceso de "liberalización

\footnotetext{
4 “[...] hay un momento de tránsito que consiste más que en prácticas ciudadanas, en procesos de implantación de instituciones propias de la democracia [...] la transición contiene elementos de una implantación. No se está proponiendo un nuevo modelo de cambio, sino una variante de la transición, una ruta particular de tránsito donde es útil la noción de implantación por el papel que juega la dimensión externa" (Torres-Rivas, 2004: 152).

${ }^{5}$ Los cinco mandatarios se comprometieron a impulsar "el perfeccionamiento de sistemas democráticos representativo y pluralista que garanticen la organización de partidos políticos y la efectiva participación popular en la toma de decisiones y aseguren el libre acceso de las diversas corrientes de opinión a procesos electorales honestos y periódicos [...]” (Páez, 1998: 202).
} 
política" y, con ello, inició la construcción de un débil sistema de partidos, y también de un débil "pluralismo político", otorgándose márgenes estrechos de participación a la oposición en el recinto parlamentario (Woldenberg, 1992; Pereyra y Woldenberg, 1989; Olvera y Avritzer, 1992). No obstante, en México la normalidad democrática "formal" tuvo de suyo el dominio de un sistema unipartidista, un partido de Estado de un régimen que algunos autores definieron como burocrático-autoritario, sin ser totalmente el tipo de régimen de los países del Cono Sur.

Los momentos clave de transición e instauración democrática ocurrieron en 1994, con la exigencia social de la "ciudadanización" de los procesos electorales y sus instituciones, y con la primera alternancia en el poder ejecutivo, en el año 2000, evento con que, para Cansino (2005), México cierra la fase de transición. En suma, desde la segunda mitad de los noventa la centralidad de los debates sobre democracia política es visible en la agenda de investigación política y social de las ciencias sociales mexicanas; tiene de suyo un imaginario político que hace de la democracia el núcleo constitutivo de una estructura procedimental con fines de ordenamiento electoral y de ejercicio de gobierno, cuyo sustento conceptual y metodológico se nutre de las vertientes clásicas y nuevas del pensamiento político estadounidense.

Concluyamos este parágrafo reconociendo que las grandes tensiones entre el proyecto y las experiencias concretas de la democracia política en Centroamérica y México definen el sentido de oposición entre el modelo analítico y su despliegue en la realidad concreta y hacen inevitable el reconocimiento de que los vectores de esta tensión no son los marcos conceptuales como tales, sino la realidad política de sociedades históricamente situadas en tiempoy en espacio (Schedler, 2004). Con casi tres décadas de experiencia democrática, el pensamiento político de la región está exhausto, y si bien el modelo de democracia liberal, como marco referencial para instituir y analizar lo instituido, se tornó en la estrella, hoy ha perdido su luz y acaso ya no la recupere.

El proyecto de la democracia liberal instituida en un pensamiento que hizo de la incertidumbre y la certidumbre momentos reactivos y decisorios que culminan en la "certeza" de orden político, reposado en la institucionalización y en la convicción del cambio político por parte de sus actores, llega a su fin, incluso como posibilidad. La institucionalización no sólo nunca llegó, sino que tampoco se quiso que llegara; el juego esperanzador de las posibilidades en la acción desde los sujetos de la democracia - partidos, regímenes políticos, ciudadanos - también llega a su fin ante el imponente poder del dinero y sus formas escandalosas de colonizar la política, que no sólo engulle a sus actores, sino también al conjunto de las instituciones que formalmente definen la estructura básica y de intermediación de los ordenamientos democráticos.

La realidad en la que opera y se sostiene la democracia política liberal no sólo le es adversa para el despliegue de sus dispositivos y ordenamientos normativos, sino que éstos han sido vaciados para sustituirlos por nuevas disposiciones legales que, sin tamiz 
alguno, legitiman la regresión autoritaria. Es un autoritarismo democrático definido por un contexto mundial, regional y hemisférico, en el que el capital coloniza la política, pero tiene especificidades propias que la tornan en una estructura de dominación, si bien inestable, en la que subyacen tensiones y fracturas entre las fuerzas económicas y una clase política en abierto proceso de descomposición.

Pero el desafío mayor de la democracia liberal bajo un capitalismo global/neoliberal es, en los países centroamericanos y en México, la construcción de subjetividades que la amenazan. Siguiendo la línea de pensamiento de Goldberg (2012), podemos decir que esta crisis, forjada mayormente en las últimas tres décadas, con énfasis en los años del presente siglo, si bien es producto de la acumulación de un recurrente ejercicio de exclusión material y política, se traduce, en la conciencia y el imaginario colectivos, en el desengaño y el autodesengaño, como el empeño y autoempeño de forjar resistencias desde esas exclusiones que la democracia política torna ordinarias, cotidianas, sin el señuelo de ser fases inevitables pero temporales para transitar a la inclusión, y con ella a sus expectativas de desarrollo y bienestar. ${ }^{6}$ Para la democracia liberal no es una cuestión menor la pérdida de esa luz siempre encendida como faro esperanzador en los deseos y anhelos de las mayorías; la democracia se torna banal y se percibe y asume como espectáculo de rabia o festejo y, en su extremo, en un ritual que les es ajeno. Con certeza saben, pues son los materiales con que se construye la vida diaria, de la pobreza, del desempleo, de los bajos salarios, de la exclusión de todo derecho básico constitucionalmente garantizado por el Estado, de la desposesión de sus territorios y de la acción represiva del Estado y sus aparatos policiales para acallar y contener las movilizaciones en defensa del derecho a la vida.

Para las ciencias sociales centroamericanas los desafíos son mayores o de mayor intensidad que en el conjunto del continente latinoamericano. Las directrices del pensamiento político de la región, que no se restringen a la democracia y sus procedimientos, convocan a un debate en cuya agenda cobran centralidad las nuevas relaciones entre democracia y Estado, entre democracia y capitalismo global. La pobreza, la corrupción, la impunidad, el crimen organizado y la seguridad son los nuevos o renovados vectores transversales que se internalizan con sentido de regularidad en la lucha y transmisión de poderes públicos y en el ejercicio de gobierno formalmente democrático.

Pero el reto mayor para las ciencias sociales, en particular para la política y la sociología, es, como insistía Zemelman, desde dónde y cómo nombrar lo no nombrado. Los bienes-

\footnotetext{
6 "No es que ahora, por primera vez, encontremos lo engañoso, lo falso, lo aberrante y simulado en todos lados [...]. Sin embargo, la generalización de esa fantasía a lo largo del tiempo y la geografía, parece tener cada vez (o época) sus propias formas y sus maneras específicas de desengaños" (Golberg, 2012: 22).
} 
promesas de la democracia — libertad, igualdad, participación política一, sujetos a las condiciones de los entornos nacional e internacional, nunca llegaron a formar parte de los acervos materiales y subjetivos de la vida cotidiana de las mayorías ciudadanas. Desde la instauración misma de la democracia política, el cambio político pareció operar en contra de las mayorías, de manera que durante casi tres décadas de gobierno democrático se incubaron condiciones de precariedad extrema que fueron más allá de la denominación de ser pobre o excluido, cuyo acendramiento fincó formas contingentes de organización y sociabilidad que difieren de todo marco espacial y temporal predictivo fincado en las metas de democracia y desarrollo, vectores de comprensión analítica y referencial del pensamiento hegemónico.

En suma, el desafío para las ciencias sociales es entonces cómo traducir social y políticamente tanto el complejo mundo de viejos y nuevos poderes tejido con los materiales de lo "anómalo" — corrupción, impunidad, delincuencia organizada, etcétera-, como las prácticas y comportamientos colectivos que se construyen y se sostienen con sentido de regularidad y contingencia desde condiciones de precariedad extrema. Ambas realidades se resisten a su explicación y comprensión con los marcos conceptuales clásicos que permiten lo propio del hacer científico, como la definición teórica precisa y el establecimiento de estándares comunes en las investigaciones.

\section{Globalización y “desdemocratización”: ¿hacia un nuevo modelo político?}

Indica Wallerstein que el sistema-mundo está en serios problemas y que los expertos y los políticos se aferran a un clavo ardiendo, cuando el problema real es el todo sistémico, sus alocados vaivenes, visibles en la inestabilidad del mercado y en las inestables alianzas geopolíticas ante la configuración de un mundo multipolar. Con un sentido de contundencia asevera que "el sistema-mundo se está autodestruyendo", su estado es el de una "bifurcación", esto es, "el sistema actual no puede sobrevivir" y la cuestión real es "qué lo reemplazará". Con sentido reflexivo y de humildad ante la complejidad del caos, sostiene Wallerstein que, si bien no podemos predecir qué clase de nuevo sistema emergerá, sí "podemos afectar la decisión entre las alternativas sustantivas disponibles", pero ello exige "un análisis realista de los vaivenes caóticos existentes, sin esconder nuestros esfuerzos políticos tras espejismos acerca de reformar el sistema instituido, o mediante intentos deliberados por ofuscar nuestro entendimiento" (Wallerstein, 2005).

Con el mismo sentido aseverativo y reflexivo, Marramao sostiene que nuestra época, que "se muestra a sí misma su tiempo como un sucederse precipitado de múltiples festividades", en realidad es una "época sin fiesta [...] signada por el fenómeno de la doble contracción de memoria y expectativa, por la implosión del porvenir en un 'futuro pasado' y por la consiguiente eternización del presente" (2013: 93). 
Ambos asertos de realidad y pensamiento son sugerentes para pensar con sentido analítico y reflexivo el presente y el horizonte de la democracia política, evitando tanto las lecturas que hacen de los precarios avances logrados su inevitabilidad como única forma de gobierno y de Estado, como una lectura que niegue lo alcanzado, y colocando sus resultados con la condición predemocrática de partida. Una primera tesis ordenadora para este pensar analítico y reflexivo es aquella que sostiene que la naturaleza de la democracia no es ni realidad ni pensamiento estático y unilineal, pues experimenta avances y retrocesos que se constituyen y sostienen en contextos históricamente determinados y situados en los que se conjuga una dinámica articuladora entre democracia, economía, sociedad y Estado (Tilly, 2010).

Bajo esta tesis, podemos invertir la lógica analítica: asumir la des-democratizacion como lo propio de la era neoliberal y no la democracia liberal representativa como marco de referencia para entender tanto el comportamiento concreto de los vectores procedimentales de la elección y la representación, como el ejercicio de gobiernos formalmente democráticos. Este ejercicio de inversión que hace de la democracia representativa un momento fugaz e intrascendente, un hecho que se reduce a su presentismo espectacular, trágico y mediático, tiene un sustento hipotético: la desdemocratización revela el tránsito del Estado Constitucional liberal-democrático a un Estado de la Economía (Mercado, 2005), una fase que no sólo disloca, degrada e inviabiliza principios constitucionales que dieron sentido de certeza y orden a la sociedad moderna capitalista, sino que también imposibilita la significación del "tránsito" del Estado, por el mercadeo recurrente del régimen político, que exige la deshistorización y desculturación de la política (Marramao, 2013: 97; Pisarello, 2011).

Esta premisa y esta hipótesis permiten dar un sentido de precisión al vocablo "desdemocratización", hoy tan recurrente para calificar a los gobiernos progresistas latinoamericanos que tienen de suyo el reposicionamiento del Estado en las funciones de conducción y regulación de la economía, que en las últimas tres décadas de proyecto neoliberal se tornan inservibles ante la prédica de autorregulación del mercado global. Salvo excepciones, la producción académica, política y mediática define la desdemocratización, como lo opuesto a la democracia liberal en la que subyace la idea de la libertad del mercado, frente al Estado, valorado este último en abierto sentido negativo. La misma línea de pensamiento se registra para la crítica de otros gobiernos bajo regímenes formalmente democráticos, para los que el vocablo des-democratización refiere prácticas que ponen en riesgo la hegemonía de la democracia política liberal exigiendo su restitución en tanto fundamento sistémico.

El sentido abiertamente ideológico y sistémico dado al vocablo des-democratización resulta productivo si le asignamos una definición contextualizada e historizada, esto es, "la des-democratización como expresión de la subordinación de la democracia política al proyecto global neoliberal", proyecto que altera en conjunto los vectores de la democracia liberal, el Estado, la economía y la sociedad. Le antecede la oposición entre capitalismo 
autorregulado y democracia y, con ello, la pujanza de contramovimientos de resistencia que explican la dialéctica democracia/des-democratización (Polanyi, 2006; Tilly, 2010). El hecho crítico, la particularidad del presente, es la ruptura del régimen político que posibilitó un campo de lucha desde esa relación tensional entre democracia y des-democratización, una ruptura visible desde los años sesenta, pero que adquiere sus rasgos definidos en lo que va del siglo XXI ante el poder omnímodo del mercado autorregulado. En este contexto, la des-democratización significa en términos llanos, ante la radicalización de la libertad del mercado global, la inexistencia en la vida concreta de ese modelo de régimen político que, por encima de sus aporías, estableció los fundamentos de un orden político que con sentido universal hizo suyos los principios y valores de libertad, igualdad y fraternidad. ${ }^{7}$

Los regímenes formalmente democráticos de hoy, por exigencia sistémica o por intereses privados, han degradado los contenidos "liberal-protectores" de las instituciones orientadas a "proteger a cada individuo respecto de la acción de otros y de todos ellos respecto de la acción del Estado" (Águila, 1997). Basta una mirada a los latinobarómetros de las últimas tres décadas para saber, en regímenes formalmente democráticos, el estado que guardan las instituciones a ella asociadas, como son: los derechos civiles, la división depoderes, las divisionesterritoriales del poder, el controldelalegalidad, el consentimiento de los gobernados y el control de los representantes, o la representación en el Estado de los intereses de los ciudadanos, entre otras (Águila, 1997).

La crudeza del diagnóstico del presente que define a la des-democratización como el hecho que modula todo el acontecer de la política actual entraña también una analítica que detona el sentido fatalista y de entrampamiento que suele hacernos presa. Nos referimos a esa tensión propia del capitalismo que hace de su historia una secuencia temporal siempre interrumpida por cataclismos o crisis que definen destrucción, ruptura, destrozo y, en paralelo, movimientos sucesivos de resistencias de escalas locales de autoprotección a la vida que, a veces, como dice Benjamin (2005), se iluminan con el relámpago de un "acontecimiento".

\footnotetext{
7 “[...] la idea de 'universalización’ transmitía la esperanza, la integración y la resolución de crear el orden; por encima de lo que indicaban los términos afines, significaba un orden universal: la creación de orden en una escala universal, verdaderamente global [...] Por eso mismo declaraba su intención de crear condiciones de vida similares para todos, en todas partes; de dar a todos las mismas oportunidades, y, tal vez, incluso crear la igualdad. Nada de ello permanece en el significado de la globalización [...] El término se refiere, ante todo, a los efectos globales, claramente indeseados e imprevistos, más que a iniciativas y emprendimientos" (Bauman, 2009: 81).

8 "La idea del liberalismo es que la justificación de la democracia consiste en su contribución a la libertad, al desarrollo y al bienestar de cada ciudadano individualmente considerado. Su fundamento es, pues, individualista tanto en sus versiones de liberalismo contractualista [...] como en aquellas más inclinadas hacia el utilitarismo. [...] En el primer caso, el individuo es la base del contrato social que establece las reglas de convivencia o de justicia. En el segundo, es la utilidad de los individuos o su agregación lo que constituye el fundamento del orden político" (Águila, 1997).
} 
Se llega así al núcleo central del problema: el reconocimiento de la crisis estructural y subjetiva de la democracia política, y el devenir de la misma, que decanta en la interrogante sobre el posible o los posibles modelos políticos construidos y sostenidos por un sistema económico que se erige autónomo, autorregulado. Se trata de un problema que para las ciencias sociales entraña la irrupción de las clásicas lecturas en las que el modelo de democracia política se asume como objeto de análisis, en el que la realidad empírica es un accidente, y como marco referencial para su analítica. El producto académico y político propositivo es generalmente el espejismo de las reformas.

No es posible reducir la analítica de la crisis de la democracia política a sí misma, ni a sus manifestaciones mediáticas de escándalo por la impunidad o el escarnio sobre los actores políticos visibles; en tanto construcción social, involucra al Estado, un Estado hoy volcado a renunciar a las instituciones que sustentan el modelo democrático "liberalprotector" (Águila, 1997). Involucra también a una sociedad hoy colonizada por el consumo (Bauman, 2004). El sentido estructural de la crisis revela el condicionamiento y alto grado de determinación que sobre ella ejerce el poder omnímodo del mercado global, que se instituye en un poder desterritorializado que subordina y coloniza en extremo a la democracia. La construcción de esta economía global neoliberal autorregulada no se explica sin los Estados nacionales y sus metamorfosis, a los que el capital global exige su reducción a Estado mínimo o a Estado policial, que no sólo pone en vilo los atributos de poder soberano y de soberanía nacional, sino también las responsabilidades de bienestar y seguridad que formalmente son de su competencia.

Sassen sostiene que las relaciones entre Estado y globalización no son excluyentes, pues si bien se registran procesos que desnacionalizan formas de la autoridad estatal, tienen la particularidad de constituirse a través de las instituciones del Estado-nación; no obstante, no son nacionales en el sentido histórico del término, pero tampoco transitan "al dominio institucional privado o global" (2012: 63 y 65). De tal registro deriva la interrogante: ¿qué hay de lo nacional en los componentes institucionales del Estado que se vinculan con la implantación y la regulación de la globalización económica? Una interrogante adicional que recupere la especificidad de dicha relación, en términos de sus impactos en las relaciones internas entre Estado y sociedad, sería: iqué hay de democracia en ese Estado nacional articulado a la globalización neoliberal y sus exigencias de autorregulación?

La respuesta a esta última interrogante abre nuevos campos analíticos poco teorizados por las ciencias sociales y realza la inconsistencia o el reduccionismo del debate sobre la democracia desde referentes empíricos de contrastación que, si bien tienen vectores comunes, como el retorno del "derecho penal del enemigo" (Jakobs y Cansino, 2003;

\footnotetext{
${ }^{9}$ Un derecho que parte de un deshumanizado presupuesto de "enemigo/no persona"; de "un retorno al pensamiento absolutista incompatible con la idea de democracia; un marco jurídico que contradice y violenta los principios y derechos fundamentales básicos del Estado, en concreto, el derecho a la presunción de inocencia, el derecho a la legalidad criminal, el derecho a la igualdad y no discriminación, y el principio de proporcionalidad o prohibición de exceso" (González, 2007: 52).
}

62 
González, 2007), las asimetrías son diferenciales, en particular si recuperamos el registro de la expansión y los impactos de la "globalización negativa" en el sur (Kapuscinsky, 2001; Cayuela, 2002). El hecho concreto en la escena internacional es la inexistencia de una relación formal, concreta y homogénea entre democracia y globalización. Es visible para los países del sur tanto el desplazamiento del derecho internacional público garantista, propio de una comunidad interestatal democrática, como la sustitución de la oferta democrática de la "tercera ola", por lo que hoy es "lo propio de los regímenes políticos del imperialismo contemporáneo", esto es, democracias sustentadas en la ficción parlamentaria para practicar la invasión, el bombardeo y el crimen de masas. ${ }^{10}$ De esta realidad, Badiou deriva la tesis de que la democracia de Estados Unidos y del mundo occidental hoy está contra los pobres, para sostener que "la democracia es impuesta de igual manera en que los conquistadores pretendían llegar a la región. Detrás de los militantes siempre hay misiones. Después de matar se convierte. Que la religión actual sea la 'democracia' no cambia las cosas" (Badiou, 2010, entrevista).

Desde las últimas tres décadas del siglo XX y los años que van del siglo XXI no existe mayor consenso sobre la profundización de la crisis de la democracia y la certeza de la naturaleza estructural de las causas que la provocan: la extrema autorregulación del mercado global, y un Centauro Transmoderno que está prácticamente imposibilitado de trascender su propia naturaleza, a menos que devenga en un "otro" (Vallespín, 2000). La base de la democracia es, ciertamente, económica, pero se instituye en un mundo global que se define por un modelo de seguridad y tecnocracia bélico, que provoca el vértigo de vivir un cambio civilizatorio.

El balance crítico sobre el proyecto y la experiencia contemporánea de la democracia resulta incompleto si no recuperamos a la sociedad en el contexto global como esfera productora de prácticas plurales y tensionales que la definen como un campo de emergencia, de reconfiguración de lo posible, siempre atravesada por fuerzas, pasiones y tensiones de los sujetos y actores sociales queinteriorizan el sentidolocal/global, sus exigenciasy exclusiones. La crisis de la democracia, al igual que la sociedad, es, así, ubicua, contingencial, sistémica y productiva con incidencia en el todo social, por lo que la realidad concreta deja de ser mero accidente para tornarse en el núcleo de toda investigación sobre las relaciones entre sociedad y globalización.

La globalización se traduce en una intensificación de las asimetrías norte/sur; dos datos citados por Bauman son inequívocos: "la riqueza de 358 'multimillonarios globales' equivale a la suma de ingresos de los 2,300 millones de personas más pobres, o sea, el 45\% de la población mundial" (Informe sobre el desarrollo humano de la ONU, citado por

\footnotetext{
10 "Entendamos esto: la paz estadounidense y 'occidental', la pazguerra democrática, cuyo contenido pleno es la seguridad del confort de los antedichos 'demócratas' contra la agresividad bárbara de los pobres" (Badiou, 2010: 25).
} 
Bauman, 2009: 95), y el 2.3\% de la riqueza global que recibía el 20\% de los países más pobres cae actualmente al 1.4\% (Bauman, 2009: 95). Es esta realidad la que define el sentido global de las sociedades del sur, que puede sintetizarse en lo que Goldberg llama "condiciones de precariedad extrema", en franca contraposición con una democracia social, sustento ineludible de la democracia política.

El desafío de las ciencias sociales del sur consiste en reconocer tanto la naturaleza irreconciliable de nuestra sociedad con la democracia liberal, como la urgencia de la recuperación analítica de las nuevas condiciones de la vida material y subjetiva creadas por la globalización. Interiorizadas en los campos de la experiencia vital, bajo múltiples formas, son estas nuevas condiciones y sus materiales, visibles en el discurrir ordinario de la vida cotidiana y en la ruptura del vínculo social moderno, las fuentes de una renovada teoría social crítica, portadora de un también "nuevo" proyecto político emancipador.

En esta línea de pensamiento, una nueva teoría social y un nuevo proyecto político emancipador deben tener en común el registro de los procesos de subjetivación que tienen lugar en las dislocaciones estructurales y, con ello, la exigencia de una epistemología del "desengaño" que suspende las lógicas del "engaño" — un mañana mejor - y las de la representación política, portadora de comunidad. Como señala Goldberg:

La condición de dis-locacion de lugares como estos es la fuente y la expresión de su ilegibilidad engendrando, tal vez una crisis de representación social y de control [...]. A lo que estas dislocaciones y locuciones, entre otras que proliferan, apuntan ahora es la posibilidad de generalización de la precariedad, sus condiciones de posibilidad motivadas por esa disolución de los límites sociales y tabúes mencionados anteriormente, así como la vergüenza que algunas veces motivan. Una precariedad tanto epistemológica como ontológica, aunque la primera no es simplemente un epifenómeno de la segunda (Goldberg, 2012: 20-21).

La tesis del autor apunta la constitución del "desengaño" también como "potencia política" que abre un nuevo pensamiento y un nuevo sujeto político:

[...] el reto es leer los desengaños como una forma de escapar de las inadecuaciones analíticas y conceptuales de los términos críticos actualmente disponibles para nosotros. ¿Cuál es el significado y valor (es) de los desengaños, del desengaño como tal? A través de las deformaciones y desengaños, otra historia, otra forma de ser, sus

\footnotetext{
"1 "Elneo-con-liberalismo - la hiperextenuación del neoliberalismoque hellamadoneo-neoliberalismoen corazón (si tiene uno) reescribe el guión histórico como simulación, como falsedad. La 'simulación' sirve tanto como compulsión como coacción, como imposición forzada sin importar las consecuencias, que como una cubierta cosmética de las deformidades y mundo-de polvo que se producen" (Goldbger, 2012: 22$)$.
} 
lecturas y significados se hacen visibles, se vuelven socialmente atrayentes, las cuales de otra manera permanecerían indiscernibles (Goldberg, 2012: 23).

Esta perspectiva, situada en la particularidad de la relación entre sociedad y democracia, entraña la definición de la naturaleza de la relación entre política y democracia liberal. El pensamiento posfundacionalista, suspendiendo el registro teórico de la política como “composición” y como "contraposición” propio de la tradición clásica (Bobbio, 1998), refuncionaliza el concepto de democracia distante del Estado para situarla en su nicho societal. Para Badiou, la democracia liberal es una caracterización normativa del Estado, en la que el parlamentarismo es una categoría política que regula una relación subjetiva con el Estado. A la interrogante de si la democracia es una categoría pertinente sostiene que sí, "puede serlo si 'democracia se toma en un sentido distinto a una forma de Estado', si no está subordinada al Estado". ${ }^{12}$ En consecuencia, indica:

[...] si "democracia" es una categoría de la política como pensamiento, es decir, si es necesario que la filosofía utilice "democracia" como categoría para captar el proceso político como tal, se ve que ésta está sustraída a la prescripción pura del Estado, ya que el Estado mismo no piensa. Resulta entonces que "democracia" no se toma tampoco allí como una forma de Estado, sino de otra manera, o en un sentido distinto (Badiou, 2000: 16).

A la interrogante sobre qué designa la democracia, “iA qué debe unirse la democracia para ser verdaderamente un acceso a la política como pensamiento que no sea su conjunción con el Estado?", la respuesta es "unir ‘democracia' a la prescripción política misma”:

"Democracia" no remitiría ni a la figura del Estado ni a la figura de la actividad política de masas, sino de forma orgánica a la prescripción política, bajo la hipótesis - la cual seguimos - de que la prescripción política no está subordinada al Estado, o al buen Estado, no es programática.

"Democracia" estaría ligada orgánicamente a la universalidad de la prescripción política, o a su capacidad de universalidad, y habría un lazo entre la palabra "democracia" y la política como tal. Política, una vez más, en el sentido en el que ella es otra que un programa de Estado. Habría una caracterización intrínsecamente democrática de la política, en la medida, por supuesto, en que la política se autodetermine como espacio de emancipación sustraído a las figuras consensuales del Estado (Badiou, 2000: 18-19).

\footnotetext{
12 "Arriesguemos una fórmula un poco bastarda: el Estado no piensa" (Badiou, 2000: 16).
} 
Esta conjunción entre situaciones particulares y política hace de la democracia una categoría filosófica que designa lo que Badiou llama "la efectividad de la política". Esto es, "la política en su coyuntura con problemas particulares". La tesis es conclusiva:

Admitamos que "democracia" designa el hecho de que la política, en el sentido de una política de emancipación, tiene por referente último la particularidad de la vida de las personas, es decir, no el Estado sino las personas tales como se presentan en el espacio público. Se ve entonces que la política sólo puede seguir siendo tal, es decir, democrática, en el tratamiento de esta particularidad de la vida de las personas, si no tolera ninguna acepción desigualitaria de ese tratamiento. De lo contrario, introduce una norma no democrática, en el sentido original en el que hablo, y deshace la conjunción, es decir, no está ya capaz de tratar lo particular desde el punto de vista de la prescripción universal (Badiou, 2000: 20-21).

La democracia y la política, "la democracia política", se desembaraza del Estado y recupera su naturaleza social; permite fraguar un renovado pensamiento político-social que, pese a sus diversos desarrollos teóricos, tiene en común los materiales con los que se construye la sociedad del nuevo milenio, sin perder de vista que en tanto sociedades del sur, se recrean o reconfiguran con ese vector asimétrico que las hace estar y no estar en la globalización, tornándose en sociedades cuyo abigarramiento devela un cambio de piel que urge explicar y comprender.

\section{Algunas reflexiones sobre la agenda posible}

Si el sentido de todo análisis de las ciencias sociales es su dimensión crítica y reflexiva, esta breve incursión en el pensamiento y la práctica de la democracia liberal representativa insiste, como horizonte de presente y de futuro, en la tarea de priorizar el análisis de las condiciones que han hecho de la democracia lo que hoy es en las sociedades centroamericanas y mexicana.

Un número importante de investigaciones de la región abocadas al análisis de los procesos electorales, al menos de las últimas dos décadas, recurrentemente arrojan resultados que tienen que ver con la destrucción y violación sistemática de los "universales procedimentales" (Vitale, 2005). Registran que medios de comunicación, liderazgos partidarios y gobierno han logrado usurpar y modular a sus intereses el goce de los derechos políticos de las mayorías, particularmente la libertad de votar frente a opciones creíbles y plurales; que los órganos electorales se tornan en instrumentos que hoy no garantizan resultados creíbles, y en igual medida que las instituciones de gobierno tampoco garantizan que en las decisiones públicas primen los intereses de las mayorías. En el mismo tono, se enfatiza que el poder de los medios coloniza a partidos 
políticos y a candidatos ante la ausencia de los derechos a la información. En atención al ejercicio de gobiernos democráticos, se insiste en la práctica flagrante de parlamentos y del poder presidencial de cambios en las reglas del juego democrático que terminan haciendo de las instituciones electorales y sus actores un poder en sí mismo. El hecho más grave, por sus secuelas, es el reconocimiento de la incursión del narcotráfico y el crimen organizado en los procesos electorales.

Estos esfuerzos analíticos de las ciencias sociales de la región que intentan abordar los procesos electorales y sus vulnerabilidades, deben acompañarse de una reflexión crítica que explore con minuciosidad las condiciones que hacen posible la democracia política que tenemos; una lectura que se interrogue sobre los límites de un modelo político que se traduce en una forma de gobierno que "no es", en tanto poderes ilimitados conjuran su permanencia distorsionada, a falta de un modelo alternativo a sus intereses. El proyecto y experiencia de la democracia liberal como pensamiento político hegemónico, en los países de estudio, manifiesta hoy una doble crisis: devela las tensiones, contradicciones y paradojas que son propias de su construcción sistémica (Zolo, 2006; Mouffe, 2006), y está prácticamente imposibilitada de ser lo que formalmente debe ser, por el poder omnímodo del mercado autorregulado y globalizado.

Los desafíos abren una agenda de investigación. El primero, insistimos, no es sólo el reconocimiento de su crisis y la exigencia de su "reconstrucción" como pensamiento hegemónico (Sartori, 2004), sino, fundamentalmente, el reconocimiento de los límites de su despliegue concreto como modelo político en atención a los vectores que lo impulsan o lo inhiben, como la geopolítica, la economía, el Estado o la sociedad, vectores que convergen en la interrogante suspendida en el tiempo: idemocracia para qué y para quién? En su sentido más profundo, para las ciencias sociales de la región implica que el sustento de la investigación política irrumpa en el marco exclusivo de los cánones del modelo de democracia liberal representativa.

El segundo se refiere al reconocimiento de la profundidad de la crisis de la democracia política liberal, visible en las condiciones de extrema pobreza y exclusión de la población mayoritaria, que abre y pone al descubierto, como constitución y encubrimiento, lo que está detrás de la democracia liberal como proyecto de gobierno y de Estado: el dislocamiento y fragmentación, cuando no su borramiento, de los antagonismos, que son "inerradicables de la política" en tanto revelan "el límite mismo de todo consenso racional" (Mouffe, 2006: 18 y 20).

El tercero, siguiendo la línea de la crítica de Torres-Rivas y otros autores, es el reconocimiento de que el proyecto y la experiencia seguida por la democracia liberal en Centroamérica y en México no se explica sin el vector geopolítico. El poder de Estados Unidos sobre los Estados y gobiernos se decanta recurrentemente en políticas y estrategias en franca oposición a principios básicos de la democracia política liberal. El tratamiento estadounidense dado a la lucha contra el narcotráfico y a la migración 
irregular son dos ejemplos ilustrativos. La militarización de la lucha contra el narcotráfico, llevada a su escala regional y continental o hemisférica, se traduce en la expansión de la violencia estatal y delincuencial; las agresivas políticas de detención y criminalización de la migración irregular se traducen no sólo en el retorno forzado que destruye las esperanzas de miles de jóvenes e incita a incursionar en las bandas delincuenciales, sino en los impactos económicos al hacer de las remesas de sus migrantes la fuente de sus economías. ${ }^{13}$ No es un hecho menor el registro de que por los territorios de Guatemala, Honduras y El Salvador pase entre el 80 y el 90 por ciento de la droga que se consume en Estados Unidos; tampoco que las remesas generen ingresos mayores que los de las actividades productivas.

En suma, es inevitable abrir una línea de investigación geopolítica bajo la hipótesis de que el gobierno de Estados Unidos hoy trafica con la democracia por el paradigma securitario, sin importar los costos sociales y los destrozos en las relaciones de cooperación y fraternidad entre los países de la región.

Un cuarto desafío para pensar la democracia política posible implica, como hemos insistido, el acercamiento analítico y reflexivo a la sociedad, a la población mayoritaria y a la ciudadanía, porque sin ella no existe ni política ni democracia alguna. La sociedad de hoy no es la que solíamos pensar en el siglo pasado; sus transformaciones derivan en antagonismos no pocas veces irreconciliables y fragmentados que inhiben el reconocimiento político de éstos. La pluralidad de la sociedad exige recuperar las dimensiones tensionales visibles y manifiestas en sus múltiples formas, pues son ellas el punto de partida y el sostén de las identidades políticas bajo las que subyacen "marcas de la exclusión" que las define como tales (Mouffe, 2006: 20).

Las sociedades centroamericana y mexicana son sociedades abigarradas. Porciones importantes de población son presa de esa doble contracción de memoria y expectativa que, como indica Marramao, es producto de la "eternización del presente", propia del tiempo global, de la sociedad del consumo, que hace de las elecciones actos "irracionales" o "emocionales", magistralmente orientados por las técnicas publicitarias utilizadas por la propaganda política (Vitale, 2005), visibles en el cinismo discursivo de partidos y candidatos: "un pan un voto", o el viejo adagio: "al pueblo pan y circo". Otras porciones

\footnotetext{
${ }^{13}$ La crisis del sistema migratorio Centroamérica-México-Estados Unidos que se reveló en el verano de 2014 como una crisis humanitaria, donde miles de menores de edad habían cruzado la frontera sur de Estados Unidos, a pesar de la implementación de medidas para reforzar la vigilancia en las fronteras, no ha tocado fondo. Se han destinado millones de dólares para financiar equipos y cuerpos de seguridad en las fronteras. En México se movilizó un número significativo de elementos de la Gendarmería Nacional, la nueva policía federal creada por el gobierno de Peña Nieto. Con el Programa Frontera Sur el número de detenciones y deportaciones se han elevado, y sin embargo la migración no se ha detenido. En 2016 comenzaría a operar el programa Alianza para la Prosperidad del Triángulo Norte, pero sus acciones tampoco tendrán el efecto esperado pues se trata de una estrategia empresarial y de seguridad que no ataca las causas profundas que producen la migración (Villafuerte y García, 2015).
} 
de población son presa de la apatía política o de una oposición que se decanta hacia la construcción de identidades de poder al margen de los poderes estatales. Constituyen sin duda porciones de población en las que se incluye la temida y a la vez esperanzadora clase media, que votan por una nueva derecha o una nueva izquierda, haciendo propios los discursos y espectáculos de aversión desenfrenada hacia la política.

Sin embargo, detrás de estas tipologías sociales presentistas subyace una sociedad mayoritaria que modula lo que Goldberg (2012: 15) define como "gente de polvo", donde la noción de "polvo" se refiere a una "condición socio-natural de la vida y sus limitaciones", y sugiere también "formas en las cuales, al enfrentar condiciones de precariedad extrema y ante [...] la abolición del límite y del tabú, la subjetividad social enfrenta la disolución y es forzada a negociar lo que significa e implica vivir actualmente en condiciones críticas". Es este vivir en condiciones críticas, un vivir hecho ordinario, producto de reducciones de soberanía y dominio estatal, un campo de análisis que las ciencias sociales debe privilegiar, pues constituye los materiales para entender a una sociedad que es forzada a negociar, pero también capaz de construir otra política a través de una vida cotidiana colectiva que le da la vuelta al modelo político instituido y la ignora. Sobre ello, en América Latina hay un trabajo intelectual y académico que abre brechas para futuras investigaciones con fines propositivos bajo el principio de que toda invención política es siempre situada; es, como indica Badiou, una ruptura subjetiva.

En suma, los retos de las ciencias sociales contemporáneas en el tiempo global son vastos. Desde los destrozos sociales, hoy visibles por ese irrefrenable mercado global, sigue siendo inevitable el vivir en sociedad, y ésta sólo es posible bajo instituciones que favorezcan las relaciones entre los individuos; instituciones que contribuyan al vínculo social bajo relaciones humanas que conjugan la singularidad y la diferencia, sin menoscabo de la búsqueda por la igualdad y la libertad. El reto mayor en las sociedades centroamericanas y de México es la irrupción de los procesos de desigualdad, un problema que va más allá de la pobreza, pero la profundización extrema de esta última no sólo niega la posibilidad de toda democracia, sino que pone en entredicho nuestra condición humana misma.

\section{Referencias bibliográficas}

Águila, Rafael de (1997). “Democracia”. En Rafael de Águila (ed.), Manual de Ciencia Política. Madrid: Trotta.

Agamben, Giorgio (2010). Estado de Excepción. Homo Sacer II. España: Pre-Textos. Agapito, Rafael (2006). Carl Schmitt. El concepto de lo político. España: Alianza.

Badiou, Alain (2000). "Razonamiento altamente especulativo sobre el concepto de democracia”. En Metapolítica, vol. 4, núm. 14, pp. 11-2l.

Badiou, Alain (2010). Filosofía del presente, Argentina: Capital Intelectual. 
Badiou, Alain. “Las ‘democracias' organizan una guerra implacable contra todos los pobres del planeta”, entrevista de Héctor Pavón. En El Clarín, 1004. Disponible en www. avizora.com/publicaciones/reportajes_entrevists/textos/0133_alain badiou_htm.

Bauman, Zygmunt (2004). Modernidad líquida. Buenos Aires: FCE.

Bauman, Zygmunt (2009). La globalización. Consecuencias humanas. México: FCE.

Benjamin, Walter (2005). Libro de los pasajes, España: Akal.

Bobbio, Norberto (1984). "Lugares clásicos y perspectivas contemporáneas sobre política”. En Norberto Bobbio y Michel A. Bovero. Origen y fundamentos del poder político. México: Enlace Grijalbo, pp. 37.64.

Cansino, César (2000). La transición mexicana, 1977-2000, México: CEPCOM.

Cansino, César (2001). "Antesala”. En Metapolítica, vol. 5, núm. 18, abril/junio, pp. 8-9.

Cansino, César (2005). El desafío democrático. La transformación del Estado en el México postautoritario, México: Jus/Ediciones CEPCOM.

Cansino, César (2006). "Adiós a la ciencia política. Crónica de una muerte anunciada”. En Metapolítica, núm. 49, vol. 10, septiembre-octubre, México, pp. 27-37.

Cansino, César (2013). “Calidad democrática en América Latina: iproyecto o utopía?” En Revista Mexicana de Ciencias Políticasy Sociales, UNAM, Nueva Época, año LVIII, núm. 217 enero-abril, México, pp. 79-98.

Cayuela Gally, Ricardo (2002). "Entrevista con Ryszard Kapuscinski. La fragilidad del mundo". En Letras Libres, julio, año IV, núm. 43, pp. 24-30

Dahl, Robert (1994). ¿Después de la revolución? Barcelona: Gedisa

De Castro, Andrés y Andrés Pedrero (2012). "El péndulo de Polanyi: de la desdemocratización a la resistencia civil". En Revista Internacional de Ciencias Sociales, núm. 31, pp. 9-24.

Farfán H., Rafael (1996). "Del paradigma político de la transición. Estudio crítico de un modelo de análisis político". En Sociológica. Transición política y procesos electorales en México y América Latina, UAM-Azcapotzalco, enero-abril, pp. 13-42.

Fernández Pardo, A. Carlos (2007). Carl Schmitt en la teoría política internacional. Argentina: Biblos.

Fukuyama, Francis (1990). “EEl fin de la historia?” En Claves de razón práctica, vol. 1, pp. 85-96.

Garretón, Manuel Antonio (1995). Hacia una nuevo era política. México, Chile: FCE.

Garretón, Manuel Antonio (1999). Democracia y des-democratización. México: UNAMCentro de Investigaciones Interdisciplinarias en Ciencias y Humanidades.

Goldbger, Theo David (2012). "Epistemología del desengaño. Topologías de lo extra/ ordinario". En Helena Chávez Mac Gregor (ed.), Estética y violencia: necropolítica, militarización y vidas lloradas, México: UNAM-MUAC, pp. 14-30.

González Cussac, José (2007). "El renacimiento del pensamiento totalitario en el seno del estado de Derecho. La doctrina del derecho penal del enemigo". En RevistaPenal, núm. 19. Disponible en: http:/www.uhu.es/revistapenal/index.php/penal/article/view/304/295. 
Hartlyn, Jonathan y Arturo Valenzuela (s/f). "La democracia en América Latina desde 1930". S.p.i. Disponible en: http://www.plataformademocratica.org/Publicacoes/14640.pdf. Huntington, P. Samuel (1994). La tercera ola. Democratización a finales del siglo XX. Barcelona: Paidós.

Kapuscinsky, Ryszard (2001). "Del muro de Berlín a las Torres Gemelas". En Claves de Razón Práctica, núm. 117, noviembre, Madrid, pp.34-41.

Jacobs, Günther y Manuel Cancio Meliá(2003). Derechopenaldelenemigo. España: Thomson Civitas.

Lander, Edgardo (1996). La democracia en las ciencias sociales latinoamericanas contemporáneas. Serie Bibliográfica FOBAL.CS, núm. 2. Caracas: CLACSO.

Lechner, Norberto (1992). "La búsqueda de la comunidad perdida. Los retos de la democracia en América Latina”. En Sociológica, núm. 19, año 7, mayo-agosto. México: Universidad Autónoma Metropolitana-Azcapotzalco, pp. 12-29.

Lechner, Norbert (1996). "La política ya no es lo que fue". En Nueva Sociedad, núm. 144, julio-agosto.

Lechner, Norbert (2002). "Los nuevos perfiles de la política. Un bosquejo". En Nueva Sociedad, núm. 180-181, julio-agosto/septiembre-octubre, pp. 263-279.

Marchart, Oliver (2009). Elpensamiento político posfundacional. México: FCE.

Marramao, Giacomo (2013). Contra el poder. Filosofía y escritura. Argentina: FCE.

Mercado, Pedro (2005). "El proceso de globalización, el Estado y el Derecho". En Guillermo Portilla Contreras (coord.), Mutaciones de Leviatán. Legitimación de los nuevos modelos penales. España: Universidad de Andalucía/AKAL, pp. 119-165.

Michels, Robert (1991). Los partidos politicos, t. I y II. Buenos Aires: Amorrortu.

Montero, Juan Carlos (2012). "La estrategia contra el crimen organizado en México: análisis de la política pública”. En Perfiles Latinoamericanos, vol. 20, núm. 39, pp. 7-30.

Morlino, Leonardo (2008). Calidad democrática entrelíderes y partidos. Florencia, Italia: Instituto Italiano di Sceinze Humane. Disponible en: http://www.ife.org.mx/docs/IFE-v2/CDD/ CDD-EventosForosAcademicos/EventosForos-2008/PPs-CalidadDemocracia/PPsCalidadDemocracia-docs/Conferencia01-LeonardoMorlino.pdf.

Mouffe, Chantal (1999). El retorno de lo político. Comunidad, ciudadanía, pluralismo, democracia radical. España: Paidós.

Mouffe, Chantal (2006). "Democracia y pluralismo agonístico”. En Derecho y Humanidades, núm. 12, pp. 17-27.

O'Donnell, Guillermo (1994). "Democracia delegativa". Publicado originalmente como "Delegative Democracy", en Journal of Democracy, vol. 5, núm. 1, enero, pp. 55-69. Disponibleen: http://www.forumjustica.com.br/wp-content/uploads/2011/10/O--Donnell_DemocraciaDelegativa.pdf.

O’Donnel, Guillermo (2002). "Ilusiones sobre la consolidación”. En Nueva Sociedad, julioagosto/septiembre-octubre, núm. 180-181, pp. 311-332. 
Olvera, Alberto y Leonardo Avritzer (1992). "El concepto de sociedad civil en el estudio de la transición democrática”. En Revista Mexicana de Sociología, núm. 4. México: UNAM.

Páez Montalbán, Rodrigo (1998). La paz posible. Democracia y negociación en Centroamérica 1979/1990. México: Instituto Panamericano de Geografía e Historia, Centro Coordinador y Difusor de Estudios Latinoamericanos, UNAM.

Pereyra, Carlos y José Woldemberg (1989). "El proceso democratizador en México". En Argumentos, núm. 5, noviembre. México: Universidad Autónoma Metropolitana-X, pp. 33-50.

Pisarello, Gerardo (2011). Un largo Termidor. La ofensiva del constitucionalismo antidemocrático. Madrid: Trotta.

Polanyi, Karl (2006). La gran transformación. Los orígenes políticos y económicos de nuestro tiempo. México: FCE.

Powell,Jr. G. Bingham (2005). "Calidad de la democracia: reciprocidad y responsabilidad". En Metapolítica, núm. 39, vol. 8, enero/febrero, pp. 77-86

Sartori, Giovanni (1993). La democracia después del comunismo. Madrid: Alianza.

Sartori, Giovanni (2004). “iHacia dónde va la ciencia política?” En Políticay Gobierno, vol. 11, núm. 2, segundo semestre.

Sassen, Saskia (2012). Una sociología de la globalización. España: Katz.

Schedler, Andreas (2004). "La incertidumbre institucional y las fronteras borrosas de la transición y consolidación democrática". En Estudios Sociológicos, núm. 1, vol. XXII, enero-abril, pp. 25-52.

Schmitter, C. Philippe (2005). "Calidad de la democracia: las virtudes ambiguas de la rendición de cuentas". En Metapolítica, núm. 39, vol. 8, enero/febrero, pp. 61-73.

Schumpeter, Joseph A. (1984). Capitalismo, socialismo y democracia. Madrid: Ediciones Folio. Tilly, Charles (2010). Democracia. Madrid: Akal.

Torres-Rivas, Edelberto (1998). "Centroamérica: democracias de baja intensidad". En Pensamiento Iberoamericano, núm. 14, julio-diciembre, pp. 221-230.

Torres-Rivas,Edelberto(1990). “Larecomposicióndelorden:eleccionesenCentroamérica. En TEIS. Revista Española de Investigaciones Sociológicas, núm. 50, abril-julio, pp. 11l-121.

Torres-Rivas, Edelberto (1991). "Centroamérica: la transición autoritaria hacia la democracia”. En Revista de Estudios Políticos, núm. 74, octubre-diciembre, pp. 431-449.

Torres-Rivas, Edelberto (2004). "Los caminos hacia la democracia en América Central". En Diego Achard y Luis E. González, Un desafio a la democracia: los partidos politicos en Centroamérica, Panamá y República Dominicana. San José: BID-Instituto Internacional para la Democracia y la Asistencia Electoral (IDEA)-OEA-PNUD, pp. 149-177.

Torres-Rivas, Edelberto (2007). La piel de Centroamérica (1930-2005). Costa Rica: FLACSO. Vallespín, Fernando (2000). El futuro de la política. España: Taurus.

Vilas, Carlos (1992). "Después de la revolución: democratización y cambio social en Centroamérica." En Revista MexicanadeSociología, vol. 54, núm. 3, julio-septiembre, pp. 3-44. 
Vitale, Hermanno (2005). "Norberto Bobbio y la democracia procedimental". Disponible en: http://e-spacio.uned.es/fez/eserv/bibliuned:filopoli-2005-26-CA504E04-81309FAl-B22B-6C683F071869/norberto_bobbio.pdf.

Wallerstein, Immanuel (2015). "Es doloroso vivir en medio del caos". En La Jornada, 25 de enero.

Weber, Max (1964). Economía y sociedad. México: FCE.

Weber, Max (1967). El político yel científico. Madrid: Alianza Editorial.

Woldenberg, José (1992). "De la revolución a la democracia”. En Nexos, núm. 173, mayo, pp. 45-47.

Zermeño, Sergio (1994). "De Tlatelolco a San Cristóbal: el laberinto de la sociedad", La Jornada Semanal, núm. 247. México.

Zolo, Danilo (2006). “La 'tragedia' de la ciencia política”. En Metapolítica, núm. 49, vol. 10/ septiembre-octubre, pp. 41-61. 


\section{Perspectivas contrahegemónicas de la democracia: discursos y prácticas otras de lo político y lo democrático}

Pablo Uc

La demacrada condición de la democracia instrumental y su raquítica ficción representativa en México y Centroamérica parece reducida a la mercantilización mediática y a la "legitimación" arbitraria de los disfuncionales "órdenes" de gobierno y el tipo de estatalidad y geopolítica dominante. De forma transversal, sin embargo, subyacen contundentes experiencias, prácticas y orientaciones conceptuales desde las cuales los pueblos en movimiento "sustancializan" experiencias concretas y contrahegemónicas de lo democrático. El reconocimiento de los procesos y los actores que dotan de sentido y 'escenifican' formas de sociedad en las que se producen "alternativas" de autogobierno y prácticas de democracia directa, participativa, comunitaria y otros formatos del quehacer político colectivo, más allá del instrumentalismo electoral partidista, implica reconocer sus tensiones y limitadas capacidades de institucionalización alternativa para lograr la persistencia de culturas políticas contrahegemónicas.

Esto conlleva a complejizar y reconocer otros locus de enunciación del proceso en el que discurre la construcción de principios de gobierno que apelan al disenso, a la impugnación del sistema dominante de democracia o a la potencia de la desconfianza organizada. Se trata de fuentes de politización que asumen a la democracia como un proceso que transcurre entre la utopía y la adaptación, y a la vez en un accionar que la concibe como promesa e insalvable problema (Rosanvallon, 2007).

Al reflexionar sobre la condición tautológica de la democracia, Vallespín (2000) revela la delimitación conceptual y el aprisionamiento del lugar al que se restringe buena parte del debate y la discusión teórica de la democracia secular, que la asume como modelo único de gobierno. "[La democracia] se ha convertido en el único sistema de gobierno legítimo justo en un momento en el que ya no es posible [ya que] cada vez nos vemos más afectados por decisiones y procesos que eluden nuestro control político directo" (Vallespín, 2010: 160161). Es decir, la democracia dominante conlleva a la pérdida de la capacidad real de la ciudadanía para definir el demos específico de la democracia a la que apela, por un 
desplazamiento forzado a los márgenes de la acción política. Esta lectura refuerza la cancelación de la polémica conceptual sobre la democracia que se constituye en la clave liberal representativa, y el peso estructural del discurso único de la democracia de mercado.

Por su parte, la perspectiva lineal sobre la supuesta historicidad en la que se desenvuelve la política funciona como una lectura modernizante y reduccionista con la cual se interpreta buena parte del debate académico sobre la democracia en México y algunos países de Centroamérica. Éste se limita al desglose de indicadores sobre el voto, el comportamiento político electoral y el argumento de la riqueza empírica de interpretar los resultados de las urnas como el principio de ordenamiento irrevocable del debate sobre democracia.

Recurrentemente, se parte del principio de que existió un momento óptimo de la práctica democrática, una ola de instauración o restauración; una correlación ideal de la democracia formal y sustancial; un proceso de maduración institucional aliado a los enfoques sobre calidad instrumental de la democracia, etcétera. Estas perspectivas suelen omitir los paradójicos ciclos del discurso de la democracia liberal y las multiformes subjetividades políticas que han sido sistemáticamente excluidas e incluso perseguidas, silenciadas o exterminadas, como parte de un violento ethos anti-democrático de los regímenes políticos. Todo esto, en pleno proceso de "instauración y transición democrática", como lo revela la historia política de los países centroamericanos y México.

Si intentamos ir más allá del umbral de la democracia como "insuficiencia política" para el cambio social, icómo concebir un debate teórico y conceptual desde los enfoques contrahegemónicos de lo democrático? ¿Cómo conceptualizar las democracias otras, lo democrático desde los márgenes?

Con el fin de conducir algunas reflexiones teóricas más precisas que permitan ampliar las posibles directrices del debate sobre democracias contrahegemónicas, en seguida se recuperan algunas variables y propuestas conceptuales que reconocen la diversidad de los sujetos producentes de lo político y las democracias otras, recurriendo a cuatro ejes de debate. El primero intenta fundamentar las cualidades y los problemas conceptuales que implica la idea de democracias otras, considerando algunos elementos de la democracia radical yelcomplejo problema de lodiverso comofundamentodelo socialylodemocrático. El segundo eje recupera el concepto de contrademocracia, como un debate que media entre la desdemocratización, los enfoques de la posdemocracia y los horizontes de organización de la desconfianza como un recurso fundamental de contrapoder.

El tercer eje recupera algunos de los principales postulados de la democracia contrahegemónica a partir de las propuestas de ampliación del canon democrático, el reconocimiento de nuevas gramáticas democráticas desde la sociedad política y prácticas que se definen como democracia de alta intensidad. Finalmente, el cuarto eje focaliza los alcances de la relación-tensión entre el concepto y las agendas de la autonomía y la democracia. 


\section{Democracias otras... lo distinto y lo diverso de lo democrático}

Con el objetivo de focalizar una parte del debate teórico de lo democrático desde la dimensión de lo posible, lo potencial y lo contrahegemónico, las perspectivas que en adelante se recuperan parten de reconocer las cualidades de lo distinto y lo diverso en los procesos de subjetivación política, asícomodela experiencia. Dimensiones fundamentales para reconocer escalas y prácticas heterogéneas en la producción de lo común y su amplio espectro constitutivo de lo político, en paralelo y más allá de las estructuras formales del Estado-nación moderno capitalista y las dinámicas del sistema mundo colonial/moderno. Estas características de alteridad han sido 'ausentadas' o negadas en las agendas y gramáticas liberales de la democracia instrumental. De allí que hablar de democracias otras implique una impugnación al lenguaje y los discursos que 'niegan' la pluralidad de lo político y lo democrático, así como al uso geopolítico instrumental de lo universal —y sus formatos y valores - como diseño global imperial/colonial. Se trata, por ello, de una impugnación al modelo homogéneo y cerrado que disuelve la potencia de lo diverso para re-significar la producción de lo común y la construcción de formas heterogéneas de gobierno y sociedad, es decir, la demo-diversidad democrática.

Estas perspectivas contrahegemónicas plantean un cuestionamiento a la teoría reduccionista de la democracia mínima antes señalado -importancia del orden, razón como principio moral y libertad como condición de posibilidad. Y a la vez intentan desbordar la dicotomía liberal clásica que ha ordenado la lectura de la política y la democracia procedimental: Estado-sociedad civil, que impide interpretar y reconocer la controversia y la contradicción misma que portan las subjetividades alternativas que se asumen como fuentes refundacionales de lo político. Además de las lecturas que apuntan a superar el ámbito político-institucional y se enfocan en interpretar el espacio de las relaciones, articulaciones y tránsitos entre Estado y sociedad civil como fuentes productoras de la democracia (Dagnino, 2008).

En este sentido, se trata de reconocer la delimitación impuesta sobre la dinámicamovimiento, las escalas y los márgenes formales del debate democrático. Esto con el fin de recuperar la potencia del 'disenso' y el 'desacuerdo' en la producción del sentido mismo de la democracia posible. Ésta cuestiona a la estructura de un sistema de gobierno definido a priori, ya que la reconoce como un fenómeno que reconfigura de forma permanente su 'direccionalidad' y sentido bajo un cuestionamiento crítico a los principios eideales normativos que se han establecidocomoinamovibles en el marcodela democracia liberal procedimental. Si la democracia expresa una manera concreta de ser de lo político, como propone Rancière (1996), entonces se necesita analizar la subjetivación de lo político desde la propia estructura de los conflictos y el entramado cultural de las sociedades - la contradictoria figura del demos como lo múltiple-, que son depositarias de la democracia, ya sea porque la definen o la padecen bajo la estructura instituida 
(potestas) que disuelve lo heterogéneo en Estado. Pero a la vez una forma Estado disuelta en mercado: la forma de gobierno que ha puesto en crisis las soberanías nacionales.

Reflexionar sobre las democracias otras conlleva a la posibilidad y al problema de reconocer interpretaciones sobre el poder hacer y el poder ser, que se producen desde formas heterogéneas de sociedad, más allá del acceso a las instancias reproductoras del statusquo. Tambiénimplicareconocerel accionardeun poderproducentedela transformación social, expresado en su potencial de ruptura y creación alternativa, sin desconocer su propia relación intrínseca con las estructuras hegemónicas a las que se enfrenta. Hablamos, entonces, del ejercicio político expresado en formas de resistencia y autodeterminación que al cuestionar las estructuras hegemónicas concentran su energía organizativa, y su caudal de potencia, en la construcción-recuperación de prácticas democráticas conformadas de abajo hacia arriba. Por ello prescinden de las instituciones de mediación fundamental, como los partidos políticos, la ciencia, el conocimiento y el lenguaje dominante, el poder económico empresarial y la ficción de la política profesional. Esto es lo que Dussel (2006) denomina una forma de democracia crítica social.

El planteamiento de Laclau y Mouffe (1987) sobre una democracia radical hace contundente la necesidad de ir más allá de "los puntos privilegiados de ruptura y de la confluencia de las luchas en un espacio político unificado, y la aceptación [...] de la pluralidad e indeterminación de lo social" (Laclau y Mouffe, 1987: 250). Esta indeterminación obliga a reconocer que cada expresión de resistencia o insubordinación en la multiforme sociedad puede ser extremadamente variada y todas ellas, incluso, reivindicar en su discurso y proceder político consignas vinculadas a lo democrático.

De allí que el debate abierto por las democracias otras implique reconocer dos aspectos problemáticos de la democracia radical. Por un lado, el sentido del antagonismo, que va más allá de una determinada relación binaria y dialéctica objetiva —entendida como oposición-, para reconocerlo como un entramado multifactorial y complejo, entre polos o campos constitutivos de lo político que se encuentran abiertos, en proceso de modificación constante que terminan por establecer los propios límites de la sociedad como un todo. Hablamos de fuentes de otredad productoras de horizontes, epistemologías, discursos y prácticas que se autodefinen como democráticas y que, sin embargo, no terminan por suturar o cerrar sus diferencias con la otredad antagónica (Laclau y Mouffe, 1987: 215-216).

Por otro lado, las propias realidades sociales del sureste mexicano y de Centroamérica demandan reconocer la existencia de un conjunto de prácticas y discursos — condicionados por el tiempo político y sus niveles de congruencia material y simbólica- que apelan a la construcción de otredades democráticas fundamentadas en divergentes contradicciones y grados de oposición "cerrada”. Esto, al auto-concebirse desde una escala de valores antiestatales y ordenamientos comunitarios fundamentados, por ejemplo, en territorialidades alternativas a la geografía política oficial; prácticas de autogobierno; mecanismos de auto- 
representación y construcción de instituciones sociales autónomas que repelen la relación antagónica (abierta) con las estructuras de Estado y su forma capital —andamiaje institucional electoral, programas de políticas sociales, transferencia de fondos desde instancias internacionales de cooperación con discursos asistencialistas, etcétera-

En todo caso, ambas posibilidades definen el límite de lo social en el interior mismo de lo social, "como algo que lo subvierte, es decir, como algo que destruye su aspiración a constituir una presencia plena" (Laclau y Mouffe, 1987: 217). En otros términos, las democracias otras desafían las estructuras hegemónicas que determinan un tipo de institucionalización, discurso y prácticas de la ficticia o efectiva democracia liberal representativa —Estado, medios de comunicación, partidos políticos, instituciones financieras...-. Pero también a las otras expresiones de sociedad depositarias de las prácticas de dominio y hegemonía que habilitan la reproducción de los discursos únicos y totalizantes; ya sea como extensión misma de la clase política en la sociedad civil o mediante las acciones tradicionales de cooptación corporativa clientelar.

Rancière lo explica como la imposible ecuación definida por el filósofo persa Otanes: el todo está en lo múltiple. "El demos es lo múltiple idéntico al todo: lo múltiple como uno, la parte como todo" (Rancière, 2006). Es decir, una razón metonímica que termina por anular la heterogeneidad de lo social, en el que persiste el demos que forma parte de la dominación y el que no. Es desde este último que surge la interrupción o impugnación a la dominación y exclusión que produce, paradójicamente, un sistema democrático determinado.

Desde esta perspectiva, surge la relación entre politización y democracia. Monedero (2012) considera que lo político constituye el reconocimiento de lo que afecta a la colectividad, es el reconocimiento de objetivos comunes y el permanente carácter potencial de conflicto ante la divergencia, el consenso y disenso ante los intereses comunes y compartidos, de lo cual deriva la politización necesaria en el ejercicio democrático emancipatorio. En todo caso, lo político es interpretado como "la capacidad social de reactuación sobre circunstancias determinadas para imponer una dirección otra al desenvolvimiento socio histórico" (Zemelman, 2001: 29, énfasis del autor), el cual contempla alternativas que no sólo se plantean, por ejemplo, en el esquema de un sistema liberal o socialista. Se trata de un desenvolvimiento capaz de producir nuevos sentidos posibles de la democracia y el ejercicio de lo político.

En otros términos, las democracias otras plantean una lectura política y epistémica que Santos (2006) define como demo-diversidad, considerada como la coexistencia de distintos formatos de democracia en un contexto histórico determinado. Formas de democracia que desbordan la fórmula liberal representativa, fundamentadas en la creatividad de iniciativas populares -institucionalizadas o no-, participativas y comunitarias, bajo la apuesta de no subordinarse unas a otras. El desafío de tal demodiversidad es "desarrollar criterios transculturales, democratizar y legitimar saberes 
alternativos, crear autoridad compartida, ubicar a los movimientos y organizaciones sociales como protagonistas de la nueva democracia, esto es, democratizar la democracia" (Zegada, 2011: 24).

Desde esta perspectiva se rebate, por tanto, la supuesta ampliación de la democracia enmarcada en una lógica binaria, aun reduccionista: democracia formal-democracia sustancial (Bobbio, 2001: 218), toda vez que nos enfrentamos a sociedades formalmente democráticas y sustancialmente fascistas. En la medida en que la tensión entre la democracia de Estado y el capitalismo desaparece, no sólo se anula la capacidad distributiva y el principio de igualdad, sino que también se impone una avanzada sistemática de violencia contra la sociedad a niveles suficientemente cruentos, como para reconocerlos en los términos propios de un fascismo multidimensional, así como el accionar de un sistema de poder en el que la expresión última de la soberanía reside en la capacidad de decidir quién puede vivir y quién debe morir, conceptualizado por Mbembe (2006) como necropolitica.

Ante este escenario, surge la necesidad también de conceptualizar a los actores de tales democracias otras y, con ello, el desafío de interrogar su capacidad de construir una agregación colectiva e incluso alcanzar una dirección hegemónica fuera de las estructuras dominantes. iEs posible?

\section{Contrademocracia e impolítica. Los límites políticos e interpretativos de la "posdemocracia"}

Una propuesta para interpretar el debate sobre democracia, en paralelo al acotado enfoque liberal procedimental y el funcionamiento de las instituciones electoralesrepresentativas de las élites "en turno", deriva de la constitución de universos sociales de desconfianza. Éstos se expresan en "contrapoderes sociales informales y también de instituciones destinadas a compensar la erosión de la confianza mediante una organización de la desconfianza" (Rosanvallon, 2007: 24, énfasis original).

La desconfianza política hacia la democracia puede ser interpretada desde la perspectiva liberal decimonónica del pensamiento ilustrado', fundamentada ésta en la división de poderes, las constituciones y toda una estructura jurídico-institucional orientada a evitar la acumulación de poderes e institucionalizar la desconfianza para impedir la invasión del poder público sobre el individuo: el Estado constitucional de derecho. Esta lectura se basa en la sospecha al poder popular y a la ciega confianza en los procedimientos del azar electivo: comicios electorales. Se trata de la expresión de una democracia fundamentada en el séptimo título enunciado por Platón: el título sin título, que no deriva de la filiación de nacimiento, ni del principio de los mejores, de los más fuertes o los más sabios, sino de la elección del dios azar. Se trataría, según Rancière, de una democracia que: 
[...] no es ni un tipo de constitución ni una forma de sociedad. El poder del pueblo no es el de la población reunida, el de su mayoría o el de las clases trabajadoras. Es simplemente el poder propio de los que no tienen más título para gobernar que para ser gobernados [...] el título anárquico a todo principio de nacimiento, filiación, fuerza o saber (Rancière, 2006: 70-71).

No obstante, la perspectiva de contrademocracia, fundamentada en la desconfianza, se expresa en el intento por velar, regular y buscar los medios que permitan un buen gobierno a través de tres modalidades: los poderes de control, las formas de obstrucción y la puesta a prueba a través del juicio. Estas prácticas de desconfianza organizada constituyen una contrademocracia, que más allá de una mera oposición representan una democracia "de los poderes indirectos, diseminados en el cuerpo social, la democracia de la desconfianza organizada frente a la democracia de la legitimidad electoral [que] apunta a prolongar y extender sus efectos; constituye su contrafuerte" (Rosanvallon, 2007: 24).

La primera dimensión de la contrademocracia se fundamenta en tres formas de poderes de control: la vigilancia, la denuncia y la calificación. En su conjunto, tienen la capacidad de poner a prueba o elevar al máximo el cuestionamiento de la reputación de un poder. Se trata de la expresión de un pueblo vigilante que delinea los contornos críticos del poder. La segunda dimensión, la de la obstrucción, se manifiesta como pueblo-veto, un poder de rechazo, expresado no sólo en la reacción electoral sino en todas las manifestaciones organizadas de resistencia al ejercicio formal del poder gubernamental. La figura de pueblo-veto "superpone una suerte de nueva democracia de rechazo a la democracia de proyecto" (Rosanvallon, 2007: 32). La tercera dimensión, el pueblo-juez, considera la judicialización de la política como su expresión más visible, ante el crítico deterioro de la legitimidad, la confianza y la credibilidad moral de los gobiernos, derivado de una tecnificación formal y superficial.

La sofisticación de los mecanismos para la rendición de cuentas (accountability) aparece como una expresión sin sentido para las sociedades que se enfrentan a una nula capacidad de escucha y respuesta efectiva de sus demandas (responsiveness). De allí la importancia de reconocer al pueblo-juez que no sólo demanda el funcionamiento efectivo de las instituciones judiciales y el respeto al Estado de "derecho", sino que también impugna el falso discurso de los Estados "arquipoliciales", que reducen las múltiples fuentes, prácticas y experiencias del derecho a un solo e incuestionado reino de la jurisprudencia. Se trata de un desafío a la potestad del Estado sobre la hegemonía de la violencia e incluso del derecho. Rancière lo explica en los siguientes términos:

[...] el reino del derecho es siempre el reino de un derecho, es decir de un régimen de unidad de todos los sentidos del derecho, postulado como régimen de identidad de 
la comunidad. Actualmente, la identidad entre democracia y Estado de derecho sirve para producir un régimen de identidad de la comunidad consigo misma, para hacer que se desvanezca la política bajo un concepto del derecho que la identifica con el espíritu de la comunidad (Rancière, 1997: 136-137).

Esta impugnación se expresa en iniciativas de Tribunales Populares, como el Tribunal Permanente de los Pueblos, así como las diversas iniciativas de procesos constituyentes que provienen de la ciudadanía y los movimientos sociales, embriones de nuevas gramáticas constitucionales y genealogías del derecho.

Según el enfoque de la contrademocracia, al pueblo elector se le contraponen de manera creciente las figuras del pueblo controlador/vigilante, pueblo-veto y pueblo-juez (Rosanvallon, 2007). De allí, la crítica al mito del ciudadano pasivo y la exaltación al reconocimiento de las expresiones de participación que van más allá de la lectura procedimentalista del voto. Recuperando incluso la perspectiva de Rousseau —que agregó a la idea de ciudadanía centrada en la representación por el voto, los derechos de opinar, proponer, dividir, debatir-, Rosanvallon considera tres dimensiones de interacción entre el pueblo y la esfera del poder: la democracia de expresión que consiste en "la toma de palabra de la sociedad [...] la formulación de juicios sobre los gobernantes y sus acciones"; la democracia de implicación que considera los medios a través de los cuales los ciudadanos se ponen de acuerdo y producen un mundo común, y la democracia de intervención que engloba todas las expresiones concretas de acción colectiva para obtener los resultados que la ciudadanía demanda (Rosanvallon, 2007: 36).

El último componente cardinal en la propuesta de la contrademocracia es el concepto de impolítica, que difiere de la idea de despolitización. Esta última implica un repliegue masivo de los asuntos públicos a la dimensión privada, signado por un consumismo político que termina potenciando el desencanto democrático; mientras que el concepto de impolítica se refiere a la falta de aprehensión global de los problemas ligados a la organización de un mundo común, es decir, el repliegue de lo político a un conjunto de asuntos sectoriales, regionales o locales que desactivan la potencia de lo político.

La democracia de oposición tiene como resultado un creciente distanciamiento entre las sociedades y las instituciones gubernamentales que gravitan alrededor de la precaria legitimidad del Estado. Pareciera que los entramados de la contrademocracia desdibujan la proposición de lo común y global de la sociedad, al punto en que el autor considera que "no hay política si las acciones no pueden inscribirse en una misma narración ni son representadas sobre un escenario público único" (Rosanvallon, 2007: 39). Esta propuesta representa una perspectiva de desafección por lo político global. 
Cuadro 1. Contrademocracia y desconfianza organizada



Fuente: Elaboración propia con base en Rosanvallon (2007).

Por su parte, Crouch (2004) propone la idea de "posdemocracia", entendida como una reducción del interés ciudadano por participar en los procesos democráticos y una pérdida contundente de poder real por parte de la clase subordinada —el mito del ciudadano pasivo- La conversión de la política a un asunto de élites cerradas constituye, según este enfoque, un retorno a tiempos pre-democráticos. En este sentido, la lectura de Crouch pareciera concebir la existencia de una democracia real, ipero en qué contexto?

Esta concepción eurocéntrica de posdemocracia tiende a desplazar "la política a un lugar neutral, con el fin de proclamar la muerte del antagonismo político y la aceptación resignada del reformismo político y la economía de mercado" (Monedero, 2012: 70). Esta lectura, por otro lado, parece confinada a una visión lineal y teleológica del tiempo político, ya que se enfrenta a la imposibilidad de interpretar lo democrático desde contextos históricos convulsos en los que el régimen liberal democrático es producto de una instauración externa o resultado de los imperativos de un diseño geopolítico. Esto es, de su imposición como sistema de gobierno convertido en una condición para transitar de contextos de guerra a procesos de paz negativa, ${ }^{1}$ como en algunos países de América Central, por ejemplo.

\footnotetext{
${ }^{1}$ La paz negativa es definida como la reducción del enfoque de paz a la ausencia de guerra declarada, de violencia directa (agresión física). La no guerra interpretada como la ausencia de conflictos armados. Mientras que la paz positiva se refiere a la superación de la violencia estructural, la armonía del ser humano consigo mismo, con los demás y con la naturaleza. Esta paz no supone la negación de la existencia de conflictos, sino, al contrario, la construcción de procesos que permitan afrontarlos y
} 
La relevancia del enfoque de la contrademocracia y el reconocimiento de la politización activa de la desconfianza organizada permiten interpretar lo democrático desde el ejercicio de una fuerza material, la resistencia, la práctica y reactividad directa. En todo caso, cabe considerar que el ejercicio político de las "sociedades en movimiento" en algunos de los territorios del sur de México y algunas experiencias en los países de Centroamérica se fundamentan en desafiar los imaginarios y las escalas preestablecidas para imaginar, configurar y disputar el sentido de lo común, constreñido a la dimensión de lo nacional.

Algunos de los procesos fundamentados en la contrademocracia erosionan el dominio de la escala y el ethos totalizante del Estado-nación moderno/colonial y fortalecen las prácticas locales-regionales mediante formatos de gobierno alternativos, anti-estatales, paralelos o, en distintos grados, autónomos. Estas prácticas reconducen lo político hacia nuevos ciclos de control o ejercicios de poder dentro y fuera del Estado, una tensión que Dussel propone reconocer en la configuración de un campo político a través de los conceptos de potentia y potestas (Dussell, 2010).

La potentia se refiere al "poder que tiene la comunidad como una facultad o capacidad que le es inherente a un pueblo en tanto última instancia de la soberanía, de la autoridad, de la gobernabilidad, de lo político" (Dussel, 2006: 16). Mientras que la "necesaria" institucionalización del poder de la comunidad, del pueblo, constituye lo que el autor denomina potestas. Se trata de una interrelación entre el punto generador del poder como facultad inherente (potentia) y su institucionalización y complejización en los heterogéneos canales constituidos en la forma Estado (el ejercicio efectivo del poder material), o cualquier estructura convertida en la depositaria (por delegación o secuestro) del poder institucional (potestas).

Más allá de la gigantesca polémica que conlleva el debate en torno a las mediaciones del poder-legitimidad,legalidad, representación, nodos de comunicación, democracia, etcétera-), lo que interesa destacar es la lectura que Dussel hace de la circulación del poder entre ambas dimensiones (ver cuadro 2). Por un lado, se concibe una posible construcción de poder regenerador, el poder delegado como potestas que es regulado por la potentia y devuelto cíclicamente (mandar obedeciendo). Por otro lado, la circulación del poder fetichizado que se convierte en poder para sí mismo (circuito de poliarquía y corrupción: mandar mandando). El desafío surge al intentar reconocer otros formatos de potestas fuera del Estado, es decir, instituciones sociales que se gestan y practican en la propia dinámica de la potentia y que surgen justamente al dinamizarse los poderes de obstrucción y el ejercicio propio de la contrademocracia.

a resolverlos de forma pacífica y justa (Fisas, 1998). 
Cuadro 2. De la potentia a la potestas

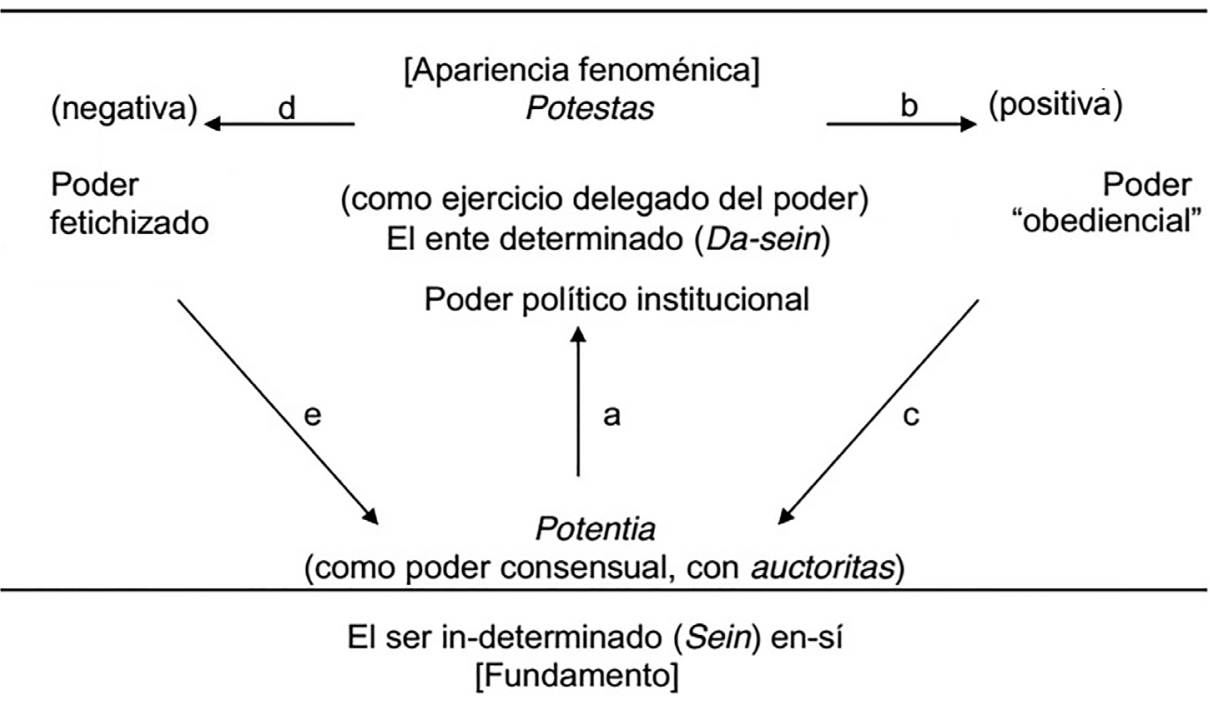

Aclaración al esquema: a) disyunción o desdoblamiento originario (ontológico) del poder primero (potentia) de la comunidad política que instituye la delegación del ejercicio del poder por instituciones y representantes (potestas) ("los que mandan"); b) ejercicio positivo del poder como fortalecimiento de la potentia; c) los que "mandan obedeciendo" (poder obediencial); d) fetichización de la potestas (se afirma a sí misma como origen soberano del poder sobre la potentia); e) el poder se ejerce como dominación o debilitamiento de la potentia: los que "mandan mandando". a-b-c: circulación del poder como regeneración; a-d-e: círculo corrupto del poder.

Fuente: Enrique Dussel (2006: 16).

¿Cómo ampliar el canon de lo democrático y lo político para interpretar las experiencias de autogobierno y las instituciones sociales autónomas que gestan formatos de poder y democracia directa, comunitaria, rotativa, sin recurrir a la potestas de arriba, a la forma Estado?

\section{Ampliación del canon democrático: democracia de alta densidad y demodiversidad}

Un debate central sobre la dimensión contrahegemónica de la democracia fue planteado en el trabajo de Avritzer y Santos (2005), Para ampliar el canon democrático. El recorrido conceptual de este debate parte de reconocer las condiciones estructurales de la democracia como modelo hegemónico de gobierno en el contexto de entreguerras (europeas: 1919-1939) y el escenario de la Guerra Fría abierto en 1945. La democracia 
liberal, convertida en la forma de gobierno hegemónica durante la Guerra Fría, restringida al caudillaje por lacaptación del poder devenidodel voto, una estructuraprocedimentalista y con contradictoria incapacidad distributiva, llevó a que la crítica marxista considerara que no era posible democratizar la relación fundamental entre producción material, capital y trabajo. Desde estas perspectivas críticas, se comenzaron a discutir modelos de democracia alternativos al liberal: la democracia participativa, la democracia popular en los países de la Europa del Este, la democracia desarrollista de los países recién llegados a la independencia, etcétera (Avritzer y Santos, 2005).

En la concepción de enfoques no hegemónicos de la democracia en el contexto de posguerra, y a partir de los argumentos de autores como Lefort, Castoriadis, Habermas, Lechner, Nun o Borón, la democracia se concibe como una gramática social y cultural de la sociedad que redefine su relación con el Estado, pero desde una perspectiva que centraliza el protagonismo de las formas heterogéneas de participación social, la cualidad histórica de la indeterminación de las sociedades y su pluralidad. Se replantean los referentes homogeneizantes desde los cuales se construye la idea de lo común como articulador de las sociedades nacionales, y la potencia sociohistórica de los movimientos sociales enfrentados a las determinaciones estructurales. Así, la democracia puede reinterpretarse como un proceso de ruptura y no sólo de reproducción, así como por múltiples tentativas para la reinstitucionalización de nuevas determinaciones, normas y leyes.

La recuperación de un discurso argumentativo vinculado al pluralismo y a las diferentes experiencias desde el Sur global es considerada por los autores como parte de una reconexión entre procedimentalismo y participación. Inspirados en el argumento de Jürgen Habermas y Joshua Cohen, la ampliación del canon democrático implica una apuesta por un procedimentalismo social y participativo: una forma de ejercicio colectivo del poder político cuya base sea un proceso libre de presentación de razones entre iguales, más que una mera autorización de gobiernos, como se concibe en las perspectivas hegemónicas de la democracia liberal (Avritzer y Santos, 2005: 42).

Otro elemento central de tal aproximación contrahegemónica se fundamenta en el rol de los movimientos sociales en la ampliación de lo político, dada su potencia de significaciones culturales que disputan la transformación de prácticas dominantes, el aumento de ciudadanía y la inserción en la política de actores excluidos. Se puso en el centro del debate la disputa por el significado de la democracia y los horizontes de posibilidad para refundar gramáticas sociales. En este debate florecieron las experiencias referenciales de América Latina y el Caribe, aunque en distintos grados, formas y momentos. A la par del discurso sobre la restauración (Sudamérica), instauración (Centroamérica) y reforma democrática (México), los procesos de "transición" en la década de 1980 trajeron consigo un debate sobre la relación entre procedimiento y participación social; el reconocimiento de las escalas no nacionales como fuentes de un nuevo eidos, es decir, determinaciones políticas basadas en la creatividad de los actores 
sociales (Castoriadis, en Avritzery Santos, 2005); asícomola relación entre representación y diversidad cultural y social. El caudal de este debate sobre la nueva gramática democrática fundamentó su discusión desde la recuperación de diversas experiencias de países del Sur global para reconceptualizar el sentido del discurso y la práctica democrática: Brasil, Colombia, Sudáfrica, Mozambique, India.

No obstante, esta riqueza experimental atravesó momentos de divergencia profunda entre algunas experiencias de América del Sur² y países como México. Más aún, con los países de Centroamérica en pleno conflicto armado y los posteriores escenarios de postguerra, enfrentados a "nuevas" variantes de violencia que cancelaron los procedimientos de democratización yelflorecimiento denuevas gramáticas democráticas. De allí la importancia misma de la metodología de la democracia contrahegemónica, capaz de reconocer actores, escalas y expresiones mismas de autorrepresentación que disputan los imaginarios y procedimientos políticos de la homogeneización impuesta por los Estados y los aparatos de democracia electoral. A esta epistemología de resignificación de lo democrático, se suman los criterios metodológicos propuestos para pensar desde una utopía crítica la denominada "democracia de alta intensidad":

[...] pasar de una teoría crítica monocultural a otra multicultural, para distinguir entre objetividad y neutralidad, para pasar de la problemática estructura-acción a la problemática acción conformista-acción rebelde, para analizar la cuestión del poscolonialismo [...] la equivalencia entre el principio de igualdad y el principio de diferencia" (Santos, 2006a: 71)

A las lecturas hechas sobre la ampliación del canon democrático, se suman otras iniciativas conceptuales orientadas a concebir la reinvención de la democracia, basada en el enriquecimiento conceptual que proviene del reconocimiento-acompañamiento a las experiencias concretas de lo neo-democrático. De estas experiencias derivan formatos concretos de democracia de alta densidad, es decir, capaces de restablecer sistemas contractuales desde la heterogeneidad de contextos, y a la vez desde matrices culturales divergentes: demodiversidad. Esto significa el reconocimiento y la aceptación de la coexistencia, pacífica o no, de diferentes modelos y prácticas democráticas alrededor del

\footnotetext{
${ }^{2}$ Un desglose sobre las manifestaciones de las nuevas gramáticas democráticas en América Latina, particularmente en varios países sudamericanos (Venezuela, Bolivia, Ecuador, Brasil, Argentina, Uruguay e incluso Chile), reconoce las siguientes características: los cambios en las tendencias políticas del mapa electoral latinoamericano; la presencia de corrientes políticas diferenciadas al interior de los Estados nacionales; la consolidación de una izquierda social desde los movimientos sociales, y los nuevos procedimientos y herramientas democráticas: referéndum, plebiscito, procesos constituyentes, etcétera (Preciado y Uc, 2009). Casi todos estos procesos, por cierto, cooptados o cancelados en México y los países de Centroamérica que atravesaban un conflicto armado.
} 
mundo que van más allá de la democracia representativa liberal. El proyecto de democracia radical y participativa propuesto por Santos gira alrededor de cuatro ejes:

[...] la preservación de la demodiversidad y el fortalecimiento del experimentalismo democrático; [...] la valoración positiva del «multiculturalismo emancipador» como forma de reconocimiento; [...] la articulación y el reforzamiento a escala local y global de las experiencias democráticas alternativas de alta intensidad, hasta ahora desarrolladas exclusivamente en contextos locales y [...] la complementación entre formas de democracia representativa y formas de democracia participativa (Aguiló, 2009: 382).

En este sentido, Mignolo reconoce que, si bien los movimientos sociales democratizadores son contestatarios a los discursos hegemónicos y los inserta en la discusión de una esfera política común, estos pueden o no reproducir la virtud o perjuicio de su origen, así como el potencial de la transformación. Se trata de un discurso que "lleva en sí el derecho a que ciertas sociedades describan y organicen a su manera la justicia, la equidad y la igualdad; pero no lleva en sí el derecho a negar y silenciar a quienes son democráticos de otra manerao, más aún, que postulan otra forma de igualdad y justicia que democracia" (Mignolo, 2008: 46, énfasis original). De allí la insistencia en distinguir entre democracia como proyecto imperial y democracia comodiversidad de proyectos, es decir, la pluriversidad como proyecto universal (Mignolo, 2008: 48, énfasis original).

La "democracia de alta intensidad" identifica cinco subcampos de relaciones sociales en los que los procesos de democratización son especialmente importantes: el espaciotiempo doméstico, de la producción, de la comunidad, de la ciudadanía, de las relaciones entre Estados. Desde allí, se reivindica como irrenunciable la redistribución y el ejercicio de poderes inclusivos, comunitarios y participativos; la reinvención de la ciudadanía desde formatos plurales y la capacidad de sustituir las relaciones de poder por formas de autoridad compartida, institucionalizadas en procesos que devienen de la capacidad de incidencia real y heterogénea en las gramáticas sociales, culturales y legales: estatutos legales y constituciones (Santos, 2003; 2006; 2010).

Esta perspectiva de democracia contrahegemónica conlleva la necesidad de un redescubrimiento democrático del trabajo, dela producción dealternativas de sociabilidad, de la democratización epistémica, e incluso de la lucha por la democracia redistributiva, capaz de convertir al Estado en componente del espacio público no estatal: el Estado como novísimo movimiento social. Lo cual conduce a reabrir la tensión democracia-capitalismo, ya que no es posible democratizar el Estado si a la vez no se democratiza la relación contractual y reguladora sobre los agentes privados - nacionales/internacionales - que han tomado un control sobre la definición del poder (Santos, 2003: 299). Se trata de la reinvención de la democracia en paralelo a la redefinición del Estado social. 
Cuadro 3. Componentes de la democracia de alta intensidad

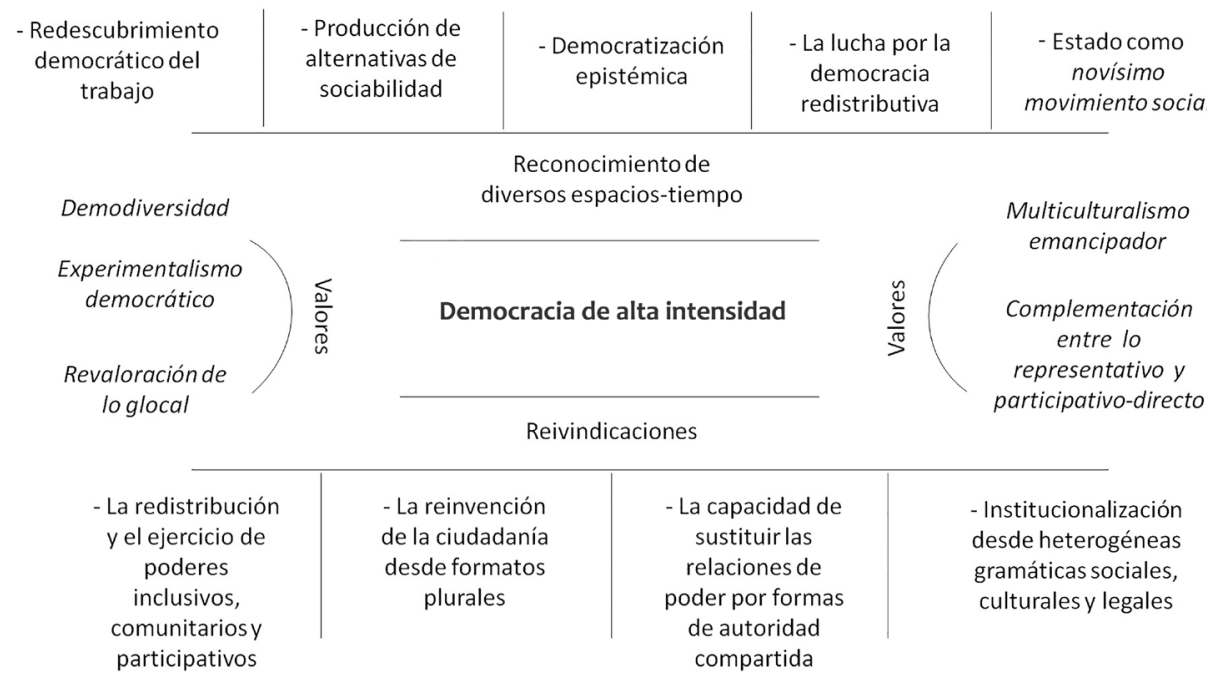

Fuente: Elaboración propia con base en Santos (2003; 2006; 2010); Mignolo (2008); Avritzer y Santos (2005).

Ante tal agenda, es importante dar paso a otra perspectiva con fundamentos radicales de lo democrático, sustentada en la autonomía y sus diversas lecturas anti-sistémicas.

\section{Autonomía y democracia: ¿más allá de la perspectiva radical?}

La perspectiva y concepto de autonomía es un referente de análisis con larga tradición en el pensamiento marxista. En esta corriente del pensamiento crítico, se ha buscado articular la idea de autonomía como emergencia del sujeto social y político, vinculado a la larga tradición filosófica kantiana de independencia, pero también al histórico desarrollo del pensamiento anarquista. A la vez, el concepto de autonomía se ha relacionado con el proyecto político de horizonte emancipatorio que, desde la perspectiva de la lucha de clases, se vinculó con la construcción del socialismo como proyecto de ordenamiento social alternativo al sistema capitalista (Modonesi, 2010: 99).

Al desentrañar algunas de las principales controversias sobre la interpretación del concepto de autonomía en el debate marxista, Modonesi reconoce la idea de "autonomía como independencia de clase — subjetiva, organizativa e ideológica- en el contexto de la dominación capitalista burguesa y la autonomía como emancipación, como modelo, prefiguración o proceso de formación de la sociedad emancipada" (Modonesi, 2010: 104). Rosa Luxemburgo insistía, por su parte, en el "movimiento mismo" de la 
clase y en la espontaneidad como recurso - "la coordinación espontánea de los actos políticos conscientes de una colectividad"-, apuntando hacia la experiencia - la lucha cotidiana - como factor fundamental de diálogo entre el ser social y la conciencia social (Modonesi, 2010: 105). Fue, entonces, alrededor de los consejos obreros soviets que se articularon los conceptos de autodeterminación, autoliberación, autogobierno, autorreglamentación y autoeducación.

La noción de autonomía ha estado estrechamente ligada, en la praxis política contemporánea, a la idea de autodeterminación, independencia nacional o incluso a la lectura sobre los límites de la esfera estatal propuesta por Marx y discutida por Engels y Poulantzas: la autonomía relativa del Estado (Tapia, 2009). La idea de autonomía relativa consiste en:

[...] pensar que históricamente se producen algunas coyunturas — que pueden ser de corta, mediana o larga duración - en las que la dirección del estado se distancia, más o menos, respecto de las determinaciones estructurales y económicas más inmediatas expresadas a través de la presencia directa de miembros de la clase dominante en el seno de los principales puestos y cargos públicos de dirección en el estado (Tapia, 2009: 111).

Esta idea de autonomía relativa no implica que el Estado se desvincule radicalmente de las estructuras dominantes del sistema capitalista, pero sí reconoce que las coyunturas de recambio de las élites o el desplazamiento de las clases dominantes en la dirección del Estado implican campos políticos más autónomos. De allí que, en varios casos en que ocurre este viraje hacia proyectos populistas o revolucionarios, reaparezcan fortalecidas las reivindicaciones nacionalistas y soberanistas. De hecho, las propias experiencias del discurso revolucionario e insurgente en nuestras regiones de estudio: el sur-sureste de México y Centroamérica, dentro de su heterogéneo caudal -marxismo leninismo, guevarismo, trostkismo, magonismo-, han recurrido a la idea de autonomía como expresión de soberanía nacional; como proyecto antiimperialista en el marco de los procesos de liberación nacional. $\mathrm{O}$, en su defecto, como expresión nacionalista antiestatal y anticapitalista, como el neozapatismo.

La autonomía pareciera expresar una sedición ante la estructura hegemónica que ordena el sistema de poder totalizado por el Estado y el capital, y a la vez una fuente de autodeterminación popular de las masas, definida como "la capacidad actual de dar contenido político a lo que haya de democratización social y de poner en movimiento el espacio que concede la democracia representativa" (Zavaleta, 1983: 243).

En todo caso, la autonomía en clave no estatal representa una expresión que parte de la autogestión de una estructura de poder, por ejemplo comunitaria, al redefinir las prácticas y los ejercicios territoriales de autogobierno, que buscan prescindir de su 
relación antagónica con el Estado y el capital para autogobernarse. Esto no implica que se abandone la estructura de poder y el conflicto, sino un cambio de lugar en el proceso de producción de los términos de la misma estructura. El "movimiento de los movimientos" contemporáneo en América Latina (Negri, 2008) se caracteriza por asumir los grandes límites de la representación democrática liberal. Su fundamento está en la participación directa y la construcción de instancias de representación-participación para reconstituir el poder constituyente popular, con el fin de incidir en la reestructuración del Estado o constituir lo político más allá de él.

En este sentido, la democracia asumida y reformulada desde las prácticas de autonomía indígena no estatal, por ejemplo, o desde prácticas con una autonomía relativa frente al Estado, parte, en primer lugar, de la ampliación del lugar para el quehacer político; de la estructura; de los actores; las escalas y las formas de gobierno. Sin abandonar la idea radical de la política que se concentra en la agonía de las partes o campos enfrentados y abiertos (desde la externalidad a la que se refieren Laclau y Mouffe, 2008), las democracias autónomas, o desde abajo — demoeleutheria (Alonso, 2015) — producen canales de energía política desde una resistencia que parte de un principio de desconexión relativa respecto a las fuentes hegemónicas en el conflicto.

En todo caso, la autonomía no es un principio o canon inamovible sino un fenómeno histórico situado políticamente. Desde allí, es posible problematizar la articulación entre democracia y autonomía, que resalta en las agendas de los movimientos sociales y pueblos en movimiento indígenas, originarios, populares y afrodescendientes, con mayor impacto en la construcción de fuentes de resistencia, construcción de alternativas y poder contrademocrático a las estructuras hegemónicas.

Resulta paradójico, siguiendo a Gramsci, concebir la disputa por la hegemonía de los bloques históricos sin considerar en el horizonte la capacidad de estas subjetividades políticas de hacerse de las instituciones hegemónicas (acceso al potestas). No obstante, los sujetos alternativos que se conforman en el campo político como movimientos sociales contestatarios - "anclados" discursiva y materialmente en diversas dimensiones de la exclusión, la opresión, la subalternización, es decir, fuera del derecho pleno para ejercer ciudadanía- "[e]n principio son portadores de reivindicaciones particulares y diferenciadas para luego interpelar a actores colectivos afines que pueden devenir en una situación estratégica o en su caso en un momento constitutivo" (Zegada, 2010: 18).

Una particular posición en el discurso político de los movimientos subalternos en América Latina y el Caribe se basa en la resustancialización de la democracia no estatal y en la capacidad de autodefinir la práctica y la teoría sobre la autodeterminación y la autonomía. La antagónica relación con el Estado se ha fortalecido en la región como parte de un proceso de descolonización del poder, del saber, del ser y de su relación con la naturaleza. La capacidad antagónica frente a la política estatal, se ha configurado en múltiples formatos de autonomía. 
Por un lado, puede volcarse hacia la autorrepresentación y el autogobierno, que reivindica su sentido de pertenencia a lo nacional mientras niega al Estado como interlocutor legítimo. Lo expulsa de lo nacional desde su práctica local de democracia radical antiestatal y paradójicamente impolítica, fundamentada en la producción de lo común en espacios-tiempos, saberes, religiosidad, autoridad, estructuras de autorrepresentación y agendas públicas múltiples, que no tienen como fin último la agenda de lo común establecida por el espacio-tiempo del Estado-nación. Se trata de una desconexión con las políticas públicas, los partidos políticos y los formatos de la democracia instrumental.

Por otro lado, esta capacidad antagónica puede orientarse a la construcción de canales que se instituyen desde una autonomía relativa frente al Estado. Algunos derivan en la autogestión territorial de su seguridad y la elección de autoridades fuera de los partidos políticos, pero demandan el reconocimiento de sus autoridades por parte del Estado. En otros casos, combinan el uso de formatos de autodeterminación con canales dominantes — sistema de partidos_ y la formación de alianzas nacionales o transnacionales. En todo caso, la interpretación de esta gama de formatos de autonomía heterogénea constituye una fuente empírica de gran importancia para la resustancialización conceptual de lo democrático.

Pensar la democracia "desde los márgenes" (Zegada, 2013) coincide con la reapropiación conceptual de la práctica autonómica y, a la vez, con un heterogéneo impulso a la producción de alternativas de autogobierno. Leyva propone repensar el quehacer autonómico desde cuatro ángulos: como forma de hacer política; como diversidad, potencia y posibilidad; como prefiguración, y como horizonte emancipatorio (Leyva, 2014: 364). Si el marxismo y el anarquismo se reconocen como las dos fuerzas históricas productoras del debate conceptual y la construcción política de la autonomía, los movimientos indígenas originarios, los movimientos feministas anticoloniales y los proyectos en defensa de la tierra, desde enfoques posdesarrollistas y anto-extractivistas, se han convertido en una de las fuentes elementales para la emergencia creativa y la práctica autonómica y democrática en América Latina.

En este sentido, Leyva recupera el universo al que se recurre desde heterogéneas experiencias para definir las gramáticas autonómicas y sus diferenciadas implicaciones teórico-epistémicas. A saber: regímenes, gobiernos, luchas, demandas, derechos, arreglos, ordenamientos, estrategias autonómicas, etcétera. De ellas destaca, por ejemplo, la dimensión de las luchas epistémicas que portan, según la autora, sujetos en pie de lucha como los (neo) zapatistas de México. En ello coincide López Bárcenas (2015), quien reconoce que el potencial que otorga la construcción de autonomía a los movimientos indígenas se expresa en el poder que detentan, no en las estructuras materiales de poder, 
sino en la palabra: gramáticas y luchas epistémicas 3 . Cabe reconocer, en todo caso, un conjunto de referentes - dentro de un complejo caudal- en torno al desarrollo conceptual de autonomía, con el fin de interpretar sus contenidos y sus alcances en el debate de las democracias otras.

El problema de la articulación entre la perspectiva de autonomía como horizonte emancipatorio y democracia es el sentido que delimita el bien común. ¿Cuál es el espectro de sociedad y gobierno para todos (más allá incluso del mejor gobierno) que plantea una autonomía territorializada que se atrinchera y aísla del Estado y de la esfera de lo nacional? El proceso de descolonización del concepto democracia puede ser un "dolor de cabeza" para mantener la congruencia histórica en el debate definido por la ciencia política. Pero lo cierto es que la práctica concreta de los movimientos en nuestra región no está condicionada por el horizonte ideológico de lo nacional. Las escalas y la definición identitaria del movimiento político autonómico,es, en este sentido, transversal a lo nacional y a la vez "glocal".

\section{Algunas conclusiones: la potencia de lo posible}

En paralelo a la reduccionista lectura liberal de la política que condiciona la incidencia de la sociedad civil en la esfera de gobierno sólo en los canales que definen el Estado, el mercado y la amalgama abstracta de poderes fácticos -con su correspondiente crítica-, los discursos y prácticas concretas para la apropiación del quehacer político producido desde las sociedades, pueblos en movimiento heterogéneos - y contradictorios - en nuestra región, constituyen posibilidades conceptuales para interpretar lo democrático en plural.

Por ello, subyacen un conjunto de interpretaciones teóricas que han derivado de las propias prácticas alternativas que algunos actores sociales, organizados bajo el proceso de organización de la desconfianza o la resistencia común contra fraudes electorales, despojo de tierras, o impugnación directa a los poderes instituidos, han rechazado para resustancializar la idea y práctica de lo democrático.

El reconocimiento de la pluralidad como praxis concreta del quehacer político y la construcción de formas de autogobierno que redefinen lo democrático encuentran fundamento en un conjunto heterogéneo de escalas, procedimientos, ciclos, horizontes, valores y tejidos de lo común que una parte de las sociedades decide asumir como disenso ante el discurso hegemónico de la democracia liberal procedimental, aunque también como alternativa política de sobrevivencia ante los sistemas de despojo y violencia que ejerce la misma estructura totalizante de dicho discurso. Se abren formas alternativas

\footnotetext{
${ }^{3}$ Desde estas perspectivas, en la tercera parte de este libro se presentan dos trabajos cardinales para interpretar la idea de democracia desde abajo y en clave autonómica desarrollados por Jorge y Carlos Alonso, uno, y otro por Xochitl Leyva y Axel Köhler.
} 
para ejercer ciudadanías heterogéneas que demandan la ampliación de las instituciones del Estado,o la construcción de instituciones paralelas.

Elaborar un balance conceptual de las democracias otras fundamenta la dimensión de lo posible, en términos de potencialidad y a la vez como una expresión concreta para identificar las gramáticas democráticas subalternas, paralelas o alternativas desde donde se ejercen prácticas directas del quehacer político. En este sentido, es posible reconocer un conjunto de resignificaciones de lo político y de la democracia misma definida desde los márgenes, en clave no estatal o desde una capacidad efectiva de incidencia-control sobre la estructura hegemónica de los Estados nacionales mediante nuevos ciclos refundacionales.

\section{Referencias bibliográficas}

Aguiló, Antoni (2009). "La democracia contrahegemónica en la teoría política de Boaventura de Sousa Santos: notas sobre un proyecto emancipador para el siglo XXI", en Presente, pasado y futuro de la democracia, pp. 377-383.

Avritzer, Leonardo y Boaventura de Sousa Santos (2005). "Para ampliar el canon democrático", en Democratizar la democracia: los caminos de la democracia participativa, México: FCE.

Bobbio, Norberto (2001) [1984]. Estado, gobierno y sociedad. Por una teoría general de la política, México: FCE.

Crouch, Colin (2004). Laposdemocracia, Madrid: Taurus.

Dagnino, Evelina (coord.) (2008). La disputa por la construcción democrática en América Latina, México: FCE.

Dussel, Enrique (2006). Veinte tesis de política, México: Siglo XXI.

Fisas, Vicenç (1998). Cultura de pazy gestión de conflictos, Barcelona: Icaria/UNESCO.

Laclau, Ernesto y Chantal Mouffe (1987). Hegemonía y estrategia socialista. Hacia una radicalización de la democracia, Madrid: Siglo XXI.

Leyva, Xochitl (2014). "De luchas autonómicas y epistémicas en tiempos de crisis y guerras múltiples”, en Escárzaga, F. y Raquel Gutiérrez (coords.), Movimiento indígena en América Latina: resistencia y transformación social III, México: CIESAS/UAM/BUAP/ CEAM.

López Bárcenas., Francisco (2015). Autonomía y derecho indígena en México, México: CENEJUS.

Mbembe, Achille (2006). "Necropolitique", en Traversées, diasporas, modernités. Raisons politiques, núm. 21, pp. 29-60.

Mignolo, Walter (2008). "Hermenéutica de la democracia: el pensamiento de los límites y la diferencia colonial”, en Tabula Rasa, Bogotá, Colombia, núm. 9, julio-diciembre, pp. 39-60. 
Modonesi, Massimo (2010). Subalternidad, Antagonismo, Autonomía. Marxismos y subjetivación política, Buenos Aires: CLACSO.

Monedero, Juan Carlos (2012). “iPosdemocracia? Frente al pesimismo de la nostalgia, el optimismo de la desobediencia”, en Nueva Sociedad, núm. 240, julio-agosto, pp. 67-86.

Negri, Toni (2008). “El movimiento de los movimientos”, en García Linera, Álvaro y Luis Tapia (coords.). Imperio, multitudy sociedad abigarrada, Buenos Aires: CLACSO.

Preciado, Jaime y Pablo Uc (2009). "Actores de la nueva gramática democrática en América Latina”, en Martins, Paulo (ed.) América Latina e Brasil em perspectiva, Brasil: Editora Universitaria/ALAS-UFPE.

Rancière, Jaques (1996). El desacuerdo. Política y filosofía, Argentina: Nueva Visión.

Rancière, Jaques (2006). El odio a la democracia, Buenos Aires: Amorrortu editores.

Rosanvallon, Pierre (2007). La contrademocracia. La política en la era de la desconfianza, Buenos Aires: Manantial.

Santos, Boaventura de Sousa (2006a). Renovar la teoría crítica y reinventar la emancipación social, Buenos Aires: CLACSO.

Santos, Boaventura de Sousa (2006b). Democratizar la democracia. Los caminos de la democracia participativa, México: FCE.

Santos, Boaventura de Sousa (2010). "La democracia revolucionaria, un proyecto para el siglo XXI. Entrevista a Boaventura de Sousa Santos. Entrevista de Antoni Jesús Aguiló", en Revista Internacional de Filosofía Política, núm. 35, octubre, Madrid.

Tapia, Luis (2009). La coyuntura de la autonomía relativa del estado, Buenos Aires: Muela del Diablo/CLACSO.

Vallespín, Fernando (2000). El futuro de la política, Madrid: Taurus.

Zavaleta, René (2009 [1983]) "Las masas en noviembre" y "Cuatro conceptos de democracia”, en Tapia, Luis (comp.). La autodeterminación de las masas, Bogotá: Siglo del Hombre Editores/CLACSO.

Zegada, María et al. (2011). La democracia desde los márgenes: transformaciones en el campo político boliviano, La Paz: CLACSO/Muela del Diablo.

Zemelman, Hugo (2001). De la historia a la política. La experiencia de América Latina, México: Siglo XXI. 



\section{Segunda parte. Centroamérica y México}

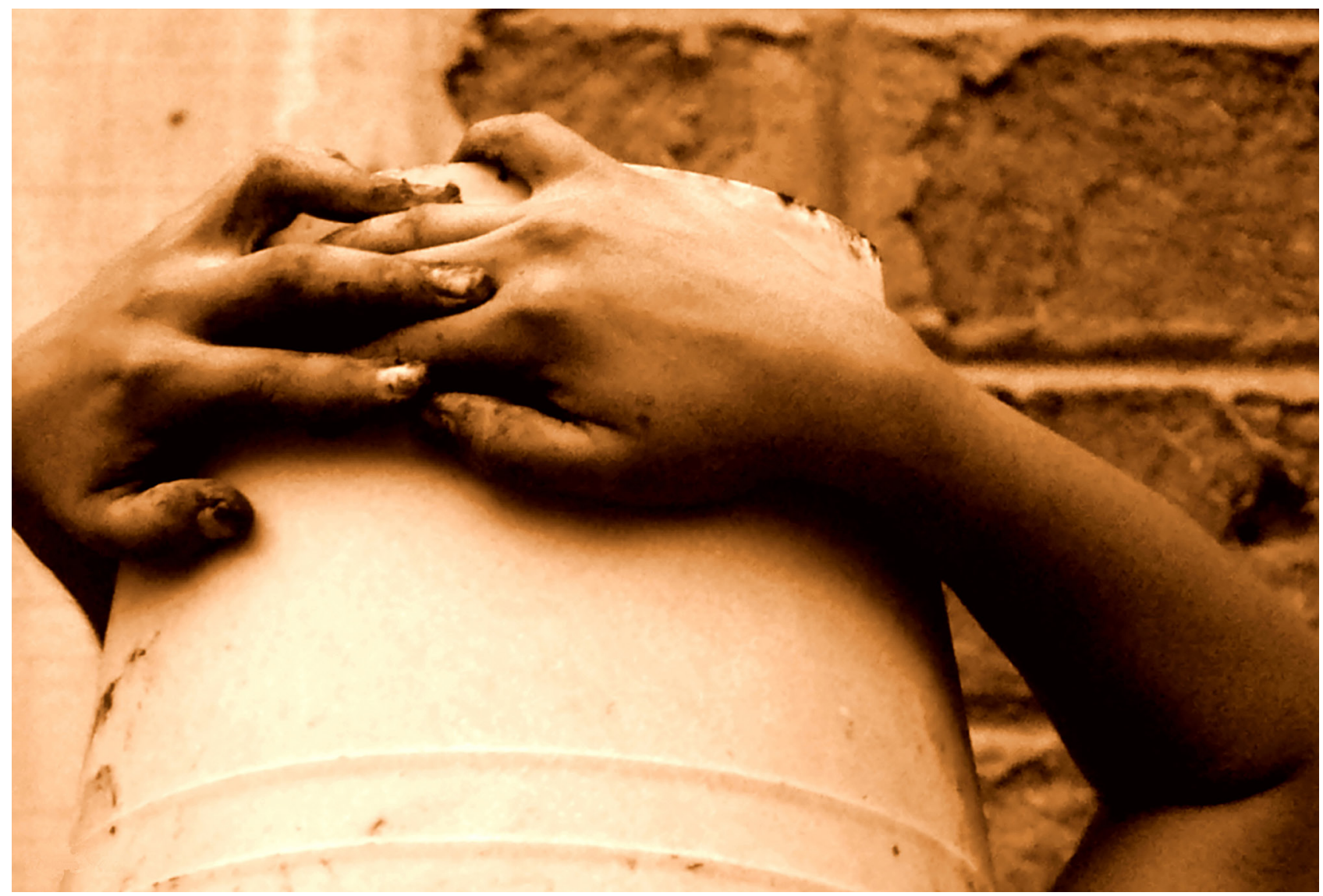




\title{
El Triángulo Norte de Centroamérica: dilemas de la democracia en una subregión conflictiva
}

\author{
Daniel Villafuerte Solís
}

\section{Introducción}

Esta contribución tiene el propósito de aportar algunas reflexiones en torno a lo que ocurre en elllamado Triángulo Norte de Centroamérica (TNCA), una subregión integrada por Guatemala, El Salvador y Honduras, estratégica en la geopolítica de Estados Unidos por las características que la definen y que dificultan el pleno ejercicio de la democracia: el mayor índice de violencia en el mundo; altos niveles de pobreza y exclusión social; crecientes flujos migratorios a Estados Unidos; además de haberse constituido en un territorio por donde pasa el 90\% de la droga que consume Estados Unidos.

Esta subregión tiene una historia particular, cuyo común denominador ha sido la existencia de regímenes militares y autoritarios, con una oligarquía que se ha venido reciclando con los cambios de la economía regional y mundial, así como la existencia de instituciones frágiles cuyo resultado son Estados débiles o "fallidos". Estas características no permiten hablar de democracias robustas y consolidadas; por el contrario, son regímenes que no transitaron de manera plena a la democracia.

Uno de los hechos más sobresalientes en la coyuntura política de la subregión es la renuncia obligada del presidente guatemalteco Otto Pérez Molina, a unos días de llevarse a cabo las elecciones presidenciales —domingo 6 de septiembre de 2015- y a cuatro meses de concluir su mandato que asumió el 14 de enero de 2012. En efecto, a la una de la madrugada del 3 de septiembre de 2015 se hizo oficial el anuncio de la renuncia de aquél, luego de una sistemática presión de la sociedad que cada sábado desde el mes de abril del mismo año se hiciera presente en el zócalo capitalino para manifestar su repudio a la red de corrupción en el gobierno y exigir la renuncia del presidente Pérez Molina.

En efecto, la "primavera guatemalteca" comenzó el 18 de abril de 2015 con presiones de la sociedad civil, a las que se fueron sumando sectores representativos de la sociedad 
guatemalteca, en especial los empresarios agrupados en el Comité Coordinador de Asociaciones Agrícolas, Comerciales, Industriales y Financieras (CACIF), las iglesias católica y evangélica que en las últimas semanas del desenlace se pronunciaron a favor de la renuncia y, finalmente, el gobierno de Estados Unidos, a través de su embajada en Guatemala. En todo este proceso, el papel de la Comisión Internacional contra la Impunidad en Guatemala (CICIG) fue determinante. La investigación realizada por este organismo de la ONU, al que Pérez Molina se había opuesto a que siguiera funcionando, ${ }^{1}$ dio como resultado una serie de detenciones de altos funcionarios y llevó a la renuncia y proceso judicial de la vicepresidenta Roxana Baldetti.

Otro acontecimiento anterior, de notoria importancia política, ocurrió en El Salvador con el triunfo del Frente Farabundo Martí para la Liberación Nacional (FMLN), que llevó a Mauricio Funes a la Presidencia de la República, y se mantendría en el poder con la elección del actual presidente, Salvador Sánchez Cerén, que comenzó su mandato el 1 de junio de 2014, en una votación sumamente reñida con el partido tradicional de derecha, Alianza Republicana Nacionalista (ARENA).

En sentido contrario, en el caso de Honduras se estrena en 2009 un nuevo tipo de golpe de Estado, donde el Congreso destituye al presidente, quien es sacado del país por militares a Costa Rica. La sospecha de que Estados Unidos estuvo detrás de esta acción se ha confirmado ahora por filtración de conversaciones. Después del golpe de Estado se instauró un periodo de transición, en medio de una represión brutal a los simpatizantes de Manuel Celaya, con Porfirio Lobo, un empresario tradicional. Posteriormente, con el gobierno de Juan Orlando Hernández, un presidente muy leal a los dictados de Estados Unidos, han ocurrido en los meses de abril a julio de 2015, con el contagio de la "primavera guatemalteca", diversas manifestaciones para pedir su destitución y la instalación de una Comisión Internacional contra la Impunidad.

Con el propósito de guiar metodológicamente nuestro trabajo, formulamos una serie de preguntas que no necesariamente tendrán una respuesta: ¿Cuál es el estado de la democracia en el Triángulo Norte de Centroamérica? ¿Se puede hablar de democracia en esta subregión o de múltiples democracias? ¿Hacia dónde se encamina la subregión en el marco de la geopolítica en el mundo de hoy? ¿Cómo se articula el modelo económico con la democracia?

\footnotetext{
${ }^{1}$ La CICIG se estableció el 12 de diciembre de 2006 y entró en vigor el 4 de septiembre de 2007, por medio del decreto 35-2007, ratificado el 23 de agosto del mismo año. El 18 de diciembre de 2013, el presidente Pérez Molina descartó ampliar el plazo para que siguiera operando este organismo y declaró a los medios: "No vamos a seguir dependiendo de organismos internacionales, tenemos que hacer nuestros propios esfuerzos [....]. Temas que investigar siempre van a haber, para eso tenemos al Ministerio Público, tenemos la Corte Suprema de Justicia y esperamos que las instituciones queden fortalecidas" (Prensa Libre, 18 de diciembre de 2013).
} 
EL TRIÁNGULO NORTE DE CENTROAMÉRICA...

\section{Coordenada metodológica}

La complejidad social, política, económica y ambiental que hoy aqueja a Centroamérica lleva entre sus ingredientes la pobreza, la desigualdad social, el desempleo, el hambre, la exclusión social, la migración internacional, el narcotráfico, la violencia de Estado y la de grupos delincuenciales —entre otros, las pandillas juveniles-, crisis alimentaria y hambre, con una economía sustentada en la industria maquiladora y un modelo extractivista que impulsa la explotación minera, la producción de palma africana y la caña de azúcar, con la consecuente contaminación y degradación de los recursos naturales de forma acelerada. Este panorama no deja expectativa para una población joven en crecimiento, cuya vulnerabilidad es creciente frente a la incapacidad del Estado para brindar protección y alternativas de desarrollo o, mejor dicho, al desarrollo.

Frente al panorama anterior, resulta problemático hablar de democracia como un campo particular y separado del resto de las esferas de la vida económica y social. En este sentido, una coordenada metodológica es ubicar los cambios en lo político, a partir de las trasformaciones en el programa económico que se vienen operando en la región y la manera en que éstas se corresponden con el ejercicio político. Además, es necesario articular el ámbito de lo social en el marco de las transformaciones del Estado.

En este sentido, resulta útil recuperar los aportes teóricos de dos autores, Ulrich Beck (1998) y Joachim Hirsch (2001), quienes desde la reflexión de la globalización plantean una serie de problemas que van en el tenor de encontrar explicaciones más allá de lo político. En primer lugar, resulta interesante retomar el planteamiento de Ulrich Beck cuando refiere que "la economía que actúa a nivel mundial socava los cimientos de las economías nacionales y de los Estados nacionales, locual desencadena una subpolitización de alcances imprevisibles". Y añade: "con esto se está dando la jubilación del Estado, se libera el capital de la camisa de fuerza del Estado y del trabajo" (Beck, 1998: 16).

De manera complementaria, Beck refiere: "Los distintos partidos políticos, sorprendidos y fascinados por la globalización debilitadora de las instituciones, han comenzado a sospechar que se pueden convertir en sus propios sepultureros" (1998: 17). La democracia supone condiciones de convivencia en una sociedad que tiene que ver con el bienestar, el empleo, la salud, la educación, la justicia, la libertad de expresión. Donde estos derechos están restringidos o sufren déficit resulta difícil hablar de una democracia en general, es necesario adjetivarla.

Por otra parte, Joachim Hirsch habla del Estado nacional de competencia, cuyo significado borda las consecuencias políticas y sociales de la globalización. En particular, el poder de las transnacionales. Este Estado descrito por Hirsch se caracteriza por "lograr la capacidad competitiva en dimensión global, en aras de la rentabilidad de los emplazamientos para el capital internacional que se torna cada vez más flexible (2001: 47). Esto se traduce en un "progresivo desmembramiento espacial y social, imposibilitando postular un proyecto 
social abarcador". En suma, en el Estado Nacional de competencia la vigilancia policial reemplaza a las prestaciones sociales, se subvenciona la educación privada en vez de construir escuelas públicas.

El Estado no es lo que alguna vez fue; se abandona cada vez más la idea de un estado soberano hacia afuera y las multinacionales se colocan como un actor independiente con un campo de acción global, de manera que la política asume la forma de negociaciones.

Mientras más intensa y directa es la influencia del capital internacional, el Estado más se independiza de los intereses de los asalariados y del empresariado no incorporado a la internacionalización (agricultores, pequeños empresarios, los nuevos emprendedores de la economía informal).

Es cierto que los países centroamericanos han transitado de un periodo de guerra civil, impulsado por fuerzas de Estados militarizados y respuestas armadas de sectores de la sociedad, a procesos de paz — en los casos de El Salvador y Guatemala, de manera negociada-, lo que ha abierto un camino a condiciones de convivencia. En el caso de Nicaragua, el triunfo de la guerrilla sandinista, a mediados de 1979, imprimió otro rumbo a la dinámica política. Por su parte, Honduras mantuvo desde mediados de los años setenta un historial centrado en gobiernos de corte militar y los presidentes provenientes de los partidos liberal y nacionalista muy apegados a los intereses oligárquicos y de Estados Unidos.

Sin embargo, hoy las sociedades centroamericanas viven distintos procesos en su práctica de gobierno, pero todos operan con un programa económico de corte neoliberal común, cuya práctica implica la erosión del sistema democrático. La experiencia reciente en Costa Rica, con el gobierno de Laura Chinchilla, dejó claro que la profundización de las políticas neoliberales lleva a distanciarse de los grupos de población mayoritarios.

Son sociedades con enormes rezagos sociales -marcadamente menores en el caso de Costa Rica-, pobreza, exclusión, desigualdad, problemas alimentarios, violencia y violencia de Estado, particularmente en los casos de Guatemala y Honduras. En medio de todo, vemos un creciente éxodo de jóvenes, mujeres y niños hacia Estados Unidos en busca de empleo y seguridad. La migración se convirtió, en tiempos de democracia y mercado, en la fuente más importante de divisas.

Si bien es cierto que los acuerdos de paz allanaron el camino para la reconstrucción de las sociedades y la instauración de la democracia, no han conducido a una realidad social y económica distinta. Son economías débiles, centradas en la mayoría de los casos en el sector de bienes primarios y en la industria maquiladora. En lo político predominan ahora gobiernos civiles con una ideología de derecha; en Guatemala, su gobierno fue encabezado en los últimos cuatro años por un ex militar.

Sin embargo, zqué hay en el fondo? En paralelo a la construcción de la democracia, se ha venido transitando en alguna medida hacia lo que Hirsch denomina Estado nacional de competencia, donde el Estado y sus instituciones colocan en primer plano la economía y los 
intereses de los grandes capitales, liderados por la empresas multinacionales, quienes negocian, hacen política a favor de sus intereses, de manera que favorezca el proceso de acumulación.

\section{El Triángulo Norte de Centroamérica hoy}

De acuerdo con datos de la CEPAL (2014), en el año 2000, la subregión del Triángulo Norte de Centroamérica (TNCA) contaba con una población de 23399000 habitantes, para el 2015 se estimó en 30941000 y la proyección para el 2025 es de 38990 000. De cumplirse esta proyección, la población habría aumentado el $67 \%$ con respecto al año 2000. Si consideramos que el escenario económico, social y político se mantiene como hasta ahora, tendríamos una realidad más compleja y difícil de superar, con viejos-nuevos problemas tales como la pobreza, las tasas de migración, polarización social y violencia.

El aparato económico, tal como está diseñado, lejos de proveer los empleos necesarios para una población en crecimiento, tenderá a aumentar el ejército de desocupados, precarizados y vinculados al sector informal. Si comparamos la migración trasnacional y el monto de las remesas entre los años 2000 y 2015, podemos tener una idea de la dimensión real del éxodo que se está operando en esta subregión. A lo largo de estos quince años, el patrón migratorio ha cambiado de manera significativa, lo que implica el desgarramiento social en los lugares de origen: la migración de mujeres, niños y adolescentes es cada vez mayor. La expulsión de la población y su inserción en el mercado laboral de Estados Unidos bajo condiciones de clandestinidad, de una ciudadanía negada o secuestrada durante muchos años, proyecta a las sociedades de origen con un futuro sombrío, que no contribuye para nada al desarrollo de un sistema democrático.

Un artículo publicado por el Migration Policy Institute revela el ritmo de crecimiento de la población centroamericana en Estados Unidos:

La población inmigrante centroamericana en los Estados Unidos ha crecido rápidamente en las recientes décadas, triplicándose de 345655 en 1980 a 1.1 millones para 1990 y casi duplicándose a 2.0 millones en 2000 . Entre 2000 y 2009, la población de inmigrantes centroamericanos creció casi alrededor de 890 000, un aumento similar gtal crecimiento de la población de 910000 durante los años 1990. Este crecimiento ha sido impulsado principalmente por inmigrantes de El Salvador y Guatemala, que representan el 41.2 y 28.7 por ciento, respectivamente, del aumento total de los nacidos en Centroamérica entre 1980 y 2009 (Terrazas, 2011).

De acuerdo con la misma fuente, los tres países que conforman el TNCA sumaron en l, 580900 migrantes en Estados Unidos en el año 2000 y para el 2009 habían aumentado a 2416500 , lo que arroja un incremento de casi el 53\%. El mayor incremento se produjo 
entre 1990 y 2000, cuando alcanzó el 97.6\%. Para 2013, la población de estos países nacida en el extranjero que vivía en Estados Unidos había alcanzado 2505000 personas, casi un millón más de lo estimado en el año 2000. Si a esta cifra se suman las personas nacidas en Estados Unidos, obtenemos 4095000.

Por países tenemos el siguiente comportamiento: en el caso de Honduras, desde 1990 la población en Estados Unidos se ha multiplicado por seis, pasando de 127000 a 791000 en 2013 (López, 2015a). Por su parte, la población guatemalteca aumentó en casi cinco veces, al pasar de 267000 a 1.3 millones en el mismo periodo (López, 2015b). Finalmente, la población salvadoreña en Estados Unidos se triplicó al aumentar de 563000 en 1990 a dos millones en 2013 (López, 2015c). ${ }^{2}$

En concordancia con el aumento de la población del TNCA en Estados Unidos, se registra un notable incremento en el envío de remesas familiares en los últimos tres lustros. En 2015 el Centro de Estudios Monetarios Latinoamericanos (CEMLA) y el Fondo Multilateral de Inversiones (FOMIN) del Banco Interamericano de Desarrollo publicaron el informe sobre remesas con el sugerente título de Las remesas a América Latina y el Caribe superan su máximo valor histórico en 2014 (Maldonado y Heyem, 2015). Y es que para este año los tres países sumaron 13114 millones de dólares, correspondiendo 5544 millones a Guatemala, 4217 millones a El Salvador y 3353 millones a Honduras. Estos tres países concentraron el 20\% de las remesas que llegaron a América Latina y el Caribe.

Una visión retrospectiva permite ver el notable incremento de las remesas y la importancia que van adquiriendo en proporción al PIB, a las exportaciones y a la inversión extranjera directa (IED). En 2000, la información de los bancos centrales de cada país revelaba que las remesas sumaron 2754.7 millones de dólares que, comparado con lo obtenido en 2014, arroja un incremento del 375\%. En el año 2000 El Salvador obtuvo 1750.7 millones de dólares; Guatemala alcanzó 563.4 millones, y Honduras 440.6 millones de dólares.

Si comparamos el monto de las remesas obtenidas en 2014 con la inversión extranjera directa que llegó a estos tres países, que totalizó 2815 millones de dólares, vemos que este rubro representó únicamente el 21.5\%. Esta correlación muestra que la migración y las remesas se convirtieron en un fenómeno estructural, que retrata el carácter de estas sociedades desgarradas. Adicionalmente, vemos que las remesas representaron para Honduras el 36.6\% de las exportaciones de bienes y servicios y superaron con mucho el valor de los principales rubros de exportación: banano, melones y sandías, legumbres y hortalizas, café, aceite de palma y camarones, que sumaron 1992 millones de dólares; en el

\footnotetext{
${ }^{2}$ Las cifras para los tres países incluyen tanto a la población que nació en la Unión Americana como a la que nació fuera de Estados Unidos; en este último caso se registró un incremento del 407\% para Honduras, del 300\% para Guatemala y del 156\% en el caso de El Salvador. Estas cifras muestran un intenso proceso migratorio.
} 
caso de El Salvador las remesas significaron el 80\% del valor de las exportaciones de bienes que alcanzaron 5272.7 millones de dólares, y para Guatemala las remesas significaron el $51.3 \%$ de las exportaciones de bienes.

La migración está articulada con la pobreza que en estos países alcanza proporciones alarmantes, un problema estructural al que se han añadido las políticas de corte neoliberal que precarizan la mano de obra y provocan desempleo y subempleo. Los datos más recientes, publicados por la CEPAL (2014), revelan que a pesar de la entrada de remesas la población en general se mantiene con un perfil caracterizado por la pobreza, lo que desmitifica la idea de las remesas como palanca del desarrollo.

El organismo indica que la pobreza en El Salvador afecta al 40.9\% de la población; en Guatemala alcanza al 54.7\%, y en Honduras llega al 69\%. Se trata de cifras en promedio, pues si se toma en cuenta sectores específicos el dato cambia; por ejemplo: para El Salvador, los grupos de edad con mayor nivel de pobreza son los de 0 a 14 años y los de 15 a 24 años, que alcanzan el 51.4 y el 41.2\%, respectivamente; en Guatemala, en los mismos grupos la pobreza afecta al 65.2 y al 50.2\%; para el caso de Honduras la situación es aún más crítica, pues en el primer grupo alcanza el 78.2 de la población y en el segundo llega al 65.3\%. También podría analizarse por región, municipio, condición rural y urbana, pero para nuestros propósitos estos datos son suficientes para mostrar la profundidad del fenómeno.

El problema del hambre, asociado a los niveles de pobreza, es otro flagelo que se niega a desaparecer en la subregión, pese a los programas implementados en los últimos años, sobre todo en Guatemala, con el gobierno de Otto Pérez y su estrategia "Hambre Cero". De acuerdo con la FAO (2014), en el periodo 1990/1992, en los tres países que conforman el TNCA había 3.5 millones de personas con hambre, cuya mayor incidencia se localizó en El Salvador y Honduras, con el 16.2 y el 23\%, respectivamente; sin embargo, para el periodo 2012-2014 la cantidad de personas había subido a 4.1 millones y la mayor ocurrencia se encontró en Guatemala con el 14.3\% de la población, seguido de El Salvador con el 13.5\%. Aunque las cifras relativas muestran un descenso, si se comparan con el periodo 2009-2011, en números absolutos se registra un incremento importante, con excepción de Honduras, donde hubo una leve mejoría.

Otro fenómeno asociado con la pobreza y la exclusión sociopolítica es la violencia criminal que no da tregua, a pesar de los múltiples programas y de la intervención norteamericana con su Iniciativa Regional de Seguridad para América Central (CARSI, por sus siglas en inglés). Hay varios elementos que explican su permanencia y recrudecimiento: a la violencia del modelo económico que se expresa en la pobreza, el desempleo y la precarización laboral, se suma, como expresión del primero, la creciente importancia del narcotráfico en la subregión.

Se podría decir que hay coincidencia entre la mayoría de los diagnósticos de organismos internacionales que abordan los temas de seguridad y violencia, en el sentido de que Centroamérica es uno de los territorios más violentos de América Latina, incluso 
a veces se dice que del mundo. El Banco Mundial publicó en 2011 un documento de síntesis en el que afirma lo siguiente: "la esperanza centroamericana de un renacimiento tras las guerras civiles se ha visto opacada por otro tipo de plaga: un torrente de crimen y violencia que primero absorbió a El Salvador, Honduras y Guatemala y que ahora amenaza a Nicaragua, Costa Rica y Panamá" (Banco Mundial, 201l:1). Más adelante, el documento precisa las cifras:

El Salvador tiene el índice de homicidios más alto de América Latina (58 por cada 100000 habitantes), y otros países centroamericanos, Guatemala y Honduras, con índices de homicidios de 45 y 43 por cada 100000 habitantes, respectivamente, se encuentran entre los primeros cinco de la región (Banco Mundial, 2011: 1).

Otro documento publicado en 2014 por la organización no gubernamental ACAPS, con base en datos de la ONU, proporciona tasas de homicidios más bajas, salvo el caso de Honduras, y sin embargo precisa:

El promedio mundial de tasa de homicidio fue en 2012 de 6.5 homicidios por cada 100000 personas. El Salvador (41.2) y Guatemala (39.9) tienen tasas más elevadas en la actualidad que durante sus respectivas guerras civiles. Honduras, a pesar de no haber sufrido una guerra civil en el pasado, se mantiene como el país más violento del mundo (90.4). Los niveles de violencia homicida existentes en el TNCA son considerablemente superiores a los de los países en conflicto armado o guerras como Sudán del Sur (60 en 2013), Afganistán (6.5 en 2012), Sudáfrica (31 en 2012) y RDC (28.3 en 2012) (ACAPS, 2014: i).

Ambos estudios coinciden en que el narcotráfico juega un papel relevante en la violencia, pero sobre todo el primero es muy insistente en este tema. El segundo plantea que el origen de la violencia es multicausal, y enfatiza que "los altos índices de pobreza, inequidad y desempleo en la región no explican por sí mismos el aumento delincuencial y de violencia" (ACAPS, 2014: i), e incluye expectativas de consumo, falta de oportunidades y de movilidad social, cambios en la estructura familiar, la portación de armas y el narcotráfico.

No es nuestra intención detenernos en este tema, sino simplemente dejar indicado que este es un fenómeno que, unido al resto de los antes referidos, configuran un escenario que no es propio de sociedades con un régimen democrático. El problema de la justicia, la impunidad y la corrupción están íntimamente vinculados a la debilidad institucional y a una democracia procedimental precaria, que excluye a amplios sectores de la sociedad.

Se podría decir que la historia de esta subregión está marcada por una historia de conflicto, por la polarización social y la violencia de Estado. Todo esto ha llevado a cerrar 
espacios deexpresión, de diálogoy negociación política y se ha dado paso a manifestaciones que por lo general han terminado, como en el caso de Guatemala, en decretos de Estado de sitio para acallar las protestas. Evidentemente, todo esto se acompaña de una debilidad institucional que no permite que la democracia avance.

Un análisis sobre el proceso de instauración de la democracia electoral-liberal en la región debe partir de esa historia de conflicto, que alcanzó un punto de quiebre con los acuerdos de paz en 1992 en El Salvador y en 1996 en Guatemala. La construcción de la democracia está pautada, de alguna manera, por dichos acuerdos que para algunos analistas han sido exitosos porque desde entonces no ha resurgido el conflicto armado. Se afirma que Guatemala y El Salvador son "casos exitosos de "estricta construcción de la paz' dado que estos países han evitado el reinicio" (Azpuru et al., 2007). Sin embargo, la construcción de la paz va más allá de un cese a las hostilidades armadas; implica atacar las causas profundas que motivaron el conflicto, y lo que se ve en el presente es que no sólo no se han resuelto las causas sino que han surgido nuevos problemas, que se resumen, como hemos apuntado arriba, en la exclusión social y la pobreza como expresión del reparto inequitativo de la riqueza.

Hay, pues, una lógica normativa orientada a los fines y los ritmos de la acumulación del capital: "este sistema de normas es el que alimenta hoy en día la guerra económica generalizada, sostiene el poder del mercado de las finanzas, engendra las desigualdades crecientes y la vulnerabilidad social de la mayoría, acelerando además el abandono de la democracia" (Laval y Dardot, 2015: 16).

En el contexto descrito, nos preguntamos: ien qué medida se puede hablar de democracia en el TNCA? Pasemos ahora a describir los procesos electorales recientes en cada uno de los países que integran el Triángulo Norte.

\section{Los procesos electorales recientes}

\section{En El Salvador}

Entre la fraudulenta elección presidencial de 1972 y los comicios de 1997 transcurrieron 25 años, periodo durante el cual la vida de la sociedad fue trastocada profundamente. Roberto Turcios, director de la revista Tendencias, expresaba que esto "nada lo ilustra mejor que la década de guerra culminada con el acuerdo negociado y con la competencia electoral de ahora, exenta de aquellos fraudes escandalosos" (Turcios, 1997: 2). Se trata de "una transición extraordinaria que arranca desde una profunda crisis histórica, se desenvuelve por la guerra encarnizada desde la constitución del Estado, y se despliega con plenitud a partir de la solución negociada al conflicto, para dar lugar a la fundación de la democracia" (Turcios, 1997). En ese año, la coalición Convergencia DemocráticaMovimiento de Unidad-FMLN gana un gran número de alcaldías, incluida la de San 
Salvador, además de una buena cantidad de escaños en el parlamento; se dice que el voto duro de ARENA, el partido gobernante, se quebró (UCA, s/f).

En efecto, desde aquel sábado 10 de enero de 1981 en que el FMLN desplegó la ofensiva en contra del gobierno, y hasta el 16 de enero de 1992, cuando se firman los Acuerdos de Paz, El Salvador vivió la destrucción del país, pero al mismo tiempo mostró las fuerzas del cambio. La transición a la democracia era esperada con gran entusiasmo; y en este sentido, Turcios se preguntaba: "iun país atrasado que estrena democracia podrá consolidarla y romper con el circulo de la pobreza? Tal es la interrogación de un futuro que ya está en marcha" (Turcios, 1997: 8).

El hecho es que el partido ARENA siguió gobernando por 18 años, hasta que en 2010 Mauricio Funes del FMLN triunfó en las elecciones presidenciales en una apretada votación, con una diferencia de 69412 votos - 1354000 votos para el FMLN frente a 1284588 para ARENA; el 51.3 y el 48.7\%, respectivamente-.

En las elecciones de 2014 el FMLN volvió a ganar; en esta ocasión el triunfo fue para Salvador Sánchez Cerén, por una diferencia de 6364 votos —el 50.11\% para el FMLN y el $49.80 \%$ para ARENA - lo que generó cuestionamientos de fraude por parte del opositor partido ARENA.

El conflicto armado había concluido; sin embargo, la nueva amenaza para la sociedad era la instauración del modelo neoliberal. Los principios del mercado acompañan la transición a la democracia, una transición que después de más de dos décadas de posconflicto no ha llegado a materializarse con plenitud. Estos principios pronto erosionaron las bases mismas de la democracia, de la comunidad, de la sociedad entera y más allá: el entorno ecológico. Además, a partir del 1 de enero del 2001 la economía salvadoreña se dolarizó, con lo que el Estado perdió la posibilidad de gestionar su propia política monetaria. Este cambio tuvo que ver con la importancia que adquieren las remesas de la migración, que van generando desestabilidad por exceso de liquidez que presionaba las tasas de interés.

En su discurso de toma de posesión, Mauricio Funes bosquejó en varios momentos un diagnóstico del país:

El estado de la administración pública que se hereda no es, de ningún modo, satisfactorio. Precisamente porque los componentes acumulados de la crisis interna son los que nos hacen más vulnerables. Todos estos años anteriores desde el Gobierno no se desplegó un esfuerzo decidido para que El Salvador fuese menos dependiente y más productivo, y por ello nos vemos obligados a comenzar con medidas de emergencia. La presente crisis nos afecta gravemente porque se careció de una estrategia clara y coherente para enfrentar sus efectos adversos. El escenario es tal que debemos hablar sin rodeos de un deterioro inaceptable de las finanzas públicas en un cuadro de economía dolarizada (Funes, 2009). 
El presidente Funes también tocó el tema de la democracia y se refirió en los siguientes términos:

Nuestra democracia se encuentra acechada por las fuerzas oscuras del narcotráfico y el crimen organizado. Por las acciones de la delincuencia. Por la situación de apremio económico que sufren miles de familias. Por el deterioro acelerado e irresponsable de nuestro entorno ambiental. Y también por las inadecuadas decisiones gubernamentales del pasado que han distorsionado la función pública al consentir la corrupción en el aparato del Estado (Funes, 2009).

Finalmente, lanzó un par de preguntas y tomó una postura de lo que sería su gobierno:

¿Cómo es posible que millones de compatriotas migrantes, trabajando duramente fuera del país, logren su realización y consigan mejorar su vida? ¿Qué nos está diciendo eso? Muy simple: que el problema no está en nuestro pueblo, en nuestra gente; sino en la mentalidad de los gobiernos y dirigentes que han conducido el país. La riqueza humana del país está dispuesta, sólo falta un gobierno sensible y patriota que la haga crecer. Yo quiero ser el presidente de ese gobierno (Funes, 2009).

La realidad es terca; a la distancia del discurso del recién estrenado presidente, Martínez refiere que en el presente casi un tercio de la población salvadoreña vive en Estados Unidos, aproximadamente 2.5 millones ${ }^{3}$, de manera que "para igualar la población de salvadoreños en Estados Unidos tendríamos que vaciar los departamentos de San Salvador, Santa Ana y Chalatenango" (Martínez, 2014), los más poblados de El Salvador. Las remesas familiares alcanzaron en 2014 una cifra historia de 4217 millones de dólares, equivalente al 20\% del PIB (Maldonado y Heyem, 2015) y al 80\% del valor de sus exportaciones FOB; no obstante, la pobreza alcanza el 40.9\% de la población y la pobreza extrema el 12.4\%.

Al término de su mandato, Funes dejó un país con un repunte de la violencia criminal, la tregua con las maras concluyó. Por ello, a finales de abril de 2014, ya en recta final de su mandato, al proponer un plan contingente de seguridad, en una entrevista expresó: "relanzar el proceso de la tregua para que no sólo sea un acuerdo entre pandillas sino que se incluya iglesias, partidos políticos, organizaciones no gubernamentales y otros sectores de la sociedad" (La Prensa Gráfica, 26 de abril de 2014).

Durante su administración, Funes hizo concesiones al gobierno de Estados Unidos, sacó al FMLN del gabinete de seguridad y puso como jefe a David Munguía Payés, un

\footnotetext{
${ }^{3}$ Nosotros hemos referido la cifra de 2 millones para el año 2013, dato que incluye a los salvadoreños nacidos en Estados Unidos.
} 
militar aliado de la Casa Blanca, a quien se le atribuye la autoría del pacto con la mara (Silva, 2014). Y es que la administración de Funes cierra con una cifra aproximada de 17355 homicidios, así como un alto déficit de empleos: entre julio de 2008 y noviembre de 2013 se registró una demanda de 270000 empleos y fueron creadas 80000 plazas, con lo que resulta un déficit de 188000 empleos.

En este sentido, una nota afirma: "Mauricio Funes terminó su mandato alejado del partido que lo llevó a la presidencia, de la oposición de las cúpulas empresariales e incluso su familia" (Labrador y Sanz, 2014). En la toma de posesión como nuevo presidente de El Salvador, Sánchez Cerén reivindicó a Funes: "trabajaremos con honradez, austeridad, eficiencia y transparencia. Queremos una sociedad que exija principios éticos a sus funcionarios [...] Los recursos del pueblo son sagrados. Tal como se hizo en este gobierno, continuaremos con el compromiso de no más corrupción" (Sánchez, 2014).

Sánchez Cerén abundó en los temas económicos y el tema de seguridad, respecto de lo cual señaló:

La seguridad ciudadana requiere que trabajemos unidos contra el crimen organizado, el narcotráfico, las extorsiones y toda expresión de violencia. Vamos a combatir la delincuencia en todas sus formas, con todos los instrumentos legales y coercitivos del Estado. La Fuerza Armada continuará acompañando las labores de la Policía Nacional Civil (Sánchez, 2014).

A unos meses de la administración de Sánchez Cerén, la violencia se recrudeció. El mes de marzo de 2015 fue el más violento de los últimos años, con un saldo de 481 asesinatos, 16 por día. Esto llevó a que el presidente ordenara la creación de tres batallones de reacción inmediata. El temor es que se llegue, como en tiempos pasados, a la aplicación de políticas de mano dura.

\section{En Guatemala}

Después de los Acuerdos de Paz de finales de 1996, se realizan elecciones generales el 7 de noviembre de 1999. Estas elecciones tienen una doble significación en tanto que se inscriben, por una parte, en el proceso de reinstitucionalización democrática y, por otra, en la culminación del proceso de paz que da como resultado el Acuerdo de Paz Firme y Duradero, con el que se pone fin al proceso de diálogo que duró diez años y por el cual la Unidad Revolucionaria Nacional Guatemalteca (URNG) termina de constituirse en partido político. Por primera vez la guerrilla participa en el proceso electoral y forma la alianza denominada Alianza Nueva Nación (ANN) (OEA, 2000: 10). Esta alianza se forma con la URNG y el DIA (Desarrollo Integral Auténtico). 
En la primera vuelta ningún partido calificó, pero un hecho destacable es que la guerrilla representada en las siglas DIA-URNG alcanzó 270819 votos, el 12.36\% de los votos válidos. Por el contrario, el Frente Republicano Guatemalteco (FRG) obtuvo 1045 820 (el 47.72\%), y el Partido de Avanzada Nacional (PAN) logró 664417 votos (el 30.32\%). El total de votos válidos para la primera vuelta fueron 2 191 512. La Misión de Observación de la OEA concluyó que los comicios "fueron libres, limpios y transparentes" (OEA, 2000: 36).

En la segunda vuelta, realizada en diciembre del mismo año, el número de votos válidos se redujo a un millón 735 096, de los cuales el 68.31\% lo obtuvo Alfonso Portillo, del FRG. En esa ocasión contendieron trece partidos políticos. Cabe destacar que Portillo fue arrestado en Guatemala en 2010, acusado de corrupción y lavado de dinero; después fue extraditado a Estados Unidos en mayo de 2013, donde después de haber admitido que participó en actos de lavado de dinero, permaneció año y medio en la cárcel. Fue liberado en febrero de 2015.

Durante el proceso electoral de 2011, dieciocho partidos postularon candidatos a cargos públicos y siete de ellos participaron en coalición: Unidad Nacional de la Esperanza-Gran Alianza Nacional (ENE-GANA), Encuentro por Guatemala-Visión con Valores (EG. VIVA), Alternativa Nueva Nación-Unidad Revolucionaria Nacional GuatemaltecaMovimiento Político WINAQ (ANN-URNG WINAQ) (National Democratic Institute/ University of Notre Dame/Acción Ciudadana, 2012:13).

Los partidos que mayores gastos de campaña efectuaron fueron: Patriota, con casi 127 millones de quetzales, seguido por LIDER, con cerca de 95 millones. El Partido Patriota llevó al general Otto Pérez Molina a la presidencia de la República con el 53.74\% de los votos; uno de sus lemas de campaña fue: "Seguridad y Empleo con mano dura". En segundo lugar quedó el candidato de LIDER con el 46.3\% de los votos válidos, y en tercer lugar, bastante alejado del segundo, el partido CREO con el 17.22\%. La coalición de izquierda integrada por la URNG-WINAQ-MAIZ-AN obtuvo el 3.4\%. La abstención fue de casi el 40\% (39.36).

En la etapa final de la administración del general Otto Pérez Molina, los resultados en términos sociales y políticos no fueron nada halagüeños. La violencia y la represión fueron una característica del régimen, con decretos de Estado de Sitio, y el nivel de conflictividad subió de manera extraordinaria.

El legado de la administración de Otto Pérez Molina fue el de un país en crisis, un gobierno que concluyó unos meses antes de terminar su periodo, en medio de un escándalo nacional por el tema de la corrupción, y en vísperas de unas elecciones de antemano cuestionadas. Las promesas de erradicar el hambre mediante su programa estrella, Hambre Cero, y las de disminuir la violencia quedaron diluidas.

Las elecciones se llevaron a cabo en los tiempos programados, con un presidente provisional: Alejandro Maldonado, con una trayectoria bastante conservadora. Como para calmar los ánimos, el nuevo presidente interino transmitió un mensaje a los jóvenes: 
No pueden dar por finalizada su tarea. En lo que queda del año debe haber una respuesta positiva, abrir espacios para jóvenes, activistas y profesionales. Esta generación que se alzó con los símbolos de la paz no puede estancarse ni acomodarse. Que trasladen su vitalidad cívica al servicio público. Podemos recuperar nuestra democracia. El pueblo está movilizado por disgusto con esquemas descompuestos. Impone que se hagan correcciones inmediatas de alto nivel moral (La Jornada, 3 de septiembre de 2015).

La crónica anunciada de la renuncia de Otto Pérez comienza el 16 de abril de 2015 cuando la CICIG y el Ministerio Público pusieron al descubierto La Línea, una red de defraudación fiscal dirigida por el entonces secretario privado de la vicepresidenta Roxana Baldetti. El 8 de mayo se produce la renuncia de la vicepresidenta y a partir de entonces el panorama político se tornó más complejo. La población exigió de manera reiterada la renuncia del presidente porque salió a la luz pública información sobre un contrato fraudulento entre el Instituto Guatemalteco de Seguridad Social (IGSS) y la Droguería Pisa, en el que fue vinculado el secretario particular de Pérez Molina. El 9 de julio es detenido el secretario general del presidente y se mantiene la presión social, en la que se suman el CACIF, la Iglesia católica y la Embajada de Estados Unidos.

En un hecho inédito en la vida del país, la renuncia oficial del presidente ocurre durante la madrugada del 3 de septiembre de 2015. La renuncia se acompaña con el encarcelamiento y la persecución de varios miembros del primer círculo del gabinete. En medio de este acontecimiento se llevó a cabo las elecciones generales.

Al mes de octubre de 2014, en Guatemala estaban registrados 28 partidos políticos. En el registro final para las elecciones presidenciales del 6 de septiembre de 2015 compitieron 14 partidos-organizaciones; sin embargo, tres de ellos reunieron a la mayoría de los votantes: LIDER (Libertad Democrática Renovada), de centro-derecha; UNE (Unidad Nacional de la Esperanza), de filiación socialdemócrata, y FCN-Nación (Frente de Convergencia Nacional). Estos tres concentraron el 63.25\% de los votos válidos, y en orden de importancia el resultado fue el siguiente: FCN-Nación, 1167030 (el 23.85\%); UNE, 967242 (el 19.76\%); LIDER, 961284 (el 19.64\%). Ninguno de los partidos pudo obtener el porcentaje legal, por lo que el 25 de octubre, en la segunda vuelta, competirán Jimmy Morales del FCN-Nación y Sandra Torres por la UNE.

La noticia más destacada fue que Manuel Baldizón, del partido LIDER, que por segunda ocasión compitió por la presidencia de la república, quedó eliminado para la segunda vuelta por una diferencia mínima con Sandra Torres. Estos resultados están asociados al efecto Pérez Molina que arrastró a sus aliados más importantes, uno de ellos el partido LIDER. Los resultados sorprendieron al propio Baldizón, quien argumentó que se había cometido fraude pues hasta el 30 de junio era el candidato que más había gastado en campaña, con poco más de 39.9 millones de quetzales, frente a 16.3 millones de Sandra Torres. 
En el ambiente político postelectoral y en la sociedad guatemalteca hay muchas interrogantes. El periódico Plaza Pública, en su editorial del 19 de septiembre de 2015, lanzó la pregunta sobre la posibilidad de una restauración del viejo régimen:

Era una de las posibilidades, y no la más remota: que la furia ciudadana se amansara con el cloroformo de las elecciones o con la reconfortante imagen de ver astillados a quienes se habían convertido en nuestros verdugos más evidentes o probables: Otto Pérez, Roxana Baldetti, Manuel Baldizón. Hay en el ambiente una gran algarabía, aires de victoria, un olor a primavera. Pero ninguno de ellos inventó nada, todos son descendientes de esta forma degradada de hacer política, y hay, en el corto plazo, una posibilidad inquietante, apenas una hipótesis todavía: iestamos al borde de una restauración solapada del antiguo régimen?

Hay dudas razonables de que las cosas no cambiarán en Guatemala a menos que el movimiento ciudadano cobre organicidad, como bien señaló el sociólogo guatemalteco Carlos Guzmán Böckler, a propósito de la caída de Otto Pérez y de las elecciones generales en el país. A la pregunta: ¿Este panorama pone a Guatemala en grave riesgo de involución?, responde sin vacilar:

Es un riesgo muy alto. La parte más hermosa del movimiento ciudadano, cuyo clamor por la dignidad en el manejo del Estado provocó la renuncia del presidente y la vicepresidenta, lleva en sus entrañas su talón de Aquiles: de ese movimiento popular, espontáneo, no salieron dirigentes. Nadie que pueda conducir la segunda fase, destinada a reformar el Estado (Elías, 2015).

En seguida se le pregunta: ¿Qué habría que hacer para evitar la vuelta al pasado? A lo que responde:

Si no surge una organización cívica fuerte en el transcurso de los próximos meses, dirigida por personas honradas y con conocimientos amplios de la realidad guatemalteca y su relación con el mundo, estamos perdidos (Elías, 2015).

Hay muchas razones para ser pesimistas. En estos días (septiembre de 2015) se está presentando el proyecto de presupuesto de ingresos para el 2016 y la élite de empresarios agrupados en el llamado G-8, que forman parte del CACIF, ya lo están impugnando, como en el pasado. El peso del llamado G-8, integrado por los grandes empresarios como Juan Luis Bosch, del conglomerado agroalimentario-inmobiliario financiero Gutiérrez-Bosch; Juan Miguel Torebiarte, del Bando Industrial; Mario Montano o Thomas Dougherty, de Cementos Progreso; Rodrigo Tejeda, de la Cervecería Centro 
Americana de la familia Castillo; José Luis Valdés, del Bando Agromercantil, y Fraterno Vila, de los ingenios azucareros (Fuentes, 2011), es definitivo para inhibir iniciativas de reformas, en este caso fiscales.

Por otra parte, la constitución y participación de la Comisión Internacional contra la Impunidad en Guatemala (CICIG) es algo revelador de la debilidad institucional y de la fragilidad de la democracia. No se puede concebir un país democrático con altas tasas de impunidad.

\section{En Honduras}

El golpe de Estado contra Manuel Zelaya en 2009 evidenció la fragilidad de la incipiente democracia y la intervención de Estados Unidos. El 28 de junio de 2009, el presidente Manuel Zelaya fue secuestrado por militares y sacado del país. Honduras estrenó una modalidad de golpe de estado, pues con el argumento de un cambio en la Constitución para la reelección del presidente, el congreso lo destituyó. Se sospechaba que el gobierno de Estados Unidos había jugado un papel importante, pero ahora se sabe por la propia confesión de la ex secretaria de Estado: "En los días siguientes [después del golpe] hablé con mis homólogos de todo el hemisferio, incluida la secretaria [Patricia Espinosa] en México. Nosotros establecimos las estrategias de un plan para restaurar el orden en Honduras y garantizar que elecciones libres y limpias se celebren rápidamente y de manera legítima, lo que haría que la cuestión de Zelaya sea irrelevante" (Weisbrot, 2014).

El golpe mostró la extrema fragilidad institucional y sus efectos se hicieron sentir en varios ámbitos: "la tasa de homicidio, ya la más alta del mundo, aumentó en un 50\% de 2008 a 20ll; la represión política y los asesinatos de los candidatos políticos de la oposición, organizadores campesinos y activistas LGBT aumentaron y continúan hasta el día de hoy" (Weisbrot, 2014). En realidad fueron cien días de manifestaciones a favor del regreso de Zelaya.

La misión de observación de la Unión Europea para las elecciones generales de 2013, celebradas luego de la crisis propiciada por el golpe de Estado, resume el contexto político de la siguiente manera:

Las elecciones generales del 24 de noviembre de 2013 se celebraron en un contexto político marcado por el golpe de Estado de junio de 2009, mediante el cual el presidente José Manuel Zelaya fue destituido y expulsado a Costa Rica. El posterior incumplimiento del Acuerdo de San José Tegucigalpa hizo que gran parte de la comunidad internacional no reconociese el gobierno de Porfirio Lobo, elegido en 2009. El acuerdo constaba de tres puntos fundamentales: el retorno de Zelaya a la presidencia hasta el fin de su mandato en enero de 2010, la renuncia a su plan de convocar una Asamblea Constituyente y el establecimiento de un gobierno de 
unidad nacional. Posteriormente, un nuevo acuerdo auspiciado por los presidentes de Colombia y Venezuela permitió el reingreso de Honduras a la OEA, de la que había sido excluida, lo que inició el camino hacia la normalización. A diferencia de lo ocurrido en 2009, en 2013 se presentaron a las elecciones candidatos de todo el espectro ideológico, tanto independientes como de nueve distintos partidos, algo que no tiene precedentes en la historia del país (Misión de Observación Electoral UE, Honduras 2013: 7).

El actual presidente, Juan Orlando Hernández — del derechista Partido Nacional-, producto de las elecciones generales recientes, fue elegido por poco más del $36 \%$ de los votantes, donde participó el $61.35 \%$ del electorado, por encima del $49.88 \%$ del proceso electoral de 2009. Hernández formó parte del congreso que fraguó el golpe de Estado, junto a Roberto Michelleti y Porfirio Lobo, el presidente anterior. Como se puede observar en el cuadro, los que obtuvieron más votos, después de Hernández, fueron Xiomara Castro del Partido Libre, Mauricio Villeda del Partido Liberal y Salvador Nasralla del Partido Anticorrupción. Los cuatro candidatos concentraron más de 3 millones de votos, esto es el 99.4\% de los votos válidos.

Honduras, resultados de elección presidencial, 24 de noviembre, 2013

\begin{tabular}{|c|c|c|c|}
\hline Candidato & Partido o coalición & Voto & $\begin{array}{c}\text { \% sobre } \\
\text { votos } \\
\text { válidos }\end{array}$ \\
\hline Orbe Solís & $\begin{array}{c}\text { Partido Demócrata } \\
\text { Cristiano }\end{array}$ & 4194 & 0.17 \\
\hline Romero Vázquez Velásquez & $\begin{array}{c}\text { Alianza Patriótica } \\
\text { Hondureña }\end{array}$ & 6105 & 0.20 \\
\hline Mauricio Villeda & Partido Liberal & 632443 & 20.30 \\
\hline Salvador Nasralla & Partido Anticorrupción & 418443 & 13.43 \\
\hline Xiomara Castro & $\begin{array}{l}\text { Libertad y Refundación } \\
\text { (Libre) }\end{array}$ & 896498 & 28.78 \\
\hline Andrés Pavón & UD-Faper & 3118 & 1.10 \\
\hline Jorge Aguilar & PINU & 4468 & 0.14 \\
\hline Juan Orlando Hernández & Partido Nacional & 1149302 & 36.89 \\
\hline Total de votos emitidos & & 3275346 & 100.0 \\
\hline Votos válidos & & 3115448 & 95.12 \\
\hline
\end{tabular}

Fuente: Misión de Observación Electoral de la Unión Europea, 2013. 
El periodo de Hernández comenzó el 27 de enero de 2014 y concluirá el 27 de enero de 2018. Se dice que fueron las elecciones más votadas en la historia de Honduras, en la que participaron 12 mil observadores nacionales y 700 internacionales, la OEA, el Centro Carter, la Unión Europea y el Departamento de Estado de Estados Unidos.

El golpista Michelleti declaró en junio de 2014 que a medio año del nuevo gobierno no se veían resultados, consideró que Honduras "sigue siendo un fracaso, sigue siendo mentira toda posibilidad de una proyección para mejorar el asunto de los empleos y seguridad. Seguimos viendo que el crimen organizado está demostrando que tiene el poder en el país y a pesar de que la policía está haciendo esfuerzos y logra capturar cantidades de gente, sigue creciendo la criminalidad" (El Heraldo, 27 de julio de 2014).

En concordancia con el crecimiento de la criminalidad, 21 congresistas demócratas de Estados Unidos pidieron al secretario de Estado John Kerry, en agosto de 2015, la suspensión de apoyos de su país al gobierno de Hernández por considerar que la participación de los militares en materia de seguridad viola los derechos humanos; ellos expresaron: "Queremos asegurarnos de que esos dólares de los contribuyentes estadounidenses no se utilizan para la vigilancia de tipo militar, actividad que podría, de hecho, ser una de las causas de esta migración, ya que exacerba la violencia en el país" (La Prensa, 19 de agosto de 2015).

La criminalidad y la corrupción son dos problemas que han venido acompañando al gobierno de Hernández. Esto ha despertado un movimiento de indignados que piden la formación de un organismo internacional de vigilancia. En este marco, el presidente de Honduras inició un diálogo nacional contra la corrupción, el 24 de junio de 2015, en el que propuso el "Sistema Integral Hondureño de Combate a la Impunidad y la Corrupción (SIHCIC); sin embargo, los manifestantes pidieron la presencia de la Comisión Internacional Contra la Impunidad de la ONU. Esta es una idea que ya había sido barajada por Thomas Shannon, consejero de primer nivel del Departamento de Estado, en el contexto de la crisis de Guatemala y en el marco de la crisis migratoria: "Creo que sería inteligente para El Salvador y Honduras buscar un aporte o una ayuda de la comunidad internacional. Cada país tiene que determinar cuál sería la estructura, pero CICIG funcionó bien" (Peña, 2015).

\section{Algunos indicadores sobre dificultades que enfrenta la democracia}

Como parte de este ensayo nos pareció oportuno incorporar información generada por Latinobarómetro que desde 1995 viene registrando la opinión pública en torno a temas como democracia y mercado, satisfacción con los gobiernos y las economías, entre otros. En esta ocasión, en su informe 1995-2015 publica una serie de indicadores, algunos de los cuales consideramos relevantes para catar el avance de la democracia en los países del TNCA. 
Un primer indicador de la crisis que vive el sistema electoral, de partidos y, en general, el sistema político, es el nivel de participación electoral. En este indicador, los países del TNCA ocupan, junto con Colombia, los más bajos niveles en los 20 años analizados. El promedio para los 18 países de América Latina estudiados alcanzó el 69.5\%, mientras que para Honduras fue del 60.6; para El Salvador el 56.7, y para Guatemala, que ocupó el último lugar, fue del $46.6 \%$. No obstante, en la última elección presidencial, Guatemala y El Salvador fueron los que mayor aumento de votantes registraron en toda la región.

Otro indicador destacable es el de satisfacción de la democracia, cuyos resultados de la encuesta sólo privilegian las respuestas de "bien satisfecho" y "muy satisfecho". En el caso de los países del TNCA, alcanza el 34\% en Honduras; el 29\% en El Salvador, y el 27\% en Guatemala. Es importante destacar que, por debajo de estos países, se encuentran Colombia, Perú, Paraguay, Brasil y, por último, México. Esto tiene que ver con el nivel de consciencia política y de empoderamiento ciudadano, que hace sociedades más exigentes.

En el indicador de apoyo a la democracia, los países que conforman el TNCA se encuentran en el último lugar en la lista: El Salvador con 41\%, Honduras con 40\% y Guatemala con 33\%. Estos datos son sugerentes porque pueden estar indicando una actitud de rechazo al tipo de democracia real que se ha ejercido en estos países.

En el indicador de elecciones limpias, sólo con respuesta de "limpias", el Latinobarómetro ubica a El Salvador con 38\%, Honduras con 33\% y Guatemala con 32\%. Cabe destacar que el más alto es Uruguay con $82 \%$ y el más bajo México con $26 \%$.

Respecto a la percepción de la reducción de la corrupción, se privilegian las respuestas "mucho", "más" y "algo". Para el caso de Honduras, sólo el 34\% de los entrevistados respondió en ese sentido; 26\% en El Salvador, y 25\% en Guatemala. Los extremos son, en el nivel más alto, Ecuador con el 52\% y, en el nivel más bajo, Brasil con el 19\%.

Finalmente, otro indicador asociado con la anterior es sobre la percepción de si "vivir en el país es cada día más inseguro". En los resultados de la encuesta se privilegió la respuesta "más inseguro". El resultado para El Salvador, de los más altos en América Latina, sólo superado por Venezuela, fue del 83\%; Guatemala el 72\%, y Honduras el 65\%.

Estos son algunos indicadores destacados para la región del Triángulo Norte de Centroamérica (TNCA), que cobran sentido a la luz de lo expuesto en apartados anteriores. Se explica por su historia particular, que de alguna manera es compartida por elresto de la región latinoamericana. Como bien señala el informe respecto a la democracia:

Aquí, en América Latina, no ha habido ni Plan Marshall, ni una Unión Europea que aplanara la cancha. Aquí la "cancha" se "aplana” de manera lenta y dispar, sin cambiar demasiado la "posición original" (Latinobarómetro, 2015: 33). 
Más adelante, el Latinobarómetro dice:

La democracia es más que todo una inspiración para los ciudadanos de la región, algo que no sucede aún, pero que se espera que suceda. Esa demanda de democracia va aparejada con bajos niveles de educación, y bajos niveles de información. La mezcla es compleja, porque no sólo está llena de prejuicios, sino también llena de historia (Latinobarómetro, 2015: 33).

Para los países del TNCA es más que eso, pues en muchas décadas la democracia no la conocen, se pasó de dictaduras a conflictos armados, y hoy el fantasma del viejo régimen ronda en países como Guatemala y Honduras. En este último se vive el desgarramiento de su tejido social; la migración de jóvenes, mujeres y niños es un indicador del deterioro y la descomposición de las sociedades, en diverso grado y sentido.

\section{Conclusión}

Centroamérica es una unidad territorial y política, heterogénea, compleja, que desde la geopolítica se incorpora a un mundo cada vez más multipolar. Es una región que vivió las consecuencias de la Guerra Fría y del neoliberalismo impulsado por Ronald Reagan. Con la imposición del modelo neoliberal se propició un cambio en la estructura económica, aunque el sector primario tradicional mantiene un peso importante en los países del TNCA. Se trata de pequeños países con recursos limitados, con capacidad de ahorro interno muy reducida dado el modus operandi de las oligarquías nacionales, por lo cual la presencia del capital externo es relevante. Éste se ha insertado en la industria maquiladora y los servicios conexos, así como en actividades extractivas, en particular la minería y la producción de agrocombustibles.

La presencia de la Casa Blanca, a través de la Agencia de Estados Unidos para el Desarrollo Internacional (USAID) como entidad que modula el quehacer político y económico en la región, pone en tela de juicio la centralidad del Estado en términos de la conducción de su desarrollo económico y político. A falta de un Estado con funciones amplias y sin limitaciones fiscales que debilitan su actuación en programas económicos y sociales, este organismo, junto con otros, se ha hecho omnipresente en toda la región. En buenamedida, los gobiernos centroamericanos sealimentan delacooperacióninternacional, pero ésta es interesada, marca rumbos de la conducción del "desarrollo" de los países.

Buena parte de los apoyos en materia de seguridad proviene del gobierno norteamericano y todos los gobiernos de la región mantienen una fuerte dependencia con Estados Unidos. A partir de este reconocimiento resulta interesante hacer una lectura de los cambios políticos y su expresión en los procesos de su emergente democracia, sus grandes debilidades y de la posibilidad real de cambio, sin olvidar que los gobiernos de los 
países del TNCA mantienen un programa económico neoliberal, extractivista, que incide en el deterioro de los recursos naturales, que excluye y empobrece a la población, con lo que generan y reproducen las condiciones para el éxodo de segmentos importantes de la población hacia Estados Unidos. Este modelo económico tensiona y condiciona el avance de la democracia, al tiempo que va dando lugar a un Estado que va perdiendo soberanía al exterior y legitimidad al interior.

Las evidencias planteadas a lo largo de este ensayo permiten concluir que la subregión del TNCA enfrenta enormes dificultades para cumplir con las características de un sistema democrático. Desde la consideración de la realidad social no puede haber democracia en países profundamente desiguales, con altos niveles de pobreza, de exclusión social y, por extensión, política. Un país que expulsa a su población, en lugar de protegerla, no puede caracterizarse como democrático. Un país donde las minorías toman las decisiones y donde los representantes en los congresos no consultan a sus electores, no puede llamarse democrático.

\section{Referencias bibliográficas}

ACAPS (Assessment Capacities Proyect) (2014). "Otras situaciones de violencia en el Triángulo Norte Centroamericano. Impacto humanitario". S.1.: ACAPS. Disponible en: http:/www.acaps.org/img/documents/o-2014-07-31-osv-hum-impact.pdf (consultado el 13 de mayo de 2015).

Azpuru, Dinorah, et al. (2007). Construyendo la democracia en sociedades posconflicto. Un enfoque comparado entre Guatemala y El Salvador. Guatemala: F\&EG Editores.

Banco Mundial (2011). Crimen y violencia en Centroamérica. Un desafío para el desarrollo. Washington D.C.: BM.

Beck, Ulrich (1998). ¿Qué es la globalización? Falacias del globalismo, respuestas a la globalización. España: Editorial Paidós.

CEPAL (2014). Anuario estadístico de América Latina y el Caribe. Santiago de Chile: CEPAL.

El Heraldo (27 de julio de 2014). "El pueblo está frustrado con este gobierno". Honduras. Disponible en: http://www.elheraldo.hn/inicio/732979-331/el-pueblo-est\%C3\%Alfrustrado-con-este-gobierno.

Elías, José (2015). “Sin organización cívica fuerte, estamos perdidos en Guatemala. El veterano sociólogo Carlos Guzmán-Böckler advierte de la falta de líderes que guíen la reforma del país centroamericano". En El País, 24 de septiembre. Disponible en: http:// internacional.elpais.com/internacional/2015/09/23/actualidad/1443045173_049356. html (consultado el 29 de septiembre de 2015).

FAO (2014). Panorama de la seguridad alimentaria y nutricional en América Latina y el Caribe 2014. Roma: FAO. 
Fuentes, Juan Alberto (2011). "El veto del G-8". En Plaza Pública, 27 de agosto. El Salvador. Disponible en: http://www.plazapublica.com.gt/content/el-veto-del-g-8 (consultado el 15 de septiembre de 2015).

Funes, Mauricio (2009). "Discurso de toma de posesión", 1 de junio, San Salvador. Disponible en: http://chichicaste.blogcindario.com/2009/06/01418-discurso-toma-deposesion-del-presidente-mauricio-funes.html (consultado el 20 de diciembre de 2010).

Hirsch, Joachim (2001). El Estado nacional de competencia. Estado, democracia y politica en el capitalismo global. México: Universidad Autónoma Metropolitana.

Labrador, Gabriel y José Luis Sanz (2014). "Funes y su bastón”. En El Faro, l de junio. El Salvador. Disponible en: http://www.elfaro.net/es/201406/noticias/15476/ (consultado el 20 de septiembre de 2014).

La Jornada (3 de septiembre de 2015). "Maldonado pide renuncia al gabinete de Otto Pérez". México. Disponible en: http:/www.jornada.unam.mx/ultimas/2015/09/03/maldonadopide-renuncia-del-gabinete-de-guatemala-1190.html (consultado el 4 de septiembre de 2015).

La Prensa Gráfica (26 de abril de 2014). "Funes anuncia plan contingencial de seguridad". El Salvador. Disponible en: http:/www.laprensagrafica.com/2014/04/26/funes-anunciaplan-contingencial-de-seguridad (consultado el 30 de mayo de 2014).

LaPrensa (19 de agosto de 2015). "Congresistas de EUA piden suspender apoyo a Honduras". Honduras. Disponible en: http://www.laprensa.hn/honduras/870770-417/congresistasde-eua-piden-suspender-apoyo-a-honduras (consultado el 13 de septiembre de 2015).

Latinobarómetro (2015). “Informe 1995-2015”. Santiago de Chile: Latinobarómetro.

Laval, Christian y Pierre Dardot (2015). Común. Ensayo sobre la revolución en el siglo XXI. Barcelona: Gedisa.

López, Gustavo (2015a). "Hispanics of Honduran Origin in the United States, 2013". Washington D.C.: Pew Reseach Center. Disponible en: http://www.pewhispanic. org/2015/09/15/hispanics-of-honduran-origin-in-the-united-states-2013/ (consultado el 28 de septiembre de 2015).

López, Gustavo (2015b). "Hispanics of Guatemalan Origin in the United States, 2013". Washington D.C.: Pew Reseach Center. Disponible en: http://www.pewhispanic. org/2015/09/15/hispanics-of-guatemalan-origin-in-the-united-states-2013/ (consultado el 28 de septiembre de 2015).

López, Gustavo (2015c). "Hispanics of Salvadoran Origin in the United States, 2013". Washington D.C.: Pew Reseach Center. Disponible en: http://www.pewhispanic. org/2015/09/15/hispanics-of-salvadoran-origin-in-the-united-states-2013/ (consultado el 28 de septiembre de 2015).

Maldonado, Remé y María Luisa Heyem (2015). Las remesas a América Latina yel Caribe superan su máximo histórico en 2014. Washington D.C.: Fondo Multilateral de Inversiones, Banco Interamericano de Desarrollo.

Martínez, Óscar (2014). "Mucho sueño americano". En El Faro, 18 de mayo. El Salvador. 
Disponible en: http://www.elfaro.net/es/201405/noticias/15368/Mucho-sue\%C3\%Bloamericano.htm?st-full_text=all\&tpl=1l (consultado el 28 de junio de 2014).

Misión de Observación Electoral de la Unión Europea (2013). Informefinal, Honduras. Elecciones Generales 2013. Tegucigalpa: la Misión.

National Democratic Institue, University of Notre Dame y Acción Ciudadana (2012). Aproximaciones a las percepciones de la ciudadanía sobre la compra de votos y la intimidación de votantes en el régimen político electoral guatemalteco. Guatemala: Cooperación de Dinamarca en Centroamérica.

OEA (2010). Observación electoral en Guatemala, 1999. Colección Observaciones Electorales, Serie Américas, núm. 25, OEA/Ser.D/XX/SG/UPD/II.25. 1 de septiembre. Washington D.C.: OEA

Peña, Fátima (2015). "El Salvador y Honduras responden a EUA que no necesitan una CICIG". en El Faro, 16 de julio. El Salvador. Disponible en: http://www.elfaro.net/ es/201507/internacionales/17191/El-Salvador-y-Honduras-responden-a-EUA-que-nonecesitan-una-CICIG.htm (consultado el 15 de agosto de 2015).

Plaza Pública (19 de septiembre de 2015). "¿Hacia una restauración del antiguo régimen?" Guatemala. Disponible en: http:/www.plazapublica.com.gt/content/hacia-unarestauracion-del-antiguo-regimen (consultado el 29 de septiembre de 2015).

Prensa Libre (18 de diciembre de 2013). "Pérez Molina descarta prórroga de Cicig”. Guatemala. Disponible en: http://www.prensalibre.com/noticias/politica/cicig-prorroga-mandatoportillo-perez_molina_0_1049895178.html (consultado el 25 de diciembre de 2013).

Sánchez Cerén, Salvador (2014). "Discurso de toma de posesión”. En La Página, l de junio. SanSalvador.Disponibleen:http://www.lapagina.com.sv/nacionales/95967/2014/06/01/ Discurso-de-toma-de-posesion-de-Salvador-Sanchez-Ceren (consultado el 25 de marzo de 2015).

Silva, Héctor (2014). "Washington y el FMLN: aprender a bailar". En El Faro, 19 de marzo. Disponible en: http://www.elfaro.net/es/201403/opinion/15092/ (consultado el 30 de abril de 2014).

Terrazas, Aaron (2011). "Inmigrantes centroamericanos en los Estados Unidos". Estados Unidos: Migration Policy Institute. Disponible en: http://www.migrationpolicy.org/ article/inmigrantes-centroamericanos-en-los-estados-unidos $\$ 5$ (consultado el 15 de enero de 2015).

Turcios, Roberto (1997). "El Salvador. Una transición histórica y fundacional". En Nueva Sociedad, núm. 150, julio-agosto, pp. $112-118$.

UCA (s.f.). Las elecciones del 16 de marzo de 1997: quiebre de la hegemonía de ARENA. San Salvador: Centro de Información, Documentación y Apoyo a la Investigación. Disponible en: http://www.uca.edu.sv/publica/eca/58lartl.html.

Weisbrot, Mark (2014). "Hillary Clinton admite su papel en el golpe de Honduras". En Boletín de Los Necios, 12 de noviembre. Disponible en: http://tortillaconsal.com/tortilla/ en/node/15357 (consultado el 30 de diciembre de 2014). 


\section{Guatemala, ihacia un nuevo paradigma de construcción de ciudadanía?}

Jahir Dabroy

\section{Introducción}

En Guatemala se han venido realizando una serie de protestas en contra de la clase política y del sistema político que le da sustento, entendiendo el sistema político como "la plasmación organizativa del conjunto de interacciones estables a través de las que se ejerce la política en un contexto limitado" (Molina, 1998: 116).

Estas protestas se arrogan el logro de haber quitado a un presidente y a una vicepresidentadela República acusados de actos de corrupción porelcasodedefraudación aduanera denominado "La Línea”, a partir del cual supuestamente se dirigía desde las más altas esferas del poder ejecutivo una estructura paralela de corrupción. Hoy (noviembre de 2015), los principales sindicados se encuentran en prisión preventiva a la espera de juicio en las próximas semanas.

Pero, irealmente fueron las protestas ciudadanas tan poderosas como se cree? iPor qué no funcionaron en otro momento? ¿Se está gestando una nueva ciudadanía en el país? ¿Puede calificarse Guatemala realmente como un referente de la organización social? Para realizar el análisis partamos de algunos puntos que permiten comprender de mejor forma la coyuntura, pero también la estructura en la que se han venido gestando los hechos.

\section{Contextualizando, zqué pasó hace 22 años?}

Guatemala es un país con un sistema político muy particular, basado en un modelo de democraciarepublicana constitucional, presidencialista pordefinición, peroparlamentario en la práctica. El modelo político guatemalteco se ha constituido desde la transición a la democracia en 1985 como un modelo que se sustenta con una Constitución Política de tendenciademócratacristiana,peroqueen laprácticacuentaconunEstadoeminentemente liberal que incluso puede ser sujeto de estudio como un sistema más bien anárquico. 
Foto 1. Manifestación del 25 de abril de 2015 en Ciudad de Guatemala

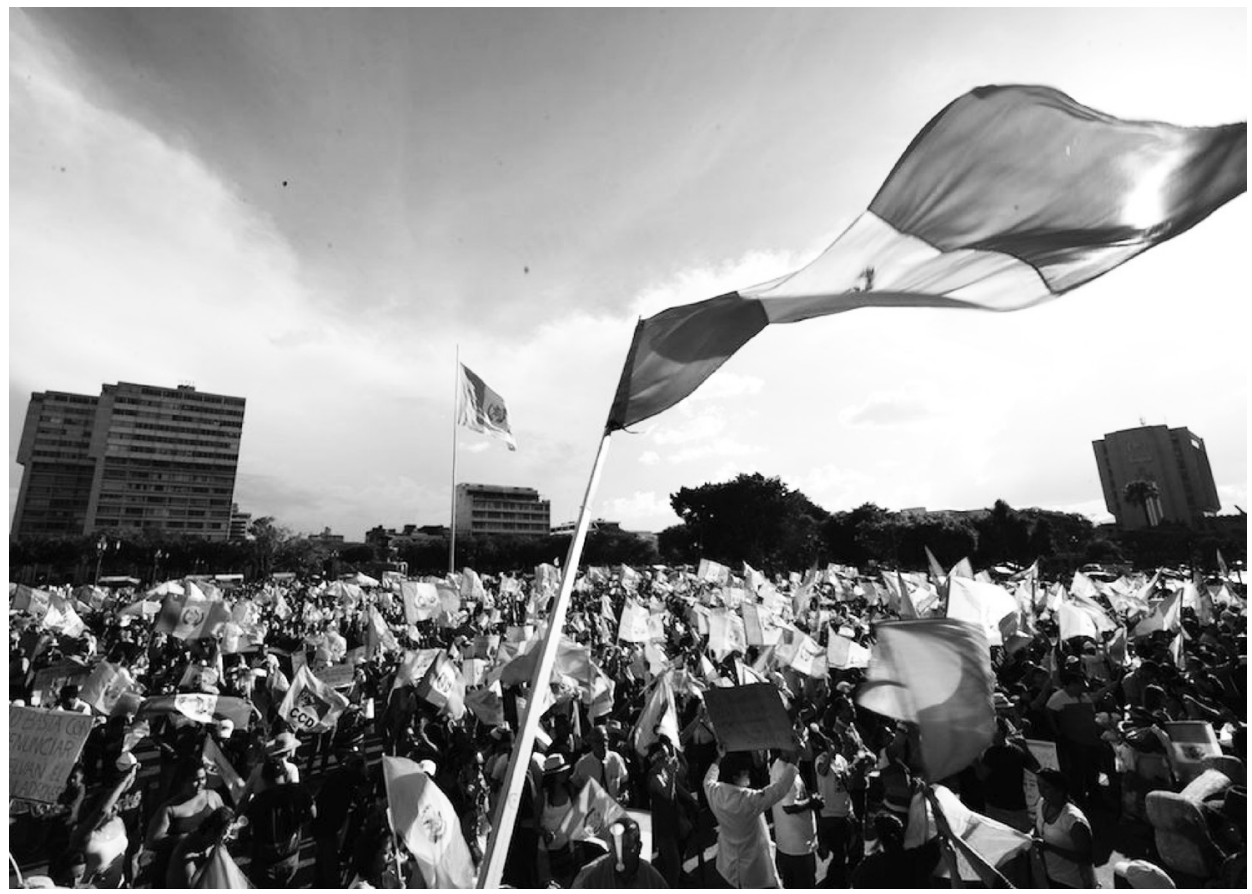

Fuente: http:/i0.wp.com/cb24.tv/wp-content/uploads/2015/08/manifestaciones-guatemala.jpg.

ElEstado de Guatemala ha sido diseñado no solamente para ser pequeño en sus funciones, sino para que funcione mal; sin recursos, sin capacidades, sin voluntad política. Obviamente se requiere de una infraestructura institucional que pueda desplegarse para la crisis, y realmente ese es el punto: en Guatemala no existen políticas de mediano ni de largo plazo, lo que conlleva a que hablemos únicamente y en forma permanente de gobiernos administradores de crisis. Esta crisis puede ser, sobre todo, social, cultural y, en menor medida, pero más determinante, económica y política.

El último tipo de crisis mencionada, la crisis política, es trascendental para el modelo. En el país, desde la transición hasta la democracia hace treinta años, hemos vivido dos crisis trascendentales para el sistema bajo esta categoría. La primera fue un intento de autogolpe de Estado al estilo de Alberto Fujimori ${ }^{1}$ por parte del expresidente Jorge Antonio Serrano Elías (1991-1993), quien el 25 de mayo de 1993, apenas a ocho años de la anhelada transición a la democracia, intentaba romper el orden constitucional del país al

\footnotetext{
${ }^{1}$ Expresidente de Perú (1990-2000).
} 
tratar de disolver la Corte Suprema de Justicia y el Congreso de la República para hacer ambos poderes del Estado a su medida. ¿La razón de esa tentativa? El excesivo nivel de corrupción que se institucionalizaba en el país con magistrados que en buena medida se prestaban a casos de corrupción en la Corte y un Congreso de la República que buscaba transar dinero a cambio de aprobar leyes de un Ejecutivo que había llegado con una bancada muy débil a hacer gobierno; en especial con tres partidos políticos que se encontraban institucionalizando, por medio de algunos de sus actores, prácticas corruptas, como ocurrió en el caso de la Democracia Cristiana Guatemalteca (DCG), la Unión del Centro Nacional (UCN) y la propia bancada de Jorge Serrano, el Movimiento de Acción Solidaria (MAS). ${ }^{2}$

¿El desenlace de esa crisis? Resistencia social ante el autogolpe, de manera que figuras de la talla de Rigoberta Menchú, por aquel entonces recientemente premiada con el Nobel de la Paz, se hacían acompañar del Procurador de los Derechos Humanos, Ramiro de León Carpio, de Nineth Montenegro, directora del Grupo de Apoyo Mutuo (GAM), una organización de derechos humanos que buscaba a desaparecidos por el conflicto armado interno, y del empresario más connotado de Guatemala, Dionisio Gutiérrez Mayorga. ${ }^{3}$

Pero, ipor qué irnos tantos años para atrás, si lo que queremos es explicar el papel de la ciudadanía en la crisis política de 2015? Aunque la respuesta no parece obvia, hay una fuerte conexión entre los hechos sucedidos en 1993 y lo acaecido, con sus propias particularidades, en 2015.

La crisis de 1993 estuvo liderada por cabezas visibles que asumieron un liderazgo sectorial —organismos de derechos humanos, lideresas sociales, sindicatos, universidad estatal, sector empresarial- que condicionaba a la clase política. Existió incluso un proceso de depuración del Congreso de la República y una transformación en nombramientos de cargos públicos que estuvieron respaldados por una reforma constitucional - la última en Guatemala-, que fue refrendada con tan sólo un 15.9\% de participación de ciudadanos empadronados (TSE, 1994).

Otro punto importante y relevante fue que no únicamente se luchó por mantener la democracia como sistema político electoral, sino que existió de manera conexa una lógica de rediseñar el Estado de Guatemala, que había sido en buena medida creado por la clase política como resultado de una Asamblea Nacional Constituyente, convirtiéndolo en un Estado facilitador de negocios privados.

Esto implicó hacer reformas a la Constitución que generaron facilidades a las lógicas del Consenso de Washington, en boga por aquel entonces, que trataban de reducir el Estado con la venta de las empresas públicas más rentables a precios irrisorios — telefonía,

\footnotetext{
${ }^{2}$ A estos tres partidos se les denominó "la trinca infernal".

${ }^{3}$ Considerado por algunas revistas de negocios como uno de los cien empresarios más importantes de la región latinoamericana (Summa, 2007).
} 
sistema de ferrocarriles o privatización del sector eléctrico, entre otros- Producto de ello, Carlos Slim es el dueño actual de la empresa de telefonía Guatel, anteriormente estatal.

Es decir, el discurso de la democracia en un ambiente que estaba determinado por el conflicto armado interno resultó ser la coyuntura idónea para garantizar la recomposición de un Estado a la medida, al menos en lo que el modelo globalizador buscaba asentarse en el tercer mundo.

Las manifestaciones públicas de aquella época tenían como variable determinante el miedo existente en la población por estarse viviendo aún el conflicto armado interno, que incluso acabaría tres años después de darle una reingeniería al Estado con la firma de los Acuerdos de Paz.

En síntesis, la crisis política de 1993 tenía una agenda temática inicial, pero no absoluta; comenzó siendo la lucha por la defensa de la democracia y terminó con reformas a la Constitución Política y una reingeniería estatal que permitiera la adaptación de la institucionalidad pública al modelo de la globalización económica que requería menos Estado y más mercado. La defensa de la democracia resulta ser únicamente el discurso, mas no la finalidad, en un ambiente que facilitaba restarle poder a la clase política y lo retornaba a la clase económica. El mecanismo idóneo fue trastocar el sistema que daba sustento a la cultura política del guatemalteco.

Foto 2. Manifestación contra Jorge Serrano Elías

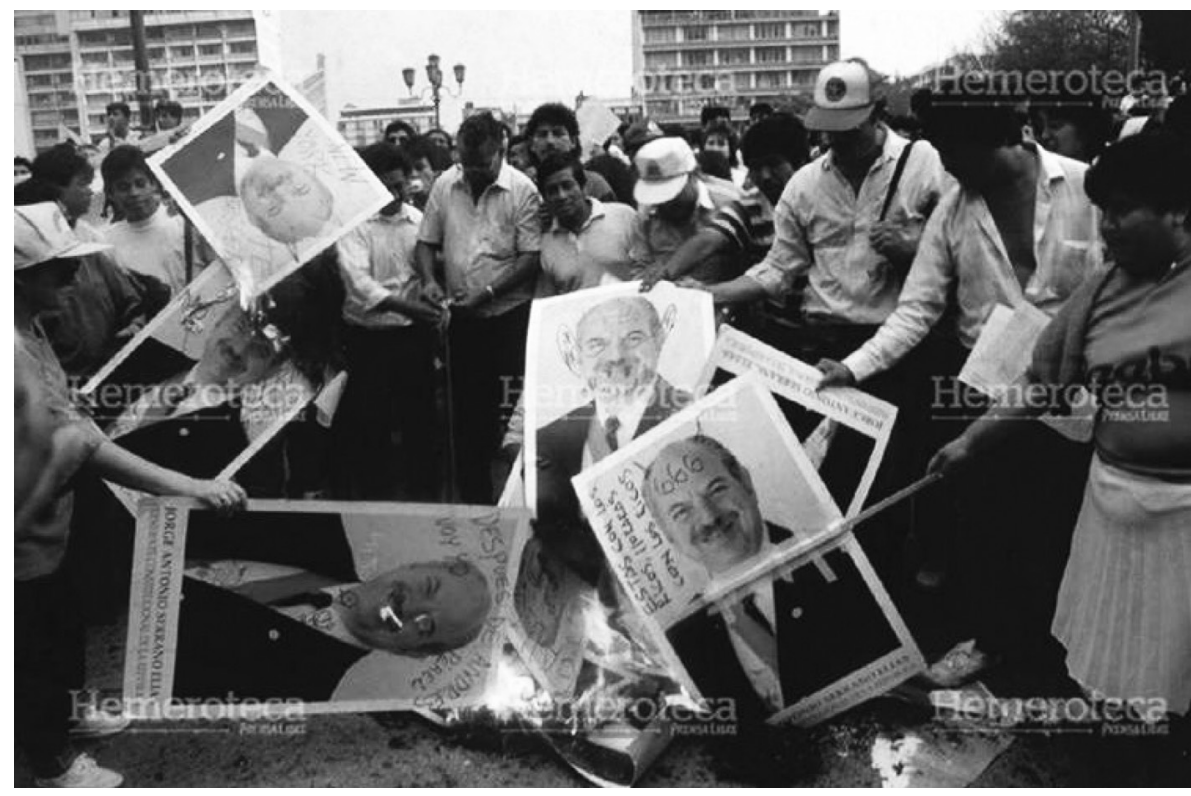

Fuente: Hemeroteca de Prensa Libre. 
El político pasó a ser el personaje corrupto, ladrón, lleno de avaricia, al que se le culpó por todo el descalabro estatal. Nunca se habló del desfinanciamiento del presupuesto público ni de las limitantes que los políticos tenían para implementar un plan de gobierno con corte ideológico definido, electo en un ambiente democrático.

Este discurso, manejado desde los medios de comunicación y reproducido en universidades y centros de pensamiento, posicionaría en el imaginario colectivo el rechazo a la política y a quienes se dedicaban a tratar de construir propuestas de gobierno.

Es a partir de esta ruptura institucional como los partidos políticos tradicionales, con ideologías definidas y formación de cuadros, fueron señalados de ser los responsables del descalabro político; ello dio paso a la necesidad de "oxigenar" la política con nuevos partidos, y surgieron así partidos franquicias (Asíes, 2013).

Estos partidos franquicias requieren sólo de financiamiento suficiente para pagar espacios en medios de comunicación y de un cacique dueño de la ficha partidaria que le permita posicionarse ante la población, sin necesidad de un plan de gobierno, equipos de trabajo o agenda programática. Alcántara (2004) señala que es una regla en América Latina que los partidos estén más preocupados por votos que por militantes, y Guatemala no es la excepción.

Es bajo este modelo como durante veintidós años se vino desarrollando la política en Guatemala, hasta que una mezcla rara de factores externos e internos detonó protestas ciudadanas que tuvieron eco en el sistema y condujeron a la renuncia del presidente y de la vicepresidenta del país, quienes se encuentran sujetos a investigación penal, privados de su libertad.

\section{Primer detonante: Manuel Baldizón y el "no te toca"}

El 25 de abril de 2015 sucedieron hechosinesperados para el sistema político guatemalteco, sobre todo para la clase política. Guatemala se encontraba cercana a una elección general, en la que se elegirían presidente y vicepresidente de la República, 158 diputados de un Congreso unicameral, 338 corporaciones municipales y 20 diputados al Parlamento Centroamericano.

En ese ambiente, parecía que Manuel Baldizón, candidato del partido Libertad Democrática Renovada (LIDER), asumiría la primera magistratura del país. Algunos se atrevían incluso a mencionar que Manuel Baldizón podría ganar en primera vuelta dada la maquinaría mediática de su partido, así como el gran flujo económico que lo llevaba a estar en permanente campaña política pese a prohibición de la Ley Electoral y de Partidos Políticos.

Incluso, los más conservadores decían ver una "potencial Venezuela", con Manuel Baldizón como presidente y una bancada fuerte en el Congreso que potenciaba su 
independencia del sector económico tradicional nacional y que tomaba distancia de aliados internacionales históricos como Estados Unidos y Taiwán.

Baldizón tenía cómo desarrollar su propio proyecto político, aunque esa autonomía, en lugar de convertirse en garantía, era más bien una potencial amenaza para la sociedad. Se conocía su vínculo con el narcotráfico y se sabía de las negociaciones bajo la mesa con el gobierno de turno para garantizar impunidad en la transición a cambio de tomar decisiones estratégicas desde antes de hacer gobierno.

Aunado a ello, se conocía su interés por dar apertura a empresas farmacéuticas hindúes y facilitar la relación político-económica con la República de China Popular, algo que tampoco generaba tranquilidad ni al status quo nacional ni al internacional.

Baldizón puso la guinda al pastel cuando consideró que dentro de su maquinaria mediática podía catapultar una idea popular a su conveniencia. Desde 1995, todos los presidentes de la República habían obtenido el segundo lugar en la elección inmediata anterior. Esto significaba que a Manuel Baldizón, quien perdió ante Otto Pérez Molina del Partido Patriota (PP) en 2011, "le tocaba" ser presidente, por lo cual desarrolló un eslogan propagandístico que decía: "le toca”. Algo tan brillante mediáticamente no había considerado variables propias de la sociología política. Las relaciones sociopolíticas son dinámicas y, por lo tanto, no pueden asumirse simplemente bajo lógicas de mercado; al final, el mensaje de "le toca" iba a ser una externalidad en un ambiente por demás convulso con una serie de hechos que se irían concatenando para dar los resultados que se dieron.

\section{Foto 3. Manifestación contra Manuel Baldizón}

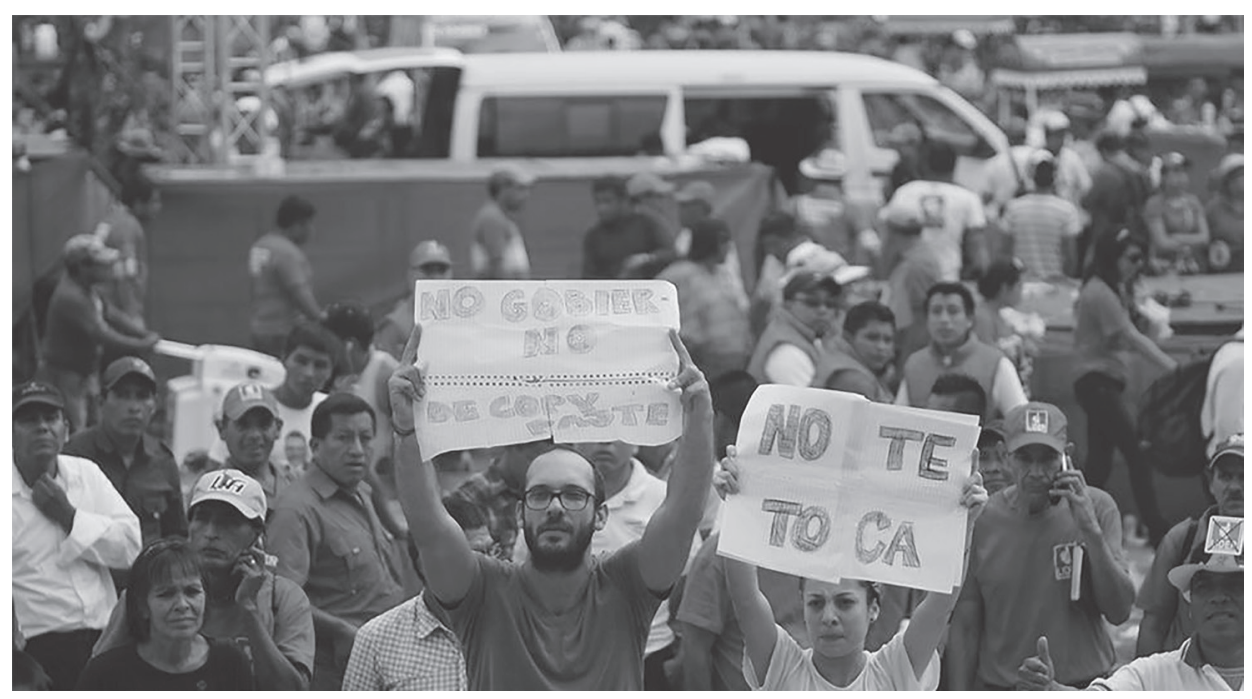

Fuente: Plaza Pública. 


\section{Segundo detonante en 2015: la vicepresidenta Roxana Baldetti}

El 19 de febrero de 2015 salió a luz pública que el Estado de Guatemala pagaría 137.8 millones de quetzales - más de 17 millones de dólares- por una sustancia que sería capaz de descontaminar el lago de Amatitlán (El Periódico, 2015), un cuerpo acuífero que ha servido como vertedero de aguas negras de la capital y áreas conurbanas.

El líquido resultó ser una solución salina con agua oxigenada que había sido calificada en Israel como dañina para la salud; sin embargo, pese a una investigación periodística que lo daba a conocer, la vicepresidenta Roxana Baldetti desmintió que fuera un derroche de dinero; incluso, salió de paseo por las aguas negras del lago de Amatitlán e invitó a los periodistas a consumir una mojarra del lago —un platillo típico del lugar-, situación que ofendió e indignó a la mayor parte de la población guatemalteca.

En diciembre de 2014, la vicepresidenta había cometido otra burla contra los guatemaltecos. Luego de una investigación periodística de un medio estadounidense que evidenciaba las malas condiciones en las que se encontraban los pacientes del Hospital de Salud Mental Federico Mora, ella adujo que el hospital estaba "re-bonito". Esto se sumó a una serie de declaraciones incoherentes y no oportunas que tendrían de fondo una investigación, por parte de la Comisión Internacional Contra la Impunidad en Guatemala (CICIG), de los casos de corrupción que se venían gestando desde el gobierno del PP.

Foto 4. Roxana Baldetti corroborando el saneamiento del lago de Amatitlán

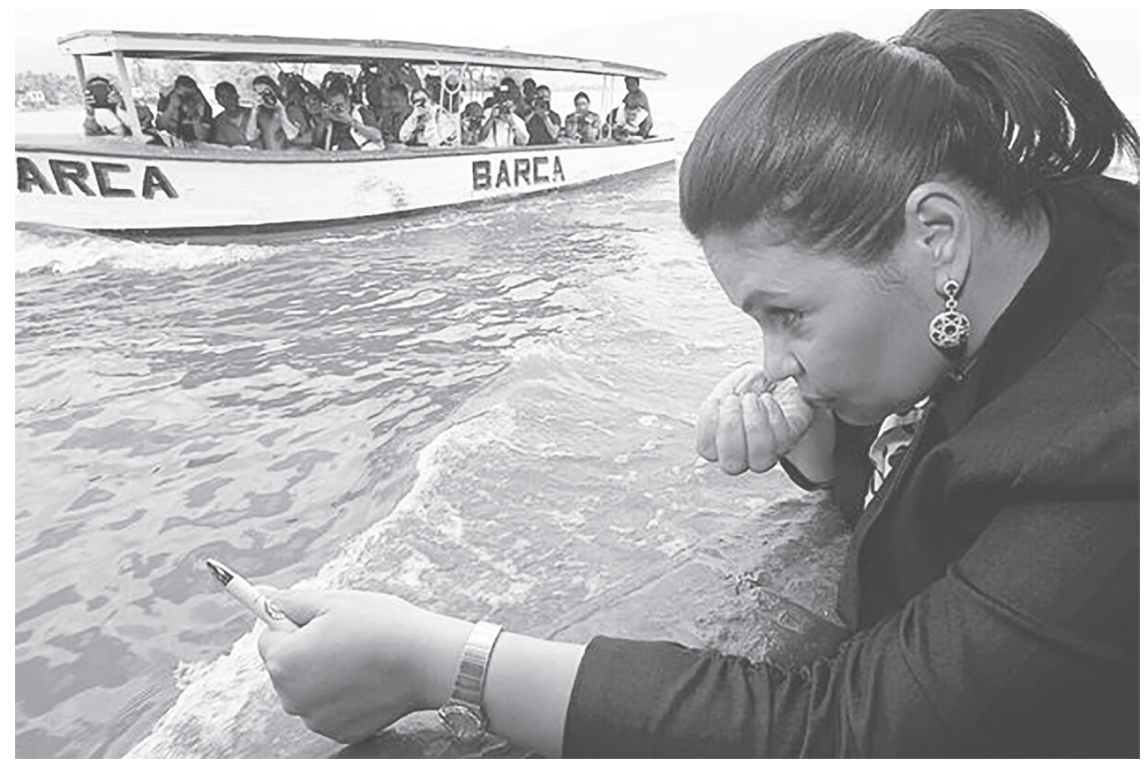

Fuente: Prensa Libre. 


\section{Tercer detonante: el caso de La Línea}

En febrero de 2015, el presidente Otto Pérez Molina y su cúpula más cercana se habían manifestado contrarios a la continuidad de la CICIG en Guatemala. Este ente de Naciones Unidas, creado en 2006 como una primera experiencia para investigar y desmantelar estructuras paralelas, necesita cada dos años de una renovación de su mandato a petición del Gobierno de Guatemala.

Todo indicaba que el mandato no se prorrogaría; sin embargo, varios hechos se concatenaron. El más fuerte de todos fue la visita de Joe Biden, vicepresidente de Estados Unidos, quien dentro de su lógica de reuniones para manifestar la postura de su gobierno para el triángulo norte con la denominada "Alianza para la Prosperidad", excluyó a Roxana Baldetti de las reuniones por medio de estrategias diplomáticas que requerían de la presencia del presidente Otto Pérez Molina. El mensaje era claro, la CICIG debía de continuar y Biden solicitó también pensar en una comisión de este tipo para Honduras y El Salvador.

Foto 5. Jefe de Ministerio Público y de la CICIG dando declaraciones por caso "La Línea"

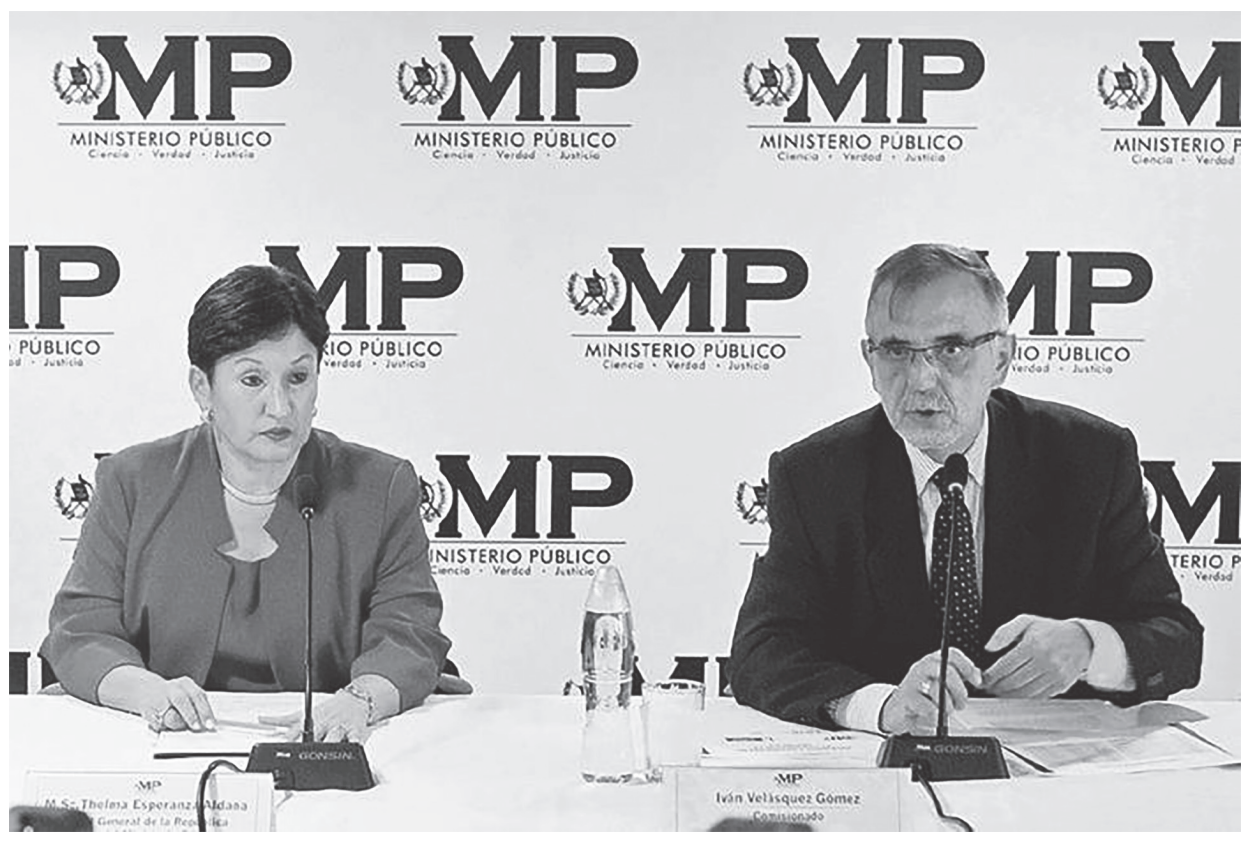

Fuente: Guatevisión.com. 
Al doblársele la mano para aceptar la continuidad de la CICIG en el mes de abril, Otto Pérez Molina se condenaba prácticamente a la horca política. La CICIG sacó a la luz, tan sólo unos días antes, una estructura de defraudación aduanera que traería consigo la renuncia de los principales actores del PP en pleno año electoral, y con ello incluso que su candidato presidencial, Alejandro Sinibaldi, prefiriera renunciar antes de ser señalado junto a la cúpula de su partido.

Esto, junto a errores de la entonces vicepresidenta Baldetti que condujeron a una disputa del presidente Pérez Molina incluso contra el propio sector empresarial nacional y a una lucha por demás perdida contra la CICIG al demostrarse que Baldetti y su entonces secretario privado Juan Carlos Monzón, en conjunto con el propio presidente, lideraban y coordinaban una red paralela al Estado dedicada al desfalco de las arcas nacionales por medio de la defraudación aduanera, ocasionaron un malestar generalizado por parte de la población que rechazaba a los políticos y su lógica de enriquecimiento por medio de la administración del Estado.

\section{Cuarto detonante: el nombramiento de Todd Robinson}

Un año antes de todos los hechos sucedidos que trastocaron el sistema político nacional, Estados Unidos nombraba como su embajador en el país a Todd D. Robinson, quien había sido encargado de negocios de dicha delegación diplomática entre los años 2009 y 2011. Luego de ello, Robinson había pasado a ser subsecretario adjunto en la Oficina de Narcóticos Internacional y Seguridad del Departamento de Estado. Durante sus treinta años como diplomático, el embajador que fue nombrado en junio de 2014 acumulaba vasta experiencia en Bolivia, República Dominicana, Colombia y El Salvador.

Guatemala pasó cerca de tres meses sin embajador del país del norte antes del nombramiento de Robinson, lo cual significaba que no sería nombrado nadie al azar. Debía ser cuidadosamente seleccionado para su misión, ser un embajador "halcón". Según fuentes no oficiales, dentro de la diplomacia los funcionarios suelen dividirse entre "palomas" y "halcones". Los primeros buscan consensos, son conciliadores y tratan de articular procesos. Los segundos, entre los que se encuentra Robinson, son diplomáticos elegidos en medio de vacíos de poder y que se requieren personalidades con autoridad (Hurtado, 2015). ${ }^{4}$

La misión era clara: impulsar a toda costa la continuidad de la CICIG y establecer las condiciones necesarias en Guatemala para que la Alianza para la Prosperidad para el Triángulo Norte tuviera asegurada su estrategia. En menos de nueve meses, Robinson sería testigo del desmoronamiento de más de la mitad del gabinete de Pérez Molina y, de paso, vería la renuncia de los primeros dos funcionarios del Ejecutivo.

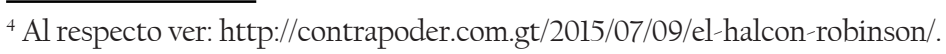


La no continuidad de la Fiscal General del Ministerio Público, Claudia Paz y Paz, una mujer a la que Estados Unidos consideró su aliada, pero que era incómoda para los gobernantes, era uno de los factores fundamentales para la presencia de Robinson. La misión de éste era recuperar y tomar total control de sus círculos de influencia en la lucha contra la corrupción, y así garantizar los intereses de la política exterior estadounidense en un país como Guatemala, donde incluso la democracia más elemental —en su forma representativa- estaba en juego.

Aunado a ello, la posibilidad de la llegada de actores con cierto poder económico e independencia en la toma de decisiones y claros vínculos con sectores oscuros como el narcotráfico, como Manuel Baldizón, hacía necesario un giro rápido y determinante del quehacer del embajador más influyente en la región.

\section{Foto 6. Otto Pérez Molina y Todd Robinson}

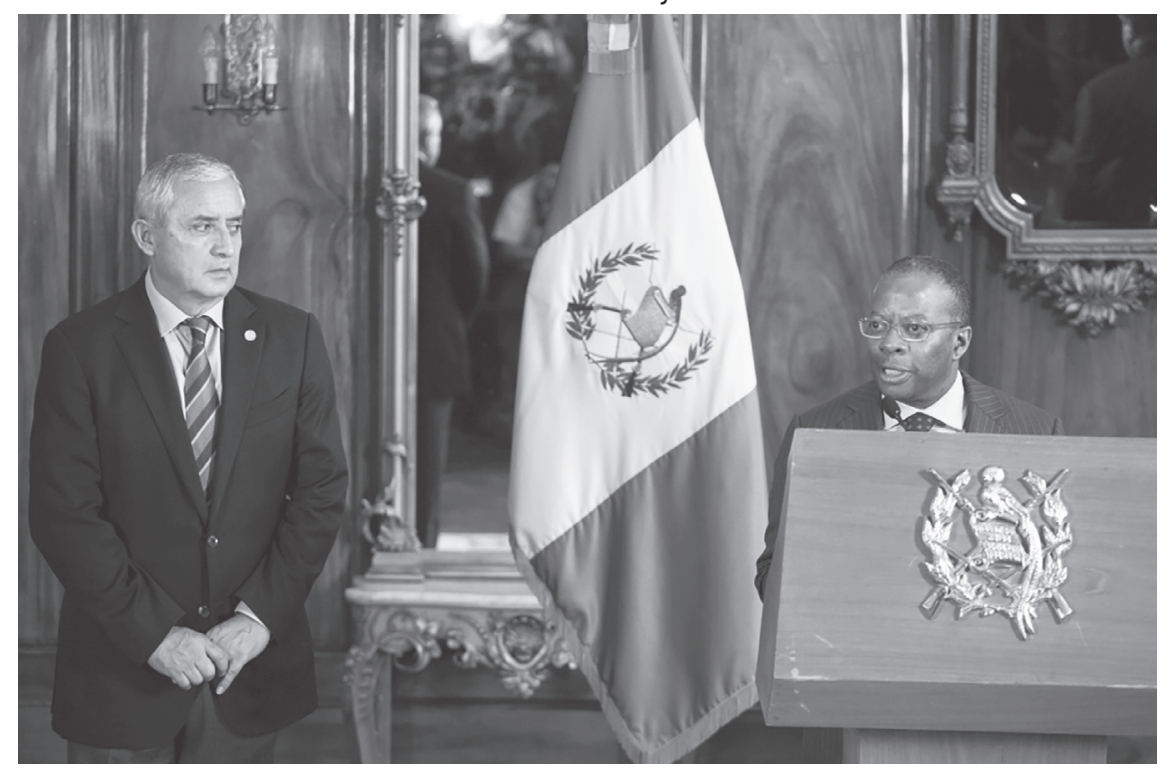

Fuente: Luis Soto, Revista Contrapoder (9 de julio de 2015)

\section{Quinto detonante: las redes sociales}

Pese a que estudios recientes como el Global Information Technology Report 2015 del Foro Económico Mundial han demostrado que en Guatemala sigue siendo bajo el uso de las redes sociales — se ubica en el puesto 75 de 143-, éstas son utilizadas principalmente por personas de áreas urbanas con capacidad de consumo y acceso a medios tradicionales de información como el periódico, la televisión y la radio. Esto posibilita en buena medida 
la construcción de discursos y de imaginarios colectivos que determinan en mucho el comportamiento y las actitudes de las personas, sobre todo cuando están en un ambiente sensible como lo es un año electoral.

Christian Lazzeri (2001) señala al respecto, en su escrito Los signos del poder: ensayo sobre la politica de Pascal, cómo los seres humanos intentamos varias cosas a la vez que parecen contradictorias pero que nutren en buena medida el quehacer humano: el deseo de ser universal y la evitación de la nada.

Por medio de las redes sociales como Facebook, Twitter e Instagram se logran ambas cosas. El usuario pasa de ser un perfecto desconocido a ser un personaje al que por unos segundos muchas personas conocen y le muestran agrado, aprecio y admiración: bastarán unos cuantos "me gusta"s para elevar la autoestima de quien comenta. A su vez, el usuario suele publicar o revisar publicaciones de otros usuarios para evitar el vacío que le genera su existencia, el sentimiento de la nada y la soledad no escogida que le produce angustia y desesperación. Bajo estas condicionantes, las redes sociales han logrado ser capaces de construir discursos e imaginarios colectivos que no requieren de mayor elaboración ni comprobación. Es suficiente con que la publicación pueda ser creíble.

Las manifestaciones populares en Guatemala que iniciaron en abril de 2015 surgieron precisamente de las redes sociales, luego de que la CICIG y el MP revelaran la existencia de una mafia que se dedicaba a la defraudación aduanera, en la que desde un inicio se evidenció el vínculo de la entonces vicepresidenta Roxana Baldetti y del presidente Otto Pérez Molina.

Se creó una página de Facebook denominada "Manifestación pacífica para pedir la renuncia de Otto Pérez Molina y Roxana Baldetti", así como el hashtag \#RenunciaYa, en Twitter. ¿El resultado? Más de 40000 personas congregadas el 25 de abril en la Plaza de la Constitución para exigir la renuncia de los altos funcionarios. En Facebook, más de 39000 personas dieron seguimiento a la página, y el día de la manifestación el hashtag \#PancartaParaElSábado se convirtió en tendencia nacional con más de 26000 retweets, en los que las personas subían lo que le demandarían a los políticos en mención. Las redes sociales posibilitaron incluso manifestaciones de guatemaltecos en diversos países del mundo como Reino Unido, Argentina, México, Francia y España (La Hora, 8 de mayo de 2015).

Además, grupos como Anonymous y \#JusticiaYa, que al parecer surgieron con jóvenes que no personalizaron su activismo político, convocaron a marchas y al encadenamiento de varios de sus miembros a las puertas del Palacio Nacional. Esto trajo como resultado que miles de personas salieran a las calles con diversas consignas particulares, pero con una sola en común: la renuncia de los mandatarios.

\footnotetext{
${ }^{5}$ Mecanismo mediante el cual un usuario de red social muestra admiración o simpatía por un comentario o publicación con respecto a lo publicado por otro usuario.
} 
La convocatoria mediante redes sociales continuó sábado a sábado. La \#MarchaDeLaDignidad del 2 de mayo - efectuada en esa fecha para diferenciarse de la del 1 de mayo que realizan anualmente los sindicatos en buena medida desprestigiados en el país y que incluso no tomaban posición en contra del gobierno, lo que para muchos evidenciaba contubernio por recibir aportes del presupuesto público - volvió a poner en evidencia el clamor general " «RenunciaYa” y generó la ilegitimidad necesaria para que el 8 de mayo Roxana Baldetti presentara su renuncia al cargo de vicepresidenta y con ello enfrentara cargos tras perder su inmunidad.

Cada fin de semana, más sectores se unían a las protestas, aunque cabe destacar que en buena medida siempre fueron urbanas, de clases medias, no indígenas y lúdicas. Se puede afirmar incluso que hubo fines de semana en que pocas personas tenían bien determinado un norte en sus protestas; se valía protestar por todo y se volvió incluso anárquica la forma de hacerlo. Eso sí, siempre se evitaron las pintas, el daño a la propiedad -pública y privada -, las palabras soeces, botar basura y aquellos comportamientos que no fueran sinónimo de construcción de ciudadanía.

En síntesis, las marchas unieron a un sector que tradicionalmente se mostró reacio a salir a las calles y a mostrar su descontento con el sistema, un sistema muy bien interiorizado en la sociedad guatemalteca.

\section{Gráfica 1. Análisis del movimiento \#RenunciaYa}



Fuente: http://clicksplan.com/analisis-del-movimiento-renunciaya-y-renunciayafase2-en-redes-sociales/. 
Gráfica 2. Análisis por género y tipo de mención
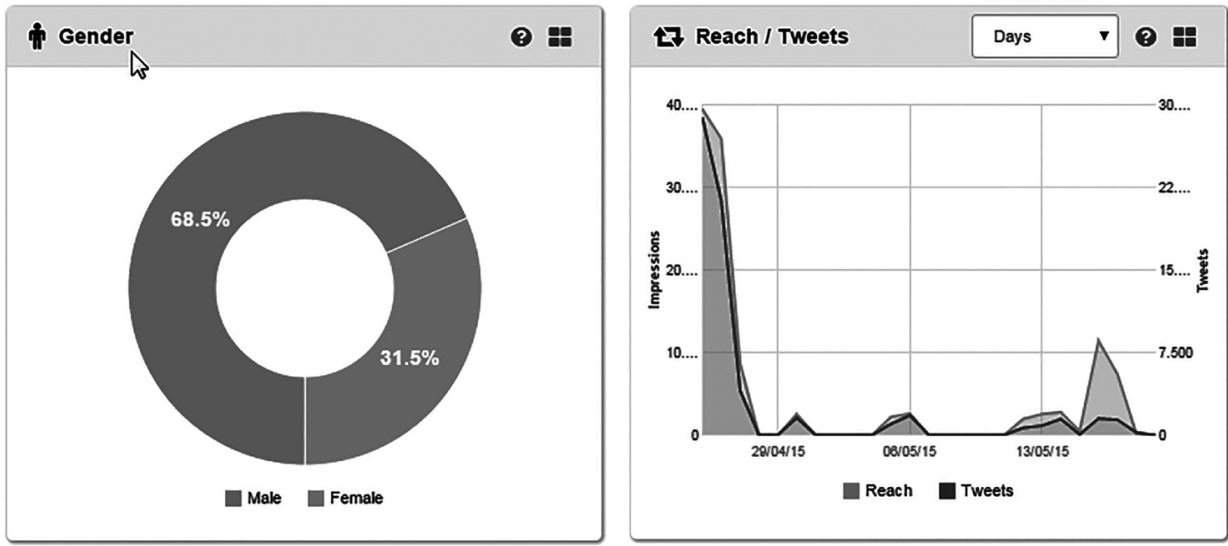

Fuente: http://clicksplan.com/wp-content/uploads/clicskplan-renunciaya-12.png

\section{Guatemala, un país altamente liberal-conservador}

El país tiene una construcción de su imaginario colectivo altamente conservadora, de tendencia liberal. En Guatemala se apuesta por el mantenimiento de la derecha y sus lógicas para la interpretación de las variables económicas, políticas, sociales y culturales. Las manifestaciones de abril a septiembre mostraron lo anterior en buena medida

Las tradiciones y los valores familiares y religiosos son propios del guatemalteco y de su sistema social. Pese a que el país está conformado por veintidós grupos indígenas y los ladinos - no indígenas-, la incidencia de estos grupos en la estructura sociopolítica es mínima, sobre todo porque Guatemala cuenta con un Estado pequeño, diseñado para funcionar en áreas urbanas, con alta autonomía individual de sus habitantes, quienes suelen suplir sus necesidades básicas bajo un modelo liberal —la salud, la educación, la seguridad, de acuerdo con la capacidad del poder adquisitivo- L Las exigencias al Estado son mínimas y por eso tras la renuncia no se continuó con mayores exigencias al sistema político.

Lo urbano y lo rural en el país están desconectados. No se suelen conocer las problemáticas, distintas conforme uno se adentra en el territorio nacional. Cada cuatro kilómetros se puede cambiar de clima y de entorno, lo que incluye el cultural y sociopolítico.

En el país el discurso nacionalista puede ser capaz de legitimar diversas acciones, aun cuando forzadamente se haya fundado como un Estado-nación; recordemos que en el país conviven varias naciones dentro de un mismo territorio, pero la administración estatal existe tan sólo para responder a los intereses de los no indígenas. Es por ello interesante ver al actual presidente que votó en primera y segunda vuelta electoral con la 
camisola de la selección de fútbol de Guatemala, y cómo incluso los fenómenos de rechazo a la clase política catapultaron a un desconocido Jimmy Morales a la presidencia del país en un ambiente por demás convulso.

Jimmy Morales representa la estabilidad política requerida por el sector económico tradicional, la legitimidad de militares retirados que lo apoyaron con la figura de la Asociación de Veteranos Militares de Guatemala (AVEMILGUA) — quienes incluso le cedieron la ficha de su partido Frente de Convergencia Nacional-y el sostenimiento del status quo que requiere la propia sociedad guatemalteca en sus capas medias, esto con el visto bueno de los Estados Unidos.

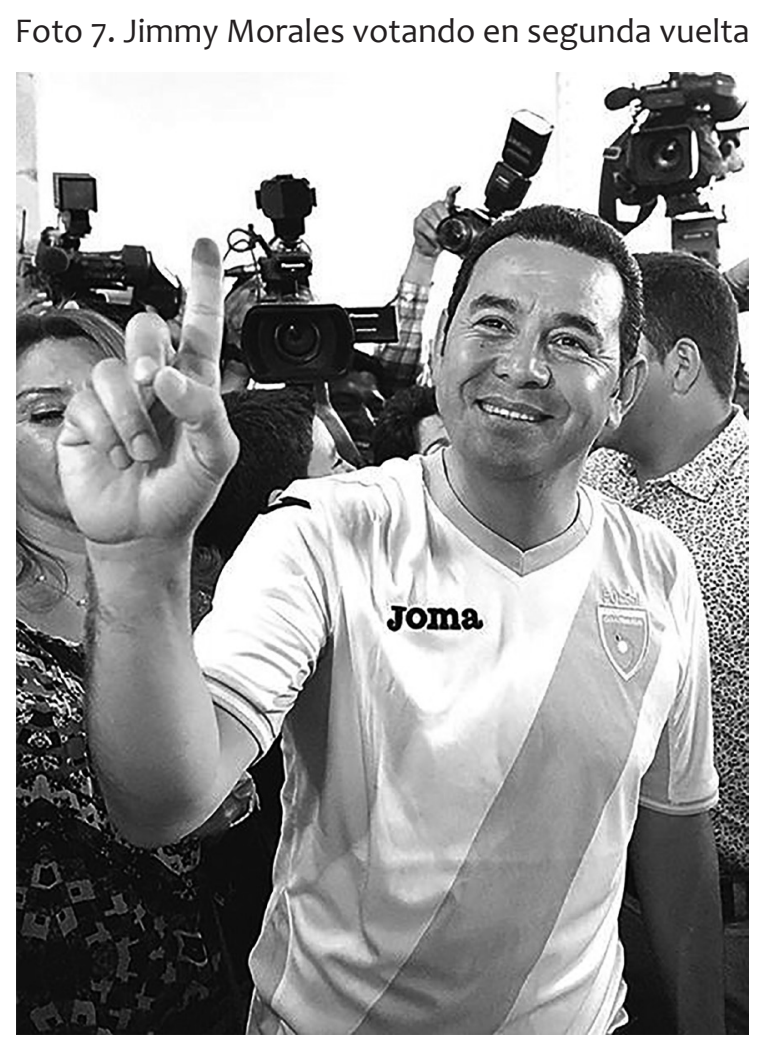

Fuente: www.diarioextra.com

\section{Para ir concluyendo}

Las manifestaciones públicas parecen tener mucho de la lógica de acción colectiva en función de una amenaza común, más que en función de la construcción de Estado. De 
hecho, el discurso de las personas siempre fue contra figuras - Baldetti y Pérez-; el cuestionamiento no fue realmente contra el sistema político, legitimado éste con la alta participación en el proceso electoral — $71.33 \%$ en primera vuelta y $56.32 \%$ en segunda vuelta-, según el Tribunal Supremo Electoral.

Elnotener cabezas visibles, a diferencia delasúltimas manifestaciones que trastocaron el sistema político, como fueron las de 1993, les genera facilidad de identificación a las personas; cualquiera cabe en el grupo que exige demandas. Sin embargo, no permite articular una agenda política de mediano y largo plazo, son de cortoplacistas.

Si bien las manifestaciones públicas parecen haber incidido en una especie de "revolución de colores" al estilo de Gene Sharp (2011), las revoluciones per se no hubiesen tenido la incidencia que tuvieron sin el caldo de cultivo perfecto que generó el interés de actores como Estados Unidos, el sector económico tradicional y la sociedad civil organizada para evitar que el Estado emprendiera un viaje sin retorno a la corrupción que se venía generalizando en el actuar gubernamental y que alcanzó niveles a todas luces evidentes y exagerados.

Hoy el país ha vuelto a ser prácticamente el mismo, con el status quo de un país liberal y conservador, tradicional, donde los ciudadanos no esperan nada del Estado y están dispuestos a resolver sus problemáticas por sí mismos. Pasaron días sin presidente o vicepresidente en el país y simplemente "no pasó nada", al parecer cada sector de la sociedad sabe a la perfección su papel y el Estado y sus instituciones tienen muy poco qué hacer.

¿Nuevo paradigma? Hoy, a un par de meses de las últimas manifestaciones populares, parece ser que la intención era recuperar el orden original a la llegada de Otto Pérez Molina y su equipo de gobierno, pero en poco parece ser que se trastoque por las manifestaciones la institucionalidad estatal. Los cambios sí parecen continuar, pero más en función de la política exterior de otras naciones que buscan generar las condiciones y los cambios necesarios en el triángulo norte de la región centroamericana, bajo intereses económicos y geoestratégicos, más que en función del fortalecimiento de una democracia que aún sigue siendo para muchos de nosotros sumamente insípida.

\section{Referencias bibliográficas}

Alcántara, Manuel (2004). Partidos políticos en América Latina. Precisiones conceptuales, estado actual y retos de futuro. Barcelona: Cidob.

Asíes (2013). Qué entendemos por partido franquicia. Asociación de Investigación y Estudios Sociales. año 28, núm. 3. Guatemala.

Foro Económico Mundial (2015). Global Information Technology Report. Genova: Italia.

García, Enrique (2015). “Estado pagará Q137.8 millones por lago de Amatitlán”. En El Periódico, 19 de febrero.

Hurtado, Paola (2015). “El halcón Robinson”. En Revista Contrapoder, 9 de julio. Guatemala. 
JAHIR DABROY

La Hora (2015). "Tras llamado en redes sociales, Guatemala alza la voz y repudia la corrupción", 8 de mayo.

Lazzeri, Christian (2001). "Los signos del poder: ensayo sobre la política de Pascal". En Jean-Louis Labarriére y Christian Lazari, Teoría política y comunicación. Barcelona: Gedisa.

Molina, Ignacio (1998). Conceptos fundamentales de Ciencia Política. Madrid: Alianza Editorial. Sharp, Gene (2011). De la dictadura a la democracia. Un sistema conceptual para la liberación. Estados Unidos: Institución Albert Einstein.

Summa (2007). "Los cien inversionistas más importantes de América Latina”. Costa Rica. TSE (1994). Memoriaelectoral: consulta popular 1994. Guatemala: Tribunal Supremo Electoral. 


\title{
Democracia desde arriba, democracia desde abajo: elecciones, poder y conflicto en la Honduras post-golpe de Estado
}

\author{
Andrés León
}

Existe un consenso bastante generalizado - tanto en términos académicos como del sentido común cotidiano - de que el golpe de Estado del 28 de junio de 2009, que expulsó al entonces presidente Manuel "Mel" Zelaya Rosales de su puesto, vino a transformar de forma profunda a la sociedad hondureña. El aumento en los índices de violencia o el nacimiento del partido político Libertad y Refundación, y la consecuente polarización del sistema de partidos políticos, tienden a ser presentados como claros ejemplos de una sociedad cada vez más fragmentada y conflictiva donde la noción misma de democracia es puesta en tela de duda (Sosa, 2014; Rodríguez, 2015).

En términos generales, la perspectiva dominante de las explicaciones que se dan del golpe de Estado, y de la consecuente crisis política y de la compleja coyuntura actual, es de corte institucional, y el problema central tiene que ver con la debilidad del Estado hondureño, los altos niveles de corrupción, la ausencia de una ciudadanía activa, los deplorables niveles de pobreza y desigualdad social, así como la violencia rampante generada por el crimen organizado, las pandillas y el narcotráfico (ver, por ejemplo, Ruhl, 2010; Mejía y Fernández, 2010; Meza et al., 2010; Salomón, 2009; Salgado, 2010).

Si bien no hay nada de malo en estas explicaciones — que más que aclarar las raíces del conflicto dan cuenta de sus manifestaciones-, es evidente que obvian o nos dicen muy poco respecto a las condiciones de posibilidad del golpe de Estado de 2009, así como de la situación actual del país. En este artículo se busca intervenir en esta discusión a partir de dos puntos de ingreso distintos pero interconectados: primero, explorando el proceso histórico de producción de una cierta formación estatal hacia finales de los setenta, y cuyas características principales - presentadas de forma muy esquemática en este artículo - tienen bastante que decir con respecto a la "crisis hegemónica" que concluye en, pero no se limita a, el golpe de Estado; segundo, explorando el proceso de producción y disputa de la hegemonía en la sociedad hondureña actual a partir de algunas perspectivas de lo que una democracia debería ser hoy en día, y la cristalización de los 
conflictos sociales alrededor de dos ejes dominantes: por un lado, lo que podríamos denominar luchas "ciudadanas" — concentradas alrededor del tema de la corrupción y la función pública-y las disputas "territoriales" —en las que distintos grupos subalternos (indígenas, afrodescendientes y campesinos, entre otros) buscan defender sus formas de vida frente a los intereses extractivistas de empresas locales y transnacionales-.

El artículo se divide en tres partes: primero, utilizando la noción gramsciana de "revolución pasiva", se hace una síntesis apretada del proceso de formación poscolonial del Estado hondureño, intentando ubicar un conjunto de dinámicas que para la década de los setenta se habían condensado en una forma de Estado particular, cuyas características generales aún siguen vibrando en la historia política hondureña y mucho tienen que decir con respecto a las condiciones de posibilidad del golpe de Estado de 2009 y la subsecuente crisis. En un segundo momento, se analiza el período que va desde la elección de Manuel "Mel" Zelaya en 2006 hasta el proceso electoral de noviembre de 2013, para mostrar la resonancia de los elementos presentados en la primera parte en la coyuntura actual del país. Finalmente, se muestra cómo estas disputas políticas se manifiestan alrededor de dichos ejes de conflicto, como una forma de sintetizar la discusión hasta ese momento y proponer desde ahí una interpretación algo distinta de la crisis.

\section{Revolución pasiva y el Estado hondureño}

En los Cuadernos de la cárcel, y en un esfuerzo por entender el proceso del Risorgimento italiano, Antonio Gramsci (1999) toma prestado de Vincenzo Cuoco el concepto de "revolución pasiva" para referirse a un proceso particular de formación de Estado en el cual, lejos del ejemplo de la burguesía francesa durante el proceso revolucionario, las nuevas clases dominantes suben al poder sin lograr concretar un liderazgo moral e intelectual sobre el resto de clases sociales. En este caso, las nuevas clases dominantes no son "progresivas" - en el entendido de barrer con el viejo régimen para crear las condiciones para el desarrollo libre de las relaciones capitalistas-, y más bien se ven obligadas constantemente a pactar y negociar con otras clases y fracciones de clase para asegurar y legitimar su dominación.

El resultado es una situación de "revolución sin revolución" o una "revolución desde arriba" en la que la dirección del proceso de transformación social necesariamente combina y articula de forma contradictoria los intereses de diferentes clases y fracciones de clases sociales; y donde las clases dominantes buscan desarrollar estrategias para dividir y desagregar a los grupos subalternos ${ }^{1}$ y confinarnos a un nivel económico-

\footnotetext{
${ }^{1}$ En este texto acojo como propia la definición que hace Rhina Roux de subalterno: "Entiendo como subalternos a todos aquellos individuos y grupos que, en el proceso social de reproducción de la existencia humana, conforman una comunidad inferior en relación con otros que deciden la
} 
corporativo de la sociedad, al mismo tiempo que dichos grupos subalternos son incapaces de construir una estrategia hegemónica capaz de resistir la capacidad de absorción, la lógica de la revolución pasiva (Thomas, 2009; Sanyal, 2013).

Desde esta perspectiva, el Estado es entendido no sólo como un instrumento de coerción que impone simplemente los intereses de la clase dominante desde arriba, sino más bien de forma integral, como una constelación de relaciones sociales dirigidas a la producción de consensos - y disensos - y la integración de los grupos subalternos dentro del proyecto expansivo de las clases dominantes (Thomas, 2009: 143). Dicho en otras palabras:

Una relación estatal no surge de las leyes escritas o de la cabeza de los gobernantes. No se reduce a promulgar una constitución o a organizar un aparato de administración pública, un ejército y una burocracia. Si el Estado es un concepto que refiere a un proceso relacional entre seres humanos ( $y$ no un aparato o conjunto de instituciones), entonces la relación estatal se conforma en el conflicto y la negociación entre élites dirigentes y clases subalternas, cuyas acciones están modeladas por la experiencia y encuadradas en entramados simbólicos cultivados en la historia. Comprender el modo de estructuración y funcionamiento de una forma estatal específica implica analizar cómo, por qué y desde dónde, en una configuración del mundo, se tejen los lazos materiales e inmateriales que unen a dominadores y dominados en una comunidad estatal: el tejido de vínculos que reproducen ese orden en la mente y en la conducta de los individuos consigo mismos y en sus relaciones con los otros, así como el conjunto de derechos, obligaciones y restricciones que, de hecho o de derecho, constituyen y recrean un modo de mandar y de obedecer, un modo de sujetarse y de insubordinarse y una forma de politicidad (Roux, 2011: 17-18).

Visto desde esta matriz analítica, el proceso de formación y formalización institucional de los Estados centroamericanos en el período postcolonial debe ser entendido como un complejo proceso de negociaciones, pactos y disputas entre diferentes grupos y clases sociales que buscaban consolidar su dominio sobre la sociedad, mediante el control de los ejes principales de extracción de renta, al mismo tiempo que generar un marco político que les permitiría acceder, ejercer y mantener dicho control en términos políticos a través

forma y los fines de ese proceso: aquellos cuya actividad vital —y no sólo productiva - está bajo el mando de otro o depende de la voluntad de otro. Así entendida, la dominación incluye no sólo el momento de la disposición y apropiación del trabajo, sino el socavamiento de la politicidad, de esa cualidad que otorga el carácter humano al proceso de reproducción de la vida, haciéndolo trascender la mera reproducción de la existencia física: la capacidad del ser humano de determinar la forma de organización de su vida social" (2002: 248-249). 
del tiempo. Esto no era una tarea fácil. La estructura económica heredada del período colonial era poco compleja y diversificada, lo que se traducía en bajos niveles de diferenciación social entre grupos, incluyendo las élites regionales. Así, los que eventualmente se convertirían en los partidos liberal y conservador se diferenciaban más en términos de su afinidad con los proyectos proindependentistas o con la Corona española, que con algún tipo de clivaje de clase (Pérez Brignoli, 1997). Más aún, como menciona Rodolfo Pastor, "la declaración de Independencia Centroamericana no postula ninguna idea nueva, no invoca un principio antiguo ni moderno. No pretende refundar nada [...] Los próceres declararon la Independencia del Reino de Guatemala [...] explicitando en el acta que lo hacían 'para evitar las funestas consecuencias de que la declarase el pueblo', presente en el recinto" (2011: 207).

Es así como, desde su nacimiento, las "nuevas" clases dominantes de las flamantes repúblicas centroamericanas presentaban un objetivo o lógica dual: por un lado "progresivo", intentando asimilar un nuevo lenguaje y conjunto de prácticas políticas importadas de Europa —elecciones, representación política, entre otras-y generar las condiciones para la acumulación de capital; y por el otro, "conservador", asegurándose de que el control de dichas transformaciones se mantendría seguramente afianzado en las manos de los grupos dominantes que salieron del período colonial. En términos de acumulación de capital, esto significaba negociar la forma de inclusión de dichas economías en el mercado global, donde, debido a la "herencia colonial" (Stein y Stein, 1970), dicha articulación se limitaba al descubrimiento de oportunidades de captura de renta en la forma de productos agropecuarios para la exportación y otras actividades extractivas, como la minería y las maderas finas.

Las relaciones entre lo político y lo económico son bastante evidentes en este caso. La capacidad de capturar rentas era fundamental para generar algún tipo de centralización institucional y expandir la penetración del poder político en los territorios, y así lograr crear algo similar a los Estados modernos europeos en que las élites centroamericanas buscaban su reflejo (Quijano, 2006). Al mismo tiempo, algún tipo de poder político centralizado era necesario para generar las condiciones de posibilidad para la acumulación de capital y la consecuente captura de rentas -infraestructura, legislación laboral, entre otras-; y algún tipo de pertenencia nacional era crucial para garantizar que los rastros de la dominación de clase fueran escondidos, o cuando menos matizados, detrás de una imagen más unificada de "nación".

Para el caso hondureño, y por lo menos hasta inicios del siglo XX, esta disputa por el control de puntos de captura de renta y por la institucionalización de algún tipo de dominación política se presentaba como un conflicto político-militar. Rachel Sieder caracteriza este período como uno en el que: “[...] la política republicana se distinguía por un intenso regionalismo, una falta de integración nacional y una casi constante intervención extranjera. La falta de capital doméstico y los recurrentes conflictos militares 
probaron ser un constante obstáculo al crecimiento económico sostenido a través del siglo diecinueve" (1995: 103).

Cabe destacar, al menos, tres elementos de esta cita. En primer lugar, la fragmentación territorial del país, la cual ha sido entendida a través del tiempo como una barrera tanto para la acumulación de capital, como para integración nacional, y que promovió un constante sentido de pertenencia regional más allá de los proyectos nacionales (Williams, 1994; Barahona, 2002). ${ }^{2}$ Lo segundo tiene que ver con la constante presencia eintervención política, económica y militar de las potencias mundiales, particularmente de Estados Unidos (Barahona, 1989). Finalmente, la falta de capital doméstico, que siempre ponía en entredichola viabilidad tanto económica como política del país y obligaba constantemente a buscar en el exterior los recursos necesarios para suturar la empobrecida realidad concreta del país, con los proyectos de desarrollo/progreso, a partir de las supuestas riquezas naturales del país (Del Cid, 1988).

No es de extrañar entonces que alrededor de estos tres elementos se fuera creando una formación estatal que buscaba, a través de las concesiones a empresas extranjeras de tierras, de exoneración de impuestos y de libertad casi absoluta para la explotación de la tierra, recursos naturales (Williams, 1994; Barahona, 2005; Soluri, 2009) y proyectos de infraestructura, crear las condiciones para el progreso del país. Esta situación puso en poco tiempo el conjunto limitado de actividades económicas en el país en mano de empresas extranjeras. El ejemplo más paradigmático de esta situación fue la entrada y consolidación de las empresas bananeras en la Costa Norte del país hacia finales del siglo XIX (Posas, 1993), donde grandes concesiones de tierras y recursos naturales fueron otorgados a varios empresarios estadounidenses para desarrollar la industria bananera a cambio de que construyeran cierta cantidad de kilómetros de línea ferroviaria. De esta manera, las élites hondureñas imaginaban que se lograría tanto promover un producto de exportación, como integrar territorialmente al país a través del sistema ferroviario. Sin embargo, en términos prácticos, las compañías cumplieron en muy pocos casos con las condiciones acordadas, construyendo sólo la línea ferroviaria necesaria para el transporte de los bananos, al mismo tiempo que, a través de lógicas clientelares, prebendas y coimas, fueron generando una situación casi simbiótica entre los gobiernos de turno y "el pulpo", como era coloquialmente conocida la United Fruit Co. en el país (Bucheli, 2006), sin que esto necesariamente se tradujera en una reducción de la lucha armada entre los caudillos de los dos partidos - Liberal y Nacional — que se disputaban constantemente el Estado/botín. ${ }^{3}$

\footnotetext{
${ }^{2}$ Por ejemplo, Robert Williams menciona que "debido a las deficientes redes de transporte, era difícil para los liberales que ocupaban altos puestos en el gobierno, transformar la agricultura de la manera que les hubiera gustado. La última palabra con respecto a las tierras y sobre quién tenía acceso a ellas lo decidían las municipalidades, quienes tendían a preservar los derechos tradicionales" (1994: 94). ${ }^{3}$ Al respecto, Sieder menciona: "bajo la influencia del capital extranjero, la política de los favores se convirtió en una característica definitoria del sistema político, ayudada e incitada por las debilidades
} 
Esta situación de inestabilidad sociopolítica y de concentración de los ejes de acumulación en la industria bananera se mantuvo como una constante, hasta que en 1933 llegó a la silla presidencial —donde permanecería durante dieciséis años- el caudillo del Partido Nacional, Tiburcio Carías Andino. Este no es el lugar para realizar un estudio detallado de lo que vino a ser conocido como el "Cariato" (ver Argueta, 2008; Cáceres y Zelaya, 2005). Para mis intereses es suficiente con apuntar algunos elementos. Primero, la llegada de Carías al poder debe ser entendida en el marco de un contexto de aumento de la combatividad del incipiente movimiento obrero que se venía gestando a la sombra del enclave. Además, regionalmente debe ser entendido ello como parte de un ascenso al poder de regímenes conservadores y autoritarios en las cinco repúblicas centroamericanas, lo que a su vez puede ser leído como la reacción desde las élites conservadoras al ascenso de un conjunto de nuevos grupos sociales en la región — sindicatos, movimiento campesino y la élite comercial pequeñoburguesaque venían, de una forma muy embrionaria, a cuestionar a los tradicionales bloques en el poder, en un momento de profunda crisis fiscal y económica, debido a la caída de los precios del banano en el período posterior a la crisis de 1929. Victor Bulmer-Thomas sintetiza bien este paso a regímenes más autoritarios y centralizados cuando menciona que en el contexto de crisis:

[...] era de esperarse que la profundidad de la crisis favoreciera a la oposición política, pero en Centroamérica — con la excepción de Costa Rica- la 'oposición' era demasiado débil para representar una fuerza política coherente, por lo que el cambio simplemente representó un cambio en el énfasis dentro de la élite dominante hacia un modelo político basado en la coerción y la represión" (Bulmer-Thomas, 1993: 348).

En este sentido, entonces, "a cambio de la preservación de los intereses de su clase, la élite, en las cuatro repúblicas del norte, estaba preparada a renunciar a todos los beneficios y prebendas acostumbrados [...]"(Bulmer-Thomas, 1993: 348).

Un segundo elemento que se desprende de esta situación tiene que ver con la separación, al menos formal, entre poder político y económico. Al delegar el gobierno en Carías, las élites podían dedicar su tiempo a algo más que pelear entre ellas por el Estado/ botín, lo que además venía a separar las dinámicas de captura de renta -a través del Estado- de los procesos de formación de clase, lo que obligaba a estas élites a buscar nuevas actividades económicas y a diversificar la estructura productiva nacional. Cabe

de la autoridad central, la enraizada tradición del caudillismo y la inestabilidad crónica que había plagado al país durante la mayor parte del siglo posterior a la independencia". En este contexto, "las élites políticas domésticas venían a funcionar como intermediarias de los intereses externos, operando rara vez con algún sentido de unidad o de interés nacional" (1995: 104). 
añadir que esta separación formal entre política y economía era también central para que los rastros de la dominación de clase quedaran escondidos detrás de lo que Abrams (1988) denomina la "máscara del Estado".

En tercer lugar, con Carías vino una profesionalización de los órganos castrenses - particularmente delafuerza aérea-, asícomolainversión en medios de comunicación - por ejemplo, el telégrafo- para integrar el territorio nacionaly lograr la concentración del poder político alrededor del gobierno central. Con estas reformas el gobierno central logró detener el ciclo de levantamientos armados — 210 entre 1932 y 1989 (Cáceres y Zelaya, 2005: 50), condición básica para la acumulación de capital y la consolidación del poder político alrededor del Estado.

En este sentido, se puede hablar del Cariato como de un régimen basado en una paz armada, en el que el gobierno logóa consolidar su poder alrededor de la producción de ciertos consensos mínimos y con la coerción militar como garante en contra de cualquier oposición a su gobierno del "orden y la paz". Dicha forma de dominación se manifestaba a su vez en términos geográficos, lo que nos permite observar "[...] la aceleración de la 'revolución' desde arriba, integración más cercana entre sociedad civil y política, la abolición de las anteriores formas limitadas de expresión política y organización de los grupos subalternos" (Thomas, 2009: 154).

En la Costa Norte del país, residencia del enclave bananero, el orden y la paz se manifestaban en dar rienda suelta a las empresas extranjeras para lidiar con sus trabajadores de la forma que lo vieran pertinente. En el resto del país, lo que Cáceres y Zelaya (2005) denominan la "Non-Banana Republic", Carías promovió un conjunto de normativas dirigidas a la diversificación productiva y a la modernización del aparato estatal. Así, si la respuesta a las luchas de los trabajadores bananeros siempre era el garrote, en el caso de las incipientes capas medias urbanas de Tegucigalpa — vinculadas en su mayoría al sector público - primaba una posición más dialogante y negociadora. En este sentido, los altos niveles de represión en contra de cualquier oposición al régimen no sólo limitaban las posibilidades de su caída, sino que también generaron un movimiento en el que los pocos elementos de oposición empezaron a gravitar hacia el Partido Liberal como polo opositor, hasta crear un clivaje político (Zuckerman, 1975) que se mantiene hasta el presente en la forma de un bipartidismo bastante marcado.

También, usando como base las grandes reservas de tierras nacionales aún existentes en el país, el Cariato promovió la distribución de tierras baldías a campesinos pobres a cambio de que produjeran alimentos para el mercado interno, lo que ayudó a consolidar económicamente al país al generar mayor producción económica, al mismo tiempo que arraigaba a un conjunto de poblaciones y hacía menos probable que pudieran ser organizados en bandas armadas por sus opositores (Zuckerman, 1975).

Visto de forma esquemática, con el Cariato vemos la prefiguración de un régimen políticodedominación basadoen una combinación entre orden autoritarioyestabilización 
económica, así como la creación de una relación sumamente cercana con las empresas bananeras. Para lograr esto, Carías aprovechó, exacerbó y articuló un conjunto de contradicciones ya presentes en el seno de la sociedad hondureña. Por ejemplo, Carías no inventó la diferenciación entre los territorios controlados por el enclave y el resto del país —dehecho, buscóformas deintegrarmáscercanamente al paísen términos territoriales-, pero sí logró capitalizar esta diferencia mediante su acercamiento diferenciado a ambos espacios. Por un lado, al dar rienda suelta a las empresas bananeras y prestarle su apoyo militar para asegurar el orden, garantizaba las condiciones de reproducción de la actividad económica más importante del país en términos de acumulación de capital. Por el otro, la antes mencionada separación entre economía y política permitía y obligaba a las élites tradicionales a dedicarse a otras actividades económicas como el ganado, el algodón y el azúcar, en un contexto de relativa paz — entendida como ausencia de conflicto armado-. Fundamental también venía a implicar la utilización de la reserva de tierras fiscales como válvula de escape de los conflictos agrarios.

Sin embargo, esta estabilidad lograda por el Cariato no podía ser permanente y para mediados de la década de los cuarenta los niveles de oposición al régimen, si bien no llegaban a un nivel que lo hicieran tambalear, seguían en constante aumento. Además, en el período de la posguerra la posición de Estados Unidos cambió con respecto a la región. Exigían ahora niveles de democratización —-formal— más amplios, así como una mejora en los precios del banano y otras materias primas, lo que vendría a mejorar significativamente las condiciones fiscales del gobierno. Sin embargo, al mismo tiempo las transformaciones impulsadas por Carías vinieron también a generar nuevas contradicciones sociales que, en este contexto, obligaban a realizar ciertos cambios para garantizar que no cambiara nada.

Después de la salida por la vía electoral de Carías en 1948, continuó un proceso de creciente crispación social que llegó posiblemente a su punto más álgido en mayo de 1954, cuando miles de trabajadores de las distintas empresas bananeras se fueron a una huelga que duró más de tres meses y que obligó al gobierno a mejorar las condiciones salariales y de trabajo y, más importante aún, a legalizar a los sindicatos dentro de la industria (Barahona, 2005). De esta manera hacían su irrupción en la escena política dos nuevos actores sociales: el movimiento obrero organizado y una pequeña burguesía industrial — constituida alrededor de la ciudad de San Pedro Sula — que había apoyado al movimiento huelguista y cuyos intereses se encontraban en contradicción con los de los terratenientes pertenecientes a la élite tradicional, concentrados fundamentalmente alrededor de Tegucigalpa, en tanto que centro del poder político (Euraque, 2001).

Otro espacio en el que empezaron a aflorar las contradicciones era la cuestión agraria. Como mencioné anteriormente, una de las formas en las que el Cariato logró consolidar su control fue a través de la distribución de tierras a familias campesinas pobres en la Non-Banana Republic, al mismo tiempo que se daba la expansión de las relaciones de 
producción capitalistas en el campo mediante la promoción de agroindustrias tales como la carne, el algodón y el azúcar (Williams, 1986). Eventualmente estos dos procesos entraron en contradicción, ya que las tierras en manos de campesinos se convirtieron en una barrera para la expansión de las dinámicas capitalistas en al menos dos direcciones: primero, limitando la extensión de tierra que podía ser centralizada; segundo, limitando el acceso a su fuerza de trabajo por parte de los terratenientes. El resultado fue un proceso de acumulación primitiva en el que un gran número de comunidades, tanto del sur como del occidente del país, fueron despojadas de sus tierras para la extensión de la agricultura industrial. En el caso de la Banana Republic, las bananeras seguían concentrando una gran cantidad de tierras ociosas, al mismo tiempo que tras la huelga de 1954 empezó un proceso de despidos que llegó a recortar su fuerza de trabajo en más de la mitad. El resultado de esta combinación entre muchas manos sin tierra y mucha tierra en pocas -y ociosas - manos se convirtió en detonante de un conjunto de conflictos por la tierra.

Sin embargo, en un período de Guerra Fría, y particularmente después de la revolución cubana en 1959 , la salida a esta crisis agraria no podía ser simplemente represiva. En el marco de la Alianza para el Progreso y bajo el control de un gobierno militar progresista o desarrollista, Honduras se embarcó entre 1962 y 1992 en la reforma agraria más expansiva y abarcadora de toda Centroamérica (Thiesenhusen et al., 1995). Es importante apuntar dos elementos de esta reforma agraria. Primero, al igual que en la mayoría de las reformas agrarias que se llevaron a cabo durante este período (Kay, 1998), ésta buscaba distribuir tierras para sofocar los posibles focos de conflicto agrario sin trastocar de ninguna forma significativa la estructura agraria del país. Segundo, el ritmo de la reforma era dado, por un lado, por la presión campesina y, por el otro, por el apoyo de un gobierno simpatético que legitimaba el proceso. Para el caso hondureño, estas dos tendencias se centraban en la "recuperación" de tierras que legalmente seguían siendo "nacionales" — fiscales y ejidales - y que, se argumentaba, habían sido ilegalmente alienadas por los terratenientes. Desde ese momento, la práctica de "recuperar" tierras nacionales se convirtió en la forma dominante de lucha del movimiento campesino hondureño (Posas, 1981).

Desde el principio todo este proceso fue confrontado por una élite recalcitrante y terrateniente que veía en cualquier movimiento de redistribución de tierra una amenaza a su posición dominante en el país. Esta situación fue degenerando en un constante proceso de conflictos entre grupos subalternos — sindicatos bananeros y movimiento campesino, sobre todo- y los sectores más conservadores de la élite, articulados alrededor del Partido Nacional y organizaciones gremiales como la Federación Nacional de Agricultores y Ganaderos de Honduras (FENAGH), creada en 1966 para intentar transformar las nuevas normativas agrarias (Sieder, 1995).

En línea con lo que he venido argumentando, la salida a esta crisis también vino desde arriba y tomó la forma de un período de control político por parte del ejército, el 
cual mediante una reforma constitucional había logrado su autonomía con respecto al poder civil en 1956. Resumiendo, entre las décadas de 1950 y 1960, el campo político hondureño se encontraba organizado alrededor de dos polos fundamentales y cuatro actores centrales. En términos de los polos tenemos, por un lado, al Partido Nacional - representante de la élite más tradicional y organizada alrededor de actividades tales como la ganadería- y, por otro, al Partido Liberal, cuya historia estaba vinculada fuertemente con la de un conjunto de nuevos grupos sociales - movimiento obrero, pero sobre todo pequeña burguesía industrial- Con respecto a los demás actores tenemos, en primer lugar, al ejército, el cual se había convertido en un actor político fundamental después de la reforma de la constitución; a los movimientos obreros y campesinos, cuya presencia vino a ser sentida de forma más clara a partir de la huelga de 1954; a las transnacionales bananeras, cuya influencia en el país venía descendiendo, debido a su cada vez menor peso dentro de la economía nacional (Bucheli, 2006), y a Estados Unidos, cuyo sello de aprobación era fundamental para la supervivencia de cualquier régimen, como la corta primavera guatemalteca al mando de Jacobo Arbenz había demostrado en 1954 (ver, por ejemplo, Dosal, 1993; Gleijeses, 1992).

Particularmente importante es el ascenso al poder político de las estructuras castrenses. Entre 1956 y 1963 el ejército apoyó la incipiente alianza entre el Partido Liberal y el movimiento sindical, en detrimento del Partido Nacional y las bananeras, en una apuesta por consolidar su poder político. Sin embargo, las políticas del nuevo régimen, particularmente en lo que respecta al tema agrario, empezaron a poner una considerable cantidad de carga sobre el juego de pesos y contrapesos que sustentaba las formas de dominación, y amenazaban con destrozar el tejido hegemónico mismo al presentar una postura más simpatética con el sector campesino, lo que era visto como una amenaza por parte de las empresas bananeras. En este contexto, el ejército decidió de nuevo cambiar de bando —expulsando en 1963 al entonces presidente Ramón Villeda Morales_ ${ }^{4}$ en una búsqueda por fortalecer y consolidar su poder político, al mismo tiempo que se cambiaba el balance de fuerzas a favor del Partido Nacional y de las élites tradicionales; pero en este caso, además, excluyendo al movimiento obrero y campesino y disminuyendo el peso político de las bananeras.

En el caso de la exclusión del movimiento obrero - y campesino- del juego de alianzas, ésta se basaba sobre todo en un sentimiento anticomunista visceral compartido por todos los demás actores - Partido Liberal incluido-, así como la insuperable diferencia de clase entre sus miembros y los líderes de ambos partidos. En el caso de la bananera, es importante recordar que su alianza durante el gobierno de Carías se fundamentaba en su capacidad de brindar un flujo constante de ingresos, así como en una

\footnotetext{
${ }^{4}$ Existen muchos paralelismos entre el golpe de Estado de 1963 y el de 2009 (ver De Castro, Mendoza y Pagán, 1985; Argueta, 2009).
} 
cierta estabilidad económica, y éste ya no era el caso para ese momento. Además, el hecho de que una buena parte de la protesta social de este período se concentrara en zonas rurales y alrededor del tema del acceso a la tierra ponía a las bananeras y a sus miles de hectáreas en reserva —ociosas - en el ojo del huracán.

En 1972 el ejército llevó a cabo un nuevo golpe de Estado - tras un corto y poco significativo período de gobierno civil- y tuvo que operar dentro de este campo de acción. La guerra en contra de El Salvador en 1969 le había permitido legitimarse como fuerza defensora de la nación —en contraposición a las élites locales, que eran vistas por la población en buena medida como las culpables del conflicto- y concentrar a su alrededor el apoyo de sectores importantes del movimiento obrero y campesino, así como de la pequeña burguesía industrial, que veía en su ascenso al poder una posibilidad de empujar su agenda política. Así, se presentaba como el único actor con las características y condiciones materiales y políticas para operar por encima de las distintas contradicciones y orientar al país del ciclo de coerción y restitución que había dominado la mayor parte de los últimas décadas, a uno más bien basado en ciertos consensos mínimos.

Sin embargo, este era un consenso controlado, en el cual el ejército pasaba a jugar el papel de árbitro principal definiendo el juego de pesos y contrapesos y abriendo ciertos espacios para que nuevos intereses y agendas pudieran ser incluidos, pero siempre desde arriba. Así, el paso a la modernización del Estado hondureño fue pasivo y revolucionario al mismo tiempo:

[...] entre 1972 y 1978, las relaciones clientelares fueron reestructuradas, recreadas y extendidas de forma selectiva en un esfuerzo por incorporar a los actores sociales emergentes en los términos definidos por aquellos que controlaban el balance de poder dentro del Estado reformista, proveyendo a este último con un limitado pero nada desdeñable nivel de legitimidad social (Sieder, 1995: 113).

Para 1982, cuando se aprobó la nueva constitución política que venía a formalizar el paso de un conjunto de gobiernos militares a civiles, una cierta forma de entender las relaciones entre dominantes y dominados, tanto en términos materiales como simbólicos, se había institucionalizado. Dicha forma estatal vino a consolidar una cierta forma de dominación que, si bien sufriría cambios significativos a través del tiempo, mantuvo y mantiene ciertas características fundamentales: una manifestación geográfica desigual, con el poder político concentrado alrededor de Tegucigalpa y el económico alrededor de San Pedro Sula; con fuertes regionalismos y una dislocación entre un marcado centralismo político y un grupo de caudillos locales; un conjunto de élites poco renovadas con un acuerdotácitoanticomunistayfuertementeclasista; conunentendimientopatrimonialista del Estado, lo que se traduce en niveles de corrupción elevados; un ejército con fuerte 
influencia en la vida social del país y que constantemente es visto como el garante de la nación frente a la corrupción de los gobiernos civiles; con un manejo vertical de la autoridad, de modo que el disenso tiende a ser homologado con subversión y reprimido fuertemente; con la exclusión de los grupos subalternos - campesinos, obreros, indígenas, etcétera - de la política formal, todo esto organizado alrededor de un régimen de acumulación basado en una limitada cartera de actividades extractivistas y la sobreexplotación de una empobrecida mano de obra.

En la siguiente sección veremos cómo estos elementos se empezaron a combinar de manera explosiva alrededor del gobierno de Manuel "Mel" Zelaya, hasta canalizarse o explotar en lo que podríamos denominar una crisis hegemónica, de la cual el país no parece salir aún.

\section{El violinista en el tejado: la llegada al poder de Zelaya y el golpe de Estado de 2009}

En 1982, en un proceso altamente tutelado por el gobierno estadounidense de Jimmy Carter, Honduras inició un proceso de transición de gobiernos militares a civiles que incluiría tanto la aprobación de una nueva constitución, como la realización de elecciones relativamente limpias y pacíficas en las que, por ejemplo, en 1986 - por primera vez desde 1933- la presidencia fue traspasada de "[...] un gobierno civil legítimo a otro de igual calidad" (Figueroa, 1993: 59).

En términos prácticos, esta transición respondía a un cierto agotamiento de las formas de dominación por coerción, instalada en el país en la forma de un régimen de "seguridad nacional", pero, sobre todo, a un, por así decirlo, trueque entre la jerarquía militar hondureña y Washington. Así, los primeros se comprometían a “[...] respetar los resultados de la elección de Asamblea Constituyente y abrir el juego a la vieja pelea liberal-conservadora hondureña pero [sic] recibir a cambio ayuda militar y financiera para modernizar las fuerzas armadas [...]" (Figueroa, 1993: 58).

Se abren así tres décadas de relativa estabilidad política marcada por un anquilosado y legalmente bien estructurado bipartidismo — entre los partidos Liberal y Nacionalque se repartía alrededor de un 95\% del total de votos en cada elección, en una dinámica de pactos y negociaciones bajo la mesa, para garantizarse el botín estatal cada cuatro años y garantizar un "clima de negocios" satisfactorio para la acumulación de capital. En términos económicos, el régimen de acumulación seguía mostrando una estructura poco diversificada, pero que había gravitado de una "Banana Republic" a una "República maquiladora" (Cuevas, 2011), mientras mantenía o buscaba impulsar otras actividades extractivistas como el monocultivo de palma africana o la minería. Y, en términos de indicadores sociales, Honduras seguía y sigue mostrando algunos de los niveles de pobreza, subempleo y desigualdad más altos de Latinoamérica (Pérez Sainz, 2014). 
El resultado: altos niveles de desafección popular con respecto a su gobierno, pero con recursos institucionales muy limitados para su canalización que no fueran la represión desde los aparatos del Estado y la migración hacia Estados Unidos. Así, en términos de estructura de dominación - y su resultante institucionalización en la forma EstadoHonduras ha mostrado históricamente una línea vertical de mando, combinada con una desigual y difusa presencia a nivel regional. Organizada políticamente desde la ciudad de Tegucigalpa, la línea de comando empieza con la figura del presidente, se expresa regionalmente a través de los miembros del Congreso y las corporaciones municipales, hasta llegar al nivel comunitario en forma de los patronatos. Cada uno de estos niveles muestra grados más o menos densos de intereses políticos y económicos que cruzan desde las empresas transnacionales, pasando por empresarios nacionales con influencia ya sea nacional, regional o local, hasta llegar a actividades de crimen organizado, como las pandillas y el narcotráfico. Es a través de esta línea de comando como los fondos públicos y las posibilidades de capturar renta institucional — botín estatal — fluyen hacia "abajo", al mismo tiempo que los votos y el apoyo político fluyen hacia "arriba". Esta situación hace que los puestos políticos sean altamente codiciados por ser espacios desde donde las élites tanto locales como regionales y nacionales, organizadas en un perfectamente institucionalizado sistema bipartidista, se disputan el control a través de un conjunto de caudillos que funcionan como mediadores entre ambos flujos.

Si a estos elementos les sumamos un aparato estatal sumido en una profunda crisis fiscal y con altos niveles de desconfianza de la población respecto a las instituciones públicas, nos podemos hacer una idea del contexto en que Manuel Zelaya Rosales asumió la presidencia el 27 de enero de 2006. Inicialmente, era imposible adivinar el conflicto que se avecinaba. Mel — como Zelaya Rosales es popularmente conocido- venía de una familia de Olancho con perfectos antecedentes liberales. Lejos del radicalismo del que sería acusado posteriormente, una de sus primeras acciones fue ratificar la importancia del CAFTA para el desarrollo del país, al mismo tiempo que su gobierno promovía leyes para aumentar la participación ciudadana en el gobierno.

Sin embargo, al intentar impulsar ciertas políticas, algunas provenientes de sus promesas de campaña, tales como recalcular la fórmula de importación de hidrocarburos para disminuir los costos de los combustibles o el aumento del salario mínimo en un 60\%, fueron generando paulatinamente una resistencia recalcitrante por parte de una élite monolítica que veía en estas reformas una amenaza a sus formas de dominación tradicionales. Como resultado, el gobierno de Zelaya se fue viendo cada vez más aislado de su propio Partido Liberal y de los otros poderes del Estado y acercándose cada vez más a ciertos sectores populares - sobre todo sindicales y gremiales - que veían en él a un aliado coyuntural para impulsar su propia agenda, y a gobiernos latinoamericanos como el de Venezuela, en una apuesta por conseguir el apoyo económico necesario para impulsar su plan de gobierno. 
Así, por ejemplo, a partir de la negativa recibida al recálculo de la fórmula de importación de hidrocarburos, Zelaya optó por entrar a Petrocaribe, lo cual, eventualmente, llevó a la entrada de Honduras al ALBA. Es así como poco a poco se fue generando un ambiente de polarización entre Mel y sus aliados coyunturales de la sociedad civil y de los demás poderes del Estado, las Iglesias católica y evangélica y los sectores empresariales tradicionales. En este sentido, las acciones de Mel y su gobierno, al que podríamos denominar populista, invocaron fuertes miedos en la élite tradicional y fundamentalmente ponían en cuestionamiento la forma de Estado que, como he venido discutiendo, estaba vigente al menos desde finales de los setenta del siglo pasado. Esto, en primer lugar, porque el acercamiento de Zelaya al ALBA evocaba miedos de la época de la Guerra Fría. ${ }^{5}$ Pero también, y no menos importante, porque Zelaya, al intentar saltarse las formas tradicionales de hacer política, pactos y negociaciones secretas en el Congreso y casas particulares e invitar a un nuevo bailarín a la pista - las organizaciones populares-, rompía con los equilibrios tradicionales entre consenso y coerción y necesariamente ponía en entredicho la legitimidad del Estado hondureño.

El resultado fue una espiral de polarización social que alcanzó su punto máximo a principios de 2009. El 28 de junio de dicho año se suponía que tendría lugar una consulta popular, conocida popularmente como la "cuarta urna". El proceso que llevó, por un lado, al gobierno a planear todo para ese día, y que a la postre dio con el secuestro de Zelaya, fue el desenlace de un conjunto más profundo de contradicciones en el seno de la sociedad hondureña que ponían en entredicho su formación estatal. En este sentido, hay que ser claros, la expulsión de Zelaya por parte del ejército no era la única alternativa existente, pero el conjunto de procesos y decisiones que se habían tomado hasta ese momento dejaban poco espacio de maniobra para que hubiera otro desenlace.

El 23 de marzo de 2009, el presidente aprobó en consejo de ministros el decreto ejecutivo PCM-05-2009, quellamaba a una consulta popular para formular a la ciudadanía la siguiente pregunta: “iEstá de acuerdo que en las elecciones generales de noviembre de 2009 se instale una cuarta urna para decidir sobre la convocatoria a una asamblea nacional constituyente que apruebe una nueva Constitución política?" El resultado positivo de la consulta popular facultaría al Poder Ejecutivo para presentar, ante el Congreso Nacional de la República, un proyecto de ley especial para colocar una cuarta urna en las elecciones generales convocadas para el mes de noviembre de 2009.

\footnotetext{
${ }^{5}$ A esto se le podría sumar el argumento de José Miguel Cruz (2010, 2011) de que una de las razones de la violencia de posguerra en Centroamérica tiene que ver con la permanencia en posiciones de poder de los "emprendedores de la violencia" que operaban durante los años setenta y ochenta. En el caso de Honduras, esto implica muchos militares en puestos de importancia en la jerarquía castrense con entrenamiento en la Escuela de las Américas e involucrados en un sinnúmero de violaciones de los derechos humanos durante los ochenta.
} 
Esto inmediatamente encendió todas las luces de alarma de los sectores opositores a Zelaya, que veían en esa "cuarta urna" un intento por su parte de seguir el ejemplo de Chávez en Venezuela: perpetuarse en la presidencia y convertir Honduras en un infierno socialista. Del otro lado, por parte de los sectores populares, la "cuarta urna" era vista más bien como una gran apuesta que les permitiría irrumpir de forma clara en la toma de decisiones del país. Así, desde ese 23 de marzo, hasta el 28 de junio, la discusión del país quedaría tan saturada por la discusión de la "cuarta urna" y la atmósfera era tan tensa, que parecía que hasta el viejo padre tiempo se había detenido, sosteniendo la respiración, para conocer cuál sería el desenlace.

La definición de los bandos era tan trillada que, si no fuera por lo que estaba en juego, habría sido hasta cómica. En contra de la "cuarta urna": el poder legislativo, el poder judicial, la sala constitucional, los sectores del gran capital, las cúpulas de los partidos tradicionales, los grandes medios de comunicación tradicionales y amplios sectores de la clase alta. A favor de aquélla: el poder ejecutivo, un partido minoritario - la Unión Democrática-, las organizaciones sociales, las organizaciones gremiales, sindicales y campesinas, varias diócesis cercanas a la teología de la liberación y algunos medios de comunicación locales, especialmente las radios comunitarias (Ruhl, 2010).

Este no es el espacio para hacer una reseña pormenorizada de lo que sucedió entre el 23 de marzo y el 28 de junio, ${ }^{6}$ basta con mencionar que cada bando movilizó todos los recursos en su haber para imponer su posición. En el caso de los sectores dominantes, el bando del "no", estos factores eran fundamentalmente la ley y el dinero. La consulta fue declarada como ilegal por las Cortes, inconstitucional por la Corte Constitucional, recibió oposición de los dos partidos tradicionales y fue atacada a través de los medios de comunicación. Mel y el sector a favor de la "cuarta urna" respondieron a cada uno de estos elementos maniobrando y buscando la forma de imponer la realización de la consulta. Un claro ejemplo de esta dinámica se dio el 25 de junio, después de que los magistrados del Tribunal Supremo Electoral ordenaran decomisar el material electoral para la "cuarta urna”. Zelaya rechazó esta acción y solicitó a sus seguidores que lo acompañaran a una "misión", que no fue otra cosa que abordar un autobús y, acompañado de una multitud de personas en caravana de automóviles, irrumpir en las instalaciones de la base aérea Hernán Acosta Mejía en Tegucigalpa y, tras un enfrentamiento, en el que los soldados prefirieron no montar un baño de sangre, retirar el material de la encuesta para supuestamente llevarlo a la casa presidencial.

Si bien hubo intentos por generar un acercamiento entre las partes y lograr una salida negociada y pactada de la crisis, al final el nivel de las apuestas políticas y de polarización era demasiado alto y lo que había funcionado en 1985 ya no podría

\footnotetext{
${ }^{6}$ Para una cronología pormenorizada de estos eventos, ver el informe de la Comisión de la Verdad (C.V.R., 2011) o el artículo de Mark Ruhl (2010).
} 
funcionar. Por ejemplo, después del 25 de junio, cuando ya era más que evidente el desenlace de todo este drama, Zelaya ofreció a Micheletti la presidencia de la futura constituyente, propuesta que fue rechazada. En este sentido, los esfuerzos de Zelaya de avanzar a pesar de todas las barreras puestas por la institucionalidad formal tenían dos efectos fundamentales: 1) colocar de forma cada vez más notoria a Zelaya y su gobierno afuera del "Estado de derecho" (Di Iorio, 2010; Martínez, 2010), y 2) demostrar a los sectores subalternos que no había nada de apolítico ni neutral en el accionar del Estado (Cálix, 2010; Miranda, 2010; Sosa, 2014).

Al final, el 28 de junio por la mañana, antes de que abrieran las urnas, el ejército respondió a los intereses de los grupos opositores a la "cuarta urna" y a la ruptura de los guiones de dominación establecidos en el país. De esta forma:

[...] siguiendo el patrón establecido por el Golpe de Estado del 3 de octubre de 1963 que derribó al doctor Ramón Villeda Morales y el golpe de barracas del 30 de marzo de 1984 que defenestró al hasta entonces todopoderoso general Gustavo Álvarez Martínez, Zelaya Rosales fue expulsado del país y llevado a Costa Rica (Salgado, 2010: 11).

Philip Abrams, en su artículo sobre la dificultad de estudiar el Estado, plantea que este:

[...] es, entonces, en todos los sentidos del término, un triunfo del ocultamiento. Oculta la historia o las relaciones de sujeción reales detrás de una máscara ahistórica de legitimidad ilusoria: se las arregla para negar la existencia de conexiones y conflictos que, de ser reconocida, sería incompatible con la autonomía reclamada y la integración del estado (Abrams, 2015).

Podríamos decir entonces que uno de los grandes efectos del gobierno de Zelaya fue quitarle la "máscara" al Estado hondureño y mostrar de forma descarnada su naturaleza de dominación de clase para que todo el mundo la pudiera ver.

Además, al invitar Mel a ese "pueblo", al que desde la redacción misma del acta de independencia las élites centroamericanas tanto miedo le han mostrado, venía a romper con una tradición - una forma de entender la relación entre dominados y dominantesinscrita en el ADN mismo del Estado hondureño. Siguiendo la discusión presentada en la sección anterior, la idea de hacer cambios para mantener el status quo, inclusive cuando significara beneficiar a los sectores subalternos, era una práctica aceptable siempre y cuando se hiciera desde arriba y reproduciendo una lógica corporativa que negara la posibilidad de unificación de dichos grupos (lo que Gramsci denomina el "momento catártico", 1999; Thomas, 2009). Es exactamente a esta tensión entre la supuesta participación popular que la legislación burguesa y liberal pone en la base de la democracia 
y la necesidad práctica de excluir a las masas de su práctica (ver, por ejemplo, Gallardo, 2007) a la que Marx se refiere en el 18 Brumario de Napoleón Bonaparte cuando menciona que:

[...] los representantes, que apelan continuamente a la opinión popular, autorizan a la opinión popular a expresar en forma de peticiones su auténtica opinión. El régimen parlamentario lo deja todo a la decisión de las mayorías; icómo, pues, no van a querer decidir las grandes mayorías fuera del parlamento? Si los que están en las cimas del Estado tocan el violín, ¿qué cosa más natural sino que los que están abajo bailen? (Marx, 2012: 93).

Zelaya Rosales y su gobierno tocaron el violín y los de abajo bailaron. Pero los bailarines tradicionales —esas élites anquilosadas y monolíticas — no querían admitir a nadie más en el salón. Sin embargo, después del golpe de Estado, el salón de baile, y por tanto las parejas participantes, ya no podrían ser las mismas y lo que antes era un evento político reservado para liberales y nacionalistas, ahora pasaría más bien a estar organizado entre "golpistas" y "resistencia".

\section{Crisis de autoridad en Honduras: del golpe a las elecciones de 2013}

Si la clase dominante ha perdido el consenso, o sea, si no es ya "dirigente", sino únicamente "dominante", detentora de la pura fuerza coercitiva, esto significa precisamente que las grandes masas se han apartado de las ideologías tradicionales, no creen ya en lo que antes creían, etcétera. La crisis consiste precisamente en el hecho de que lo viejo muere y lo nuevo no puede nacer: en este interregno se verifican los fenómenos morbosos más variados (Gramsci, 1999: 37 t. II).

Estas palabras — que son las utilizadas por Antonio Gramsci para definir una "crisis de autoridad" - sirven para ilustrar el proceso que se abrió en Honduras a partir del golpe de Estado de 2009. Lejos de resolver tal crisis, el secuestro y consecuente expulsión de Zelaya no hizo más que profundizar la polarización de la sociedad e introducirla en una espiral de violencia y crispación social que parece estar bastante lejos de terminar. En este sentido, vale también la pena preguntarse si el objetivo del golpe era verdaderamente resolver la crisis, o generar ese interregno que menciona Gramsci, para poder acelerar y consolidar la estrategia de clase neoliberal en el país (Duménil y Lévy, 2004).

Después de un corto gobierno de facto, por el entonces presidente del Congreso Nacional y copartidario de Zelaya Rosales, Roberto Micheletti, en noviembre se llevaron a cabo unas elecciones altamente cuestionadas — por ejemplo, la oposición al golpe de Estado se negó a participar- de las que salió ganador Porfirio "Pepe" Lobo, del Partido Nacional, y con ello se buscaba legitimar la expulsión de Zelaya. Dicho 
gobierno tuvo dos metas fundamentales: por un lado, lograr su reconocimiento internacional, y en segundo lugar, profundizar la agenda neoliberal en el país. Con respecto a este segundo punto, cabe mencionar: 1) la aprobación en 2010 de la Ley del Programa Nacional de Empleo por Horas, que formalizaba y legalizaba el trabajo por destajo; 2) la Ley de Promoción de la Alianza Público-Privada, de ese mismo año, que venía a constituir el marco jurídico para permitir concesionar en manos privadas, empresas y obras públicas; la Ley de Minería, en 2012, la cual abría ciertos portillos para la explotación de minerales a cielo abierto, ignorando la lucha de más de diez años de comunidades y organizaciones comunitarias en su contra, y la Ley Orgánica de las Zonas de Empleo y Desarrollo Económico (ZEDES), aprobada en 2013 y conocida como la ley de las "ciudades modelo", la cual, según su página oficial, permite concesionar, por un cierto período de tiempo, "espacios territoriales altamente atractivos a la inversión nacional y extranjera" y que "tienen personalidad jurídica, están autorizados a establecer su propia política y normativa, creados con el propósito de acelerar el cumplimiento de las metas del Plan de Nación y facilitar condiciones que permitan al país la inserción en los mercados mundiales bajo reglas altamente competitivas y estables" (¿QUÉ ES UNA ZEDE? - ZEDE, s.f.).

Como mencionaba anteriormente, este avance de la reforma vino acompañado a su vez por un aumento en los niveles tanto de violencia como de la protesta social. Con respecto al segundo punto, si durante el gobierno de Zelaya Rosales mucha de la movilización social se empezó a centralizar alrededor de la "cuarta urna" y aprovechó la coyuntura para impulsar ciertas agendas, en el período posterior al golpe de Estado se ha regresado a una lógica más bien defensiva y hasta cierto punto gremial, con la excepción quizás de la resistencia a las "ciudades modelo". Así, según un estudio de la Secretaría de Justicia y Derechos Humanos (citado por Sosa, 2014), para 2012 hubo 212 manifestaciones de conflicto, número que sube a 497 en 2013, y en su mayoría se concentraron en temas económicos (30.8\%), seguridad ciudadana (18.3\%), educación (13.3\%) y medioambiente (9.2\%).

Esta fragmentación dentro de la protesta no deja de ser un poco irónica si se toma en cuenta que inmediatamente después del golpe nació el Frente Nacional de Resistencia Popular (FNRP) como plataforma que buscaba articular a todos los sectores opositores al nuevo régimen. Sin embargo, dicha fragmentación no parece tan fortuita si se toma en cuenta que en mayo de 2011 la asamblea general del FNRP, bajo la insistencia de Zelaya, constituyó el partido Libertad y Refundación (LIBRE) ${ }^{7}$ como brazo electoral de la

\footnotetext{
${ }^{7}$ La creación del partido LIBRE es en parte el resultado de las negociaciones llevadas a cabo entre Porfirio Lobo y Manuel Zelaya en Cartagena de Indias, conocidas como el Acuerdo para la Reconciliación Nacional y la Consolidación del Sistema Democrático en la República de Honduras. Entre los puntos incluidos en dicho acuerdo, está el regreso de Zelaya Rosales a Honduras. Este es un punto importante, ya que sólo unos meses antes, a finales de 2010, la misma Asamblea General del
} 
resistencia. A partir de dicho momento, el interés general de las estructuras formales del FNRP se plegó a los intereses, objetivos y necesidades electorales de LIBRE y, por tanto, la convocatoria más generalizada a la movilización social en las calles fue dando paso a actividades más de corte proselitista; es decir, se pasó de las dinámicas y temporalidades de la disputa política popular — por nombrarla de alguna manera-, a las de la disputa electoral, donde los niveles de confrontación deben ser controlados. Esta no era la posición de todos los sectores de la resistencia, claro está. Berta Cáceres, una de las directoras fundadoras del Consejo Cívico de Organizaciones Populares e Indígenas de Honduras (COPINH), sintetiza de forma clara esta tendencia en una entrevista publicada en noviembre de 2011:

Creo que la decisión de concentrarse únicamente en la batalla electoral es un gran error, porque desde nuestra visión, la liberación de los pueblos no será obra de un partido sino de la lucha popular, de los movimientos sociales y políticos. Hay que incluir toda su diversidad y riqueza, que no es un signo de debilidad sino de fortaleza. La Resistencia en Honduras tiene una particularidad especial, que es muy diversa, y esto la hace extremadamente compleja, pero sabemos que en este momento la única manera de contrarrestar el avance del neoliberalismo, de la impunidad, del golpismo y la violación de los derechos humanos, es con las luchas sociales, con la organización del pueblo, construyendo poder desde abajo, desde otra perspectiva y concepto. Hay varios temas que están en entredicho, como por ejemplo el tema del Poder. ¿Por qué se piensa que el Poder está sólo en el hecho de ganar el Ejecutivo? Nosotros hemos dicho: pregúntenle a Mel Zelaya si realmente tuvo el poder, siendo presidente. Le dieron un golpe de Estado. Y volvió a quedar claro que el Poder lo tienen los gringos, las trasnacionales, el ejército y las 25 familias. Por eso nosotros apostamos a una construcción de Poder desde abajo, y a prácticas políticas diferentes en nuestros movimientos sociales. Prácticas horizontales, incluyentes que estén muy abiertas a entender esa diversidad, que tienen experiencias diferentes en su organización, en demandas, en exigencias, en perspectivas sobre qué Honduras queremos refundar. Todo esto se diluye si sólo se apuesta a la vía electoral.

En lo que respecta al tema de la violencia, según datos del Observatorio Nacional de la Violencia de la Universidad Autónoma de Honduras, entre 2004 y 2009 —año del

FNRP había votado en contra de las propuestas de presentarse como partido político a las elecciones presidenciales de 2013. Es sólo mediante el regreso de Zelaya y el apoyo que recibe de las bases que se revierte esa primera votación y creando a LIBRE en el proceso. Qué tanto de esto fue pensado y pactado en Cartagena, es difícil de decir a ciencia cierta. 
golpe - se duplicó el número de homicidios, pasando de una tasa de 30.7 por cada cien mil habitantes a una de 66.8. En términos absolutos, este aumentoes aún más espeluznante cuando advertimos que de los 5265 asesinatos reportados en 2009, se pasó a más de diez mil en 2012. En términos generales, las explicaciones dadas para este aumento de la violencia tienden a gravitar alrededor del aumento de la pobreza y de la desigualdad social, de la "ausencia" de Estado, de los altos niveles de impunidad y de la corrupción de la policía y en menor medida del ejército y, por supuesto, alrededor del crimen organizado (ver, por ejemplo, Ten Velde, 2012; De la Torre y Álvarez, 2011; Quispe, 2012). Son mucho menos frecuentes los estudios que buscan explicar este aumento en la violencia más bien desde una perspectiva histórica y relacionada con el proceso de institucionalización misma de la violencia en los Estados centroamericanos (ver, por ejemplo, Cruz, 2011; 2010). Sin embargo, en ambos tipos de acercamiento se privilegia un estudio institucional en el que con un mejor funcionamiento de los aparatos estatales y las instituciones públicas y una participación más activa de la sociedad se podría solucionar el flagelo de la violencia.

Miproblema con estos acercamientos es que, por un lado, intentan leerla conformación del Estado hondureño desde una perspectiva etnocentrista y occidentalista en la cual, al fin y al cabo, la raíz de la violencia se encuentra en la falta de un desarrollo institucional similar al de Estados Unidos o Europa; ${ }^{8}$ por otro lado, porque al pensar en la violencia como un efecto de estos elementos, olvidan que ésta también es a causa de aquéllos. Dicho en otras palabras, que la violencia es tanto un elemento constitutivo como constituido por las formas en las cuales las relaciones entre dominantes y dominados han sido incorporadas al tejido mismo de los Estados de la región. Ya en 1983, Ignacio Martín-Baró (2003: 89) había propuesto algo similar cuando desde El Salvador argumentaba que:

Si se puede hablar con propiedad de una "violencia institucionalizada" en América Latina es porque existe un tipo de violencia contra la población mayoritaria que está incorporada al ordenamiento social, que es mantenida por las instituciones sociales y que se encuentra justificada y aun legalizada en el ordenamiento normativo de los regímenes imperantes. La explotación de los trabajadores, sobre todo del campesino y del indígena, la continua represión a sus esfuerzos organizativos, el bloqueo factual a la satisfacción de sus necesidades básicas y a las exigencias de su desarrollo humano, todo ello como parte del funcionamiento "normal" de las estructuras sociales, constituye una situación en la que la violencia contra las personas está incorporada a la naturaleza del orden social, bien llamado "desorden organizado" o "desorden establecido".

\footnotetext{
${ }^{8}$ Para un argumento similar con respecto a la narrativa de los "Estados fallidos", ver Bilgin y Morton (2004).
} 
En Centroamérica este "desorden organizado" ha venido de la mano de una lógica de revolución pasiva, mediante la cual se han venido formando los distintos Estados de la región. Para el caso hondureño, nos plantea que es fundamental ver el contexto estructural más amplio dentro del cual el aumento de la violencia viene siendo producido. En este sentido, mi argumento sería que dicha violencia tiene que ser entendida como parte de la crisis de autoridad en la que se encuentra el Estado hondureño y donde las élites se han visto obligadas a apelar a la coerción ya institucionalizada dentro de la formación estatal para mantener su dominio sobre el resto de la sociedad.

Ahora bien, este desorden organizado tiene varios elementos que es importante tomar en cuenta. El primero es que el aumento de la violencia ha sido ubicado como un problema de seguridad y ha sido abordado desde una perspectiva de militarización de la sociedad. Sólo por dar algunos ejemplos: 1) en agosto de 2011 inició la operación militar Xatruch, supuestamente dirigida a controlar el problema de violencia en el departamento de Colón, pero que en la práctica ha operado como una ocupación militar de una región marcada por conflictos por la tierra (Edelman y León, 2014; Boyer y Peñalva, 2012); 2) a finales de junio de 2013 fue creada la Estrategia Interinstitucional en Seguridad y Toma Integral Gubernamental de Respuesta Especial de Seguridad, conocida como la Fuerza TIGRES; 3) en agosto de 2013 también fue aprobada la Ley de Policía Militar de Orden Público (PMOP). De esta manera, la separación entre policía y fuerzas militares se ha diluido, con las segundas pasando a ser el bastión de la estrategia de seguridad del gobierno. El problema con este tipo de situación es que:

[...] incrementar los cuerpos armados, multiplicar sus instrumentos mortíferos, ubicar guardias públicos y privados por doquier resulta, casi fatalmente, en cuerpos armados que utilizan sus armas e instrumentos mortíferos, en guardias que hacen uso de su poder y provocan así la represalia violenta sin que, en última instancia, se pueda distinguir lo que es defensa de lo que es ataque, lo que es protección de lo que es agresión (Martín-Baró, 2003: 86).

Esto se vincula con el histórico problema de impunidad que se ha vivido en el país ya que, al no quedar clara la distinción entre las partes, es más difícil definir responsables. El resultado es una situación de gran incertidumbre, donde la supuesta violencia proveniente del crimen organizado se presenta como una pantalla para ataques más focalizados hacia personas de ciertos grupos particulares como periodistas, líderes campesinos, mujeres o personas de la comunidad LGBT. 
ANDRÉS LEÓN

\section{A manera de cierre: las elecciones de 2013 y la continuación de la crisis}

En noviembre de 2013 se llevaron a cabo unas de las elecciones más anticipadas en la historia cercana hondureña. Después de una campaña marcada y saturada por la discusión sobre la violencia y la inseguridad que vivía el país, y con el golpe de Estado de 2009 de trasfondo, era evidente que se jugaba algo más que simplemente la elección de un nuevo gobierno de turno. Todo el proceso estuvo marcado por una clara polarización entre el Partido Nacional y su candidato Juan Orlando Hernández — presidente hasta ese entonces del Congreso Nacional y promotor incansable de la militarización del tema de seguridad- y el Partido Libertad y Refundación (LIBRE) con su candidata Xiomara Castro de Zelaya, esposa de Manuel Zelaya.

Al final, en la que ha sido una de las contiendas electorales más apretadas en la historia del país, Juan Orlando Hernández obtuvo casi el 37\% de la votación, seguido por Xiomara Castro con cerca del 29\% y por Mauricio Villeda, candidato del Partido Liberal, con poco más del 20\%. En términos generales, esta elección ha sido leída como la que vendría a romper el histórico bipartidismo en el país (Rodríguez, 2015; Sosa, 2014). Esto claramente es cierto si se toma en cuenta la significativa caída del Partido Liberal y la consolidación de LIBRE como segunda fuerza en el país, tanto en términos de votación presidencial como de presencia en el Congreso - 37 de 128 diputados, contra los 48 del Partido Nacional y los 27 del Partido Liberal-.

Sin embargo, dicha acotación debe ser matizada si se toman en cuenta al menos tres elementos. El primero es que, si se suma el caudal de votos alcanzado por LIBRE al de los liberales, se llega a un número de poco más del 48\%, cifra similar a los niveles históricos del Partido Liberal. Segundo, y sumado a esto, en las elecciones internas llevadas a cabo para definir a las personas candidatas a puestos elegibles, LIBRE presentó una única candidatura a nivel presidencial - Xiomara Castro-, pero cinco tendencias, de las cuales una estaba conformada mayoritariamente por figuras provenientes del movimiento social y popular — Fuerza de Refundación Popular-, y otra, la 28 de Junio, por personas provenientes de los partidos políticos tradicionales, fundamentalmente del Partido Liberal y cercanos a Mel y su gobierno. La gran mayoría de las candidaturas electas provenía de la 28 de Junio, es decir, de políticos de tradición, lo que pone bastante en entredicho la idea de LIBRE como una fuerza completamente nueva. Finalmente, esta ruptura del bipartidismo queda en tela de juicio cuando se pasa del nivel nacional y de Congreso aldelas alcaldías y regidurías, dondeel Partido Liberal superó significativamente a LIBRE - 83 alcaldías contra 31-. Esto parecería plantear que, si bien hay reacomodos dentro de las cúpulas partidarias, la territorialización de la forma electoral del sistema de dominación sigue operando de manera similar. O, para ponerlo en términos de Neil Smith (2008), que el bipartidismo en Honduras está muerto, pero es dominante. 
Por otra parte, el gobierno de Hernández se ha concentrado desde el principio en dos temas fundamentales: la seguridad y la atracción de inversión extranjera directa. Con respecto al primer tema, la policía militar se ha vuelto una presencia constante en las calles hondureñas y, si bien ha habido un leve descenso en la tasa de asesinatos, la población sigue viviendo en un constate estado de miedo. Además, se mantiene la falta de confianza en los cuerpos de seguridad debido a su constante participación en violaciones de derechos humanos. En lo que respecta a la atracción de inversión extranjera directa, el gobierno está buscando crear las primeras ZEDES en los departamentos de Valle o Choluteca, con financiamiento surcoreano, así como expandir la extensión dedicada al monocultivo de palma africana y seguir promoviendo la construcción de proyectos hidroeléctricos y la minería a cielo abierto.

El resultado ha sido un aumento de la protesta social que se ha encauzado en dos direcciones. Por un lado, el gobierno ha sido el blanco de varias denuncias de corrupción, que incluyen el desfalco por más de 330 millones del Instituto Hondureño de Seguridad Social, así como la donación de las empresas involucradas a la campaña del Partido Nacional. Dichas manifestaciones, si bien tienen una presencia nacional, se han concentrado sobre todo en los centros urbanos y cuentan con una significativa presencia de personas jóvenes. Autodenominados como los "indignados", sus protestas deben ser leídas en conjunto con el movimiento ciudadano anticorrupción guatemalteco que llevó a la renuncia de Otto Pérez Molina a la presidencia de dicho país. En este sentido, puede ser considerada como una movilización que podríamos denominar de corte "ciudadano", donde lo que se busca es un mejor manejo del aparato estatal. También muestra, en la forma de este profundo descontento, la crisis tan profunda de legitimidad que está sufriendo el sistema político hondureño, lo que remite a la idea de la crisis de autoridad antes mencionada y a cómo los acuerdos y entendimientos con respecto a las relaciones entre dominados y dominantes están siendo cuestionados. La violencia de la que han sido blanco muchas de estas manifestaciones y los líderes de las diferentes organizaciones participantes habla también de la apelación a la coerción como forma de mantener las estructuras de dominación.

Por el otro lado, los proyectos extractivistas promovidos desde el gobierno se han encontrado con la resistencia de un conjunto de comunidades campesinas, indígenas y afrodescendientes que buscan defender sus territorios y con ellos sus formas de vida y de estar en el mundo. Paradigmáticos de estos movimientos son el COPINH y su lucha en los territorios ancestrales lencas en el occidente del país en contra de la construcción de proyectos hidroeléctricos y la minería (Cardoza, 2014), lucha que le ha valido a Berta Cáceres, a quien ya mencioné anteriormente, el Goldman Environmental Prize en 2015 por su lucha en contra de un proyecto hidroeléctrico en Agua Zarca; la Organización Fraternal Negra Hondureña (OFRANEH), la cual trabaja desde hace varios años en la defensa de las comunidades garífunas de la Costa Norte del país de los intentos por 
distintos inversionistas nacionales y extranjeros de apropiarse de sus tierras para la expansión del monocultivo palmero y la construcción de megaproyectos turísticos (Brondo, 2013); finalmente, las diferentes organizaciones campesinas presentes en el Bajo Aguán, en el departamento de Colón, que al menos desde el año 2000 vienen realizando un conjunto de recuperaciones de tierras que consideran que les fueron arrebatadas ilegalmente a principios de los noventa por un grupo de terratenientes, incluyendo al recientemente difunto Miguel Facussé, y que los pone en el centro de la disputa por la expansión del monocultivo palmero (Edelman y León, 2014).

Lo que tienen en común estos casos es el enfrentamiento entre comunidades empobrecidas y los intereses del gran capital nacional y extranjero, con el Estado tomando en la mayoría de los casos el lado de los últimos y anteponiendo la protección del lucro y la propiedad privada a la vida de sus ciudadanos. El resultado ha sido una gran cantidad de muertos y otras violaciones de los derechos humanos y la dominación de la impunidad. Así, si las manifestaciones en contra de la corrupción, y lo que más genéricamente podríamos llamar el "mal gobierno", ponen en entredicho al sistema político, estas disputas territoriales vienen a obstaculizar y a poner en duda el régimen dominante de acumulación en el país.

En este contexto, se vuelven especialmente vigentes las observaciones realizadas por Ignacio Martín-Baró con respecto a El Salvador de los ochenta:

Al considerar que la plenitud de la persona se logra mediante el tener y acumular privados, el sistema establecido refuerza aquella violencia y agresión que hace posible laconsecución de escasos recursos, comoes la de El Salvador, la capitalización no se puede lograr si no es mediante la violencia ejercida en la distribución de los beneficios del trabajo productivo: la propiedad privada se vuelve, por lo mismo, privadora de lo que otros necesitan, alimentando la holganza de los pocos con la miseria de los muchos (Martín-Baró, 2003: 125).

\section{Referencias bibliográficas}

Abrams, Philip, Akhil Gupta y Timothy Mitchell (2015). Antropología del Estado. México: Fondo de Cultura Económica.

Argueta, Mario (2008). Tiburcio Carías: anatomía de una época. Tegucigalpa: Guaymuras.

Argueta, Mario (2009). Ramón Villeda Morales: luces y sombras de una primavera política. Tegucigalpa: Guaymuras.

Barahona, Marvin (1989). La hegemonía de los Estados Unidos en Honduras: (1907-1932).

Tegucigalpa: Centro de Documentación de Honduras.

Barahona, Marvin(2002). Evoluciónhistóricadelaidentidadnacional. Tegucigalpa: Guaymuras. 
Barahona, Marvin (2005). Honduras en el siglo XX: una síntesis histórica. Tegucigalpa: Guaymuras.

Bilgin, Pinar, y Adam David Morton (2004). From "Rogue" to "Failed" States? The Fallacy of Short-Termism*. En Politics, vol. 24, núm. 3, pp. 169-180.

Boyer, Jefferson C. y Wilfredo Cardona Peñalva (2012). "Daring to Hope in the Midst of Despair: The Agrarian Question within the Anti-Coup Resistance Movement in Honduras". En Jennifer Burrell y Ellen Moodie (eds.), Central America in the New Millennium: Living Transition and Reimagining Democracy. Amsterdam: CEDLA, pp. 64-79.

Bondo, Keri Vacanti (2013). Land Grab: Green Neoliberalism, Gender, and Garifuna Resistance in Honduras. Phoenix: University of Arizona Press.

Bucheli, Marcelo (2006). Good Dictator, Bad Dictator: United Fruit Company and Economic Nationalism in Central America in the Twentieth Century. Illinois: College of Business at Illinois. Disponible en: http://www.business.uiuc.edu/Working_Papers/papers/06-0115.pdf (consultado el 2 de noviembre de 2014).

Bulmer-Thomas, Víctor (1993). "La crisis de la economía de agroexportación (19301945)”. En Edelberto Torres Rivas (coord.), Historia general de Centroamérica. Madrid: Sociedad Estatal Quinto Centenario, pp. 325-398.

Cáceres, Miguel y Sucelinda Zelaya (2005). "Honduras. Seguridad productiva y crecimiento económico: La función económica del Cariato". En Anuario de Estudios Centroamericanos, vol. 31, pp. 49-91.

Cálix, Álvaro (2010). "Honduras: de la crisis política al surgimiento de un nuevo actor social”. En Nueva Sociedad, núm. 226, pp. 34-51.

Cardoza, Melissa (2014). “Cuentan los pueblos que viven por El Río Gualcarque: La lucha del Copinh contra la Represa Río Blanco en Honduras”. En Claudia Composto y Mina Navarro (eds.), Territorios en disputa: Despojo capitalista, luchas en defensa de los bienes comunes naturales y alternativas emancipatorias para América Latina. México: Ediciones Desde Abajo.

De Castro, Stefanía Natalini, María de los Ángeles Mendoza Saborío y Joaquín Pagán Solórzano (1985). Significado histórico del gobierno del Dr. Ramón Villeda Morales, 10. Tegucigalpa: Editorial Universitaria.

Cruz, José Miguel (2010). "Estado y violencia criminal en América Latina. Reflexiones a partir del golpe en Honduras". En Nueva Sociedad, núm. 226, pp. 67-84.

Cruz, José Miguel (2011). "Criminal Violence and Democratization in Central America: The Survival of the Violent State". En Latin American Politics and Society, vol. 53, núm. 4, pp. 1-33.

Cuevas Molina, Rafael (2011). De Banana Republics a repúblicas maquileras: la cultura en Centroamérica en tiempos de globalización neoliberal (1910-2010). San José: EUNED.

C.V.R. (2011). Para que los hechosno serepitan: informe de la Comisión dela Verdady la Reconciliación. Honduras: Comisión de la Verdad y la Reconciliación. 
De la Torre, Verónica y Alberto Martín Alvarez (2011). "Violencia, Estado de Derecho y políticas punitivas en América Central”. En Perfiles Latinoamericanos, vol. 19, núm. 37, pp. 33-50.

Del Cid, José Rafael (1988). "Populating a Green Desert: Population Policy and Development. Their Effect on Population Redistribution. Honduras, 1876-1980". Tesis de doctorado en Filosofía, University of Texas, Austin.

Di Iorio, Marco Cáceres (2010). The Good Coup: The Overthrow of Manuel Zelaya in Honduras. Terrace, BC: CCB Publishing.

Dosal, Paul J. (1993). Doing Business with the Dictators: A Political History of United Fruit in Guatemala, 1899-1944. Lanham: Rowman \& Littlefield Publishers.

Duménil, Gérard y Dominique Lévy (2004). Capital Resurgent: Roots of the Neoliberal Revolution. Harvard: Harvard University Press.

Edelman, Marc y Andrés León (2014). "Ciclos de acaparamiento de tierras en Centroamérica: Un argumento a favor de historizar y un estudio de caso del Bajo Aguán, Honduras". En Anuario de Estudios Centroamericanos, vol. 40, núm. 1, pp. 195-228.

Euraque, Darío (2001). El capitalismo de San Pedro Sula y la historia política hondureña (18701972). Tegucigalpa: Guaymuras.

Figueroa Ibarra, Carlos (1993). “Centroamérica: entre la crisis y la esperanza (1978-1990)”. En Edelberto Torres Rivas (coord.), Historia general de Centroamérica. Madrid: Sociedad Estatal Quinto Centenario.

Gallardo, Helio (2007). Democratización y democracia en América Latina. Bogotá: Ediciones Desde Abajo.

Gleijeses, Piero (1992). Shattered Hope: The Guatemalan Revolution and the United States, 19441954. New Jersey: Princeton University Press.

Gramsci, Antonio (1999). Cuadernos de la cárcel. México: Era.

Kay, Cristóbal (1998). "Latin America’s Agrarian Reform: Lights and Shadows". En Land Reform, Land Settlement and Cooperatives, núm. 2, pp. 9-31.

Martín-Baró, Ignacio (2003). Poder, ideología y violencia. Madrid: Trotta.

Martínez, Juan Ramón (2010). Diario del retorno: lo ocurrido en Honduras, a partir del 28 de junio del 2009. Tegucigalpa: Ediciones 18 Conejo.

Marx, Karl (2012). El Dieciocho Brumario de Luis Bonaparte. Madrid: Alianza Editorial.

Mejía, Joaquín y Víctor Fernández (2010). El golpe de Estado en Honduras desde una perspectiva de los Derechos Humanos. Tegucigalpa: ERIC-SJ y MADJ.

Meza, Víctor, Ramón Romero, M. Gamero et al. (2010). Golpe de Estado: partidos, instituciones y cultura política. Honduras: Centro de Documentación de Honduras. Disponible en: http://ww.cedoh.org/resources/Publicaciones/Libros/Libro-partidos.pdf(consultado el 21 de octubre de 2015).

Miranda, Jorge (2010). Crónicas del golpe de Estado en Honduras. Tegucigalpa: Editorial Carmina. 
Pastor, Rodolfo (2011). Historia mínima de Centroamérica. México: El Colegio de México.

Pérez Brignoli, Héctor (1997). Breve historia contemporánea de Costa Rica. México: Fondo de Cultura Económica.

Pérez Sainz, Juan Pablo (2014). Mercados y bárbaros: la persistencia de las desigualdades de excedente en América Latina. Costa Rica: FLACSO.

Posas, Mario (1981). El movimiento campesino hondureño: una perspectiva general, vol. 2. Tegucigalpa: Guaymuras.

Posas, Mario (1993). "La plantación bananera en Centroamérica (1870-1929)". En Edelberto Torres Rivas (coord.), Historia general de Centroamérica. Madrid: Sociedad Estatal Quinto Centenario, pp. 1ll-166.

¿QUÉ ES UNA ZEDE? - ZEDE (N.d.). Disponible en: http://zede.gob.hn/?page_id=2 (consultado el 25 de octubre de 2015).

Quijano, Aníbal (2006). “Don Quijote y los molinos de viento en América Latina”. En Investigaciones Sociales, vol. X, núm. 16, pp. 347-368.

Quispe, Juvenal (2012). Honduras: evidencias de un Estado fallido y la urgencia de la refundación. Tegucigalpa: Editorial Luna Color.

Rodríguez, Cecilia Graciela (2015). "Honduras: hacia una reconfiguración del sistema partidario tras las elecciones generales de 2013”. En Colombia Internacional, núm. 85, pp. 209-226.

Roux, Rhina (2002). “La política de los subalternos”. En Gerardo Ávalos Tenorio (coord.). Redefinir lopolítico. México: UAM-X, CSH, Depto. de Relaciones Sociales, pp. 229-255.

Roux, Rhina (2011). "El Mito, la tierra, el príncipe". En Argumentos, vol. 24, núm. 65, pp. 11-35.

Ruhl, J. Mark (2010). "Honduras Unravels". En Journal of Democracy, vol. 21, núm. 2, pp. 93-107.

Salgado, Ramón (ed.) (2010). Crisis institucional y golpe de Estado en Honduras. Tegucigalpa: Universidad Pedagógica Nacional Francisco Morazán.

Salomón, Leticia (2009). "El golpe de Estado en Honduras: caracterización, evolución y perspectivas”. S.p.i. Disponible en: http://www.alboan.org/docs/articulos/canales/ alboan/LAEVOLUCIONDELGO.pdf (consultado el 4 de noviembre de 2014).

Sanyal, Kalyan (2013). RethinkingCapitalistDevelopment:Primitive Accumulation, Governmentality and Post-Colonial Capitalism. Nueva Delhi: Routledge India.

Sieder, Rachel (1995). "Honduras: The Politics of Exception and Military Reformism (1972-1978)”. En Journal of Latin American Studies, vol. 27, núm. 1, pp. 99-127.

Smith, Neil (2008). "Comment: Neo-Liberalism: Dominant but Dead”. En Focaal, núm. 5l, pp. 155-157.

Soluri, John (2009). Banana Cultures: Agriculture, Consumption, and Environmental Change in Honduras and the United States. Austin: University of Texas Press. 
Sosa Iglesias, José Eugenio (2014). "Honduras: entre criminalidad, enfrentamiento mediático, protesta social y resultados electorales cuestionados". En Revista de Ciencia Política, vol. 34, núm. l, pp. 203-219.

Stein, Stanley J. y Barbara H. Stein (1970). La herencia colonial de América Latina. México: Siglo XXI.

Ten Velde, Liza (2012). El nexo entre drogas y violencia en el Triángulo del Norte, el papel del narcotráfico en la violencia delictiva y las respuestas de política pública en Guatemala, El Salvador y Honduras. Amsterdam: Transnational Institute. Disponible en: https://www.tni.org/es/ publicacion/el-nexo-entre-drogas-y-violencia-en-el-triangulo-del-norte?context=595 (consultado el 25 de octubre de 2015).

Thiesenhusen, William C. et al. (1995). Broken Promises: Agrarian Reform and the Latin American Campesino. Nueva York: Westview Press, Inc.

Thomas, Peter D. (2009). The Gramscian Moment: Philosophy, Hegemony and Marxism. Amsterdam: BRILL.

Williams, Robert Gregory (1986). Export Agriculture and the Crisis in Central America. Chapel Hill: UNC Press Books.

Williams, Robert Gregory (1994). States and Social Evolution: Coffee and the Rise of National Governments in Central America. Chapel Hill: UNC Press Books.

Zuckerman, Alan (1975). "Political Cleavage: A Conceptual and Theoretical Analysis". En British Journal of Political Science, vol. 5, núm. 2, pp. 231-248. 


\section{Mesianismo político en El Salvador: análisis de discurso de los candidatos de ARENA y el FMLN en las campañas electorales presidenciales de 2004 y 2009 \\ Carlos Mauricio Hernández}

\section{Introducción}

Analizaremos desde la categoría de mesianismo político dos campañas electorales para presidente de la República de El Salvador — 2004 y 2009— por parte de los dos partidos políticos más importantes de la realidad política actual, la Alianza Republicana Nacionalista (ARENA) y el Frente Farabundo Martí para la Liberación Nacional (FMLN). Con ello se pretende evidenciar un elemento constitutivo de la cultura política salvadoreña - y muy probablemente de América Latina - que apela a aspectos de carácter religioso en campañas electorales en un Estado nominalmente secular. Se han seleccionado así discursos significativos de los candidatos en 2004, Schafik Hándal (FMLN) y Antonio Saca (ARENA), y de Rodrigo Ávila (ARENA) y Mauricio Funes (FMLN) para el año 2009. Corresponde a la última elección ganada por ARENA (de derecha) y la primera ganada por el FMLN (de izquierda), respectivamente.

El criterio de selección ha sido la magnitud del evento en que se dieron y el desarrollo de ideas claves en su campaña o el lugar de publicación. Se entiende aquí por discurso de campaña electoral lo declarado por un candidato presidencial con el fin de convencer a la población para que vote por él en mítines, entrevistas periodísticas, comunicados en prensa escrita y foros de discusión. Cada discurso fue analizado utilizando cinco mitos políticos o arquetipos míticos de carácter religioso: mesías, bestia, peste, horizonte utópico y pueblo. Esto no quiere decir que los candidatos armaron sus discursos a partir de ellos ni tampoco que estos elementos constituyeron explícitamente la línea oficial de los candidatos, sino que se trata de categorías que para efectos de estudio se utilizan en el análisis crítico de las campañas antes mencionadas. 


\section{Política y democracia en El Salvador. Un breve marco contextual}

Existen al menos dos hechos históricos que son claves para comprender los procesos electorales contemporáneos en El Salvador. El primero de ellos es la elección de la Asamblea Constituyente en 1982, y el segundo la firma de los Acuerdos de Paz en enero de 1992. Con la Constituyente se puso fin a la coyuntura política posterior al golpe de Estado del 15 de octubre de 1979, el cual derivó en cambiantes Juntas Revolucionarias de Gobierno que asumieron roles legislativos. Las elecciones para la Asamblea Legislativa se habían realizado en 1978, dos años más tarde correspondía la realización de nuevos comicios, pero con el mencionado golpe quedaron suspendidos y el orden constitucional se vio alterado considerablemente. El Salvador pasó casi tres años sin Parlamento, lo cual demuestra la convulsión política y militar de esos años marcados por el inicio de la guerra civil.

Por ello, para el Consejo Central de Elecciones, tribunal electoral conformado por Junta Revolucionaria de Gobierno, las elecciones del 28 de marzo de 1982 fueron:

Las primeras elecciones efectivamente libres en los últimos 50 años sin presencia ni participación de un "partido oficial", con la garantía de absoluta neutralidad e imparcialidad de la Fuerza Armada la cual estuvo vigilante y garante de los comicios; constituyó este evento, en fin, clara demostración de altura cívica de todo un pueblo que se volcó a las calles en forma masiva, desafiando la violencia y desoyendo las amenazas de la ultraizquierda (Consejo Central de Elecciones, 1982: 5).

Según las cifras oficiales, los votantes casi llegan a los dos millones - 1.9 millones-, una cantidad alta en relación con otros procesos electorales cercanos en el tiempo - 1.2 millones aproximadamente para la elección presidencial de 1977 y 1.4 millones aproximadamente en la elección presidencial de 1984- De este proceso electoral surgieron el gobierno provisional de Álvaro Alfredo Magaña Borja, la Constitución Política que entró en vigencia en 1983 y que aún rige en el presente la República de El Salvador y los procesos electorales hasta hoy en día. Desde entonces, se realizan elecciones legislativas y municipales cada tres años y las presidenciales cada cinco años: la primera de ellas fue en 1984 y la última en 2014.

Aunque en su momento las elecciones se publicitaron como la salida al conflicto bélico que había iniciado con fuerza años atrás — se llegó a difundir la disyuntiva: elecciones o guerra civil-, en la práctica no estaban representadas las fuerzas políticas de izquierda y, por tanto, no podía ser el proceso electoral la alternativa real para resolver las diferencias de los principales bandos en pugna. 
A nadie se le oculta, ni a Estados Unidos, ni a la Junta, ni al PDC, ni a los otros partidos que van a elecciones que el proceso electoral no es la salida del actual conflicto. Y esto no tanto por sus debilidades intrínsecas, sino porque no toma en serio el conflicto y sus causas, y sobre todo, a sus protagonistas (ECA, 1982: 11).

Fue en las elecciones de 1994 cuando participó por primera vez en comicios municipales, legislativos y presidenciales el Frente Farabundo Martí para la Liberación Nacional (FMLN), uno de los protagonistas del conflicto armado. Primero fue fundado como grupo guerrillero en diciembre de 1980, y fue convertido a partido político después de la negociación que puso fin a la guerra a través de los Acuerdos de Paz firmados en el Castillo de Chapultepec, México, el 16 de enero de 1992.

Así pues, firmada la paz, se han realizado con la frecuencia temporal establecida en la Constitución los eventos electorales correspondientes a alcaldes, diputados y presidentes. Para el caso de las elecciones presidenciales, han sido en total cinco, en las que los dos grandes partidos, uno de izquierda y el otro de derecha, han competido por llegar a la dirección del Ejecutivo: 1994, 1999, 2004, 2009 y 2014.

\section{Mitos políticos en El Salvador: del mesías al pueblo}

El concepto de "imaginario social" es una categoría de análisis usada por las ciencias sociales que permite un acercamiento teórico al tema aquí desarrollado. De entrada, se puede indicar que ese imaginario está impregnado de "arquetipos míticos" que a su vez derivan en "mitos políticos", que están presentes en los discursos de los candidatos en períodos electorales.

Es Cornelius Castoriadis quien sostiene que el individuo sólo existe en la sociedad y por la sociedad. Por ello, la conducta individual estará determinada por toda una serie de patrones o instituciones que se crean y se difunden en la sociedad:

No hay que preguntarse icómo se explica que la mayor parte de la gente "aun cuando tenga hambre" no robe? y ni siquiera hay que preguntarse icómo se explica que los individuos continúen votando por un determinado partido aun después de haber sido engañados repetidamente? Antes bien, hay que preguntar: icuál es la parte de nuestro pensamiento y de todos los modos de ver las cosas y hacer las cosas que no está condicionada o determinada en un grado decisivo por la estructura y las significaciones de nuestra lengua materna, por la organización del mundo que esa lengua expresa, por nuestro primer ambiente familiar, por la escuela, por todos esos "haz esto" y "no hagas esto" que nos han acosado constantemente, por las opiniones que circulan, por las maneras de hacer que nos imponen los artefactos innumerables en medio de los cuales estamos inmersos, etcétera? (Castoriadis, 2005: 67). 
Así, cada sociedad crea una concepción de mundo que luego se interioriza en el individuo a través de todas las instituciones sociales: la escuela, la familia, la iglesia, etcétera. Luego el individuo interactúa con esa visión de mundo sin la cual no podría ni desarrollarse ni estar en contra de la misma. Se trata, en suma, de una red compleja de:

Significaciones que empapan, orientan y dirigen toda la vida de la sociedad considerada y a los individuos concretos que corporalmente la constituyen. Esa urdimbre es lo que yo llamo el magma de las significaciones imaginarias sociales que cobran cuerpo en la institución de la sociedad así considerada y que, por así decirlo, la animan. Semejantes significaciones sociales imaginarias son, por ejemplo, espíritus, dioses, Dios, polis, ciudadano, nación, estado, partido, mercancía, dinero, capital, tasas de interés, tabú, virtud, pecado (Castoriadis, 2005: 68).

Castoriadis explica que constituyen imaginarios sociales en el sentido de ser creaciones sociales que sólo existen en tanto instituidas en una colectividad. Por tanto, tienen una función ideológica que explica y que da sentido a determinadas prácticas concretas; son, en palabras del autor, el ánima que mueve el modo de ser de las sociedades. De ahí que, aunque sean ideas imaginarias en sentido estricto, en una sociedad un mito, por ejemplo, puede ser considerado real en la medida en que se forma parte de ese conjunto de ideas que explican y dan sentido a la práctica individual y social.

Es la institución de la sociedad lo que determina aquello que es "real" y aquello que no lo es, lo que tiene sentido y lo que carece de sentido. La hechicería era real en Salem hace tres siglos y aún más "el Apolo de Delfos era en Grecia una fuerza tan real como cualquier otra" (Marx)... Toda sociedad es un sistema de interpretación de mundo; y aun aquí el término "interpretación" resulta superficial e impropio. Toda sociedad es una construcción, una constitución, creación de un mundo, de su propio mundo (Castoriadis, 2005: 69).

Los mitos de cualquier índole, en esta perspectiva, aunque carezcan de racionalidad o realidad, cobran importancia en la medida en que se convierten en parte de ese imaginario social que anima la práctica pues, como sostiene Bonazi: "El conocimiento mítico y el racional coexisten en la estructura psicológica del hombre", es decir, sea en la sociedad tradicional o en la sociedad moderna (2005: 982); de ahí su propuesta de "profundizar el estudio del mito político como fenómeno constitutivo y no aberrante de la realidad social". Para este autor, el mito político, de la misma manera que el mito: “[...] consiste en relatos estructurados simbólicamente, y por lo tanto con un sentido sobredeterminado, vinculado no de modo analítico sino emotivo con determinadas situaciones de hecho y destinadas a instituir formas privilegiadas de acción, cuya 'verdad' el relato mítico mismo funda" (Bonazi, 2005: 981-982). 
Al estar relacionados con el sentido general del mito, los mitos políticos se construyen a partir de figuras religiosas o de lo que Bonazzi llama arquetipos míticos: "La presencia en el mito político de verdaderos mitologemas reconducibles a arquetipos míticos como la edad de oro o la reconquista del Edén, la fundación por parte de héroes civilizadores, el libro sagrado, la transformación y la inversión de los papeles, etc." (Bonazi, 2005: 982).

Y es que la forma de los mitos puede ser de índole religiosa — como es el caso de los mitos aquí utilizados para analizar los discursos de los candidatos presidenciales de ARENA y el FMLN-, pero también pueden tomar la forma de superhéroes o actores de telenovelas, tal como señala Omar Rincón en un estudio sobre los presidentes latinoamericanos y su forma de comunicarse en el espacio político:

Más que gobernar o hacer política desde la izquierda o la derecha o desde las ideas, se produce espectáculo, televisión y melodrama. La gran historia política de nuestros días es de amor más que de ideologías, y esa telenovela busca la refundación de la nación. ¿Cómo es la trama? La hipótesis narrativa dice que hombre puro (pongamos que hablamos de Uribe, Correa, Chávez, Evo) salva a mujer equivocada (el pueblo, que se lo ha dado a tantos, que lo han engañado y ultrajado). Quien encarne el gobierno debe tener pasión por el poder y carisma personal para parecer presidente y el liderazgo político para convertirse en galán de verdad (Rincón, 2008: 6-7).

Pero, entonces, ipor qué utilizar las figuras del “mesías", la "bestia”, la "peste”, el "horizonte utópico" y el "pueblo" como parte de lo que se puede considerar la mitología política salvadoreña y no la del hombre puro o del superhéroe? Fundamentalmente porque se parte aquí de que existen mitos políticos con un claro fondo religioso, tal es el caso salvadoreño, en donde estas cinco figuras son apocalípticas, sacadas del relato bíblico. Por otro lado, esta mitología conecta con el presidencialismo, donde el protagonismo lo tiene el presidente de la República.

Por estas dos razones, se defiende aquí que es más pertinente la mitología para analizar los discursos de los candidatos presidenciales de ARENA y el FMLN en las campañas de los años 2004 y 2009, que hacerlo desde la perspectiva del hombre puro o del superhéroe. ${ }^{1}$

\section{El mesianismo en campañas electorales: un patrón de cultura política}

Los arquetipos míticos utilizados para analizar los discursos de los cuatro candidatos a presidentes se han seleccionado a partir de la idea expuesta por Nataly Guzmán sobre los

\footnotetext{
${ }^{1}$ Al parecer, los arquetipos de hombre puro o superhéroe serían más pertinentes para analizar los discursos de la persona cuando ésta ya ocupa el cargo de presidente.
} 
mitos en la realidad política salvadoreña. En la misma línea de tener en consideración la categoría de mito político, esta autora afirma: "No se discute el mito como fantasía exótica, sino como fundamento de ciertas creencias, estructuras, relatos de cultura, relatos de imaginación. Se discute, pues, el mito y su relación con la política, pues el mito no es algo del pasado como se asume comúnmente" (Guzmán, 2009: 359).

De esta manera, al estudiar la campaña electoral del partido ARENA, ella descubrió que los elementos clásicos de la narrativa propagandística de este partido político contienen estos cinco mitos:

Mesías (la figura presidencial que promete luchar por el bienestar de la patria), la peste (los "peligros" de un cambio de "sistema"), la bestia (el enemigo de la libertad nacional), el horizonte utópico (el progreso que sólo los constantes pueden vislumbrar con esperanza), y el pueblo (que recibirá una recompensa a través de su trabajo y de su fe, con limitaciones que no deben cuestionarse porque son parte de un sacrificio) (Guzmán, 2009: 359).

Sin embargo, aquí se defiende que esta narrativa también se puede observar en los discursos presidenciales tanto de ARENA como del FMLN, en las dos campañas electorales seleccionadas. El mito alrededor del cual se articulan los demás es el del "mesías", que representa al candidato en su lucha y sacrificio por una mejor sociedad en beneficio del "pueblo", quien se encuentra en una situación de peligro. Es precisamente la "bestia" quien representa al candidato contrario, culpable de una "peste", y ésta representa todos los males que sufre y que sufriría el pueblo si ganara las elecciones aquélla. En cambio, al votar por el candidato bajo la figura del "mesías", se estaría encaminando hacia un "horizonte utópico", que representa el proyecto o la promesa de campaña de crear una mejor nación para el "pueblo", en donde se solucionan todos los males actuales que se padecen (ver cuadro l).

Cuadro 1. Los cinco mitos políticos en las campañas electorales presidenciales de 2004 y 2009 en El Salvador

\begin{tabular}{ll}
\hline Mito político & \multicolumn{1}{c}{ Descripción básica } \\
\hline El mesías & $\begin{array}{l}\text { Figura central aplicada al candidato que protegerá a la patria de todo } \\
\text { peligro. }\end{array}$ \\
\hline La bestia & $\begin{array}{l}\text { Hace referencia al principal candidato contrario, al que se considera } \\
\text { un peligroso “enemigo” de la patria por atentar contra la tranquilidad, } \\
\text { la libertad y el bienestar de la sociedad. }\end{array}$ \\
\hline La peste & $\begin{array}{l}\text { Es la maldad contra la cual se pretende luchar, es traída a la sociedad } \\
\text { por la Bestia. }\end{array}$ \\
\hline
\end{tabular}




\begin{tabular}{ll}
\hline $\begin{array}{l}\text { El horizonte } \\
\text { utópico }\end{array}$ & $\begin{array}{l}\text { Expresa la meta o el ideal por conseguir si se vota por el candidato } \\
\text { mesiánico. }\end{array}$ \\
\hline El pueblo & $\begin{array}{l}\text { Beneficiario del “sacrificio" de la labor mesiánica del candidato al } \\
\text { llegar a ser presidente. }\end{array}$ \\
\hline
\end{tabular}

Fuente: Elaboración propia.

Los extractos de los discursos seleccionados enmarcados en uno de estos cinco arquetipos míticos pueden también expresar a la vez otro u otros. Lo importante será entonces la contextualización de esas selecciones.

De esta forma se concluye que el fenómeno de simbolizar al candidato a presidente de la República de forma mesiánica ha sido recurrente en las dos campañas electorales y en los cuatro candidatos estudiados, lo que en última instancia evidencia que la cultura política en El Salvador contiene rasgos constitutivos de carácter religioso que la alejan del ideal secular, según el cual la Iglesia y la religión deben estar separadas del quehacer político.

\section{La campaña de 2004}

La campaña electoral presidencial de 2004 comenzó varios meses antes de la fecha oficial proclamada por el Tribunal Supremo Electoral (TSE). Los candidatos de los dos principales partidos fueron: Schafik Hándal, por el FMLN, y Antonio Saca, por ARENA. Ambos fueron proclamados candidatos de sus respectivos partidos en el mes de julio de 2003, Saca el día 14 y Hándal el 27.

El ganador en esa contienda fue Antonio Saca con más del 57\% a favor, frente al $35.65 \%$ de votos a favor del candidato efemelenista. Una interpretación de este resultado fue analizada, a partir de la campaña proselitista, por José Manuel González, de la siguiente manera:

La campaña de ARENA fue planificada, vigilada y estratégicamente dispuesta para hacer de su candidato una figura omnipresente, creíble y accesible. Contrario a ello, el FMLN no mostró dominio de la planificación estratégica de su propaganda y, de esta manera, permitió que creciera la imagen natural que la sociedad tenía de la línea ideológica del partido y de su candidato (González, 2004: 416).

La tesis de fondo manejada por González es que ARENA supo manipular de mejor forma el imaginario social salvadoreño durante la campaña, mientras que el FMLN no logró ser competitivo porque precisamente manejó mal ese imaginario social. Esto no significa que la campaña electoral programada por el partido de derecha haya sido más justa, verídica, 
honesta o de "altura". Más bien significa que los temores, los anhelos, las esperanzas y las demandas de la mayoría de la población salvadoreña fueron utilizados con mayor habilidad por su candidato.

\section{El mesías}

Este primer mito está relacionado con la forma de gobierno llamada presidencialismo. Debido a que el sistema político y electoral en El Salvador está impregnado por esta forma de gobierno, los candidatos a la presidencia hablan de sí mismos colocándose características personales extraordinarias. A continuación se presenta cómo los candidatos presidenciales de ARENA y el FMLN asumieron para sí mismos el mito del mesías que trae consigo la sociedad perfecta - horizonte utópico- para acabar con todos los males - la bestia y su peste - que afectan al pueblo, al cual se debe.

La historia personal. Los candidatos presidenciales de ARENA y el FMLN hicieron alusión a su historia personal con el objetivo de justificar por qué ellos y no otras personas habían sido las elegidas para ese cargo. Al argumentar sobre su candidatura presidencial, Schafik Hándal planteó que durante su vida ha sido constante su lucha por mejorar las condiciones de vida del pueblo.

Eso le llevó a asumir el reto de luchar por convertirse en presidente de El Salvador. Así lo expresa en las siguientes líneas:

Yo toda mi vida, que es larga, la he dedicado a luchar porque el pueblo viva mejor y por la democracia en el país. Conozco bien cada rincón de todo el país, lo conozco bien, conozco bien los problemas que tiene la gente [...] saben que soy una persona honesta, una persona de palabra, que cumple con su palabra y sabe que por eso yo voy a combatir la corrupción de manera incesante, sin tregua (Hándal, Foro Presidencial, 2003).

En esta misma línea, pero en otro discurso como candidato presidencial, agrega: "A mí me corresponde el honor de ser el candidato del FMLN a la Presidencia de la República. A lo largo de toda mi vida enfrenté numerosos retos. Desde muy joven tomé la decisión de acompañar y participar en las causas justas del pueblo" (Hándal, 2008: 15).

Con estas palabras Hándal, sin decirlo, se mostró como el mesías que El Salvador necesitaba. Esa misma actitud tuvo el candidato presidencial de ARENA, Elías Antonio Saca, ya que se presentó durante la campaña, e incluso en la toma de posesión presidencial, como un mesías:

La gente está exigiendo un presidente honesto y yo tengo las manos limpias... Soy un hombre conocedor de los problemas. Yo soy un líder. Conozco las interioridades, 
conozco los problemas de los salvadoreños. He tocado los grandes temas nacionales y estoy capacitado para abordarlos desde la perspectiva gubernamental. Históricamente, yo soy un hombre de retos (Saca, Foro Presidencial, 2003).

En las siguientes líneas, Saca aparece como el hombre modelo de superación económica personal. Afirmó que con su vida demostró que es posible triunfar en este país: "Mi historia personal demuestra que en El Salvador es posible la movilidad social. Que puedes venir desde abajo, que te puedes esforzar y entregar a algo positivo y que, al final de cuentas, tienes un éxito, incluso, puedes aspirar a ser el Presidente de la República" (Saca, He triunfado en El Salvador, 2003: 10).

Saca describió de la siguiente manera qué significó para él tener éxito y subir en la escala social para cumplir su sueño de mejorar sus condiciones de vida sin necesidad de emigrar a Estados Unidos o a otro país del primer mundo. El día en que tomó posesión, recalcó la idea de lo que llamó "sueño salvadoreño", en contraste con el llamado "sueño americano" - superación económica que se logra al emigrar y trabajar en Estados Unidos-: "Yo hice realidad mi propio sueño salvadoreño con trabajo y sacrificio, con limitaciones y angustias. Ese esfuerzo lo pongo hoy al servicio del país [...] Quiero entregarme por completo a El Salvador, porque a mi país y a mi gente les debo todo lo que soy" (Saca, Discurso de toma de posesión presidencial, 2004: 11).

De esta forma, Saca se presentó como el hombre con características extraordinarias que, desde el poder, pretende ponerse al servicio del pueblo para crear las condiciones necesarias a quienes viven en pobreza y así lograr que otras personas puedan seguir sus pasos.

Capacidad especial para gobernar. La capacidad especial en que tanto Hándal como Saca hicieron hincapié es la de saber gobernar. Para ello, no basta con ser honesto; plantearon que era necesario que el presidente fuera alguien dialogador, concertador y con carácter para llevar a cabo las medidas políticas adecuadas para la realidad salvadoreña. Hándal dijo al respecto:

He sido siempre una persona muy persistente en la lucha por aquello en que creo. Cualesquiera que sean los obstáculos. He sido siempre y sigo siendo muy concertador. Pero no nos confundamos, también muy combativo cuando me enfrento a hechos, opiniones y acciones que considero negativas (Handal, El pueblo salvadoreño, cuando se decide, puede, 2003: 10).

Pero, además, Hándal aseguró no padecer del vicio del que padecen sus contrincantes, en referencia no sólo al candidato presidencial de ARENA, sino a otros personajes de ese mismo partido político: 
No mentiría como se ha venido mintiendo, constantemente se dice que este país es una maravilla, que el pueblo está bien, que aquí se ha avanzado enormemente... una imagen internacional que no corresponde a la realidad del país [...] Otra cosa que no haría es cerrar las puertas al diálogo y a la concertación (Handal, Foro Presidencial, 2003).

Finalmente, Hándal se presentó como alguien capaz incluso de acabar en su período presidencial con el analfabetismo y la pobreza: "Al final de mi gobierno no habrá un ciudadano de este país que no sepa leer ni escribir. Atacaremos, hasta su final, y eliminaremos las enfermedades que brotan asociadas a la pobreza" (Hándal, 2008: 152).

Por su parte, Saca hizo alarde de poseer las características de un ser humano extraordinario para gobernar:

Soy una persona de consenso, y siempre estoy dispuesto a negociar y a platicar. Primero me voy a sentar con el COENA y luego con la población, porque es importante hablar con la gente y saber qué les duele, pero estaré disponible siempre para escuchar a todos los sectores (Saca, El vicepresidente debe ser clave en el gabinete, 2003: 6).

Saca aseguró que esa capacidad para dialogar y encontrar consensos se la forjó a lo largo de su experiencia cotidiana, no en espacios políticos ni académicos:

Yo estoy acostumbrado a escuchar, porque vengo de la escuela de la vida. Sería incomprensible que al asumir esta investidura creyera ser el dueño de la verdad. La realidad del país la vamos a vivir y a resolver juntos. Quiero una vez más hacer mía la frase de San Agustín: "No busques qué dar; date a ti mismo". Este sabio pensamiento espiritual, que ha guiado constantemente mis acciones personales, hoy inspira el Proyecto Social del Gobierno (Saca, Discurso de toma de posición presidencial, 2004: 9).

Así afirma su entrega personal al proyecto mesiánico para el cual está llamado, primero a nivel estrictamente personal, después familiar y ahora político. Saca se presenta como el hombre que se dará a sí mismo, como lo haría un Mesías. Su capacidad alcanzaría no sólo para mejorar indicadores económicos y sociales, sino para crear un poder ejecutivo con aires de perfección democrática:

Yo quisiera, al final de un período presidencial, dejar mejor los indicadores no sólo económicos sino sociales del país [...] Será un estilo de gobierno cercano a la gente, integrador e integrado, transparente [...] intolerable con la corrupción, 
firme y trabajaremos arduamente por conseguir la plena vigencia del estado de derecho (Saca, Ofrezco un gobierno cercano, 2003: 8).

Sin embargo, el ser mesías también exige ser un hombre tan extraordinario y magnánimo que su conducta implica no guardar rencor, no aprovecharse del poder ni ser corrompido por éste. "Salvadoreños, amigos y compatriotas todos: soy Tony Saca su presidente, y seguiré siendo el mismo, porque el poder no me cambiará" (Saca, Discurso de toma de posesión presidencial, 2004: 11).

\section{Labestia}

En relación con el mito del mesías, se presenta a continuación la forma en que aparece en el discurso de los candidatos presidenciales, Hándal y Saca, el mito de la bestia, es decir, de la personificación que hace cada cual de su rival. En este caso, se toma como rival no sólo la persona contrincante, sino también el partido que representa. Para el caso de Hándal, la bestia es tanto Antonio Saca como ARENA; mientras que para Saca, la bestia es personificada por Schafik Hándal y su partido, el FMLN.

En el discurso de Hándal, su contrincante y el partido de éste fueron presentados como una bestia que no traería al país, a la nación salvadoreña ni a la patria ningún cambio beneficioso: "La dirigencia de ARENA y su candidato sólo pueden ofrecer más de lo mismo, y apuestan a dividir profundamente a la nación difundiendo temory aterrorizando, en vez de discutir los cambios que el país necesita con urgencia en un clima de altura y reflexión" (Hándal, 2008: 23).

Lo que Hándal argumentaba era que el cambio que beneficiaría al país sería el suyo y no el de ARENA, puesto que este partido representa todo lo negativo de la realidad política y social. En palabras de Hándal, ARENA había sido la culpable de una serie de males como los que se señalan:

Autoritarismo y cierre a toda concertación, pérdida acelerada de soberanía y autodeterminación nacional [...] con riesgos crecientes para la democracia y graves amenazas de padecimiento aún mayores por la fanática persistencia en este modelo neoliberal fundamentalista del pequeño grupo de dueños del país, del partido ARENA, del gobierno y de los principales medios de comunicación, que se han enriquecido de manera insaciable con esta tragedia del pueblo salvadoreño y que ahora ciegos por el dogmatismo neoliberal, se aferran a un extremismo desesperado y amedrentador para evitar el cambio que ya no puede ser impedido (Hándal, 2008: 22).

ARENA y Saca, representados en la bestia que maltrata y que se aprovecha de la población, en la lógica discursiva de Hándal, son los culpables de todo aquello que afecta al país: la 
corrupción, la pobreza, la falta de espacios democráticos, la desigualdad social y económica y el ataque a la soberanía nacional. Tal fue la perspectiva que hizo de ARENA y su candidato, que los llegó a tildar de antipatriotas: "iTodos tienen espacio en este gran cambio que hemos proclamado! iSólo los corruptos y los antipatriotas no caben en este gran abrazo de unidad de la nación salvadoreña!" (Hándal, 2008: 149-150).

Por su parte, el candidato del partido de derecha hizo constantemente señalamientos a Hándal y al FMLN caracterizándoles implícitamente de ser una bestia amenazante de la nación salvadoreña. En clara alusión a sus contrincantes, afirmó:

Hay múltiples amenazas a nuestra estabilidad y a nuestro modelo democrático de vida; sin embargo, la convicción ciudadana es el mejor escudo frente a cualquier intento de regresión... Nuestro pueblo reconoce la lucha de ARENA para superar los tiempos oscuros del populismo y la guerra [...] Desde que los salvadoreños logramos resolver de una manera pacífica y ejemplar un conflicto armado tan destructivo como el que sufrimos por más de una década, El Salvador ha afianzado el camino hacia la democracia plena (Saca, Discurso de toma de posesión presidencial, 2004: 2).

Finalmente, el gran problema que Saca señaló del FMLN y su candidato fue la falta de claridad, credibilidad y consistencia del proyecto político que abanderaban. De ahí que, contra el peligro que representa la bestia, Saca aseveró tener la solución: "Esto quiere decir reglas claras del juego, con un gobierno que sea absolutamente claro, con un gobierno que genere credibilidad al país; con un gobierno que sepa a dónde llevar al país y que no inventemos en el camino" (Saca, Foro Presidencial, 2003).

\section{Lapeste}

Estrechamente relacionado con el mito anterior, aparece este cuarto mito. ¿Qué se quiere expresar con ello en el lenguaje de los candidatos? Simboliza precisamente el proyecto político que tiene la bestia - el partido político contrario por antonomasia y su candidato presidencial— para la nación. Para Hándal, la peste es el neoliberalismo impulsado por ARENA, y para Saca, la peste es el socialismo o comunismo del FMLN.

Hándal afirmó que la peste traída por ARENA al pueblo salvadoreño tiene un nombre específico: "El FMLN previó y dijo claramente desde el comienzo de la aplicación del modelo neoliberal que traería consecuencias nefastas" (Hándal, 2008: 23). En los siguientes párrafos se describe esto con detalles:

Nos trajo estancamiento, desempleo, incremento de la emigración, más delincuencia, desborde de la corrupción, destrucción del medio ambiente, deterioro profundo de la salud de la población, fracaso del sistema educativo, y frustración masiva de la 
juventud que aún no ve espacios en el presente ni encuentra con certeza su lugar en el porvenir en suelo patrio (Hándal, 2008: 22).

Para culminar la representación de la peste, Hándal planteó dónde está la causa de todos esos males que padece El Salvador: la ambición de poder y de dinero. Esa lógica de acumulación es la que estaría de fondo en el neoliberalismo:

Nuestros ríos están contaminados, nuestro aire está viciado, nuestros bosques están desapareciendo. Todo ello violenta la creación y atenta contra la vida y la dignidad del ser humano. El poder del dinero, y la ambición por acumular más y más riquezas, nos está llevando a la destrucción de nuestra tierra. El Salvador está postrado, golpeado, herido [...] sufre de enfermedad, de corrupción y violencia (Hándal, 2008: 122).

En contraste, para Saca la peste que trae el FMLN y su candidato atenta contra la democracia y la libertad de expresión, se trata de un ordenamiento político llamado socialismo o comunismo propio de aquellos países como Venezuela — en la actualidady Cuba, el país que por antonomasia representa ese modelo, que en la lógica discursiva de ARENA es incongruente con el sistema de libertades y la democracia que ellos ofrecen. Por ello, cada vez que Saca menciona ser alguien que defenderá la libertad de expresión y que no abrirá relaciones con Cuba, está de fondo la relación que hace entre el proyecto "comunista" del FMLN y todos los males de aquél país que ARENA le asocia: "Soy un hombre probado en el tema de la libertad de expresión. Yo creo que la libertad de expresión y la democracia son hermanas gemelas, nacen juntas, se desarrollan juntas, crecen juntas y hasta mueren juntas" (Saca, Foro Presidencial, 2003).

Asimismo, Saca acusó al proyecto efemelenista de ser una fantasía que se vende como la panacea a todos los males que se padecen, cuando en realidad se trata de todo lo contrario. En este sentido, el candidato de derecha aseveró: "no estamos inventando fórmulas, imaginados paraísos, ni ofreciendo magia. Venimos de la realidad, vivimos en ella, nos debemos a ella" (Saca, Discurso de toma de posesión presidencial, 2004: 6).

Por último, este candidato siempre relacionó el proyecto del FMLN con países llamados socialistas como China y Cuba: "A mí me parece que debemos apostarle a una estrecha relación con los Estados Unidos [...] Con Cuba no tendremos relaciones. Aspiramos tener relaciones con países democráticos" (Saca, 2003: 9). Así, Cuba representa el socialismo, la peste que trae consigo el FMLN, y Estados Unidos el sistema de libertades que ARENA promulga y defiende. 


\section{Horizonte utópico}

El cuarto mito utilizado en la campaña electoral es la respuesta al mito de la peste. Se trata del horizonte utópico, el ideal de sociedad que busca el candidato. Es el proyecto que encarna las soluciones que da el mesías a todos los problemas que aquejan al pueblo. En este apartado, los extractos seleccionados de los discursos expresan la utopía o ideal de nación que cada uno plantea.

Hándal visualiza a la nación de El Salvador de la siguiente manera: "El FMLN es ya el partido que une a la nación salvadoreña [...] Juntos, sin exclusión alguna, vamos a convertir El Salvador en una tierra de oportunidades, en un país con esperanza, donde se quiera y se pueda vivir" (Hándal, 2008: 149).

Como se vio arriba, a pesar de que en sus estatutos el FMLN afirma ser un partido que implantaría el socialismo, el candidato de este partido en esta campaña electoral afirmó que su meta inmediata era solucionar los problemas de la población: "No estamos hablando del socialismo ya, ni de expropiar la propiedad privada. Se trata de enfrentar las dificultades que agobian a la población" (Hándal, 2008: 176). Así cobra sentido el matiz que le puso al horizonte utópico sobre la abolición del sistema capitalista, ya que de lo que se trata es de "la abolición del capitalismo neoliberal dentro de nuestro país" (Hándal, 2008: 174).

La meta es entonces lograr un país en donde sea posible desarrollar una vida digna, con trabajo, oportunidades y seguridad. Según él, esa meta se puede lograr gobernando bajo los parámetros establecidos en la Constitución de la República, en donde no se establece un sistema socialista o comunista, sino un ordenamiento político más bien liberal:

Para el cambio no hace falta traer e implantar otro modelo extranjero, de ningún otro país, tenemos un modelo de Estado, de país y de sociedad definido por la Constitución de la República (Hándal, 2008: 23).

Nadie perderá su empleo, ningún riesgo se cernirá sobre las familias, las propiedades o las empresas. Las reglas de mi gobierno serán claras, ya están escritas en la Constitución y en las leyes de la República (Hándal, 2008: 157).

En relación con la idea anterior, aparece otro componente medular en el horizonte utópico de este candidato: el vivir en democracia.

El principal logro de los Acuerdos de Paz, que fue el inicio de un proceso de democratización que no ha llegado a la profundidad que debe llegar y que se ha quedado en un simple ejemplo de participar en elecciones cada cierto tiempo, que 
no satisface a la mayoría de la población, a la mayoría de la ciudadanía y se expresa eso en que se abstiene la mayoría; debe profundizarse en el proceso democrático; debellevarse democracia participativa, mejor dicho, de representativa a participativa en todos los niveles, y si llega, esa será la fuente del progreso del país (Hándal, Foro Presidencial, 2003).

En el horizonte utópico planteado por el candidato de ARENA, el punto de partida fue hacer énfasis en lo que habrían logrado los tres presidentes anteriores de ese partido:

Yo voy a construir sobre lo que ya se ha construido, yo voy a construir sobre lo que ya se ha logrado. La historia del país de los últimos 15 años nos ha generado un país inmensamente mejor al país que teníamos antes de las destrucciones. Tenemos un país con mayor institucionalidad, tenemos un país con apertura, tenemos un país en donde hay avances sustantivos en la salud, donde hay avances sustantivos en la reforma educativa (Saca, Foro Presidencial, 2003).

Pese a esta exaltación de lo realizado en los tres períodos presidenciales de ARENA anteriores a Saca, donde pareciera que en el país casi se habían eliminado todos los problemas que padece la sociedad, el candidato no dejó de lado presentar en su campaña lo que esperaba conseguir con sus acciones desde la presidencia. De ahí que para Saca la búsqueda del bienestar de toda la población, o bien común, fuera una idea recurrente en su campaña: "Anhelamos una sociedad unida, tejido social intacto, una población integrada y un gobierno integrados. Humano por la solidaridad y la subsidiaridad del Estado, creando un país de oportunidades donde el progreso es riqueza, y la equidad es igualdad de oportunidades" (Saca, Ofrezco un gobierno cercano, 2003: 8).

A la par de esas condiciones ideales para la sociedad salvadoreña, Saca prometió ser un ejecutivo con profundo sentido humano y que lo social estaría en la base de todas las acciones por tomar: "Lo social no es un complemento de nada, sino la base de todo [...] Seremos un gobierno, ante todo, con un profundo sentido humano" (Saca, Discurso de toma deposesión presidencial, 2004: 4).

Por último, en ese horizonte utópico no podía faltar la idea de profundizar la democracia. Pareció hacer una crítica a la democracia representativa y decantarse por una democracia más participativa, como se lee en las siguientes líneas:

El pueblo tiene el poder; nosotros sólo somos sus representantes. En esa línea, con la participación de las distintas fuerzas del país, nuestro Gobierno impulsará un Acuerdo Nacional que habrá de buscar, entre otras cosas, una inaplazable Reforma del Estado que nos lleve a una profunda Reforma Electoral cuyo objetivo será fortalecer nuestra democracia (Saca, Discurso de toma de posesión presidencial, 2004: 9). 
En la medida en que hizo énfasis en la idea de fortalecer la democracia, dio a entender que no basta con las elecciones y la representatividad para hablar de esa forma de gobierno en sentido estricto.

\section{Elpueblo}

El último de los mitos con el que se cierra este análisis del discurso de los candidatos presidenciales es una especie de síntesis de los cuatro anteriores. Por el pueblo, el mesías se entrega a la lucha, le salva de la peste que trae la bestia y trabaja por el horizonte utópico, todo en beneficio de lo que llaman "el pueblo". Tanto Hándal como Saca no precisan a qué se refieren con ese concepto:

Ver a nuestro pueblo sumido en la pobreza y la desesperanza, agobiado por el hambre, las enfermedades, la precariedad de sus viviendas, el abandono frente a los embates de la naturaleza [...] Si hay unarazón por la que decidíaceptarel compromiso de ser candidato del Frente, es porque quiero ver a mi pueblo libre de la esclavitud y el ultraje que significa la pobreza y la miseria (Hándal, La ruta de la esperanza, 2008: 152).

Las palabras anteriores pertenecen al discurso de Hándal. Las que siguen pertenecen al candidato presidencial de ARENA. La lógica es la misma al hablar de pueblo: "El pueblo salvadoreño, al que nos debemos, nos verá actuar, y juzgará la transparencia de nuestras acciones. Si alguna cosa no camina por falta de entendimiento, ese mismo pueblo sabrá donde están los obstáculos" (Saca, Discurso de toma de posesión presidencial, 2004: 4).

El tono melodramático utilizado por Hándal para referirse a los males de lo que llama el pueblo es compartido por Saca, cuando habla del pueblo salvadoreño: "Mi gobierno siempre estará con los salvadoreños, allí donde ellos sufren, allí donde ellos necesitan sentir que alguien comprende sus adversidades y sus necesidades. Y también donde ellos sueñan y confían en una vida mejor" (Saca, Discurso de toma de posesión presidencial, 2004: 9).

Como se vio más arriba, cuando ambos candidatos se presentaron como mesías, el telón de fondo fue este último mito. Las palabras pronunciadas por Hándal expresan una idea que fue compartida con Saca: "al pueblo salvadoreño que nos escucha y que es la razón de nuestro trabajo y nuestra lucha diaria" (Saca, Discurso de tomadeposesión presidencial, 2004: 22). Finalmente, la promesa hecha por Hándal contiene la esencia de este mito: "trabajar sin descanso por los intereses del pueblo" (Hándal, La ruta de la esperanza, 2008: 149). La pregunta no respondida por ambos candidatos fue: iquién es el pueblo? isólo los pobres? Quedó en la ambigüedad la referencia a lo que cada cual llamó el "pueblo" o, como aparece en los estatutos de ambos partidos, el verdadero pueblo salvadoreño. 
Con todo lo expuesto se puede concluir de esta campaña electoral que, pese a las diferencias obvias entre los dos candidatos, Saca considerado de derecha y Hándal de izquierda, los dos coinciden en la idea de nación expresada en sus discursos de campaña electoral, una idea similar en ambas lógicas discursivas. Ambos hacen un diagnóstico de la nación salvadoreña catalogándola de estar en una situación dramática y, por eso mismo, necesitada de la acción política de un personaje y de su proyecto para transformar esa realidad indeseada; todo ello sin profundizar en las causas y soluciones viables o efectivas de las problemáticas sociales.

En complemento con el diagnóstico, ambos candidatos plantearon una utopía de país, en el que se podrá vivir sin ninguno de los males que lo aquejan en la actualidad, siempre y cuando se elija al candidato adecuado.

\section{La campaña de 2009}

Después de muchos rumores, se confirmó que el periodista Mauricio Funes sería el candidato presidencial del partido de izquierda en El Salvador. Su proclamación fue considerablemente más anticipada a las hechas por ambos partidos en las elecciones de 2004. Fue el 11 de noviembre de 2007, a dieciséis meses para las votaciones, cuando el FMLN hizo oficial el nombramiento de Funes como su candidato presidencial. En el partido ARENA, después de unas elecciones internas conflictivas, salió proclamado como candidato presidencial Rodrigo Ávila, el 15 de marzo de 2008.

En esta ocasión, quien salió ganador de los comicios fue el candidato efemelenista con el 51.32\% contra el 48.68\% del candidato arenero Rodrigo Ávila. A diferencia de las elecciones de 2004, sólo estuvieron en competencia ARENA y el FMLN, después de que los otros partidos de menor tamaño decidieran no participar.

En la lógica planteada por González para analizar estos resultados, se puede afirmar que en estas últimas elecciones el FMLN leyó mejor el imaginario político salvadoreño al poner a un candidato que supo manejarse frente a los medios y frente a la ciudadanía durante toda la campaña. Aunque, señala González, esta campaña tuvo una peculiaridad:

Ambos partidos políticos en contienda generaron una campaña publicitaria de emblemas y heráldicas mitológicas, aludiendo a la imagen de la tierra prometida, la Biblia, los valores éticos y morales y los símbolos patrios como forma de señalar los pilares fundamentales sobre los que se basa la propuesta política de las instituciones que representan (González, 2009: 379).

La estrategia de la campaña electoral del partido ganador llegó esta vez al grado de presentar a su candidato como una especie de guerrero o de héroe medieval. Una figura muy capaz de seducir a un electorado con un tipo de imaginario social salvadoreño: 
"Mauricio Funes adquirió la personificación del guerrero monarca, justo, que en lugar del cetro y el orbe sostenía la constitución y la pluma, amparados por la fe y defendiendo la nación, por ende, dispuesto a la batalla" (González, 2009: 377).

La conclusión para ambas campañas, a la luz de los resultados, es que triunfa aquel partido que mejor conecta sus discursos y su campaña mediática. Así, quedarían relegados a un segundo plano el contenido de los programas de gobierno y la posición ideológica en sentido estricto, es decir, en coherencia con el ideario de los estatutos. De esta manera también quedó relegada la fidelidad a sus propios estatutos. Lo importante fue convencer al electorado de que votasen por el candidato elegido por el partido político y no por el contrario.

\section{El mesías}

La narrativa utilizada en la campaña de 2009 coincide con la ejecutada en la campaña electoral de 2004. De ahí que nuevamente se expongan a continuación los cinco mitos utilizados para analizar los discursos de Schafik Hándal y Antonio Saca; ahora para examinar los discursos de Rodrigo Ávila (ARENA) y Mauricio Funes (FMLN).

La historia personal. Se inicia este apartado con las palabras del candidato arenero en las que menciona su experiencia académica y laboral, que colocaría al servicio de los problemas que aquejan a la población:

Por más de quince años he luchado incansablemente contra flagelos que han sacudido nuestro país, contra la delincuencia, contra el narcotráfico, contra el secuestro, contra las pandillas criminales, y hoy hermanos y hermanas de ARENA, hermanos y hermanas de El Salvador me comprometo ante ustedes, ante toda la nación que como presidente seguiré luchando con la misma energía contra la pobreza, contra la exclusión (Ávila, Discurso en la “Cruzada por El Salvador”, 2008: 5).

La misma lógica discursiva de Ávila la expresó Mauricio Funes, al hablar de sí mismo y de su historia en los medios de comunicación:

La profesión periodística me dio la gran posibilidad de tomar contacto directo con la realidad salvadoreña. Vi, sin que nadie me lo cuente, el rostro dramático de un país sumido en el atraso, la injusticia, la exclusión y la pobreza [...] Después de esta toma de conciencia de la realidad, comprendí que no podía seguir siendo un mero espectador y un comentarista de este drama (Funes, 2008).

Aligual que Ávila, Hándal y Saca, Funes afirmó que ser candidato a la Presidencia significaba en su vida personal el momento culmen de todos los retos a los cuales se ha enfrentado: 
Tengo 48 años de edad y en toda mi vida he debido enfrentar diferentes retos y desafíos, pero ninguno de ellos me provoca tanta responsabilidad y devoción como el formar parte del equipo de hombres y mujeres que hará posible una transformación sin precedentes de nuestro país (Funes, Discurso de Mauricio Funesen laXXIVConvención Nacional de FLML, 2008).

Ese reto y desafío, defendió Funes, lo llevó a dejar su cargo periodístico para inmiscuirse en el ámbito de la política, dejando atrás el hecho de ser un mero espectador y comentarista para convertirse en protagonista de los cambios que el país necesita.

Esta historia personal a la que hacen referencia los candidatos presidenciales se complementa con las alusiones a sus capacidades especiales para presentarse mesiánicamente para gobernar desde el Ejecutivo, como si fuese el centro único de poder político capaz de solucionar todos los males habidos y por haber.

Capacidad especial para gobernar. Ávila se autodefinió como parte de las personas nacionalistas puras, utilizando la frase textual de Roberto d'Aubuisson, líder mítico del partido de derecha, en las que se resalta su capacidad especial para entregarse a los demás:

A los nacionalistas puros que nunca buscan elogios, que saben que es mejor dar que recibir, a los que en su vida tienen como abogados al señor y después como juez al tiempo, a los que aman su patria y se entregan a defenderla. Es a la gente como ustedes y como yo que tenemos el deseo y voluntad de ayudarnos entre nosotros y construir un país más justo (Ávila, Discurso en la "Cruzada por El Salvador", 2008: 4).

Por su parte, el candidato del FMLN mencionó a lo largo de la campaña sus capacidades especiales para gobernar el país. En primer lugar, se hizo ver como una persona de carácter fuerte para enfrentarse a los desafíos que requiere ser presidente de la República: "Yo como presidente no seré títere de nadie ni de ninguna fuerza política o poder establecido. Mi compromiso con la verdad en mis años de ejercicio periodístico habla del talante que he debido forjar para enfrentar el poder" (Funes, Discurso de Mauricio Funes en la XXIII Convención Nacional del FMLN, 2007: 4).

Finalmente, con las siguientes palabras se refleja el deseo de un candidato mesiánico por transformar la realidad:

Quiero ser el líder de la paz, de la unión y del progreso. Quiero ser el líder de la justicia social. Quiero ser el líder de la verdadera reconstrucción del país... Si el camino fuese fácil nosotros no habríamos sido llamados. Nosotros fuimos llamados porque aquellos que estuvieron todos estos años en el poder ya no tenían más respuestas para nuestros problemas (Funes, Discurso de triunfo electoral, 2009). 
La meta por alcanzar sería hacer un nuevo El Salvador, que responda a los intereses de lo que llama Funes el pueblo y hacer hincapié en presentarse como ese mesías esperado para encarnar lo que la ciudadanía clama.

\section{Labestia}

En lo relativo a presentar al contrincante electoral de la peor manera posible, es decir, el mito de la bestia, no se debe perder de vista que no se ataca únicamente al candidato en sí, sino también al partido y a cualquier otra persona vinculada. En el caso de Ávila, la bestia es Funes y el FMLN. Para Funes, Ávila, ARENA y también Saca, en tanto que presidente de la República del partido de derecha, fueron colocados bajo esta figura.

Así pues, en el discurso electoral de Ávila, el FMLN y su candidato fueron tildados de mentirosos, haraganes y conflictivos, entre otros calificativos de esa índole. La argumentación para descalificar a sus adversarios giró en torno a la idea de que el llamado comunismo o socialismo es un mal en sí mismo:

Nadie puede esperar trabajo de los que nunca han trabajado. Nadie hermanos puede esperar amor de los que siempre han odiado. Pero más allá de lo que todos sabemos, porque todos sabemos lo que significan los comunistas, lo que está en juego en las próximas elecciones es la construcción de una nueva historia para nuestro país (Ávila, Discurso en la “Cruzada por El Salvador”, 2008: 1-2).

Como se vio antes, en el discurso de Ávila no faltó la vinculación entre el FMLN y los catalogados como "dictadores": Fidel Castro en Cuba y Hugo Chávez en Venezuela. En esta lógica derechista, el FMLN no sólo está relacionado con ese tipo de personajes, sino con terroristas. Por ello, su llamado fue a defender sobre todas las cosas la libertad, amenazada según él por los “comunistas” en su afán de llegar al poder:

La libertad es como el aire. Ahorita ustedes están respirando y sienten el aire en los pulmones. Pero antes que yo les dijera esto, ni cuenta se habían dado que estaban respirando. Lo hacían automáticamente. Igual es la libertad. La libertad es vida. Es algo precioso igual que el aire [...] Pero sólo aquellos pueblos que pierden la libertad, se dan cuenta de lo valioso que es tener libertad. En Venezuela hay un slogan que están manejando: "No sabíamos que éramos felices, nunca nos dimos cuenta que éramos dichosos". Porque hasta ahora que han perdido la libertad están añorando eso que tenían hace algún tiempo (Ávila, Discurso en sede departamental de ARENA, 2008). 
En similares términos a los de Ávila se expresó Funes para referirse a sus contrincantes electorales, con la diferencia de que, para el candidato de izquierda, la figura de la bestia se utilizó para referirse al partido ARENA, sus períodos presidenciales y su candidato de las elecciones presidenciales de 2009: "A los gobiernos de ARENA y a su candidato que ha fracasado, dos veces, como jefe de policía, se les debería caer la cara de vergüenza, que después de casi 20 años en el gobierno éste sea el único récord que han obtenido" (Funes, Discurso en la XXIV Convención Nacional del FMLN, 2008).

Para Funes, el fracaso de ARENA y su candidato en la lucha contra la delincuencia se debe a que tienen una mentalidad retrógrada y medieval, aunada a su malicia intrínseca delincuencial:

El Presidente y su gobierno juegan con las necesidades del pueblo [...] Sólo los que queremos un cambio estable en el país acabaremos con este problema. Siendo candidato, el Presidente Saca aseguró que durante su gobierno "a los malacates se les acabaría la fiesta”. No sólo no se les ha acabado la fiesta, la han trasladado a casa presidencial (Funes, Discurso en la XXIII Convención Nacional de FMLN, 2007).

Para terminar en la caracterización que hizo Funes sobre ARENA y su candidato, no podía dejar de lado el hecho de llamarles mentirosos. Expresó que ARENA sólo en las campañas habla de beneficiar al pueblo, pero ya en el poder se olvidan del mismo: ARENA acostumbra a "prometer en las campañas electorales para pedir el voto, pero una vez en el gobierno terminan dándole la espalda al pueblo" (Funes, Discurso en la XXIV Convención Nacional del FMLN, 2008).

Como se ve, ambos candidatos comparten la misma lógica discursiva a la hora de referirse al candidato contrincante debido a que cada cual busca hacer ver al otro como lo peor para el país.

\section{Lapeste}

En este tercer mito, Ávila y Funes se acusaron mutuamente de traer en el fondo miserias y toda una serie de males para El Salvador, es decir, se atacó el proyecto neoliberal en el candidato de derecha y el comunismo en el candidato del FMLN. Ávila consideró el comunismo y su variante, el socialismo del siglo XXI, como la peste traída por Funes, y éste a su vez habló del neoliberalismo y las medidas aplicadas por los presidentes de la República por parte de ARENA.

Al respecto, Ávila expresó que el FMLN ha sido el partido político representante en El Salvador del comunismo de la Guerra Fría, pero que en la actualidad es el partido que defiende e impulsa el llamado socialismo del siglo XXI, iniciado en Venezuela con el presidente Hugo Chávez. Ésa es la peste que habría que atacar: "Estoy hablando de 
reimpulsar el proyecto histórico de ARENA, que nació como un partido que se enfrentó a la amenaza del comunismo y esa amenaza en otra dimensión siempre está latente por el socialismo del siglo XXI" (Ávila, Quiero una derecha más incluyente, 2008: 9).

¿En qué consiste para El Salvador el socialismo del siglo XXI? En palabras de Ávila, consiste en una serie de problemas que a continuación detalla: "Una época de estatizaciones, control de precios, expropiaciones, atentados a la libertad de expresión, atentados a la libertad de cultos y todas esas ideas que empobrecen y que llevan a la miseria moral, a la miseria espiritual de los pueblos" (Ávila, Discurso en la "Cruzada por El Salvador", 2008: 2). De ahí que el llamado que hizo a su militancia y a la población votante fue a no elegir el proyecto efemelenista porque traería todos los males que pudieran existir. Ese llamado lo centró a partir de la idea de defender la libertad, no coexistente con el socialismo del siglo XXI ni con el comunismo, según este candidato.

¿Cómo se identifica el mito de la peste en Funes? Con el diagnóstico que presentó en algunos de sus discursos y que se presenta en las líneas que siguen. En primer lugar, destaca del siguiente párrafo el problema de la migración ilegal hacia Estados Unidos y el problema de la inseguridad pública:

Cada día se ven forzadas a salir del país entre 400 a 500 personas en busca de mejores oportunidades de empleo y mejores ingresos [...] El mes pasado cerró con una tasa promedio de 10 homicidios por día [...] Para las autoridades de seguridad pública el que hoy se cometan dos o tres asesinatos menos al día de los que se cometían hace tres años es un éxito. Para los y las salvadoreñas, sólo cuando nuestros hijos puedan vivir con seguridad, sólo cuando podamos salir a nuestros trabajos o regresar de ellos sin el temor de ser asesinados, sólo cuando dejemos de vivir en la zozobra diaria de que algo nos pueda ocurrir, entonces podremos hablar de que las políticas de combate a la delincuencia están dando resultados (Funes, Discurso en la XXIII Convención Nacional del FMLN, 2007: 2).

Para seguir caracterizando la peste que ha traído ARENA, Funes señaló otro problema relacionado con la migración: el desempleo. Este mal es tan grande que causa dolor en todo el círculo familiar:

Pude ver el dolor en las madres, los padres, las hermanas y hermanos de las víctimas de la violencia que padecemos. He percibido el drama familiar que viven miles de mujeres que quedan solas con sus hijos tratando de sobrevivir, mientras su compañero de vida arriesga la vida para tratar de irse a Estados Unidos a buscar el trabajo y el salario que aquí se le niega. He visto de cerca las angustias y miserias que produce el desempleo y la falta de un trabajo decente (Funes, Discurso en la XXIV Convención Nacional del FMLN, 2008). 
Esas desatinadas decisiones gubernamentales del pasado aluden a lo realizado desde el Ejecutivo dirigido por ARENA, enmarcadas dentro de una estrategia económica de "corte neoliberal que no ha producido el bienestar y el crecimiento prometido" (Funes, Discurso en laXXIV Convención Nacional del FMLN, 2008).

\section{Horizonte utópico}

Como se ha señalado arriba, este cuarto mito se utiliza para identificar en el planteamiento de los candidatos presidenciales aquí estudiados su ideal de sociedad. Es la promesa que hace el mesías como respuesta ante la peste que trae la bestia. Este ideal de sociedad, a fin de cuentas, terminaría por favorecer al pueblo, por el cual el mesías hace el sacrificio de luchar desde el Ejecutivo.

El discurso electoral de Ávila tuvo como eje la promesa de hacer un país más justo, en donde fuera posible el progreso individual y colectivo. A continuación se plantean otros elementos que desglosan la promesa arenera:

Un país más justo que es la casa de todos, un país más justo donde nadie se sirve con la cuchara más grande, un país más justo es donde el éxito no se acapara ni es motivo de envidia, sino una posibilidad real para todo salvadoreño que se esfuerce y trabaje [...] rechazamos la idolatría al mercado [...] rechazamos el culto al individualismo [...] rechazamos la malsana ambición por acumular posesiones y la obsesión materialista. Creemos en las oportunidades de un mundo globalizado, pero por encima de ello están los intereses de esta tierra, que es nuestra patria y que se llama El Salvador (Ávila, Mensaje del candidato a la Presidencia de la República por ARENA, 2008).

En este ideal de sociedad que buscaría Ávila se podría decir que dos elementos desentonan con claridad de los estatutos de ARENA y de lo expresado por Saca anteriormente: primero, el hecho de hablar de un sistema económico que no deje funcionar al mercado en libertad total sin la intervención del Estado - aparentemente se trata de una crítica al neoliberalismo-; y otro, el rechazo al llamado individualismo, que en principio plantea la búsqueda de bienestar y el progreso individual sin importar la situación de otras personas. Los demás aspectos mencionados están en sintonía con la promesa de hacer del país un paraíso para la población o el pueblo.

Finalmente, dentro de este horizonte utópico no podía faltar la mención sobre la democracia: "Aspiramos a un país siempre en paz y con seguridad ciudadana. Un país democrático [con un estilo de] gobierno abierto al diálogo, a la búsqueda de consensos y de amplia participación ciudadana y política por medio de las organizaciones de la sociedad civil" (Ávila, Programa de gobierno ciudadano 2009-2014 "País más justo", 2009). 
Para Funes, al igual que para Hándal, la meta no es hacer de El Salvador un país socialista o comunista, sino resolver todos los problemas del pueblo:

Se equivocan quienes aseguran que por construir estas relaciones internacionales acabaremos copiando modelos de otros países. El modelo de gestión económica, política y social que implementaremos responderá a las necesidades de los y las salvadoreñas, buscará una relación armoniosa con el medio ambiente, protegerá los escasos recursos naturales con los que aún contamos, hará posible el surgimiento de una sociedad justa y solidaria, que priorice los programas de beneficio y protección de la niñez y la juventud, y que potencie el papel de la mujer en el desarrollo (Funes, Discurso en la XXIII Convención Nacional del FMLN, 2007: 5).

No es el debate entre capitalismo o socialismo el que debe ocupar nuestras energías, el debate actual sobre el que deberán elegir los salvadoreños es entre democracia o autoritarismo, entre cambio o continuismo, entre pasado o futuro. Lo que buscamos es construir un país próspero, altamente educado, libre de pobreza, de exclusión, de discriminación de género. Un país justo y seguro, equitativo, solidario y en democracia (Funes, Discurso de Mauricio Funes en la XXIV Convención Nacional del FMLN, 2008).

No tomar postura por el socialismo alejó a Funes de los estatutos de su partido político, que plantea ser un partido socialista que busca construir desde el triunfo en elecciones el camino hacia ese sistema en aras de eliminar el capitalismo. No obstante, en su ideal de sociedad, la democracia es el elemento infaltable para asegurar todos los demás beneficios que de ella se desprenderían: la paz, la seguridad pública y social, el progreso, el respeto por los derechos humanos y la estabilidad económica y política, pero sin asociar estos elementos con un régimen de tipo capitalista o socialista.

\section{Elpueblo}

La constante mención de la palabra pueblo en los diferentes discursos de los candidatos presidenciales se coloca como el último de los mitos utilizados en el imaginario político salvadoreño. La ambigüedad y falta de precisión en torno a este concepto en los discursos electorales presidenciales hace que cada cual lo mencione como el destinatario de los beneficios - horizonte utópico - del sacrificio hecho por el mesías al cuidarlo de la bestia y su peste.

Ávila identificó el triunfo de ARENA con el triunfo del pueblo. A su vez, parece que en su concepción el pueblo son los pobres: 
Vamos a ganar más alcaldes, más diputados y la Presidencia de la República. Hacia la victoria vamos con todo. Una vez más ganará el pueblo salvadoreño [...] Ha llegado el momento de reimpulsar el proyecto histórico de ARENA, para convertir la paz política en paz social, para dinamizar el progreso a favor de las necesidades sentidas de los más pobres (Ávila, Mensaje del candidato a la Presidencia de la República por ARENA, 2008).

Para este candidato, su partido tiene en su esencia una opción por ayudar a los pobres en sus problemas. Él se enmarca en esa lucha por hacer que ARENA y su proyecto no pierdan ese rumbo hacia el pueblo o los pobres:

Es momento de que el partido puede aterrizar en lo que siempre fue, una derecha popular, orientada a atender los problemas de los más pobres del país, que tenga puesto su enfoque en lo social, porque a veces siento que en los partidos la preocupación más grande es ganar elecciones (Ávila, Quiero una derecha más incluyente, 2008: 9).

Cuando se refirió al pueblo, Funes utilizó este tipo de expresiones: pueblo de mi patria, pueblo salvadoreño y pueblo empobrecido, por lo que algunas veces pareció que entendería por pueblo lo referido a la población pobre: "En mi gobierno los únicos privilegiados serán los más vulnerables, los que viven en situación de indefinición, lo que nuestro Obispo Mártir, Monseñor Oscar Arnulfo Romero, buscó a través de su apostolado" (Funes, Mensaje con motivo de su afiliación al FMLN, 2008).

El pueblo o los pobres, que al parecer serían la mayoría de la población salvadoreña, son quienes habrían puesto el mandato de un cambio de gobierno dirigido por Funes: "Estamos cumpliendo con el mandato del pueblo de ponernos al frente de este proceso de cambio que ya está en marcha y que es irreversible" (Funes, Mensaje con motivo de su afiliación al FMLN, 2008). Sin embargo, en otro discurso pareció extender el concepto pueblo a todas las personas que viven en el territorio nacional o que, aunque vivan fuera, son parte de esta comunidad política llamada nación salvadoreña:

Saludo a esa fuerte y hermosa esperanza que es el pueblo salvadoreño, a ese gran número de mujeres, hombres, niños y niñas que viven en el territorio nacional y fuera del mismo y que diariamente inspiran nuestra convicción por construir la patria de todos y de todas (Funes, Discurso de Mauricio Funes en la XXIV Convención Nacional del FMLN, 2008).

En síntesis, sobre este mito, en las campañas electorales de 2004 y 2009, los dos partidos políticos que se disputaron la presidencia de la República apelaron constantemente a que 
trabajarían por favorecer con todas sus medidas al pueblo, sin especificar qué se debe entender por pueblo o quiénes son las personas que en verdad lo conforman.

\section{Conclusiones}

Con esta revisión de algunos discursos de cuatro candidatos en elecciones presidenciales en El Salvador, queda evidenciada, a mi juicio, la fuerte relación que existe entre aspectos considerados puramente religiosos con otros de carácter político y cómo los partidos políticos, conscientes o no de ello, pretenden jugar mediáticamente con las creencias de fe muy arraigadas en el modo de ser de la sociedad salvadoreña.

La figura central de estos mitos es el mesías, que simboliza el ciudadano candidato a la presidencia. Básicamente, las dos grandes características que se le adjudican son: primera, posee una historia personal que evidencia la capacidad de enfrentar y superar problemas de todo tipo a lo largo de su vida. Esto garantiza que, de igual forma, superará los problemas que encuentre desde la conducción del Estado. Bajo esta característica fundamental se enmarcan las siguientes: experiencia de movilidad social en sentido ascendente, experiencia laboral que permite al candidato vivenciar los problemas y dificultades que enfrenta la mayoría de la ciudadanía, con lo cual logra un conocimiento pleno de lo que habría que solucionar desde el Estado, y una vida intachable en su comportamiento ético.

La otra gran característica adjudicada a la figura mesiánica es su capacidad especial para gobernar que no tiene cualquier otro ciudadano. En ella se enmarca que el candidato debe ser concertador, dialogador, con profundo espíritu democrático, con una sensibilidad especial ante el dolor humano, respetuoso de las leyes de la República, honesto, con carácter fuerte ante la corrupción y los malos ciudadanos, autónomo, tolerante con las creencias religiosas y, sobre todo, capaz de solucionar todo tipo de problemas, como si éstos se pudieran resolver con una varita mágica y no con una transformación que implica la acción de otras instituciones estatales que no se circunscriben al Ejecutivo.

Con todo, este ejercicio de análisis refleja, por un lado, que los mitos no han desaparecido del mundo actual, aunque permanecen de forma más sutil y compleja que en el pasado; por esto mismo, las ciencias sociales tienen en su estudio un desafío ineludible. Y, por otro lado, se evidencia un fenómeno típico de la cultura política salvadoreña: aún existen elementos de carácter religioso en las prácticas e imaginarios sociales sobre el quehacer político. Así pues, el ideal secular de separar tajantemente a la Iglesia y a la religión del Estado aún está lejano de esta realidad. 


\section{Referencias bibliográficas}

Ávila, R. (13 de julio de 2008). Discurso enla “Cruzadapor El Salvador". San Salvador: Instituto de Formación Política Mayor Roberto d'Aubuisson.

Ávila, R. (9 de junio de 2008). Discurso en sede departamental de Arena. San Salvador.

Ávila, R. (2008). "Mensaje de Rodrigo Ávila, candidato a la Presidencia de la República por ARENA". En La Prensa Gráfica, 17 de marzo, El Salvador, p. 27.

Ávila, R. (2008). "Quiero una derecha más incluyente". En La Prensa Gráfica, 17 de marzo, El Salvador, p. 9.

Ávila, R. (15 de marzo de 2009). Discurso Ing. Rodrigo Ávila. San Salvador: Instituto de Formación Política Mayor Roberto d'Aubuisson.

Ávila, R. (2009). Programa de gobierno ciudadano 2009-2014 "País más justo". San Salvador: ARENA.

Bonazi, T. (2005). "Mito político". En N. Bobbio, N. Matteucci y G. Pasquino (eds.), Diccionario de política. México: Siglo XXI. pp. 976-985.

Castoriadis, C. (2005). Los dominios del hombre. Barcelona: Gedisa.

Consejo Central de Elecciones (1982). Elecciones marzo 1982. San Salvador: Secretaría de Información de la Presidencia de la República.

Funes, M. (ll de noviembre de 2007). Discurso de Mauricio Funes en la XXIII Convención Nacional del FMLN. San Salvador: Departamento de Prensa del FMLN.

Funes, M. (17 de agosto de 2008). "Discurso de Mauricio Funes en la XXIV Convención Nacional del FMLN". En sitio web oficial del FMLN. Disponible en: http://fmln.org. sv/detalle.php?action=fullnews\&id=48 (consultado el 12 de abril de 2010).

Funes, M. (27 de agosto de 2008). "Mensaje de Mauricio Funes con motivo de su afiliación al FMLN". En sitio web oficial del FMLN. Disponible en: http://fmln.org.sv/detalle. php?action=fullnews\&eid=48 (consultado el 12 de abril de 2010).

Funes, M. (17 de marzo de 2009). "Discurso de triunfo electoral". En sitio web oficial del FMLN. Disponible en: http://fmln.org.sv/detalle.php?action=fullnews\&id=243 (consultado el 12 de abril de 2010).

González, J.M. (2004). "El mito de una campaña de altura: estudio de la propaganda proselitista de la campaña electoral de 2004". En Estudios Centroamericanos, año 59, núm. 667, mayo, pp. 407-417.

González, J.M. (2009). "El imaginario medieval de la política salvadoreña. Estudio iconológico e iconográfico de la campaña proselitista de ARENA y el FMLN en la campaña electoral de 2009". En Revista Realidad, núm. 120, abril-junio, pp. 373-387.

Guzmán, N. (2009). "La reproducción del discurso de ARENA en la prensa escrita y en la publicidad en el período electoral presidencial 2009". En Revista Realidad, núm. 120, abril-junio, pp. 357-371. 
Hándal, S. (2003). "El pueblo salvadoreño, cuando se decide, puede". En El Diario de Hoy, 23 de noviembre, El Salvador, p. 10.

Hándal, S. (16 de diciembre de 2003). "Foro Presidencial". En LaPrensa Gráfica. Disponible en: http://archive.laprensa.com.sv/especiales/2004/elecciones/foroslpg/20031216foro presidencial.pdf (consultado el 10 de enero de 2011).

Hándal, S. (2003). "Queremos un país exportador". En El Diario de Hoy, 24 de noviembre, El Salvador, p. 12.

Hándal, S. (2008). La ruta de la esperanza. San Salvador: Instituto Schafik Hándal.

Rincón, O. (2008). Los telepresidentes: cerca del pueblo lejos de la democracia. Bogotá: Centro de Competencia en Comunicación para América Latina Friedrich Ebert Stiftug.

Saca, A. (2003)." El vicepresidente debe ser clave en el gabinete". En LaPrensa Gráfica, 14 de julio, El Salvador, p. 6.

Saca, A. (16 de diciembre de 2003). "Foro Presidencial". En La Prensa Gráfica. Disponible en: http://archive.laprensa.com.sv/especiales/2004/elecciones/foroslpg/20031216foro presidencial.pdf (consultado el 10 de enero de 2011).

Saca, A. (2003). "He triunfado en El Salvador". En El Diario de Hoy, 15 de julio, El Salvador, p. 10.

Saca, A. (2003). "Ofrezco un gobierno cercano". En El Diario de Hoy, 24 de noviembre, El Salvador, p. 8.

Saca, A. (1 de junio de 2004). Discurso de toma de posesión presidencial. San Salvador, El Salvador: Instituto de Formación Política Mayor Roberto d'Aubuisson. 


\title{
¿Extracciones y consultas? La minería y los derechos de los pueblos indígenas como un mentís de la democracia en Guatemala
}

\author{
Manuel Ignacio MartínezEspinoza
}

\section{Introducción ${ }^{1}$}

Las recientes denuncias sobre una red criminal de desfalco al erario público articulada desde el Poder Ejecutivo, las manifestaciones de protesta social multitudinarias y la dimisión y el procesamiento de altos funcionarios -incluidos el presidente Otto Pérez Molina y la vicepresidenta Roxana Baldetti- en el marco de un proceso electoral general con alta fragmentación partidaria ${ }^{2}$ ocurren en Guatemala, como argumenta Torres Rivas, a partir de una descomposición multilateral — política, social, cultural — que genera una profunda crisis de gobierno y de Estado que cuestiona la existencia de una democracia en el país centroamericano (Torres Rivas, 2015b).

Evidentemente, los sucesos recientes son factores que espolean los análisis sobre la democracia en Guatemala. Sin embargo, dada su inmediatez y espectacularidad, tales acontecimientos pueden propiciar sesgos cognitivos al confinar los debates a lo coyuntural, a lo político-institucional o a lo clasista — clase media urbana—, soslayando asíunaperspectivahistóricay, sobretodo, unenfoque holísticoqueintegrelamultiplicidad de ámbitos, actores, intereses, procesos e instituciones ${ }^{3}$ que conforman lo democrático.

\footnotetext{
${ }^{1}$ El autor agradece a la Dra. María del Carmen García Aguilar los comentarios realizados a una versión preliminar del presente texto, los cuales fueron un insumo relevante para precisar y profundizar críticamente el contenido del escrito. No está de más señalar que el resultado final es entera responsabilidad del autor.

2 Para revisar un recuento detallado de los sucesos de la crisis política en Guatemala, revísese http://www.plazapublica.com.gt/content/cronologia-de-la-indignacion-la-crisis-y-los-cambios (consultado el 4 de septiembre de 2015).

${ }^{3}$ Institución entendida no sólo como organización oficial, sino como el marco (formal o informal) que tiene la pretensión de regular las relaciones humanas, dando orden, estabilidad y certidumbre a la interacción de los actores mediante la creación de acciones pautadas y la determinación de las
} 
Enraizando su enfoque en el postulado anterior, en el presente texto se reflexiona en torno a la democracia en Guatemala. La pretensión es distinguir bases significativas que perfilen de forma determinante los rasgos de la democracia guatemalteca. Esto es: no una generalización del tipo de democracia, sino tan sólo fuerzas y procesos que influyen categóricamente en su caracterización. Para ello, se adopta un enfoque que concibe la democracia con tres fundamentos epistémicos: 1) que su ámbito de acción sobrepasa el del sistema político, 2) que, aunque tiene elementos hegemónicos fundantes, es más un proceso multifactorial y pluriespacial que un hecho consumado, y 3) que aunque la teoría política establezca directrices, incluso morales, la experiencia en el país debe evaluarse de forma situada e histórica.

De esta manera, la tesis que se argumentará en el presente texto es que la democracia en Guatemala está determinada por el enfrentamiento constante e irresuelto entre actores, instituciones, discursos y procesos contradictorios que se efectúa en el marco de un Estado que preserva su núcleo fundacional. Para ejemplificar tal argumento se analizará el caso de la minería y los derechos de los pueblos indígenas.

La exposición se desarrollará en cuatro apartados. En el primero, de corte conceptual, se estipularán lineamientos analíticos sobre la definición de democracia que permitan evaluar el término en la práctica. En el segundo apartado se indagará sobre los factores nodales que repercuten en el tipo de democracia en Guatemala. En el tercero, se examina el caso de la minería y los pueblos indígenas como un ejemplo indicativo del talante democrático en el país. Y, por último, en el cuarto apartado, se esbozan unas reflexiones finales a manera de cierre.

\section{¿De qué hablamos, cuando hablamos de democracia?}

Etimológicamente, democracia significa "poder del pueblo" (demos, pueblo, y kratos, poder). Tal raíz es determinante, pues si hay un eje común en la teoría política es que, al hablar de democracia, se aluda histórica, descriptiva - lo que es- y prescriptivamente - lo que debería ser - a una manera particular de conformar y ejercer el poder político:

Desde la época clásica hasta hoy el término ‘democracia’ siempre ha sido empleado para designar una de las formas de gobierno, o sea, una de las diversas maneras bajo las que puede ejercerse el poder político. Específicamente designa la forma de gobierno en la que el poder político es ejercido por el pueblo (Bobbio, 1999: 188).

oportunidades (a través de incentivos y castigos), construyéndose así expectativas, interpretaciones y preferencias. Esto es, las normas, valores y reglas en los ámbitos donde ocurra interacciones entre personas. Para análisis sobre el concepto de institución, véase North (1995), March y Olsen (1997) y Peters (2003). 
La tendencia en la teoría política, entonces, es la de circunscribir la democracia a una entidad política —-forma de Estado, forma de gobierno o régimen político— que, además, se estructura en torno a fundamentos normativos, teóricos y procedimentales concretos: los delliberalismo. Como afirma Giovanni Sartori: "hoy, democracia esliberal-democracia" (Sartori, 1992: 27).

La democracia como entidad política se establece en torno a un basamento toral: el poder del pueblo como principio constitutivo y fundamento de legitimidad de los procesos y entidades que afectan al poder político en su acceso o conformación y su ejercicio o desempeño. En ese sentido, lo contrario a la democracia será la autocracia o, lo que es lo mismo, la autoinvestidura (Sartori, 1992: 61).

Aun cuando existen numerosos modelos, ${ }^{4}$ en un tono general se puede plantear la existencia de tres grandes arquetipos de la democracia que responden a diversas teorías políticas: la democracia representativa, la democracia participativa y la democracia radical.

El modelo representativo de la democracia, que se sustenta en el liberalismo, es la forma generalizada que adoptan las democracias contemporáneas. Corresponde a lo que se ha nombrado como concepción hegemónica de la democracia (Avritzer y De Sousa, 2004) que, entre otras características, pone acento en el individualismo, entiende la libertad como no interferencia, valora positivamente la apatía política y se concentra en los diseños electorales. Autores característicos de ese modelo son Joseph Schumpeter, Samuel Huntington y Robert Dahl.

La democracia participativa, sustentada en teorías políticas republicanas y neorrepublicanas, tiene la intención de implicar más a los ciudadanos en los asuntos decisorios; es decir, se acerca más a una democracia directa. Sustentado en críticas a las deficiencias de la democracia representativa, este modelo de democracia concibe la libertad como no dominación y se funda en una participación constante de los miembros de la comunidad política, quienes deliberan sobre los asuntos públicos y deciden de forma consensual. Algunos autores básicos de este modelo de democracia son Carol Pateman, Crawford Macpherson y Jürgen Habermas.

Por último, en el modelo radical se expande la concepción de la democracia, de la circunscrita a una entidad política al resto de las relaciones humanas. Sustentada en corrientes de pensamiento sobre la autonomía, para la democracia radical la libertad se entiende como emancipación, la horizontalidad debe estar presente en la cotidianidad y el conflicto y la pluralidad se identifican como factores innatos de la democracia. Entre los autores que han articulado argumentos a favor de este enfoque están Chantal Mouffe, Ernesto Laclau y Jacques Rancière.

\footnotetext{
${ }^{4}$ Algunos autores que han elaborado modelos de democracia son: Held (1992), Lijphart (2000) y Macpherson (1987).
} 
Un plano relevante para la definición de democracia en este texto es un factor contextual: su aplicación en América Latina. Esto significa que esa democratización reiniciada en el subcontinente a partir de los años setenta del siglo pasado, a la par del agotamiento de los proyectos nacional-desarrollistas y del modelo burocrático autoritario, ${ }^{5}$ encarnó en su mayoría, y casi de forma exclusiva, la creación o reforma de instituciones garantes de un sistema electoral efectivo y de una competencia partidaria auténtica. A decir de Norbert Lechner, se optó por una definición mínima de democracia que configuró regímenes electorales con manejos tecnocráticos del poder político (Lechner, 1999).

Como se verifica incesantemente con el discurrir de los años, las democracias en América Latina no han desmontado totalmente los esquemas de dominación autoritarios ni han servido plenamente para coadyuvar al desarrollo socioeconómico de la población latinoamericana. Como se planteó en un relevante informe del Programa de las Naciones Unidas para el Desarrollo (PNUD, 2004), la democracia en América Latina tiene una peculiaridad compartida: elecciones efectivas con altos niveles de pobreza y desigualdad. O sea, que los sistemas latinoamericanos han avanzado en los derechos políticos, pero cuentan con niveles deficientes en los derechos civiles y sociales. A ese tipo de democracias en América Latina se las ha caracterizado como "democracias delegativas", 6 "democracias restringidas" o simplemente "democracias malas". ${ }^{8}$

No obstante, la democracia en América Latina, si bien cuenta con propiedades formales del modelo representativo - las cuales son mínimos irrenunciables en cuanto entidad política一, es un término que está en contienda por las lagunas de su ejercicio institucional y por las experiencias latinoamericanas de diversos espacios, actores y escalas que entrañan procesos democráticos más allá de la concepción hegemónica.

Recapitulando, en esta brevísima revisión conceptual sobre la democracia se han querido realzar tres argumentos: 1) que al definir la democracia se ha aludido comúnmente

\footnotetext{
${ }^{5}$ Proceso catalogado por Daniel Zovatto como "una transición doble: del autoritarismo a la democracia y de economías fuertemente intervenidas por el Estado y cerradas a economías abiertas y orientadas al mercado". Además, en algunos países, sobre todo los de Centroamérica, la transición también implicó pasar de la guerra a la paz (Zovatto, 2001: 143).

${ }^{6}$ El término "democracia delegativa" se refiere a regímenes que combinan situaciones democráticas con autoritarias; en concreto, regímenes con componentes caudillistas, plebiscitarios y no institucionales, donde el representante elegido asume un rol de "salvador de la patria" (O’Donnell, 1997).

${ }^{7}$ La acepción "democracias restringidas" se refiere a aquellas donde la autodeterminación colectiva se circunscribe a un mero mecanismo legitimatorio: se restringe al ámbito electoral para fortalecer al Poder Ejecutivo y que éste imponga los imperativos de la modernización económica (Lechner, 1999). ${ }^{8}$ Las democracias en América Latina, pero sobre todo en Centroamérica, han sido calificadas como democracias malas porque, al no resolver la pobreza y la desigualdad ni garantizar la seguridad personal, defraudan las esperanzas o llenan de incertidumbre a la gente (Torres Rivas, 2010).
} 
a una forma de conformación y ejercicio del poder político que tiene como condición sine qua non que el pueblo sea el protagonista —objeto y sujeto- de tal proceso; 2) que, aun cuando existen múltiples conceptualizaciones y tradiciones teóricas, existe una concepción hegemónica de la democracia proveniente del liberalismo que, a partir de concepciones normativas vinculadas al individualismo y al mercado, la reduce a un ámbito específico - el sistema político institucionalizado-y a un proceso concreto - el electoral- y 3) que en América Latina se institucionalizó una concepción mínima de democracia que ha ido mostrando sus vacíos, a saber, amén de los enclaves autoritarios, la pobreza, la desigualdad y la seguridad, pero, a la par, ha registrado experiencias de democratización que amplían la concepción hegemónica.

A pesar del historial analítico que la acompaña, de haber sido abordada por múltiples corrientes de pensamiento político, de admitir una concepción hegemónica y de contener un cúmulo de experiencias contextualizadas bajo su efigie -o precisamente por todo ello-, la democracia es un concepto en disputa expansiva e incesante. Ello es una característica que no debe verse como limitante, sino todo lo contrario, como una potencialidad, porque al ser un territorio de contestación perenne sobre su contenido y sus límites, el debate sobre la democracia "democratiza" el concepto.

Por lo anterior es que, antes de elegir una definición de trabajo que omita o limite la complejidad y las disputas teórico-empíricas que confluyen en torno al concepto, se ha optado por determinar líneas analíticas para enmarcar el examen a la democracia en Guatemala, lo cual se emprende a continuación, empezando por registrar sus directrices generales y continuando con el análisis del caso de la minería y los pueblos indígenas.

\section{El talante de la democracia en Guatemala}

Los cargos políticos en Guatemala, especialmente el de presidente de la República, se han renovado mediante elecciones desde 1985. Así, el recambio de dirigentes políticos en Guatemala se ha cumplido en los últimos treinta años mediante ocho procesos electorales — contando ya el de 2015-, en general legítimos, y no a través de golpes de Estado ni elecciones manifiestamente fraudulentas; ha sido éste, pues, el periodo más largo de su historia. Esto quiere decir que se ha cumplido con los cuatro atributos que las investigaciones politológicas contemporáneas han determinado como factores sine qua non de una democracia y su mínimo procedimental: elecciones libres, sufragio universal, participación abierta y libertades civiles (Collier y Levitsky, 1998).

A pesar de su relevancia — son mínimos irrenunciables en cuanto forma de gobierno-, tales criterios resultan insuficientes para definir Guatemala como una democracia de forma categórica, incluso desde la concepción hegemónica identificada en el apartado anterior, pues es imprescindible explorar a detalle los actores, instituciones y procesos políticos vinculados al sistema electoral. Por ejemplo, desde un punto de 
vista liberal sobre la democracia, Sonnleitner sostiene que la democracia guatemalteca enfrenta cuatro problemas estructurales: 1) la escasa inscripción y participación ciudadanas, que revelan los límites de la inclusión política; 2) la fragmentación de los actores colectivos y de los conflictos sociales, que se traduce en una fugaz polarización político ideológica de la ciudadanía y en la carencia de un polo de izquierda organizado; 3) las deficiencias, el descrédito y la débil — sino es que prácticamente inexistenteinstitucionalización del sistema de partidos políticos, así como 4) la preeminencia de los liderazgos personalizados y una curiosa continuidad de las dinámicas políticas a nivel local (Sonnleitner, 2009: 528).

Dada la falta de cumplimiento cabal de los atributos mínimos, y recuperando el posicionamiento del PNUD en el sentido de que la democracia en América Latina es una experiencia histórica particular en la región que debe ser entendida y evaluada en su especificidad (PNUD, 2004), en el análisis sobre los rasgos generales de la democracia en Guatemala es conveniente revisar estructuras y procesos más allá de los del sistema político y con un panorama histórico.

Para lo anterior, se adopta la premisa de que existen coyunturas críticas que son la génesis de instituciones que, aun con sus reformas posteriores, son susceptibles de seguir tendencias direccionadas desde esas coyunturas. En ese sentido, la hipótesis que se esgrime es que el carácter de la democracia contemporánea en Guatemala ha sido mediado por el proceso del cual emergió. ${ }^{9}$

¿Cuál es la etapa que identifica como de coyuntura significativa para el surgimiento de la democracia contemporánea en Guatemala? El período 1982-1986 (Sáenz de Tejada, 2013), o incluso desde 1978 (Villamizar, 2009), cuando la idea de liberalizar el régimen militar, hasta ese entonces vigente, comenzó a ganar mayores adeptos, lo que también se reflejó en la conformación de bases de institucionalidad - Constitución política, Leyes electoral y de partidos políticos, Corte de Constitucionalidad- que sustentaron la elección del civil Vinicio Cerezo Arévalo como presidente de Guatemala en 1985. Este

\footnotetext{
${ }^{9}$ Tal posicionamiento remite a la adopción de un enfoque de path dependence; que tradicionalmente se traduce como "dependencia del camino" y se entiende como que eventos pasados explican resultados presentes. Evidentemente, es un enfoque que se ha acusado de determinista y que, en el clásico antagonismo entre estructura versus agencia, o determinismo versus voluntarismo, se posiciona del lado de la estructura. De hecho, es un enfoque ya empleado para procesos contemporáneos de Centroamérica (Mahoney, 2001), y que ha sido criticado (Viales, 2007). Sin embargo, lo que en realidad se postula en este texto es una perspectiva de "dualidad de estructura" al estilo de Anthony Giddens, es decir, que los actores producen el sistema que les limita pero que no determina sus acciones. Con más concreción, se sigue la propuesta de Arrellano y Lepore (2009), donde el path dependence se traduce como patrón de dependencia y se define como una secuencia histórica en la que eventos iniciales ponen en movimiento distintos patrones institucionales que se reproducen a lo largo del tiempo, pero en donde los actores toman decisiones sopesando costos y beneficios pero enmarcados en dinámicas de poder - distribuidos inequitativamente- .
} 
hecho y la promulgación de una nueva constitución crearon, para Edelberto Torres Rivas, una situación democrática en la que se erosiona el poder autocrático y surgen posibilidades para la edificación de una democracia política (2004).

Las coyunturas significativas son factibles de generar instituciones relevantes, pero también de traslucir la confluencia de procesos que inciden determinantemente en los resultados emanados de tales coyunturas. ¿Qué proceso toral se evidencia en la coyuntura significativa de la democratización en Guatemala? ${ }^{10}$ La contingencia de la clase dominante por enfrentar una crisis de la matriz oligárquica y de legitimidad política producida, de forma interna, por el desgaste del poder autocrático y del conflicto armado, así como, de forma externa, por la reestructura mundial del capitalismo y el fin de la Guerra Fría."

Por ello, suscribiendo los postulados de Edelberto Torres Rivas, lo acontecido en Guatemala a partir de la década de 1980 no fue más que un cambio de régimen, que pasó de uno autoritario a uno democrático electoral. Este cambio de régimen político no implicó la restauración de una tradición interrumpida, sino una instauración o, en términos del autor, una "implantación"; es decir, la promoción y puesta en práctica de instituciones y procesos nuevos - los "demoliberales" - a una realidad que, dadas sus condiciones internas, no sólo no los rechazó, sino que facilitó su implementación (Torres Rivas, 2004). ${ }^{12}$

La implantación de la democracia en Guatemala aconteció en el contexto de una crisis económica y un conflicto armado interno, escenario, en suma, que se contrapuso a los dictados teóricos y a las experiencias previas de democratización. Efectivamente, a mediados de la década de 1980, en Guatemala se libraba una cruenta batalla militar ${ }^{13}$ y simultáneamente se padecía un profundo desequilibrio macroeconómico que puso en

\footnotetext{
${ }^{10}$ Para conocer con mayor precisión los acontecimientos de la coyuntura significativa hacia la democracia en Guatemala, incluidos debates sobre las fuerzas y la tipología de los procesos de democratización, consúltese: Azpuru et al. (2007), Brett (2006), Sáenz de Tejada (2013) y Villamizar (2009).

${ }^{11}$ Para Edelberto Torres Rivas, se trataba de una doble crisis: por un lado, de una crisis global de la dominación económica y estatal y, por otro lado, del colapso final de la dominación oligárquica (Torres Rivas, 1983).

${ }^{12}$ De hecho, el autor identifica la "implantación" como una variante de las transiciones que procede como dimensión externa en un contexto de triunfo del capitalismo (Torres Rivas, 2004: 152). Conviene recordar que para Manuel Antonio Garretón fueron tres los tipos de democratización política en América Latina: 1) las fundaciones democráticas, 2) las transiciones y 3) la extensión y las reformas democráticas (Garretón, 1999). Según lo analizado, lo sucedido en Guatemala encalla en el apartado primero.

${ }^{13}$ La Comisión para el Esclarecimiento Histórico cifró el saldo de muertos y desaparecidos de dicho enfrentamiento en más de doscientas mil personas (CEH, 2004). Para Edelberto Torres, lo que hubo durante 36 años en Guatemala no fue un conflicto armado, sino una represión permanente de un Estado con rasgos totalitarios que asesinó sistemáticamente también a la oposición democrática, civil y pacífica (Torres Rivas, 2004: 159).
} 
riesgo la capacidad de endeudamiento y pago del Estado guatemalteco frente al sistema financiero internacional. Tal escenario resultaba un contrasentido frente a la mayoría de las prescripciones emanadas de las ciencias sociales, desde las que se postulaba que la democracia, así fuese meramente electoral, necesitaba de condiciones de estabilidad social y económica como requisitos previos para su instauración..$^{14}$ Además, en Guatemala primero se generaron las condiciones institucionales y la elección de un gobierno civil que el inicio del proceso y la firma de los Acuerdos de Paz, lo que también es diferente de experiencias previas, como en el caso de África, donde antes de buscar el cambio del régimen político primero se buscó la paz.. ${ }^{15}$

Otro factor distintivo de la democratización en Guatemala fue la influencia de poderosos actores externos para el impulso y consecución del proceso. Se ha documentado que tanto Estados Unidos como el sector empresarial aparecieron como fuerzas preponderantes en la liberalización política del régimen; los primeros, en el marco de un contexto internacional de caída del comunismo que facilitó el interés por "ordenar su traspatio", y los segundos como un cálculo para favorecer la liberalización del mercado. ${ }^{16}$ Por lo anterior, se puede argumentar que, sin obviar la relevancia de las demandas sociales y los movimientos guerrilleros, la apertura del régimen político en Guatemala siguió más una ruta del modelo procesual "de arriba hacia abajo" que de "abajo hacia arriba" ${ }^{17}$ Ello tal vez explique una de las características principales del sistema político de Guatemala: la exclusión institucional de la izquierda revolucionaria.

Por último, pero no menos trascendente, la democratización en Guatemala sólo implicó "un cambio parcial en las estructuras de adopción de decisiones, de la influencia de los grupos de intereses clasistas" (Torres Rivas, 2010b: 143). Expresado de forma refractaria, la democratización en Guatemala no modificó, ni se planteó hacerlo, la estructura estatal ni sus fundamentos económicos. De hecho, como se mencionó atrás, una interpretación es que el cambio de régimen político acaeció como estrategia para

${ }^{14}$ Por ejemplo, Seymour Lipset establece cuatro requisitos económicos, políticos y sociales para la construcción de una democracia estable: 1) la consolidación del Estado, 2) un nivel adecuado de desarrollo económico, 3) una estructura social equilibrada, y 4) un sistema político apropiado y funcional (García Jurado, 2002).

${ }^{15}$ Para Edelberto Torres Rivas, este proceso, que también ocurrió en El Salvador y Nicaragua, se debió tanto a la descomposición del control político de los militares como a una estrategia para deslegitimar a los movimientos guerrilleros (Torres Rivas, 2004).

${ }^{16}$ Algunos textos donde analiza la influencia de Estados Unidos y del sector privado como variables explicativas de la democratización en Guatemala son: Azpuru et al. (2007), McCleary (2003), Rouquié (1994), Torres Rivas (2004) y Villamizar (2009).

${ }^{17}$ Dos de los modelos analíticos de procesos políticos son el "de arriba hacia abajo" (top-down) y el "de abajo hacia arriba” (bottom-up) que hacen referencia gráfica a los actores e intereses que promueven y dirigen un proceso político, ya sea desde la clase dirigente (top-down) o desde el sector popular (bottom-up). 
afrontar, además de una crisis de legitimidad política, la reestructura mundial del capitalismo. El régimen político, entonces, se liberalizó para preservar su naturaleza económica bajo presiones internas y externas.

En términos generales, el Estado en Guatemala es el resultado de un proceso histórico iniciado con el rompimiento del pacto colonial, estructurado por las necesidades de una economía agraria-comercial y guiado por la oligarquía como élite dominante. ${ }^{18}$ En la formación del Estado guatemalteco, entonces, irrumpen tres elementos como factores sine qua non que nuclean el proceso: la herencia colonial como regulador social, la economía como factor prioritario de estatización y lo oligárquico como el ethos de la dominación; éstos son los componentes que integran su núcleo fundacional.

El componente colonial ha permitido el establecimiento de jerarquías sociales basadas en fenotipo o raza que erige una "pigmentocracia" que valora negativamente el color de la piel y el porcentaje de sangre indígena. Así, lo racial ha ocupado "un lugar hegemónico en el discurso y en las actitudes del núcleo oligárquico, en la medida en que aparece como una constante histórica a lo largo de los siglos y porque en la actualidad esta élite se sigue autodefiniendo en función de un criterio de autoadscripción étnico racial" (Casaús Arzú, 1998: 139-140). Ello explica que los pueblos indígenas hayan sido subalternizados en las esferas social, política, económica y cultural del país.

Lo económico será el instigador de la estatización, pues sólo hasta que el sistema agrario-comercial se va constituyendo es cuando emerge la necesidad de construir una autoridad central y estable que asista y apuntale dicho sistema para producir y vender al exterior: "Es natural que entonces la formación del Estado nacional forme parte de la misma historia de la formación de las economías de exportación y de los sectores de clase que contribuyen y se aprovechan de ese resultado" (Torres Rivas, 1980: 580).

En tercer lugar, si bien es un término potencialmente problemático, ${ }^{19}$ lo oligárquico suele vincularse con el poder de las clases agrarias en el momento de la articulación del país al mercado mundial. En esa medida, es un estilo de preeminencia económica, política y social que creó un aparato estatal al servicio de un objetivo prioritario: la constitución y florecimiento de la economía agraria exportadora. Aun cuando su base fue económica, el poder de la oligarquía se extendió en lo político:

\footnotetext{
${ }^{18}$ Para revisar a profundidad la formación del Estado en Guatemala, se recomienda consultar a Torres Rivas (1980 y 2010b).

${ }^{19}$ Se ha confundido a la oligarquía con términos como aristocracia, plutocracia o burguesía, pero no es lo mismo. Para Torres Rivas, la oligarquía en Centroamérica se define con base en tres elementos: 1) el carácter extranjero de su núcleo que, aunque absorbió a mestizos, lo mantuvo como un grupo diferenciado del resto de la población a través de la endogamia y sólidas redes de parentesco, expuestas como linaje, que se utilizó como factor de diferenciación sociorracial; 2) su vinculación con la tierra y con los campesinos adscritos a esta, antes que con el capital; es decir, su naturaleza agraria y su función en el mercado mundial, y 3) un estilo político hermético aun cuando enarbola una ideología pseudoliberal (Torres Rivas, 2011).
} 
Lo primero, porque la reproducción parasitaria de la riqueza agraria — la renta de la tierra y la subordinación de la fuerza de trabajo - otorga al dueño de la tierra un poder desproporcionado, superior a sus posibilidades económicas; lo segundo, porque como consecuencia de lo anterior, esa preeminencia solo puede, o tiende a expresarse políticamente (Torres Rivas, 1987: 33).

Por lo atrás planteado, la democratización en Guatemala no sólo no conllevó la transformación del núcleo fundacional del Estado sino que éste cimentó el proceso de liberalización del régimen político. Ello se comprueba en el fundamento económico del Estado — su participación en el mercado mundial— que, como se verá más adelante, ha sido salvaguardado y expandido en el régimen democrático.

Los anteriores no son de ninguna manera factores exhaustivos pero sí se consideran relevantes para caracterizar, al menos en términos generales, la democracia en Guatemala. Así pues, la implantación de la democracia en Guatemala significó la respuesta estratégica para afrontar tanto una profunda crisis política como la reestructuración del capital. La democratización equivalió a una liberalización política para coadyuvar a la rearticulación de Guatemala al mercado mundial, no a una refundación del Estado o sus fundamentos económicos.

Aun con sus particularidades, ello puede articularse con otros análisis críticos sobre la democratización en América Latina, donde suele plantearse en términos generales que el proceso de liberalización política fue funcional a la liberalización económica generada por una reestructuración mundial del capitalismo, al adoptar, enmarcar y extender a las estructuras y los procesos políticos los principios del mercado y que, como resultado de ello, el modelo de democracia adoptado en el subcontinente fue mínimo — sólo representativo y procedimental, prácticamente un mero régimen electoral-, distanciándolo así de las demandas de igualdad y justicia socioeconómicas. ${ }^{20}$

Retomando los postulados teóricos de la sección anterior, la democracia en Guatemala se ha circunscrito al sistema político pero, a pesar de haber incorporado diversas pautas de derechos humanos a su ordenamiento jurídico, los resultados en las áreas de justicia social, desarrollo humano y seguridad ciudadana son deficientes. Tan sólo por aportar algunos datos: siendo el país más poblado de Centroamérica con 15438000 habitantes, en Guatemala el promedio de esperanza de vida al nacer es de 71.4 años - lo que representa el nivel más bajo de Centroamérica-, el porcentaje de población en pobreza es de 53.7\% - la segunda cifra más alta sólo por detrás de Honduras-, el coeficiente de Gini es de 0.590 - lo que lo convierte en el país más desigual de la región-, la participación del gasto público en educación y salud corresponden al 2.9\% y el 2.4\%, respectivamente, del PIB — que son las participaciones más bajas de Centroamérica- y el porcentaje de la

${ }^{20}$ Véase Borón (2003), Lechner (1999), Petras y Morley (1997) y Roitman (2005). 
población que afirma haber sido víctima de algún acto de delincuencia es del 20.8\%, el más alto de Centroamérica (PEN, 2014: 19-64).

Las deficiencias de la democracia guatemalteca son el corolario de la coyuntura significativa que la procreó y, en esa lógica, traslucen los actores, los intereses y los procesos hegemónicos en tal coyuntura. Pero, además, esas deficiencias también patentizan las dinámicas que perpetúan el talante de la democracia en Guatemala; esto es, la confrontación incesante de actores e instituciones de índole contradictoria que, más que provocar procesos de refundación de lo institucional, pretende resolverse con la imposición de los códigos hegemónicos, lo cual dificulta la estabilidad y la eficacia del régimen político. Tal condición se puede ejemplificar con el caso de la minería y los derechos de los pueblos indígenas.

\section{La minería y los derechos de los pueblos indígenas}

Desde la instauración de la democracia en Guatemala, los gobiernos se han centrado en una inserción del país a la economía global mediante políticas neoliberales que promueven la presencia del capital extranjero (Bastos y De León, 2015: 54). Ello se enmarca en una etapa del capitalismo que se caracteriza por un proceso de acumulación por desposesión (Harvey, 2004) en el que el modelo extractivo ${ }^{21}$ funciona como uno de sus factores constitutivos (Giarracca y Teubal, 2010). Indudablemente, la actividad que ha sido la punta de lanza de este proceso es la minería.

Ciertamente, desde la segunda mitad de la década de 1990 las actividades mineras han ido aumentando en Guatemala. Así, por ejemplo, de 1997 a 2011 el Ministerio de Energías y Minas otorgó 398 licencias de exploración y explotación, cifra que multiplica por tres el número de las que se habían otorgado antes de ese periodo. ${ }^{22}$ Actualmente, se han concedido 342 licencias mineras y existen 552 licencias en trámite (Bastos y De León, 2015: 55). Como resultado de ello, el 28\% del territorio de Guatemala se encuentra concesionado a alguna empresa minera (Nolasco, 2011). Aunque las licencias mineras cubren veinte de los veintidós departamentos en los que se divide Guatemala, se concentran en los de Izabal, San Marcos, Huehuetenango y Alta Verapaz, con población mayoritariamente indígena (ORACACNUDH, 2012: 210; Yagenova, 2012: 13-14).

\footnotetext{
${ }^{21}$ Se entiende el modelo extractivo como los actores, estructuras y procesos vinculados a la extracción de recursos naturales a gran escala. Para análisis especializados sobre el concepto, véase Grigera y Álvarez (2013) y Gudynas (2013).

${ }^{22}$ La licencia minera es el instrumento legal que respalda al titular en la ejecución de sus operaciones mineras. En Guatemala se identifican tres tipos de licencias: de reconocimiento, de exploración y de explotación MEM (2004).
} 
El acceso e incursión a los territorios concesionados por parte de las empresas mineras ha seguido una lógica de hermetismo, cooptación, división, desinformación y hasta represión:

Prácticamente en toda comunidad a la que llegó una empresa se dio un patrón común: se instalaba antes de tener las licencias y sin avisar oficialmente, sin hacer caso de las consultas u otras formas de expresión ciudadana, comprando terrenos por medio de intermediarios y sin decir para qué eran. Se apoyaban en algunos pocos vecinos a los que daban empleo y favorecían —algunos de ellos seleccionados por ser autoridades comunitarias-. A quienes no querían vender, se oponían, o cuestionaban las formas, se les amenazaba e intimidaba de modo más o menos abierto (Bastos y De León, 2015: 55).

Evidentemente, la mayoría de las comunidades residentes delos territorios concesionados, muchas veces en coalición con organizaciones no gubernamentales, Iglesia y diversos sectores sociales, se han organizado para denunciar los impactos ambientales, las violaciones jurídicas, los pocos beneficios económicos y su nula participación en dichos proyectos mineros.

Como tono distintivo de tales movilizaciones, las denuncias se han planteado en una gramática de derechos humanos y con más precisión, dada la alta incidencia de afectación a pueblos indígenas, ${ }^{23}$ esgrimiendo derechos colectivos. Tal reivindicación es consecuente con el proceso de reconocimiento discursivo e institucional de un marco jurídico-normativo internacional de derechos de los pueblos indígenas acaecido en América Latina en las últimas décadas, ${ }^{24}$ lo cual se confirma en Guatemala con la ratificación del Convenio 169 sobre Pueblos Indígenas y Tribales de la Organización Internacional del Trabajo, así como con el Acuerdo sobre Identidad y Derechos de los Pueblos Indígenas - anexo de los Acuerdos de Paz-, ambos firmados en 1996.

Sin embargo, aunque el Estado guatemalteco ha admitido discursivamente el marco jurídico-normativo internacional de derechos de los pueblos indígenas, cada vez que las

\footnotetext{
${ }^{23}$ Se ha documentado que los pueblos indígenas son el sector poblacional más afectado en los proyectos extractivos, pues los espacios con mayor diversidad biológica coinciden con los territorios habitados por ellos - entre el 70\% y el 90\% de las tierras de mayor diversidad biológica están al cuidado exclusivo de comunidades indígenas - Consúltese: RAFI (1997), Toledo (2001) y WWF (2000). De hecho, el extractivismo ha sido la principal causa de la violación a los derechos de los pueblos indígenas en los últimos años (ORACACNUDH, 2012: 186-255). En el caso de Guatemala, según cifras oficiales, el 41\% de la población es indígena, es decir, casi seis millones y medio de personas.

${ }^{24}$ Para revisar el contenido del marco jurídico-normativo internacional de derechos de los pueblos indígenas y su impacto en América Latina, se recomienda consultar la siguiente bibliografía: Anaya (2005), Brysk (2000), Martínez (2015), Rodríguez-Piñero (2007) y Vázquez (2008).
} 
comunidades residentes en los territorios concesionados a la minería se oponen a tales proyectos y reivindican sus derechos colectivos al territorio, a la salud, al autogobierno, a la participación y a la identidad cultural, las respuestas gubernamentales se han caracterizado frecuentemente por la intimidación, la militarización, la represión, el encarcelamiento y hasta el asesinato de los indígenas (Bastos y De León, 2014); en suma, todo el repertorio de acciones que se conocen como "criminalización de la protesta social". 25

Ante tal escenario, las comunidades afectadas han optado por implementar un mecanismo que, amparado en el marco jurídico-normativo de derechos colectivos, ha buscado promover la participación, incentivar la movilización y legitimar sus demandas. Se trata de las llamadas "consultas comunitarias de buena fe". ${ }^{26}$ Estas consultas sobre la minería iniciaron el 18 de mayo de 2005 en Comitancillo (San Marcos). Desde esa fecha y hasta febrero de 2015 se han celebrado 114 consultas $^{27}$ en 74 municipios, siendo los de mayor convocatoria Huehuetenango, Quiché, Quetzaltenango, San Marcosy Totonicapán —conocido como el altiplano indígena-.

Dichos ejercicios participativos consisten en una pregunta expresa a los asistentes sobre su aprobación de los proyectos mineros en sus territorios; luego, aquéllos votan - usualmente de forma pública a mano alzada-, se registran los resultados y se levanta un acta testimonial de los mismos. Según datos del año 2010 (CSA et al.: 2010), cerca del 99\% de los participantes en las consultas se han opuesto a los proyectos extractivos en sus territorios.

Aunque las consultas comunitarias no cumplen a cabalidad con el espíritu del marco jurídico-normativo internacional de derechos de los pueblos indígenas, ${ }^{28}$ los convocantes han fundamentado dichos ejercicios participativos recurriendo tanto al

\footnotetext{
25 "Una de las deficiencias más graves en la protección de los derechos humanos en los últimos años es la tendencia a la utilización de las leyes y de la administración de justicia para castigar y criminalizar las actividades de protesta sociales y las reivindicaciones legítimas de las organizaciones y movimientos indígenas en defensa de sus derechos. Según algunos informes, esas tendencias adoptan dos formas: la aplicación de leyes de emergencia, como las leyes contra el terrorismo, y el procesamiento de manifestantes como autores de delitos comunes (por ejemplo, la intrusión en propiedad ajena) para reprimir las protestas sociales" (Stavenhagen, 2008: 85).

${ }^{26}$ Se recomienda repasar los siguientes textos para examinar a detalle el tema de las consultas comunitarias: CSA et al. (2010), Fulmer (2011), Trentavizi y Cahuec (2012) y Walter y Urkidi (2015).

27 Fuente: https://ayssaestrategia.com/consultas-comunitarias-realizadas-en-guatemala-duranteel-2014/295 (consultado el 8 de febrero de 2015).

${ }^{28}$ Según se indica tanto en el Convenio 169 como en la Declaración de las Naciones Unidas sobre los Derechos de los Pueblos Indígenas, "el objetivo de la consulta con los pueblos indígenas sobre proyectos que les afectan es llegar a acuerdos y al consentimiento" (Anaya, 2011: 12). Esto es, la consulta como un proceso de diálogo y negociación de buena fe, en el que las partes involucradas buscan alcanzar acuerdos, lo cual no ha ocurrido con las consultas comunitarias pues, sobre todo, no han incluido a todas las partes interesadas.
} 
Convenio 169 de la Organización Internacional del Trabajo, como al Código Municipal de Guatemala, el cual prevé la posibilidad de recabar la opinión de las comunidades indígenas en asuntos relevantes factibles de ser de su incumbencia. Diversos sectores - principalmente el empresarial y el gubernamental central- han objetado el propósito, el método y, sobre todo, el carácter vinculante de las consultas comunitarias, que es el tema más polémico al respecto. A tal grado esto último, que la Corte de Constitucionalidad tuvo que pronunciarse concluyendo que los resultados de las consultas comunitarias no son vinculantes con las acciones de los poderes públicos en Guatemala. Sin embargo, la Corte asentó que la consulta "es un derecho fundamental de carácter colectivo, integrado plenamente en el bloque de constitucionalidad guatemalteco", ${ }^{29}$ pero que existe un vacío reglamentario sobre el particular en el ordenamiento jurídico de Guatemala.

Precisamente, la última parte del fallo de la Corte de Constitucionalidad en torno a las consultas comunitarias posiciona el caso de la minería y los derechos de los pueblos indígenas en el punto focal sobre la democracia que este texto quiere recalcar: la colisión de instituciones contradictorias como factor de incidencia perniciosa a la democracia. Y es que, a pesar de las obligaciones internacionales del Estado guatemalteco, ${ }^{30}$ el país no cuenta con un marco jurídico pertinente para implementar el derecho a la consulta de los pueblos indígenas; ya no digamos en la legislación extractiva, ${ }^{31}$ sino en la específica, pues ni la ratificación del Convenio 169 ni el Acuerdo sobre Identidad y Derechos de los Pueblos Indígenas han servido para generar leyes secundarias e instancias tendientes a consumar los derechos colectivos, en este caso, de dimensión participativa - consulta, consentimiento libre, previo e informado y la participación en el ciclo completo de las políticas públicas-.

Por sifuera poco, el Estado de Guatemala también ha incumplido con sus obligaciones adquiridas en el Sistema Interamericano de Derechos Humanos. Concretamente, con unas medidas cautelares ${ }^{32}$ que la Corte Interamericana de Derechos Humanos otorgó a

\footnotetext{
${ }^{29}$ Sentencia de la Corte de Constitucionalidad, Expediente 3878-2007 (2009), Considerandos VI y V.

${ }^{30}$ Son cinco los instrumentos internacionales en los que se fundamenta el derecho de consulta y que ha ratificado el Estado de Guatemala: el Convenio 169, la Declaración de Naciones Unidas sobre Derechos de los Pueblos Indígenas, la Convención Internacional sobre la Eliminación de todas las Formas de Discriminación Racial, el Pacto Internacional de Derechos Económicos, Sociales y Culturales y la Convención Americana sobre Derechos Humanos.

${ }^{31}$ La Ley de Minería en Guatemala no requiere de la consulta con los pueblos indígenas antes de aprobar licencias. Lo mismo ocurre con el resto de la legislación para aprobar proyectos extractivos, como la Ley Forestal, la Ley de Hidrocarburos o la Ley General de Electricidad.

${ }^{32}$ Medida cautelar MC-260-07. Según establece el Reglamento de la CIDH, en situaciones de gravedad y urgencia la CIDH podrá solicitar que un Estado adopte medidas cautelares para prevenir daños irreparables a las personas o al objeto del proceso en conexión con una petición o caso
} 
dieciocho comunidades indígenas del departamento de San Marcos afectadas por el que tal vez sea el proyecto minero más controversial, el de la mina Marlin, de la empresa Montana Exploradora, subsidiaria de la canadiense Glamis Gold Ltd., y que ocupa 6.5 kilómetros cuadrados en la frontera entre los municipios de San Miguel Ixtahuacán y Sipakapa. ${ }^{33}$ Esas medidas cautelares, otorgadas en 2010 , estaban destinadas a garantizar la vida e integridad de las comunidades indígenas, por lo que la Corte Interamericana solicitó al Gobierno de Guatemala, entre otros requerimientos, suspender los trabajos de la mina Marlin, descontaminar las fuentes de agua, atender los problemas de salud e implementar sistemas de protección con la participación de los beneficiarios. Sin embargo, al momento de redactar este texto (septiembre de 2015), y más de cinco años después de dictadas, las medidas cautelares de la Corte Interamericana aún no se implementaban en Guatemala.

En conclusión, los actores, instituciones y procesos de las actividades extractivas, concretamente de la minería, se contraponen flagrantemente al sistema jurídico de protección de los derechos humanos, específicamente de los derechos de los pueblos indígenas. Los discursos, las instancias y las actividades de ambas esferas se confrontan frenéticamente al responder a intereses y formas diferenciadas y hasta opuestas. La contradicción institucional de origen, como se detalla en el cuadro l con los ordenamientos jurídicos específicos, instiga la conflictividad pues los antagonismos suelen resolverse por vía de hechos a favor del sector extractivo; ello, como puede inferirse, propicia la transgresión sistemática de los derechos de los pueblos indígenas.

$$
\text { Cuadro } 1 \text { Disposiciones jurídicas contradictorias en minería y derechos }
$$
de los pueblos indígenas

\section{Tratados que salvaguardan derechos Leyes e instrumentos que los humanos e indígenas contradicen}

La Constitución Política de la República de Guatemala promete proteger los derechos territoriales y las tierras comunales e individuales de los pueblos indígenas.
La Ley de Minería de 1997 declara que todo subsuelo, los minerales y los yacimientos de hidrocarburos son propiedad del Estado guatemalteco.

pendiente, así como a personas que se encuentren bajo su jurisdicción. Véase: http://www.cidh.oas. org/medidas/2010.sp.htm.

${ }^{33}$ Para profundizar en el caso de la mina Marlin, se recomienda consultar la siguiente bibliografía: Anaya (2011), Castagnino (2006), OCGCI (2010), Sánchez (2012), Van de Sandt (2009), Yagenova (2012) y Zarsky y Stanley (2011). 
El Convenio 169, ratificado por Guatemala en 1996, protege los derechos territoriales de los pueblos indígenas y el derecho a ser consultados sobre los proyectos y leyes que afecten a sus territorios.

La Declaración de Naciones Unidas sobre Derechos de los Pueblos Indígenas salvaguarda el derecho al consentimiento libre previo e informado.

El Código Municipal, la Ley de

Descentralización y la Ley de Consejos de Desarrollo Urbano y Rural de Guatemala protegen la autonomía municipal y la toma de decisiones a nivel local, así como la consulta comunitaria realizada según las tradiciones y sistemas propios de los pueblos indígenas.

La Declaración de Naciones Unidas sobre Derechos de los Pueblos Indígenas les reconoce su derecho a decidir sobre su propio desarrollo y uso de los recursos naturales, así como conservar los recursos, medio ambiente y capacidad de sus tierras.

La Ley de Protección y Mejoramiento del Medio Ambiente dice que es obligación del Estado proteger y mejorar el medio ambiente, regular la descarga de contaminantes y proteger el agua. La Constitución de la República de Guatemala prohíbe el uso de las aguas nacionales como reservorio de desperdicios contaminados del medio ambiente o radioactivos.
La Ley de Minería vigente no reconoce el derecho a la consulta y al consentimiento libre, previo e informado. Las empresas mineras tienen derecho a expandir el área de sus operaciones si es necesario para el proyecto y de prolongar su licencia por veinticinco años.

El fallo de la Corte de Constitucionalidad de Guatemala de 2007 declara que las consultas comunitarias no son vinculantes e insiste en que la minería es de interés nacional.

La Ley de Minería permite el uso gratuito e ilimitado del agua por parte de las empresas mineras. No establece regulaciones de contaminación o del uso de químicos en el agua. Promueve la explotación de recursos naturales como camino al desarrollo nacional.

Fuente: OCMAL (2011: 81).

Este recorrido del caso de la minería transnacional en Guatemala ha mostrado que existen tensiones entre el orden jurídico-institucional del Estado guatemalteco y el derecho internacional público y su derivación en el derecho internacional de los derechos humanos, así como con los principios liberales que, al menos discursivamente, fundamentan tales ordenamientos. Sin embargo, ello no debería orillar la reflexión al ámbito meramente jurídico, sino sobre todo subrayar y rescatar el carácter político del 
caso. Porque lo que hay de trasfondo no son meros discursos ecologistas o intereses comerciales que buscan dirimirse judicialmente, sino que se enfrentan, al menos reconociblemente, dos visiones del mundo opuestas que se traducen en comunidades, prácticas y relaciones sociales, económicas, culturales y ambientales que, al colisionar con la imposición de una de ellas, sobrepasan y, en ese sentido, muestran las limitaciones de una concepción hegemónica de la democracia.

Porque, por un lado, están las empresas mineras transnacionales que, en una etapa capitalista de acumulación por desposesión, se insertan en Guatemala - y en el resto de América Latina - cobijadas por un Estado, régimen y clase política que facilita su despliegue en el país con apoyos institucionales, tales como reformas legislativas a modo, respaldos administrativos, ventajas tributarias - las regalías que las empresas pagan no superan el 5\% del mineral extraído - y estrategias discursivas para amalgamar a la minería con campos semánticos vinculados al desarrollo y, en ese sentido, calificar a los actores contrarios a la minería como opuestos al progreso/crecimiento de Guatemala.

Pero, por otro lado, se encuentran comunidades, organizaciones y hasta autoridades locales que, basadas en cotidianidades que superan lo puramente mercantil, se congregan, no sin conflictos internos, para oponerse al modelo extractivo apelando a una heterogeneidad de métodos que legitiman sus posturas al anclarse en lo local, en la protección del medioambiente y en el señalamiento de las contradicciones demoliberales.

El caso de la minería en Guatemala expone la pluralidad de actores, cosmovisiones y organización de lo político en el país, pero también exhibe las contradicciones de un Estado, régimen y clase política que enmascara la adopción de modelos de acumulación y de despojos bajo efigies de institucionalidad y, sobre todo, las limitaciones de una concepción hegemónica de la democracia que, al reducirse a lo mínimo, se muestra inoperante e insuficiente para procesar "democráticamente" el conflicto suscitado ante el choque de posturas, optando por una estrategia de orden que no es más que la expansión del modelo extractivo y el aplazamiento de sus opositores.

\section{De contradicciones, falacias y senderos de la democracia en Guatemala}

En marzo de 2008 tuve la oportunidad de conversar con doña Dominga Vásquez Julaju, exalcaldesa indígena y primera mujer en ocupar dicho cargo en Sololá. A pesar de que mis preguntas se dirigían a conocer su experiencia en un proyecto de cooperación de la Comisión Europea en Guatemala, ella se refería insistentemente a otro tema: las extracciones mineras en sus territorios.

Con indignación pero con bravía lucidez, doña Dominga Vásquez reflexionó sobre el significado y los impactos de la minería, sobre las acciones de resistencia y reivindicación de las comunidades indígenas y sobre las obligaciones y las maniobras del Estado 
guatemalteco ante tales conflictos. Como resultado de esa charla, supe sobre un tema prioritario en ese entonces emergente, distinguí sus repercusiones potenciales en distintos pero interconectados ámbitos y, sobre todo, me interesé por conocer más sobre los efectos de la minería en los derechos de los pueblos indígenas.

De entre los vastos y esclarecedores razonamientos que doña Dominga Vásquez me legó, destacó uno que está en sintonía con la tesis del presente texto. Doña Dominga me había narrado sobre las condiciones herméticas de la concesión a la mina Marlin, sobre la movilización de las comunidades en contra de dicho proyecto y sobre la represión de la policía y el ejército que incluyó el asesinato a un miembro de la comunidad. Además, me contó sobre la intimidación jurídica a los líderes indígenas. En ese contexto, me expresó lo siguiente:

Entonces, la gente se está manifestando en contra pero eso no lo están tomando en cuenta, como que no valdría nada, como si no existiéramos nosotros los pueblos indígenas. Seestán dando los negocios entre el gobierno y las empresas transnacionales pero nunca hemos sido consultados. Dicen que es por nuestro propio desarrollo pero ipor qué están aceptando el uno por ciento de las regalías, si es para el desarrollo de cada uno de los pueblos? Ahí, la mayor ganancia se la está llevando la empresa, y entonces no queda nada para el pueblo, y aunque quedara, pero nosotros realmente no queremos la destrucción de la Madre naturaleza o de los recursos naturales, porque se contaminan, se degradan, se desaparecen, por ejemplo, el agua se contamina. Y total, que realmente nosotros estamos bien claros de que la minería nos trae destrucción, y que en un futuro la muerte, tanto humana como de animales y de las plantas. Entonces, voy a que hay un convenio, pero no se respeta y que hay una manifestación de inconformidad pero se obvia, son indiferentes hacia las expresiones, hacia las manifestaciones de las personas, especialmente de los pueblos indigenas (entrevista a doña Dominga Vásquez Julaju. Sololá, Guatemala, 14 de marzo de 2008).

A mi juicio, la reflexión anterior de doña Dominga Vásquez sintetiza fehacientemente las dinámicas contemporáneas de la minería en Guatemala y su efecto en el estatus de la democracia. Esto es, la imposición de un modelo extractivo que, presentado con un discurso de desarrollo y progreso, genera ganancias elevadas a las empresas e ingresos mínimos al Estado. En esta actividad, las comunidades de los territorios concesionados son las más afectadas al ver vulnerados sus derechos a la vida, a la salud, al autodesarrollo, al territorio, al medioambiente, a la consulta y al consentimiento libre, previo e informado. Pero, sobre todo, su derecho a ser personas —individuales o colectivas - con visiones, proyectos y organizaciones diferentes a las hegemónicas. Dada la ausencia de mecanismos institucionales efectivos para dirimir tales conflictos, las comunidades utilizan un amplio repertorio de acción colectiva para oponerse y reivindicar sus derechos colectivos, pero, 
más que ser atendidas con base en un paradigma demoliberal, suelen recibir prácticas tendientes a criminalizar sus manifestaciones de disconformidad. Esto, a pesar de que el Estado guatemalteco ha reconocido e incorporado el marco jurídico-normativo de derechos de los pueblos indígenas y de que ha contraído obligaciones con el Sistema Interamericano de Derechos Humanos.

Tal esquema es consecuente con la democracia en el país. Como fue expuesto en el apartado II, lo que se cataloga como tal en el país no fue más que una liberalización del régimen político comorespuesta a una profunda crisis política interna y a requerimientos geoestratégicos externos. La democratización fue un proceso de implantación peculiar que no modificó ni el núcleo fundacional del Estado ni sus fundamentos económicos.

Muy posiblemente lo anterior explique que, a pesar de que desde 1985 la dirigencia políticaguatemalteca se renueva con base en elecciones en generallegítimas, los resultados del mismo periodo indican serias deficiencias en las materias de justicia social, desarrollo humano y seguridad ciudadana. Aun con grandes narrativas y acciones, Guatemala sigue siendo un país pobre, desigual, inseguro. Es, como la calificó Edelberto Torres Rivas, una "democracia mala" porque, al ser incapaz de satisfacer las condiciones mínimas de vida, defraudan esperanzas y llenan de incertidumbre a la gente (Torres Rivas, 2010).

Tal particularidad de la democracia tiene correlación directa con la situación del Estado. Actualmente podemos caracterizar al Estado guatemalteco como: mínimo, es, por delante de Honduras, el país con menor número de entidades públicas en Centroamérica; ineficaz, es el que menos ingresos recibe por carga tributaria; indolente, el que menos invierte en educación y salud; y endeudado porque lleva más de una década de balance fiscal negativo (PEN, 2014), además de subyugado a actores e intereses externos. Obviamente, estas condiciones debilitan a la democracia con situaciones de inestabilidad y prácticas autoritarias.

Como buen testimonio del talante del Estado y de la democracia en Guatemala, la minería ha sido una actividad que se ha incrementado en el país en los últimos años debido a los requerimientos del capitalismo en su etapa de acumulación por desposesión; es decir, por actores, designios e ideologías hegemónicas y vinculadas a los grandes capitales. Siendo parte del modelo extractivo, los proyectos mineros se implantan sin ningún tipo de consulta o consentimiento a las comunidades, extraen recursos minerales y con ello deterioran los ecosistemas. Como se ha verificado, en Guatemala existe una alta correlación entre licencia minera y conflictividad (IRALEP, 2010).

Quienes marchan con consignas, quienes participan en las consultas comunitarias y quienes han buscado la salvaguarda de sus derechos por vía judicial, lo confirman: el poder del pueblo no lo es mediante las instituciones públicas. Así sea con todos los tratados de derechos humanos a su favor, por vías pacíficas o simplemente teniendo múltiples evidencias de afectaciones a la salud y a los ecosistemas, los proyectos mineros siguen creciendo, así como el número de los territorios concesionados. 
Aquí conviene traer a colación las líneas analíticas sobre el concepto de democracia que se establecieron en el primer apartado, porque si bien es cierto que existe una concepción hegemónica de la democracia sobre la cual se han edificado instituciones, promovido enfoques y auspiciado prácticas, y la cual Guatemala ha adoptado, no es única ni mucho menos indiscutible; todo lo contrario, es una concepción en disputa, tanto teórica como empíricamente.

La democracia liberal contemporánea — sea en su fachada pluralista, deliberativa o hasta multicultural - trata de enrejar la diversidad para poder amaestrarla y administrarla a través de dispositivos razonados que reducen la multiplicidad y el desorden a la armonía y la unidad. En tal proceso, la institución jurídica absorbe, elimina y supera el conflicto, para estructurar al liberalismo, el cual aspira al orden y uniformidad como valor central (Sanín, 2014). Como afirman los teóricos que han sido catalogados como "posfundacionalistas" (Marchart, 2009), se trata de una estratagema en la que se confunde el poder constituyente con el poder constituido, donde se disuelve o convierte el constituyente en el espacio del constituido (Badiou, 2003), donde la construcción de lo político instaura un punto a partir del cual la sociedad es dominada y cognoscible (Lefort, 1988), estableciendo un garante trascendente: el Estado, que es la única instancia del poder, del saber y de la ley (Laclau y Mouffe, 1987). Se trata del trabamiento o clausura de la democracia que bloquea otro poder que no sea el ya constituido, que impone formas y narrativas de lo político y lo que es jurídicamente negociable, para aplazar las demandas populares antagónicas, buscando deslegitimar y desarticular otros actores, espacios, discursos y procedimientos políticos.

Una de las lecturas del caso de la minería en Guatemala es que no sólo la concepción hegemónica de la democracia tiene deficiencias y grietas, sino que además al amparo de sus contradicciones están emergiendo otras formas, otras comunidades, otras narrativas que, sobre la base de las reivindicaciones - la disputa a lo hegemónico-, replantean la democracia, reafirmando que, tal como lo refirieron Ernesto Laclau y Chantal Mouffe, no hay un único espacio de constitución de lo político (Laclau y Mouffe, 1987).

Lo que se entiende hegemónicamente como democracia en Guatemala es un mentís, un hecho que se refuta incesantemente a sí mismo. Se reconocen el potencial sesgo cognitivo de generalizar o confinar la complejidad a un solo caso, pero la minería y los derechos de los pueblos indígenas ejemplifican el talante más evidente de la democracia en Guatemala: el enfrentamiento constante e irresuelto entre actores, instituciones y procesos contrapuestos que se efectúa en el marco de un Estado que preserva su núcleo fundacional. El mantenimiento de la concepción hegemónica de la democracia conlleva el riesgo de que cada vez más se vacíe de democracia.

Aun así, hay otra propiedad de la democracia con la que se opta por concluir. Es una de sus esencias, uno de sus motores que ha sido desacreditado. Porque, a pesar de lo extendido e institucionalizado, la democracia continúa siendo un ideal, una aspiración, 
un horizonte por construir a través de revitalizar la libertad y la igualdad. Por eso, a pesar de ser un mentís, la democracia en Guatemala es también el germen de otra democracia; una más allá de lo liberal, de lo político-institucional y de lo hegemónico. Las consultas comunitarias y las recientes manifestaciones de protesta social multitudinarias lo confirman, pues conviene no olvidar que, como enunció James Scott, "las promesas incumplidas del sistema de dominio representan el principal terreno de acción de los subalternos". La democracia en Guatemala, como en el resto de la región y del continente, es también aquello por lo que se sigue resistiendo, luchando y refundando.

\section{Referencias bibliográficas}

Anaya, James (2005). Los pueblos indígenas en el Derecho internacional. Madrid: Trotta.

Anaya, James (2011). Informe del Relator Especial de Naciones Unidas sobre los Derechos de los Pueblos Indígenas, James Anaya. Adición: Observaciones sobre la situación de los derechos de los pueblos indígenas de Guatemala en relación con los proyectos extractivos, y otro tipo de proyectos, en sus territorios tradicionales. Apéndice: la situación de los derechos humanos de las comunidades afectadas por la mina Marlín, en las municipalidades de San Miguel Ixtahuacán y Sipacapa, Departamento de San Marcos (Guatemala.) Nueva York: ONU. Disponible en: http://unsr. jamesanaya.org/docs/special/20ll_report_guatemala_advanced_version_sp.pdf.

Arrellano Gault, David y Walter Lepore (2009). "Poder, patrón de dependencia y nuevo institucionalismo económico. Límites y restricciones de la literatura contemporánea". En Gestióny Política Pública, vol. XVIII, núm. 2. México: CIDE, pp. 253-305. Disponible en: http://www.gestionypoliticapublica.cide.edu/num_anteriores/Vol.XVIII_No. II_2dosem/David_Arellano_y_Walter_Lepore.pdf (consultado el 8 de septiembre de 2015).

Avritzer, Leonardo y Boaventura de Sousa Santos (2004). "Para ampliar el canon democrático". En Boaventura de Sousa Santos (coord.), Democratizar la democracia. Los caminos de la democracia participativa. México: Fondo de Cultura Económica.

Azpuru, Dinora et al. (2007). Construyendo la democracia en sociedades posconflicto. Un enfoque comparado entre Guatemala y El Salvador. Guatemala: F\&EG editores. Disponible en: http:/ www.idrc.ca/EN/Resources/Publications/openebooks/340-9/index.html\#page_574 (consultado el 4 de septiembre de 2015).

Badiou, Alain (2003). Infinite Thought: Truth and return to Philosophy. Londres: Continuum.

Barber, Benjamin (1984). Strong Democracy, Participatory politics for a New Age. California: University of California Press.

Bastos, Santiago y Quimy de León (2014). Dinámicas de despojo y resistencia en Guatemala. Comunidades, Estado y empresas. Guatemala: Diakonía, Colibrí Zurdo.

Bastos, Santiago y Quimy de León (2015). “Guatemala: construyendo el desarrollo propio en un neoliberalismo de posguerra”. En Revista Pueblos y Fronteras Digital, vol. 10, núm. 
19. México: UNAM, pp. 52-79. Disponible en: http://www.redalyc.org/articulo. oa?id=90638786004 (consultado el 17 de septiembre de 2015).

Bobbio, Norberto (1999). Estado, gobierno y sociedad. Por una teoría general de lapolítica. México: Fondo de Cultura Económica.

Boron, Atilio (2003). Estado, capitalismo y democracia en América Latina. Buenos Aires: CLACSO.

Brett, Roddy (2006). Movimiento social, etnicidad y democratización en Guatemala, 1986-1996. Guatemala: F\&\&G Editores.

Brysk, Alison (2000). From Tribal Village to Global Village: Indian Rights and International Relations in Latin America. Stanford: Stanford University Press.

Casaús Arzú, Marta Elena (1998). La metamorfosis del racismo en Guatemala. Uk'exwachixiik ri Kaxlan Na'oojpa Iximuleew. Guatemala: Cholsamaj.

Castagnino, Vincent (2006). Minería de metalesy derechos humanosen Guatemala. La mina Marlin en San Marcos. Guatemala: Brigadas de Paz Internacionales.

CEH (Comisión para el Esclarecimiento Histórico) (2004). Conclusiones y recomendaciones: Guatemala memoria del silencio. Guatemala: F\&G Editores.

Collier, David y Steven Levitsky (1998). "Democracia 'con adjetivos': innovaciones conceptuales en estudios comparativos”. En Ágora, núm. 8, pp. 99-122.

CSA (Confederación Sindical de Trabajadores y Trabajadoras de las Américas), CSI (Confederación Sindical Internacional), CPO (Consejo de los Pueblos de Occidente) y MSICG (Movimiento Sindical, Indígena y Campesino Guatemalteco) (2010). El derecho de consulta de los pueblos indígenas en Guatemala: la ruptura entre el discurso y la práctica. Guatemala: CSA, CSI, CPO, MSICG.

Dahl, Robert (1992). La democraciay sus críticos. Barcelona: Paidós.

Fulmer, Amanda (2011). "La consulta a los pueblos indígenas y su evolución como herramienta de negociación política en América Latina. Los casos de Perú y Guatemala”. En Apuntes:RevistadeCiencias Sociales, vol. 38, núm. 68, pp. 37-62. Disponible en: http://revistas.up.edu.pe/index.php/apuntes/article/view/77/61 (consultado el 11 de octubre de 2015).

García Jurado, Roberto (2002). "Seymour M. Lipset y los requisitos de una democracia estable”. En Argumentos, núm. 40. México: UAM-Xochimilco, pp. 127-148.

Garretón, Manuel Antonio (1999). Democracia y democratización. México: UNAM-Centro de Investigaciones Interdisciplinarias en Ciencias y Humanidades.

Giarracca, Norma y Miguel Teubal (2010). "Disputas por los territorios y por los recursos naturales: el modelo extractivo”. En Revista ALASRU. Nueva Época, núm. 5. Texcoco, México, pp. 113-133.

Grigera, Juan y Laura Álvarez (2013). “Extractivismo y acumulación por desposesión. Un análisis sobre las explicaciones de agronegocios, megaminería y territorio en la Argentina de la posconvertibilidad". En Theomai, núm. 27-28. Argentina, pp. 80-97. 
Gudynas, Eduardo (2013). “Extracciones, extractivismos y extrahecciones”. Observatorio del Desarrollo, núm. 18. Montevideo. Disponible en: http://www.extractivismo.com/ documentos/GudynasApropiacionExtractivismoExtraheccionesOdeD2013.pdf (consultado el 20 de abril de 2015).

Habermas, Jürgen (1999). La inclusión del otro. Estudios de Teoría política. Barcelona: Paidós.

Harvey, David (2004). "The New Imperialism: Accumulation by Dispossession". En Socialist Register, vol. 40. The Merlin Press, pp. 63-87.

Held, David (1992). Modelos de democracia. México: Alianza Editorial.

IRALEP (2010). Comprendiendo la conflictividad por minería en Guatemala. Guatemala: IRALEP.

Laclau, Ernesto y Chantal Laclau (1987). Hegemonía y estrategia socialista. Hacia una radicalización de la democracia. Madrid: Siglo XXI.

Lechner, Norbert (1999). "Estado y sociedad en perspectiva democrática”. En Estado, democracia y ciudadanía. Papeles de Investigación, p. 12. Buenos Aires.

Lefort, Claude (1988). Democracy and Political Theory. Minneapolis: University of Minnesota Press.

Lijphart, Arend (2000). Modelos de democracia. Barcelona: Ariel.

Macpherson, Crawford (1987). La democracia liberal y suépoca. Madrid: Alianza Editorial.

McCleary, Rachel (2003) Imponiendo la democracia: las elites guatemaltecas y el fin del conflicto armado. Guatemala: Artemis Edinter.

Mahoney, James Lee (2001). The Legacies of Liberalism: Path Dependence and Political Regimes in Central America. Baltimore: The Johns Hopkins University Press.

March, James G. y Johan P. Olsen (1997). El redescubrimiento de las instituciones. La base organizativa de la politica. México: Fondo de Cultura Económica.

Marchart, Oliver (2009). El pensamiento político posfundacional. La diferencia politica en Nancy, Lefort. Badiou y Laclau. Buenos Aires: Fondo de Cultura Económica.

Martínez Espinoza, Manuel Ignacio (2015). "Reconocimiento sin implementación. Un balance sobre los derechos de los pueblos indígenas en América Latina”. En Revista Mexicana de Ciencias Políticasy Sociales, Nueva Época, año LX, núm. 224. México: UNAM, pp. 247-274. Disponible en: http://www.revistas.unam.mx/index.php/rmspys/issue/ view/3919/showToc.

MEM (Ministerio de Energía y Minas) (2004). Caracterización de la minería en Guatemala. Guatemala: Ministerio de Energía y Minas-Dirección General de Minería.

Mouffe, Chantal (1999). El retorno de lo político. Comunidad, ciudadanía, pluralismo, democracia radical. Barcelona: Paidós.

Nolasco, Silvia (2011). Impactos de la minería metálica en Centroamérica. San Salvador: OCMAL.

North, Douglass C. (1995). Instituciones, cambio institucional y desempeño económico. México: Fondo de Cultura Económica.

O'Donnell, Guillermo (1997). Contrapuntos. Ensayos escogidos sobre autoritarismo y democratización. Buenos Aires: Paidós. 
OCGCI (On Common Ground Consultants Inc.) (2010). Evaluación de los Derechos Humanos de la Mina Marlin de Goldcorp. Vancouver: OCGCI.

OCMAL (Observatorio de Conflictos Mineros de América Latina) (2011). Cuando tiemblan los derechos: extractivismo y criminalización en América Latina. Quito: OCMAL.

ORACACNUDH (Oficina Regional para América Central del Alto Comisionado de las Naciones Unidas para los Derechos Humanos) (2012). Diagnóstico sobre la situación de los derechos humanos de los pueblos indígenas en América Central, t. I. Panamá: Oficina del Alto Comisionado de las Naciones Unidas para los Derechos Humanos, Embajada de Noruega. PEN (Programa Estado de la Nación) (2014). Estadísticas de Centroamérica 2014. San José: Programa Estado de la Nación. Disponible en: http://www.estadonacion.or.cr/images/ stories/biblioteca_virtual/otras_publicaciones/ECA-2014.pdf (consultado el 13 de septiembre de 2015).

Peters, Guy (2003). El Nuevo Institucionalismo: Teoría Institucional en Ciencia Política. Barcelona: Gedisa Editorial.

Petras, James y Morris Morley (1997). Los ciclos políticos neoliberales: América Latina "se ajusta" a la pobreza y a la riqueza en la era de los mercados libres. Nueva York: Universidad Estatal de Nueva York.

PNUD (Programa de las Naciones Unidas para el Desarrollo) (2004). La democracia en América Latina. Hacia una democracia de ciudadanos y ciudadanas. Buenos Aires: Aguilar, Altea, Taurus, Alfaguara.

RAFI (Rural Advancement Foundation International) (1997). Confinamientos de la Razón. Monopolios Intelectuales. Ottawa: RAFI. Disponible en: http://www.etcgroup.org/sites/ www.etcgroup.org/files/publication/pdf_file/Confinamientos.pdf (consultado el 18 de mayo de 2013).

Rodríguez-Piñero, Luis (2007). "La internacionalización de los derechos indígenas en América Latina: iel fin de un ciclo?" En Salvador Martí I Puig (ed.). Pueblos indígenas y política en América Latina. El reconocimiento de sus derechos y el impacto de sus demandas a inicios del siglo XXI. Barcelona: Fundació CIDOB, pp. 181-200.

Roitman Rosemann, Marcos (2005). Las razones de la democracia en América Latina. México: Siglo XXI.

Rouquié, Alain (1994). Guerra y pazen América Central. México: Fondo de Cultura Económica.

Rubio Carracedo, José(2006). "Democracia participativa: la construcción de la ciudadanía activa y del espacio público democrático”. En Poder Ciudadano, edición 18. 1 de Octubre de 2006. Disponible en: http://www.poderciudadano.org.pe/?p=508 (consultado el 9 de octubre de 2010).

Sáenz de Tejada, Ricardo (2013). "La democratización en Guatemala: algunas interpretaciones en contienda" En Revista Estudios Digital, núm. 1. Guatemala: USACEscuela de Historia. Disponible en: http://sitios.usac.edu.gt/revistahistoria/index. php?id=64 (consultado el 6 de septiembre de 2015). 
Sánchez Monge, Geiselle Vanessa (2012). Estudio sobre las dimensiones económicas de la actividad minera en Guatemala. El caso de la Mina Marlin, en San Marcos. Informe final. Guatemala: IPNUSAC.

Sanín Restrepo, Ricardo (2014). Teoría crítica constitucional. La democracia a la enésima potencia. Valencia: Tirant lo Blanch.

Sartori, Giovanni (1992). Elementos de teoría política. Madrid: Alianza Editorial.

Sonnleitner, Willibald (2009). "Dos décadas de elecciones en Guatemala: en las fronteras de la democratización”. En Estudios Sociológicos, vol. XXVII, núm. 80. México: COLMEX,pp. 509-549. Disponible en: http://www.redalyc.org/articulo.oa?id=59820676006 (consultado el 12 de septiembre de 2015).

Stavenhagen, Rodolfo (2008). Los pueblos indígenas y sus derechos. México: UNESCO.

Toledo, Víctor Manuel (2001). "Biodiversity and Indigenous Peoples". En Simon A. Levin (ed.). Encyclopedia of Biodiversity, t. 3. California: Academic Press, pp. 451-463.

Torres Rivas, Edelberto (1983). "Derrota oligárquica, crisis burguesa, revolución popular: sobre las dos crisis en Centroamérica”. En D. Castillo (ed.), Más allá de la crisis. México: CIAP.

Torres Rivas, Edelberto (1987). Centroamérica, la democracia posible. San José: Educa, FLACSO Costa Rica.

Torres Rivas, Edelberto (2004). "Los caminos hacia la democracia política en América Central”. En Diego Achard y Luis E. González (coord.), Un desafío a la democracia. Los partidos políticos en Centroamérica, Panamá y República Dominicana. San José: BID, IDEA, OED, PNUD, pp. 149-178.

Torres Rivas, Edelberto (2010). "Las democracias malas de Centroamérica. Para entender lo de Honduras, una introducción a Centroamérica”. En Nueva Sociedad, núm. 226, marzo-abril.

Torres Rivas, Edelberto (2010b). El Estado en Guatemala: iorden con progreso? Guatemala: PNUD.

Torres Rivas, Edelberto (2011). Revoluciones sin cambios revolucionarios. Ensayos sobre la crisis en Centroamérica. Guatemala: F\&\&G Editores.

Torres Rivas, Edelberto (2015b). “Guatemala: la corrupción como crisis del gobierno”. En Nueva Sociedad, núm. 257. Disponible en: http://nuso.org/media/articles/downloads/ COY1_Torres_Rivas_258.pdf (consultado el 3 de septiembre de 2015).

Trentavizi, Bárbara y Eleuterio Cahuec (2012). Las consultas comunitarias de "buena fe" y las prácticas ancestrales comunitarias indígenas en Guatemala. Guatemala. Disponible en: http://www.iripaz.org/listado_docs/pueblos_indigeneas/Las\%20Consultas\%20 comunitarias\%20indigenas.pdf (consultado el 25 de septiembre de 2015).

Van de Sandt, Joris (2009). Conflictos mineros y pueblos indígenas en Guatemala. La Haya: CORDAID. Disponible en: http://www.ciel.org/Law_Communities/Guatemala/ 
Cordaid\%20Guatemala\%20ES\%20broch-DEF.pdf (consultado el 26 de febrero de 2015).

Vázquez Marcial, Manlio Favio (2008). "La construcción del concepto de sujetos de derechos indígenas en el discurso de los derechos humanos". Tesis de maestría, FLACSO-Sede México.

Viales Hurtado, Ronny José (2007). “Gobernabilidad democrática en América Central. Una propuesta de análisis path dependence de carácter neo institucional a partir de la crítica de los planteamientos de J. Mahoney. El caso de El Salvador entre 1930 y 1960". En Diálogos. Revista Electrónica de Historia, vol. 8, núm. 1. San José: Universidad de Costa Rica. Escuela de Historia, pp. 26-43. Disponible en: http://historia.fcs.ucr.ac.cr/articulos/2007/voll/3_ Gobernabilidaddemocratica_AC.pdf (consultado el 28 de agosto de 2015).

Villamizar Lamus, Fernando (2009). "La tercera ola democratizadora". En Revista Auctoritas Prudemtium, núm. 3. Guatemala: Universidad del Istmo. Disponible en: http://www.unis.edu.gt/ap/fetch/tercera-ola-democratizadora-guatemala.pdf (consultado el 30 de agosto de 2015).

Walter, Mariana y Leire Urkidi (2015). "Consultas comunitarias. Respuesta a la minería a gran escala en América Latina”. En Fabio de Castro, Barbara Hogenboom y Michiel Baud (coords.). Gobernanza ambientalen América Latina. Buenos Aires: CLACSO, pp. 331370. Disponible en: http://biblioteca.clacso.edu.ar/clacso/se/20150318053457/ GobernanzaAmbiental.pdf $\neq$ page=332 (consultado el 20 de octubre de 2015).

WWF-International and Terralingua. (2000). Indigenous and Traditional Peoples of the World and Ecoregion Conservation: An Integrated Approach to Conserving the World's Biological and Cultural Diversity. Switzerland: WWF-International and Terralingua.

Yagenova, Simona Violetta (coord.) (2012). Laindustriaextractivaen Guatemala:políticaspúblicas, derechos humanos y procesos de resistencia popular en el período 2003-2011. Guatemala: FLACSO. Disponible en: http://www.alainet.org/images/FLACSO \%20-\%20Armado\%20-\%20 La\%20Industria\%20extractiva\%20y\%20su\%20impacto\%C5\%A0.pdf (consultado el 3 de septiembre de 2015).

Zarsky, Lyuba y Leonardo Stanley (2011). Buscando oro en el altiplano de Guatemala: beneficios económicos y riesgos ambientales de la mina Marlin. Medford, Instituto de Desarrollo Global y Medio Ambiente. Disponible en: http://www.ase.tufts.edu/gdae/policy_research/ marlinminespanish.pdf (consultado el 12 de octubre de 2014).

Zovatto G., Daniel (2001). "La reforma político-electoral en América Latina: evolución, situación actual y tendencias. 1978-2000”. En Revista del CLAD, núm. 2l. Caracas, pp. 143-188. 


\section{Democracia, confianza y ciudadanía en México Juan Mora Heredia
Margarita Jiménez Badillo}

\section{Introducción ${ }^{1}$}

A poco más de dos lustros de alternancia, México sigue inmerso en un inconcluso trasiego político-cultural. Se esperaba la instauración de un poder republicano igualitario y justo, que a su vez promoviera una distribución más equitativa de la riqueza social; en su lugar tenemos procesos electorales marcados por una intrincada normatividad, partidos políticos convertidos en empresas corporativas y una clase gobernante desprestigiada ante la sociedad; escenario bajo un ambiente estructural de mayor exclusión social, desafección política y creciente inseguridad pública. La promesa de una transición pronta y expedita quedó limitada al enfrentar una porfiada realidad en la que siguen vigentes acciones y privilegios de viejo cuño.

En este entorno en el que vive la sociedad mexicana, oportuno es plantearnos si la sola aplicación de reglas político-electorales posibilitan una esencia democrática. Si bien referirse a un régimen democrático es pensar en la concurrencia de los diferentes grupos sociales a las zonas de poder institucional - vía partidos políticos, parlamentos y gobierno-, también lo son las implicaciones del factor simbólico-cultural en la reorganización de la vida pública, en términos de construcción de identidades políticas y formas de intervención social. De ahí que en este estudio se planteen interrogantes, una vez instalada la democracia electoral en el país: icómo ha sido recibida y procesada ésta por los mexicanos?, iqué percepción tiene dicho colectivo acerca de la democracia, así como de las implicaciones en sus formas de participación y condición ciudadana? Tales son los ejes que rigen la presente propuesta.

\footnotetext{
${ }^{1}$ Artículo desarrollado en el marco del Observatorio de las Democracias: Sur de México y Centroamérica. Centro de Estudios Superiores de México y Centroamérica (CESMECA) de la Universidad de Ciencias y Artes de Chiapas (UNICACH). San Cristóbal de Las Casas, Chiapas.
} 
El período de la posguerra en la década de los setenta evidenció una inexorable transformación ante el embate de variados procesos asociados con la globalización y el agotamiento del paradigma del trabajo como eje de la vida social. Una excepcional coyuntura ${ }^{2}$ que sirve de fundamento para la aplicación de reformas económicas con estrictos ajustes en materia fiscal, de empleo, salarial o de consumo, que si bien estabilizaron las economías, sus impactos negativos en materia social son claramente visibles con la multiplicación de la pobreza, ganando escenario agrupamientos otrora marginados y que hoy tienen mayor visibilidad y reconocimiento público.

Este "auge", en el caso de los países europeos, se inscribe en el marco de la crisis del modelo económico de bienestar social y la fragmentación de los actores políticos tradicionales. Sociedades complejas con un estado en retirada que hizo emerger la contradicción entre la idea de igualdad de derechos políticos ciudadanos y elreconocimiento a la diversidad invocado por la pluralidad multicultural. Las democracias contemporáneas, por tanto, han afrontado nuevos desafíos en el ámbito de la representación política, sin estar plenamente resueltos los quebrantos causantes de dichas acciones colectivas.

De ahí que en años recientes sean reavivados los debates teóricos en torno a la ciudadanía y la sociedad civil como alternativas de interpretación. Fijada la inclusión del "otro" como elemento primordial en el montaje de un mundo más justo y equitativo, desplazando los privilegios de antaño, su institucionalización no ha resultado sencilla. En lo más inmediato de este proceso, el modelo democrático se ha impuesto desde el siglo XX como pauta de gobierno predominante en buena parte del orbe, legitimada por su compromiso de fortalecer la condición ciudadana a partir del reconocimiento universal de los derechos políticos.

Se trata de un ideal democrático encaminado a materializar dicho propósito, vía el impulso de un sistema de representación en el que los gobernados, a través del sufragio universal, eligen a sus delegados, la gestión legislativa, y de un diseño institucional en el quepartidos políticosy parlamento son nodalesparaelfuncionamiento. Laintermediación política es necesaria para legitimar decisiones gubernamentales, aunque ésta ha derivado en una dilatada inclinación por su lógica procedimental. Un quehacer cuyo foco de atención es la estrategia de poder de las élites, expresado en los mecanismos y formas de acceso a las esferas de decisión política. Sobre el particular, ya desde la década de los noventa David Held anotaba:

\footnotetext{
${ }^{2}$ Momento epocal de gran trascendencia en el campo social con el surgimiento de actores emergentes reivindicando los derechos civiles, la libertad de expresión, la lucha anticolonialista. Estos eventos pusieron en crisis al "consenso ortodoxo", en tanto que visión doctrinaria predominante en el discurso social, y ello dio apertura y reconocimiento a teorizaciones marginadas o ignoradas durante el lapso de la Guerra Fría. Se produjo un cisma epistemológico de gran calado, que obligó a una reestructuración de los paradigmas predominantes (Castañeda, 1987). Para tener un panorama económico y político de esta transformación en el mundo occidental (ver Habermas, 1994; Paramio, 1988; Escalante, 2015).
} 
En el siglo XX la teoría de la democracia se ha centrado, en concreto, en el contexto organizativo y cultural de los procedimientos y en los efectos que ese contexto tiene en el "gobierno de la mayoría”. Desdeel desarrollo de la teoría del elitismo competitivo en la obra de Max Weber y Joseph Schumpeter hasta la elaboración del pluralismo clásico en los escritos de Robert Dahl, o la crítica de estas ideas en los escritos de los marxistas contemporáneos, el centro de atención de la teoría de la democracia moderna han sido las condiciones que favorecen o impiden la vida democrática de una nación (Held, 1992: 362).

A pesar de las desmesuradas expectativas promovidas por los apologistas del mundo libre ante el "triunfo de la democracia", ${ }^{3}$ lo cierto es que, al desplomarse el adversario que servía para justificar las presumibles bondades de los sistemas e instituciones democráticas, resulta más claro ahora advertir muchas de sus insuficiencias y limitaciones. Se han puesto a la orden del día los problemas de ingobernabilidad democrática que en un pasado reciente hallaron condiciones propicias para ser disimuladas y contenidas. Igualmente, se advierte una tendencia a ultranza por atribuir al cuerpo político-electoral una influencia excesiva en la configuración o no de un orden político estable y gobernable, soslayando las condicionantes socioeconómicas y político-culturales en las que opera.

En esta tesitura, para Latinoamérica el tránsito a la democracia se centró en abrir paso a las libertades políticas, luego de años de gobiernos autoritarios que limitaron al mínimo las prácticas ciudadanas. La oleada democrática de los años setenta y ochenta, presente en todo el continente latinoamericano, fue la respuesta al dilema: reforma o revolución. ${ }^{4}$ De esta forma, lo mismo dictaduras militares que gobiernos populistas o autoritarios enfrentaron el juicio de las urnas, inaugurando con ello un nuevo talante de legitimidad

\footnotetext{
${ }^{3}$ Es de no olvidar que para el avance y consolidación de este proyecto democratizador, encaminado a inclinar la balanza hacia el bloque occidental en el ocaso de la guerra fría, un papel fundamental lo desempeñó la Comisión Trilateral, una organización donde coincidían personalidades del mundo político, económico y académico, de Japón, Estados Unidos y Europa, enfocados a analizar las tendencias del mundo desarrollado. Fue un bastión intelectual determinante para redefinir el mapa geopolítico, el sistema financiero internacional, y con él las relaciones económicas mundiales. En el terreno político, una de las tesis centrales promovidas por este grupo era la de la ingobernabilidad, producto de la insuficiencia del Estado para satisfacer las demandas sociales. Rebasado en sus capacidades, como fruto de un intervencionismo económico que no le correspondía, hermanado al apogeo de acuerdos corporativos con las masas, la situación obligaba al saneamiento de las finanzas públicas y un incremento de las libertades políticas. En consecuencia, la crisis de gobernabilidad sólo podría ser atajada con un Estado mínimo, y una amplia democracia política. Véase La Comisión Trilateral y la coordinación de políticas del mundo capitalista (CIDE, 1977-1978).

${ }^{4}$ Acerca de este debate presente en el pensamiento latinoamericano, icónica es la obra de Norbert Lechner, en particular La conflictiva y nunca acabada construcción del orden deseado, Madrid, CIS, 1984. Igualmente, Los límites de la democracia, Buenos Aires, CLACSO, 2 t., 1985.
} 
en función de la cual se proyectaba la modernización institucional del orden político y económico en el continente; una eventualidad política y económica a la que México no fue ajeno.

Deesta manera, a pesardelas ensalzadas virtudes dispensadas a la matriz democráticoelectoral en el apuntalamiento de este proceso democratizador, indispensable es rastrear los alcances de dicha situación en la dimensión participativa. Si bien referirse a un régimen democrático es pensar en la concurrencia de los diferentes grupos sociales a las zonas de poder institucional vía partidos políticos, parlamentos y gobierno, también lo son las implicaciones del ingrediente simbólico-cultural en la reorganización de la vida pública, en términos de construcción de identidades políticas y formas de intervención social.

Según los datos ofrecidos por las encuestas de opinión, entre los mexicanos existe una frágil vocación asociacionista, que concentra su mayor incidencia en el espacio familiar y de amigos cercanos. Y cuando se llega a participar en propósitos colectivos, se hace de manera esporádica y casual. Por igual, contra el anhelo de las élites liberales de una mayor participación política formal, ésta no exhibe un aumento en su condición. En su lugar, es por demás evidente el rechazo entre la mayoría de la población hacia las entidades y actores vinculados al circuito institucional - diputados, policía, partidos, gobernadores, etcétera-, aunque a contramano exista apoyo y aceptación al ideal de la democracia como forma de gobierno.

Con esta ambivalencia atravesando la transición política, imprescindible es indagar sobre qué bases valorativas se está cimentando la asociación entre los diferentes grupos sociales, así como referir las variadas estrategias de cooperación, formales e informales, que posibilitan el fortalecimiento de acciones colectivas con sentido público. Una y otra son piezas clave para forjar el imaginario ciudadano en su arquitectura simbólica y de organicidad política.

A partir de esta premisa, para el desarrollo del presente estudio, se utilizan datos de las Encuestas de Cultura Política (ENCUP) de 2001, 2003, 2005, 2008 y 2012, realizadas por el Gobierno federal; una década de registros que brindan pistas acerca de las tendencias sobre las cuales se ha deslizado el cambio cultural y político de México en este lapso.

\section{La idea de democracia y sus expectativas}

El año 2000 fue un punto de inflexión en la vida política de México, con la transferencia del mando gubernamental del Partido Revolucionario Institucional (PRI), a una nueva élite política agrupada en el Partido Acción Nacional (PAN). Este proceso fue históricamente relevante, con una sobredimensionada campaña mediática enfocada a vender la imagen de Vicente Fox como promotor de la demandada innovación política. Evidente fue el éxito obtenido, para lo cual el imaginario de una sociedad educada en la 
cultura política del caudillo resultó altamente propicio; ello sin dejar de lado el apoyo que brindaron grupos de variado signo para atraer el voto útil a favor del candidato Fox.

Se inauguró así una trascendente oportunidad política que motivó un amplio júbilo colectivo, pues se consideraba que el país ingresaba a una promisoria etapa de modernización institucional. Un par de sexenios después, en medio de una gran frustración por las expectativas no cumplidas, el partido derrotado en 2000 y en 2006 habría de tener un retorno triunfante, y dejó para el análisis los efectos de esos doce años en la transformación del país. Al situarse como uno de los temas de interés la indagación en el desmontaje del patrón autoritario y su desplazamiento por la noción democrática, surgió la pregunta expresa: icree usted que México vive en una democracia? Los mexicanos respondieron lo señalado en la gráfica 1 .

Gráfica 1. Percepción de si México vive en una democracia

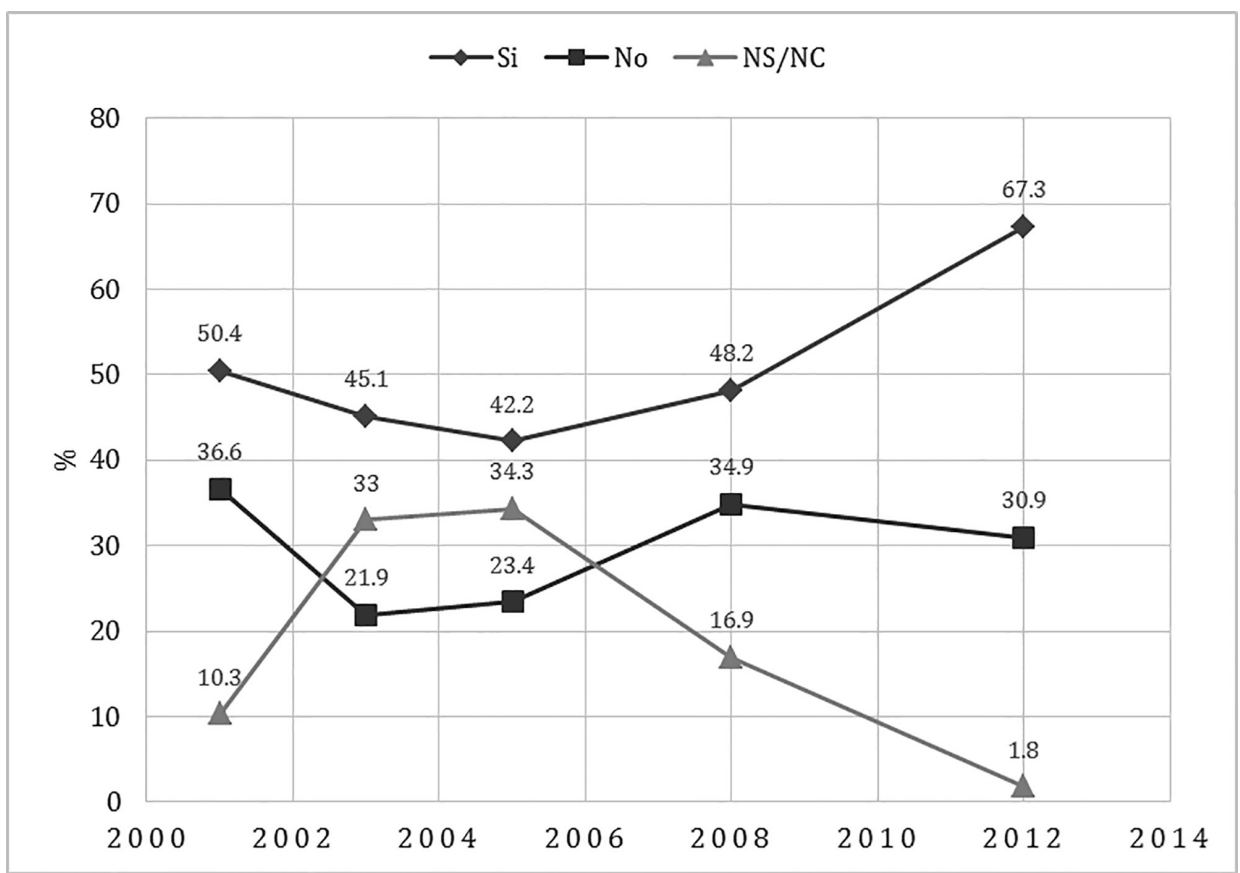

Es importante distinguir dos aspectos: por un lado, después de las elecciones de 2000, apenas la mitad de la población admitía que en México se vivía una democracia; una percepción del 50.4\% en 2001, con tendencia a la baja en los siguientes años, hasta tener un repunte del $67.3 \%$ en 2012. Resalta la cifra registrada inicialmente, ya que nos presenta una sociedad polarizada en la que uno de cada dos mexicanos asume como 
democratizadoras las modificaciones políticas e institucionales en curso, mientras que la otra parte manifiesta su escepticismo o incredulidad. Sustancialmente, ello es resultado de la frustración ante las promesas incumplidas del candidato del PAN, quien aseguraba que realizaría un golpe de timón en el acontecer político del país. Confiando en su extrovertida personalidad, se pensaba que su liderazgo llevaría a buen puerto la ensalzada transición política. En una suerte de democracia “delegativa” (O’Donnell, 1994), los votantes le otorgaron a Vicente Fox la legitimidad a través de las urnas, esperando una renovación expedita y a fondo del régimen, situación que, sin embargo, quedó frenada.

Por otra parte, los números referidos a las categorías "no sabe" y "no contestó" son altos durante el foxismo, incluso por encima del "no", para exhibir un declive al final de la década. El sentido de estos datos revela perplejidad ante un fenómeno sin precedentes en la historia política del país, ya que por años se habían realizado elecciones diseñadas y escrutadas desde el gobierno, con un partido hegemónico que abarcaba todos los ámbitos de la organización social. Tales restricciones concitaban una legítima aspiración democrática, la cual es coligada directamente con las libertades individuales. Una dualidad complementada con elecciones creíbles y transparentes como mecanismo de conexión entre sociedad y gobierno.

De ahí que, cuando se invoca el espíritu democrático, éste se vincula inmediatamente con las libertades individuales —expresión, organización, creencia- y con el sufragio universal, engarce que, sin embargo, presenta el problema de la ausencia de un precedente republicano, de percibir la democracia como una representación abstracta. Se trata de un modelo deseable, pero sin un entramado de normatividades e institucionalidades que sirva de soporte a un vigoroso Estado de derecho, regulador de la convivencia social, donde los valores de reconocimiento, libertad y tolerancia sean el fundamento en las reglas de actuación tanto para gobernantes como gobernados.

En ese sentido, la valoración exhibida por los mexicanos en los gobiernos panistas fue de una mayor estima a las libertades, en semejanza a lo vivido en sexenios previos. Ello fue acompañado de una considerable eficiencia procedimental en los procesos electorales. No obstante la persistencia de comicios polémicos, hubo un balance favorable a la infraestructura electoral, aunque la misma sea objeto de debate por su elevado costo para el erario y aunque dicha funcionalidad no haya sido reforzada con una completa nitidez en el uso de los recursos por parte de sus actores políticos. De esta forma, el desaliento es con los políticos y sus prácticas, no con las instituciones en sí, discrepancia que se traduce en desafecto hacia los políticos y a cierto tipo de instituciones consideradas taxativas para las libertades de los individuos.

Hay, pues, una profunda estima de la sociedad mexicana por sus libertades, incluso por encima del bienestar económico, tal como se observa en el gráfica 2, cuando se realiza la pregunta: ¿qué tan dispuesto estaría usted a sacrificar sus libertades a cambio de vivir sin presiones económicas? En contraparte, la indecisión del "no sabe" o "no contestó" 
disminuye sustancialmente, lo cual manifiesta un progreso en el fortalecimiento de una convicción política, sea cual sea ésta.

Gráfica 2. Sacrificar sus libertades, a cambio de vivir sin presiones económicas

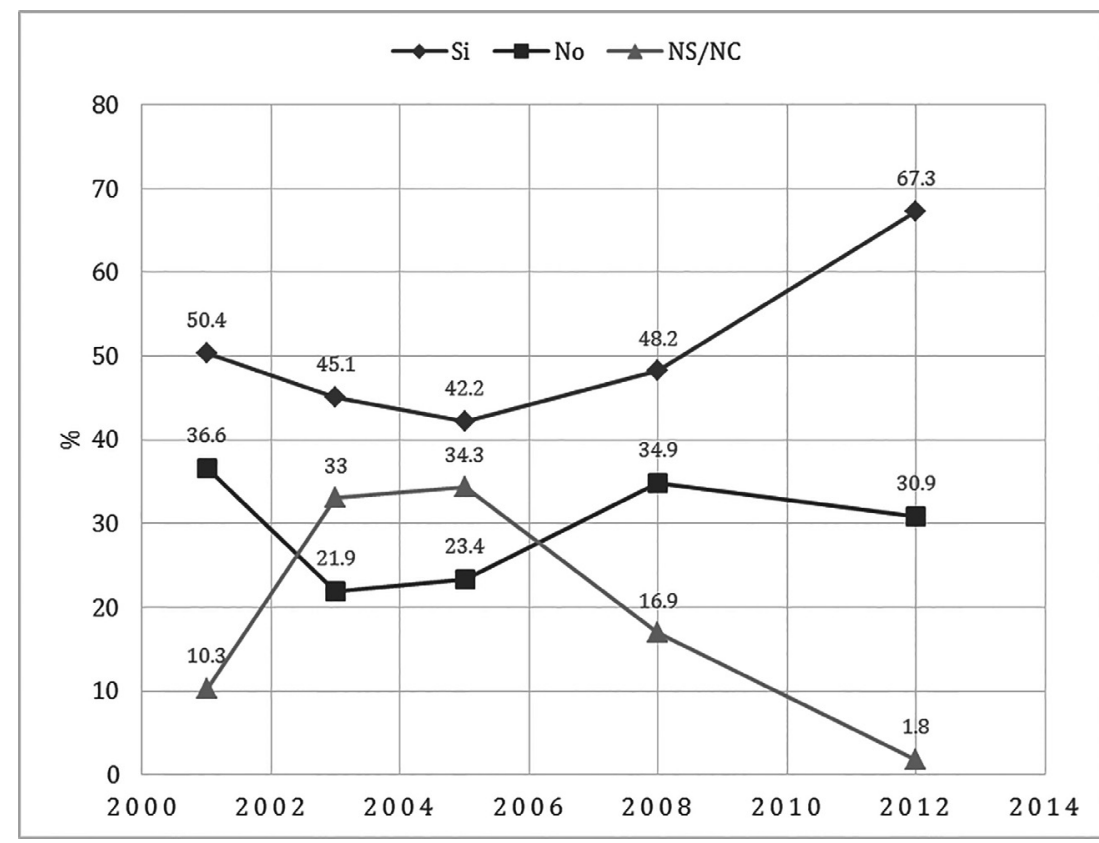

Fuente: ENCUP.

Las elecciones de 2012 sirvieron para cerrar doce años de sucesión partidista. Esto dio paso a una nueva mudanza y a enormes desafíos por afrontar. En suma, si ha de evaluarse la influencia de la alternancia en el arraigo de este imaginario en la sociedad, todo parece indicar que fue precaria con una escasa satisfacción de la población en la democracia, como es posible advertir en la gráfica 3.

Durante la primera década del siglo XXI, entre 60 y 70 de cada 100 mexicanos se conciben "poco satisfechos" con la democracia desplegada en el país, mientras un promedio del 5\% en ese mismo período están "muy satisfechos", y del 14 al 25\% se consideran "nada satisfechos". Incluso el rubro de "ns/nc" registra dígitos superiores -6 a 12\%- a los que se consideran "satisfechos". Este desafecto indica la frágil proximidad, reconocida por los mexicanos, entre el programa electoral y sus vivencias cotidianas. Un proyecto sobre el cual se estructuró la idea de la transición democrática, pero que no logró cuajar y estuvo lejos de satisfacer las reivindicaciones presentes en diferentes 
ámbitos desde el inicio de la alternancia. Hubo momentos con ligeros despuntes en la preferencia, pero sin alcanzar la consolidación total.

Desde este panorama nacional, algunos momentos coyunturales parecen influir en la percepción acerca de la democracia. En los primeros años del gobierno foxista, ante un giro político aguardado, pero no cristalizado, el desencanto es patente. Más adelante, el pluralismo partidario y el crecimiento de un potencial Gobierno de izquierda, condensado en el liderazgo de Andrés Manuel López Obrador, hacen renacer la expectativa de transformación. La renovada confianza en la democracia electoral es fortalecida por la oleada de gobiernos de izquierda en el continente latinoamericano. Dicha finalidad tendrá su quiebre en unas polémicas elecciones presidenciales de 2006, en las que por una minúscula diferencia el PAN repitió al frente del gobierno, pero dejando grandes dudas en la realización del proceso. Las secuelas fueron un Instituto Federal Electoral debilitado, una sociedad políticamente confrontada y un presidente legal con bajos niveles de legitimidad.

\section{Gráfica 3. Satisfacción democrática}

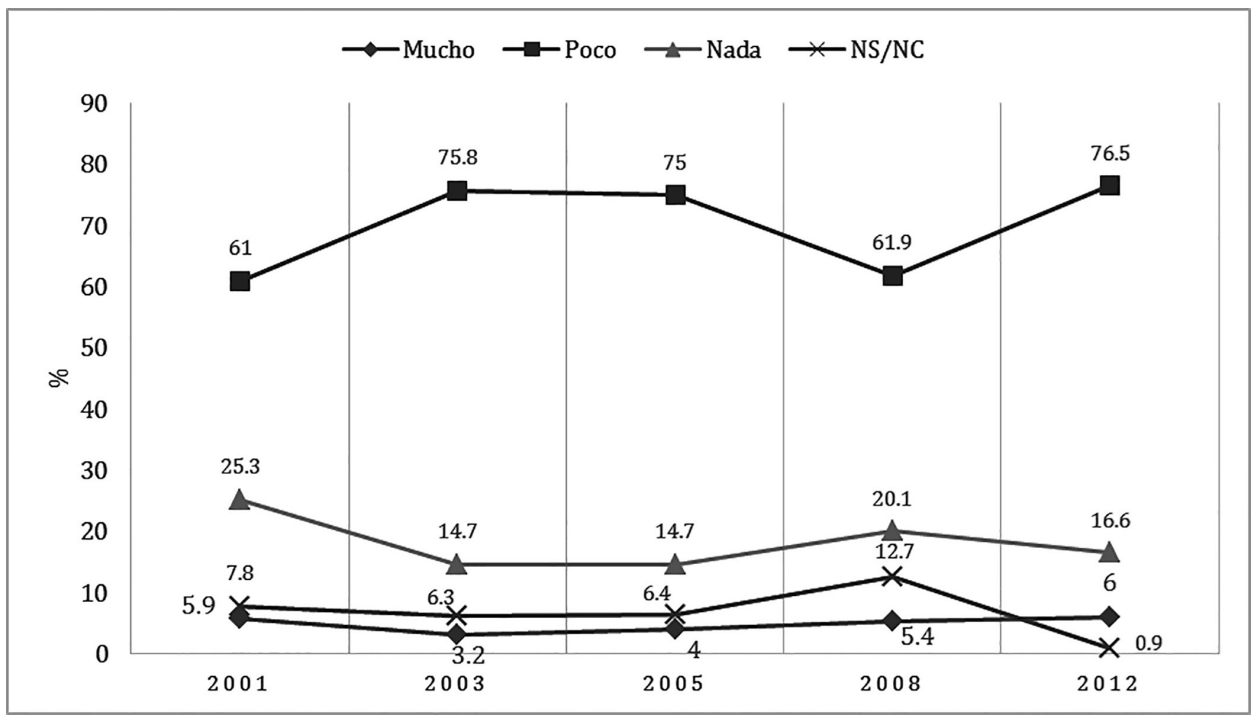

Fuente: ENCUP.

Esta fractura institucional y social nos permite entender el descenso en la idea de representación democrática compendiada en la encuesta de 2008, aunque en 2012 apunta una recuperación sustantiva en la directriz prefigurada en años previos. Una pauta de opinión factible de ser explicada por el resurgimiento de la movilización política 
conducida por Andrés Manuel López Obrador. Con el país encarando una severa crisis financiera mundial, una persistente desigualdad social y el desborde de la inseguridad pública, de nueva cuenta, la expectativa del líder dirigiendo el cambio esperado, vía la contienda electoral, se hizo presente..$^{5}$ El resultado no le fue favorable a la Coalición Movimiento Progresista (PRD/PT/MC), y ganó la elección Compromiso por México (PRI/PVEM), con una votación suficiente para declararla legal, no obstante la acusación a los triunfadores de usar medios ilícitos para allegarse las preferencias electorales.

Pertinente es hacer ahora algunas consideraciones relativas al comportamiento electoral de los mexicanos durante las recientes décadas. Si se atienden los sesgos del binomio participación/abstencionismo en los diferentes comicios, desde 1961 a la fecha se observa una tendencia a la baja en la actividad electoral. Según la gráfica 4, entre 1961 y 1976 la participación registraba una constante arriba del 60\%, y el abstencionismo menos del 40\%, en tanto que para 1979, estrenándose la primera reforma política del régimen priista, después de varias décadas de férreo control, hubo un equilibrio entre participación y abstención.

La paridad se rompe en 1982, cuando en medio de una severa crisis económica y política, las elecciones presidenciales arrojaron una participación superior al 70\% y un abstencionismo de menos del 30\%. El resto de la década de los ochenta estuvo marcado por lo que Rolando Cordera y Carlos Tello denominan "la disputa por la nación”, que se tradujo en la instauración de un nuevo modelo económico, acompañado de una áspera confrontación intraélites en el partido hegemónico, pugna que derivó en la salida del PRI de la llamada "corriente democrática", la cual, aliada a diferentes grupos de izquierda, contendería en las elecciones de 1988 bajo el membrete de Frente Democrático Nacional.

Esta crisis política abrió la expectativa de una posible transformación por la vía electoral que se expresó con un incremento en la participación de 1991. Esta efervescencia se mantuvo presente en todo el decenio, aunque con motivaciones diferentes: en 1994, acicateada por el desasosiego ante un eventual desbordamiento de la violencia, después del levantamiento armado del EZLN en Chiapas y el asesinato del candidato del PRI a la presidencia Luis Donaldo Colosio; en 1997, la ciudadanización del IFE y la pluralidad partidista animaron la expectativa de una superación pronta del antiguo régimen.

Después de la euforia de 2000, es notable la caída de la participación electoral durante todo el período de la alternancia panista, hasta que volvió a desplegar un brote importante en las elecciones de 2012, para desplomarse nuevamente en 2015. En suma, se constata que hubo una asistencia importante a las urnas por parte de los mexicanos en situaciones emergentes, aquellas en las que ellos consideran que su participación podría coadyuvar a una contención del conflicto, o bien apoyar el cambio. Tal motivación está estrechamente vinculada con el fenómeno de la comunicación política o el marketing electoral, con los

\footnotetext{
${ }^{5}$ Cabe destacar que la ENCUP 2012 fue levantada entre el 17 y el 28 de agosto de 2012.
} 
mass media desempeñando un papel nodal, construyendo escenarios ideales o catastróficos según el interés en juego. De esta forma, pensar el componente electoral como evidencia irrefutable de una robustecida condición democrática en la sociedad mexicana es algo que conviene asumir con las debidas reservas.

\section{Gráfica 4. Participación electoral}

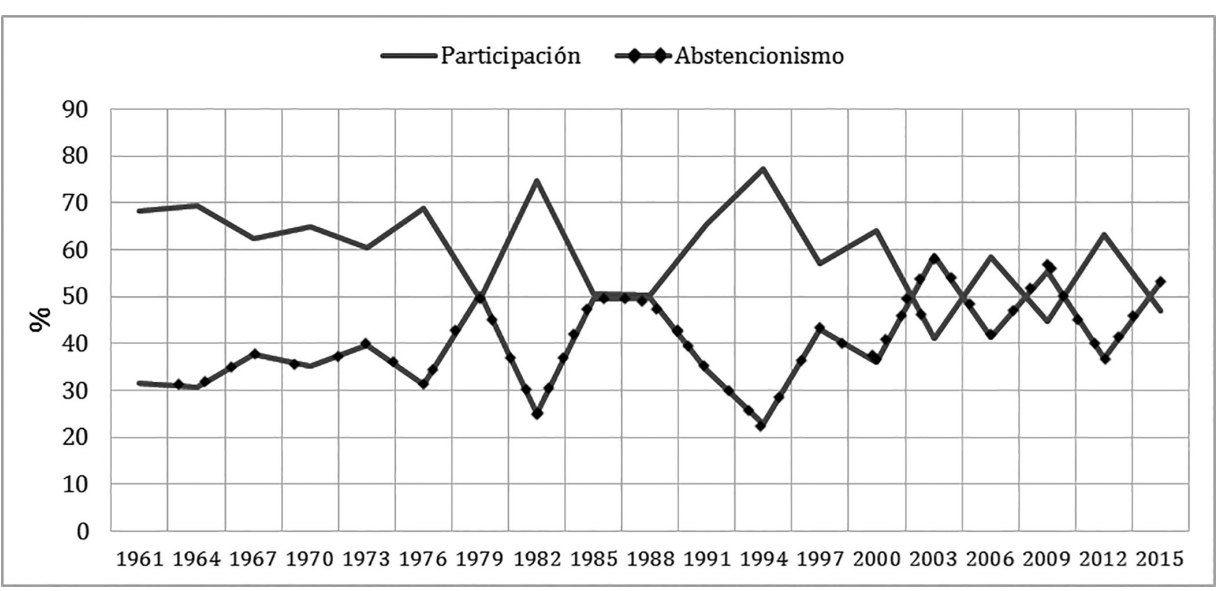

Fuente: Almanaque mexicano 2008, IFE 2009, 2012.

En retrospectiva, durante el esplendor del partido hegemónico, con una sociedad altamente corporativizada, la participación en las urnas fue, en buena medida, inducida. Por lo tanto, a pesar de que las jornadas electorales se realizaron en tiempo y forma, no se podría hablar de la existencia de una raigambre democrática en la que los electores se reconozcan como parte del poder público, y se sientan representados en la toma de decisiones. En cuanto que esto no fue así, no hay en el imaginario político una tradición democrática. Consecuentemente, ¿cómo querer ser democráticos, si en el antecedente histórico no existe un referente al respecto?

La apertura político-electoral de finales de los años setenta abrió tímidamente las puertas para una expresión libre del voto ${ }^{6}$ y proyectó entre la población la confianza de

\footnotetext{
${ }^{6}$ Así, "el comportamiento electoral se considera una conducta que vincula a la población con el poder, es decir, a la sociedad con el Estado y que se manifiesta a través del voto [...]. El voto tiene entonces la función de legitimar al gobierno, de darle una base de consenso, pero al mismo tiempo sirve para poner límites a los líderes políticos que deben someterse cada cierto tiempo al escrutinio de los ciudadanos para maximizar su posibilidad de ser reelectos. El sufragio cumple también una función de control político, en la medida en que ofrece canales institucionales para la manifestación de demandas, preferencias e incluso disensos y, desde luego, para el cambio pacífico de las élites gobernantes" Peschard (2000).
} 
que su decisión para elegir gobernantes estaría validada por una sólida certidumbre legislativa. Dicha certeza se asentaba en la figura de un sistema electoral eficiente y funcional, cuyo punto culminante fue la ciudadanización del IFE en los años noventa.

A partir de este diseño, México apostaba por el fortalecimiento de un andamiaje electoral para conducir su experiencia de cambio político, a diferencia de otros países como España, Portugal y los del Cono Sur, que se inclinaron por pactos fundacionales para reconstruir su extenuada convivencia política. La construcción de un sistema de partidos plural y de un sistema electoral competitivo fue el basamento de la mecánica política, que como tal sentaba las bases para el rumbo futuro de esta incipiente apertura política.

Bajo esta óptica, el perfeccionamiento de los engranajes operativos para realizar comicios se convirtió en la razón de ser de la discusión política, en tanto se emplazaba como su principal gestor al IFE, y éste, eficaz en ese rubro, se ponía a la vanguardia de sus pares en el mundo, como ejemplo a seguir por varias naciones dada su pulcritud en la organización de elecciones.

Empero, la formalidad institucional no se explica por sí misma, ni mucho menos es ajena a los intereses de poder. Esta premisa quedó al descubierto con la distorsión que sufrió la elección de consejeros del IFE en el año 2003. Los intereses partidarios se impusieron entonces al interés público, al elegirse con base en cuotas y acuerdos tras bambalinas a los árbitros electorales. El estigma a cuestas puso en duda la imparcialidad del IFE en sus decisiones y minó su fortaleza y confianza ante los actores políticos, hasta verse rebasado por los acontecimientos durante los comicios presidenciales de 2006. El polémico resultado derivó en el impulso de una nueva reforma electoral en 2007, así como en la sustitución de la mitad de la consejería electoral del IFE.

Con esta fractura como antecedente, después de las elecciones de 2009 analistas del más variado signo ideológico ${ }^{7}$ advertían el agotamiento del modelo electoral como pivote

\footnotetext{
${ }^{7}$ Entre otros, Merino, Mauricio. "La vuelta del dinosaurio”, en El Universal, 8 de julio de 2009; Valdés Ugalde, Francisco. "¿Más de lo mismo?", en El Universal, 19 de julio de 2009, también "1996-2009”, El Universal, 26 de julio de 2009; Aguilar Villanueva, Luis. "La responsabilidad de gobernar”, en Reforma, 15 de julio de 2009; Dresser, Denise. "Anular es votar", en Reforma, 15 de junio de 2009; Casar, María Amparo. "Cambio o continuidad", en Reforma, 14 de julio de 2009; Aguayo Quezada, Sergio. "Ética y política" en Reforma, 14 de julio de 2009, y del mismo autor "Ética y cinismo", en Reforma, 8 de julio de 2009; Meyer, Lorenzo. "Vencieron ipero convencieron?", en Reforma, 9 de julio de 2009; Reyna, José Luis. “iNuevo PRI?", en Milenio Diario, 13 de julio de 2009; del mismo autor, "iSin salida?, en Milenio Diario, 20 de julio de 2009; Silva-Herzog Márquez, Jesús. "La receta y el quejido”, en Reforma, 13 de julio de 2009; Aziz Nassif, Alberto. "Un juguete chino", en El Universal, 21 de julio de 2009 y "¿Qué hacer con este sistema político?”, en El Universal, 28 de julio de 2009; Cárdenas, Jaime. "Medidas urgentes para desmantelar el autoritarismo”, en Emeequis, 20 de julio de 2009; Hernández, Juan Luis. "Volver al poder sin convicción democrática", en Emeequis, 20 de julio de 2009; Córdova, Arnaldo. "Después de las elecciones. El bloque en el poder", en La Jornada, 12 de julio de 2009; Córdova Vianello,
} 
de la transformación social y política. En algunos más abiertamente, en otros no tanto, se hace patente la coincidencia en reconocer la limitación de la democracia electoral como eje de una transformación esencial en el régimen político mexicano. En otros términos, se subraya la necesidad de avanzar en la reestructuración o el desmantelamiento de las reglas autoritarias sobre las cuales se edificaron los privilegios de las élites, componendas que se mantienen intactas al no ser objeto de negociación en las reformas políticas de la transición.

Los factores del poder, como los llamó en su momento Pablo González Casanova, ${ }^{8}$ son el ejército, el clero, empresarios nacionales y extranjeros y caciques regionales, quienes influyen en las decisiones públicas. Se suma a los anteriores el dilatado enclave de los corporativos vinculados con los mass media, en particular el duopolio de las televisoras, cuyo emporio económico se fundó y afianzó bajo el amparo de las dispensas políticas obtenidas de todos los partidos que han participado en el gobierno, los que procuraban con ello beneficiarse de espacios u opiniones favorables a sus intereses en las diferentes emisiones televisivas.

A contramano, mientras la institucionalidad política está en vías de reconstrucción en su dimensión formal, a su alrededor se gestan vacíos y debilidades ostensibles, con dimensiones encontradas entre sí. Existe una normatividad encaminada a trazar el diseño institucional, loable en toda la extensión, pero que al dejar intactas las prerrogativas creadas en el pasado, se confronta con una lógica de ampliación e imposición de intereses por parte de los poderes fácticos.

Es decir, por un lado se intenta construir una nueva institucionalidad política, en tanto que en el otro extremo los diferentes actores juegan su propio juego, sin restricción

Lorenzo. "Rediseñar al Estado", en El Universal, 29 de julio de 2009; Romero, Jorge Javier. "Quieren una oligarquía bipartidista”, en El Universal, 13 de agosto de 2009.

8 Al respecto dice: "Los verdaderos factores de poder en México — como en muchos países hispanoaméricanos - han sido y en ocasiones siguen siendo: a) los caudillos y caciques regionales y locales, b) el ejército, c) el clero, d) los latifundistas y los empresarios nacionales y extranjeros. Se trata en todos los casos, de instituciones que han influido o influyen directamente en la decisión gubernamental, y cuya acción como instituciones políticas no sólo era ajena a la teoría euroamericana de la democracia (para la vida política todos ellos deberían haberse organizado como ciudadanos), sino que incluso la mayoría eran el blanco de toda ideología liberal" (González Casanova, 1980: 45-46). También es de revisar el ilustrativo ensayo de María Amparo Casar. "Poderes Fácticos. Ella señala ahí algunos rasgos de los poderes fácticos, tales como: "l) No dependen de la voluntad de los ciudadanos ni de sus representantes, pero condicionan la representación; 2) no son parte formal de toma de decisiones, pero tienen instrumentos para influir de manera desproporcionada en las decisiones reservadas a los poderes públicos, en particular al Ejecutivo y al Legislativo; 3) no tienen representación formal en el Congreso o en el gobierno pero pueden poner vetos a la acción pública; 4) crecen al amparo, con el beneplácito, cuando no con el contubernio de las autoridades, pero las vuelven su rehén; 5) derivan una "renta" extraordinaria de la que están excluidos otros actores" (Casar, 2009). 
alguna a sus ambiciones o privilegios. Queda como una retórica pomposa y hueca la idea de fortalecer el Estado de derecho. Sin un pacto político que los comprometa a reivindicar un proyecto de Estado, los grupos de interés se desbordan imponiendo su ley; hacen del gobierno su rehén, y de los recursos en las diferentes instancias — desde la federal hasta la municipal, pasando por los espacios legislativo y judicial - un apetitoso botín.

A pesar de los loables esfuerzos procedimentales, México no avanzó en la transformación de la estructura de poder real. Los actores de viejo cuño persisten en sus maniobras para mantener sus zonas de influencia, para lo cual realizan una mutación ajustándose a la normatividad, promovida y avalada por ellos, para legitimar su actuar. Con una institucionalidad y legalidad votada desde las esferas del poder, las élites justifican sus privilegios amparados en el discurso electoral. ${ }^{9}$ En suma, conforme ha transcurrido el tiempo de la democracia, más palpable es la insuficiencia de los dispositivos solamente electorales, para hablar de un cambio político de fondo.

De esta forma, la democracia mexicana nos brinda un paisaje con personajes que cambian de partido varias veces, con agrupamientos que promueven a sus candidatos al resguardo de cuotas partidistas, con servidores públicos que no rinden cuentas de sus gestiones y manejan la información y los bienes a su cargo a su discreción, y con una clase política que arropa a su estirpe para incorporarla al circuito de poder. Pero todos forcejeando por obtener los mayores beneficios para su causa, al margen del interés público y de la deseable construcción de la polis.

Estamos, pues, frente a un galimatías donde coexiste un moderno sistema electoral del más alto grado de funcionalidad, con un quehacer político revestido por los más añejos valores corporativos y autoritarios. Esto da forma a un híbrido político, ${ }^{10}$ con una reconocida democracia electoral, pero muy lejos de una democracia liberal donde libertad e igualdad sean el denominador común para toda la sociedad.

En este contexto, siendo las elecciones del año 2000 la coyuntura más importante de los últimos tiempos, la mecánica del cambio, asentada sólo en lo electoral, dejó de atender una reforma de Estado profunda. Se impuso una visión conservadora (Valadés, 2014) que obstruyó las esperadas modificaciones de fondo. A la parte de las libertades

\footnotetext{
${ }^{9}$ El conflicto de clase es una noción que el Estado mexicano ha sido muy cuidadoso de mantener alejado del imaginario de la sociedad mexicana. En ese sentido, se ha difundido la idea de que las condiciones de vida son resultado de las bondades del gobierno, y más recientemente de los esfuerzos individuales. En consecuencia, para tener un avance en materia de igualdad y justicia social, la vía es el voto legitimando a los gobernantes. Lo paradójico del asunto es que esos gobernantes son protagonistas ligados directa o indirectamente a las élites que por años han impuesto su hegemonía en el país.

${ }^{10}$ Esta democratización inconclusa, donde se tiene una solvente democracia electoral, pero que la misma no le alcanza para hablar de una democracia liberal plena, ha colocado a muchos países en una suerte de zona gris, lo cual empieza a ser tema de investigación por parte de algunos autores (Diamond, 2004; Schedler, 2004; Levitsky y Way (2004).
} 
políticas y sus respectivas instituciones - parlamento, sistema de partidos, procesos electorales - se le otorgó un trascendental empuje, pero quedó a la espera la implementación de correcciones en el esquema de distribución de la riqueza social, capaz de mitigar la desigualdad. ${ }^{11}$ Asimismo, se postergó desarrollar un Estado de derecho acorde con los desafíos actuales, para una resolución eficiente y justa de los conflictos (Woldenberg, 2014). Estas omisiones o descuidos han deteriorado paulatinamente la armonía social, y con ello la confianza en las instituciones y su debido entramado legal. A ese respecto, icuáles son las impresiones proyectadas por los mexicanos? Es lo que se explora en el apartado siguiente.

\section{Confianza en las instituciones y los actores políticos}

La confianza en las instituciones es considerada nodal para el correcto funcionamiento de los gobiernos, así como de su legitimidad. Pero iqué es la confianza? Avanzando en su delimitación, ésta se refiere a la expectativa que tiene el individuo A con relación al individuo B, de modo que A espera que B no tenga un comportamiento o respuesta hostil hacía él. Se tiene la creencia de recibir un trato o recompensa benévola a la acción realizada. Existe una certidumbre positiva respecto a lo que el "otro" hará en reciprocidad. Tal situación, de darse, sirve de base para la cooperación y la solidaridad comunitaria. Sin confianza, no es posible llevar a cabo una u otra acción, y esto derivará en distanciamiento y fragmentación colectiva.

Ahora bien, se han identificado dos tipos de confianza, la social y la política. La primera alude a la que el individuo tiene en su círculo inmediato: aquellos cercanos a él, los que conoce y puede visualizar horizontalmente, familiares, vecinos, amigos. En un segundo plano, fuera del ámbito personal, existen entidades abstractas. Otorgar confianza a las instituciones es confiar en una entidad intangible, así como en sus representantes. Como se puede apreciar, la confianza social sobresale en el perímetro de la vida privada, en tanto que la confianza política se circunscribe a la esfera pública. De esta forma, "la confianza política en una institución conlleva la creencia de que ésta no actuará de una forma arbitraria o discriminatoria que resulte dañina para nuestros intereses o los del país, sino que nos tratará, a nosotros y a los demás ciudadanos, de una forma igualitaria, justa y correcta" (Montero, 2008: 21). Por ende, confiar en las instituciones es indicativo de considerar que las mismas se están guiando por principios de equidad y justicia para todos.

\footnotetext{
${ }^{11}$ Sobre el particular, destacan los resultados presentado por el Consejo Nacional de Evaluación de la Política de Desarrollo Social (CONEVAL), en los que se indica que el 46.2\% de la población vive en situación de precariedad y el 9.5\% en pobreza extrema (El Universal, 24 de julio de 2015), una condición ratificada en un estudio paralelo realizado por Gerardo Esquivel para OXFAM-México (2015).
} 
Establecido lo anterior, en su estatus de democracia emergente, oportuno es plantearse qué panorama ofrece el país durante su proceso de alternancia, y cómo está la confianza política de los mexicanos respecto a las instituciones insignes del sistema electoral, así como de sus respectivos actores — que para el caso serían los congresistas, partidos políticos o cargos sujetos a elección popular-. Para ese efecto se retoman los resultados de la ENCUP aplicada en agosto de 2012, en la que se pregunta, en una escala de calificación de 0 a 10 —-donde 0 es nada y 10 es mucho - , qué tanto confía en las siguientes instituciones. El resultado se concentra en el cuadro l:

Cuadro 1. Confianza en las instituciones

\begin{tabular}{|c|c|c|c|}
\hline Institución & Calificación & Institución & Calificación \\
\hline Familia & 7.8 & Organizaciones ciudadanas & 5.2 \\
\hline Médicos & 6.6 & Gobierno & 5.1 \\
\hline Iglesias & 6.4 & Gobernadores & 5.0 \\
\hline Maestros & 6.3 & Jueces & 5.0 \\
\hline Ejército & 6.1 & SCJN & 5.0 \\
\hline Televisión & 6.1 & $\begin{array}{l}\text { Delegados/Presidentes } \\
\text { municipales }\end{array}$ & $4 \cdot 9$ \\
\hline Militares & 6.0 & Redes sociales & 4.8 \\
\hline Radio & 5.8 & Empresarios & 4.7 \\
\hline Vecinos & 5.8 & Sindicatos & 4.5 \\
\hline $\mathrm{CNDH}$ & $5 \cdot 7$ & Diputados & 4.4 \\
\hline $\begin{array}{l}\text { Organizaciones } \\
\text { indígenas }\end{array}$ & 5.6 & Senadores & 4.4 \\
\hline IFE & $5 \cdot 5$ & Partidos políticos & 4.4 \\
\hline Prensa & 5.5 & Policía & $4 \cdot 3$ \\
\hline Presidente & $5 \cdot 3$ & & \\
\hline
\end{tabular}


En términos generales, las calificaciones son bajas, salvo la de la familia, que es moderadamente alta. Se muestra una tendencia a la desconfianza para buena parte de las instituciones sociales y políticas, la cual un par de años después será refrendada con el Informe País sobre la calidad de la ciudadanía en México presentado por el Instituto Nacional Electoral; un panorama que da cuenta de la fragilidad en la textura de la coexistencia social y política. Sobre el particular, es de recordar que para mantener una convivencia pacífica y armónica toda sociedad requiere de una certidumbre en los vínculos personales e institucionales. Para generar solidaridad se necesita de una reciprocidad equitativa en las acciones del otro. Sólo de esa manera se puede construir una comunidad incluyente. Consiguientemente, lo que tenemos son ínsulas de intereses individuales y grupales, cuyo crecimiento sin restricción obstaculiza la fundación de un dimensión pública fuerte.

Frente al mundo privado de las relaciones y confianzas interpersonales, el mundo moderno formuló la creación de entidades abstractas garantes de los derechos individuales, pero teniendo como eje rector, priorizar la vida pública. Así fue el surgimiento del Estado para garantizar la convivencia de todos en colectivo, haciendo coexistir los diferentes intereses particulares. Ese ha sido el papel nodal de las instituciones en los recientes dos siglos, con una ingeniería institucional cada vez más elaborada de acuerdo con la exigencia de los tiempos. Y en esa urdimbre es donde se sitúa toda la estructura electoral diseñada para hacer del sufragio universal y de la representación política los fundamentos de la democracia como forma de gobierno contemporánea.

Retomando los datos del cuadro l, destaca una valoración baja en todos los actores relacionados con el proceso electoral. La más alta es la del IFE (5.5). Le siguen en ese orden el presidente (5.3), gobernadores (5.0) y delegados o presidentes municipales (4.9). Casi al final de la escala quedan los diputados (4.4), senadores (4.4) y partidos políticos (4.4). Sólo la policía es la instancia con peor calificación después de ellos. Una valoración ciertamente histórica, pero que en tiempos de democratización se esperaría presentara otro perfil. Lo que estos datos revelan es la precaria afinidad entre la población y el circuito electoral.

Dos sexenios panistas no pudieron establecer un nexo más estrecho entre Estado y sociedad, aunque son de reconocer los esfuerzos para modificar el entramado institucional en el plano formal. También es de señalarse la situación de una ciudadanía inerme ante los agravios de la clase política que, amparada en el pregón democrático, sigue actuando bajo las viejas prácticas supuestamente erradicadas con la transición política. Pensada como un espacio de apertura para la participación de todos los intereses, la alternancia no consumó estos propósitos. La democracia político-electoral, en tanto mecanismo de articulación de este objetivo, se ha quedado constreñida a un buen ejercicio discursivo aprovechado por las élites en todas las dimensiones para autonombrarse como modernas, aunque sin avanzar en el fomento de un modelo social más igualitario. 
En este contexto, la política para la población mexicana ha quedado encasillada como una actividad delimitada a los territorios donde se mueven los políticos: el parlamento, los partidos, la presidencia y las dependencias de gobierno; puntos distantes de la sociedad, inaccesibles e impunes. Quizás sea posible saber lo que pasa en estas instancias a través de los medios de información, mas no hay una identidad de ascendencia e influencia sobre éstas, mucho menos capacidad de incidir en los procesos decisorios. A pesar de ser puestos de representación elegidos en las urnas, no existe un autorreconocimiento de potestad ciudadana que se considere parte de la soberanía políticay, por ende, delEstado. Por tanto, se registraun distanciamientoentre gobernantes y gobernados, lo cual se traduce en un escaso interés por la política en sí, es decir, en una desafección política.

Con lo antes dicho, parece existir una concepción dual de la política entre los mexicanos vinculada a las instituciones plasmadas en leyes, y otra asociada a la conducta de los comisionados de éstas, que serían los funcionarios y los legisladores. Los políticos viven en un mundo extraño al del ciudadano ordinario; así lo percibe éste. Su conexión con la clase política sólo es posible en las elecciones, para después volverse a separar sin historial alguno. Los individuos se enteran pasivamente de lo que pasa en ese ambiente a través de los medios de comunicación, pero está neutralizado a manifestar su rivalidad o desacuerdo contra el quehacer de los políticos. Ello por dos razones: la ausencia de eficaces mecanismos institucionales para participar, y un conservador ordenamiento valorativo que les impide abiertamente manifestar su desavenencia cuando así lo amerita el caso.

Definitivamente, la política ${ }^{12}$ como mecanismo resolutivo de conflictos no ha sido interiorizada entre la sociedad y la clase política. Para unos, llegar a ocupar un cargo público es sinónimo de inmunidad y manejo discrecional de los recursos sin tener que rendir cuentas. Y para los otros, es aceptar que así son las cosas porque la institucionalidad - léase legalidad - lo estipula de esa manera. Es decir, la política es reducida a una mera función instrumental para el inicuo ejercicio de poder. Queda con ello evidenciada la vigencia de una cultura política autoritaria y corporativa, más viva que nunca, no obstante las transformaciones institucionales realizadas.

\footnotetext{
${ }^{12}$ Sobre el particular, importante es destacar lo polémico del término en sí mismo. Es una noción que para el común de la gente se asocia al engaño, el favoritismo, la corrupción, la mentira, la imposición. En suma, lo más negativo de la conducta humana que a su vez se concentra en el grupo de los profesionales de esta actividad. Consecuentemente, hablar de clase política es hablar de los peores males. Empero, es de señalar que esta situación, la más visualizada, es sólo una de las dimensiones de la política. Al respecto, la terminología en inglés ha sido útil para acotar los diferentes ámbitos por donde transcurre el actuar y pensar político. Así tenemos tres vocablos valiosos: polity, que hace referencia a la normatividad, la institución, alude al ejercicio de poder; politics refiere a las conductas de los individuos en su lucha por el poder, y policy se orienta a la gestión gubernamental, intervención sobre las relaciones sociales (ver Vallés, 2002: 45-52).
} 


\section{Reflexiones finales}

A pesar del enorme aparato electoral desplegado, las prácticas y los valores de antaño son moneda corriente entre los actores de la vida política en México. Los partidos predominantes en la transición han seguido reproduciendo estas rutinas. En ese sentido, ciertamente tenemos alternancia de partidos y gobiernos, pero los estilos políticos siguen siendo los mismos del viejo régimen. Tal situación conduce a cuestionarse acerca de la inequívoca pero no suficiente renovación del régimen de poder que sirvió de soporte al PRI por más de setenta años. Conocer ese complejo entramado le ha ayudado a este partido para su regreso triunfante a los primeros planos del gobierno.

Amparado en la legalidad electoral, hoy día se vive la alternancia priista, después de dos sexenios de vigencia del PAN. Con ello se justifica la democracia electoral como sustentante de la concurrencia política en el México contemporáneo. Una rendija de apertura política derivada de los convulsos años sesenta y setenta, que dio pie para la institucionalización en la lucha política de actores otrora marginados. Aunque el proceso de toma de decisiones se seguía circunscribiendo al selecto circuito de poder ya establecido, se formalizó la pluralidad en la participación, pero no para incidir en las decisiones.

Si bien se han realizado varias reformas electorales (1986, 1990, 1994, 2003, 2005, 2007), en contraparte sólo dos reformas políticas $(1977,1996)$ se han llevado a cabo, y éstas en su momento trastocaron perceptiblemente las fibras del régimen de poder. Esta reticencia de la clase política hegemónica para liberar los mecanismos de acceso, y por ende de transformación del poder, fue rápidamente percibida entre la población desde los primeros años de la alternancia, lo cual se ha traducido en una notable desafección hacia la política y las instituciones que la circundan.

Al respecto, las instituciones que acaparan la mayor preferencia de los mexicanos son las de corte tradicional como la familia, la iglesia o el ejército. En el extremo opuesto, las instituciones modernas como el parlamento, los partidos o la Suprema Corte de Justicia de la Nación ocupan los lugares con menor confianza. En ese sentido, una ciudadanía informada, organizada y capaz de promover un proyecto de sociedad propio es inexistente en la actualidad. Quizás sea posible cubrir esta meta en el mediano y largo plazo, dados los fuertes déficits en materia de valores civilizatorios modernos en nuestra sociedad mexicana, tanto entre la clase política como entre la población en general. Como ya se apuntó, la cultura patrimonial y autoritaria sigue fuertemente afianzada en todos los campos de la vida.

Vinculado entre los mexicanos su aprecio por la democracia con la satisfacción de necesidades básicas, el desencanto es notable al no obtener los beneficios esperados. Obligado resulta preguntarse de dónde emana ese impulso, especialmente cuando el país no se ha caracterizado por un pasado democrático. Es posible afirmar la defensa de la 
democracia política, que tiene su eje petitorio en la defensa de sus recursos reproductivos. Esto es, la democracia para países de bajo desarrollo se ha convertido en un factor de sobrevivencia antes que de acuerdo civilizatorio pleno.

$\mathrm{O}$, lo que es igual, ante el juicio de los sujetos políticos, la vía político-electoral emerge como ese eventual medio de acción política a través del cual evitar el desplome total del bienestar conseguido. Ante la ausencia de engranajes que permitan incidir en el régimen de poder, la vertiente electoral se ha convertido en un medio más de resistencia; pero, al paso del tiempo, denota su agotamiento para cumplir ese objetivo. Este desgaste está asociado con una economía estancada y un dilatado clima de inseguridad, y con ello se gesta un complejo ambiente para la legitimidad del proyecto de país en turno. Es un asunto que, a reserva de una agudización de la crisis institucional, obliga a las élites progresistas a revisar el puntal de la vida política del país.

En el plano de los principios normativos, durante estos años de cambio político se confiaba en que la democracia política impulsaría al país hacia la concertación de intereses y la integración de todos éstos en la comunidad; aquélla, sin embargo, ha quedado constreñida. La política inmediata se impuso a la ética, y esto fracturó el equilibrio sobre el cual descansaba su virtuosismo. Roto tal contrapeso, el proyecto de largo plazo quedó desdibujado y ocuparon su lugar medidas de corto alcance conducentes a preservar simple y llanamente el orden. El medio se impuso al fin. El conflicto por el poder en sí obstaculizó la tarea de construcción de la polis.

Esta circunstancia obliga a modificar la discusión acerca de la democracia, así como a recargarla de sentido ${ }^{13}$ para que reúna las condiciones necesarias para cumplir con su objetivo civilizatorio. El debate ${ }^{14}$ parece querer crecer tímidamente entre algunos sectores de las élites intelectuales; de avanzar la discusión, es necesario recuperar el análisis del régimen político, enfatizando en las transformaciones o evolución de las estructuras de poder propias de los tiempos de dominación priista: corporativismo, cultura política, ordenamientos jurídicos, sobre las cuales se edificó el autoritarismo mexicano se mantienen en esencia intactas. Resulta necesaria una profunda reforma de estado, si hay la intención de transitar a un estadio político de mayor calado.

Para concluir, sería conveniente rescatar un viejo señalamiento de Habermas en Problemas de legitimación en el capitalismo tardío, redactado a principios de los setenta, una década antes de la simbólica caída del Muro de Berlín, y del arribo de la oleada democrática, donde advertía sus reservas al respecto.

\footnotetext{
${ }^{13}$ Donde "resulta importante no solamente quién decide sino también qué cosa se decide" (Cerroni, 1986: 12).

${ }^{14}$ Acerca de este necesario examen, en fechas recientes se cuenta con los escritos de Agustín Basave, "La deserción democrática", en El Universal, 13 de abril de 2015, o la serie de artículos de Héctor Aguilar Camín, "Repensando la democracia”, los días 7, 8, 9 y 10 de abril de 2015, en el diario Milenio.
} 
La democracia ya no se asocia con la igualdad política en el sentido de una distribución igual del poder político, es decir, de las oportunidades de ejercer el poder; la igualdad política sólo significa ahora el derecho formal al acceso al poder con iguales posibilidades, es decir, el derecho igual a ser elegido en posiciones de poder. La democraciayanopersigueelfinderacionalizarelpoder socialmediantelaparticipación de los ciudadanos en procesos discursivos de formación de voluntades, más bien tiene que posibilitar compromisos entre las élites dominantes (Habermas, 1975: 148).

\section{Referencias bibliográficas}

Aguayo Quezada, Sergio (2008). El almanaque mexicano. México: Aguilar.

Casar, María Amparo (2009). "Poderes fácticos”. En Nexos, núm. 376, abril. México.

Castañeda, Fernando (1987). "La crisis de la epistemología". En Revista Mexicana de Sociología, enero-marzo. México: IISUNAM, pp. 1-87.

Cerroni, Umberto (1986). "La democracia como problema de la sociedad de masas". En Estudios Políticos, núm. 2, vol. 5, nueva época, abril-mayo. México: FCPyS-UNAM.

Diamond, Larry (2004). "Elecciones sin democracia. A propósito de los regímenes híbridos". En Estudios Políticos, núm. 24, enero-junio. Medellín.

Encuesta Nacional sobre Cultura Política y Prácticas Ciudadanas (ENCUP) 2001, 2003, 2005, 2008 y 2012. Secretaría de Gobernación. Disponible en: http://www.encup.gob. $\mathrm{mx} /$ (consultado 20 de junio de 2015).

Escalante Gonzalbo, Fernando (2015). "Los años setenta. Breve historia del neoliberalismo". En Nexos, núm. 449, mayo. México.

Esquivel, Gerardo (2015). Desigualdad extrema en México: Concentración del poder económico y político. Disponible en: http://www.oxfammexico.org/desigualdad-extrema-enmexico-concentracion-del-poder-economico-y-politico/\#.VcP7pPnGov0.

González Casanova, Pablo (1980). La democracia en México. México: ERA.

Habermas, Jürgen (1975). Problemas de legitimación en el capitalismo tardío. Buenos Aires: Amorrortu.

Habermas, Jürgen (1994). Ensayos políticos. Barcelona: Península.

Held, David (1992). Modelos de democracia. México: Alianza Editorial.

Instituto Federal Electoral (2014). Informe País sobre la calidad de la ciudadanía en México. México: IFE, COLMEX. Disponible en: http://www.ine.mx/archivos2/portal/ DECEYEC/EducacionCivica/informePais/ (consultado el 10 de abril de 2015).

La Comisión Trilateral y la coordinación de políticas del mundo capitalista (1977/1978). Cuadernos Semestrales, núm. 2 y 3. Estados Unidos, México: Perspectiva Latinoamericana, CIDE.

Lechner, Norbert (1996). "La política ya no es lo que fue". En Nueva Sociedad, núm. 144, julio-agosto. Caracas. 
Lechner, Norbert (2004). “Entrevista a Norbert Lechner”. En Polis, núm. 7. Disponible en: http://polis.revues.org/6377 (consultado el 19 marzo de 2015).

Levitsky, Steven y Lucan A. Way (2004). "Elecciones sin democracia. El surgimiento del autoritarismo competitivo”. En Estudios Políticos, núm. 24, enero-junio. Medellín.

Montero, José Ramón, Sonja Zmerli y Ken Newton (2008). “Confianza social, confianza política y satisfacción con la democracia". En Revista Española de Investigaciones Sociológicas, núm. 122. Madrid.

Nogueira, Marco Aurélio (1994). "Democracia política, gobernabilidad y representación”. En Revista del CLAD Reforma y Democracia, núm. 1. Caracas.

O’Donnell, Guillermo (1994). "Delegative Democracy”. En Journal of Democracy, vol. 5, núm. 1. Paramio, Ludolfo (1988). Tras el diluvio. La izquierda ante el fin de siglo. México: Siglo XXI.

Paramio, Ludolfo (1996). "La sociedad desconfiada”. En Leviatán, núm. 66. Madrid.

Peschard, Jacqueline (2000). "Comportamiento electoral”. En Laura Baca Olamendi et al. (comps), Léxico de la politica. México: FLACSO, FCE, SEP-CONACYT, Heinrich Böll.

Sánchez Rebolledo, Adolfo (2015). "Desencanto, partidos y minorías". En La Jornada, 26 de junio.

Schedler, Andreas (2004). "Elecciones sin democracia. El menú de la manipulación electoral”. En Estudios Políticos, núm. 24, enero-junio. Medellín.

Valadés, Diego (2014). "Renovar el poder". En Reforma, 25 de noviembre.

Vallés, Josep M. (2002). Ciencia política. Una introducción. Madrid: Ariel.

Woldenberg, José (2014). “De tres, uno”. En Reforma, 20 de noviembre. 


\section{Chiapas, la democracia que no fue}

Jesús Solís Cruz

\section{Introducción}

Las últimas dos elecciones locales en Chiapas (2012-2015) han sido inéditas en cuanto a los resultados y a las implicaciones para las instituciones políticas locales. En la entidad, en el marco de la democracia electoral, se han registrado en el gobierno estatal dos alternancias políticas, coincidentes además con las registradas en el Gobierno federal. La primera ocurrió en el año 2000. En el ámbito federal, con esta primera e histórica transición política se avistó el fin del ciclo de transición democrática para dar lugar al afianzamiento de la democracia representativa (neo)liberal en el país. En Chiapas, por su lado, con la primera transición se planteaba también el cierre de su propio ciclo de transición democrática y la creación de un nuevo campo de disputa electoral sustentado en la competencia y pluralidad partidistas.

La segunda transición política fue en 2012. En Chiapas, con esta transición se dio término a doce años de gobiernos provenientes de amplias coaliciones partidistas lideradas por el Partido de la Revolución Democrática (PRD); y a nivel federal se puso fin a doce años de gobierno emanados del Partido Acción Nacional (PAN), y con ello el retorno del Partido del Revolucionario Institucional (PRI) al poder ejecutivo.

A diferencia de la primera transición en que se registró una diferenciación en los partidos que asumieron los gobiernos: el PAN en el ámbito federal y coaliciones pluripartidistas lideradas por el PRD a nivel local; en la segunda, el partido que ganó la presidencia de la república (PRI) fue el mismo que secundó la alianza encabezada por el Partido Verde Ecologista de México (PVEM), ganadora de la gubernatura de Chiapas.

Aunque las transiciones, la pluralidad partidista e incluso la alineación entre partidos gobernantes a nivel federal y estatal parecieran ser indicio de robustecimiento de un sistema de partidos o indicativo de fortalecimiento de las reglas y valores de la democracia 
electoral en la entidad; en el caso de Chiapas, observados estos procesos con detenimiento, revelan más bien un utilitarismo político de los grupos en el poder formal que, arribados a tal posición por las vías de la democracia procedimental, buscan no sólo mantenerse, sino además constituirse en grupos de interés predominantes, anulando principios básicos del sistema representativo político y de división de los poderes que postulan el equilibrio en el ejercicio del poder.

Paradójicamente, esta práctica utilitaria, desarrollada en un sistema político representativo moderno, renueva uno de los problemas más antiguos de la teoría política democrática: la formación de facciones y los medios o las formas de su contención. La alternativa del pasado: democracia representativa, hoy encuentra serias limitaciones al no poder "por sí mismo [ser ...] condición suficiente para la protección de los ciudadanos: no puede por sí mismo impedir que los elegidos degeneren en una poderosa facción explotadora" (Held, 2012: 116).

En el anterior sentido, los partidos políticos que dan cobijo a estos grupos de interés, más que instrumentos de la democracia o mediadores para construir instituciones representativas de los intereses colectivos (Cerroni, 1991), devienen en un fin en sí mismo. Es el caso del PVEM, partido con dominio en los poderes legislativo y ejecutivo en Chiapas.

Lo anterior, concebido como axioma de trabajo en este capítulo, es problematizado en las siguientes preguntas, que aunque sin respuesta explícita servirán como guía en el análisis y reflexión: 1) icómo Chiapas pasó de ser "granero electoral" del PRI a "territorio verde"2 en un período de tiempo tan corto (1991-2012), en el que además ocurrieron dos transiciones políticas en la gubernatura estatal?, y 2) iqué representa este cambio para la democracia electoral chiapaneca, después de haber registrado un incipiente sistema de partidos plural y competitivo?

Para trabajar sobre este axioma y preguntas retomaré el proceso electoral local de julio de 2015, en el que se renovaron alcaldías y diputaciones locales. Haré una descripción del proceso enfatizando los resultados y las nuevas tendencias en la composición del poder político partidista. A efectos de contrastar estos resultados y apoyar mi argumentación, referiré las condiciones y cualidades de procesos comiciales del pasado inmediato (2006 y 2012); en el mismo sentido, al comienzo de este capítulo desarrollo un

\footnotetext{
${ }^{1}$ En un sentido general, por utilitarismo político en este trabajo se entiende la acción política que tiene como premisa la actuación de agentes movidos por sus propios motivos egoístas, racionalmente calculados bajo la fórmula de la consecución de fines en los que el ingreso o utilidad supere el coste. Para una ampliación del enfoque de este tipo de acción política, desarrollado principalmente en las décadas de 1940 y 1950, véase Anthony Downs (2001). Al cierre del capítulo vuelvo sobre el tema.

${ }^{2}$ Frase publicitaria del Partido Verde Ecologista de México (PVEM) con la que se alude a la presencia y predominio del partido en determinada región del país y en algún puesto de representación popular: alcaldía, diputación, senaduría o gubernatura.
} 
parágrafo para exponer los derroteros de la democracia electoral en la entidad en la historia reciente. Concluyo con algunas líneas de análisis y reflexión sobre la democracia existente en Chiapas, tratando de señalar las dificultades que enfrenta una sociedad como ésta para el afianzamiento de principios democráticos.

\section{Los derroteros de la democracia electoral en Chiapas: una lectura de su historia reciente}

Chiapas, en el concierto confederado de nuestro país, ha representado una "reiterada excepcionalidad" en cuanto a su vida social y política. En este sentido, mientras en el resto del país las tendencias en las preferencias político-partidistas se diversificaban y profundizaban, en parte por la reforma política de finales de 1970 que amplió y complejizó el campo político electoral y en parte también por la ruptura interna que sufrió el PRI a finales de la década de 1980, en esta entidad este partido, en las elecciones para presidente de la República de 1988, obtenía el 89\% de los votos válidos (Gómez y Valdés, 1997). Todavía en las elecciones intermedias de 1991 en Chiapas el PRI mantenía un dominio casi innegable. Tal excepcionalidad llevó a ciertos analistas a caracterizar a Chiapas como "el granero electoral" de ese partido (Sonnleitner, 2012).

Sin embargo, a partir de la década de 1990 el voto partidista de los chiapanecos registró una ligera diversificación. Por ejemplo, en 1991, en las elecciones municipales el partido de oposición que más creció fue el PRD, que obtuvo el 8\% de los votos, en tanto que el PRI disminuyó su votación del 87 al 80\%, en relación con las elecciones de 1988 (Gómez y Valdés, 1997: 197). En términos absolutos, por el contrario, en ese mismo proceso electoral se muestra que el PRI ganó 108 de 110 ayuntamientos, uno lo ganó el PAN y en otro más (Mazatán) se anularon las elecciones debido a la quema de material electoral (Pineda, 2012: 116).

Los resultados de ese proceso electoral parecen confirmar el dominio del PRI a nivel de ayuntamientos en la entidad, pero si se observa la conflictividad social poselectoral se notará cierto declive en el dominio de este partido y debilidad en el sistema electoral. En este campo de conflictividad diversas organizaciones de masas, por la vía de la acción pública contenciosa, cuestionaron los resultados electorales y fueron objeto de controversia treinta ayuntamientos, derivando once de estos en Consejos Municipales. Entre 1992 y 1993 se registraron conflictos en veinticinco ayuntamientos, de los cuales en diecisiete fueron depuestas las autoridades electas y nombrados en su lugar Consejos Municipales (García, 2003: 125).

En 1994, en la elección para presidente de la República, el PRI redujo su votación a la mitad en la entidad: 45\%, en relación con la elección de 1988 (Gómez y Valdés, 1997). En ese mismo año, en la elección para gobernador el PRI ganó con el 50.45\% de la votación total, y con un importante repunte entre la preferencia electoral le siguió el PRD con el 
34.96\%; por debajo de ambos, el PAN con el 9.20\%. Los restantes partidos contendientes obtuvieron el $5.51 \%$ de los votos. En términos absolutos el PRI obtuvo 501611 votos, el PRD 347 633, el PAN 91512 y los demás partidos de oposición 53527 (García, 2003: 136).

En estos procesos electorales tuvo particular impacto el alzamiento armado del Ejército Zapatista de Liberación Nacional (EZLN), y en subsecuentes procesos comiciales también este grupo se convertirá en actor relevante, bien para avivar o para retraer las tendencias y niveles de votación. ${ }^{3}$ Incluso, fue actor clave para alentar las sucesivas reformas político-electorales de la segunda mitad de la década de 1990 a nivel federal y estatal, que buscaron la autonomía y ciudadanización de los árbitros electorales. ${ }^{4}$

En concordancia con lo que venía ocurriendo en el entorno nacional en materia de reconfiguración del sistema de partidos, en Chiapas marcadamente después de 1994 la disputa por la representación del electorado se encontraba entre tres principales fuerzas políticas: PRI, PRD y PAN, aunque en las contiendas participaban un mayor número de partidos. Por ejemplo, en la de gobernador y presidente de la República en 1994 participaron nueve; no obstante, como se ha señalado, la dinámica de estos procesos estuvo definida por los tres antes mencionados.

Esta reconfiguración, de "unipartidismo" o partido hegemónico a competitivo y plural, avizoraba un fortalecimiento de la democracia electoral en la entidad. En escena se podía hallar entonces organismos políticos que habían ido ganando presencia en la democracia formal de Chiapas desde antes de la década de 1990, como el Partido Auténtico de la Revolución Mexicana (PARM), el Partido Popular Socialista (PPS), el Partido Demócrata Mexicano (PDM) y el Partido Frente Cardenista de Reconstrucción Nacional (PFCRN); así como partidos que apenas ingresaban a la competencia político electoral, como el del Trabajo (PT, registrado en 1994) y el Verde Ecologista de México (PVEM). O nuevos con registro estatal, como el Partido Democrático Chiapaneco (PDCH) y el Partido Frente Cívico (PFC), creados ambos en 1995 (García, 2003: 129).

A la luz de la tendencia señalada, claramente Chiapas entraba en la ruta de transición de un sistema de partidos no competitivo a otro plural y competitivo. Las elecciones locales, al menos en lo que concierne a la renovación de ayuntamientos de los años 1995 y 1998, así lo confirmaban. ${ }^{5}$ Para ilustrar esta tendencia, sólo baste señalar que en la elección

\footnotetext{
${ }^{3}$ Willibald Sonnleitner (2012) ha analizado los cambios de posición política que con respecto a la democracia electoral ha tenido el EZLN en Chiapas desde su irrupción, yendo de asumir una postura estratégica en la contienda electoral para gobernador en 1994, al apoyar abiertamente al candidato postulado por el PRD, pasando por la promoción del abstencionismo hasta el boicot activo como el ocurrido en las elecciones federales en la entidad en 1997.

${ }^{4}$ Consúltese el trabajo de María del Carmen García (2003) donde documenta los cambios y reformas en materia legislativa electoral en el periodo posconflicto neozapatista; véase también Jesús Pineda de la Cruz (2012).

${ }^{5}$ Las elecciones para diputados locales en 1995 parecen contravenir la tendencia a la pluralidad
} 
de 1995, de los 110 municipios en los que se realizaron comicios en 84 ganó el PRI, en dieciocho el PRD, en cinco el PAN, en dos el PT y en uno el PFCRN. La misma tendencia se observó en los comicios para ayuntamientos de 1998: de 111 municipios en los que hubo elecciones, 87 los ganó el PRI, dieciocho el PRD y seis el PAN (García, 2003: 139).

Con la tendencia al declive del dominio del PRI en la entidad, se arribó a los procesos comiciales de 2000 en los que se votó, por una diferencia de siete semanas, para presidente de la República (2 de julio) y para gobernador y diputados locales (tercer domingo de agosto).

Una amplia coalición denominada Alianza por Chiapas, encabezada por el PRD, PAN, PT y PVEM, ${ }^{6}$ postuló como candidato al gobierno del estado al senador priista Pablo Salazar Mendiguchía.

Los resultados del proceso electoral nacional, que dieron el triunfo al candidato del PAN (Vicente Fox), terminaron definiendo, como ha sido frecuente en la historia política de Chiapas, el proceso comicial local. Así, en el año 2000 se registró en la entidad la primera alternancia en el gobierno del estado, surgido éste de una amplia coalición antipriista. En términos porcentuales la Alianza por Chiapas ganó con el 51.50\% del total de votos, mientras que sus dos contrincantes obtuvieron: PRI, el 46.68\%, y el Partido Democracia Social (PDS) el 0.38\%.

La estrategia aliancista posibilitó también reducir el número de curules del PRI en el Congreso local. De veinticuatro distritos electorales, la Alianza ganó quince y el PRI nueve. ${ }^{7}$ Destaca entre los resultados que la Alianza obtuvo la mayor parte de sus votos en los distritos con cabeceras en las ciudades más importantes del estado: Tuxtla Gutiérrez, Tapachula y Comitán, al igual que en espacios con creciente población urbana como Villaflores, Chiapa de Corzo, Palenque y Tonalá.

El PRI, por otro lado, obtuvo la mayoría de votos en los distritos con población mayoritariamente indígena, cuyas cabeceras municipales son Las Margaritas, Ocosingo, Tenejapa y Chamula.

En el sexenio siguiente, con el mismo esquema de alianzas, la denominada Por el Bien de Todos -integrada por el PRD, PT y Convergencia - postuló al expriista Juan Sabines a la gubernatura del estado, quien ganó la misma con el $48.55 \%$ del total de votos. Le siguió la Alianza por Chiapas -integrada por el PRI y el PVEM- con el 48\% de votos.

Una alternancia más en el gobierno estatal habría de registrarse en Chiapas doce años después de la primera. De nueva cuenta, bajo la fórmula de la coalición el PVEM, junto

y competitividad, pues de veinticuatro distritos el PRI ganó veintiuno. Los tres restantes se distribuyeron del siguiente modo: dos para el PAN y uno para el PRD.

${ }^{6}$ Además de estos cuatro partidos con registro, integraron esta coalición otros cuatro sin registro: Partido Centro Democrático (CD), Partido Alianza Social (PAS), Partido Sociedad Nacionalista (PSN) y Partido Convergencia Democrática (PCD).

${ }^{7}$ En la elección inmediata pasada el PRI había ganado veintiuno, el PAN dos y el PRD uno. 
con el PRI y el Partido Nueva Alianza (PANAL), postuló en 2012 al senador pevemista Manuel Velasco Coello a la gubernatura del estado, quien con el $67.14 \%$ del total de votos ganó la contienda, asestándole un fuerte revés electoral al PRD y al PT, que en esta ocasión — coligados con el partido Movimiento Ciudadano- obtuvieron tan sólo el 17.41\% del total de votos. Partidos que en el pasado habían sido cabeza de coaliciones y formalmente gobierno en dos periodos -2000-2006 y 2006-2012 - sufrieron una fuerte caída electoral.

Destaca de este proceso electoral, además de la segunda alternancia en el poder estatal, el desbordado triunfo electoral del PVEM en las alcaldías y diputaciones locales.

Si bien hay una tendencia ascendente y gradual de los puestos de representación popular ganados por el PVEM, es particularmente notorio lo acontecido en las elecciones de 2012 y, como veremos adelante, lo sucedido en 2015. En 2001 el PVEM ganó cuatro alcaldías; en 2004 también cuatro alcaldías como partido unitario, y en coalición con el PRI otras cuatro; en 2007, como partido unitario, cinco, y en coaliciones con diversos partidos -PRD, PRI, PT, partido Convergencia- dieciséis; en 2010, como partido unitario, quince, y en coaliciones - PRD, PRI, PT; PAN, Convergencia y PANAL - cuatro.

El mayor salto, como se ha mencionado antes, ocurrió en 2012, cuando superó incluso al PRI — que obtuvo 4l一, partido que había sido históricamente hegemónico en este nivel de gobierno, al ganar 53 presidencias municipales de 122. En la legislatura local la coalición encabezada por el PVEM se hizo con el control, al sumar el 70.73\% del total de escaños.

En otro escrito (García, Solís y Pérez, 2014) se han identificado dos hechos que explican el excepcional ascenso del PVEM en los cargos de elección popular. El primero está relacionado con el registro de una "debilidad institucional persistente" en la que las reglas y las normas, al igual que las instituciones políticas formales, propias de una red constitucional en una poliarquía: congreso, poder judicial y partidos políticos (O’Donnell, 1997), son subvertidas por el poder ejecutivo local.

El segundo hecho tiene que ver con la falta de equidad en la competencia electoral. Juan Sabines Guerrero, electo gobernador en 2006 vía coalición liderada por el PRD, en sus funciones de gobierno generó, siendo de un partido opositor, un comportamiento de disciplinamiento político al ejecutivo federal en turno, que concluyó en rupturas con los partidos que le postularon y, conforme avanzó el proceso electoral de 2012, en una abierta labor proselitista a favor de los partidos y la alianza PVEM-PRI. Gobiernos municipales, organismos políticos con representaciones en los municipios y grupos políticos locales constituidos recibieron, en incontables casos, la indicación de cambiar de militancia, declinar o favorecer a los partidos Verde Ecologista y Revolucionario Institucional, bien como partidos unitarios o en alianza (García, Solís y Pérez, 2014).

Ambos hechos revirtieron el incipiente pluripartidismo y competitividad electoral de la década de 1990 y de principios de 2000, y favorecieron el reavivamiento de prácticas y 
concepciones del ejercicio del poder centradas en la figura del gobernante, condicionando los procesos comiciales y los relevos venideros en el poder, como adelante se analizará.

Un primer indicio de la renovación de estas prácticas fue la continuidad de funcionarios de primer nivel —entre otros, el secretario de Gobierno- en el gobierno de Manuel Velasco Coello nombrados en el periodo anterior. En poco más de medio año el nuevo gobierno funcionó con prácticamente el mismo gabinete del antecesor, y cuando hizo los nuevos nombramientos claramente entró en consideración el equilibrio de intereses de los grupos políticos acuerpados en los partidos que lo postularon. Lo que podría tomarse como una virtud incluyente en un gobierno, formado por funcionarios provenientes de diversos partidos políticos, resultará en una debilidad estructural y en proliferación de grupos de intereses que perseguían sus fines valiéndose del campo multipartidista.

\section{Entre el multipartidismo y el vaciamiento de la representación política en Chiapas}

En 2015, en Chiapas se registraron dos procesos electorales: el de diputados federales, realizado el 7 de junio, y el local para renovar alcaldías y diputaciones locales, el 19 de julio. Aquí me detendré a analizar el de orden local. Para tal fin situaré a continuación dos hechos clave ocurridos en el ambiente preelectoral, que por su naturaleza habrán de repercutir en el mismo proceso comicial; después describiré el multipartidismo local registrado en este proceso, y al cierre del parágrafo haré lo propio con el desarrollo del proceso comicial y sus resultados.

En la última reforma política electoral en México (2014) se decretó, entre otras innovaciones, la prerrogativa del Instituto Federal Electoral —renombrado en esta misma reforma como Instituto Nacional Electoral - de organizar, vigilar y calificar tanto los comicios federales como los estatales. Los de orden local hasta entonces habían tenido como árbitros a entes institucionales en cada entidad del país, con autonomía para conducir todo el proceso comicial. Entre los argumentos que favorecieron la reorganización de las competencias institucionales estuvo el de anular injerencias de los poderes gubernamentales y fácticos en los comicios locales.

En Chiapas esta reforma topó en principio con una resistencia formulada desde los poderes constituidos. El Congreso del estado, ante el mandato de hacer coincidir las elecciones federales con las locales como ocurrió en otras entidades del país, presentó una interpelación a la Suprema Corte de Justicia de la Nación (SCJN) para que el mandato en este caso no tuviera lugar. La SCJN dio cabida a la interpelación y resolvió que "por única vez" debían celebrarse los comicios locales y federales de forma separada.

Este hecho, la interpelación y resolución favorable a los reclamantes, deviene relevante para la comprensión y explicación del proceso comicial y sus resultados. 
Por un lado, a nivel federal, en el contexto del recrudecimiento de la violencia privada y estatal y del repunte de la protesta social por los hechos de Ayotzinapa, el proceso electoral estaba siendo fuertemente impugnado y la legitimidad de la institución encargada de organizarlo en debacle. La percepción del riesgo de "contaminación" del proceso federal al local debió ser un factor que llevó a los poderes constituidos - legislativo - a implementar acciones para mantener separados los comicios. Por otro lado, la impugnación al mandato federal, que incluso encontró apoyo en la autonomía confederada, develaría, a la conclusión del proceso electoral, el propósito de los grupos en el poder de mantener el control sobre el desarrollo de las elecciones locales.

Un segundo hecho abona en la fundamentación de la lectura anterior. En fechas próximas a los comicios federales y locales, el secretario general del gobierno del estado renunció al cargo para asumir la presidencia estatal del PVEM. Este personaje, que en la coyuntura del primer gobierno de transición en el estado (año 2000) y en posteriores cargos de representación que ocupó había mostrado dotes de liderazgo y habilidad para la organización de sectores populares, en este nuevo proceso resultaría clave por sus destrezas para sumar voluntades políticas, garantizar continuidades y agenciarse nuevos votos, en una entidad en la que el poder local, como referimos antes, en su mayoría se halla en manos del PVEM. Este movimiento implicaría para la arena política chiapaneca el trazo de las nuevas coordenadas de la situación política en la que habrían de ocurrir las elecciones federales y locales. Si comprendemos que por la presidencia de partidos - nacionales y estatales- pasa la definición de nombres de candidatos a puestos de elección popular, y advertimos que la experiencia en una secretaría de primer nivel es un importante capital político en una coyuntura como la de las elecciones, cobra sentido entonces todo el paisaje coalicionista liderado por el PVEM: la acción de este partido en municipios en donde no tenía presencia, el aval a candidaturas en algunos casos con poca aceptación del electorado, e incluso la emergencia de dos nuevos partidos con registro local alineados a las directrices políticas del gobierno estatal.

Veamos ahora el proceso comicial. En él participaron nueve partidos políticos: siete con registro nacional - PRI, PAN, PRD, PT, PVEM, PANAL, MC - y dos de reciente creación y con registro local — Partido Chiapas Unido (PCU) y Partido Mover a Chiapas (PMC)-.

En la contienda para la renovación de alcaldías fueron cuatro las coaliciones registradas: PVEM-PANAL, PRI-PVEM-PCU-PANAL, PRI-PVEM-PANAL y PRIPCU. Y como se verá adelante, a excepción de la establecida entre el PVEM y el PANAL las demás tuvieron pobres resultados.

Para las diputaciones locales se registraron tres coaliciones. El rasgo particular de las mismas es que fueron integradas por cuatro partidos - PRI, PVEM, PANAL y PCU-, 
que hicieron juego en el orden de prelación y que restaban o sumaban a alguno de los partidos según la valoración de fuerza del partido que encabezaba en el distrito electoral en disputa. Las coaliciones fueron: PRI-PVEM-PANAL-PCU, PVEM-PANAL-PCU y PRI-PVEM-PCU.

En cuanto a la integración de coaliciones, tanto para la renovación de alcaldías como para las diputaciones, es notorio que ninguno de los partidos que pueden ser considerados de oposición en Chiapas - PAN, PRD, PT, MC - formó alianzas.

Es importante destacar, en el caso de los dos partidos con registro local, que la integración de estas formaciones políticas respondió más a una estrategia de dispersión del voto de un electorado inconforme y desencantado con la actuación de los poderes locales, que podía capitalizar la oposición, que a una auténtica apropiación ciudadana de los organismos y mecanismos de la democracia electoral. El caso que claramente lo muestra es el del Partido Mover a Chiapas, fundado por un exfuncionario de primer nivel del gobierno estatal que capitalizó sus redes de relaciones políticas de estilo clientelar, construidas en el pasado cuando ocupó otros cargos de representación popular, al igual que recursos materiales y simbólicos ligados al gobierno estatal en este proceso electoral. En este último sentido, la imagen y sello de este partido se asemejó a la usada oficialmente por el gobierno del estado.

Por lo que respecta a la jornada electoral, en el marco de la Sesión Permanente del Consejo General del Instituto de Elecciones y Participación Ciudadana (IEPC), este organismo informó que de un total de 5958 casillas, se instalaron 5948. Se informó también de hechos de violencia en los municipios de Ocosingo, Villaflores, Salto de Agua, Soyaló, Berriozábal, Pueblo Nuevo, Venustiano Carranza, Mazatán, El Parral, Siltepec, Chilón y Bejucal de Ocampo. ${ }^{8}$

De acuerdo con el Código de Elecciones y Participación Ciudadana, el proceso de cómputo de los votos iniciaba el 22 de julio y terminaba el 25 del mismo mes. Fue el 27 de julio cuando el IEPC dio por concluido el proceso electoral. Los datos presentados por este instituto arrojan los siguientes resultados: elecciones en 24 distritos electorales y en 120 de 122 municipios. En dos de estos, Belisario Domínguez y Nicolás Ruiz, por razones de violencia no hubo procesos comiciales.

Según los datos publicados por el IEPC en la elección de miembros de ayuntamiento, el PVEM se sostiene como la principal fuerza política en la entidad al ganar 59 alcaldías. ${ }^{9}$ De este total, en 15 lo hizo como partido unitario, en 42 coaligado con el PANAL, y en dos municipios más ganó: uno en coalición con el PRI y el PANAL y otro coaligado con el PRI, el PANAL y el PCU. Destaca que en los casos de coaliciones el PVEM fue cabeza de ellas (ver mapa l).

\footnotetext{
${ }^{8}$ Consultado el 21 de julio de 2015 en www.iepc-chiapas.org.mx.

${ }^{9}$ En la elección de 2012 el PVEM por vía unitaria y en alianzas ganó 54 alcaldías.
} 
Mapa 1. Elecciones de miembros de ayuntamiento.

Proceso electoral local ordinario 2015

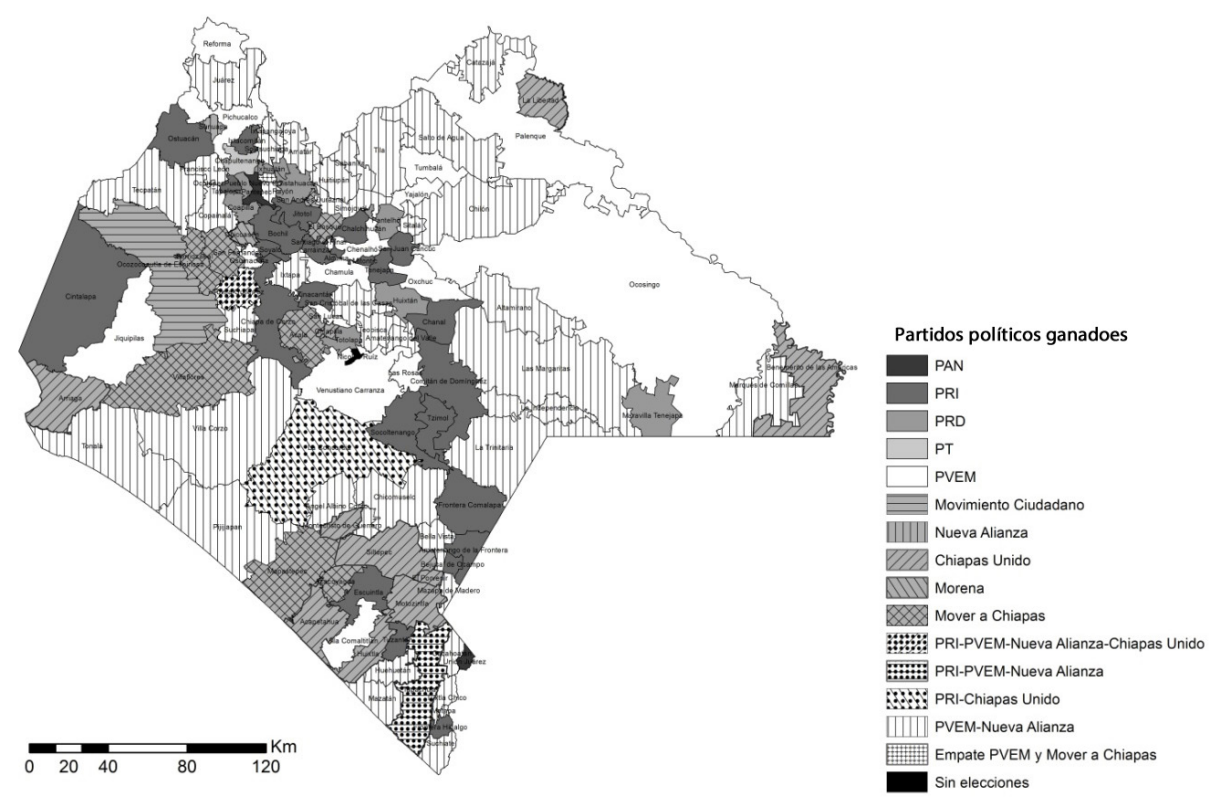

Fuente: Elaboración propia con base en los resultados publicados por el IEPC en su página web, consultada el domingo 26 de julio de 2015. El trabajo técnico estuvo a cargo de la Lic. Giovana Oceguera.

Sumados los votos obtenidos por vía unitaria y en coalición, el PVEM obtuvo un total de 754 025, una cifra importante en este proceso considerando que los votos válidos fueron 2100 435. Es decir, consiguió cerca del 36\% de la votación total.

El PRI, por vía unitaria, consiguió veinticinco alcaldías, y en coalición tres: una con PCU, otra con PANAL y PVEM, y una más con PVEM, PANAL y PCU, como se mencionó antes; se constituye así a nivel municipal en la segunda fuerza política en la entidad. El número de votos captados en la competencia electoral por vía unitaria por el PRI fueron 393 667. Porcentualmente representa cerca del 19\% del total de votos.

Contendiendo como partido unitario, el PCU ganó las elecciones en diez alcaldías y en dos más coaligado: una con el PRI y otra más integrada por el PRI, el PVEM y PANAL. El partido Mover a Chiapas (PMC), en la contienda electoral por las alcaldías, de forma unitaria consiguió el triunfo en diez. Ambos partidos de reciente creación se posicionaron, respectivamente, como tercera y cuarta fuerza electoral local en la entidad. En números absolutos estos partidos captaron: PCU 202418 votos y PMC 181684 votos. 
Porcentualmente, al PCU le representa la captación del 9.7\% y a Mover a Chiapas el 8.7\% del total de los votos válidos.

En conjunto, los votos obtenidos por todos estos partidos representan casi el $75 \%$ del total emitido y válido. Esto es particularmente relevante porque significa que los partidos del gobierno estatal en funciones, al igual que los partidos de reciente creación también políticamente afines al ejecutivo, se constituyen en gobierno. Es decir, estamos ante el predominio de gobiernos - estatal y locales- que, aunque de composición multipartidista, son de un mismo perfil político-doctrinario. En tal sentido, los resultados muestran un estrechamiento de opciones políticas a pesar del aumento en el número de partidos contendientes.

En lo que toca a los resultados obtenidos por los partidos opositores al gobierno, fueron los siguientes: el PRD logró el triunfo en ocho alcaldías. El número de votos que recibió este partido en esta contienda fue de 118 197, casi el 5.6\% del total de votos válidos. El PAN, por su parte, triunfó en dos alcaldías y en este proceso sumó un total de 121658 votos, es decir, el 5.8\% del total de los votos emitidos. El PT logró ganar también dos alcaldías y registró en esta contienda un total de 35373 votos, lo que le significó la obtención del $1.7 \%$ del total de votos.

Los partidos Movimiento de Regeneración Nacional (MORENA), Movimiento Ciudadano (MC) y PANAL ganaron una alcaldía cada uno. De este grupo, como partidos unitarios contendientes, destaca MORENA por un número total de votos recibidos de 114 781, frente a 22015 obtenidos por PANAL y a 37452 obtenidos por MC. Para MORENA este resultado le significa la obtención de cerca del 5.5\% del total de votos válidos en este proceso, mientras que para MC cerca del $1.8 \%$ y para PANAL poco más del 1\%.

Se registra como hecho inédito en este proceso electoral la inscripción de candidaturas independientes en los municipios de Ángel Albino Corzo, Francisco León, Palenque, San Fernando, Tapachula, Tecpatán, Tuxtla Gutiérrez y Venustiano Carranza, aunque las mismas no prosperaron en la obtención de algún puesto de representación popular.

En el proceso de elección de diputados locales por el principio de mayoría relativa, la coalición integrada por los partidos PRI, PVEM, PANAL y PCU obtuvo el triunfo en dieciséis de los veinticuatro distritos. El número de votos que esta coalición obtuvo (724 726) representa el 35.5\% del total registrado (2 041 812). La coalición integrada por PVEM, PANAL y PCU ocupa el segundo lugar en el número de distritos ganados: seis. Esta alianza obtuvo un total de 246729 votos, lo que representa poco más del 12\% del total de votos válidos. Los dos distritos restantes fueron ganados, uno por la alianza PRI, PVEM, PCU, y otro por el PVEM (ver mapa 2). Es decir, en la legislatura local tiene predominio como partido cabeza de alianza el PRI, seguido del PVEM, pero en suma es una legislatura que por mayoría absoluta está dominada por estos dos partidos, los mismos que llevaron al poder al actual gobernador del estado. 
Mapa 2. Elección de diputados por el principio de mayoría relativa.

Proceso electoral ordinario 2015



Fuente: Elaboración propia con base en los resultados publicados por el IEPC en su página web, consultada el domingo 26 de julio de 2015. El trabajo técnico estuvo a cargo de la Lic. Giovana Oceguera.

Cabe destacar, por el número de votos obtenidos, los casos de partidos políticos que además de no hacer alianzas y no ganar, de forma unitaria hicieron postulaciones de candidatos, como MORENA que recibió 173207 votos, el 8.5\% del total, y el partido Mover a Chiapas que obtuvo 165080 votos, poco más del 8\% del total. A los anteriores partidos le siguieron en orden descendente, por el número de votos captados: el PRD que logró 112,610, y el PAN 111 521, el 5.5\% y el 5.4\% de la votación general, respectivamente.

En este proceso, como lo señalado para el de elección de alcaldías, se registró por vez primera una candidatura independiente en el distrito II (Tuxtla Gutiérrez Poniente).

El nivel de participación ciudadana correspondiente a la elección de diputados por el principio de mayoría relativa fue del 62.33\%.

Según información emitida por el IEPC del proceso de elección de diputados, resultaron electos por mayoría 13 mujeres y 11 hombres. Y en la contienda por las alcaldías resultaron electas 36 mujeres y 84 hombres. ${ }^{10}$

${ }^{10}$ La Jornada, "PVEM, principal ganador en Chiapas", 29 de julio de 2015, p. 28. 
En vista de los anteriores resultados, cabe preguntarse si en Chiapas las elecciones - iplurales y competidas? - representan la condición indispensable de la democracia, como ha llegado a sostenerse para otros ámbitos (Loaeza, 2008). O son tan sólo un medio por el cual se reproducen los intereses privados de grupos de poder, que en la búsqueda del predominio buscan incluso anular la posibilidad de supervivencia, elemental en un régimen democrático, de adversarios políticos.

Abre interrogantes también sobre la vigencia y arraigo de la clase política partidista de izquierda en Chiapas, que tuvo notoriedad en la segunda mitad de la década de 1990 y principios de la de 2000 y pareció marcar la apertura de un ciclo pluralista democrático. ¿Estamos ante el cierre de este ciclo, con el retorno de prácticas políticas coercitivas y faccionales, o ante dinámicas y expresiones políticas que justo por sus condiciones plurales y divergentes son propias de un régimen democrático?

\section{...la democracia que no fue}

Los resultados del proceso electoral local antes presentados, como los de los comicios federales que dieron el triunfo a la alianza PRI-PVEM en la totalidad de distritos - doceen la entidad, trazan el presente y el horizonte inmediato de una democracia liberalparlamentaria que en Chiapas ha dejado de ser tal.

El saldo de la contienda electoral local, aunque lo mismo cabría decir para la federal, niega, entre otros, uno de los componentes clave de la democracia: la representación. Ésta en el caso chiapaneco está negada en sus propios términos porque los "representantes" electos, depositarios en teoría de la voluntad de la ciudadanía votante, representan los intereses de gobierno y de los grupos insertos en él. La creación de partidos locales "a modo", al igual que el disciplinamiento y alineamiento de los gobiernos locales a las directrices de los grupos en el gobierno estatal en el período preelectoral, como fue denunciado públicamente en medios de comunicación, ${ }^{11}$ confirman lo anterior.

Hay en ese sentido una regresión a concepciones predemocráticas de representación (Shapiro et al., 2009) en la que primaban intereses corporados no necesariamente compartidos por los representados, y en la misma línea se puede afirmar que en el caso de Chiapas se ha creado un sistema político de corte utilitario en el que las máximas que guían las acciones políticas de cada agente — sean partidos políticos, coaliciones o individuo - sonlapersecucióndesuspropiosfines conelmenorcoste, yelemprendimiento

11 http://www.chiapasparalelo.com/noticias/chiapas/2015/07/chiapas-el-pvem-contra-el-priy-contra-si-mismo/por Gabriela Coutiño, consultado el 12 de enero de 2016. Y véase también http://www.chiapasparalelo.com/opinion/2015/08/el-gran-perdedor-de-las-elecciones-enchiapas/por Sarelly Martínez, consultado el 12 de enero de 2016. 
de acciones se realiza teniendo en consideración que la utilidad o el ingreso excederá el coste. $^{12}$

En el mismo tenor, lo que se registra es un vaciamiento de la legitimidad democrática de los gobiernos y legislatura locales hoy constituidos, en tanto que la competencia partidista fue prácticamente inexistente y los ganadores fueron tres partidos nacionales y dos locales con intereses mancomunados, sin diferencia política e ideológica alguna, y cuyos votos alcanzados fueron producto de prácticas políticas denunciadas como fraudulentas por representantes de partidos opositores al gobierno, ${ }^{13}$ y no de la ratificación de la confianza ciudadana en los representantes populares.

En tal sentido, el caso chiapaneco resulta revelador de lo que para otras latitudes se ha identificado como crisis de democracia, entendida como soberanía popular y deliberación pública en torno a intereses compartidos, y “creciente 'comodificación' de la política en nombre de la democracia” (Castro-Gómez, 2015: 305).

\section{Coda}

Aunque merecerían mayor profundidad analítica, sólo apunto para finalizar dos hechos relacionados con las circunstancias poselectorales en Chiapas que reiteran y profundizan el cuestionamiento sobre el alcance de la democracia como sistema de gobierno en esta entidad, bajo el sentido en que se ha descrito y desarrollado.

El primero de estos hechos es el conflicto por alcaldías. Aunque focalizados - Tuxtla Gutiérrez, Ocosingo, Oxchuc, Chanal, Chamula y, con sus particularidades, Frontera Comalapa-, los conflictos han reanimado los fantasmas de la crisis de legitimidad de los gobiernos electos y de los procedimientos que los han llevado al poder. ${ }^{14}$

En el mismo sentido de crisis de legitimidad está el segundo hecho que quiero referir y tiene que ver con los agentes encargados de arbitrar los procesos comiciales. Se trata de

\footnotetext{
${ }^{12}$ Anthony Downs (2001) abrió en la década de 1950 la discusión sobre la teoría económica de la acción política, y en la misma planteó la hipótesis siguiente: "En una democracia los partidos políticos formulan su política estrictamente como medio para obtener votos. No pretenden conseguir sus cargos para realizar determinadas políticas preconcebidas o de servir a los intereses de cualquier grupo particular, sino que ejecutan políticas y sirven a grupos de intereses para conservar sus puestos. Por lo tanto, su función social (que consiste en elaborar y realizar políticas mientras se encuentran en el poder) es un subproducto de sus motivaciones privadas (que buscan obtener la renta, el poder y el prestigio que supone gobernar)" (Downs, 2001: 96). Una hipótesis que tiene vigencia en el actual contexto chiapaneco. ${ }^{13} \mathrm{http}: / /$ www.milenio.com/politica/elecciones_chiapas-prd_y_pan_elecciones_chiapas-madero_y_navarrete_ chiapas_0_557944486.html por Liliana Padilla, consultado el 8 de febrero de 2016.

${ }^{14}$ Sobre el registro en prensa de la conflictividad poselectoral en Chiapas, véase http://www.elfinanciero. com.mx/nacional/estallan-conflictos-postelectorales-en-chiapas.html por Ángeles Mariscal (consultado el 8 de febrero de 2016).
} 
la destitución de tres consejeros electorales locales por haber inobservado el criterio de paridad de género en el registro de candidaturas y por las irregularidades relacionadas con el voto de ciudadanos residentes en el extranjero. ${ }^{15}$ Destaca de esta situación, además de la destitución por haber incurrido en falta, que aun cuando todos los consejeros fueron hallados responsables de haber cometido las mismas faltas, se desestimó el procedimiento de remoción en el caso de la consejera presidenta y de tres consejeros más, "a pesar de que quedó demostrada su responsabilidad respecto de las conductas que se le imputaron", debido a que no se alcanzó la mayoría calificada en la Comisión que evaluó el caso. ${ }^{16}$

\section{Referencias bibliográficas}

Castro-Gómez, Santiago (2015). Revoluciones sin sujeto. Slavoj Zizek y la crítica del historicismo posmoderno. México: Akal, Inter Pares.

Cerroni, Umberto (1989). Reglas y valores en la democracia. Estado de derecho, Estado social, Estado de cultura. México: CONACULTA, Alianza Editorial.

Downs, Anthony ([1957]2001). "Teoría económica de la acción política en una democracia”, en Dieztextos básicos de Ciencia Política. Barcelona: Ariel, pp. 93-11l.

García Aguilar, María del Carmen (2003). "Política y sociedad en Chiapas, 1970-2000.

Las utopías, los intereses, las realidades". Tesis de doctorado en Ciencias Sociales con especialidad en relaciones de poder y cultura política, México, División de Ciencias Sociales y Humanidades, Universidad Autónoma Metropolitana-Xochimilco.

García Aguilar, María del Carmen, Jesús Solís Cruz y Flor María Pérez Robledo (2014). "Chiapas. Elecciones 2012". En Margarita Jiménez Badillo (coord.), Calidad de democracia en elecciones para gobernador en el Sur-Sureste de México. México: Plaza y Valdés, Universidad Autónoma de Guerrero.

Gómez Tagle, Silvia y María Eugenia Valdez Vega (1997). “Chiapas”. En Silvia Gómez Tagle (coord.). 1994: las elecciones en losestados, t. I. México: La Jornada Ediciones, CRIMUNAM, pp. 179-209.

Held, David (2012). Modelos de democracia. Madrid: Alianza Editorial.

Instituto de Elecciones y Participación Ciudadana (IEPC) (s.f.). "Resultados electorales 2015".

Disponible en: http:/www.iepc-chiapas.org.mx/ (consultado el 21 de julio de 2015).

Loaeza, Soledad (2008). Entre lo posible y lo probable. La experiencia de la transición en México. México: Planeta.

\footnotetext{
${ }^{15}$ Datos provenientes del "Acuerdo del Consejo General del Instituto Nacional Electoral por el que se aprueba la convocatoria para la designación de las consejeras y los consejeros electorales del organismo público local del estado de Chiapas", descargado el 21 de marzo de 2016 de http://www. iepc-chiapas.org.mx/archivos/acuerdos-INE/2016/INE_CG116_2016.pdf.

${ }^{16}$ Datos provenientes del “Acuerdo del Consejo General del Instituto Nacional Electoral...”.
} 
O'Donnell, Guillermo (1997). Contrapuntos. Ensayos escogidos sobre autoritarismo y democratización. Buenos Aires: Paidós.

Pineda dela Cruz, Jesús (2012). LatransicióndemocráticadeChiapas. Competenciay competitividad electoral 1991-2010. Tuxtla Gutiérrez, Chiapas: UNICACH.

Shapiro, Ian, Susan Stokes, Elisabeth Jean Wood y Alexander S. Kirsher (ed.) (2009). Political representation. Estados Unidos: Cambridge University Press.

Sonnleitner, Willibald (2012). Elecciones chiapanecas: del régimen posrevolucionario al desorden democrático. México: El Colegio de México. 


\title{
Yucatán y el alcance estabilizador de las elecciones convergentes de 2015
}

\author{
Efrain Eric Poot Capetillo
}

El objetivo del presente trabajo es analizar las elecciones yucatecas celebradas el 7 de junio de 2015, en el contexto de la concurrencia con el proceso electoral federal, como mecanismo estabilizador regional ante el entorno nacional políticamente convulso. Para ello se retoman y adecuan ocho aspectos de la metodología utilizada por el Observatorio Nacional sobre la Calidad de la Democracia en Méxicol para evaluar la competencia política y calidad de las elecciones, que permitieron identificar la relación existente entre los altos índices de participación electoral y las características de: la población económicamente activa, la baja remuneración salarial, los altos índices educativos y de seguridad, el bipartidismo PRI-PAN y la incipiente sociedad civil local, cuestiones todas ellas asociadas a la escasa diversificación de la estructura social local.

\section{El contexto nacional}

El Gobierno federal encabezado por Enrique Peña Nieto, congruente con el Pacto por México que concretó con los tres principales partidos políticos mexicanos - PRI, PANy PRD-,impulsó las reformas laboral, política y educativa que, a pesar de las voces críticas de diversos sectores de la sociedad, fueron aprobadas por el poder legislativo; sin embargo, la implementación de las dos últimas reformas ha resultado muy problemática.

La reforma política creó la nueva Ley General de Instituciones y Procedimientos Electorales que dotó de mayores atribuciones al árbitro electoral, transformándolo de Instituto Federal Electoral (IFE) en Instituto Nacional Electoral (INE), y reconociendo a

\footnotetext{
${ }^{1}$ El proyecto del Observatorio Nacional sobre la Calidad de la Democracia en México forma parte de la Red de Investigación Sociedad Civil y Calidad de la Democracia del Consejo Nacional de Ciencia y Tecnología.
} 
los institutos electorales de los estados como organismos públicos locales (OPL), además de conferir al Consejo General del INE el nombramiento de los consejeros integrantes de los Consejos Generales Estatales de los OPL. Asimismo, por vez primera la citada ley reconoció la posibilidad de registro de las candidaturas independientes para los diversos cargos de elección popular.

La estrategia para implementar la reforma educativa generó la movilización de la Coordinadora Nacional de Trabajadores de la Educación (CNTE), corriente interna disidente del Sindicato Nacional de Trabajadores de Educación (SNTE), con presencia mayoritaria en los estados de Chiapas, Oaxaca, Michoacán y el Distrito Federal, que se opone a la evaluación de los docentes para el otorgamiento de plazas magisteriales y cambios escalafonarios, esgrimida por la Secretaría de Educación Pública como el instrumento principal para garantizar el mejoramiento de la calidad educativa en el país. La CNTE asegura que se trata en realidad de modificar las condiciones laborales del magisterio, ya que no se ha contemplado en dicha reforma la revisión de los planes de estudio de las escuelas normales ni el mejoramiento de la infraestructura de las mismas.

Precisamente la desaparición forzada de 43 estudiantes de la normal rural de Ayotzinapa, cuando se movilizaban por el incremento de plazas para profesores formadores de normalistas, becas de estudio y mejoras de la infraestructura destinada a aulas y dormitorios estudiantiles, puso al descubierto la complicidad entre autoridades, policía del municipio de Iguala y el "crimen organizado", lo que generó una de las movilizaciones nacionales más intensas de diversos sectores sociales, exigiendo la aparición con vida de los estudiantes y el castigo a los culpables de la agresión directa o la omisión del cumplimiento del deber de los cuerpos de seguridad estatal y federal.

El desacierto de la actuación gubernamental, principalmente en torno a la reforma educativa y la desaparición de los normalistas, generó un descontento ciudadano contra la inseguridad, la violencia criminal, la corrupción, la impunidad de funcionarios y miembros de la clase política y con el desempeño partidista. Pero lo inédito en términos de la calidad del proceso electoral de 2015 se dio cuando los movimientos de protesta usaron, como mecanismo de presión para ser escuchados, el llamado a evitar la realización de las elecciones, e implementaron bloqueos, tomas o ataques a instalaciones del INE, así como llamados a no ejercer el derecho al voto, lo que afectó gravemente la confianza ciudadana en la institución electoral, que hasta hace algunos años fue de las más confiables.

Aunque en menor medida, esas muestras de descontento también se hicieron presentes en el ánimo del electorado yucateco, sobre todo la relacionada con la demanda de aparición con vida de los 43 estudiantes normalistas, que tuvo como principal escenario la ciudad de Mérida y logró movilizar conjuntamente a estudiantes de las instituciones de educación superior públicas y privadas con sedes en la entidad: la Universidad Autónoma de Yucatán, el Centro de Investigaciones y Estudios Avanzados del Instituto Politécnico Nacional, las unidades académicas de la Universidad Nacional Autónoma de México, la Universidad Marista, la Universidad Modelo. 


\section{Datos sociodemográficos de Yucatán y el municipio de Mérida}

El estado de Yucatán ocupa la parte norte de la península del mismo nombre, y tiene como vecinos a los estados de Campeche y Quintana Roo, situados al oeste y este respectivamente; le corresponden 38402 kilómetros cuadrados de superficie, en la que se asientan sus 106 municipios que el gobierno de la entidad ha organizado en siete regiones geográficas (ver anexo l).

La entidad cuenta con una población total de 1818948 habitantes, 896562 son hombres y 922386 son mujeres. 511308 cuentan con educación primaria, 241 120 con educación secundaria y 367052 con educación pos-básica. La población económicamente activa es de 926 718; de esta cifra, 542907 son hombres y 356488 son mujeres, y a su vez la población económicamente no activa es de 537320 habitantes (INEGI, 2010).

La más dinámica de las regiones es la noroeste, a la que pertenece Mérida, ciudad donde se concentran las principales actividades industriales y de servicios; la menos favorable sería la región oriente, cuya cabecera es la ciudad de Valladolid (Secretaría de Fomento Económico del Estado de Yucatán, 2012: 50) (ver anexos 2 y 3). El índice de marginación del estado de Yucatán es de 0.4314 y se presenta en grado alto en casi todas sus regiones (ver anexo 4), de ahí que la distribución porcentual de los ingresos a nivel municipal se encuentre marcada por la inequidad, pues de los 261554 millones de pesos que en 2013 se reportaron - 1.5\% de los ingresos del país-, 205879 millones de pesos, el 78.7\%, los concentró el municipio de Mérida (INEGI, 2014) (ver anexo 5).

En el municipio de Mérida habitan 830732 personas, el 42.5\% de la población de la entidad; el $51.7 \%$ son mujeres y el $48.3 \%$ son hombres. El 10\% de los meridanos de cinco años y más - 74 709- habla una lengua indígena, el 95\% del porcentaje anterior es hablante de maya (INEGI, 2010). ${ }^{2}$ En la ciudad de Mérida se concentran los servicios educativos, médicos, comerciales, gubernamentales, financieros e inmobiliarios, que figuran entre las principales actividades económicas de la entidad (INEGI, 2014).

\section{Condiciones políticas}

\section{Distritos electorales: federales y estatales}

El estado de Yucatán se encuentra dividido en cinco distritos electorales federales y en quince de carácter estatal; de los primeros, el III y IV tienen como cabecera la ciudad de Mérida, que funge también como sede de los distritos electorales estatales I, II, III, IV, V, VI y VII, y también forma parte de este último distrito el municipio de Kanasín.

\footnotetext{
${ }^{2}$ Desde la segunda mitad de los años noventa, del siglo pasado, es cada vez más notoria la presencia de indígenas provenientes del estado de Chiapas dedicados a la venta de productos artesanales, golosinas y aseo de calzado, por las calles céntricas de la ciudad capital del estado.
} 
Las elecciones de 2015 se libraron en un contexto político estatal dominado por el PRI que ostentaba la gubernatura, 64 gobiernos municipales de 106, el Congreso Local con sus quince diputaciones y cuatro de las cinco diputaciones federales en las que se divide la entidad - I, II,III y V-; en tanto que la oposición se distribuía los cargos públicos de la siguiente forma: el PAN gobernaba en 35 ayuntamientos, incluido el de la capital del estado, siete diputaciones estatales y una diputación federal; el PRD gobernaba en cinco municipios y contaba con dos diputados locales; en tanto que el PVEM tenía un municipio y un diputado local; por último, el PNA controlaba un ayuntamiento. Mención aparte merecen los senadores, los dos de mayoría pertenecientes a las filas blanquiazules y la senaduría de primera minoría tricolor. Dicha composición de la representación política es una clara manifestación del bipartidismo que caracteriza a Yucatán desde los años ochenta del siglo pasado.

\section{El padrón, la lista nominal y la participación ciudadana}

El padrón electoral estatal estuvo integrado por 1471564 ciudadanos y la lista nominal empleada para los comicios de mayo de 2015 la integraron 1436608 electores, lo que representó una cobertura del 97.62\%, de los cuales acudieron a emitir su voto 1009343 ciudadanos, lo que significó una participación ciudadana del 70.26\%. El listado nominal del municipio de Mérida, con sus 627531 ciudadanos, representó el $43.68 \%$ del electorado yucateco; 382655 meridanos acudieron a las urnas, lo que significó el 67.97\% de participación ciudadana (IEPAC, 2015; INE, 2015).

\section{Las nuevas reglas del juego: INE, IEPAC}

La reforma política aprobada en 2014 que creó el Instituto Nacional Electoral, al que dotó de nuevas atribuciones, generó la adecuación de la normatividad electoral de la entidad, y se promulgó el 28 de junio de 2014 la Ley de Instituciones y Procedimientos Electorales del Estado de Yucatán, mediante la que el Instituto de Procedimientos Electorales y Participación Ciudadana del Estado de Yucatán (IPEPAC) se transformó en Instituto Electoral y de Participación Ciudadana de Yucatán (IEPAC), nombre con el que pasó a formar parte de la estructura del INE pero como organismo público local (OPL).

El nombramiento de los nuevos consejeros integrantes del Consejo General del IEPAC, tal y como marca la Ley Electoral Nacional, corrió a cargo del Consejo General del INE que tuvo que seleccionar de entre 124 aspirantes a siete: María de Lourdes Rosas Moya, María Patricia Isabel Valladares Sosa, José Antonio Gabriel Martínez Magaña, Antonio Ignacio Matute González, Carlos Fernando Pavón Durán, Jorge Miguel Valladares Sánchez y Naybi Janeth Herrera Cetina. 
Seis de los consejeros tenían experiencia de participación en los institutos electorales federales o estatales porque se habían desempeñado como funcionarios en la estructura operativa del IFE o como consejeros distritales, municipales o generales; sólo uno de ellos no contaba con ese tipo de experiencia. Sin lugar a dudas, el conocimiento de la manera de operar del órgano electoral federal por parte de algunos integrantes del consejo facilitó la coordinación de tareas entre la Junta Local del INE y el IEPAC, a pesar de lo inédito del proceso.

\section{Funcionarios de casilla}

Las labores de capacitación de los funcionarios de casilla corrieron a cargo del personal de la Junta Local del INE; para el 29 de mayo de 2015 se había capacitado al 98.24\% de los 22761 ciudadanos designados como funcionarios de casilla, todo ello a pesar de la negativa a participar como tales, encontrada en sectores de clase media alta de la ciudad de Mérida, y de las bajas en el número de ciudadanos ya capacitados, que eran cooptados por los partidos políticos para fungir como sus representantes de partido ante las casillas electorales, ofreciéndoles un pago por sus servicios, hecho que resultaba muy atractivo pues la subvención ofrecida era mayor a la entregada por la autoridad electoral para cubrir viáticos el día de la elección. Cabe mencionar, sin embargo, que esta práctica tan extendida en anteriores comicios, en gran medida se inhibió con las nuevas disposiciones legales, pues se emplearon métodos que permitieron detectar a todo aquel ciudadano que ya capacitado renunciara a desempeñarse como funcionario para impedirle presentarse como representante partidista (INE, 2015b).

Fueron 1081 funcionarios de las mesas directivas de casillas de un total de 15174 requeridos quienes no llegaron a cumplir con esta obligación el día de las elecciones, lo que representó el $7.7 \%$ del total requerido para las 2525 casillas que funcionaron en todo el estado. La mayoría de los ciudadanos que no cumplió su encomienda argumentó problemas personales y fueron sustituidos por ciudadanos que se encontraban formados en la fila de votantes, a los que se les dio una breve capacitación, pero ninguno de ellos actuó como presidente ni secretario de la casilla (Cárdenas, 2015: s.p.).

\section{El Consejo Electoral Municipal de Mérida}

El Consejo Electoral Municipal de la capital del estado fue prácticamente el mismo que funcionó durante el proceso electoral 2011-2012, pues dos de sus suplentes se convirtieron en consejeros propietarios; ambos habían ocupado el mismo cargo durante la elección 2010. Sin embargo, desde su propia sesión de instalación generó muchas polémicas, al grado de que estuvo bajo el escrutinio constante de los partidos y medios de comunicación, situación que incluso se presentó hasta la misma sesión de escrutinio, que ocupó cinco 
días y generó suspicacias respecto a un intento de acortar o de plano revertir la ventaja del abanderado panista respecto al del priista.

Muchas de las observaciones, inconformidades y quejas de los partidos políticos respecto a la actuación de la Junta Local del INE y de la OPL derivaban de los alcances limitados de dichas instancias para resolver de manera expedita asuntos locales, lo que provocó airadas protestas, ignorando o soslayando que dicha situación se había producido debido a la transferencia de atribuciones al Consejo General del INE, en apego a las nuevas disposiciones legales que en materia electoral promovieron las dirigencias nacionales de los partidos políticos en el marco de la reforma electoral de 2014.

\section{El Tribunal Electoral del Estado de Yucatán}

La conformación del Tribunal Electoral del Estado causó la inconformidad del PAN, pues la designación del Senado de la República recayó en tres exfuncionarios del anterior Instituto de Procedimientos Electorales y Participación Ciudadana (IPEPAC); dos exconsejeros (Fernando Bolio Vales y Lissette Cetz Canché) y del exdirector de capacitación electoral (Armando Valdés Morales), pues consideraban no apropiado que el personal se moviera entre una y otra instancia electoral para ocupar los cargos disponibles (Domínguez, 2014a y 2014b).

\section{Seguridad pública y conflictos electorales}

Una de las características más destacables de Yucatán a nivel nacional es sin duda la seguridad pública reflejada en los bajos índices de homicidios. En 2014 sumaron 48, lo que significó dos homicidios por cada cien mil habitantes, y en 2015 hubo un incremento en las cifras al pasar a 53, lo que significó un aumento del 26.99\% de casos recibidos en el Ministerio Público.

Sin embargo, la actuación de la policía estatal y las municipales, así como del Ministerio Público para atender las quejas y solicitudes realizadas por periodistas y partidos opositores a lo largo del desarrollo del proceso electoral, suscitó severos cuestionamientos debido a que parecieron responder exclusivamente a los intereses de autoridades y candidatos emanados del PRI, pues prácticamente ninguna queja o denuncia fue atendida con prontitud, e incluso hay cuestiones pendientes de resolver, como el caso de la pasividad y hasta complicidad mostrada por la policía ante la solicitud de ayuda de un reportero agredido por personas que resguardaban una bodega ubicada en el periférico de Mérida, en donde al parecer se almacenaban artículos para distribuir en la campaña de los candidatos del PRI en el estado. Las imágenes captadas por el reportero fueron el motivo para que un grupo de veinticinco individuos bloquearan el paso de su vehículo, le obligaran a descender del mismo, le quitaran a la fuerza el celular y las llaves de su auto, 
amenazaran con golpearlo y borraran los archivos del teléfono, transcurriendo todo en presencia de una patrulla con dos agentes que nunca intervinieron, aunque uno de ellos, como justificación a su actuación, expresó lo siguiente: "Es la política, jefe, nada puedo hacer" (Megamedia, 2015a: s.p.).

En los municipios del interior del estado fue donde se produjeron con mayor frecuencia agresiones verbales y físicas entre los simpatizantes de los diversos partidos contendientes por las alcaldías; en vísperas de la jornada electoral, cinco de ellos fueron catalogados por el IEPAC como "focos rojos": Tinum, Izamal, Tekom, Temozón y Maxcanú (Domínguez, 2015: s.p.).

Sin embargo, durante el desarrollo de los comicios se presentaron enfrentamientos entre simpatizantes de los partidos contendientes y la intervención de autoridades municipales y fuerzas de seguridad que amedrentaron o hicieron detenciones arbitrarias. Incluso el senador panista Daniel Ávila fue detenido un par de horas por la policía del municipio de Tekom, cuando simplemente acompañaba a sus simpatizantes en la fila de votación para evitar la materialización de las amenazas de agresión de que habían sido objeto.

La situación más grave aconteció en la villa de Temax, cabecera del municipio del mismo nombre, en donde fueron incendiados vehículos y un par de jóvenes perdieron la vida a consecuencia del enfrentamiento entre dos pandillas de la ciudad de Mérida, las que fueron contratadas para enfrentarse en dicho lugar con el fin de provocar temor y abstencionismo entre los votantes panistas, cuyo candidato concentraba las mayores intenciones de voto. Los resultados favorables al panismo demostraron lo estéril del uso de la violencia (Domínguez, 2015a: s.p.).

\section{La selección de las candidaturas}

En estas segundas elecciones intermedias -federales y locales- de tipo concurrente, la cantidad y diversidad de cargos de elección en juego permitió a los partidos contendientes usarlos como mecanismo de negociación para definir las distintas candidaturas, canalizar reales o potenciales descontentos de aspiraciones malogradas o enmendar errores de precandidatos que significaran un alto costo político.

En el PRI la distribución de candidaturas asumió como lógica buscar el equilibrio entre los grupos locales más fuertes, sus nexos con grupos nacionales -léase Gobierno federal y estructura dirigente partidista-, presencia o arraigo en la entidad y tipo de preparación para el desempeño del cargo de elección en juego, y puso especial énfasis en armonizar las decisiones en torno a las diputaciones federales y estatales. El control del aparato gubernamental a nivel estatal y federal fue factor determinante para mantener la cohesión organizativa, ya que también los cargos públicos estatales y federales sirvieron en la lógica del intercambio de espacios políticos para aquellos candidatos que no resultaron nominados a puestos de elección popular. 
Así, ante la necesidad partidista de contar con cuadros experimentados en el quehacer legislativo, orientado a la aprobación de la agenda reformista del Gobierno federal encabezado por Enrique Peña Nieto, fue postulado como candidato a diputado federal por la vía plurinominal Jorge Carlos Ramírez Marín, que se desempeñaba como titular de la Secretaría de Desarrollo Agrario, Territorial y Urbano (SEDATU); por vía similar fue postulada la exgobernadora Ivonne Ortega Pacheco, quien dejó el cargo de secretaria nacional del PRI.

Diputados estatales salientes y afines a los distintos grupos fueron promovidos a diputaciones federales o a cargos gubernamentales federales o estatales que quedaron acéfalos debido a la postulación de sus titulares a cargos de elección, tal como fue el caso de Pablo Gamboa Miner, responsable de la Coordinadora Metropolitana del Estado de Yucatán (COMEY) e hijo del influyente diputado Emilio Gamboa Patrón. Exdiputados federales pasaron a desempeñar cargos en el gobierno estatal, y funcionarios estatales pasaron a encabezar candidaturas a regidurías o a diputaciones estatales - uninominales o plurinominales-.

Fue en el terreno municipal en donde la estrategia de alineación y equilibrio de intereses entre el Gobierno federal y los grupos nacionales, estatales y municipales encontró sus mayores dificultades. En los municipios más importantes, económicamente hablando, la decisión se inclinó hacia los intereses federales y estatales - Mérida, Progreso, Kanasín, Umán, Tizimín, Valladolid—, en tanto que en los más pequeños - la mayoría - jugó un papel importante el control que los grupos locales tuvieran de los consejos municipales.

El PAN, mediante comicios internos, eligió a buena parte de sus candidatos, otros fueron designados directamente por la dirigencia nacional, sobre todo aquellas candidaturas etiquetadas como "reservadas" para dar cumplimiento a las disposiciones en materia de equidad de género o candidaturas indígenas.

El resto de los partidos aplicaron aquellos criterios de selección de candidaturas que sus dirigencias, nacionales y estatales, creyeron más adecuadas y flexibles como para dar cabida a los precandidatos priistas o panistas perdedores en las alcaldías, que en muchos casos terminaron por convertirse en sus candidatos.

Los únicos partidos que contaron con candidatos en las cinco diputaciones federales, las quince diputaciones de mayoría relativa y diez de representación proporcional estatales y en los 106 ayuntamientos, fueron el PRI y el PAN. El PRD registró 59 candidaturas, algunas de ellas bajo la figura local de candidaturas comunes con el PAN y el PT. el MORENA participó en 49, el PT en 31 y el MC en 19. Obtuvieron su registro dos candidatos "independientes", José Canul Dzul y Gabriel Arturo May Peniche, que se postularon a las presidencias municipales de Acanceh y Yaxkukul, respectivamente. 


\section{Mérida}

Mención aparte merecen los acontecimientos suscitados en torno a la definición de la candidatura por el ayuntamiento de Mérida, pues por ser la sede de la capital del estado se ha convertido en el principal escenario de confrontación electoral entre panistas y priistas, máxime que de las diez administraciones municipales que se han sucedido durante el período que va de 1991 a 2015, nueve han sido blanquiazules; la contienda también se extiende a los distritos electorales federales II y V y los que corresponden a la legislatura estatal del I al VII, en algunas de los cuales se ha dado la alternancia.

En el Partido Acción Nacional se decidió la candidatura a favor de Mauricio Vila Dosal, a partir de un acuerdo urgente al que llegaron los tres principales aspirantes a la candidatura después de un escándalo mediático en el que se vio involucrado el entonces diputado federal Raúl Paz Alonso, quien parecía tener asegurada la nominación, y que fue interpretado por la dirigencia nacional y estatal como de grave riesgo para perder el control político de la alcaldía meridana.

El Partido Revolucionario Institucional también contó con tres aspirantes a la nominación como candidatos a la presidencia municipal. Después de sondeos de opinión pública y conversaciones internas, se decidió que el secretario de Desarrollo Social del Gobierno del Estado, Nerio Torres Arcila — perdedor de la contienda municipal de 2012 - encabezara la planilla de regidores tricolores, y así también figuró como candidato común de los partidos Verde Ecologista de México y Nueva Alianza.

La postulación de Ana Rosa Payán Cervera como candidata a presidenta municipal de Mérida por el Partido Movimiento Ciudadano (MC) llamó poderosamente la atención pública, ya que de esta manera ella ponía fin a sus intentos de retorno a las filas panistas, a las que había renunciado en 2007 como muestra de su inconformidad con la elección del abanderado panista a la gubernatura. Las expectativas estaban puestas en que pudiera canalizar las simpatías del electorado meridano por la imagen de buen gobierno dejada durante las dos ocasiones en que fue alcaldesa (1991-1993 y 2001-2004), lo que también se reflejó en la votación alcanzada como candidata a la gubernatura en 2007 por el Partido del Trabajo y por el entonces Partido Convergencia Ciudadana.

Los otros candidatos a la primera regiduría de Mérida fueron: Carlos Carvajal Borges por el PRD y el PT, y Gilda María Aké y Hoil por el debutante partido MORENA.

\section{Desempeño de partidos políticos}

Los diez partidos políticos con registro definitivo: PAN, PRI, PVEM, PRD, PT, MC, PANAL, o de carácter condicionado: MORENA, PH, PES, en mayor o menor medida registraron candidatos, de manera individual o en forma de candidatura común. En conjunto, los partidos políticos acreditaron 50000 representantes ante las casillas 
electorales; el PRI cubrió el 100\% de ellas, le siguió el PAN con aproximadamente el 85\% de cobertura estatal y el 100\% de las instaladas en la ciudad de Mérida; los otros partidos quedaron muy rezagados o de plano registraron como representantes a militantes de partidos aliados, situación que fue muy común observar entre el PVEM y el PRI.

Hay que destacar que también fueron acreditados 1503 observadores electorales, 741 de los cuales correspondieron a ocho agrupaciones y el resto fueron solicitudes individuales; sin embargo, debe destacarse que existe la presunción de que algunos partidos usaron, como parte de sus estrategias de "defensa del voto" o "verificación del voto de sus partidarios", el registro legal de organizaciones poco conocidas para inscribir a simpatizantes como observadores electorales, es decir, como parte de sus mecanismos de movilización de votantes, como son las "brigadas" y "casas amigas" que usualmente funcionan el día de las elecciones.

Los partidos políticos — salvo el PT y Movimiento Ciudadano (MC), que perdieron estos derechos en las elecciones pasadas - tuvieron a su disposición \$89225817.19 pesos mexicanos a través de sus prerrogativas económicas encaminadas a la captación del voto y actividades específicas, cantidad que se distribuyó de la siguiente manera: PRI, \$30 278 587.78; PAN, \$29 592 71l.92; PRD, \$8 164 642.86; PVEM, \$6 255 814.25; Nueva Alianza, \$6 174 4ll.77; los partidos nuevos: Partido Encuentro Social (PES), Partido Humanista (PH) y Movimiento de Regeneración Nacional (MORENA), recibieron cada uno \$2 524970.56 , y a los candidatos independientes se les destinó \$1 184736.93 (Cárdenas, 2014: s.p.)

El INE multó a los partidos por un monto de \$9 356 970.19, debido a irregularidades en las que incurrieron sus candidatos en Yucatán en sus gastos de campaña en las pasadas elecciones del 7 de junio. Las sanciones más altas fueron para el Movimiento Ciudadano con $\$ 4756424.10$, y para el PAN con \$2 681 835.89, y el que recibió menor sanción fue el PES con $\$ 2804$; los otros partidos sancionados fueron: PT con $\$ 844$ 125.50, PRD con \$649 889.10, PH con \$130 526, Nueva Alianza con \$94 074.20, PVEM con \$83 419, PRI con $\$ 65503.40$ y MORENA con $\$ 48$ 369. El único caso que se dio en Yucatán de rebase del tope de gastos de campaña fue el del candidato independiente a la alcaldía de Acanceh, José Raúl Dzul Canul (Megamedia, 2015b: s.p.).

\section{Cobertura de medios}

La empresa Orbit Media fue contratada por el IEPAC para realizar el análisis de cobertura de medios en el estado de Yucatán y entregó cuatro informes parciales y un acumulado. En todos ellos destacaba la neutralidad en la difusión de las noticias electorales por parte de los noticieros y periódicos de la capital del estado, lo que atribuyó a las disposiciones de la nueva Ley Electoral y a la existencia de medios de comunicación que son equilibrados, equitativos y neutrales. 
Del 5 de abril al 3 de junio se analizaron 6822 piezas informativas de contenido electoral: 4102 fueron de prensa escrita (59.4\%), 1474 de radio (22.5\%) y 1246 de televisión (18.1\%). En prensa escrita el PRI tuvo el 65.5\% de las notas publicadas, el PAN el 27.2\%, el PRD el 20.1\%, MC el 15.7\%, Nueva Alianza el 2.2\% y el PVEM el 1.1\%. En la radio y la televisión locales, el mayor espacio también fue para el PRI con el 44\%, seguido del PAN con el $21 \%$, Movimiento Ciudadano con el $17 \%$, PRD con el $12.7 \%$ y, por último, MORENA con el $4.6 \%$.

Los medios de comunicación monitoreados por la prensa escrita fueron: Al Chile, Diario de Yucatán, Lai, DePeso, La Verdad, Por Esto, Tribuna de Yucatán y Milenio. Las estaciones locales de radio monitoreadas fueron Rasa, Radio Fórmula y Grupo Rivas. Los canales de televisión fueron TV Azteca, Televisora Yucateca (Canal 13) y Grupo Sipse.

De los diez partidos políticos que participaron en estas elecciones, sólo tuvieron presencia en los medios PRI, PAN, PRD y Movimiento Ciudadano, y fueron casi imperceptibles Nueva Alianza y el PVEM, aunque este último tenía como candidatos a los mismos del Revolucionario Institucional, y los que no figuraron fueron el Partido del Trabajo, el Humanista y Encuentro Social.

Hay que señalar que hubo partidos que estuvieron en desacuerdo con dicho informe, y también fue cierto que las acciones de los diversos niveles de gobierno se dieron a conocer como noticias, cuando se trató de inserciones pagadas por las propias autoridades, lo que hizo que muchos medios impresos se colocaran en los límites entre lo legal y el delito electoral; sin embargo, es justo reconocer que las nuevas disposiciones en materia de delitos electorales inhibieron las arraigadas malas prácticas de gobiernos, partidos y medios de comunicación (Domínguez, 2015b: s.p.).

\section{Empresarios y política}

A lo largo de los últimos diez años, ante el repliegue de la actividad de los organismos cívicos locales en el terreno de los procesos electorales, la iniciativa privada, a través de sus propias agrupaciones, participa de manera activa y crítica en los consejos consultivos impulsados por los gobiernos federal, estatal o municipal, y también promueve con determinación la participación de la sociedad en los procesos electorales, al igual que ha sido la principal promotora de foros y debates de los diversos candidatos a los principales cargos en juego — sobre todo a la gubernatura y presidencia municipal de Mérida- De manera destacada, la COPARMEX ha encabezado los esfuerzos en torno a la campaña "Sal a votar" que promueve a través de todos los medios a su alcance: espectaculares, propaganda en medios, transporte público, comercios y restaurantes que ofrecen a los votantes artículos gratuitos o descuentos con sólo mostrar el dedo pulgar marcado con la tinta indeleble usada en las casillas electorales. Existen otras organizaciones que de manera discreta se suman a las labores de la observación electoral. 


\section{Resultados electorales}

Los cinco candidatos del PRI a diputados federales se alzaron con el triunfo, como también lo hicieron trece - de quince- que compitieron por diputaciones estatales, que incluyeron los distritos I, II, III, VI y VII, con cabecera en Mérida. El PAN ganó en los distritos IV y V de la misma demarcación, por lo que la legislatura se completó con diez diputados más, electos por la vía plurinominal: seis del PAN y cuatro más que correspondieron cada uno a: PRD, PVEM, NA y MORENA (ver anexos 6 y 7 ).

En la integración del Congreso fue impugnada una decisión del Consejo General del IEPAC, que esgrimiendo el criterio de la "paridad de género" decidió reconocer como legisladoras a tres candidatas panistas por la vía plurinominal, en detrimento de tres candidatos del mismo partido, quienes impugnaron y ganaron ante la sala superior del Tribunal Electoral del Poder Judicial de la Federación, que resolvió el reconocimiento de sus triunfos sentenciando "que no puede estar por encima de la votación la paridad de género, no se puede forzar para imponerse al voto popular".

Los triunfos en los 106 municipios del estado se distribuyeron así: 69 correspondieron al PRI, veinticuatro al PAN, cinco a NA, cuatro al PRD, tres al PVEM y uno al MORENA. En cuanto a la alcaldía de Mérida, a pesar del triunfo de los priistas en las diputaciones federales y en cinco de siete de los distritos estatales con sede en dicho lugar, la planilla de regidores postulados por el PAN fue la vencedora, pero lo destacable es la integración plural del cabildo, pues además de las once regidurías panistas, el PRI se quedó con cinco, y el Movimiento Ciudadano, el MORENA y el PRD obtuvieron cada cual una regiduría (ver IEPAC, 2015).

\section{A manera de reflexión}

A pesar de la precaria situación económica que vive el estado, patente en la inequitativa distribución de los ingresos y en los índices de marginalidad debido a la concentración de los mejores empleos, servicios y remuneraciones en la ciudad de Mérida y su zona metropolitana, la población económicamente activa alcanza a ser el 51\% del total de habitantes, y el porcentaje de quienes han cursado estudios que van de educación básica a pos-básica alcanza el $61.54 \%$, situación que, aunada a los altos índices de seguridad que se viven en el territorio, ha contribuido al estallido de graves conflictos sociales.

Aunque la entidad no es ajena a la recepción e influencia de los movimientos sociales que se producen en el ámbito nacional e incluso surgen movilizaciones de solidaridad hacia ellos, lo que se ha impulsado son formas coyunturales de organización alternativa que han resultado autolimitadas por la condición estudiantil que guarda la mayoría de sus integrantes; esto, sin lugar a dudas, ha pesado para evitar la articulación de esfuerzos con otras organizaciones locales. 
En la entidad yucateca, el malestar existente hacia la clase política del país no ha desbordado los canales institucionales, y los procesos electorales aún gozan de amplia aceptación entre los yucatecos de diversos sectores sociales, sea por convicción ciudadana o por conveniencia clientelar. La infiltración de las estructuras gubernamentales y partidos políticos en la localidad es inexistente o aún no se presenta de la manera tan descarnada como se ha manifestado en otras entidades federativas.

La actuación de los cuerpos policíacos y el Ministerio Público en cuanto a la atención de las denuncias relacionadas con presuntos delitos electorales deja mucho que desear debido a que, en la mayoría de los casos, aquéllos se muestran omisos a asumir sus responsabilidades, lo que notoriamente favorece a la causa del partido tricolor.

El funcionamiento apegado a la legalidad de las distintas instancias electorales y la incorporación como consejeros electorales del OPL de personal con trayectoria en la estructura electoral federal para facilitar la cooperación con la Junta Local del INE, sin lugar a dudas abonan a la credibilidad en los procesos electorales y ello ha ayudado a solventar las dificultades que tuvo la aplicación de la nueva legislación electoral nacional.

Lo anterior se refuerza con la actitud asumida por la iniciativa privada como principal promotora de la participación ciudadana en la elección de sus autoridades y, por supuesto, la cada vez más frecuente cobertura equilibrada que los medios de comunicación dan a las campañas de los distintos partidos.

La alta competitividad electoral se manifiesta en la competencia bipartidista protagonizada por el PRI y el PAN, que se distribuyen y alternan muchos de los cargos de elección de los diversos niveles de gobierno, pero también a nivel del congreso local y los municipios comienza a reflejarse la actual pluralidad política a través de las diputaciones y regidurías alcanzadas por la vía de la representación proporcional.

Por todo lo anterior nos atrevemos a afirmar que en el caso de Yucatán los procesos electorales tienen el alcance de ser el principal mecanismo estabilizador de las disputas por el control político estatal a través de la lucha partidista, es decir, que el sistema de representación política es reflejo de la escasa diferenciación o diversificación de la estructura social local.

\section{Referencias bibliográficas}

Cárdenas, Israel (2014). "IEPAC aprueba aumento al financiamiento de los partidos políticos". En Milenio Novedades. Versión electrónica del día 16 de octubre de 2014. Disponible en: http://sipse.com/milenio/iepac-aprueba-aumento-financiamientopartidos-politicos-117909.html (consultado el 13 de enero de 2016).

Cárdenas, Israel (2015). “Ciudadanos dejaron 'vestido y alborotado' al INE”. En Milenio Novedades. Disponible en: http://sipse.com/milenio/elecciones2015-yucatan-ciudadanosdejaron-vestido-alborotado-ine-158976.html (consultado el 10 de febrero de 2016). 
Domínguez Massa, David (2014a). “Dividen opiniones. PAN y PRI con posturas opuestas por el tribunal”. En Diario de Yucatán. Versión electrónica del 4 de octubre de 2014. Disponible en: http://yucatan.com.mx/merida/politica-merida/dividen-opinione (consultado el 13 de enero de 2016).

Domínguez Massa, David (2014b). "Respaldan a Funcionarios. El PRD avala la designación del Tribunal Electoral”. En Diario de Yucatán. Versión electrónica del 5 de octubre de 2014. Disponible en: http://yucatan.com.mx/merida/politica-merida/ respaldan-funcionarios (consultado el 13 de enero de 2016).

Domínguez Massa, David (2015). “Candidatos sustituidos”. En Diario de Yucatán. Versión electrónica del 7 de junio de 2015. Disponible en: http://yucatan.com.mx/merida/ politica-merida/candidatos-sustituidos (consultado el 16 de marzo de 2016).

Domínguez Massa, David (2015a). "Enfrentamiento entre panistas y priístas deja dos muertos en Temax". En Diario de Yucatán. Versión electrónica del día 7 de junio de 2015. Disponible en: http://yucatan.com.mx/yucatan/politica-yucatan/enfrentamiento-entrepanistas-y-priistas-deja-dos-muertos-en-temax (consultado el 13 de febrero de 2016).

Domínguez Massa, David (2015b). "Difusión objetiva. Destacado papel de medios locales en las campañas”. En Diario de Yucatán. Versión electrónica del 23 de junio de 2015. Disponible en: http://yucatan.com.mx/merida/elecciones-merida-2/difusion-objetiva (consultado el 13 de enero de 2016).

IEPAC (2015). "Participación ciudadana". Disponible en: http://www.iepac.mx/ resultados-electorales/2015/PARTICIPACION-CIUDADANA-DIPUTADOS.pdf (consultado el 10 de enero de 2016).

INE (2015a). "Segundo informe trimestral 2015". México: INE, Dirección Ejecutiva del Registro Federal de Electores. Disponible en: http:/www.ine.mx/archivos2/DS/ recopilacion/JGEor201508-25in_01P02-04xFE.pdf (consultado el 10 de enero de 2016).

INE (2015b). “Acta de Sesión ordinaria del 29 de mayo de 2015”. Mérida: Consejo Local de la Junta Local del INE en Yucatán.

INEGI (2010). Censo de poblacióny vivienda. México. Disponible en: http://www.censo2010. org.mx.

INEGI (2014). "Distribución de los ingresos por Municipio, 2013". En Minimonografía. Yucatán. Censos Económicos 2014. México: INEGI. Disponible en: http://www.inegi.org. $\mathrm{mx} /$ est/contenidos.p.royectos/ce/ce2014/doc/minimonografias/myuc_ce2014.pdf (consultado el 14 de marzo de 2016).

La Verdad (2015) "Revelan neutralidad electoral en medios de Yucatán”. Disponible en: http:// laverdaddiario.com/revelan-neutralidad-electoral-en-medios-en-yucatan/527912/ (consultado el 14 de marzo de 2016).

Megamedia (2015a). "Agreden a un reportero. Los ataques, cerca de una bodega, ante un policía”. En Diario de Yucatán. Versión electrónica del día 5 de mayo de 2015. Disponible 
en: http://yucatan.com.mx/merida/politica-merida/agreden-un-reportero (consultado el 13 de febrero de 2016).

Megamedia (2015b). "Millonarias multas electorales". En Diario de Yucatán. Versión electrónica del día 22 de julio de 2015. Disponible en: http://yucatan.com.mx/merida/ politica-merida/millonarias-multas-electorales (consultado el 13 de enero de 2016).

Secretaría de Fomento Económico (2012). "Guía del Inversionista Yucatán”. Disponible en: http:/www.sefoe.yucatan.gob.mx/files-content/general/bebb9ld03be72clc6510a aabc7a39b50.pdf (consultado el 15 de marzo de 2016).

Anexo 1. Estado de Yucatán, división regional y municipal

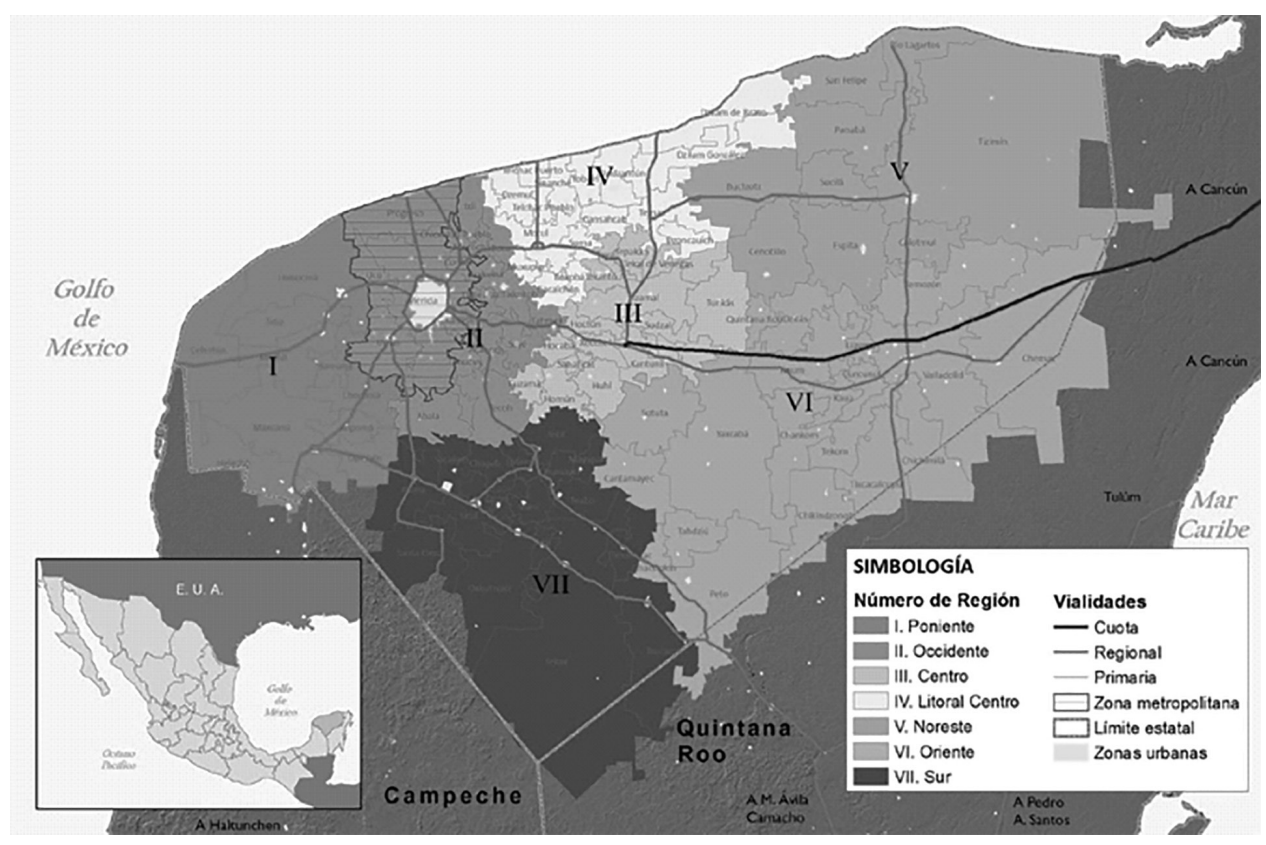

Fuente: Gobierno del estado de Yucatán 
Anexo 2. Regiones y sus vocaciones económicas

\begin{tabular}{|c|c|c|c|c|}
\hline Región & Municipios & Cabecera & Vocación & $\begin{array}{l}\text { Principales } \\
\text { actividades } \\
\text { económicas }\end{array}$ \\
\hline $\begin{array}{l}\text { Región I } \\
\text { Poniente }\end{array}$ & $\begin{array}{l}\text { Celestún, Chocholá, Halachó, } \\
\text { Hunucmá, Kinchil, Kopomá, } \\
\text { Maxcanú, Opichén, Samahil y Tetiz. }\end{array}$ & Maxcanú & $\begin{array}{l}\text { Sector primario } \\
\text { y actividades } \\
\text { ecoturísticas. }\end{array}$ & \\
\hline $\begin{array}{l}\text { Región II } \\
\text { Noroeste }\end{array}$ & $\begin{array}{l}\text { Abalá, Acanceh, Baca, Ixil, Chicxulub } \\
\text { Pueblo, Conkal, Kanasín, Mérida, } \\
\text { Mocochá, Progreso, Seyé, Tahmek, } \\
\text { Tecoh, Timucuy, Tixkokob, } \\
\text { Tixpehual, Ucú, Umán y Yaxkukul. }\end{array}$ & Mérida & $\begin{array}{l}\text { Actividad } \\
\text { primaria, } \\
\text { industria, } \\
\text { comercio y } \\
\text { servicios. }\end{array}$ & \\
\hline $\begin{array}{l}\text { Región III } \\
\text { Centro }\end{array}$ & $\begin{array}{l}\text { Cuzamá, Hocabá, Hoctún, Homún, } \\
\text { Huhí, Izamal, Kantunil, Sanahcat, } \\
\text { Sudzal, Tekal de Venegas, Tekantó, } \\
\text { Tepakán, Teya, Tunkás y Xocchel. }\end{array}$ & Izamal & $\begin{array}{c}\text { Industria y } \\
\text { turismo. }\end{array}$ & \\
\hline $\begin{array}{l}\text { Región } \\
\text { IV Litoral } \\
\text { Centro }\end{array}$ & $\begin{array}{l}\text { Bokobá, Cacalchén, Cansahcab, } \\
\text { Dzemul, Dzidzantún, Dzilam de } \\
\text { Bravo, Dzilam González, Dzoncauich, } \\
\text { Motul, Muxupip, Sinanché, Suma, } \\
\text { Telchac Pueblo, Telchac Puerto, } \\
\text { Temax y Yobaín. }\end{array}$ & Motul & $\begin{array}{c}\text { Agricultura, } \\
\text { industria y } \\
\text { turismo. }\end{array}$ & \\
\hline $\begin{array}{l}\text { Región V } \\
\text { Noreste }\end{array}$ & $\begin{array}{l}\text { Buctzotz, Calotmul, Cenotillo, Espita, } \\
\text { Panabá, RíoLagartos, San Felipe, } \\
\text { Sucilá y Tizimín. }\end{array}$ & Tizimín & $\begin{array}{l}\text { Actividad } \\
\text { pecuaria } \\
\text { y turismo } \\
\text { sustentable. }\end{array}$ & $\begin{array}{l}\text { Agricultura } \\
\text { de temporal, } \\
\text { ganadería } \\
\text { extensiva, } \\
\text { forestal, } \\
\text { pesca y } \\
\text { servicios. }\end{array}$ \\
\hline $\begin{array}{l}\text { Región VI } \\
\text { Oriente }\end{array}$ & $\begin{array}{l}\text { Chankom, Cantamayec, Chacsinkín, } \\
\text { Chemax, Chichimilá, Chikindzonot, } \\
\text { Cuncunul, Dzitás, Kaua, Peto, } \\
\text { Quintana Roo, Sotuta, Tahdziú, } \\
\text { Tekom, Temozón, Tinum, } \\
\text { Tixcacalcupul, Uayma, Valladolid y } \\
\text { Yaxcabá. }\end{array}$ & Valladolid & $\begin{array}{l}\text { Agropecuaria, } \\
\text { turismo cultural e } \\
\text { industria. }\end{array}$ & $\begin{array}{l}\text { Agricultura } \\
\text { de temporal, } \\
\text { comercio y } \\
\text { actividad turística. } \\
\text { Agricultura } \\
\text { de temporal y } \\
\text { servicios. }\end{array}$ \\
\hline $\begin{array}{l}\text { Región VII } \\
\text { Sur }\end{array}$ & $\begin{array}{l}\text { Akil, Chapab, Chumayel, Dzán, Mama, } \\
\text { Maní, Mayapán, Muna, Oxkutzcab, } \\
\text { Sacalum, Santa Elena, Teabo, Tekax, } \\
\text { Tekit, Ticul, Tixméhuac y Tzucacab. }\end{array}$ & Ticul & $\begin{array}{l}\text { Producción } \\
\text { agrícola e } \\
\text { industria del } \\
\text { calzado. }\end{array}$ & \\
\hline
\end{tabular}

Fuente: Secretaría de Fomento Económico (2012). “Guía del Inversionista Yucatán”. Disponible en: http:// www.sefoe.yucatan.gob.mx/files-content/general/bebb9ld03be72clc6510aaabc7a39b50.pdf (consultado el 15 de marzo de 2016).

Nota: Extensión: 39612 kilómetros cuadrados, 2.0\% del territorio nacional (Marco Geoestadístico, 2005). 
Anexo 3. Mapa de Regionalización Noreste del Estado de Yucatán

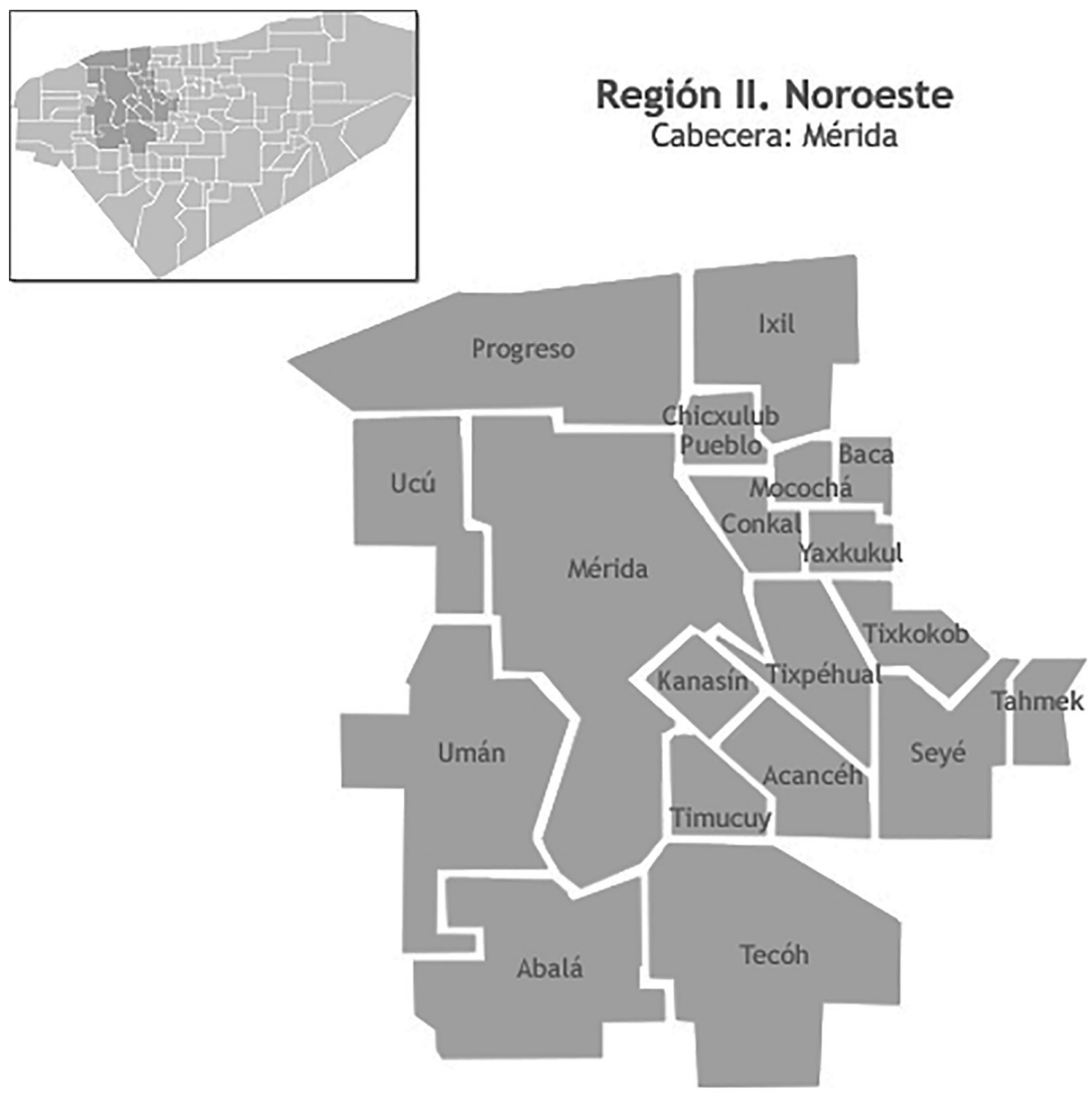


Anexo 4: Yucatán, localidades por grado de marginación y tamaño de localidad, 2005

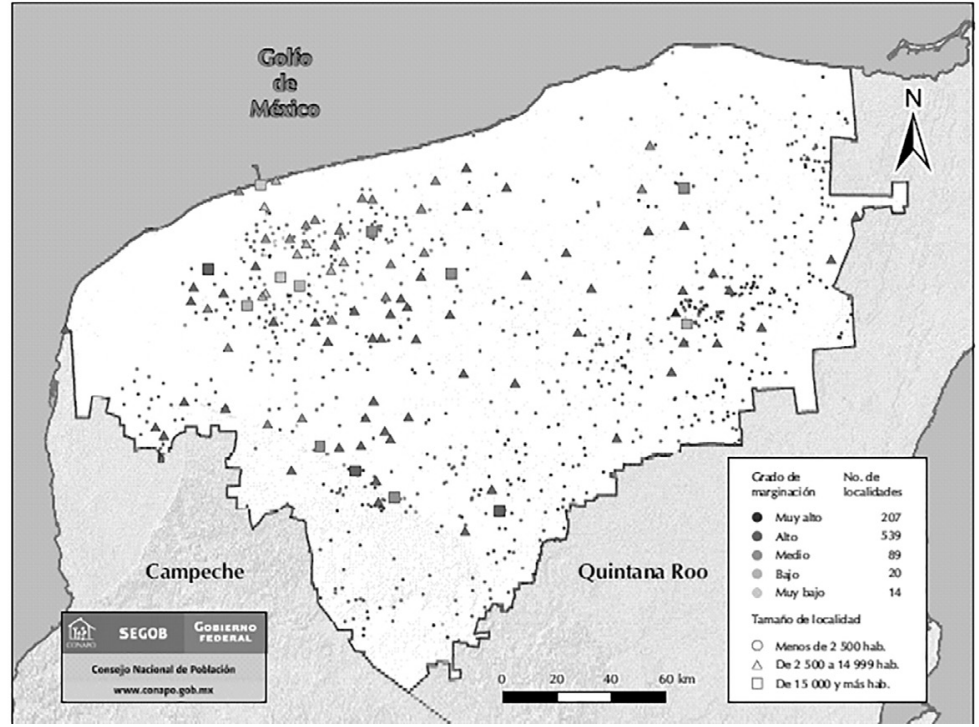

Fuente: Estimación del CONAPO con base en el II Conteo de Población y Vivienda 2005.

Anexo. 5 Distribución de los ingresos por municipio del estado de Yucatán, 2013

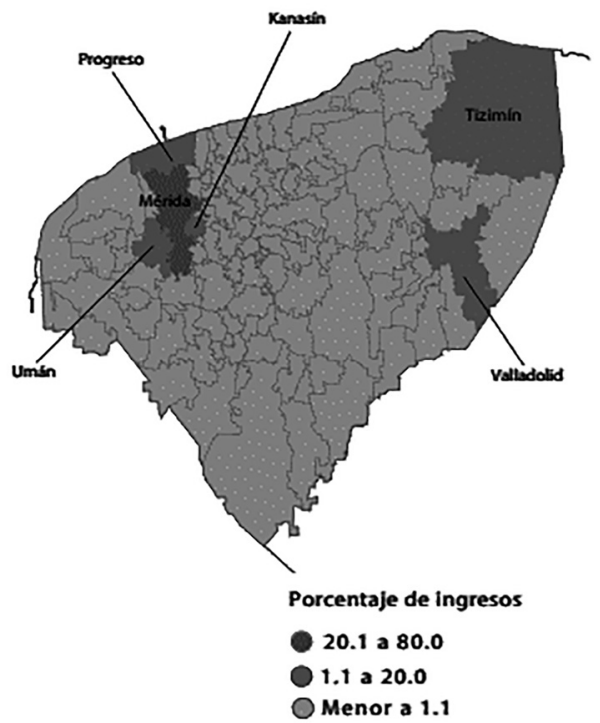

Fuente: INEGI (2014) Minimonografía. Yucatán. Censos Económicos 2014. 
EFRAÍN ERIC POOT CAPETILLO

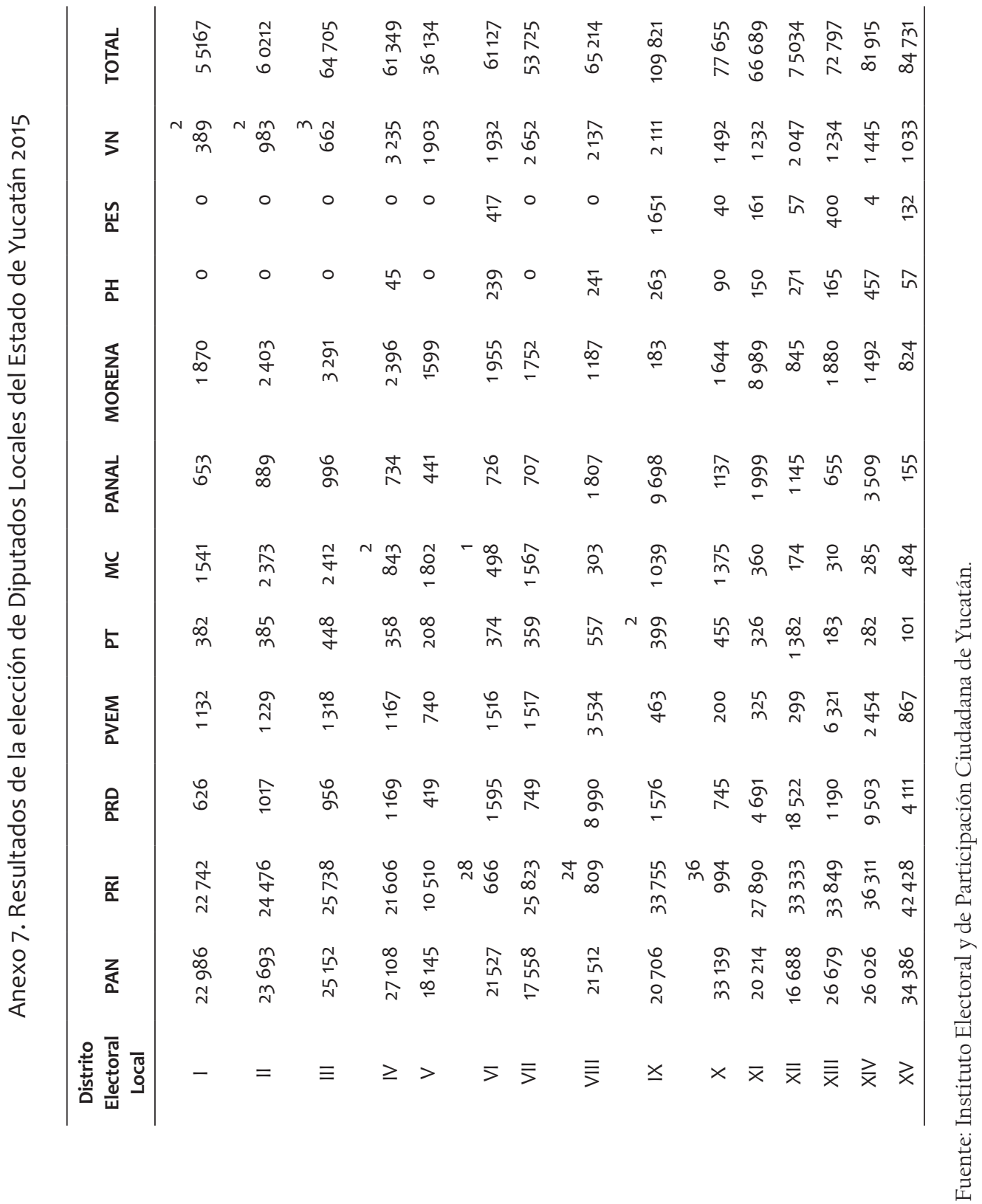




\section{Tercera parte. Democracias otras}

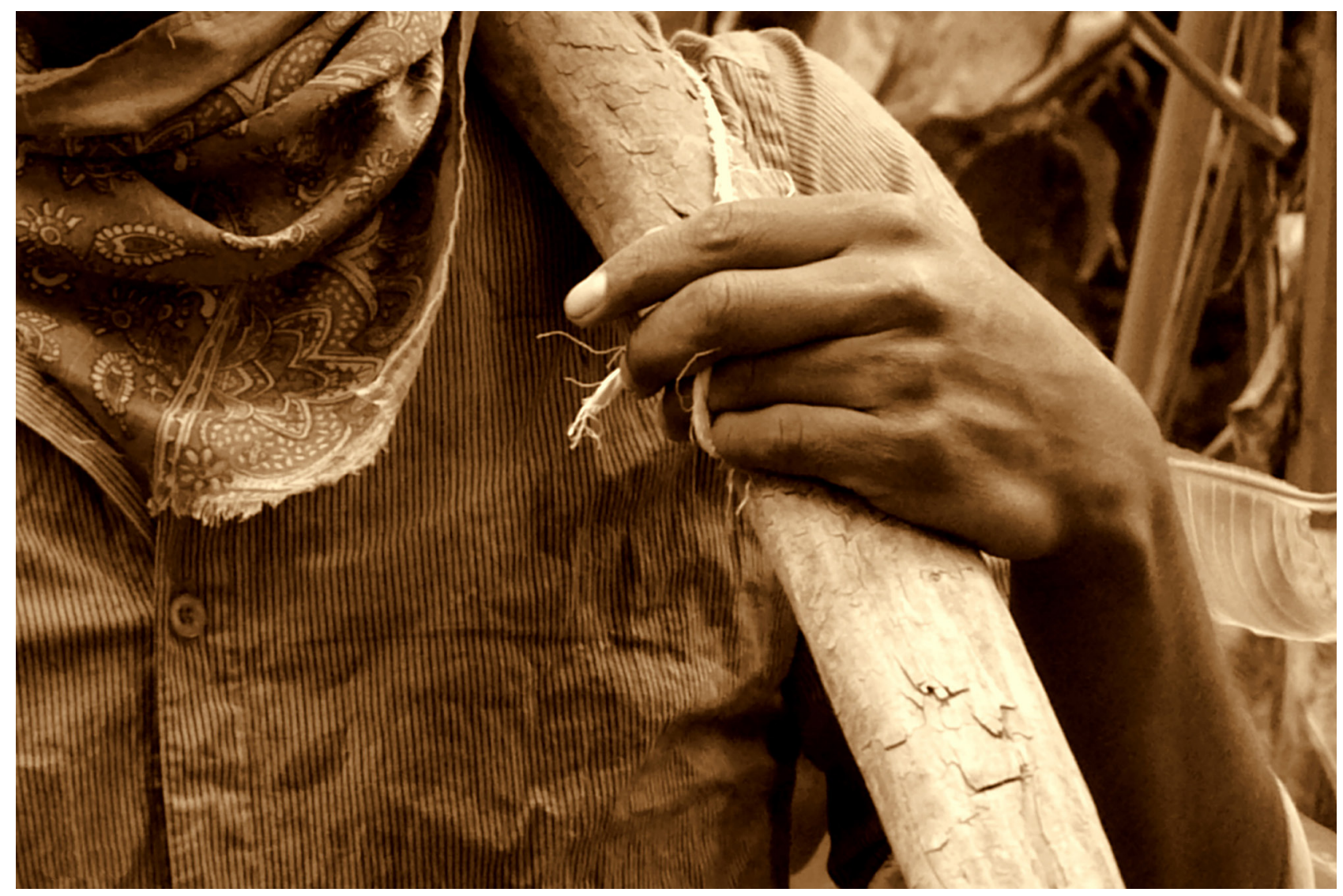




\title{
Profundizaciones en torno a la demoeleuthería
}

\author{
Carlos Alonso Reynoso \\ Jorge Alonso Sánchez
}

Hemos tenido el atrevimiento de considerar que la práctica de la autonomía de los de abajo podría expresarse de manera más contundente por medio del concepto demoeleuthería (la libertad de los de abajo). La unión de estos dos términos remite a otra conjunción, la de los términos demos y kratos, que se ha difundido como el poder del pueblo, pero la historia ha constatado que, donde hay kratos, el amplio demos de abajo sufre dominación. ${ }^{1}$ En esta forma, la demoeleuthería, esa libertad de los de abajo forjadora de autonomía, habría que entenderla en el sentido del primer curso de la libertad, según los zapatistas, que se encuentra lejano de la democracia imperante cooptada por la oligarquía que la ha vaciado e impedido, y que al apoderarse de ella la ha dejado sin sentido (Alonso y Alonso, 2015). En una primera incursión consideramos que la experiencia zapatista era una buena ejemplificación de esta búsqueda de la libertad de los de abajo. Ahora queremos dar nuevos pasos en este sentido teniendo en cuenta de nuevo el proceso del zapatismo.

\section{Algunas precisiones}

Para avanzar en el conocimiento de la demoeleuthería conviene reflexionar sobre la contraposición entre ser y tener. Existe una tensión entre estos dos conceptos. Gabriel Marcel explica que tener no implica ser porque no somos lo que tenemos. El tener puede cosificar. No debemos olvidar el contacto con la naturaleza. No hay que tener la naturaleza, pues el tener lleva al dominio. El tener es transmisible. Hay un tener como

\footnotetext{
${ }^{1}$ Alain Badiou ha considerado que se puede tomar el poder sin dejarse tomar por él. Pero esa posibilidad filosófica ha sido desmentida por la historia. No ha habido quienes habiendo tomado el poder estatal no hayan sido moldeados a sus exigencias para proseguir la dominación (ver: http://www.eldiario.es/ interferencias/Alain_Badiou-Syriza_6_375922434.html).
} 
posesión, y hay un tener como una característica. La posesión es algo disputable, apunta Marcel al ser en situación y al ser en marcha. La existencia que se quiere separar del ser no quiere existir. La experiencia es indispensable. El ser es participación. En la juntura de la existencia y del ser es cuando interviene la libertad, que no es un tener, sino que es ser. La implicación libre nos pasa de la existencia al ser. El ser es una disposición creadora. Se habla de tener o perder la libertad, pero la libertad no es un tener, sino un ser; soy, somos libres. La libertad implica capacidad de elección, porque en cuanto libres, somos. No somos mientras no decidimos. Testificamos nuestra libertad con nuestra actuación. Libertad implica disponer de nosotros autónomamente. El ser pleno es el ser libre porque estamos implicados en nuestra libertad, mientras que el ser se degenera en el simple tener. Debemos cuidar de no alienar nuestra libertad. Al crear estamos en el campo del ser. La decisión libertaria de sí con los demás es ser. El acto libre se presenta como un acto significativo, porque la libertad no es una cadena de causas y efectos, sino la expresión del sí mismo. El acto libre contribuye a lo que somos. Un humano interiormente vacío no puede ser libre. La libertad requiere plenitud interior. Lo humano encerrado en sí mismo no es libre, la libertad se da en la apertura a los otros; en lo que se va creando es cuando uno puede reconocerse como libre. Cuando nos cosificamos, nos traicionamos. La libertad está en la generosidad y querer tener libertad sin valores es suicida. La libertad no es lo que satisface caprichos. La libertad se expresa en el compromiso con los demás. La libertad conlleva responsabilidad. La libertad no está en el tener sino en el ser porque nos hace ser. El ser es relación o, mejor dicho, co-presencia. La esperanza es un acto de libertad. Los humanos no poseen la libertad, sino que se hacen libres (Marcel, 1935).

Fromm alude a Marcel y recomienda su lectura. Advierte que prefiere hacer un análisis social y psicológico empírico de dos modos de existencia y trata del egoísmo y del altruismo, a la vez que critica que la sociedad actual haya hecho prevalecer el tener sobre el ser. En este sentido, plantea que la avaricia y la paz se excluyen porque el tener se opone al ser. Considera que ante el afán capitalista tal vez hayamos perdido el instinto de conservación. Unos se doblegan ante el tener, mientras otros se centran en las personas. No se trata de poseer más conocimientos, sino de conocer profundamente. Exhorta a librarse de las cadenas del tener. Los bienes no son malos en sí, pero sí el aferrarse a ellos. La libertad no es un dejar hacer, ni es arbitrariedad. Ser libres no es librarse de los principios guías. Se teme a la libertad por el peligro de fracasar. Critica que la relación de la gente con la naturaleza se haya vuelto hostil. Se perdió la armonía entre la humanidad y la naturaleza y se la ha sometido a los fines destructivos del lucro (Fromm, 1976).

Fanon (1961) consideró la descolonización como liberación del ser porque la colonización niega el ser, lo que sucede no sólo con la colonización externa, sino con los colonialismos internos. De esta forma, la demoeleuthería está implicada en todo proceso de descolonización y en la lucha contra toda clase de colonialismos. El mito de la democracia 
ha conducido a ver como valores democráticos algunos que no lo son. Se dice que con democracia la vida es más libre, pero en la realidad eso se niega porque la actual democracia es un sistema de dominación que ha sido impuesto dado que se elige a quienes dominan. La democracia actual es más un mercado de votos que respalda el mercado de bienes y servicios. Esta democracia no tiene que ver con la humanización de las relaciones humanas. Para que el poder respetara los derechos humanos se tendrían que cambiar las estructuras. Hay que construir una sociedad más justa. Pero esta democracia no es justa (Hinkelammert, 2015). Históricamente se ha dado una alianza entre el llamado libre mercado y muchas dictaduras. La cárcel de la libertad es tanto el mercado como el Estado. Habría que construir una sociedad libre, justa y solidaria (Fernández y Silnik, 2012). La demoeleuthería implica los procesos para esa liberación.

La certeza de ser plenamente humanos radica en la certeza de ser libres, aunque la libertad no puede quedarse como certeza interna porque consiste en llevar decisiones a la realidad, en transformar el mundo de acuerdo con la decisión tomada. El llamado mundo libre es lo que se podría denominar la libertad real, parafraseando aquello del socialismo real. El liberalismo priva de la libertad al hombre universal, mientras el neoliberalismo se muestra enemigo de todo pensamiento de liberación de los que han sido privados de libertad por el sistema capitalista. Pero la aspiración de los explotados es ejercer la libertad, aplicar sus propias decisiones. La libertad no es para asegurar la subsistencia, sino para realizar las decisiones. Se ha recomendado leer el libro de Marx, El capital, poniendo en el centro la libertad y no la riqueza. Esto implica hacer una lectura libertaria del capital, porque lo que importa no es sólo repartir las riquezas, sino la repartición de la libertad, es decir, apropiarse de los medios de producción es un medio y no un fin. No hay ninguna clase que deba dirigir a las demás (Rey, 2012: 25-67).

En el contexto de estas discusiones resulta pertinente problematizar un poco más los procesos del capitalismo en cualquiera de sus etapas, y más en la actual, en la que predominan las corporaciones trasnacionales. El capitalismo es un amplio proceso de desposesión tanto de los trabajadores, como de los pueblos y de los amplios sectores populares. Se despoja al trabajador del producto de su trabajo, pero también a los pueblos de sus territorios y de los bienes existentes en ellos. Se expolia la naturaleza misma de su propia conservación. Esta desposesión implica arrebatar haberes que son indispensables para que la gente subsista y sea. De esta manera, no sólo el colonialismo, sino todo el capitalismo atenta contra el ser de la gente al despojarla del sustento fundamental de su vida y de su ser. La demoeleuthería es la lucha por conservar ese ser en armonía con la naturaleza y no sólo se refiere a la superación de las colonizaciones, sino a las defensas contra la explotación, la expoliación y la desposesión capitalista. Una de las alternativas al capitalismo es que la gente tenga lo indispensable para sobrevivir dignamente en armonía con la naturaleza. Se trataría así de ese sustento que resulta condición indispensable para propiciar el ser. 
RecomiendaZibechiconocer los modos en que ejercen el controllasclases dominantes, porque los de arriba crean nuevas formas de opresión, en ocasiones brutales, las más de las veces sutiles e invisibles. Habrá que observar qué características tiene la dominación, pero también cuáles son sus puntos débiles. Se tendrá que construir un tipo de organización para operar dentro de la dominación, con la perspectiva de escapar de ella, de liberarse de ella. Siguiendo la postura de James Scott, se necesitan organizaciones capaces de construir espacios seguros fuera del control de los poderosos. Hay que mantener el deseo de libertad (Zibechi, 2015a). Las búsquedas para liberarnos son parte de la dinámica de la demoeleuthería, que es el antídoto contra las élites, es el instrumento para impedir que las élites nos digan qué se tiene que hacer.

Hay muchas formas de resistir todo tipo de poder, y si la comunicación se usa como forma de ese poder que controla, es posible emplear la tecnología del poder para crear resistencias. Mientras hay quienes quieren combatir al Estado para apoderarse de él, la demoeleuthería impulsaría a combatir al Estado para liberarse de él. En este sentido, Clastres detectó que existían comunidades que querían impedir que se constituyera el Estado. No obstante, éste apareció y dominó, lo que hay que ver es cómo, una vez instalado el Estado, liberarse de él.

Debemos profundizar las relaciones que se establecen entre poder y demoeleuthería, Estado y demoeleuthería, democracia y demoeleuthería, movimientos y demoeleuthería, resistencia y demoeleuthería, los "más allá" de todo esto y la demoeleuthería. Toda la estructura de poder se creó para que la gente no pueda discernir ni debatir con más información, sino para impedirle complejizar, por lo que para liberarse de esa manipulación hay que explorar contextos, indagar procesos, despertar la capacidad crítica. La demoeleuthería es discernimiento colectivo.

La demoeleuthería tiene que ver con organizarse y tejer resistencias, conjuntar nexos horizontalmente. Hay quienes señalan la necesidad de una articulación estratégica horizontal frente a las políticas de devastación contra el movimiento popular (Esteva, 2015). La demoeleuthería se podría explorar como esos procesos de emancipación desde abajo que implican ensayos de autonomía que van erosionando el despojo capitalista y las dominaciones, tanto estatales como de otra naturaleza, que engloban los poderes heterónomos. La demoeleuthería también contribuye a ese cambio de cultura política que van forjando los movimientos populares en pos de la emancipación (Zibechi, 2015b) e impulsa la práctica de otra cultura, asentada en otros valores, además de que propicia la creación de nuevas relaciones sociales en esa dinámica de salirse de las relaciones de competencia e impulsar lo solidario (Zibechi y Rath, 2015). La demoeleuthería también contribuye a esa creación de lenguajes que son herramientas de sobrevivencia, que no apelan a una teoría del saber absoluto, sino a esas relaciones entre comunidades y ciclos vitales de la naturaleza (Prada, 2015a).

La demoeleuthería implicaría esa liberación que propicia el debatir entre todos la institucionalidad que se debe crear y revisar continuamente para cambiarla también a 
partir del proceso autonómico de debatir y decidir conjuntamente. Sería algo más denso y complejo que lo que se ha señalado como democracia directa, porque es posible realizar eso no sólo en niveles pequeños, sino en confederaciones de una gran cantidad de núcleos. Se plantea la hipótesis de que la demoeleuthería podría ser una pista de búsqueda en el sentido de cómo poder zafarse de los imperativos de explotación, dominación y destrucción de nuestro medio vital, y ensayar caminos alternos para conseguir convivencias que salvaguarden la naturaleza y lo humano.

Proponemos que se examine si toda una dinámica desde abajo para crear un mundo nuevo no es precisamente esa liberación del capital y del Estado implicada en lo que destacamos como demoeleuthería, esa conquista libertaria de autonomía para decidir sin imposiciones ni explotaciones cómo vivir y convivir solidariamente. Planteamos que esa expresión creativa no heterónoma puede llamarse demoeleuthería.

En la autonomía intervienen combinadamente la libertad, la democracia, la justicia y la solidaridad, en esa búsqueda de la demoeleuthería que es esa libertad solidaria de enfrentar juntos los problemas horizontalmente, de atreverse a crear soluciones entre todos, debatidas, experimentadas, corregidas, que implican la libertad y las decisiones comunes sin dominantes; una búsqueda que subsume y complementa los elementos que suelen destacarse en la democracia de los de abajo para instaurar una democracia libertaria. La demoeleuthería es una experiencia profundamente colectiva.

La demoeleuthería no es una cosa, sino una búsqueda, algo heurístico que conduce a que se vaya llenando de significados prácticos libertarios. Habría que ver la demoeleuthería como pregunta, como proceso, como proyecto que se vive de algo menor y se puede ir ampliando y, por lo tanto, seguir en su búsqueda perdiendo el miedo a la libertad y construyendo con imaginación y creatividad a partir de sujetos colectivos en continuo diálogo y debate, impulsando consensos y formas en constante ensayo. Se trata de esa libertad no egoísta sino solidaria, y más bien se trata de una gran gama de libertades que buscan cooperar horizontalmente sin sujetarse a amos.

Podríamos avanzar en esta profundización por medio del examen de cuatro reflexiones zapatistas. La primera tiene que ver con la práctica de su propia justicia, la segunda corresponde a lo expresado en una publicación que recoge las intervenciones de dirigentes zapatistas en el seminario de mayo de 2015, la tercera corresponde al segundo curso de la escuelita zapatista que impartieron zapatistas de niveles medios y de base, y la cuarta a lo expuesto en la revista zapatista de abril de 2015.

\section{La justicia zapatista y la demoeleuthería}

La sección correspondiente a la justicia zapatista se puede ilustrar de manera muy amplia por medio de un estudio que hizo de ella Paulina Fernández Christlieb (2014) con el título Justicia Autónoma Zapatista. Lo que sigue es lo que nos ilustra este libro. 
Por medio de numerosas entrevistas colectivas en cuatro municipios de la selva tseltal, este libro muestra que los zapatistas tienen grandes capacidades para construir su proyecto de vida, y que existen formas de organización, gobierno, democracia y justicia alternativas a la dominación. Se contrapone la justicia zapatista a la justicia imperante en México, la cual es víctima del dinero, la corrupción, la arbitrariedad y la impunidad. Las entrevistas con las personas de mayor edad revelan la carencia de justicia en la época de las fincas, de las graves injusticias que constituían todo el sistema de explotación, despojo y vejación. Se destaca cómo el territorio común en la época zapatista ha sido la base de una justicia otra, la autónoma. Se explora cómo las autoridades autónomas actúan como mediadoras, escuchando a las partes, investigando y buscando la reconciliación, para de esa manera resolver los conflictos de mutuo acuerdo. Si alguien merece castigo, lo paga con trabajo colectivo.

Saber impartir la justicia autónoma es algo que se va aprendiendo y enriqueciendo en sus formas. Los zapatistas van comparando las situaciones de injusticias antes de 1994 y las experiencias de la impartición de la justicia autónoma. No deja de llamar la atención el hecho de que personas no zapatistas acudan a dicha justicia.

El capítulo primero explora las aportaciones de los de más edad, quienes recuerdan el trato de animales que se les daba en las fincas; ellos narran con dolor las violaciones de que eran objeto las mujeres de los trabajadores. Se presentan estrujantes memorias y testimonios de la crueldad de esa vida, con narraciones vivas y detalladas que van dando cuenta de la gran explotación y de las terribles injusticias que debían soportar para sobrevivir bajo la opresión de los finqueros, de lo ominoso y odioso del mandar arbitrario y abusivo de éstos, de la humillación, los golpes, los insultos, los castigos, los malos tratos, todo con complicidad del gobierno. Todo esto implicaba una sujeción opresiva, una falta de libertad. Pero también se da cuenta de cómo en silencio la gente se fue organizando hasta que ocurrió el levantamiento armado y de cómo con él empezaron los cambios. La libertad interna que los llevó a una liberación mayor ha rendido importantes frutos porque ahora el trabajo es íntegro para la gente y ya no paga impuestos. Y una parte importante de esos cambios tiene que ver con la justicia autónoma.

En el capítulo segundo se explica cómo se nombran las autoridades en el gobierno autónomo zapatista. Las tierras recuperadas y los trabajos colectivos son las bases de dicho gobierno. Preexistía una cultura comunitaria que sirvió de base para la construcción de la actual autonomía. Los recursos naturales que están en territorio autónomo son para beneficio colectivo, por lo que se cuidan y defienden. Se liberaron ellos y liberaron también a la madre tierra de la explotación capitalista. Las comunidades saben cuáles son sus colindancias y hasta dónde tienen atribuciones para intervenir. Cada pueblo avisa a sus autoridades los problemas que se deben resolver. El conocimiento del territorio es primordial para la organización administrativa del mismo. Cuando hay problemas entre territorios de diferentes caracoles, tienen que plantearlos juntos. El acuerdo es respetar 
cada uno sus territorios y los de los demás. Se trata de la vivencia de una libertad compartida y organizada.

Las asambleas deciden cómo se sufragan los gastos comunes. De lo que se produce en colectivo, una parte es para el consumo y otra para su venta que solventa otro tipo de necesidades. Una parte del colectivo es para el pueblo y otra se destina para lo regional. Hay fondos colectivos para muchos trabajos, como por ejemplo para limpiar caminos. Lo relativo a la salud y a la educación autónomas sale de lo colectivo. También hay áreas de trabajo. Se nombran responsables locales, agentes, comisariados y promotores de salud y educación elegidos por el pueblo dependiendo de cómo se hayan comportado las personas; y no importa si no saben leer y escribir, lo que importa es que hagan el trabajo que les corresponde.

Los pueblos deciden en libertad cómo repartir la tierra, cómo organizar el trabajo y cómo distribuir la producción. Libremente llegaron al acuerdo de no recibir nada del gobierno ni de los partidos políticos. Las comunidades tienen libertad e independencia económica que les permiten generar sus propios recursos. Esto da sustento a la independencia política para establecer sus reglas que toman en plena libertad. Todo este proceso es una ejemplificación de la demoeleuthería. En la elección de las autoridades se experimenta otro tipo de democracia, no la devaluada a la que se nos ha acostumbrado. No hay privilegios. El pueblo libremente elige, nombra, no lo hacen unos cuantos. Los jóvenes y las mujeres tienen derecho a participar y recibir el nombramiento de autoridades. No se elige a los que "echan trago", porque éstos no darían buen ejemplo. Se busca gente de calidad, por lo que se elige a los que participan, tienen buena conducta y acatan las normas zapatistas de mandar obedeciendo. Se eligen según el calendario de las comunidades por elección directa y abierta. En los municipios autónomos se convoca a asambleas de comunidades, las cuales proponen nombres. Desde los doce años se puede hacer uso de la palabra, pero el voto sólo se ejerce a partir de los dieciséis. Se eligen nombres, no cargos. Luego se ve quién tiene más votos y dependiendo de esto se distribuyen los cargos. En la postulación de candidatos para los municipios autónomos intervienen representantes de todas las comunidades que se reúnen en las asambleas comunitarias o municipales, según se requiera. Los representantes llevan nombres a las comunidades y regresan a la asamblea municipal con las votaciones. Así se van conformando los consejos autónomos. Una vez nombrados, si no cumplen se les cambia. De manera similar se hacen las elecciones para las Juntas de Buen Gobierno. La asamblea de zona propone nombres y se va a las comunidades. Se respetan las propuestas de zonas y se vota sobre ellas. En la asamblea salen los nombres y se llevan a los pueblos, que votan a seis personas por cada municipio. Quien tenga más votos queda como agente, le sigue el suplente, y todo el equipo de trabajo se va conformando de acuerdo con los votos: secretario, tesorero, comandante de Policía, etcétera. En cada pueblo hay un equipo de policías. El agente es el que se encarga de la justicia. En otro tiempo viene la elección de 
comisariado, secretario, tesorero, Consejo de Vigilancia y su secretario, que tienen el encargo de cuidar el terreno de la comunidad. Existe la Comisión Agraria, con su presidente, secretario y tesorero, y la Comisión de Honor y Justicia con su equipo.

Según los municipios, hay algunas variaciones en el número y nombre de cargos. Por ejemplo, no en todos los pueblos hay vocal. También hay un comité de educación con su secretario y tesorero; comité de salud general, comisión de salud reproductiva, con su respectivo equipo; comité de compañeras de las tres áreas - parteras, hueseras y expertas en plantas medicinales - y representantes de trabajos colectivos: presidente de trabajos colectivos de mujeres, con secretaria y tesorera, y presidente de trabajos colectivos de hombres con su equipo, comisión de desarrollo, etcétera.

Las autoridades autónomas están para atender problemas de los pueblos y evitar los potenciales. Los policías autónomos no están armados ni uniformados, no tienen funciones permanentes, sino que auxilian al agente autónomo.

Los presidentes respectivos mueven su equipo, pero no lo mandan. Se reúnen las autoridades de los municipios autónomos para hacer el plan de trabajo colectivo. Hay funciones de información y vigilancia que se vinculan entre sí y con el trabajo de los consejos municipales. Se vigila todo el trabajo, se investigan bien los problemas. Los caracoles cumplen funciones en la organización y marcha de cada zona. Es el espacio de encuentro general, punto de reunión para coordinar el trabajo de la autoridad autónoma. En las Juntas de Buen Gobierno la organización interna se divide por turnos. Las juntas se integran por seis personas elegidas en cada municipio. Dos personas de cada municipio se trasladan cada diez días para asumir la función de autoridades y se distribuyen responsabilidades. Los miembros de las juntas actúan de manera horizontal. Se elige a uno para que lleve el control, pero esto no implica jerarquía, otro se encarga de la tesorería y otro apunta los asuntos. Cuando regresan después de un mes no desempeñan el cargo que tenían antes, pues se rotan.

Las comunidades vigilan que todas las autoridades cumplan. En la definición de sus tareas y en la solución de problemas interviene el pueblo, porque no por ser autoridades, mandan, y todos opinan sobre todo. La rotación en los cargos es otro de los principios del gobierno autónomo zapatista para dar oportunidad a todos. Todo cargo es un servicio gratuito, y también se atienden las responsabilidades personales. Si se tiene que trabajar en otra localidad, los pueblos apoyan. Las autoridades de los municipios autónomos van dos días a la semana a la oficina; los de las juntas son diez, pero siempre hay quienes están a cargo. Además, es deber de la autoridad informar al pueblo, que decide libremente porque la elección es libre, directa y abierta. En las asambleas se acuerda quiénes ejercerán como autoridades, desempeñando cargos durante periodos de tiempo, aunque quien fue elegido puede ser removido si no cumple. Todo esto implica la práctica compleja de esa libertad de los de abajo de elegir, gobernarse y vigilar a sus autoridades. 
El capítulo tercero trata sobre los pasos de la justicia, que es algo específico pero no separado del proceso de la misma autonomía. Los zapatistas comparan su justicia con lo que sucede en los municipios oficiales. La justicia zapatista no es negocio, no se cobra, no se vende. Se imparte por igual a propios y extraños que acuden a la justicia zapatista. Se le da razón al que la tiene sin importar si es o no zapatista. Se investigan los conflictos. Se oye al acusador, al acusado y a los testigos. La justicia autónoma se logra por medio del acuerdo. En los pueblos entienden por justicia resolver los problemas, pero también la distribución de los productos de los trabajos colectivos.

Hay políticas comunitarias zapatistas para la aprobación de leyes y reglamentos. Las autoridades consultan a la asamblea del pueblo cuando se presentan asuntos difíciles. La justicia la deben hacer las autoridades, aunque el pueblo decide libremente cómo quiere que trabaje la autoridad y está enterado de cuándo los agentes van a arreglar un problema. Si estos no pueden, se convoca a la asamblea y obedecen lo que el pueblo determina. Los problemas suelen estar relacionados con las parejas, la familia, robos, daños a siembras, problemas con las mangueras de agua, chismes, alcoholismo, animales que daña cultivos, amenazas o violaciones. Se levantan actas y se buscan soluciones por medio del acuerdo entre las partes para que haya reconciliación en diálogo. En faltas menores basta la amonestación y reparación del daño. Por ejemplo, si alguien tira un árbol, debe sembrar dos. Si hay reincidencia, se sanciona con trabajo de tres a cinco días dependiendo del problema. Hay algunas cárceles y a los presos se les cuida y alimenta, pero deben trabajar para conseguir su comida. En los problemas de violación, asesinato, asalto, siembra de droga o tráfico de madera o de personas se reúne la asamblea. Si el pueblo no puede llegar a una solución, se pasa el caso al municipio autónomo y, si no, a la Junta de Buen Gobierno y a la asamblea de zona. Se suele llegar a altas instancias cuando los que tienen el problema no se entienden entre sí. Es diferente cuando las comunidades zapatistas sufren la agresión, como una invasión de tierras recuperadas, porque en este caso las investigaciones las hacen varias comisiones que hablan con los dirigentes de las organizaciones que quieren tomar las tierras y se trata de llegar a acuerdos, pero nunca se habla con instancias del gobierno oficial. Cuando no hay solución se hacen denuncias públicas. Haber incursionado en la justicia zapatista, crearla, experimentarla, hacerla proceso, nació de una acción libre colectiva y de una recreación continua de esa misma libertad de los de abajo para dar densidad a la misma autonomía.

En el capítulo cuarto se hace una valoración general de la justicia autónoma en resistencia. Se recuerda que no debemos perder de vista que las comunidades zapatistas están asediadas por una guerra en contra suya y que la contrainsurgencia ha adquirido varias modalidades que combinan elementos militares, políticos, económicos, judiciales y psicológicos. El gobierno trata de hacer prevalecer en los medios de comunicación sus versiones oficiales y usa paramilitares para agredir. Una táctica gubernamental ha sido la invasión y el despojo de tierras recuperadas para tratar de enfrentar a los indígenas entre 
sí. Otra táctica es desalentar a los zapatistas para que dejen de serlo y obstruir la construcción de la autonomía para dividir y debilitar. Algunos se dejan comprar y pasan a servirle al gobierno. Cuando esto sucede, pierden esa libertad que habían ganado en la práctica de la autonomía. Pero el zapatismo con su tenaz lucha muestra las capacidades y alcances de la libertad de los de abajo.

Por otro lado, apunta la autora que aun dentro de la autonomía hay problemas. La construcción de una alternativa de vida comunitaria y de organización económica, política y social, no sólo independiente del Estado y contraria a la tendencia dominante, es difícil. Los caminos de la libertad no son fáciles. Hay prácticas comerciales propias del sistema capitalista que permiten extraer parte importante de los recursos económicos que las comunidades zapatistas destinan a su libre autodeterminación política. Las potenciales ganancias de los trabajos colectivos se ven disminuidas en cuanto sus productos entran en contacto con el eslabón inmediato de la circulación capitalista. Se ven obligados a vender la producción a "coyotes" (intermediarios) al precio que éstos fijan. Cuando en lugar de vender se ha querido apoyar a otra zona zapatista, surge el problema de cómo mover un mayor volumen de productos. Hay también lastres sociales que históricamente han excluido a las mujeres y que dificultan su participación. El camino de la autonomía es arduo. Algunos quisieran tener una propiedad individual a partir de las tierras recuperadas, cuando es sabido que éstas son para el trabajo colectivo. Hay gente que sale de la organización, pero no de las tierras. Las religiones también tratan de cambiar la conciencia de las bases de apoyo en las comunidades, diciendo que la lucha no sirve. También hay falta de recursos para diversas actividades de la organización.

Otro problema tiene que ver con la permanencia de los promotores de educación y salud, pues ya entrenados quieren volver a su trabajo familiar porque no reciben pago, sino ayuda de parte de la comunidad. También existen problemas cuando algunos beben alcohol y no cooperan en el trabajo colectivo.

No obstante, los cambios logrados por la autonomía son palpables porque están liberados y organizados. Comparan no sólo con el pasado, sino con el presente de las comunidades no zapatistas, y ven las ventajas de la autonomía, porque ahora nadie los manda, son libres, tienen su propio gobierno. Un aspecto que valoran mucho es la eficiencia y pertinencia de la justicia zapatista, por eso mucha gente no zapatista acude a esta justicia y no a la oficial. Familia, asamblea y escuela autónoma contribuyen a la formación de los adolescentes y jóvenes que van nutriendo las filas zapatistas, quienes se van fogueando en esa libertad de los de abajo. La educación política de ser zapatista pasa de generación a generación. Las narraciones de los de más edad son importantes en esto. Las comunidades resisten, luchan, trabajan y van construyendo otro tipo de vida, libre, en la que ellos son los que deciden y no dependen de nadie más. Es la expresión viva y continua de la demoeleuthería. 
En uno de los comunicados zapatistas recientes, se lee:

De arriba, no vendrán nunca jamás la verdad ni la justicia; de arriba sólo hay que esperar simulación, engaño, impunidad, cinismo; el criminal de arriba siempre tendrá absolución y recompensa, porque quien lo juzga es el mismo que le paga; son lo mismo criminales y jueces. Como zapatistas que somos, miramos y escuchamos no sólo nuestra rabia, nuestro coraje, nuestro odio hacia quienes allá arriba se sienten dueños y señores de vidas y destinos, de tierras y subsuelos; y hacia quienes se venden, con sus movimientos y organizaciones, traicionando su historia y principios. Miramos y escuchamos que sólo se reciben mentiras y burlas de quienes dicen administrar la justicia y en realidad sólo administran la impunidad y fomentan el crimen. Porque en este mundo que dolemos, el criminal está libre y el justo está preso; quien asesina es premiado y quien muere es calumniado. Pero también miramos y escuchamos que cada vez son más las voces que desconfían, que no se dejan, que se rebelan. Cada injusticia cometida no hace sino abrir el camino para que esos odio y rabia se organicen. La verdad y la justicia tendremos que construirlas desde abajo. Así tendremos la verdad y la justicia no como una limosna de arriba, sino como una conquista de abajo. ${ }^{2}$

Ese abajo que busca justicia verdadera como parte esencial de la autonomía es la expresión de la libertad de los de abajo. La justicia zapatista apunta a aquel señalamiento de Castoriadis (2000) de que la sociedad justa es aquella donde la cuestión de la justicia se encuentra permanentemente abierta. Todo esto es parte de cómo viven los zapatistas la libertad de los de abajo.

\section{La demoeleuthería y la lucha zapatista anticapitalista}

El capitalismo siempre atenta contra la libertad de los de abajo de manera integral: en lo económico, político, social e ideológico. Cómo ven la lucha anticapitalista desde la libertad de los de abajo lo ejemplifica de manera muy contundente otro libro que corresponde al primer tomo del seminario zapatista de mayo de 2015 en el que se recogen las intervenciones de la Comisión Sexta del EZLN. El libro se tituló con el mismo nombre del seminario: Elpensamiento crítico frente a la hidra capitalista (2015). Lo que sigue corresponde a lo planteado en esa publicación.

En marzo de 2015, a pesar del incremento de la actividad militar y paramilitar contra la zona del EZLN, el zapatismo inició la organización de ese seminario

\footnotetext{
${ }^{2}$ Subcomandantes Insurgentes Moisés y Galeano, "De arriba no vendrán la verdad ni la justicia”,16 de agosto de 2015. http://enlacezapatista.ezln.org.mx/2015/08/18/16380/.
} 
internacional. El subcomandante Galeano difundió un comunicado en el que se planteaba que el pensamiento crítico para los zapatistas tenía la función del centinela. Advirtió sobre el síndrome del vigía que se agota en su tarea y ya no percibe el peligro y compartió que el zapatismo miraba que venía una catástrofe mientras otros seguían con sus mismos métodos de lucha, por eso quería invitar a un seminario o semillero para que otros dijeran lo que estaban viendo. A quienes invitaron les solicitaron que no llevaran modas, dogmas, pensamiento haragán o mentiras, sino palabras que provocaran y alentaran reflexión. La invitación implicaba el ejercicio reflexivo de una libertad de pensamiento que se pusiera al servicio de la acción para defenderse de las amenazas con la libertad de los de abajo del capitalismo, y para garantizar que esa libertad pudiera proseguir por caminos que iluminaran sus pasos.

En el homenaje a Luis Villoro y a Eduardo Galeano que se realizó inmediatamente antes del inicio del seminario, el subcomandante Galeano apuntó que, pese a que aquellos dos no se conocieron, estuvieron juntos construyendo una misma libertad. Precisó que era necesaria la organización para liberarse del sistema capitalista. Aludió a la lucha del pueblo kurdo por la libertad, y recalcó que cada quien debía luchar por la libertad en el rincón del mundo donde vivía. Recordó que ser zapatista era organizarse y trabajar colectivamente, sin venderse, para destruir el sistema capitalista. Estos énfasis apuntan al meollo de la demoeleuthería.

El prólogo de la publicación corre por cuenta del subcomandante Galeano: "De cómo llegamos a la cofa del vigía y lo que desde ahí miramos" (El pensamiento crítico..., 2015: 7-17). Los zapatistas invitan a que compartamos una doble vista zapatista: la que tienen hacia dentro de su organización y lo que miran afuera. Esas miradas detectan cambios, y las miradas han cambiado también. Dan cuenta los zapatistas de lo que son repasando y contrastando cómo era y es la economía zapatista, cómo está siendo su resistencia y rebeldía y el papel tan destacado de la lucha de mujeres. Hacia adentro y hacia afuera se distingue cómo era antes, qué sigue igual y qué ha variado. Nos advierten que lo que pasa puede explicarse de varias formas, pero que la teoría debe salir airosa de una confrontación con la realidad. El libro es una reflexión sobre la práctica con pensamiento crítico, práctica con teoría. Se hacen avistamientos y se mira la hidra capitalista, cuál es la cabeza principal y cómo le han ido saliendo nuevas cabezas. Nos dicen que preguntan para desatar más dudas e insisten en que el zapatismo necesita conceptos, teorías y pensamiento crítico para dar cuenta de lo que ocurre en su interior y para ver los cambios económicos que permitieron la toma y ejecución de sus propias decisiones, porque la rebeldía y la resistencia pudieron crecer en el zapatismo y de manera preponderante en las mujeres zapatistas. Resistencia y rebeldía nombran su lucha y exhortan a usar el pensamiento crítico, constatando que el capitalismo se hace cada vez más cruel y poderoso.

El subcomandante Moisés se refirió a la coyuntura electoral mexicana y aclaró que el zapatismo no llamaba a no votar ni tampoco a votar: 
Como zapatistas que somos lo que hacemos, cada que se puede, es decirle a la gente que se organice para resistir, para luchar, para tener lo que se necesita [...] Lo que nos interesa es conocer más de cómo resistimos y enfrentamos las muchas cabezas del sistema capitalista que nos explota, nos reprime, nos desprecia y nos roba [...] Nosotros entendemos que hay quienes creen que sí van a poder cambiar el sistema con votar en las elecciones. Nosotros decimos que está cabrón porque es el mismo mandón el que organiza las elecciones, el que dice quién es candidato, el que dice cómo se vota y cuándo y dónde, el que dice quién gana, el que anuncia y el que dice si fue legal o no. Las soluciones las hace el pueblo, no los líderes, no los partidistas (El pensamiento crítico..., 2015).

Precisó que al zapatismo no le interesaba lo que hacían los de arriba para tratar de convencer a la gente de abajo de que la tomaran en cuenta. En la disputa de si había que votar o no hacerlo, el zapatismo decía que lo importante es organizarse para resistir y luchar.

En un apartado relacionado con "algo de lo que ha cambiado", Moisés narra los cambios que se han ido dando en las comunidades zapatistas. Estas intervenciones se encuentran en dos apartados sobre la economía política en las comunidades zapatistas. Hablaron cinco mujeres zapatistas. La joven Selena se refirió a la guerra que hacía el gobierno y el capitalismo a los jóvenes, y cómo la juventud en el zapatismo, siendo pobre en bienes materiales, era rica en su forma de pensar. La base de apoyo Lizbeth explicó cómo vivía el zapatismo la autonomía y cómo el pueblo mandaba y su gobierno obedecía. La comandanta Dalia narró el proceso de despertar de las mujeres en la defensa de sus derechos y que ya no son humilladas, porque saben que si no se organizan el capitalismo acabará con todos. La comandanta Rosalinda recordó que hubo mujeres que fueron reclutadas por el EZLN y narró cómo se fueron formando. La comandanta Miriam narró la deplorable situación que vivían las mujeres en Chiapas antes del levantamiento zapatista en 1994, cuando eran como mercancías y no tenían descanso, con la triple explotación, y cómo con la organización se habían ido liberando. El subcomandante Galeano destacó que habían hablado tres generaciones de mujeres del EZLN y se mencionó la resistencia de los varones hacia la liberación de las mujeres en el proceso zapatista. Enfatizó: "lucharon contra nosotros y nos derrotaron", y se alegró de que se tratara de una victoria irreversible. En este proceso de liberación de las mujeres zapatistas, haber captado que tenían libertad de hacer lo mismo que los varones fue fundamental, de modo que conquistaron dicha libertad. La demoeleuthería tiene una fuerte carga femenina.

El subcomandante Moisés tuvo diversas intervenciones relativas a la economía política desde las comunidades zapatistas y a la resistencia y rebeldía. En dichas intervenciones se encuentra un pensamiento complejo y profundo que conviene explorar. Siguiendo la narrativa zapatista, se realizan comparaciones de lo que era su realidad antes 
del levantamiento de 1994 y lo que está ocurriendo con su experiencia de autonomía durante los últimos veinte años, además de ofrecer otras comparaciones en torno a cómo viven las comunidades no zapatistas y las comunidades donde se construye la autonomía zapatista.

Señaló que en tierras zapatistas se elegían autoridades autónomas con democracia verdadera, habían conquistado su libertad y se hacía otra justicia, la del pueblo organizado. Destacó que los pueblos coordinaban sus asambleas donde se empezaba por opinar y por buscar propuestas de las cuales se estudiaban sus ventajas y desventajas para optar por lo mejor, pero antes de terminar el proceso de decisión se llevaban esos resultados a los pueblos para llegar a una decisión que brotara de abajo. Existe un denso y arduo trabajo de ir construyendo libremente entre todos las decisiones, lo que precisamente constituye la demoeleuthería. Recalcó que ser gobierno en el zapatismo no era tener el poder. En cuanto a los que decían que para ser gobierno sólo había dos caminos, el de las armas o el de los votos, habría que recordarles que existían otras opciones, como comprar el gobierno, lo cual había hecho el actual presidente del país, y que se podía mandar sin gobierno. Apuntó que al capitalismo no se le podía quitar lo malo, porque era un sistema en el que unos cuantos se enriquecían del trabajo de otros, e insistió en que había que organizarse y unir las organizaciones por un mundo donde los pueblos mandaran y el gobierno obedeciera.

La primera reflexión es que antes, para el capitalismo, las regiones indígenas eran como lugares de reserva y no tenían mucho interés en los indígenas que han vivido de la madre tierra, a los que tenían olvidados, pero había terratenientes que fueron acaparando las mejores tierras y empujando a los indígenas hacia cerros que no les servían. Los terratenientes defendían lo que despojaban por medio de gente armada a su servicio, y a los indígenas los utilizaban como mano de obra mal pagada. No había clínicas ni escuelas, ni programas para los indígenas. Luego vino un segundo despojo cuando los lugares de los que echaron a los indígenas también querían convertirlos en mercancías. Entonces el gobierno quiso privatizar los ejidos. Cuando se levantaron los zapatistas, el gobierno empezó a hacer carreteras y llevar programas, a poner algunas escuelas y clínicas, pero, en ellas, o no está el doctor o no hay medicinas. Los proyectos gubernamentales tienen la finalidad de controlar a la gente, de someterla, y constituyeron una manera de llevar a cabo su guerra de contrainsurgencia. Los que dejaron privatizar sus ejidos se quedaron sin la tierra que les daba sustento, por lo que los zapatistas vieron que el gobierno hizo inútiles a los hermanos partidistas por los programas, y ya no trabajan la tierra.

Al levantarse, los zapatistas recuperaron la tierra para las comunidades que ya se habían organizado, pero la tierra recuperada estaba muy maltratada y daba pocos productos. Han trabajado la tierra colectivamente y los zapatistas fueron descubriendo poco a poco cómo cuidar la tierra y cómo repartir sus productos. Se llevan a cabo trabajos colectivos a nivel local, regional, municipal y zonal, esta última forma corresponde a las 
Juntas de Buen Gobierno. Ha habido procesos que van avanzando poco a poco y ven que han ido rasguñando al capitalismo con sus nuevas formas de producir.

Los zapatistas fueron detectando lo que implicaba la resistencia que los ha llevado a crear su propia escuela y su propio sistema de salud. Las compañeras empezaron con la idea de no recibir limosnas del gobierno y valerse por sí mismas en un acto heroico de liberación. Se optó por no recibir nada del gobierno y por trabajar la tierra.

Dado que es un proceso difícil, los zapatistas van inventando, ensayando y viendo cómo resultan las cosas, corrigiendo los errores. De los trabajos colectivos salen recursos para hacer alguna movilización para apoyar a otros hermanos, pero no para exigir nada al gobierno. ${ }^{3}$ Cuando reciben ataques, no piden nada al gobierno, sino que hacen denuncias públicas.

Otra enseñanza que han obtenido es que hay que organizarse para avanzar. La economía de los zapatistas se da en lucha, en resistencia. Pocas veces manejan dinero aunque para movilizarse sí lo necesitan.

Se vio que debía haber apoyos para las familias de los promotores de salud y educación por parte del trabajo colectivo. También se vio que, cuando había que hacer algún trabajo colectivo de zona, debían trasladarse desde comunidades lejanas y eso generaba gastos, por lo que se distribuyeron los trabajos colectivos para tratar de reducirlos. Todos trabajan colectivamente. Si alguien no lo quiere hacer, debe aportar recursos propios. Se observó que los pueblos, las regiones, los municipios y las zonas debían ponerse de acuerdo en cómo querían trabajar, distribuyendo el tiempo para la familia y para lo colectivo — en cada comunidad se ponen de acuerdo sobre cuántos días deben destinar para cada tipo de trabajo-.

Hay bancos autónomos, como Banpaz y Banamaz, y hay también bancos autónomos comunitarios, que se crearon para solventar compras de sal, jabón, azúcar o abarrotes y para solventar gastos derivados de la salud de la familia. En los bancos comunitarios se presta a las personas zapatistas y no zapatistas y se cobra un interés mensual. Con estos ejemplos, se observa que el gobierno no interfiere en lo político, lo ideológico, lo económico, lo cultural o lo social. ${ }^{4}$

Hubo muchas reflexiones sobre la resistencia y la rebeldía. Moisés explica que la resistencia implica ponerse fuerte, duro, para dar respuesta a todo, cualquiera sean los ataques del enemigo, del sistema; y rebelde es ser bravo o brava para responder o para llevar a cabo acciones, según lo que convenga. Los zapatistas descubrieron que resistir no es sólo no recibir los sobrantes del gobierno, sino además resistir las amenazas o

\footnotetext{
${ }^{3}$ Ver: http://enlacezapatista.ezln.org.mx/2015/05/04/economia-politica-desde-las-comunidades-isubcomandante-insurgente-moises-4-de-mayo/.

4 Ver: http://enlacezapatista.ezln.org.mx/2015/05/05/economia-politica-desde-las-comunidadesii-subcomandante-insurgente-moises-5-de-mayo/.
} 
provocaciones que hace el enemigo, sin tener miedo. Para que haya resistencia debe haber primero organización, pues hay que organizar dicha resistencia en una lucha política pacífica. Aunque hay ánimo de liberarse, para ello es necesario primero organizar esa libertad. Se produce un conjunto de resistencias, como resistir las burlas que reciben sobre su autonomía o resistir las provocaciones del ejército, la policía, las organizaciones sociales o los medios, con sus bombardeos psicológicos para desanimarlos. La resistencia se aplica tanto individual como colectivamente con disciplina, por medio de acuerdos.

La resistencia y la rebeldía dan seguridad a la organización y pueden gobernarse y desarrollar sus propias iniciativas libremente. Implican llevar a cabo acciones en los terrenos económico, político e ideológico, y se ven errores pero se van corrigiendo; este es otro de los aspectos muy importantes de su libertad.

La resistencia y la rebeldía la demuestran en que no piden permiso a nadie porque son libres y están formando una nueva generación de jóvenes en libertad. ${ }^{5}$ Han iniciado una desobediencia organizada en la que la resistencia y la rebeldía se van multiplicando y no tienen fin.

Los zapatistas saben que deben tener claras las razones de su resistencia y rebeldía y reflexionan que eso les da vida y motivación para construir su autonomía; van resolviendo sus necesidades, enfrentaron lo relativo a la educación y a la salud, a sus leyes, reglamentos y justicia. Con su resistencia y rebeldía van viendo cómo practicar y mejorar sus siete principios del mandar obedeciendo, en los que figura que el pueblo manda y el gobierno obedece; con estos principios han logrado hacer mucho trabajo político e ideológico, a través de mucha formación sobre cómo ven el capitalismo y mucha evaluación también de cómo se encuentran como organización, porque el capitalismo no los va a dejar en paz dado que los quiere subyugar.

Su resistencia y rebeldía les ha dado la fuerza para ejercer la libertad colectiva. Primero se tiene en cuenta la decisión del pueblo, y de ahí echan a andar y experimentan. Moisés insiste en que su resistencia y rebeldía es lo que les ha ayudado a mejorar haciendo en la práctica lo que quieren hacer en libertad, porque los pueblos tienen la libertad de sustituir a la autoridad que no cumple, o de llamarle la atención o sancionarla. Su resistencia y rebeldía les ha dado la libertad para crear, inventar e imaginar cómo trabajar mejor su gobernar para alcanzar una mejor vida, y eso les está ayudando a descubrir cómo mejorar el trabajo de sus gobiernos autónomos. Con resistencia y rebeldía los pueblos zapatistas tienen el derecho de decir su palabra y de ser escuchados. Los pueblos con libertad de expresión son libres para pensar y plantear, "libres para opinar lo que les parece o lo que no les parece, libres para proponer lo que piensan de cómo mejorar o de proponer de nueva forma; tienen libertad para estudiarlo, pensarlo, para presentar nuevas propuestas.

\footnotetext{
${ }^{5}$ Ver: http://enlacezapatista.ezln.org.mx/2015/05/06/resistencia-y-rebeldia-i-subcomandante-insurgentemoises-6-de-mayo/.
} 
Tienen libertad para analizar y después pueden decir si les parece o no les parece, tienen libertad de discutir" para llegar a lo mejor a través de acuerdos, para decidir lo que se tiene que llevar a cabo.

Otro logro de su resistencia y rebeldía se refleja en el rescate de la cultura, que incluye las prácticas de parteras y hueseras y de uso de plantas medicinales. Por medio de su resistencia y rebeldía entendieron que el EZLN debía entregar la herencia de la lucha a la nueva generación. Siendo un ejército, se manejaba con órdenes. Cuando se llegó a la construcción de la autonomía, el zapatismo entendió que el gobierno autónomo no debía dar órdenes sino llegar a acuerdos, de modo que lo que digan los pueblos es lo que se tiene que cumplir. Los zapatistas caminan, trabajan, experimentan y luchan armados de resistencia y rebeldía. ${ }^{6}$

La resistencia y rebeldía también los impulsa a vigilar las prácticas de sus autoridades y sus gobiernos autónomos, a exponer problemas y encontrar soluciones entre todos. Las autoridades autónomas no actúan por su cuenta, pues todos sus trabajos son discutidos por las bases de los pueblos y deben ser aprobados por ellos, por eso les lleva tiempo discutir si se acepta o no un proyecto. La resistencia y rebeldía zapatista impulsa las tres instancias del gobierno autónomo. El pueblo tiene que recibir información sobre cómo van las cosas que se hacen en salud, educación o agroecología, y las autoridades deben rendir informes y cuentas de lo que entra y sale y cómo se ha gastado. Por eso los pueblos inventaron la Comisión de Vigilancia y la Comisión de Información, para constatar que lo que se informe esté de acuerdo con la verdad. Las autoridades plantean a los pueblos lo que piensan hacer y ellos discuten y deciden lo que debe hacerse.

La resistencia y rebeldía son fundamentales para la justicia autónoma zapatista, con la que se resuelven problemas para que los zapatistas se reorganicen y se reeduquen, para mejorar sus medios de comunicación - emisoras comunitarias-, para practicar su nueva democracia y para sus nuevos sistemas de educación y salud.

Por su resistencia y rebeldía los zapatistas son tenaces para encontrar sus soluciones. Trabajan su resistencia y rebeldía, organizándolas, luchando, orientando, mejorando. Por ellas tienen seguridad, y esto les ayuda a cuidarse. Con ellas llevan a cabo comparticiones e idearon y llevaron a la práctica lo que se ha llamado la escuelita zapatista.

La resistencia y rebeldía les ha ayudado a ir inventando, creando, imaginando, porque no hay manuales. Se evalúan los trabajos para ir mejorándolos y avanzando según se presentan los problemas, para resolverlos con imaginación, con su práctica. ${ }^{7}$

\footnotetext{
${ }^{6}$ Ver: http://enlacezapatista.ezln.org.mx/2015/05/07/resistencia-y-rebeldia-ii-subcomandante-insurgentemoises-7-de-mayo/.

${ }^{7}$ Ver: http://enlacezapatista.ezln.org.mx/2015/05/08/resistencia-y-rebeldia-iii-subcomandante-insurgentemoises-8-de-mayo/.
} 
Para que haya resistencia y rebeldía debe haber un impulso desde la libertad, y esa endíadis les permite precisamente proseguir viviendo dicha libertad. Con esa libertad de los de abajo deciden organizarse y también mantener y mejorar la organización, pues sin ella no pueden ser libres. Con libertad deciden cómo construir su economía autónoma, y con libertad resisten ante los embates del Estado y del capital. Deciden libremente no pedir permiso a nadie para ser como van siendo y practicar lo que se proponen. Deciden libremente inventar y desarrollar sus iniciativas, hacer su economía autónoma comunitaria, nombrar a sus autoridades, vigilarlas y cambiarlas si es el caso, crear, recrear y cuidar su cultura, impulsar su propia salud y educación. Deciden libremente cómo ensayar, equivocarse y corregir. Deciden resistir amenazas y provocaciones. La rebeldía y resistencia son dinámicas, y como espiral se potencian mutuamente, no son unívocas y se multiplican adoptando las modalidades que libremente van adoptando. En libertad crean su autonomía que les da vida y fuerza para proseguir y practican el mandar obedeciendo. Hay un ejercicio colectivo de libertad. La combinación de rebeldía y resistencia les da fortaleza, les permite decir su propia palabra, opinar, proponer, analizar y ejecutar. Hay un continuo ejercicio de experimentación con plena libertad. Libremente han optado por no rendirse, no venderse y no claudicar. Todo este complejo entramado constituye su experiencia de la demoeleuthería.

En la segunda parte del libro se ofrece la mirada zapatista a la hidra capitalista con seis intervenciones del subcomandante Galeano, quien recomendó preguntarse: “iy si no?" Habría que ver si la crisis del capitalismo, que ciertamente es de grandes dimensiones, es terminal. Habría que captar las raíces del sistema mundo. Se refirió a los datos presentados por el Congreso Nacional Indígena que revelaban una violenta estrategia de despojo por todo el país. El zapatismo cruzaba datos, pues había ciudades que engullían tierra campesina, e indígenas y campesinos se convertían en migrantes sin salir de lo que había sido su tierra. Se está llevando a cabo un proceso en el que todo se convierte en mercancía, crece la violencia de género y existe una guerra mundial que tiene a la humanidad por enemigo. Insistió en que había que indagar por qué ocurría esto y no otra cosa. Recomendó actualizar la genealogía del capitalismo y se refirió a los datos de Luis Gonzalo Arredondo, quien mostraba que había dinero que no se encontraba respaldado por trabajo porque el capitalismo había creado un dinero ficticio. Las deudas usaban un incierto trabajo futuro, el capital financiero robaba a manos llenas y se ponía como aval la misma naturaleza. Había una carrera de despojo vil en la que sucumbían las pensiones, y se preveía que en la dinámica del capitalismo actual quebrarían países enteros e incrementaría la población migrante. Recordó que el pensamiento crítico era un desafío, que el lenguaje también era una forma de resistencia.

El subcomandante Galeano abordó lo que denominó el método zapatista. Dijo que Ayotzinapa era el dolor y la rabia y a los familiares de los normalistas desaparecidos que estuvieron en el seminario les pidió que hicieran llegar las palabras zapatistas a los 
ausentes, las cuales señalaban que no tenían que creer en quienes les decían que el apoyo se medía con calles abarrotadas y plazas colmadas. Lo importante era que cualquiera de abajo que conociera su historia simpatizaba con su lucha en demanda de verdad y de justicia. Les sugirió no desfallecer porque faltaba mucho por andar, y que lo que aterrorizaba a los de arriba era la perseverancia de la rebeldía y la resistencia de abajo, que no se rendía ni se vendía. Les dijo que no temieran ser abandonados por quienes buscaban administrarlos, venderlos y desecharlos y que temieran dejar caer su lucha, pues mientras la mantuvieran tendrían la admiración de muchos en México y el mundo.

En cuanto al capitalismo, apuntó que había quienes pensaban que era un muro indestructible pero se le iban haciendo grietas. Al zapatismo no le preocupaba la supuesta omnipotencia y eternidad del muro porque sabían que ambas eran falsas. A los de Ayotzinapa les recalcó que se habían convertido en una grieta en el muro del sistema y que no dejaran que se cerrara porque por esa grieta respiraban no sólo sus hijos, sino miles de desaparecidos que faltaban en el mundo. En otra intervención recordó que el sistema dominante era el capitalismo, y que no era dominante sólo en un aspecto, sino que tenía modos diversos de atacar. El objetivo del seminario era iniciar, abajo y a la izquierda, un debate que abundara en ideas y los zapatistas esperaban que siguieran más semilleros para alumbrar la práctica y la transformación de la realidad, pues el capitalismo no era omnipresente ni inmortal porque existían resistencias. El motor del pensamiento crítico era el cuestionamiento. Habló de la tormenta que veía el zapatismo y se refirió a una crisis económica como nunca antes se había dado que convertía lo básico, como el agua, el aire o la luz, en mercancías, a la pérdida de legitimidad de las instituciones tradicionales y a la corrupción escandalosa de las clases políticas. La mayoría de las grandes empresas antes nacionales eran prestanombres de los grandes capitalistas mundiales atados a la banca internacional y recalcó que esa realidad se sintetizaba en la palabra Ayotzinapa, que no era la excepción, sino la regla. Los usos y costumbres de la clase política corrupta se habían trasladado al crimen organizado, y no al revés. La mecánica de la tortura, la matanza, el descuartizamiento y la exhibición de las víctimas son patrimonio de los políticos. El gobierno administra el caso de Ayotzinapa y disfruta cada paso del terror. El zapatismo había visto que una mayor crisis se avecinaba y que no se anunciaría, sino que se situaría en todas partes. Ante esto, el zapatismo se había preparado y preguntaba a gente cercana qué era lo que percibían.

El capitalismo actual trata de invadir territorios antes ignorados, desplazando a sus habitantes, y quiere convertir a la naturaleza en un conjunto de mercancías. Los pueblos originarios defienden la naturaleza porque motiva su supervivencia y la de la humanidad, analizan los numerosos medios de despojo y tratan del robo "legalizado" que realizan las empresas mineras, las que explotan madera, etcétera. El mismo sistema jurídico es un medio de despojo. Los medios de despojo son violentos, y la violencia es el arma del despojo. Se hace ver que se necesita la ciencia para la lucha y el método que proponen es 
reconstruir la genealogía del capitalismo para detectar lo que ha cambiado y lo que perdura desde el inicio de este sistema hasta nuestros días. Cuando ven hacia dentro, también recurren a la metodología de la genealogía del zapatismo.

Los zapatistas hacen ver que el capitalismo es un crimen y que en él hay un modus operandi que debe detectarse. El capitalismo produce miseria, destrucción y muerte y avanzan el despojo y la destrucción sobre los pueblos indígenas en ese afán de convertir todo en mercancía. También se ha incrementado la violencia de género. El capitalismo vomita ahora millones de desocupados. Aunque permanecen los fundamentos básicos del capitalismo, se han ido agregando nuevas modalidades. El capitalismo se ha convertido en una guerra mundial en contra de la humanidad.

El capitalismo actual vive de deudas y especulaciones. Las naciones en su endeudamiento ponen como garantía los recursos naturales. La columna vertebral del capitalismo es la guerra, una guerra contra la población sobrante. Los zapatistas llaman la atención sobre el hecho de de que se necesita una clarificación del Estado, y entender el capitalismo y el Estado requiere de un quehacer técnico y analítico que no puede hacerse sino por medio de un trabajo colectivo.

La tercera parte del libro tiene que ver con la pregunta iqué hacer? El subcomandante Moisés apunta a la necesidad de la organización, y tanto él como el subcomandante Galeano proponen la multiplicación de semilleros donde se expongan análisis científicos y se vayan eligiendo las miradas que más convengan a los diversos colectivos.

El quehacer zapatista responde a la necesidad de organizarse y esto lo recomienda también a los demás, pues sólo los organizados sabrán qué hacer. La organización es básica para la resistencia y la rebeldía, para el trabajo y la lucha. Los zapatistas advierten que están cambiando las cosas y también las formas de lucha y exhortaron a abandonar las diferencias entre los que no quieren ser capitalistas y a que se organicen y apoyen unos a otros, a que compartan, se coordinen y luchen juntos. Recapitulan que el capitalismo está acabando con los pueblos de mil maneras, y no hay que dejar éstos que sigan siendo explotados. En cada lucha se tiene que ver qué sirve y qué no del semillero zapatistas y de los otros semilleros, pero los zapatistas están convencidos de que lo que los une es librarse del capitalismo y liberar a la madre tierra porque el capitalismo la está destruyendo. También advierten que el tiempo pasa y no se puede recuperar, por lo que se tienen que lanzar a hacer lo que piensan, aunque el enemigo también trate de hacer su resistencia. Sin embargo, los explotadores son unos cuantos y los explotados millones, por lo que hay que poner en la práctica los pensamientos de los de abajo, aunque la tarea sea grande. Primero hay que entender qué es lo que se quiere, buscar ideas, escuchar todas las opiniones, y de ahí escoger y encontrar un acuerdo común, lo que une. El tiempo exige y, si no se hace caso, pronto se verán los resultados adversos.

Escudriñar el capitalismo en sus modalidades actuales, tratar de comprenderlo para saber enfrentarlo es también una tarea libertaria, implica la expresión densa de la demoeleuthería. 
Una reflexión acerca de este primer volumen del seminario de mayo la publicó Gilberto López y Rivas (2015), quien señaló que se trataba de un debate teórico práctico de las resistencias y rebeldías anticapitalistas, que era un texto provocador, pedagógico, imaginativo, que lo cuestionaba todo con coherencia y profundidad, pues había apuntado los cambios, las alteraciones y las formas de explotación, represión, discriminación y despojo, y las había interpretado. El volumen mostraba cómo los pueblos zapatistas no se rendían, no claudicaban y luchaban por un cambio total. Contrastaba cómo vivían las comunidades hacía treinta años y cómo viven ahora las comunidades zapatistas; también establecía una importante diferencia entre las formas de enfrentar la vida por parte de las comunidades zapatistas en relación con lo que hacían las que no lo eran. López y Rivas llamó la atención sobre el hecho de que con el levantamiento zapatista el Estado inició una política de contrainsurgencia para evitar la expansión del zapatismo, pero los zapatistas habían recuperado la madre tierra y se habían organizado colectivamente combinando diversas formas de trabajo agrario a nivel de pueblos, regiones y municipios. Algo poco común era que los zapatistas reconocían públicamente sus errores, pero entre sus aciertos estaba que habían descubierto la resistencia en las varias formas de hacer trabajo colectivo, reaccionando ante quienes habían sido enviados por el gobierno para vigilarlos, por lo que llegaron a la conclusión de que no había que recibir nada del mal gobierno. Desarrollaron una gran cantidad de tareas en la producción, el comercio, la salud y la educación, lo cual fue dando sustento al proceso autonómico. La economía zapatista respondía a las necesidades de resistencia y, por ejemplo, con la economía rebelde se pagaban las clínicas zapatistas.

Las mujeres habían conquistado la libertad de opinar, discutir y participar en las múltiples tareas de resistencia y autonomía, enfrentando la guerra de contrainsurgencia y los espejismos del capitalismo. Cuando se fueron desprendiendo de la dependencia económica de los varones pudieron tomar libremente sus propias decisiones. Los varones zapatistas habían aceptado su derrota ante la emergencia de los derechos de las mujeres. López y Rivas enfatizó que las tres partes de los apuntes en torno a las resistencias y rebeldías resultaban fundamentales para comprender la lucha zapatista, y que el análisis del capitalismo actual y qué hacer para liberarse de él implicaba la capacidad de discernir, proponer alternativas, irlas ensayando y poner en práctica libremente una lucha contra dicho capitalismo para construir una sociedad de nuevo tipo. Toda esta dinámica conllevaba el impulso de la demoeleuthería.

\section{La demoeleuthería en el segundo curso de la escuelita zapatista}

Los zapatistas convocaron a quienes aprobaron el primer nivel a que cursaran el segundo nivel de la escuelita zapatista. Propusieron que la fecha fuera a finales de julio e inicios de 
agosto de 2015 y aclararon que en esta ocasión no sería en tierras zapatistas, sino por medio de un video que se mandaría con clave para que pudieran verlo los aprobados del primer nivel. Explicaron que esta modalidad se debía a que constataban que la gente pasaba por una situación económica difícil y que se había recrudecido la represión gubernamental contra los pueblos originarios y el magisterio democrático. Enfatizaron que por medio del video querían que los participante los miraran y escucharan, tomaran lo que creyeran que les pudiera servir y dejaran de lado lo que juzgaran que no les sería útil. Anunciaron que habían organizado los niveles del 2 al 6 en tal forma que la gente no tuviera que ir a tierras zapatistas con frecuencia, sino tal vez cada año. Lo importante era seguir hablando con ellos y aprenderse mutuamente, y advirtieron que sí habría clases y sus respectivos exámenes.

En el video correspondiente al segundo grado, un grupo de maestros y maestras zapatistas harían sus explicaciones y precisaron que en el video se verían y escucharían compañeros y compañeras zapatistas que explicarían una parte de la genealogía de la lucha zapatista. Recordaron que los alumnos ya habían visto, escuchado y convivido con bases de apoyo zapatistas, con sus familias y sus Votanes, pero aclararon que eso era sólo una parte de la lucha por la libertad según el zapatismo y que faltaban más partes. Les estaban dando piezas de un rompecabezas. Parte del segundo grado implicaba además estudiar el capítulo I del primer tomo de la obra recién aparecida titulada El pensamiento crítico frente a la hidra capitalista (2015), y, después de ver, escuchar y estudiar lo mencionado en el video y en el libro, cada uno tendría que escribir seis preguntas que debería mandar a una dirección electrónica. La fecha para hacer esas preguntas iba del 3 de agosto al 3 de octubre de 2015. Aunque las preguntas se formularan individualmente, las respuestas se darían de manera colectiva porque los zapatistas las juntarían, y en escritos y grabaciones ofrecerían sus respuestas. Recordaron que en el modo zapatista las preguntas siempre eran más importantes que las respuestas y subrayaron que lo que les interesa no son las certezas sino las dudas, porque las certezas inmovilizan y las dudas hacen que se desate la búsqueda. Exhortaron a seguir apoyándose mutuamente entre quienes luchan por la verdad y la justicia y desafían al poder y al Estado en las calles y en los campos de todas las geografías, entre los que no claudican, ni se venden, ni se rinden, porque la resistencia y la rebeldía son las que rompen las geografías y los calendarios de arriba, y porque en las raíces de la libertad siempre hay un $\mathrm{NO},{ }^{8}$ que es un grito de rebeldía. El segundo curso profundizó en la libertad según los zapatistas, y por lo tanto en la clarificación de la libertad de los de abajo.

En el video participaron zapatistas de los caracoles La Realidad, Oventic, La Garrucha, Morelia y Roberto Barrios. ${ }^{9}$ Hubo veintiséis participantes - tres mujeres y el resto

\footnotetext{
${ }^{8}$ Ver: http://enlacezapatista.ezln.org.mx/2015/07/27/segundo-nivel-escuela-zapatista/.

${ }^{9}$ En el caracol de La Realidad, ubicado en la selva fronteriza, sus habitantes son tojolabales, tseltales y
} 
hombres-, ocho de los cuales hablaron en su lengua, por lo que participaron traductores de ambos sexos. Los maestros de este grado hablaron con una enorme bandera mexicana detrás. Cada maestro en su intervención decía del pueblo que procedía, a qué municipio autónomo pertenecía y a qué Caracol.

Algunos de los maestros del segundo curso narraron cómo habían sido reclutados por comisarios políticos del zapatismo en la clandestinidad allá por los tempranos años ochenta. Quien los contactaba les hacía ver cómo había una gran explotación, una gran injusticia, cómo tenía el capitalismo y el gobierno sometido al pueblo; estaban convencidos de que había que decir "ya basta". Una vez que habían aceptado ingresar a las filas del zapatismo, su primera tarea era examinar en su comunidad quiénes podían ser reclutados. Se iban conformandogrupos de una decena de personas entrelos quefueran confiables, mantuvieran en secreto la organización y tuvieran un comportamiento digno, que no "tomaran trago", no fueran peleoneros, no tuvieran relaciones con personas del gobierno ni con los rancheros. Formado ese grupo, sus integrantes se reunían lejos de los ojos de los demás para tener asambleas y cuidaban esmeradamente la seguridad. Algún maestro habló de que había formación política para "concientizar" a todos; otro habló de "orientar". Para acudir y regresar de sus reuniones no iban en grupo, sino de uno en uno. Periódicamente recibían visitas delosinsurgentes, quienes les hablaban con mayor claridad. El proceso de emergencia del movimiento zapatista y el reclutamiento de sus primeros militantes fue un proceso de profunda libertad para examinar la situación de opresión, desprecio y explotación, y para lanzar el grito rebelde de "ya basta". Se fue proponiendo a otros este examen y libremente se fueron incorporando al movimiento. Esto fue forjando un dinamismo de demoeleuthería. Hubo posteriormente un proceso de formación de los responsables del EZLN, y se enseñaba y vivía la disciplina libremente aceptada. Con esa preparación realizaban los trabajos que se acordaban con el mayor sigilo, y en esta forma se fue extendiendo la organización. Se empezó por pelotones, luego por batallones y después por regimientos; también se prepararon lo que se llamó reservas, y además estaban las bases de apoyo. Hubo muchas concentraciones y los pueblos fueron viendo que se trataba de algo serio e importante. La seguridad fue fundamental para el crecimiento de la organización. Otra tarea tenía que ver con convencer a sus compañeras para que los dejaran hacer esas tareas y los apoyaran cuando iban a lugares lejanos para asistir a reuniones. Cuando había problemas, se platicaba con las familias. Este proceso fue difícil y largo con un esmerado cuidado de la seguridad y de todo lo relativo a la comunicación que circulaba y a las informaciones al mando superior. Al principio no había radios y todo el contacto se hacía entre enlaces. Había que evitar que el ejército oficial, el

mames y tiene cuatro municipios autónomos; en el caracol de Oventic, situado en Los Altos chiapanecos, hay tsotsiles y tseltales y tiene siete municipios autónomos; en el caracol de La Garrucha, situado en la Selva Tseltal, hay cuatro municipios autónomos; en el caracol de Morelia, situado en la zona Tzots Choj, hay tseltales, tsotsiles y tojolabales y tiene siete municipios autónomos; en el caracol Roberto Barrios, situado en la zona norte chiapaneca, hay choles, zoques y tseltales, y tiene siete municipios autónomos. 
enemigo, supiera de ellos. También había campamentos donde entrenaban los milicianos, pues necesitaban prepararse. Había que comprar armas, mochilas, machetes, botas y otros instrumentos que los combatientes necesitaban. Inició la preparación militar y sobre temas económicos y políticos, y en este proceso el trabajo colectivo fue básico. Se buscaban ideas y formas para que la gente no se desanimara y para que siguiera con entusiasmo. Se construyeron casas de seguridad y se consideró que había que organizar a las mujeres porque era necesaria su presencia. Una compañera quedó como responsable, formó el grupo de compañeras y fue creciendo su organización porque era indispensable que apoyaran a los insurgentes. Las esposas estaban pendientes de mandar al miliciano su comida - tostadas y pinole-, de mantener a la tropa en las concentraciones y de ocuparse del abastecimiento. Otra de las tareas de las mujeres antes del levantamiento fue hacer los uniformes de los milicianos. También eran importantes en la realización de fiestas y bailes. Fueron haciendo sus colectivos, como los de panadería, pero se vio que eso no bastaba y que era importante un trabajo de las mujeres más amplio para que apoyaran en la comunicación cuidando la seguridad del pueblo, viendo qué personas extrañas pasaban o quiénes llegaban de afuera y qué buscaban. Cuando se hizo la consulta en 1993, fueron las compañeras las que dijeron que ya no aguantaban la explotación. El último día de 1993, cuando salieron los milicianos, ellas les prepararon los alimentos que llevaban, pero no sólo eso; por ejemplo, había una pista de aterrizaje y mujeres zapatistas tumbaron la torre y se hicieron con el aparato de radio que ahí había. Se vio también que las mujeres podían hacer el trabajo que realizaban los hombres y se fue avanzando en el proceso libertario.

Se diversificaron los métodos y formas de lucha. La organización del EZLN fue clandestina, pero también se impulsó otra organización abierta para disimular, la Alianza Campesina Independiente Emiliano Zapata, que fue la que el 12 de octubre de 1992 tiró la estatua de uno de los invasores españoles. Se combinaban las luchas y los métodos de lucha. Estaban la formación, la comunicación y la seguridad. Se veía que se requería dinero para hacer las movilizaciones, y para conseguirlo se atendió la economía de la organización.

La gente no vivía bien, no había tierra, techo, educación, salud ni buena justicia. Salinas de Gortari privatizó los ejidos y la gente no tenía dónde trabajar. A los indígenas no los tomaban en cuenta, no había democracia ni independencia y vieron que debían oponerse al despojo. Había inconformidad con los malos gobiernos, por eso se organizaron y se prepararon mucho soterradamente durante diez años en los que hacían reuniones y organizaban fiestas para levantar ánimos de lucha. El ánimo crecía cuando se constataba lo que hacían otros pueblos y los trabajos colectivos también los animaban.

En cada nivel ha habido responsabilidades específicas. El pueblo local necesita orientación para animar a los milicianos, para cuidarlos, obedecer en los trabajos que se van a hacer y apoyar a los milicianos para que tengan sus equipos. Cuando se ve que llega gente extraña, se tiene que informar al nivel regional. El responsable también informa de 
los problemas locales, organiza los trabajos colectivos e informa de sus avances. Los responsables regionales se eligen entre los responsables locales, y e 1 responsable regional debe convocar a la asamblea regional, juntar a los compañeros y después llevar la información de lo discutido y acordado en la reunión. Otras responsabilidades son hacer planes de trabajos colectivos, preparar a los milicianos, hacer la crítica y la autocrítica y dar cursos a los responsables locales y a los pueblos.

Las mujeres zapatistas plantearon que habían trabajado mucho. Destacaron como elemento fundamental la libertad para participar, ser agentas, comisionadas, promotoras, etcétera. Abrieron los ojos. Aprendieron a no tener miedo, a hacer el trabajo colectivo, a manejarse con los grupos y a ser responsables con el pueblo. Reconocen que han avanzado mucho y que han ido aprendiendo muchas cosas, como el uso de las plantas medicinales. Dicen que han alcanzado logros pero que les han implicado sufrimiento, hambre, frío y cansancio. Pese a lo conseguido saben que todavía les falta mucho y que deben trabajar más coordinadas, tenermucha disciplinay saber cómovan a cuidar suluchay organización.

Se enfatizó que dos elementos esenciales para la lucha fueron el compañerismo - apoyarse, ayudarse - y la unidad, y a estos dos elementos los consideraron métodos de lucha zapatista. Los maestros profundizaron en los principios de la organización del zapatismo: el principal es instaurar un gobierno que obedece mientras el pueblo manda, y el segundo consiste en: no engañar a las bases, no asaltar ni robar, sino mantenerse del propio trabajo, no ingerir bebidas alcohólicas, no sembrar, traficar ni consumir drogas, no violar, no rendirse, no venderse ni claudicar. Cada responsable local explicaba estos principios a sus bases.

En 1994 se levantaron y la sociedad civil pidió que hubiera paz. La sociedad civil se metió en medio de los dos ejércitos. Escucharon los zapatistas las peticiones de la sociedad, se hicieron los diálogos de la catedral y se firmaron los acuerdos de San Andrés, pero el Congreso no cumplió con los acuerdos, por lo que dejaron de lado el diálogo con el gobierno e hicieron realidad los acuerdos en la práctica. También dieron seguimiento al diálogo con la sociedad, con el pueblo mexicano, e hicieron una consulta nacional. Ahora están cumpliendo con lo que se comprometieron con el pueblo mexicano, al que no van a traicionar como a ellos los traicionó el gobierno. Desde el principio los zapatistas organizaron sus municipios autónomos, aunque el gobierno los atacó. Pero vieron que la autonomía no era tener un local o una construcción, sino que estaba en la mente y en el corazón. No se dieron por vencidos y siguieron con su autonomía, de modo que ahora ya tienen las Juntas de Buen Gobierno y han aprendido a gobernarse. Han estado preparando a sus jóvenes y siguen avanzando, pero anunciaron que pronto mostrarían otra construcción en su dinámica de autonomía y que los alumnos verían cómo la van a mejorar.

Los maestros insistieron en cómo había nacido la organización zapatista para que los alumnos vieran qué les podía servir en cuanto a organización y seguridad. Plantearon que 
se hablaba de la historia de la organización zapatista para que los alumnos aprendieran a mover y organizar su comunidad, su colonia o su pueblo. También dijeron que esperaban que los alumnos tomaran el ejemplo de la lucha, de cómo iniciar una organización y de cómo hacerla avanzar. ${ }^{10}$

Destacó Manuel Rozental que el zapatismo ha encargado a un muy amplio conjunto de miembros medios y de base de la organización que fueran los maestros de este segundo curso; que la claridad que han alcanzado en cuanto a economía y justicia la ponen en práctica en su vida diaria; que se ejerza la libertad de pensar, opinar, escuchar y participar colectivamente; que construyan su propia autonomía sin esperar a que alguien les diga qué hacer. Señaló que se nota que hay resistencias acumuladas, que son resistencias con memoria. La escuelita nos muestra que las comunidades se miran y profundizan en sus procesos de autonomía y enseña cómo el zapatismo lucha por un cambio total para destruir al sistema capitalista y que la palabra sin acción organizada es ciega. También se ve la urgencia de ir tejiendo resistencias. ${ }^{.1}$ Ese proceso ha sido la expresión de la libertad de los de abajo.

El método seguido al principio consistió en reflexionar sobre el estado de opresión, explotación y dominación para incitar la libertad de rebelarse. La opción libertaria de rebeldía conlleva otra decisión importante: se trata de una larga lucha que conlleva la libertad de comprometerse en la resistencia. Una tercera opción libre es crear la autonomía, que es un espacio necesario para el ejercicio de la libertad, lo que implica poner en práctica el método de comparar lo que pasaba con la sujeción y lo que sucede con la construcción de la autonomía. Se invita a los alumnos a que reflexionen sobre la opresión, dominación, explotación, marginación y agresión al sumo grado de una guerra del capitalismo, para que reafirmen su rebeldía y resistencia y para que libremente hagan búsquedas de creación de liberación por medio de la autonomía. Se les invita a tomar la libertad de atreverse a pensar, a dudar, a preguntar, y a optar libremente por arriesgarse a la creación de una sociedad nueva desde abajo.

\section{La demoeleuthería atisbada por medio de una visión compleja del zapatismo}

El subcomandante insurgente Moisés escribió la sección editorial de la revista Rebeldía Zapatista aparecida en abril de 2015, donde mostraba algunos planteamientos que se tratarían en el seminario de mayo. Moisés planteó que en el capitalismo imperaban asesinos, criminales, injustos, encarceladores, despojadores, desalojadores, corruptos,

\footnotetext{
${ }^{10}$ Ver: http://enlacezapatista.ezln.org.mx/video-segundo-nivel/.

${ }^{11}$ Intervenciones de Manuel Rozental en el seminario para reflexionar sobre la hidra capitalista que se organizó el 15 de agosto de 2015 de manera virtual enlazando colectivos de diez países.
} 
tramposos, mentirosos, ambiciosos e inhumanos. Propuso olvidar a los de arriba y reconciliarse entre los de abajo, conocerse, compartirse. Exhortó a que los pueblos se oyeran y crearan entre ellos para que, con su unión, se liberaran. Necesitaban organizarse con muchas formas de rebeldía y resistencia; practicar, trabajar, estudiar y corregir para hacer mejor. Propuso no cansarse de buscar libertad, justicia y democracia, que el pueblo decidiera por sí mismo (Subcomandante Moisés, 2015: 1-3). Todo esto tiene que ver con la demoeleuthería.

En este mismo número de la revista se publicaron intervenciones de los zapatistas en el Primer Festival Mundial de las resistencias y rebeldías contra el capitalismo de finales de 2014 y principios de 2015 que trataron sobre diez temas: gobierno autónomo zapatista, mujeres en lucha y la autonomía, justicia, la libertad, democracia, terrenos o campos de lucha, resistencia, la unidad, tierra y territorio y, por último, trabajos colectivos.

En el tema de gobierno autónomo zapatista se apuntó que no había líderes, que todos los integrantes de estos gobiernos eran importantes, que las autoridades elegidas por el pueblo eran vigiladas por el mismo y que todos juntos construían sus leyes y sus reglamentos. Se hacían propuestas y se discutían en asambleas. Creaban, hacían, agregaban, deshacían, cambiaban e imaginaban. El gobierno era colectivo.

En el segundo tema, relacionado con las mujeres y la autonomía, ellas decían que necesitaban organizarse porque veían que había muchas desapariciones, por lo que muchas mujeres sufrían un grave dolor por sus hijos y familiares. Recalcaron que había que organizarse para que el mismo pueblo decidiera, hombres y mujeres. Reconocían que las mujeres zapatistas ya tenían la libertad y el derecho de hacer sus propios trabajos, que primero permitieron que sus esposos e hijos estuvieran en la lucha, y luego ellas se incorporaron a lo que realizaban los hombres. La libertad de las mujeres zapatistas ha consolidado su autonomía, su demoeleuthería.

En el tercer tema, relacionado con la justicia, se reconocía que los problemas más graves eran las violaciones, los asesinatos y la drogadicción. No había un espacio para la readaptación. Al delincuente lo hacían participar en los trabajos colectivos para que contribuyera a su alimentación, la de su familia y la de las personas afectadas. Los zapatistas hacían campañas para que no se cometieran esos delitos y la justicia se ejercía no como mercancía.

En el tema de la libertad se destacaba que con su organización habían conquistado la libertad que les había sido quitada. Por su lucha ahora los zapatistas tenían libertad de expresión y habían construido un nuevo sistema para gobernarse, en el que proponían y no se imponía, representaban y no suplantaban, obedecían y no mandaban. La libertad la veían como un derecho de todos. En libertad, opinaban, proponían, discutían, analizaban y decidían cómo querían su educación, su salud, su justicia y su democracia. Dentro de su libertad conquistada construían un nuevo sistema de gobernarse construyendo en la práctica la igualdad entre hombres y mujeres. Hombres y mujeres tenían la libertad y el 
derecho de hacer el mismo trabajo, como ser representantes en las tres instancias de gobierno y en cada área de trabajo. Construían con su libertad su nueva educación, salud, otra justicia y otra democracia, la verdadera. Con esa libertad construían una nueva cultura que beneficiaba al pueblo, una nueva forma de hacer política, una nueva ideología que le daba vida al pueblo. Con su libertad hacían todos sus planes de cómo querían gobernarse en autonomía, con sus leyes y reglamentos. Señalaban que en el mal sistema no había libertad. El zapatismo no necesitaba profesionales políticos que gobernaran porque en realidad eran sus pueblos los que se estaban gobernando. Este tema tocaba de lleno lo que denominamos su demoeleuthería, pero ésta no se circunscribía sólo a eso porque en la visión zapatista todos los temas se imbrican como nudos inextricables donde el conjunto está implicado.

En el tema de democracia se decía que el sistema y los malos gobiernos le habían quitado a la gente el derecho y la libertad a opinar, analizar, estudiar, proponer y decidir. Criticaban a los que vendían su voto, pero que cuando esto se hacía en realidad no se estaba comprando la democracia. El sistema siempre buscaba al más malo para que gobernara, en cambio, los zapatistas en su organización usaban la democracia preguntando al pueblo cómo quería que fuera su autoridad y la elegían en reuniones, con acuerdos. Usaban la democracia dentro de su autonomía pues se consultaba y se preguntaba a todo el pueblo, el cual tenía el poder, y no las autoridades. Los pueblos hacían campañas sin gastar porque no se hacía propaganda ni se compraban votos. Elpueblo analizaba, estudiaba, discutía y decidía. Asíseinvolucraban todos en esta otra democracia y no esperaban que el gobierno hiciera cambios, sino que para el cambio se requería que el pueblo se organizara, decidiera e hiciera lo que quería. Como se ve, este tema está íntimamente conectado con el anterior de la libertad y de alguna manera se complementan. Eso lo vemos como parte de la demoeleuthería.

En cuanto a los campos de lucha, se advertía que el sistema capitalista utilizaba los campos de control donde dominaba y explotaba al pueblo: lo político, lo ideológico, lo económico, lo social, lo cultural, lo psicológico y lo militar. Los capitalistas utilizan los medios como la televisión, la radio o el internet para manipular y mentir. Los zapatistas hacían reuniones para ver cómo tenía que ser la educación, la salud, las leyes y los reglamentos. Se veía que el sistema capitalista atacaba a la gente ideológicamente, por lo que construían su propia ideología. No daban ni recibían nada de los malos gobiernos, que utilizaban lo económico como medio de control a través de proyectos para que la gente no se organizara, sino que se dividiera. Los malos gobiernos eran cómplices de los narcotraficantes y de los que lavaban dinero. El sistema creaba también organizaciones sociales para controlar a la gente y usaba la represión, además de que saqueaba los recursos naturales de los pueblos. Los zapatistas recordaban que estaban organizados militarmente para defenderse, pero por ahora tenían guardadas sus armas porque era mejor no usarlas para lograr la libertad, la justicia y la democracia. Estos tres conceptos se encontraban conectados y, por lo tanto, los podemos interpretar dentro de la demoeleuthería. 
En el tema de resistencia hablaban de cómo habían resistido en los diversos campos de lucha durante los más de veinte años de su autonomía. Resistían ideológicamente tanto en lo externo como en lo interno. En lo externo estaban los medios ideológicos con los que atacaba el mal gobierno, y hacia adentro el zapatismo rompía viejas costumbres en torno a las mujeres haciendo ver que tenían capacidad de gobernar, relegando el conformismo, rescatando su propia historia y concluyendo con el alcoholismo y la drogadicción. Había resistencia pues los zapatistas formaban su propia educación y comunicación. Había resistencia económica pues no pagaban impuestos y no aceptaban los programas del gobierno. Habían creado su propia salud y recuperaron miles de hectáreas que tenían los finqueros, que trabajaban colectivamente. Habían creado sus propios bancos y estaban resistiendo la guerra psicológica que les hacían. Como hemos vista la resistencia forma parte de su demoeleuthería.

En el tema de trabajos colectivos destacaban que colectivamente se planeaba y se trabajaba. Cuando se hacían movilizaciones su usaban recursos que salían del trabajo colectivo, con los que también sostenía la educación y salud autónomas. En el tema de tierra y territorio, destacaban que el sistema capitalista todo lo había convertido en mercancía, se despojaban a los pueblos y se les destruía por medios de leyes que favorecían a los de arriba. Señalaban que un grave daño era el que hacían las semillas transgénicas, que destruían, esterilizaban y generaban dependencia. Todos los males del capitalismo los enfrentaban con su autonomía, y la autonomía la vemos implicada en la demoeleuthería.

Un tema complejo y amplio para los zapatistas ha sido el de la unidad. Los zapatistas han dicho que con unidad, organización, lucha, acuerdos, resistencia y rebeldía han estado construyendo una nueva sociedad. Con unidad, trabajo y lucha han impulsado la igualdad entre hombres y mujeres; se lograron las trece demandas - tierra, trabajo, techo, alimentación, salud, educación, información, cultura, independencia, libertad, justicia, democracia y paz-, y han podido enfrentar al monstruo criminal del capitalismo y le han dicho no más al despojo y destrucción de su tierra. Han constatado que con unidad, trabajo, lucha, organización, rebeldía y resistencia se pueden detener encarcelamientos, persecuciones, asesinatos, desapariciones, secuestros, drogadicción, tortura, violaciones, maltrato, amenazas, provocación, discriminación, desprecio, olvido, humillación, amenazas represión; despojo, explotación, robo, pobreza, marginación, desigualdad, injusticia; dominación, imposición, manipulación, traición y corrupción. Los zapatistas con su unidad de lucha han podido organizarse y resistir en lo económico, político, social, cultural y militar y han visto que se necesita unidad en lo económico para que todos los recursos sean para el bien del pueblo. Insisten en la necesidad de unidad de políticas y en no perder de vista al enemigo principal. Con todo esto amalgamado estaban defendiendo la madre tierra de los destructores capitalistas, y seguirían construyendo lo que les hacía falta poner en práctica. Los zapatistas exhortaban a los de abajo a unirse para no permitir que los ricos neoliberales, que sí 
estaban unidos, saquearan las riquezas de los pueblos (EZLN, 2015: 4-32). Estas argumentaciones son de gran calado teórico y de gran potencialidad práctica. Lejos se encuentran de la visión eurocentrista de los conceptos claros y distintos, separados en la cabeza aunque en la realidad vital esto no se exprese así. Las ideas básicas del zapatismo las han plasmado y las viven en un sólido tejido, en una red que se expande rizomáticamente, y todas se implican mutuamente y se potencian y dinamizan, enlazándose, amarrándose, mezclándose, comprometiéndose inextricablemente. Esta complejidad la vemos compendiada en la libertad de los de abajo, en la demoeleuthería.

\section{La demoeleuthería como pista}

Los zapatistas han explicado con mucha nitidez cuál es el método zapatista en cuanto a escudriñar atentamente todo, dudar, preguntar, buscar, ensayar, atreverse a equivocarse y tener la sensatez de corregir en una continua búsqueda y mejora de su autonomía. Dos formulaciones compendian esto: caminar preguntando y mandar obedeciendo al pueblo. Pero el conjunto de sus reflexiones nos muestra que también hay otro método constante en ellas, y éste consiste en escudriñar la génesis y el desarrollo de sus propias comunidades autónomas. Como se podrá ver en las reflexiones que hemos revisado en este escrito, se remontan a cómo estaban las comunidades antes del levantamiento zapatista y cómo se encuentran en el presente. No sólo hacen el contraste con su pasado, sino con el presente de las comunidades que dependen del Estado y no siguen los pasos de la autonomía. En esa comparación han detectado los perjuicios del capitalismo y del mal gobierno, por una parte, y las ventajas de su autonomía anticapitalista lograda por una tenaz lucha pertrechada por la rebeldía y la resistencia. Su autonomía la hacen vivir y la impulsan por medio del examen colectivo de las situaciones, su discernimiento, la libre decisión de lo que se debe hacer y la puesta en práctica de lo decidido con un atento examen de sus resultados. Este dinamismo del mandarse solos sin depender de otros es lo que hemos compendiado en la demoeleuthería, la cual resulta una pista de interpretación del meollo de la vitalidad autonómica anticapitalista y de la nueva sociedad que han ido creando con gran capacidad de invención.

Ha habido una cosmogénesis; y en la tierra, además, una biogénesis y una antropogénesis como etapas de una evolución compleja. La aparición del pensamiento ha cambiado la vida en el planeta. Hemos llegado al momento en que el dominio del pensamiento capitalista está poniendo en peligro la vida humana en el planeta. El pensamiento capitalista se traduce en una vertiginosa y contundente actividad. Para salvarnos, el pensamiento anticapitalista debería ser mucho más activo. Debemos esforzarnos por constatar lo que llega a ser y lo que está detrás de la apariencia fenoménica. Debemos acudir a lo experimental observable, a su recurrencia y a la constatación de sus 
efectos. Ante los errores, no debemos arredrarnos, sino volver a ensayar. El pensamiento anticapitalista puede ser la liberación del peligro al que nos está empujando el capitalismo si se traduce en acción eficaz. El zapatismo, tanto en el seminario de mayo de 2015 como en el segundo curso de la escuelita, nos ha propuesto no perder de vista la génesis y los procesos del capitalismo, pero también el origen de la experiencia zapatista. El capital quiere disciplinar y sujetar, así como aprovechar en su favor a los seres humanos y a la naturaleza. No tolera la rebeldía y menos la resistencia, pero la rebeldía y la resistencia son el único camino de liberación. Se ha llamado la atención sobre que para entender la actuallucha delos pueblosindígenas no se puedeuno quedaren paradigmas evolucionistas y dualistas, sino que hay que abordarla desde la perspectiva de la complejidad, la cual implica una articulación integrada y compleja combinando repeticiones e innovaciones. Se mantienen memorias, pero se adoptan innovaciones. No tratan de llegar linealmente a un fin, a un progreso, sino de armonizarse y comunicarse con la madre tierra (Prada, 2015b). Ese proceso se logra si se busca y consigue la libertad de los abajo, la demoeleuthería. Se podría ver este concepto como la expresión de la lucha de clases, pero no reducirse a ella. Efectivamente el capitalismo actual ha ido modificando las clases que existían en otras etapas capitalistas. Ahora ha crecido en gran manera lo que se llama el precariado, en el que se incluyen esos sectores que el actual proceso ha excluido y que somete con cruda represión si se le oponen, y hasta los va exterminando. Se han incrementado las migraciones para conseguir un poco más de salario, aunque el encontrado suele ser bajo, y hay migrantes que ni logran insertarse en el proceso directo de la explotación. Así, hay una gran cantidad de sobreexplotados en su propia tierra y en tierras ajenas y una gran cantidad de "sobrantes", eliminables para el sistema. A quienes resisten y se oponen se les aplican medidas bélicas de exterminio. No habría que perder de vista que aun los excluidos en su necesidad de sobrevivir contribuyen a las ganancias capitalistas por las vías de la deuda. Hay colectivos que defienden a la madre tierra de la depredación y destrucción del afán capitalista de engullirlo todo en su lógica de ganancia sin pausas. Todo ese conjunto es ese abajo popular para sobrevivir y para redignificarse necesita luchar fuertemente a fin de liberarse tanto del capitalismo como de las sujeciones estatales. Pablo González Casanova ha considerado que las fuerzas liberadoras no pueden sólo pensar en lucha de clases, sino hacer un esfuerzo de análisis muy grande (González, 2015). Y esas nuevas luchas van más allá del capital y del Estado para poder alcanzar y afianzar la libertad de los de abajo, en un quehacer tenso de la demoeleuthería. En este sentido, hay miradas más allá que implican trascendencia con respecto al sistema capitalista e inmanencia en cuanto a la transformación emancipatoria. Esto es lo que tratan de vivir las comunidades zapatistas y que muestran como algo que puede darse desde ahora y que podría verse desde la demoeleuthería. 


\section{Referencias bibliográficas}

Alonso, Carlos y Jorge Alonso (2015). En busca de la libertad de los de abajo: la demoeleuthería. Guadalajara, México: Universidad de Guadalajara.

Castoriadis, C. (2000). Le monde morcelé. París: Seuil.

El pensamiento crítico frente a la hidra capitalista: memoria audiovisual del semillero (2015). México: Medios Libres.

Esteva, Gustavo (2015). “Tejidos de resistencia”. En La Jornada, 17 de agosto. Disponible en: http://www.jornada.unam.mx/2015/08/17/opinion/019alpol.

EZLN (2015). "Compartición en el Primer Festival Mundial de las Resistencias y las Rebeldías contra el Capitalismo: donde los de arriba destruyen los de abajo reconstruimos". En Rebeldía Zapatista, núm. 4, abril, pp. 4-32.

Fanon, Franz (1961). Les damnés de la terre. París: Maspero.

Fernández Christlieb, Paulina (2014). Justicia autónoma zapatista. México: Ediciones Autonomy@s.

Fernández Nadal, Estela y Gustavo David Silnik (2012). Teología profana y pensamiento crítico. Conversaciones con FranzHinkelammert. Buenos Aires: CLACSO.

Fromm, Erich (1976). To Have or to Be? Nueva York: Blommsbury Academy.

González Casanova, Pablo (2015). "El capitalismo omite la historia humana". En La Jornada, 4 de septiembre. Disponible en: http://www.jornada.unam.mx/2015/09/04/ cultura/a03nlcul.

Hinkelammert, Franz (2015). Solidaridad o suicidio colectivo. Madrid: Rebelión.

López y Rivas, Gilberto (2015). Reseña del libro El pensamiento crítico frente a la hidra capitalista. Participación de la Comisión Sexta del EZLN, Tomo I. En Rebelión, 27 de agosto de 2015. Disponible en: http://www.rebelion.org/noticia.php?id=202547.

Marcel, Gabriel (1935). Etreet Avoir. París: Aubier.

Prada Alcoreza, Raúl (2015). "Territorios indígenas y descolonización”. En Bolpress, 17 de agosto. Disponible en: http://www.bolpress.com/art.php?Cod=2015081709.

Prada Alcoreza, Raúl (2015b). "Autonomías y descolonización”. En Bolpress, 22 de julio. Disponible en: http://www.bolpress.com/art.php?Cod=2015072202.

Rey, Pierre Philippe (2012). "Por una antropología de la liberación”. En María Guadalupe Moreno y Jaime Tamayo (coords.), Procesos políticos y revolución. Guadalajara, México: Universidad de Guadalajara.

Subcomandante Moisés, "Editorial". En Rebeldía Zapatista, núm. 4, abril, pp. 1-3.

Zibechi, Raúl (2015a). "Dominación de tiempo completo". En La Jornada, 7 de agosto. Disponible en: http://www.jornada.unam.mx/2015/08/07/opinion/018a2pol.

Zibechi, Raúl (2015b). Descolonizar el pensamiento crítico y las rebeldías: autonomías y emancipaciones en la era del progresismo. Buenos Aires: Bajo Tierra Ediciones.

Zibechi, Raúl y Jorge Rath (2015). “Es posible salir del facilismo?”. En Rebelión, 21 de agosto. Disponible en: http://www.rebelion.org/noticia.php?id=202378. 


\title{
Las guerras, la otra política y los medios indígenas en movimiento
}

\author{
Xochitl Leyva Solano \\ Axel Köhler
}

\section{Introducción}

El presente capítulo se inserta en parte de este libro, sección que enfatiza "las otras democracias" o, mejor dicho, las otras prácticas democráticas, las prácticas otras de la política y lo político. Todo ello lo abordaremos a partir de tejer tres ejes o hilos. Primero nos referiremos a la naturaleza de las guerras en curso que hoy son consustanciales a esas prácticas "otras" democráticas. En segundo lugar haremos alusión a algunas experiencias organizativas dadas en contextos de guerra "donde deliberadamente el ejercicio de lo político le da la espalda al juego electoral y al gobierno". 'Y en tercer lugar exploraremos cómo los medios y el video indígena en resistencia y en movimiento son claves para la construcción de esa otra política que reta, descentra y desalambra la democracia representativa, hoy por hoy, aún dominante a pesar de estar en crisis. La crisis de la democracia liberal representativa es sin duda una de las múltiples aristas de lo que hoy llamamos crisis civilizatoria o crisis sistémica. ${ }^{2}$

\footnotetext{
${ }^{1}$ Véase el documento producido por el Equipo del Observatorio (2015: 5).

${ }^{2}$ Diferentes pensadores y actores han nombrado de distintas maneras lo que hoy vivimos: "IV Guerra Mundial", "lento, silencioso y letal holocausto social", "la democracia disciplinaria", "crisis sistémica", "crisis capitalista", "crisis mundial del capitalismo", "crisis de la civilización occidental capitalista" o bien "crisis del patrón civilizatorio hegemónico". Todas estas conceptualizaciones ponen énfasis en distintos aspectos, pero de alguna manera coinciden en que la crisis que estamos viviendo como humanidad es global, sistémica, y va más allá de ser solamente una crisis económica o financiera. Para varios analistas se trata de una crisis multifacética que es simultáneamente medioambiental, energética, alimentaria, migratoria y bélica. Al mismo tiempo, otros señalan que la crisis actual se manifiesta como crisis política en una triple dimensión: crisis de la hegemonía del imperialismo, de legitimidad del Estado moderno y de la democracia liberal representativa, así como crisis cultural y ética en cuanto crisis de valores, de proyectos de vida, de las formas de identidad y subjetividad
} 
XOCHITL LEYVA SOLANO, AXEL KÖHLER

\section{¿Qué guerra(s), qué despojos, qué horrores?}

Los pueblos originarios en diferentes partes del mundo están librando arduas luchas en contra del sistema capitalista global en su fase actual, aunque históricamente, en América Latina y el Caribe. Sabemos que han enfrentado despojos y violencias que nos remiten a tiempos de la conquista-ocupación europea, pero si miramos del presente hacia el pasado, podemos retomar lo que afirma el geógrafo David Harvey (2004: 109) sobre la diferencia entre el libre comercio de mercancías y la libertad de movimiento para el capital financiero:

Por una parte, los flujos de crédito son vitales para las inversiones productivas [...] pero el capital financiero abarca también una gran cantidad de actividad improductiva en la que el dinero se usa simplemente para obtener más dinero mediante la especulación en mercancías futuras, valores monetarios, deuda y demás. [...] la intervención del capital financiero respaldada por el poder estatal frecuentemente puede volverse acumulación por otros medios. Una alianza non sancta entre los poderes estatales y los aspectos depredadores del capital financiero forma la punta de lanza de un "capitalismo de rapiña" dedicado a la apropiación y devaluación de activos, más que a su construcción a través de inversiones productivas (Harvey, 2004: 110-111).

Harvey propone llamar "acumulación por desposesión" a estos otros medios de acumulación y devaluación basadas en la depredación, el fraude y la violencia. En ausencia de una fuerte revitalización de la acumulación sostenida a través de la reproducción ampliada, es decir del crecimiento, la acumulación por desposesión se ha vuelto "la marca distintiva del nuevo imperialismo centrado en EUA" (Harvey, 2004: 120).

En términos históricos Harvey nos remite a la descripción que hizo Karl Marx, a finales del siglo XIX, de los procesos de "acumulación originaria" del capital. Dichos procesos se leen como un catálogo de lo que está pasando en las últimas décadas, no sólo en México, sino en muchos países de América Latina y del mundo, pero sobre todo en tierras y territorios de los pueblos originarios:

[L]a acumulación originaria revela un rango amplio de procesos. Estos incluyen la mercantilización y privatización de la tierra y la expulsión forzosa de las poblaciones campesinas; la conversión de diversas formas de derechos de propiedad — común, colectiva, estatal, etcétera— en derechos de propiedad exclusivos; la supresión del

dominantes. Otros hacen especial énfasis en la crisis de las estructuras y de las formas dominantes de conocimiento (ver las referencias bibliográficas en Leyva, 2015, t. I: 23-24). 
derecho a los bienes comunes; la transformación de la fuerza de trabajo en mercancía y la supresión de formas de producción y consumo alternativas; los procesos coloniales, neocoloniales e imperiales de apropiación de activos, incluyendo los recursos naturales; la monetización de los intercambios y la recaudación de impuestos, particularmente de la tierra; el tráfico de esclavos; y la usura, la deuda pública y, finalmente, el sistema de crédito. El Estado, con su monopolio de la violencia y sus definiciones de legalidad, juega un rol crucial al respaldar y promover estos procesos (Harvey, 2004: 113).

Dado que estos procesos históricos de "acumulación primitiva” u “originaria” siguen más que vigentes, Harvey propuso sustituir estos términos por el concepto de "acumulación por desposesión". Por su parte, los y las que hoy día resisten de muchas formas a las políticas y las prácticas económicas neoliberales basadas en el credo del "mercado libre", lo hacen porque han experimentado en carne propia que la liberalización mercantil no está conduciendo a un estado de bienestar en el que todos estamos viviendo mejor, sino que está produciendo mayores niveles de desigualdad social, violencia y sufrimiento para las mayorías. Detengámonos y escuchemos lo que nos dicen al respecto los organizadores y participantes en la Primera Compartición de Pueblos Originarios de México con Pueblos Zapatistas, un encuentro convocado por el Ejército Zapatista de Liberación Nacional (EZLN) y llevado a cabo en agosto de 2014 en territorio autónomo zapatista con los miembros del Congreso Nacional Indígena (CNI). Escuchemos de viva voz parte de las declaraciones emitidas desde dicha Compartición. La primera declaración titulada "No olvidamos a nuestr@s muert@s, pres@s, desparecid@s" inicia con un conciso resumen de la represión sufrida por los pueblos originarios. Dice a la letra:

La guerra contra nuestros pueblos indígenas dura ya más de 520 años, el capitalismo se nació de la sangre de nuestros pueblos y a los millones de nuestros hermanos y hermanas que murieron durante la invasión europea, hay que sumar los que murieron en las guerras de independencia y de reforma, con la imposición de las leyes liberales, durante el porfiriato y en la revolución.

En esta nueva guerra de conquista neoliberal la muerte de nuestros pueblos es la condición de vida de este sistema.

En las últimas décadas miles y miles de nosotros hemos sido torturados, asesinados, desaparecidos y encarcelados por defender nuestros territorios, nuestras familias, nuestras comunidades, nuestra cultura, nuestra vida misma.

No olvidamos. Porque esa sangre, esas vidas, esas luchas, esa historia son la esencia de nuestra resistencia y de nuestra rebeldía en contra de quienes nos matan; en la vida y en la lucha de nuestros pueblos ellos viven (CNI y EZLN, 2014a). 
Esta declaración presenta un panorama de lo que los firmantes llaman "nuestr@s muert@s más recientes", que incluye 87 personas con nombresy apellidos; "nuestr@s desaparecid@s", que incluye 15 personas, y "nuestr@s pres@s", 39 personas. Cierra con la sección titulada "hermanos y hermanas bajo hostigamiento y amenazas", seis personas de distintos estados dela república mexicana, principalmente de Chiapas, Oaxaca, Michoacán, Jalisco, Veracruz, Puebla y el Estado de México. La declaración concluye con el lema: "De nuestro dolor nació nuestra rabia, de la rabia nuestra rebeldía y de la rebeldía nacerá la libertad de los pueblos del mundo".

La segunda declaración del CNI y el EZLN, "sobre el despojo a nuestros pueblos", arranca afirmando: "Si no nos han matado en 520 años de resistencia y rebeldía no lo harán ahora ni nunca”. Reproducimos textualmente algunos párrafos que nos permiten conocer la forma en que los asistentes a la Compartición, desde una teoría encarnada, nos presentan lo que llaman "la guerra de exterminio" en curso, identificando el principal enemigo y su manera de operar:

La lucha que somos es diversa y al enemigo lo nombramos despojo porque es lo que vemos, morimos y vivimos todos los días, de manera colectiva como es el maíz, como es el compañero Galeano, como es el compañero David y como son nuestros hermanos y hermanas a los que ha sido arrebatada la vida en esta guerra de exterminio.

Es tan diverso ese despojo que tiene un solo nombre, y se llama capitalismo.

Desde un principio el capitalismo se ha crecido del DESPOJO y de la EXPLOTACIÓN. DESPOJO e INVASIÓN, son la palabra que mejor describe lo que llamaron conquista de América, despojo y robo de nuestras tierras, de nuestros territorios, de nuestros saberes, de nuestra cultura. DESPOJO, acompañado de guerras, de masacres, de cárcel, de muertes y más muertes, que se hacen vida colectiva porque aquí estamos los pueblos que somos, que seguimos siendo...

En la actualidad los capitalistas neoliberales, con el apoyo de todos los partidos políticos y los malos gobiernos encabezados por el criminal y jefe paramilitar Enrique Peña Nieto, están aplicando las mismas políticas de despojo a gran escala que aplicaron los liberales del siglo diecinueve, los carranzas o los obregones, apuntalándose en la militarización y paramilitarización, asesoradas por los cuerpos de inteligencia estadounidense, en aquellas regiones donde las resistencias se enfrentan al despojo.

Al igual que los gobiernos de aquellos tiempos, los actuales gobernantes están entregando nuestros territorios y los bienes que se nombran de la Nación a las grandes empresas nacionales y extranjeras, buscando la muerte de todos los pueblos de México y la de nuestra madre tierra, pero la muerte entre nuestros pueblos se renace en colectivo... (CNI y EZLN, 2014b). 
La declaración presenta veintinueve "espejos" en los que se reflejan con detalle los despojos que se han multiplicado, que "se hacen luchas y resistencias en las que vemos espejos que se reflejan en el espejo que somos". Entre los múltiples despojos territoriales que señala la declaración se encuentran: el saqueo ilegal de minerales y maderas preciosas por parte de grupos del crimen organizado en contubernio con los tres niveles del "mal gobierno"; saqueo que está acompañado de asesinatos y desapariciones de comuneros y ejidatarios en resistencia. La explotación petrolera y de gas natural que conlleva innumerables accidentes colaterales, derrames y destrucción medioambiental. Proyectos para la construcción de vías carreteras y de ferrocarriles, así como de complejos de desarrollo turístico cuya construcción causa daños al medioambiente y no respeta los sitios sagrados. Concesiones a empresas mineras, muchas de las cuales operan a cielo abierto y usan químicos tóxicos para la extracción. ${ }^{3}$ Instalación de parques eólicos y aerogeneradores que implican el despojo de tierras comunales y la destrucción de lugares sagrados, además de tener múltiples efectos colaterales para las aves y la vida silvestre. La construcción de presas hidroeléctricas que involucran la inundación de tierras comunales, el establecimiento de reservas ecológicas que arrebatan el control territorial a los pueblos, la extracción de agua de varios ríos y manantiales para el abastecimiento de grandes ciudades y empresas agroindustriales en detrimento de la población local y su producción agrícola. La renta y compra de tierras en comunidades para la siembra de cultivos transgénicos de soya y de maíz que afectan los cultivos no transgénicos de la región.

La pintura del horror, del despojo y la violencia que nos presentan los asistentes a la Compartición no puede dimensionarse en sus justos términos sin apuntar que el actual gobierno federal encabezado por el priista Enrique Peña Nieto (2012-) ha abandonado el discurso y la estrategia del anterior presidente panista Felipe Calderón Hinojosa (2006-2012), quien implementó "la guerra contra el narcotráfico", con un saldo de 80000 asesinatos (International Crisis Group, 2015), en el que destaca el feminicidio, con un crecimiento de 155\% (Rama y Díaz, 2014); la cifra de desaparecidos se estima en 22000 (Human Rights Watch, 2014), y el número de desplazados por la violencia en el país ascendió a 281418 (Rubio, 2014). Según datos del INEGI, en 2013 el número de hogares donde al menos un miembro ha sido víctima de un crimen fue de 10.7 millones (Cawley, 2014).

Ante la espiral de violencia masiva que la primera trajo consigo y ante el fracaso en alcanzar sus objetivos, Peña Nieto primero renombró "la guerra contra el narcotráfico" como "lucha contra el crimen organizado", enfatizando discursivamente "la política de seguridad nacional", pero a partir de abril de 2016, en un discurso ante la Organización de

\footnotetext{
${ }^{3}$ Según las propias cifras gubernamentales, actualmente están vigentes 25566 títulos mineros en México que cubren, en conjunto, 25747 hectáreas, equivalentes a $13 \%$ del territorio nacional (México. Presidencia de la República 2014: 528).
} 
las Naciones Unidas (ONU) enfatizó la dimensión mundial del problema, reconociendo las limitaciones del "paradigma prohibicionista" en lo que llamó ya "la guerra contra las drogas", al tiempo que anunciaba un giro para enfrentar en México "el problema mundial de las drogas", "desde una perspectiva de Derechos Humanos [sic], prevención y salud pública, que ponga en el centro el bienestar de las personas" (EPN, 2016: s.p.). Como sabemos, en México los discursos de los políticos tienen muy poca credibilidad ante la evidencia de sus actos. Veamos como muestra un botón.

En lo que va en el régimen presidencial actual, los medios masivos de comunicación han bajado tanto la intensidad como la forma en la que reportaban en el sexenio pasado la creciente violencia en el país. Sin embargo, basta referirnos a un reciente informe basado en las investigaciones de Acción Urgente para los Defensores de Derechos Humanos, A.C. (ACUDDEH), la Campaña Nacional contra la Desaparición Forzada y el Comité Cerezo, donde se afirma que la nueva estrategia no ha logrado fortalecer la seguridad pública ni reducir la violencia institucional y social ni tampoco las violaciones graves a los derechos humanos de los y las mexicanas. ${ }^{4}$ Por ejemplo, en 2014, el discurso gubernamental y el de los medios masivos de comunicación a su servicio nos quieren convencer de que hay únicamente dos caminos: uno que lleva al avance del país y el otro que significa su retroceso. En esta lógica, los "ciudadanos buenos" son los que dan su apoyo a las políticas gubernamentales que supuestamente sólo pretenden "un futuro mejor para México". En el otro lado, se encuentran los "inconformes" que desde la visión gubernamental sólo apuestan a que México se quede en el atraso.

Para fomentar esta visión son centrales los canales televisivos privados del duopolio Televisa y TV Azteca, los cuales se encargan de resignificar las movilizaciones y la protesta social como estancamiento, retroceso y estorbo al progreso nacional. De hecho, está en curso en el país una estrategia legal y mediática para someter a los participantes de movimientos y protestas sociales al proceso penal. Dicha estrategia tiene varios objetivos: 1) deslegitimizar la inconformidad y criminalizar la protesta en la opinión pública. A los

\footnotetext{
${ }^{4}$ Con similares afirmaciones existe un sinnúmero de informes llevados a cabo por organismos regionales, nacionales e internacionales, por ejemplo ver: Amnistía Internacional (2012, 2014a y 2014b), el Centro de Derechos Humanos Fray Bartolomé de Las Casas, A.C. (2011 y 2013), la Comisión Interamericana de Derechos Humanos (2013) y Human Rights Watch (2011). Al respecto cabe aclarar que la guerra se está librando también en el terreno de datos y cifras, así como en sus interpretaciones. Es importante aclarar que no estamos abogando por simplemente reconocer que existe una pluralidad de opiniones e interpretaciones políticas, sino que nuestro punto es más bien que está en curso una verdadera "guerra estadística" en la que el gobierno no cumple con su responsabilidad de proveer datos confiables y transparentes acerca de su actuar y de lo que está sucediendo en México. Una estrategia del actual gobierno federal, por ejemplo, ha sido cambiar los criterios estadísticos de su antecesor lo que le arrojó de inmediato cifras favorables para comprobar el éxito de sus actuales políticas de seguridad. Aún con esta nueva estrategia de manejo estadístico, no queda duda alguna respecto a la gravedad de la situación que vive el país.
} 
que protestan o se movilizan se les presenta como delincuentes; 2) enfocarse en las acciones rebeldes y sacar de foco el contenido profundo del descontento y de los conflictos sociales; 3 ) sumergir a los que protestan en el proceso desgastante de la defensa legal de las acusaciones levantadas en su contra. Pero ello nuevamente tiene que ser visto en el marco de la creciente militarización ${ }^{5}$ que, en México, acompaña la actual política de reformas constitucionales y de seguridad nacional, todas ellas garantes antes que nada del modelo neoliberal y de su hija, la democracia liberal representativa.

Pero, como afirma en su informe la ACUDDEH, el Estado mexicano también recurre al paramilitarismo ${ }^{6}$ para imponer su política económica neoliberal, estrategia que le permite evadir, ante la opinión pública, su responsabilidad directa en actos de terror (ACUDDEH, 2014: 19). La ACUDDEH misma nos ofrece una sistematización de "datos duros" que permite entender el comportamiento de las agresiones que han sufrido los y las defensoras de los derechos humanos en el periodo que va de junio de 2013 a mayo de 2014. Afirma que en Chiapas "la represión política no sólo va dirigida a un sector específico de personas defensoras de derechos humanos, sino prácticamente a todo el movimiento social" (ACUDDEH, 2014: 37). De los 204 casos registrados en dicho periodo - los cuales constituyen 274 eventos violatorios a los derechos humanos (agresiones y ataques) Chiapas fue el estado con mayor incidencia (38 casos, o sea, 18.62\% del total), seguido por elDistrito Federal(17.64\%), Oaxaca(15.19\%)yelEstadode México(13.23\%)(ACUDDEH, 2014: 36).

Pero, aún más, Chiapas en ese recuento de cifras se encuentra entre los estados mexicanos donde la modalidad de la detención arbitraria y el encarcelamiento por motivos políticos es una constante (ACUDDEH, 2014: 59). Dicha situación se agrava con lo que el Centro de Derechos Humanos Fray Bartolomé de Las Casas, A.C. (el Frayba)

\footnotetext{
${ }^{5}$ Entendemos por este término el incremento de los efectivos militares, en número y posiciones físicas; la capacidad real de las fuerzas armadas de controlar el territorio geográficamente y determinar con su presencia la vida política, económica y social; así como su presencia e influencia en el aparato de Estado, en los poderes ejecutivo, legislativo y judicial, y en los niveles federal, estatal y municipal de gobierno (Global Exchange, CIEPAC y CENCOS, 2000: 109).

${ }^{6}$ Como destaca el informe de la ACUDDEH (2014: 19), es difícil documentar el paramilitarismo, pero está claro que no puede surgir ni desarrollarse al margen de la protección del Estado que casi siempre dice combatirlo (Global Exchange, CIEPAC y CENCOS, 2000: 137) definen la paramilitarización como "producto de una estrategia elaborada desde las estructuras militares y avalada por el gobierno federal mexicano". En cuanto a los paramilitares, "son aquellos que actúan junto a la institución militar, pero que al mismo tiempo ejercen una acción desviada, deformada de lo militar, en un doble ambiente", pues defienden sólo los intereses de "un sector privilegiado dominante" y no de toda la sociedad y, además, operan clandestinamente para ocultar su identidad y garantizar su impunidad (Global Exchange, CIEPAC y CENCOS, 2000: 139). En México, el paramilitarismo opera actualmente bajo tres formas: lo integran miembros del Ejército quitándose el uniforme oficial; desertores o ex integrantes del Ejército financiados por el crimen organizado o civiles entrenados por militares o mercenarios (ACUDDEH, 2014: 19).
} 
nombra como el "Conflicto Armado Interno no resuelto en Chiapas" desde hace veintidós años. El Frayba destaca en su boletín del 18 de agosto de 2014 que "la contrainsurgencia sigue operando" en Chiapas pues "persiste la guerra integral de desgaste hacia los pueblos que luchan y resisten, usando tácticas mediáticas que incluyen la utilización de conceptos tales como derechos humanos, interculturalidad, derechos colectivos de los pueblos indígenas, vaciándolos de contenido" (Frayba, 2014: 1).

El pronunciamiento del Frayba enfatiza la existencia de una estrategia mediática usada por el gobierno del estado en la que "el reconocimiento" y "el respeto" discursivo a las comunidades autónomas, las Juntas de Buen Gobierno y el EZLN se enfrentan a la cruda realidad de la "ausencia de acciones directas para cambiar la situación de riesgo constante que viven las comunidades zapatistas [...] Esta actitud de indiferencia mantiene y provoca conflictos que son llamados intercomunitarios como una manera de ocultar la contrainsurgencia, el objetivo es generar cansancio entre la población que resiste, que lucha" (Frayba, 2014: 2). ${ }^{7}$

Como muchos analistas hemos señalado, la estrategia contrainsurgente en Chiapas, lanzada después del levantamiento zapatista del 1ํㅡe enero de 1994, trasciende lo militar y se modifica en diversos momentos a lo largo de estos veintidós años (1994-2016). Utiliza tanto recursos económicos como políticos, militares, sociales, psicológicos, epistémicos y mediáticos. Se ha valido del control territorial militar a través de la instalación de cuarteles, campamentos, retenes y patrullajes, e incluso de la confrontación militar directa, la implementación de políticas sociales contrainsurgentes y de campañas mediáticas - en internet, televisivas y radiofónicas - Como hemos mencionado, se trata de una "guerra integral de desgaste" en la que los diferentes niveles de gobierno y los medios masivos de comunicación a su servicio presentan el conflicto armado interno no resuelto como "conflicto inter o intracomunitario" ${ }^{8}$ acaecido entre indígenas por motivos

\footnotetext{
${ }^{7}$ Las estadísticas gubernamentales reflejan a su modo este asunto. En el cuadro titulado "Conflictos relacionados con pueblos indígenas de México” (México. Presidencia de la República, 2014: 44) aparece Chiapas con un total de veintiún conflictos, entre ellos siete agrarios y diez sociales. En este cuadro, el total de conflictos ocurridos en diecinueve estados de la república suma 88, es decir, Chiapas representa $24 \%$ del total.

${ }^{8}$ Como ejemplo, véase el contenido del discurso gubernamental en el Libro blanco sobre Acteal (Procuraduría General de la República, 1998: 30, 48) en el que la Masacre de Acteal se explica a la letra así: "La Procuraduría General de la República ha documentado la existencia de grupos de civiles armados en el municipio de Chenalhó, no organizados, articulados, entrenados ni financiados por el Ejército Mexicano ni por otras instancias gubernamentales, sino que su gestación y organización responde a una lógica interna determinada por la confrontación, entre las comunidades y dentro de las comunidades, con las bases de apoyo zapatistas. [...] Además de poseer grandes valores comunitarios, la idiosincrasia indígena presenta una actitud de intolerancia cuando se trata de resolver conflictos con una minoría disidente y respetar sus derechos humanos. Si a ello se agrega la persistente ausencia de un Estado de Derecho en la zona, es posible conocer la lógica que ha impulsado a las comunidades
} 
religiosos o étnicos, por problemas de tierra o de recursos naturales, por confrontaciones partidarias, por enemistades personales y por brujería. Frente a esto y ante unos acuerdos de paz no cumplidos por la parte gubernamental y el congreso de la nación, el EZLN ha suspendido el diálogo con el gobierno y se niega categóricamente a recibir recursos económicos del "mal gobierno".

En ese contexto, los programas gubernamentales para el campo o para "combatir a la pobreza" se han convertido en parte medular de la política social contrainsurgente que busca no sólo generar bajas en las bases de apoyo del EZLN, sino aislarlas y exterminarlas. Con dichas políticas se fomentan, inducen y provocan tensiones, divisiones, violencias, asesinatos y muertes en el territorio autónomo zapatista. Dichos programas no sólo se dirigen contra el zapatismo, sino que, en general, contribuyen a debilitar y desactivar las capacidades autogestivas y autónomas de los y las "ciudadanos(as)" mexicanos(as). A ello hay que sumar que la política social contrainsurgente promueve la feminización de la pobreza al utilizar a las mujeres campesinas, indígenas y mestizas de escasos recursos económicos como instrumentos de control de las familias y la población local para someterles a las redes clientelares y de corrupción que operan en diferentes momentos y niveles, pero, sobre todo, durante los procesos electorales y a través de los partidos políticos, como ya vimos a detalle en las primeras dos partes de este libro.

\section{El video indígena iarma de lucha para construir la otra política y las prácticas de gobierno autónomo desde abajo?}

Ahora retomemos algunas experiencias organizativas dadas en esos contextos de guerra donde deliberadamente el ejercicio de lo político le da la espalda y descentra y reta el juego electoral y al gobierno. Aquí parece pertinente preguntarnos cómo luchan y resisten las comunidades de pueblos originarios y — nosotros - sus aliados solidarios en medio de la guerra total o la guerra de exterminio en curso que nos ha tocado vivir. ¿Cómo ellos hacen o pueden hacer frente a los medios masivos de comunicación que juegan un papel central en esas guerras ${ }^{9}$ y en esas democracias liberales representativas?

Existen muchos modos de resistir, de rebelarse y de crear prácticas autonómicas desde abajo, desde los pueblos, las comunidades y las organizaciones en resistencia.

a resolver los conflictos a su interior a través de diferentes formas de violencia, como medio para hacer justicia por propia mano". Llama la atención que dicho libro estuvo accesible electrónicamente en internet en un sitio gubernamental y ahora no hay rastro de él en ningún sitio oficial.

${ }^{9}$ Para un análisis más detallado de las guerras, las luchas epistémico-políticas y la video(auto) representación maya en Chiapas, véase el trabajo colaborativo realizado por los coordinadores del PVIFS y sus dialogantes (Leyva, 2012; Jiménez y Köhler, 2012; Estrada y Köhler, 2013; Estrada, 2016). 
Uno de ellos es la creación desde la sociedad civil de lo que los zapatistas nombran como los "medios libres, autónomos, alternativos o como se llamen" (Subcomandante Insurgente Galeano, 2014: s.p.) que hacen uso, por ejemplo, del internet, la radio y la televisión comunitaria o ciudadana, los medios impresos y audiovisuales propios, el muralismo, el graffiti, los corridos, los fanzines, etcétera. Entre esos medios audiovisuales encontramos el "video indígena" o "video controlado por indígenas" (Halkin, 2006; Estrada, 2016 $)^{10}$ hecho en Chiapas y en otras partes de América Latina por los miembros de los pueblos originarios y afrodescendientes. Él refleja, por lo general, una estrecha imbricación de los movimientos indígenas y afrodescendientes con los movimientos sociales más amplios en cuanto a sus temas y las denuncias, demandas y propuestas que presenta. Tanto los procesos de producción como los productos mismos evidencian frecuentemente una convergencia y colaboración de sus realizadores de pueblos originarios y afrodescendientes, con activistas no indígenas.

Por lo que hemos visto y vivido en Chiapas y en el continente latinoamericano al acompañar por dos décadas los procesos organizativos de videoastas y comunicadores comunitarios, podemos afirmar que el "video indígena" es algo más que un instrumento, una herramienta o un medio de comunicación. Es, sobre todo por el contexto en el que surge, un arma de lucha, de denuncia y de defensa, un arma usada en contextos de insurrección, movilización y guerra. Un arma utilizada para emitir un grito bien fuerte, un iYa Basta! de reproducir injusticias, violencias, despojos, jerarquías, asimetrías, racismos, paternalismos, tutelajes, ventriloquias, controles y disciplinamientos.

Esta arma de lucha y de defensa sirve hoy en muchos puntos del continente americano para enfrentar los despojos de lo que los hombres y mujeres zapatistas han llamado "la hidra capitalista" (EZLN, 2015) y las violencias de la globalización neoliberal, así como para construir autonomías indígenas con o sin permiso de los Estados-nación, las cuales implican en muchos casos:

\footnotetext{
${ }^{10}$ En un artículo reciente hemos intentado caracterizar el cine y video indígena de cara al cine etnográfico. Destacamos las diferencias, primero, en cuanto al propósito -el para qué y para quiény el público al que se dirigen ambos tipos de producciones; segundo, respecto al punto de vista y el lugar de enunciación de sus realizadores; tercero, el control de la producción en los aspectos centrales y, cuarto, las distintas políticas de acercamiento a los sujetos representados y su involucramiento en la producción (Estrada y Köhler, 2013: 95). Recalcamos también que los enfoques temáticos de los videoastas indígenas en toda América son la autodeterminación de sus pueblos, el reconocimiento de sus derechos y el respeto de sus espacios y su territorialidad. En sus mensajes videográficos sobresale el intento de sensibilizar a la gente, de imprimir una sensibilidad propia y de expresar sentimientos que salen del corazón de los pueblos. Un objetivo central compartido es el de dar a conocer la situación de sus pueblos y hacer videos que realmente sirvan, como una especie de unificador en la diversidad lingüística y cultural y frente a la fragmentación religiosa y organizacional. Igualmente significativo es el realce de la dignidad indígena a través de estas producciones (Estrada y Köhler, 2013: 97-98).
} 
- búsqueda de soberanía alimentaria,

- reclamo de derechos — de mujeres, indígenas, humanos, jóvenes y niños y niñas-,

- recuperación de tierras y territorios,

- recuperación y revaloración de conocimientos, saberes y lenguas propias,

- autodefensa para garantizar la seguridad comunitaria y regional,

- educación y salud autónoma,

- construcción de la otra justicia.

La idea del video como un arma la escuchamos por vez primera en el año 2000, cuando el agrocomunicador comunitario Crisanto Manzano Avella, originario de Tanetse de Zaragoza, en la Sierra Juárez de Oaxaca, nos compartiera sus saberes y reflexiones acerca de la producción audiovisual hecha por ellos mismos, los miembros de pueblos originarios. Crisanto Manzano (2000) destacó que "el arma del video" sirve para recuperar las costumbres, tradiciones y lenguas en las comunidades porque "permite retroceder en el tiempo, grabar y guardar sucesos en el momento que ocurren y así crear una memoria histórica de nuestros pueblos". Aunque los temas de sus videos podrían ser encajonados por alguna arrogancia académica en una corriente "culturalista" o "espiritual" del video indígena, no es para nada casual que Crisanto Manzano mismo haya optado por buscar el control de la imagen audiovisual. Al igual que muchos de sus compañeros y compañeras videoastas y comunicadores comunitarios, él percibe las luchas por los derechos culturales como un frente importante en contra del olvido y a favor de la memoria social de los pueblos.

Citemos también al videoasta maya tseltal Mariano Estrada Aguilar, quien señala la importancia de la comunicación indígena audiovisual como "estrategia de lucha" para la producción de la memoria tanto adentro de las organizaciones y comunidades como para conectarse entre los pueblos originarios a nivel continental. Al respecto afirma:

Era el trato discriminatorio y la respuesta del gobierno que nos obligó a no sólo seguir luchando por una mejora de nuestra vida material, sino por el reconocimiento más amplio de los pueblos indígenas. [...] Asimilamos esa tecnología que no es un invento de los compañeros indígenas, es un invento de compañeros de fuera, para hacer comunicación indígena, como una comunicación más que nos comunica tanto de adentro hacia fuera y de afuera hacia dentro (cita tomada de Estrada y Köhler, 2013: 83).

José Alfredo Jiménez Pérez, comunicador comunitario maya tsotsil de la organización Sociedad Civil Las Abejas de Acteal, municipio de Chenalhó, profundiza sobre el tema del "adentro" y el "afuera": 
También quiero destacar que nuestros videos tienen un doble propósito. El primero es la comunicación interna para nuestro pueblo y organización. El segundo es la comunicación externa para gente de la sociedad civil nacional e internacional, para que se pueda informar de lo que sucede en las comunidades y pueblos originarios, ya que en los medios masivos no figuramos como sujetos activos, ni de la política, ni de la historia de nuestro país. Pues a través de los videos se transmiten nuestras palabras, pensamientos, inconformidades, demandas y acciones, no solamente las de la organización a la que pertenezco, sino de los movimientos sociales de los que formamos parte (cita tomada de Jiménez y Köhler, 2012: 334).

Al respecto, pero en otras latitudes, el cineasta, fotógrafo y músico Eriberto Gualinga, miembro del pueblo originario kichwa de Sarayaku en la Amazonía ecuatoriana, afirmó:

Antes el que hablaba era sólo el Estado y nosotros por más que hablábamos casi no nos creían porque ellos manejaban los medios, manejaban la televisión, la radio, la prensa. Hasta que nosotros empezamos a utilizar las mismas herramientas, las mismas armas para defendernos, entonces la situación cambió. Ya teníamos imágenes en movimiento, fotografía, video para mostrar lo que somos nosotros (cita tomada de Fajardo, 2016: 77, cursivas añadidas).

Para comprender en sus justas dimensiones estas palabras, es necesario conocer a fondo la forma en que ese pueblo en resistencia hizo frente a la petrolera argentina llamada Compañía General de Combustibles durante el periodo de 1996 a 2012 desde una doble estrategia: la legal y la mediática. En la primera demandaron al Estado ecuatoriano frente a la Corte Interamericana de Derechos Humanos y, en la segunda, se apropiaron de las tecnologías de información y comunicación y por medio de su página web, su vocería y los audiovisuales producidos por ellos mismos implementaron no sólo una campaña mediática sino "la construcción de toda una política de representación dinámica y posicionada como parte de su repertorio de lucha por la defensa y autodeterminación territorial y cultural" (Fajardo, 2016: viii). ${ }^{11}$

\footnotetext{
"Para conocer más de los pioneros en el movimiento del uso del video para la defensa de los derechos - humanos, indígenas, de las mujeres, de los jóvenes - y del territorio, ver el trabajo audiovisual de los y las miembros de la Coordinadora Latinoamericana de Cine y Comunicación de los Pueblos Indígena (CLACPI), accesible en http://www.clacpi.org/, así como de la organización de la sociedad civil global llamada WITNESS (https://witness.org/). Se puede también consultar el artículo titulado "El video como defensa del territorio contra desalojos forzosos", publicado el 10 de junio de 2015 en http://www.periodismociudadano.com/2015/06/05/video_desalojos_latam/.
} 


\section{La otra política zen paralelo o a contrapelo del "tímido proceso de democratización electoral"?}

Queremos ahora sustentar un poco mejor nuestro planteamiento del video indígena como arma de lucha en medio de resistencias, movilizaciones y guerras y verlo a contraluz de la evolución de la democracia representativa en Chiapas. Pero antes de abordar ese punto también debemos mencionar la controversia que nuestra afirmación generó en un foro público celebrado en San Cristóbal de Las Casas, Chiapas. En él algunos activistas de medios libres nos cuestionaron porque dijeron que con esta perspectiva estábamos promoviendo la guerra y no valorando la dimensión de "medio" y "herramienta" que tiene el video indígena. Agradecimos la crítica fraterna y reconocimos que se corría ese riesgo, pero a la vez señalamos que muchas veces por usar conceptos políticamente correctos estamos ocultando dimensiones de la realidad que están ahí, queramos verlas o no, queramos nombrarlas o no. O dicho de otra manera: la forma en que nombramos es clave para orientar la forma en que actuamos, pensamos, luchamos, vivimos.

En ese sentido no es casual que mayas de Chiapas, organizados y en pie de lucha, incursionaran en 1992 en la video(auto)representación como parte de sus luchas políticas como "organizaciones independientes". Independientes de los partidos políticos, de las organizaciones no gubernamentales y del gobierno. Ello sucedió cuando el movimiento indígena, negro y popular tomaba fuerza a nivel continental y, en Chiapas, el movimiento campesino entraba en una nueva fase después de haber sido fuertemente reprimido por un militar, miembro de la oligarquía chiapaneca, quien fuera entonces gobernador del estado. Como nos cuenta el videoasta y músico maya tseltal Mariano Estrada Aguilar (2010), fue en ese contexto cuando él y otro joven también miembro de la organización campesina llamada Comité de Defensa de la Libertad Indígena (CDLI)-Xi'nich arrancaron el primer proceso de capacitación videográfica por mandato organizacional en el marco de las fuertes movilizaciones y luchas por la tierra y por los derechos humanos e indígenas que en esos años tomaron las calles de la ciudad de Palenque y marcharon hasta la capital del país.

Todo ello se daba, más que de manera paralela, a contrapelo de lo que algunos analistas entonces identificaron como "el tímido proceso de democratización electoral", que en Chiapas se venía gestando desde 1991 cuando los resultados electorales revelaron la existencia de núcleos de oposición significativos que empezaron a cuestionar el monopolio del partido hegemónico. Sólo baste recordar que en las elecciones federales de 1988, Chiapas le había dado al candidato priista Carlos Salinas de Gortari el porcentaje de votación más alto de toda la república $(89.8 \%$ ) y que por mucho tiempo a Chiapas se le consideró el "granero electoral" del PRI (Sonnleitner, 2000: 112-113). O bien que desde 1824 - cuando Chiapas se independiza de Guatemala - el centralismo federalista construye las prioridades de este estado, sus élites y sus economías regionales. En un 
presente más cercano, entre 1970 y 1990, se puede ver que los partidos políticos son secundarios en la historia de Chiapas y la democracia electoral frágil e incipiente (García, 2003).

Sin embargo, el alzamiento zapatista desde una de sus aristas ha sido visto "como el punto culminante de una crisis política que es de sistema pero que se expresa en Chiapas de manera particular y detona muchas otras facetas de la crisis nacional" (García, 2003). Será éste el factor más importante que contribuya en Chiapas a dar un giro radical en lo político, en lo civil, legislativo, partidista, electoral y de vida cotidiana. Así, por ejemplo, en las elecciones de 1994 si bien Chiapas se abrió al "multipartidismo" y a la "alternancia electoral", lo que entonces se vio con optimismo y como parte de la entonces llamada "transición democrática mexicana", hoy nos muestra su peor cara: su descomposición, mercantilización y grado de corrupción, baste para ello ver los textos de nuestros colegas chiapanecos y mexicanos en este libro. Pero lo que a continuación brevemente vamos a abordar tuvo que ver más con la construcción a contrapelo de lo que el EZLN y las redes neozapatistas llamaron "la otra política" en su dimensión comunicativa, donde la ética orienta la práctica y donde el pueblo manda y el gobierno obedece (ver en este libro el capítulo de Alonso y Alonso).

\section{Guerra de baja intensidad, la otra política, el video y la autonomía zapatista}

A partir de 1994, luego de levantarse en armas y declararle la guerra al gobierno mexicano, las y los zapatistas han puesto en juego diversas estrategias políticas y civiles para bien administrar y bien gobernar su territorio y su población. Ante el incumplimiento de los Acuerdos de Paz, la autonomía zapatista de facto ha logrado poner al servicio de su causa la radio, el video, internet, el género musical de los corridos, el arte plástico de los murales y las artesanías, para comunicar literalmente a todo el mundo quiénes son, qué hacen y cómo luchan.

En febrero de 1998 se realizó, en territorio autónomo, el primer taller de capacitación en video para las y los jóvenes zapatistas. El interés por las cámaras nació del encuentro de dos mundos diversos - el zapatista y el solidario — ${ }^{12}$ y en uno de los momentos más álgidos de la guerra contrainsurgente. De hecho, el primer taller se sucedió a dos meses de que paramilitares de Chenalhó masacraran en Acteal a diecinueve mujeres, catorce niñas, cuatro niños, ocho hombres y cuatro no nacidos, al tiempo que el gobierno priista ejecutaba, con lujo de violencia, el desmantelamiento de varios municipios autónomos zapatistas, expulsaba a más de cien extranjeros y perseguía lo mismo a defensores de derechos humanos que a miembros de la diócesis de San Cristóbal de Las Casas y de las

\footnotetext{
${ }^{12}$ La documentalista Alexandra Halkin (2006) narra y reflexiona sobre cómo se dio este proceso del que ella misma fue promotora, fundadora y coordinadora.
} 
organizaciones no gubernamentales simpatizantes con las demandas políticas del zapatismo (Global Exchange, CIEPAC y CENCOS, 2000: 129).

En cuanto a la auto(video)representación zapatista, podemos señalar que es parte medular de sus prácticas autonómicas y de su resistencia. De hecho, así lo podemos ver si miramos las veintinueve producciones realizadas por jóvenes zapatistas entre 1998 y 2007: ocho muestran al mundo sus estrategias de lucha cívico-política - consultas, marchas, caravanas, recorridos, silencios, aniversarios-; cinco fueron realizadas por mujeres que hablan de sus trabajos colectivos como forma de resistencia y de subsistencia; cuatro muestran la forma en que opera la salud y la educación autónoma; otros cuatro registran su producción orgánica y su lucha por el agua, mientras que dos demuestran su lucha por la tierra y el territorio; otros dos hablan del arte zapatista y dos más denuncian ataques, desalojo, hostigamientos y la "guerra integral de desgaste". También hay un video dedicado al tema de la familia indígena y otro que enfoca la espiritualidad zapatista en Los Altos de Chiapas.

En particular detengámonos en el video intitulado "La resistencia", realizado por jóvenes zapatistas bases de apoyo y producido por ProMedios ${ }^{13}$ en el año 2001. Cuatro años después de la masacre de Acteal y uno después de lo que se ha dado en llamar "la alternancia”, es decir, en el año 2000, por vez primera, luego de más de siete décadas en el poder, el PRI perdió las elecciones presidenciales frente al PAN. En su campaña electoral el candidato panista Vicente Fox Quesada había prometido resolver "el conflicto de Chiapas" en quince minutos, y si bien, una vez en el poder, hizo reacomodos de tropas, retenes y destacamentos, la promesa no fue cumplida. Ello lo podemos ver en las imágenes del video "La resistencia", donde, en 2001, se evidencia la continua presencia y actividad militar en la llamada "zona de conflicto". Mientras el entonces presidente difundía por los medios masivos su política triunfalista, las bases de apoyo zapatista movían en sus redes - locales, nacionales e internacionales - su voz y sus imágenes. Sus videos jugaban un papel central en esta guerra política y mediática.

Volvamos al video "La resistencia": éste inicia con imágenes en movimiento del ejército mexicano rodeando a comunidades o moviéndose en sus alrededores en camiones pesados llenos de militares. Pero el foco del video está puesto más bien en las comunidades base de apoyo del EZLN y su resistencia frente a la presencia militar en la zona. Así vemos a la gente de las comunidades movilizarse frente a las incursiones militares, con voces enérgicas y puños elevados. De esra manera logran que los vehículos y los soldados se retiren de sus comunidades. Música indígena tradicional de tambor y pito, así como el himno zapatista, contribuyen a darle vigor a la alegría que transmiten las imágenes de resistencia activa. Intertítulos anuncian y enumeran concisamente las agresiones en la

\footnotetext{
${ }^{13}$ Para mayor información de ProMedios se puede consultar http://www.promediosmexico.org/ o bien https://www.youtube.com/user/PromediosMexico/videos.
} 
Selva Lacandona: "San Rafael. Agresión militar", "Seguridad pública en Nazareth", "Incursión militar en Galeana", "Protesta en La Garrucha por el asesinato de Guadalupe Méndez".

En la penúltima secuencia, bases de apoyo están organizando una marcha al campamento de Jolnachoj en Los Altos de Chiapas para exigir la salida del ejército. Es un día sumamente brumoso. A su llegada, hacen volar aviones de papel y entonan consignas: "Aquí, allá, ila lucha seguirá!" y “iZapata vive... la lucha sigue!" En alerta vemos salir a los soldados de sus cabañas con armas de alto poder para posicionarse en defensa de su campamento, pero algunas mujeres valientes empiezan a gritarles y a empujarlos. Sobre la imagen de un muñeco vestido de militar que la gente arrastra por el camino, una voz en off masculina nos informa que "más tarde los militares de Jolnachoj se retiraron del campamento".

Viene otro intertítulo: “iSeñales de paz?” Y la voz en off relata: "27 de enero de 2001, movimiento militar en La Garrucha”. Vemos una barda de malla ciclónica y unas decenas de militares tomando posición. La voz en off pregunta: "¿Estas son las señales positivas para reiniciar el diálogo? ¿Cuánto tiempo más tenemos que resistir?” Le siguen imágenes de niños y niñas alegres que están entrecortadas con las de militares en movimiento. El mensaje es contundente: la lucha es por la vida y en contra de los proyectos de muerte. El video termina con la imagen de un mural que trae en letras grandes la palabra "RESISTENCIA", específicamente "La RESISTENCIA de las mujeres contra la militarización en las comunidades campesinas en zona zapatista". Debajo de la leyenda ondula una bandera roja y al lado derecho está la representación graffitera de una foto muy conocida de Pedro Valtierra tomada en 1998 en el municipio de Chenalhó e intitulada "Mujeres de X'oyep". La foto muestra a las mujeres empujando a soldados para evitar la incursión militar a su comunidad. En el video destaca una estética realista con cámara a mano, sonido directo de la cámara y ninguna iluminación artificial. Al parecer su objetivo principal es la documentación y la denuncia de la presencia militar en zonas autónomas, pero también animar a la resistencia comunitaria y a las demás en curso en el planeta Tierra.

Al ponerse a la venta entre los solidarios las veintinueve producciones realizadas por jóvenes zapatistas, se contribuye a generar fondos para sostener las prácticas autonómicas defacto, así como el proyecto videográfico y su infraestructura, a la vez que cumple con la importante tarea de contrainformar hacia fuera y promover la solidaridad (inter)nacional con la causa zapatista. La tecnología del video permite también la comunicación entre comunidades para resolver asuntos comunitarios y organizativos que se difunden en circuitos propios de recepción. Como los mismos videoastas mayas afirman, ellos tienen también el objetivo de documentar su propia cultura, su resistencia y su visión de futuro para uso de su propia gente. Para ello están creando un acervo videográfico con grabaciones de fiestas y ceremonias, asambleas comunitarias, rezos de los mayores, saludos a la tierra, peticiones al sol y, sobre todo, relatos y lecciones de los ancianos (Petrich, 2000). Están caminando lo que han llamado "La memoria, contra el olvido". 
Contrainsurgencia, masacre de Acteal, verdadera democracia, justicia y comunicación comunitaria

La organización Sociedad Civil Las Abejas es una agrupación pacifista que lucha por la reivindicación y respeto de los derechos humanos e indígenas. Se fundó en Chenalhó en 1992 como una forma de hacer frente a las injusticias cometidas contra mujeres y hombres comunitarios y para lograr la liberación de sus presos..$^{14}$ Actualmente es la organización que lleva adelante el proceso legal, mediático y político para exigir justicia por el crimen de Estado cometido en Acteal. Al respecto, los hombres y mujeres de Las Abejas nos narran en su sitio web:

Para principios de 1997 el conflicto político en la zona comienza a complejizarse y los grupos paramilitares actúan de manera constante tomando represalias en contra de quienes no aceptan sumarse a su causa. Posteriormente, pugnas entre zapatistas y prístas por el derecho de explotación de un banco de arena en el paraje de Majomut vendrá a ser una excusa usada por los paramilitares para incrementar las acciones de violencia.

La olade temor que se desencadenó como consecuenciadel continuo hostigamiento de los habitantes de las comunidades por parte de los grupos paramilitares, llevó al desplazamiento de alrededor de 9,000 personas en el área que tuvieron que ser reacomodadas en comunidades simpatizantes con sus respectivos filiaciones políticas que sirvieron como campamentos de desplazados. Asimismo, el reacomodo poblacional masivo significó numerosas amenazas y la presencia de varios cuarteles militares a la entrada de las comunidades, muchos de los cuales permanecen hasta la fecha.

La escalada del conflicto llevó a que el 22 de diciembre de 1997, un grupo de tsotsiles equipados con armas de grueso calibre dispararan en contra de 45 personas Abejas (18 mujeres adultas, cinco de ellas con embarazos hasta de 7 meses de gestación; 7 hombres adultos; 16 mujeres menores de edad, entre los 8 meses y los 17 años de edad; 4 niños entre los 2 y los 15 años de edad) e hirieron a 26, en su mayoría menores de edad, varios de ellos resultaron con lesiones permanentes.

Las personas atacadas se encontraban refugiadas en la comunidad de Acteal debido al continuo hostigamiento de grupos armados que quemaban sus casas y cultivos, y robaban sus pertenencias. Estaban completamente desarmados, realizando una jornada de ayuno y oración en la capilla de la comunidad de Acteal para pedir por la paz en la región. El ataque fue perpetrado por alrededor de 90 personas, según refieren testigos oculares y el hecho de que un puesto de operaciones

\footnotetext{
${ }^{14}$ Ver más sobre su historia en su sitio web http://acteal.blogspot.mx/.
} 
mixtas (fuerza militar, judicial y de seguridad pública) se encontrara asentado a 200 metros ha servidoparajustificar las opiniones que apuntan haciauna responsabilidad directa del Estado mexicano (tomado de http://acteal.blogspot.mx/p/la-masacrede-acteal.html).

Por su parte, el comunicador comunitario maya tsotsil José Alfredo Jiménez narra cómo él, siendo parte de Las Abejas, inició sus trabajos de comunicación inmediatamente después de la masacre de Acteal. Con el fin de denunciar el crimen de Estado cometido, Las Abejas adquirieron un transmisor de radioy, más tarde, siguieron con la capacitación en periodismo. Ya en 2001, entraron de lleno a la capacitación en videoproducción con el apoyo de redes y personas solidarias con su lucha (Jiménez y Köhler, 2012). Pero retomemos la voz colectiva de Las Abejas para entender, desde su perspectiva, la relación entre justicia, "verdadera democracia" y medios comunitarios:

Vemos que la guerra de contrainsurgencia del mal gobierno hacia nuestra lucha son de varias caras y mucha gente cae en esa trampa, porque cuando se trata de dinero la gente cae en eso, porque sí hay mucha necesidad y pobreza en las comunidades. Pero sabemos que esos proyectos no traen paz y justicia a nuestras comunidades y sobre todo no es lo que buscamos, sino, que nuestra demanda como las de otros pueblos y del mismo EZLN va más allá de unas migajas desechables. Esto resumido, es lo que hace falta analizarlo y reflexionar con programas de radio, para que la gente ya no se deje manipular, sino, que realmente sepamos lo que necesitamos hacer para una verdadera transformación social. Pero sin una información verdadera y en tsotsil, seguiríamos sumergidos en la desinformación y de las mentiras de los medios masivos de comunicación aliados con el estado.

Pensamiento y Corazón... para una comunicación comunitaria. La comunicación que queremos desde el Área de Comunicación de la Sociedad Civil Las Abejas de Acteal: [Queremos] que la comunicación sea de alguna manera un instrumento o herramienta para informar a la gente. Dar a conocer la sabiduría, los problemas, la lucha de Las Abejas. Que la comunicación, sea como el azadón, el machete, el bastón para sembrar la milpa, el frijol. Cuando tenemos comida, el corazón de una familia está contento. Que la comunicación sirva para una educación popular.

No queremos una comunicación como la que encontramos normalmente en los medios masivos que existen en nuestro país, sino que queremos construir una alternativa a esos medios que nos acallan con mentiras y manipulan la realidad; para los que sólo somos objetos folclóricos por quienes hay que sentir lástima. Queremos ir a buscar la verdad que muchas veces está escondida y tener medios que nos permitan comunicarla a los pueblos de otros estados y países. Medios para que podamos retratar la grandeza de nuestra lucha, que nos permitan convencer a 
nuestros hermanos y nuestras hermanas de distintos lugares que es posible y necesaria la construcción de otro mundo con paz, justicia y dignidad.

Queremos una comunicación que nos dé pie a construir una política verdadera, con participación de la gente. Queremos ofrecer información para que nuestro pueblo conozca los problemas que tiene, comprenda de donde vienen y tenga herramientas para participar activamente en su resolución. De esta forma se logra la construcción de una verdadera democracia, una planteada desde el pueblo organizado que lucha por construirse un buen vivir.

La comunicación que estamos construyendo en Las Abejas es integral ipor qué? En el sentido de que tenemos que ser nosotros y nosotras los que tenemos que fomentar este trabajo y que la visión y contenido de la comunicación tanto en video y en radio sean emanados desde la cosmovisión tsotsil, de los hombres y mujeres verdaderas (tomado de http://acteal.blogspot.mx/p/area-de-comunicacion-de-lasabejas.html, cursivas añadidas).

\section{Lo electoral a contrapelo}

Para cerrar este apartado regresemos al carril de lo electoral para mostrar la otra cara de la moneda de la política chiapaneca. Una vez celebradas las elecciones en 1994, la derrota de la oposición bajó los ánimos nacionales; sin embargo, en Chiapas, el impacto del EZLN y de la participación masiva y la movilización encabezada por las organizaciones campesinas-indígenas "independientes" contribuyó sustancialmente al derrumbe de la hegemonía tradicional del PRI. Por ejemplo, entre 1991 y 1994, el PRI pasó de obtener el $76 \%$ de los votos a sólo alcanzar el 49\%, es decir, perdió aproximadamente 143000 de sus 640000 electores de 1991. Esta tendencia se confirmó y acentuó en las elecciones estatales de 1995 y en las federales de 1997, en las que a pesar del aumento cuantitativo en la lista nominal, el PRI solamente recibió 315950 votos, es decir, menos de la mitad de los obtenidos en 1991. Mientras, entre 1995 y 1998, la oposición ganó 25 y 39 presidencias municipales, respectivamente, de un total de 111 (Sonnleitner, 2000: 145, 178, 207).

Entre 1994 y 1998, en Chiapas se celebraron cuatro procesos electorales a la par que los diferentes niveles de gobierno impulsaban, fomentaban una guerra de baja intensidad y políticas contrainsurgentes que lo mismo atentaban contra el EZLN que contra todo seguidor de sus demandas políticas. En ese mismo periodo, el número de indígenas en la Cámara de Diputados y el interés de los partidos por "la cuestión indígena" aumentó considerablemente. Por ejemplo, el PRI elaboró un documento ad hoc y el PRD modificó sus estatutos para obligar a tener una cuota de diputados indígenas. Por su parte, las organizaciones campesinas e indígenas otrora "independientes" de Chiapas se lanzaron a la negociación con el gobierno del estado a la par de la conquista del poder local municipal 
(véase el caso de Ocosingo) o continuaron con sus luchas municipalistas (véase el caso de Simojovel) alentadas por la impronta zapatista de "justicia, democracia y libertad". La incipiente pero inacabada democratización electoral que se dio entre 1991 y 1998 sin duda dio impulso a dos de las tres dimensiones constitutivas de la ciudadanía: la cívica y la política (Marshall y Bottomore, 1992), pero no logró implementar mecanismos de redistribución socioeconómica ni de procuración imparcial de justicia, elementos esenciales en un auténtico Estado de derecho (Sonnleitner, 2000: 208).

\section{A manera de conclusión}

Hay un término que ha encontrado bastante eco tanto entre investigadores académicos como entre activistas de la comunicación. Nos referimos al concepto "medios ciudadanos" y su relación con la reconstrucción democrática. De hecho, una de nosotras ha colaborado en una "radio ciudadana" como una alternativa real y concreta de contribuir a hacer crecer los derechos a la libre expresión en un contexto de guerra integral de desgaste. Nos referimos a la experiencia personal-colectiva que tuvimos en la estación de radio Frecuencia Libre FM 99.1 en San Cristóbal de Las Casas, Chiapas. Dicha radio fue fundada en 2002 por feministas, activistas y profesionistas miembros de organizaciones no gubernamentales a pesar de que en la legislación mexicana esta posibilidad no se contemplaba. Se trata de una "radio ciudadana e independiente que basa su trabajo en la participación voluntaria y comprometida de cada persona que la integra, su objetivo es contribuir a la "construcción de una sociedad justa, igualitaria y democrática a través del ejercicio del derecho a la libre expresión y el cuestionamiento a las formas de ejercicio de poder, que generan y mantienen este sistema de desigualdades sociales" (www.facebook. com/Frecuencia.Libre.99.1/info?ref=page_internal, cursivas añadida).

En Colombia, la comunicóloga Clemencia Rodríguez (2001, 2011), con base en su trabajo con medios no institucionales en situaciones de conflicto armado, acuñó dentro de la academia el concepto de "medios ciudadanos" frente a los conceptos de "medios comunitarios" y "medios alternativos". Rodríguez apunta que los primeros se definen a partir de quiénes los producen —organizaciones comunitarias, colectivos de base- o de acuerdo con el tipo de licencia de difusión que el Estado les otorga. ${ }^{15}$ Respecto a los segundos, ella afirma que se les define frecuentemente en tanto lo que no son, por ejemplo,

\footnotetext{
${ }^{15}$ En Colombia, a diferencia de Chiapas y México, los "medios comunitarios" son legalmente reconocidos y el Estado emite licencias de difusión para "organizaciones comunitarias". Aunque no todas esas organizaciones promueven luego una verdadera participación comunitaria, Rodríguez (2011: 24-26) prefiere llamar "medios ciudadanos" exclusivamente a los medios comunitarios que cultivan deliberadamente procesos de transformación y empoderamiento en sus productores y audiencias.
} 
frente a los medios dominantes o una comunicación vertical, en vez de hacerlo, a su juicio, por lo que son. Agrega que "lo alternativo" siempre implica una relación reactiva frente a lo dominante y, por tanto, la aceptación de un estatus inferior (Rodríguez, 2009: 17-18).

Rodríguez comenta que con el término "medios ciudadanos" "buscaba redirigir el análisis alejándolo de cualquier comparación con los medios masivos y los medios comerciales, para concentrarse más bien en los procesos culturales y sociales que se desencadenan cuando las comunidades locales se apropian de las tecnologías de información y comunicación" (Rodríguez, 2009: 18). Para ello retoma la apuesta de Chantal Mouffe sobre la democracia radical y los ciudadanos, definidos éstos como "aquellas personas que asumen su ciudadanía mediante la participación en prácticas políticas cotidianas" (Rodríguez, 2009: 18). Este autor utiliza el término "medios ciudadanos" para nombrar los medios alternativos, comunitarios o radicales que facilitan, desencadenan y mantienen procesos de construcción de ciudadanía; procesos de cambio provocados por sus participantes.

En situaciones de conflicto armado, los "medios ciudadanos" — afirma Rodríguez (2011: 3, 22) - facilitan espacios y procesos de comunicación en los que la población civil puede reconstruir lazos tradicionales de solidaridad y crear nuevos lazos y así reparar el tejido social desgarrado, reapropiarse de espacios públicos que han sido abandonados a causa del terror, fortalecer estrategias de resolución no violenta de conflictos y organizar acciones colectivas. En pocas palabras, los medios ciudadanos "pueden convertirse en herramientas poderosas para el empoderamiento de comunidades civiles y para fortalecer procesos de buen gobierno, la transparencia y la rendición de cuentas" (Rodríguez, 2011: 4). ${ }^{16}$

Autocríticamente, Clemencia Rodríguez (2009: 17) señala lo problemático del concepto que acuña, afirma que a pesar de que su definición se distancia del concepto estatal de "ciudadanía", "tiene connotaciones ineludibles de inclusión y exclusión en funcióndelestatuslegaldelosderechosdelciudadano:unestatusnegadosistemáticamente a millones de personas por causa de su nacionalidad, su cualificación laboral, su posibilidad de acceso a los servicios de salud o su orientación sexual" (Rodríguez, 2009: 20). Como ya se ha apuntado, el concepto de ciudadanía "sólo tiene sentido si hay quienes están excluidos" (Zibechi, 2008: 23-24), por lo que muchos movimientos y organizaciones sociales y políticas están buscando superarlo y de plano no lo usan. Lo mismo podemos decir de conceptos tales como "democracia" y "democratización", que los Estados europeos y norteamericanos han abanderado como conceptos globales del "buen gobierno" pero que, como sabemos, son en gran medida parte integral de la expansión del sistema capitalista neoliberal patriarcal. Sin embargo, tanto la vigencia como la aplicabilidad planetaria de estos conceptos se encuentran ahora cuestionadas, y no sólo por los movimientos sociales o antisistémicos.

\footnotetext{
${ }^{16}$ Traducción de Axel Köhler.
} 
No se trata aquí de acuñar conceptos como parte de un juego contemplativo que sólo a la academia le resulta interesante; por el contrario, vemos en la coyuntura actual que tanto en la academia como en varios movimientos se está - por distintas razonesrenombrando lo que se quiere enfatizar. Así, si regresamos a la conferencia de prensa dada en el marco de la Compartición del CNI y el EZLN, el subcomandante insurgente Galeano (2014) nombró como "medio compa" a aquellos medios gestionados por colectivos de activistas — compañeros y compañeras - en los que el individuo está completamente diluido. Ahí no cuenta la autoría individual como en aquellos que nombró como "medios de paga", sino el contenido de la información que proviene directamente de los actores. El subcomandante Galeano planteó que en el "medio compa" "el medio principal de comunicación es la escucha" y que los "compañeros y compañeras de los pueblos originarios son especialistas en el arte de la escucha, en la comunicación por excelencia" (Subcomandante Insurgente Galeano, 2014). Los únicos medios - agregó- capaces de cumplir con ese cometido de "la escucha" son los medios libres, autónomos y alternativos y, por ello, planteó que a largo plazo podrían llenar el vacío que se está produciendo ahora con la decadencia de los "medios de paga".

Para cerrar este capítulo, señalaremos que el videoactivismo maya chiapaneco y sus realizadores en pie de lucha son parte de lo que podríamos llamar "medios en movimiento", porque escuchan, documentan, proponen y acompañan desde adentro las insurgencias, resistencias, rebeliones y autonomías de sus pueblos. Acompañan movimientos más amplios que requieren de comunicaciones propias y abonan a la construcción de medios no comerciales, no institucionalizados, no pagados. En ese marco, los "medios indígenas en movimiento" se vuelven parte central de la construcción y creación de la otra política, a la vez que son también armas de lucha que cumplen tareas importantes de visibilizar, fortalecer la resistencia y la memoria colectiva, contrainformar ante los medios hegemónicos que están al servicio del poder o de los poderes fácticos.

\section{Referencias bibliográficas}

ACUDDEH (Acción Urgente para Defensores de Derechos Humanos, A.C.), Campaña Nacional contra la Desaparición Forzada y Comité Cerezo México (2014). La defensa de los derechos humanos en México: una lucha contra la impunidad. Junio de 2013 a mayo de 2014. México: ACUDDEH y Rosa Luxemburg Stiftung. Disponible en: http://comitecerezo. org/IMG/pdf/informeweb.pdf (consultado el 25 de agosto 2014).

Amnistía Internacional (2012). Culpables conocidos, Víctimas ignoradas. Tortura y maltrato en México. Londres y Madrid: Amnesty International Publications y Editorial Amnistía Internacional. Disponible en: http:/amnistia.org.mx/nuevo/wp-content/uploads/2014/07/ Mexico_Tortura_y_Maltrato_ll_10_2012.pdf(consultado el 20 agosto de 2014). 
Amnistía Internacional (2014a). Losretos de Méxicoenmateriadederechoshumanos. Memorándum de Amnistía Internacional para el presidente Enrique Peña Nieto. Reino Unido: Amnistía Internacional, Secretariado Internacional. Disponible en: http://amnistia.org.mx/ nuevo/wp-content/uploads/2014/07/Mexico_los_retos_en_materia_de_derechos_ humanos_18_02_2014.pdf(consultado el 20 agosto de 2014).

Amnistía Internacional (2014b). Fuera de control. Tortura y otros malos tratos en México. Reino Unido: Amnistía Internacional, Secretariado Internacional. Disponible en: http:// amnistia.org.mx/nuevo/wp-content/uploads/2014/09/INFORME_TORTURA_AIM. pdf (consultado el 9 septiembre de 2014).

Cawley, M. (2014). Mexico Victims' Survey Highlights Under-reporting of Crime, In Sight Crime. Disponible en: http:/www.insightcrime.org/news-briefs/6062-mexico-victimizationsurvey-highlights-reporting-gap (consultado el 20 agosto de 2014).

Centro de Derechos Humanos Fray Bartolomé de Las Casas, A.C. (2011). De la crueldad al cinismo. Informe sobre tortura en Chiapas. México: Editorial Fray Bartolomé de Las Casas, A.C. Disponible en: http://www.frayba.org.mx/archivo/informes/120608_info_final. pdf (consultado el 20 agosto de 2014).

Centro de Derechos Humanos Fray Bartolomé de Las Casas, A.C. (2013). Entre la política sistémica y las alternativas de vida. Informe sobre la situación de los derechos humanos en Chiapas durante los gobiernos federal y estatal 2006-2012. México: Editorial Fray Bartolomé de Las Casas, A.C. Disponible en: http://www.frayba.org.mx/archivo/informes/130212 informe_frayba_prov.pdf (consultado el 20 agosto de 2014).

Centro de Derechos Humanos Fray Bartolomé de Las Casas, A.C. (2014). "La contrainsurgencia sigue operando en Chiapas". Pronunciamiento del 18 de agosto de 2014. México. Disponible en: http://www.frayba.org.mx/archivo/boletines/140818_ pronunciamiento_contrainsurgencia.pdf (consultado el 20 agosto de 2014).

Comisión Interamericana de Derechos Humanos (2013). Derechos humanos de los migrantesy otras personas en el contexto de la movilidad humana en México. Preparado por la Relatoría sobre los Derechos de los Migrantes de la Comisión Interamericana de Derechos Humanos, Organización de los Estados Americanos. OEA/Ser.L/V/II. Doc. 48/13. Disponible en: http://www.oas.org/es/cidh/migrantes/docs/pdf/Informe-MigrantesMexico-2013.pdf (consultado el 20 agosto de 2014).

Congreso Nacional Indígena y Ejercito Zapatista de Liberación Nacional (2014a). No olvidamos a nuestr@s muert@s, pres@s, desparecid@s. Primera Declaración de la Compartición sobre Represión en contra de nuestros pueblos. Disponible en: http://espoirchiapas.blogspot. $\mathrm{mx} / 2014 / 08 / \mathrm{cni}$-ezln-no-olvidamos-nuestrs-muerts.html (consultado el 22 agosto de 2014).

Congreso Nacional Indígena y Ejercito Zapatista de Liberación Nacional (2014b). Si no nos han matado en 520 anos de resistencia y rebeldía no lo harán ahora ni nunca. Segunda Declaración de la Compartición sobre el despojo a nuestros pueblos. Disponible en: http://espoirchiapas. 
blogspot.mx/2014/08/2a-declaracion-del-cni-ezln-sobre-el.html (consultado el 22 agosto de 2014).

Equipo del Observatorio de las democracias: Sur de México y Centroamérica (2015). "Crisis del Estado y degradación democrática en México. Preámbulo del proceso electoral 2015". San Cristóbal de Las Casas, Chiapas: Observatorio de las democracias: Sur de México y Centroamérica, CESMECA-UNICACH [documento inédito].

Estrada Aguilar, M. (2010). “Dignidad Indígena”. En A. Köhler, X. Leyva Solano, X. López Intzín, D.G. Martínez Martínez, R. Watanabe, J. Chawuk et al. Sjalel Kibeltik. Sts'isjel ja Kechtiki'. Tejiendo nuestras raíces. México: RACCACH, CESMECA-UNICACH, CIESAS y UNAM, pp. 273-279.

Estrada Aguilar, M. (2016). "Los instrumentos modernos de comunicación dentro de los pueblos indígenas". Disponible en: http://www.clacpi.org/mariano-estrada-losinstrumentos-modernos-de-comunicacion-dentro-de-los-pueblos-indigenas/.

Estrada Aguilar, M. y A. Köhler (2013). "Desde y para los pueblos originarios: Nuestra video-producción en Chiapas, México”. En Revista Chilena de Antropología Visual, núm. 21, pp. 80-103.

EZLN (2015). El pensamiento crítico frente a la Hidra Capitalista I. Participación de la Comisión Sexta del EZLN. México: EZLN.

Fajardo Camacho, A. (2016). Sarayaku y las TIC: una lucha por la autodeterminación territorial. Quito: Departamento de Antropología, Historia y Humanidades. Tesis de maestría en Antropología Visual y Documental Antropológico, Facultad Latinoamericana de Ciencias Sociales-Sede Ecuador.

García Aguilar, M. del C. (2003). Política y sociedad en Chiapas 1970-2000. Las utopías, los intereses, las realidades. Tesis de doctorado en Ciencias Sociales con Especialidad en Relaciones de Poder y Cultura Política, División de Ciencias Sociales y Humanidades de la UAM-Xochimilco.

Global Exchange, CIEPAC (Centro de Investigaciones Económicas y Políticas de Acción Comunitaria, A.C.) y CENCOS (Centro Nacional de Comunicación Social, A.C.) (2000). Siemprecerca, siempre lejos: las fuerzas armadas en México. México: Global Exchange, CIEPAC y CENCOS.

International Crisis Group (2015). Peña Nieto's Challenge: Criminal Cartels and Rule of Law in Mexico, Latin America Report, núm. 48. Disponible en: http://www.crisisgroup.org// media/Files/latin-america/mexico/048-pena-nietos-challenge-criminal-cartels-andrule-of-law-in-mexico.pdf.

Halkin, A. (2006). "Fuera de la óptica indígena: zapatistas y videístas autónomos". En Revista Chilena de Antropología Visual, núm. 7, pp. 71-92. Disponible en: http://www. antropologiavisual.cl/halkin_esp.htm (consultado el 15 julio de 2014).

Harvey, D. (2004). "El 'nuevo' imperialismo. Acumulación por desposesión”. En Socialist Register 2004,pp. 99-129. Londres: Merlin Press. 
Human Rights Watch (2014). Resumen de país, México enero de 2014. Disponible en: http:// www.hrw.org/es/world-report/2014/country-chapters/121995.

Jiménez Pérez, J.A. y A. Köhler (2012). "Producción videográfica y escrita en co-labor. Un camino donde se encuentran y comparten conocimientos". En I. Kummels (coord.), Espacios mediáticos. Cultura y representación en México. Berlín, Alemania: Edición Tranvía, Verlag Walter Frey, pp. 318-345.

Leyva Solano, X. (2015). "Breve introducción a los tres tomos". En Xochitl Leyva, Jorge Alonso, R. Aída Hernández, Arturo Escobar, Axel Köhler, Aura Cumes, Rafael Sandoval et al. Prácticas otras de conocimiento(s). Entre crisis, entre guerras. México: Cooperativa Editorial RETOS, PDTG, IWGIA, GALFISA, Proyecto Alice, Taller Editorial La Casa del Mago, t. I, pp. 23-34.

Leyva Solano, X. (2012). "Luchas autonómicas y epistémicas en tiempos de crisis y guerras múltiples”. En F. Escárzaga, R. Gutiérrez, J.J. Carrillo, E. Capece y B. Nehe, B. (coords.), Movimiento indígena en América Latina: resistencia y proyecto alternativo, t. III. México, D.F.: UAM-I e Instituto de Puebla, pp. 209-225.

Marshall, T.H. y T. Bottomore (1992). Citizenship and Social Class. Londres: Pluto Press.

Manzano Avella, C. (2000). "Cátedra el documental y el imaginario: del así es al así lo veo". En Diplomado en Antropología Visual, Cine y Medios de Comunicación. San Cristóbal de Las Casas, Chiapas: CIESAS-Sureste y CESMECA-UNICACH, 23 de octubre.

México. Presidencia de la República (2014). Segundo Informe de gobierno 2013-2014. Anexo estadístico. México: Gobierno de los Estados Unidos Mexicanos. Disponible en: http:// www.presidencia.gob.mx/segundoinforme/ (consultado en septiembre de 2014).

México. Procuraduría General de la República (1998). Libro blanco sobre Acteal. México: Gobierno de los Estados Unidos Mexicanos.

Ni seguridad, ni derechos. Ejecuciones, desapariciones y tortura en la "guerra contra el narcotráfico" de México (2011). Estados Unidos: Human Rights Watch. Disponible en: http://www. hrw.org/sites/default/files/reports/mexicollllspwebwcover.pdf (consultado el 15 julio de 2014).

Peña Nieto, E. (2016). "Discurso del presidente Enrique Peña Nieto en la UNGASS 2016”. En Boletín de la ONU, Comunicado núm. 16/083, 19 de abril. Disponible en: http://www. cinu.mx/comunicados/2016/04/el-problema-mundial-de-las-dro/.

Petrich, B. (2000). "Consolidan red de videoastas indígenas. Los documentales, un instrumento de contrainformación usado por las comunidades zapatistas", en La Jornada, 13 de octubre. Disponible en: http://www.jornada.unam.mx/2000/10/13/014nlpol. html (consultado el 12 de junio de 2005).

Rama, Anahí y Lizbeth Díaz (2014). "Violence against Women 'Pandemic' in Mexico". En Reuters. Disponible en: http:/www.reuters.com/article/2014/03/07/us-mexico-violencewomen-idUSBREA2608F20140307. 
Rodríguez, C. (2001). Fissures in the Mediascape. An International Study of Citizens' Media. Cresskill, NJ: Hampton Press.

Rodríguez, C. (2009). "De medios alternativos a medios ciudadanos: trayectoria teórica de un término". En Folios, núm. 21 y 22. Colombia: Facultad de Comunicaciones, Universidad de Antioquia, pp. 13-25.

Rodríguez, C. (2011). Citizens' Media against Armed Conflict. Disrupting Violence in Colombia. Minneapolis y Londres: University of Minnesota Press.

Rubio Díaz Leal, Laura (2014). Desplazamiento interno inducido por la violencia: una experiencia global, una realidad mexicana. México: ITAM.

Sonnleitner, W. (2000). "Promesas y desencantos de una democratización electoral incipiente pero inacabada (1991-1998)". En Juan Pedro Viqueira y Willibald Sonnleitner (coords.). Democracia en tierras indígenas. Las elecciones en Los Altos de Chiapas (1991-1998). México: CIESAS, El Colegio de México, IFE, pp.107-208.

Subcomandante insurgente Galeano (2014). Conferencia de prensa del EZLN con Medios Libres, autónomos, alternativos o como se llamen. En Caracol 1, La Realidad, Municipio Autónomo de San Pedro Michoacán, Chiapas, México, 10 agosto. Disponible en: http://www. cgtchiapas.org/noticias/conferencia-prensa-subcomandante-galeano-medios-libres (consultado el 15 de agosto de 2014).

Zibechi, R. (2008). Autonomíasyemancipaciones. América Latinaen movimiento. Lima: Programa Democracia y Transformación Global y Fondo Editorial de la Facultad de Ciencias Sociales, Universidad Nacional Mayor de San Marcos.

\section{Referencias videográficas}

Antonio, Manuel, José Guadalupe y V. Mariña (eds.) (2001). La resistencia [DVD]. En Compilación 6. Municipio de Francisco Gómez, Caracol II y III, Chiapas, México: Proyecto de Medios de Comunicación en Chiapas.

Compilación 1-19 [DVD] (2007). México: Proyecto de Medios de Comunicación Comunitaria en Chiapas. 


\title{
Desde abajo, por la izquierda y con la Tierra: la diferencia de Abya Yala/Afro/Latino/América
}

\author{
Arturo Escobar
}

\author{
Salgo a caminar \\ por la cintura cósmica del sur \\ piso en la región \\ más vegetal del tiempo y de la luz \\ siento al caminar \\ toda la piel de América en mi piel \\ $y$ anda en mi sangre un río \\ que libera en mi voz su caudal. \\ (Mercedes Sosa, "Canción con todos"). \\ Soy el desarrollo en carne viva \\ (Calle 12, "Latinoamérica")
}

En una nota reciente en América Latina en Movimiento titulada "La crisis del pensamiento crítico latinoamericano", el profesor Emir Sader (2015) lamenta "la relativa ausencia de la intelectualidad crítica" latinoamericana, particularmente en momentos de ataques renovados de la derecha contra los gobiernos progresistas. ${ }^{1}$

Al pensamiento crítico no le faltan ideas [...] tiene que pelear por espacios, pero falta mucho más participación, faltan entidades que convoquen a la intelectualidad crítica a que participe activamente en el enfrentamiento de los problemas teóricos y políticos con que se enfrentan los procesos progresistas en América Latina [...] Hoy

\footnotetext{
${ }^{1}$ Una versión anterior de este texto fue presentada como ponencia magistral en la VII Conferencia de la CLACSO, Medellín, Noviembre 10-14, 2015. Agradezco a Pablo Gentili y Fernanda Saforcada la invitación a este importante evento. Igualmente, agradezco comentarios recibidos a la versión inicial por Manuel Rozental, Eduardo Gudynas, Patricia Botero, Charo Mina Rojas, Betty Ruth Lozano, Carlos Rosero, Laura Gutiérrez, Xochitl Leyva, Gustavo Esteva y Enrique Leff.
} 
es indispensable rescatar la articulación entre pensamiento crítico y lucha de superación del neoliberalismo, entre teoría y práctica, entre intelectualidad y compromiso político concreto (Sader, 2015).

Hay mucho que atender en el llamado del profesor Sader. En particular, todas y todos debemos pensar seriamente en la rearticulación epistémica, económica y política de los procesos de dominación a niveles nacional, continental y global, y siempre debemos estar dispuestos a aceptar el llamado para renovar la pregunta por la praxis, incluyendo la relevancia del intelectual en la vida pública de nuestras sociedades. Sin embargo, en juego están también varias preguntas clave que todo análisis del pensamiento crítico latinoamericano (PCL) está obligado a considerar: iqué constituye el PCL hoy en día?, ipodemos acotarlo dentro del pensamiento del progresismo o de la izquierda?, ¿qué es exactamente lo que está en crisis?, ¿el pensamiento de los gobiernos progresistas?, ¿de las izquierdas?, ¿agotan estas categorías el campo, en mi opinión mucho más vasto y quizás inexhaustible, del pensamiento crítico de las comunidades, los movimientos y los pueblos? Más aún, icuál es el papel del pensamiento crítico en las transformaciones sociales?

Como se sugiere en el subtítulo del presente artículo, ya no estamos meramente frente a un continente unificado en su historia y su cultura, América Latina, sino frente a un pluriverso, un mundo hecho de muchos mundos. Los mundos indígenas y afrodescendientes en particular han cobrado una importancia inusitada en la redefinición de una supuesta identidad y realidad compartidas, de allí el nuevo léxico de Abya Yala/ Afro/Latinoamérica. No es una denominación ideal, dada la diversidad interna de cada uno de los tres ejes identitarios, y esconde otros ejes claves — rural/urbano; clase, género, generación, sexualidad y espiritualidad-, pero es una manera inicial de problematizar, y al menos hacernos tartamudear, cuando con tanta naturalidad invocamos a "América Latina". 2

\section{Dos hipótesis sobre el pensamiento crítico en Abya Yala/Afro/ Latinomérica $^{3}$}

El argumento que quisiera desarrollar en estas páginas es precisamente que el PCL no está en crisis; más aún, pudiera decirse que está más vibrante y dinámico que nunca. Las

\footnotetext{
${ }^{2}$ Me atrevería a pensar que la canción "Latinoamérica" del grupo puertorriqueño Calle 13 despliega esta multiplicidad de mundos, de saberes y de prácticas que es el continente.

${ }^{3}$ El texto que sigue está escrito en la tradición latinoamericana del ensayo. No tiene por lo tanto referencias bibliográficas ni a autores particulares, con contadas excepciones. Una bibliografía extensa sobre estos temas se encuentra en A. Escobar, Sentipensar con la Tierra: nuevas lecturas sobre desarrollo, territorialidad, y diferencia (Medellín: UAL, 2014).
} 
contribuciones teórico-políticas para repensar la región reverberan a lo largo y ancho del continente, en los encuentros de los pueblos, en las mingas de pensamiento, en los debates de movimientos y colectivos, en las asambleas de comunidades en resistencia, en las movilizaciones de jóvenes, mujeres, campesinos y ambientalistas, y sin duda también en algunos de aquellos sectores que tradicionalmente se han considerado los espacios del pensamiento crítico por excelencia, tales como la academia y las artes. ${ }^{4}$

Un listado de las tendencias más notables del PCL tendría que incluir, entre otras, las críticas a la modernidad y la teoría decolonial; los feminismos autónomos, decoloniales, comunitarios y de mujeres indígenas y afrodescendientes; la diversa gama de debates ecológicos y de economías alternativas, incluyendo la ecología política, la economía social y solidaria, las economías comunales y los comunes; las posiciones autonómicas; otras y nuevas espiritualidades; y las diferentes propuestas de transiciones civilizatorias, interculturalidad, el posdesarrollo, el Buen Vivir y el el post-extractivismo. Más importante aún, toda genealogía y catálogo del PCL hoy en día tiene por fuerza mayor que incluir las categorías, saberes y conocimientos de las comunidades mismas y de sus organizaciones como una de las expresiones más potentes del pensamiento crítico. Esta última proposición constituye el mayor desafío para el PCL dado que la estructura epistémica de la modernidad - ya sea liberal, de derecha o de izquierda - se ha erigido sobre el borramiento efectivo de este nivel crucial del pensamiento, y es precisamente este nivel el que emerge hoy en día con mayor claridad y contundencia, como veremos.

Un análisis de la coyuntura regional y planetaria y de cómo ésta se refleja en los debates teórico-políticos del continente nos lleva a postular las siguientes hipótesis: primero, queel PCL no está en crisis, sinoen efervescencia; segundo, quelos conocimientos delos pueblosen movimiento, de las comunidades en resistencia y de muchos movimientos sociales están en la avanzada del pensamiento para las transiciones, y cobran una relevancia inusitada para la reconstitución de mundos ante las graves crisis ecológicas y sociales que enfrentamos, más que los conocimientos de expertos, las instituciones y la academia. Aclaro que esto no quiere decir que estos últimos sean inútiles, sino que ya son claramente insuficientes para generar las preguntas y pautas para enfrentar las crisis.

Para verlo de esta manera, sin embargo, es necesario ampliar el espacio epistémico y social de lo que tradicionalmente se ha considerado el PCL para incluir, junto al pensamiento de la izquierda, al menos dos grandes vertientes que desde las últimas dos décadas han estado emergiendo como grandes fuentes de producción crítica; a saber, aquella vertiente que surge de las luchas y pensamientos "desde abajo", y aquellas que están sintonizadas con las dinámicas de la tierra. A estas vertientes las llamaremos "pensamiento autonómico" y "pensamiento de la tierra", respectivamente.

\footnotetext{
${ }^{4}$ La noción de comunidades en resistencia es desarrollada en el libro de investigación-acción colectiva (IAC), compilado por Patricia Botero (2015). Ver también Botero y Palermo (2013).
} 
Mencionemos por lo pronto que el primero se refiere al pensamiento, cada vez más articulado y discutido, que emerge de los procesos autonómicos que cristalizan con el zapatismo pero que incluyen una gran variedad de experiencias y propuestas a lo largo y ancho del continente, desde el sur de México al suroccidente de Colombia, y desde allí al resto del continente. Todos estos movimientos enfatizan la reconstitución de lo comunal como el pilar de la autonomía. Autonomía, comunalidad y territorialidad son los tres conceptos claves de esta corriente.

Con pensamiento de la Tierra, por otro lado, nos referimos no tanto al movimiento ambientalista y a la ecología, sino a aquella dimensión que toda comunidad que habita un territorio sabe que es vital para su existencia: su conexión indisoluble con la Tierra y con todos los seres vivos. Más que en conocimientos teóricos, esta dimensión se encuentra elocuentemente expresada en el arte - tejidos-, los mitos, las prácticas económicas y culturales del lugar, y las luchas territoriales y por la defensa de la Pacha Mama. Esto no la hace menos importante, sino quizás más, para la crucial tarea de todo pensamiento crítico en la coyuntura actual, a la cual nos referiremos como "la reconstitución de mundos".

No podré situar el argumento dentro de la larga e ilustre historia del PCL. Digamos solamente que desde algunas perspectivas - como el pensamiento decolonial- la genealogía de un "pensamiento otro" se extiende hasta la Colonia misma, encontrándose en la obra de ciertos intelectuales indígenas y cimarrones libertarios. Digamos igualmente que a través del siglo XIX los debates críticos del continente vieron capítulos que aún conservan cierta relevancia, desde aquellos que planteaban la disyuntiva entre civilización y barbarie, hasta los debate tempranos sobre la modernidad latinoamericana ya en las postrimerías del siglo, originando tensiones entre visiones conservadoras pero antiliberales (Arielismo) y "nuestramericanas" anti-imperialistas (Martí) que también conservan relevancia. Ya en los albores del siglo XX entran a jugar un papel importante el marxismo y el anarquismo, y para mediados de siglo se da el famoso debate entre los filósofos Leopoldo Zea y Augusto Salazar Bondi sobre si existe o no una filosofía de nuestra América.

Es de anotar que todos estos debates, sin embargo, toman lugar dentro de los cánones eurocéntricos, sin preguntarse a profundidad por su relevancia para las comunidades y "las masas" del continente. ${ }^{5}$ Habría que esperar hasta la denuncia radical del maestro Orlando Fals Borda, en su libro Ciencia propia y colonialismo intelectual (1970), y el influyente libro de Paulo Freire, Pedagogía del oprimido (1970, publicado en portugués en 1968) para que se estremeciera el edificio epistémico de las academias tanto críticas como de izquierda y se empezara a tomar en serio lo que hoy llamaríamos "los conocimientos otros" de los mundos subalternos.

\footnotetext{
${ }^{5}$ Una útil reseña y argumento crítico sobre de los avatares de PCL se encuentra en el libro del filósofo colombiano Santiago Castro Gómez (1996).
} 
Esta es sin duda una exposición completamente insuficiente y quizás acomodada de la rica tradición del PCL, pero la incluyo en aras de las dos hipótesis expuestas. Los movimientos de educación y comunicación popular inspirados por Fals — con su investigación acción participativa, IAP- y Freire motivaron una infinidad de movilizaciones transformadoras en los setenta y ochenta, con frecuencia de la mano de las luchas revolucionarias alimentadas por el marxismo y la diversidad de izquierdas, pero siempre enfatizando la necesidad de tomar en serio los conocimientos de los pueblos. Hoy en día, en las vertientes autonómicas y del pensamiento de la Tierra encontramos ecos de este valioso legado, aunque con una radicalización epistémica mayor que la de las propuestas de aquellas décadas.

Quisiera, para los efectos de este escrito, definir el PCL como el entramado de tres grandes vertientes: el pensamiento de la izquierda, el pensamiento autonómico y el pensamiento de la Tierra. Estas no son esferas separadas y preconstituidas sino que se traslapan, a veces alimentándose mutuamente, otras en abierto conflicto. Mi argumento es que hoy en día tenemos que cultivar las tres vertientes, manteniéndolas en tensión y en diálogo continuo, abandonando toda pretensión universalizante y de poseer la verdad. Dicho de otra manera, a la formula zapatista de luchar "desde abajo y por la izquierda", hay que agregar una tercera base fundamental, "con la Tierra" - hasta cierto punto implícita en el zapatismo - En la siguiente sección comenzaré por hacer unas anotaciones breves sobre la importancia crucial del "pensamiento de la izquierda", para luego ofrecer un bosquejo, necesariamente provisional, de las otras dos vertientes. ${ }^{6}$

\section{El pensamiento de la izquierda y la izquierda del pensamiento}

Quétantas cosas es laizquierda: teoría, estrategia, práctica, historia de luchas, humanismo, imágenes, emociones, canción, arte, tristezas, victorias y derrotas, revoluciones, momentos bellos y de horror, y muchas otras cosas. Cómo no seguir inspirándonos en los momentos más hermosos de las luchas revolucionarias socialistas y comunistas a través de su potente historia; al menos para mi generación, cómo no seguir conmoviéndose por la carismática figura del Che, o de un Camilo Torres esperando la muerte con un fusil en la mano que nunca disparó, iconos estos que continúan engalanando las paredes de las universidades públicas de Colombia y el continente y que aún nos hacen sonreír al verlas. Cómo no

\footnotetext{
${ }^{6}$ No abordaré en este texto la cuestión de si estas tres vertientes constituirían una "nueva izquierda", o si las vertientes autonómicas y de la Tierra deben ser vistas como diferentes a esta. De acuerdo con esta última opción, el espectro político "derecha-izquierda" se estaría estallando, dando paso a una gran variedad de opciones, no como "terceras vías" sino como manifestaciones auténticas de nuevas formas de ver la práctica política. Tampoco me detendré a analizar la diferenciación entre "progresismo" e "izquierda" (ver los escritos recientes de Eduardo Gudynas sobre este tema).
} 
pensar en el intenso rojo de las banderas de las movilizaciones campesinas y proletarias de otrora, de campesinos leyendo los ubicuos libritos rojos mientras esperan marchar por el derecho a la tierra. ${ }^{7}$ Cómo no incorporar en toda lucha y en toda teoría los principios de justicia social, los imaginarios de igualdad de clase y los ideales de libertad y emancipación de la izquierda revolucionaria.

A nivel teórico, esimperantereconocerlas múltiples contribuciones del materialismo dialéctico y el materialismo histórico, su renovación en el encuentro con el desarrollismo —dependencia - el ambientalismo - marxismo ecológico- el feminismo, la teología de la liberación, el postestructuralismo — por ejemplo, Laclau y Mouffe-, la cultura - por ejemplo, Stuart Hall, los estudios culturales latinoamericanos, la interculturalidad-, y lo pos y decolonial. Sin embargo, aunque esta amplia gama de teorías sigue siendo claramente relevante, hoy en día reconocemos con facilidad los inevitables apegos modernistas del materialismo histórico — como su aspiración a la universalidad, la totalidad, la teleología y la verdad que se le cuelan incluso a través del agudo lente analítico de la dialéctica-. Más aún, no se puede desconocer que vamos aprendiendo nuevas formas de pensar la materialidad de la mano de la ecología económica, las teorías de la complejidad, la emergencia, la autopoiesis y la autoorganización y de las nuevas formas de pensar la contribución de todo aquello que quedó por fuera en la explicación modernista de lo real, desde los objetos y las "cosas" con su "materialidad vibrante" hasta todo el rango de lo no-humano - microrganismos, animales, múltiples especies, minerales-, que tanto como las relaciones sociales de producción son determinantes de las configuraciones de lo real. En estas nuevas "ontologías materialistas" hasta las emociones, los sentimientos y lo espiritual tienen cabida como fuerzas activas que producen la realidad.

Quisiera recalcar dos nociones de este breve recuento; por un lado, la ruptura de los nuevos materialismos con el antropocentrismo de los materialismos de la modernidad. Del otro, y como corolario, el "desclasamiento epistémico" a que se ven abocadas aquellas vertientes que usualmente consideramos de izquierda. Por desclasamiento epistémico me refiero a la necesidad de abandonar toda pretensión de universalidad y de verdad, y a una apertura activa a aquellas otras formas de pensar, de luchar y de existir que van surgiendo, a veces con claridad y contundencia, a veces confusas y titubeantes, pero siempre afirmativas y apuntando a otros modelos de vida, en tantos lugares de un continente que pareciera estar cercano a la ebullición. ${ }^{8}$ Este desclasamiento convoca a los

\footnotetext{
${ }^{7}$ Tengo en mente las hermosas pinturas y grabados de la pintora colombiana maoísta — del MOIRClemencia Lucena - aunque ya poco conocidos-, uno de los más elocuentes documentos de la época, en un potente estilo neo-realista latinoamericano. Por supuesto, podríamos recordar a Antonio Berni, los muralistas mexicanos o guayasamín, entre tantas y tantos artistas de izquierda, por no entrar en el teatro, la literatura, o la música.

${ }^{8}$ Como bien lo dijo el ecólogo mexicano Víctor Toledo refiriéndose a las luchas ambientales,
} 
pensadores de izquierda a reflexionar más allá del episteme de la modernidad, a atreverse a abandonar de una vez por todas sus categorías más preciadas, incluyendo el desarrollo, el crecimiento económico, el progreso y el mismo "hombre". Los conmina a sentipensar con la Tierra y con las comunidades en resistencia para rearticular y enriquecer su pensamiento.

Debequedarclaro que no me he detenido aquía analizar la diferencia entre progresismo e izquierda, ni las bien informadas críticas al neo-extractivismo de los gobiernos progresistas o el aparente agotamiento del modelo progresista neo-extractivista y desarrollista. Tampoco abordare los debates por la renovación de la izquierda, en este momento importantes en países como Brasil, Venezuela, Ecuador, Argentina y Bolivia. Finalmente, he obviado analizar la apropiación por parte de algunos de los gobiernos progresistas de conceptos potencialmente radicales como el buen vivir y los derechos de la naturaleza. ${ }^{9}$ Es necesario anotar, sin embargo, que desde la perspectiva aquí expuesta toda política de izquierda basada en la exclusión de otros puntos de vista, la supresión de la crítica y la represión de organizaciones de base por no estar de acuerdo con el oficialismo sólo puede representar una visión estrecha y cuestionable del pensamiento crítico de izquierda. Es de esta forma que las izquierdas oficiales se apropian y desvirtúan las experiencias y categorías de los pueblos y los movimientos. El debate sobre este tipo de progresismo está cobrando cada vez más intensidad en el continente, con justa razón. Confío en que las dos vertientes que exploro a continuación aporten elementos nuevos para este debate.

\section{El pensamiento de lo desde abajo}

\section{La tierra manda, el pueblo ordena, y el gobierno obedece. Construyendo autonomía ${ }^{10}$}

Un fantasma recorre el continente: el fantasma del autonomismo. Y podríamos continuar: "Todas las fuerzas de la vieja [Latinoamérica] se han unido en santa cruzada para acosar a ese fantasma [Y] a es hora de que los [autonomistas] expongan a la faz del mundo entero sus conceptos, sus fines y sus tendencias, que opongan a la leyenda del fantasma del

"Latinoamérica hierve" (IV Congreso Latinoamericano de Etnobiología, Popayán, 28 de septiembre a 2 de octubre de 2015). Las luchas ambientales a nivel mundial están siendo recogidas en el Atlas de justicia ambiental, mantenido por el grupo ICTA en la Universitat Autonoma de Barcelona (ver: http:ejatlas. org). Viendo este atlas, uno podría decir que los mundos hierven porque están destruyendo la Tierra.

${ }^{9}$ Ver los textos recientes de Gudynas, Zibechi, Acostay Svampa, entre otros, sobre estos temas.

${ }^{10}$ Incluido al final de los "Diez principios del buen gobierno" en la entrada de algunas de las comunidades autónomas zapatistas (ver: http://www.cgtchiapas.org/denuncias-juntas-buen-gobierno-denuncias/ jbg-morelia-denuncia-ataque-orcao-con-arma-fuego-bases). 
[autonomismo] un manifiesto del propio partido". No será un manifiesto de un solo partido, en este caso sin duda, sino una multiplicidad de manifiestos para la multiplicidad de mundos de que nos hablan los compañeros zapatistas, un mundo donde quepan muchos mundos. Serán las múltiples visiones de aquellos "que ya se cansaron de no ser y están abriendo el camino" (Rozental), de los sujetos de la digna rabia, de todas y todos los que luchan por un lugar digno para los pueblos del color de la Tierra.

Es innegable que esta segunda vertiente que proponemos, el autonomismo, es una fuerza teórico-política que comienza a recorrer Abya Yala/Afro/Latinoamérica de forma sostenida, contra viento y marea y a pesar de sus altibajos. Surge de la activación política de la existencia colectiva y relacional de una gran variedad de grupos subalternos: indígenas y afrodescendientes, campesinos, pobladores de los territorios urbanos populares, jóvenes, mujeres solidarias. Es la ola creada por los condenados de la tierra en defensa de sus territorios ante la avalancha del capital global neoliberal y la modernidad individualista y consumista. Se ve en acción en tantas movilizaciones de las últimas dos décadas, en encuentros inter-epistémicos, en mingas de pensamiento, cumbres de los pueblos y en convergencias de todo tipo donde los protagonistas centrales son los conocimientos de las comunidades y los pueblos que resisten desde las lógicas de vida de sus propios mundos. Involucra a todos aquellos que se defienden del desarrollo extractivista porque saben muy bien que "para que el desarrollo entre, tiene que salir la gente", como con frecuencia lo manifiestan las lideresas y líderes afrocolombianos que experimentan el desplazamiento de sus territorios bajo las presiones del llamado progreso.

A nivel teórico, el autonomismo se relaciona con una gran variedad de tendencias, desde el pensamiento decolonial y los estudios subalternos y postcoloniales hasta las epistemologías del sur y la ecología política, entre otros. Tiene un parentesco claro con nociones tales como la descolonización del saber, la justicia cognitiva y la interculturalidad. Pero su peso teórico-político gravita en torno a tres grandes conceptos: autonomía, comunalidad y territorialidad, sólo el primero de los cuales tiene alguna genealogía en las izquierdas, especialmente en el anarquismo. Las nociones de comunidad en particular están reapareciendo en diversos espacios epistémico-políticos, incluyendo las movilizaciones de indígenas, afrodescendientes y campesinos, sobre todo en México, Bolivia, Colombia, Ecuador y Perú. Cuando se habla de comunidad se usa en varios sentidos: comunalidad, lo comunal, lo popular-comunal, las luchas por los comunes, comunitismo - activismo comunitario-. La comunalidad - la condición de ser comunal - constituye así el horizonte de inteligibilidad de las culturas de la América profunda e igualmente de luchas nuevas, aun en contextos urbanos; es una categoría central en la vida de muchos pueblos, y continúa siendo su vivencia o experiencia más fundamental. Todo concepto de comunidad en este sentido se entiende de forma no esencialista, entendiendo "la comunidad" en toda su heterogeneidad e historicidad, 
siempre surtiéndose de la ancestralidad —el tejido relacional de la existencia comunal一, pero abierta hacia el futuro en su autonomía.

El autonomismo tiene su razón de ser en la profundización de la ocupación ontológica de los territorios y los mundos-vida de los pueblos-territorio por los extractivismos de todo tipo y por la globalización neoliberal. Esta ocupación es realizada por "un mundo hecho de un mundo" — capitalista, secular, liberal, moderno, patriarcal—, que se arroga para sí el derecho de ser "el Mundo", y que rehúsa relacionarse con todos esos otros mundos que se movilizan cada vez con mayor claridad conceptual y fuerza política en defensa de sus modelos de vida diferentes. El autonomismo nos habla de sociedades en movimiento, más que de movimientos sociales —Zibechi, refiriéndose a la ola de insurrecciones indígenas y populares que llevaran al poder a Evo Morales-, y podríamos hablar con mayor pertinencia aún de "mundos en movimiento", porque aquello que emerge son verdaderos "mundos relacionales" donde prima lo comunal sobre lo individual, la conexión con la Tierra sobre la separación entre humanos y no-humanos, y el buen vivir sobre la economía."

En el lenguaje de la "ontología política", podemos decir que muchas luchas étnicoterritoriales pueden ser vistas como luchas ontológicas por la defensa de otros modelos de vida. Interrumpen el proyecto globalizador de crear un mundo hecho de un solo mundo. Dichas luchas son cruciales para las transiciones ecológicas y culturales hacia "un mundo en el que quepan muchos mundos" - el pluriverso-. Constituyen la avanzada de la búsqueda de modelos alternativos de vida, economía y sociedad. Son luchas que enfrentan "entramados comunitarios" y "coaliciones de corporaciones transnacionales",

\footnotetext{
${ }^{11}$ El autonomismo es un fenómeno de los movimientos y colectivos; sus expresiones teórico-políticas se encuentran en estos colectivos, incluyendo muchos movimientos indígenas, de afrodescendientes y campesinos; está siendo conceptualizado por un creciente número de intelectuales y activistas, entre los cuales cabe mencionar a Gustavo Esteva, Raquel Gutiérrez Aguilar, Xochitl Leyva, Raúl Zibechi, Manuel Rozental, Vilma Almendra, Patricia Botero, John Holloway, Silvia Rivera Cusicanqui, Carlos Walter Porto Goncalves, el Colectivo Situaciones, Luis Tapia, y los intelectuales aymara Pablo Mamani, Julieta Paredes, Felix Patzi y Simón Yampara, entre otros. Muchos de estos actores convergieron recientemente en Puebla, en el Primer Congreso Internacional de Comunalidad, organizado por Raquel Gutiérrez y sus colaboradores (ver: http://www.congresocomunalidad2015.org/). Una importante vertiente relacionada se encuentra en los enfoques interculturales y decoloniales adelantados en el Doctorado en Estudios Culturales Latinoamericanos de la Universidad Andina Simón Bolívar en Quito dirigido por Catherine Walsh. También hay un nutrido grupo de pensadoras y pensadores de la autonomía y la comunalidad centrado en la ciudad de Popayán, Colombia, en intercambio continuo con comuneros e intelectuales nasa, misak, campesinos, y afrodescendientes de la región del Norte del Cauca, particularmente en torno a la Maestría en Estudios Interdisciplinarios del Desarrollo —un bastión del pensamiento autónomo, comunal y decolonial - y del evento bianual "Tramas y Mingas por el Buen Vivir" (ver: https://tramasymingasparaelbuenvivir.wordpress.com/2015/06/24/tramas-ymingas-para-el-buen-vivir-2015/).
} 
buscando la reorganización de la sociedad sobre la base de autonomías locales y regionales (Gutiérrez, 201l: 9-34); la autogestión de la economía bajo principios comunales, aun si articuladas con el mercado, y una relación con el Estado pero solamente para neutralizar en lo posible la racionalidad de éste. En resumen, son luchas que buscan organizarse como los poderes de una sociedad otra, no-liberal, no-estatal y no-capitalista. Aunque esta defensa surge de raíces - parcialmente- comunitarias y no-capitalistas, implica toda una historia de relacionamiento con la modernidad capitalista. "Se trata de recuperar, reconstruir y revitalizar el lugar y el territorio, esta vez para la reproducción de la vida" — dicen los compañeros y compañeras nasa del suroccidente colombiano- y con ello dar curso a formas contrapuestas de la pretensión capitalista totalizante y homogenizante" (Quijano, 2012: 210).

La autonomía es de esta forma una práctica teórico-política de los movimientos étnico-territoriales - pensarse "de adentro hacia afuera", como dicen algunas lideresas afrodescendientes en Colombia, o "cambiando las tradiciones tradicionalmente", y cambiando la forma de cambiar, como dicen en Oaxaca (Esteva)-. "La clave de la autonomía es que un sistema vivo encuentra su camino hacia el momento siguiente actuando adecuadamente a partir de sus propios recursos", nos dice el biólogo Francisco Varela, definición que aplica a las comunidades. Implica la defensa de algunas prácticas, la transformación de otras y la invención de nuevas prácticas. Podemos decir que en su mejor acepción la autonomía es una teoría y práctica de la interexistencia, una herramienta de diseño para el pluriverso.

El objetivo de la autonomía es la realización de lo comunal, entendida como la creación de las condiciones para la autocreación continua de las comunidades — su autopoiesisy para su acoplamiento estructural exitoso con sus entornos cada vez más globalizados. Como dicen los comuneros indígenas misak del Norte del Cauca de Colombia, hay que "recuperar la tierra para recuperarlo todo [...] por eso tenemos que pensar con nuestra propia cabeza, hablando nuestro propio idioma, estudiando nuestra historia, analizando y transmitiendo nuestras propias experiencias así como la de otros pueblos" (Cabildo Indígena de Guambia, 1980, citado en Quijano, 2012:257). O como lo expresan los nasa en su movilización, la "minga social y comunitaria!, "la palabra sin acción es vacía. La acción sin la palabra es ciega. La acción y palabra sin el espíritu de la comunidad son la muerte". Autonomía, comunalidad, territorio y relacionalidad aparecen aquí íntimamente ligados, constituyendo todo un marco teórico-político original dentro de esta segunda vertiente del pensamiento crítico de Abya Yala/Afro/Latinoamérica.

\section{El pensamiento de la Tierra}

La relacionalidad — la forma relacional de ser, conocer y hacer, definida como aquellas configuraciones socionaturales donde nada preexiste sin las relaciones que lo constituyen, 
sino que todo se constituye profundamente en relación con todo- es el gran correlato de la autonomía y la comunalidad. Así puede verse en muchas cosmovisiones de los pueblos, tales como la filosofía africana del Muntu o concepciones de la Madre Tierra como la Pachamama, Nuke mapu o Uma Kiwe, entre muchas otras. También está implícita en el concepto de crisis civilizatoria, siempre y cuando se asuma que la crisis actual es causada por un modelo particular de mundo - una ontología - la civilización moderna capitalista de la separación y la desconexión, donde humanos y no humanos, mente y cuerpo, individuo y comunidad, razón y emoción, etcétera, se ven como entidades separadas y autoconstituidas.

Las ontologías o mundos relacionales se fundamentan en la noción de que todo ser vivo es una expresión de la fuerza creadora de la tierra, de su auto-organización y constante emergencia. Nada existe sin que exista todo lo demás - "soy porque eres", porque todo lo demás existe, dicta el principio del Ubuntu surafricano-. En las palabras del ecólogo y teólogo norteamericano Thomas Berry, "la Tierra es una comunión de sujetos, no una colección de objetos". El mandato de la Tierra del que hablan muchos activistas nos conmina por consecuencia a "vivir de tal forma que todos puedan vivir". Este mandato es atendido con mayor facilidad por los pueblos-territorio: "Somos la continuidad de la tierra, miremos desde el corazón de la tierra" (Marcus Yule, gobernador nasa). No en vano es la relación con la Tierra central a las luchas indígenas, afro y campesinas en el contexto actual.

Desde esta perspectiva, el gran desafío para la izquierda y al autonomismo es aprender a sentipensar con la Tierra, a escuchar profundamente tanto el grito de los pobres como el grito de la Tierra (L. Boff, Laudato Si). Es refrescante pensar que de las tres vertientes mencionadas la más antigua es esta tercera. Viene desde siempre, desde que los pueblos aprendieron que eran Tierra y relación, expresiones de la fuerza creadora del universo, que todo ser es ser-Tierra. Existe en el pensamiento cosmocéntrico que subyace los tejidos y entramados que conforman la vida, aquel que sabe, porque siente, que todo en el universo está vivo, que la conciencia no es prerrogativa de los humanos sino una propiedad distribuida en todo el espectro de la vida. Es el pensamiento de aquellos que defienden la montaña contra la minería porque ella es un ser vivo, apu (M. de la Cadena), o los páramos y nacimientos de agua porque son el origen de la vida, con frecuencia lugares sagrados donde lo humano, lo natural y lo espiritual se funden en un complejo entramado vital. Yace también en el fundamento de la recomunalización de la vida, la relocalización de las economías y la producción, la defensa de semillas, el rechazo a los transgénicos y los TLC, y la defensa de la agroecología y la soberanía alimentaria (Gutiérrez).

Podemos decir, sin caer en anacronismo alguno, que las cosmogonías de muchas culturas del mundo son el pensamiento primigenio de la Tierra. También fue, y sigue siéndolo parcialmente, el pensamiento de las comunidades matriarcales, como lo lleva explicando la feminista alemana Claudia von Werlhof por más de dos décadas con su 
teoría crítica del patriarcado; no matriarcales en el sentido de la predominancia de la mujer, sino de culturas donde priman la cooperación, el reconocimiento del otro, la horizontalidad, la participación y la sacralidad en vez de la agresión, el dominio, la guerra, el control y la apropiación de las sociedades patriarcales que, poco a poco, a través de sus cinco mil años de historia, se ha ido apoderando de todas las sociedades del planeta. De forma similar lo entiende el biólogo chileno Humberto Maturana a partir de su concepción de "culturas matrísticas" y de la "biología del amor", aquellas culturas que viven en la profunda conciencia la interconexión de todo lo que existe y que se resisten a una trayectoria vital basada en la apropiación y el control porque su "emocionar" dicta, precisamente, el respeto y la convivencia (Von Werlhof, 2015; Maturana y Verden-Zöller, 1993). ${ }^{12}$

El pensamiento de la tierra subyace las concepciones de territorio. "Tierra puede tener cualquiera, pero territorio es otra cosa”, dicen algunos mayores afrodescendientes en el Pacífico colombiano, gran territorio negro. El territorio es el espacio para la enacción de mundos relacionales. Es el lugar de aquellas y aquellos que cuidan la tierra, como lúcidamente lo expresaran las mujeres de la pequeña comunidad negra de La Toma en el Norte del Cauca, movilizadas contra la minería ilegal de oro: "A las mujeres que cuidan de sus territorios. A las cuidadoras y los cuidadores de la Vida Digna, Sencilla y Solidaria. Todo esto que hemos vivido ha sido por el amor que hemos conocido en nuestros territorios [...] Nuestra tierra es nuestro lugar para soñar con dignidad nuestro futuro [...] Tal vez por eso nos persiguen, porque queremos una vida de autonomía y no de dependencia, una vida donde no nos toque mendigar, ni ser víctimas". ${ }^{13}$ Por ende el slogan de la marcha, "El territorio es la vida y la vida no se vende, se ama y se defiende".

También encontramos el pensamiento de la Tierra en la cosmoacción de muchos pueblos indígenas centrada en la defensa del territorio y en sus Planes de Viva. El territorio es "el espacio vital que asegura la pervivencia como pueblo, como cultura en convivencia con la naturaleza y los espíritus. El territorio es nuestro verdadero libro histórico que mantiene viva la tradición de quienes habitamos en él. Representa y describelos principios y prácticas de nuestra cultura. Implica la posesión, control y dominio del espacio físico y espiritual. Como espacio colectivo de existencia, posibilita la convivencia armónica entre los pueblos. Fundamenta la cosmovisión indígena como razón de nuestra pervivencia”. ${ }^{14}$ Por eso su estrategia está encaminada a "recuperar la tierra para recuperarlo todo, autoridad, justicia, trabajo, por eso tenemos que pensar con nuestra propia cabeza, hablando nuestro propio idioma, estudiando nuestra historia, analizando y transmitiendo nuestras propias

\footnotetext{
${ }^{12}$ Ver la Escuela Matrística, fundada por Maturana y Ximena Dávila Yáñez, en http://matriztica.cl/ Matriztica/.

${ }^{13}$ Carta abierta de Francia Márquez, lideresa de La Toma, 24 de abril de 2015.

${ }^{14}$ Consejo Regional Indígena del Cauca, CRIC, citado en Quijano (2012: 209).
} 
experiencias así como la de otros pueblos". ${ }^{5}$ De igual manera, el Plan de Vida del pueblo misak se explica como una propuesta de "construcción y reconstrucción de un espacio vital para nacer, crecer, permanecer y fluir. El plan es una narrativa de vida y sobrevivencia, es la construcción de un camino que facilita el tránsito por la vida, y no la simple construcción de un esquema metodológico de planeación". ${ }^{16}$

Por esto muchos pueblos describen su lucha política como "la liberación de la Madre Tierra”. La pregunta clave para estos movimientos es: ¿cómo mantener las condiciones para la existencia y la re-existencia frente al embate desarrollista, extractivista y modernizador? Esta pregunta, y el concepto de liberación de la Madre Tierra, son potentes conceptos para toda práctica política en el presente: para la izquierda y los procesos autonómicos tanto como para las luchas ambientales y por otros modelos de vida. Vinculan justicia ambiental, justicia cognitiva, autonomía y la defensa de mundos (J. Martínez-Alier, V. Toledo). En esteregistrotambién encontramos el movimiento por los Derechos de la Naturaleza dentro de concepciones genuinamente biocéntricas, más allá de discursos o referencias superficiales a la sustentabilidad o la Pachamama (E. Gudynas).

Para nosotros los urbano-modernos, que vivimos en los espacios más marcados por el modelo liberal de vida (la ontología del individuo, la propiedad privada, la racionalidad instrumental y el mercado), la relacionalidad constituye un gran desafío, dado que se requiere un profundo trabajo interior personal y colectivo para desaprender la civilización de la desconexión, del economismo, la ciencia y el individuo. Quizás implica abandonar la idea individual que tenemos de práctica política radical. ¿Cómo tomamos en serio la inspiración de la relacionalidad? ¿Cómo re-aprendemos a inter-existir con todos los humanos y no-humanos? ¿Debemos recuperar cierta intimidad con la Tierra para reaprender el arte de sentipensar con ella? ¿Cómo hacerlo en contextos urbanos y descomunalizados? Desafortunadamente, el progresismo, y quizás buena parte de la izquierda, están lejos de entender este mandato. Como bien dice Gudynas (2015), ni la derecha ni la izquierda "entienden la naturaleza".

\section{Comentario final: isalir de la modernidad?}

El desclasamiento epistémico de la izquierda implica atreverse a cuestionar el desarrollo, el mal llamado progreso y la modernidad. Sólo de esta forma podrá el pensamiento de izquierda participar en pensar y construir las transiciones civilizatorias que se alumbran desde el pensamiento autonómico y de la Tierra. Como es bien sabido, el progresismo de las últimas dos décadas ha sido profundamente modernizador, y su modelo económico

\footnotetext{
${ }^{15}$ Cabildo Indígena de Guambia, 1980, citado en Quijano (2012: 257).
}

${ }^{16}$ Cabildo y Taitas 1994; citado en Quijano (2012: 263). 
está basado en el núcleo duro de premisas de la modernidad, incluyendo el crecimiento económico y el extractivismo.

Tanto en el Norte Global como en el Sur Global, el pensamiento de las transiciones tiene muy claro que las transiciones tienen que ir más allá del modelo de vida que se ha impuesto en casi todos los rincones del mundo con cierta visión dominante de la modernidad. ${ }^{17}$ Salir de la modernidad sólo se logrará caminando, apoyándose en las tres vertientes. Sanar la vida humana y la Tierra requieren de una verdadera transición "del período cuando los humanos eran unafuerza destructiva sobreel planeta Tierraal período cuandolos humanos establecen una nueva presencia en el planeta de forma mutuamente enriquecedora", como lo expresan Thomas Berry y Leonardo Boff. Significa caminar decididamente hacia una nueva era, que estos ecólogos denominan como "Ecozoica" — la era de la casa de la vida-. El cambio climáticoes solamente una delasmanifestaciones máspatentes dela devastación sistemática de la vida por la modernidad capitalista.

La liberación de la madre Tierra, concebida desde el cosmocentrismo y la cosmoacción de muchos pueblos-territorio, nos invitan a "disoñar" el diseño de mundos. Este acto de "disoñacion" y de diseño tiene como objetivo reconstituir el tejido de la vida, de los territorios y de las economías comunalizadas. Como lo dice un joven misak, se trata de convertir el dolor de la opresión de siglos en esperanza y ésta en la base de la autonomía. ${ }^{18}$ Para los activistas afrocolombianos del Pacífico, tan impactado por las locomotoras desarrollistas, esta región es un Territorio de Vida, Alegría, Esperanza y Libertad. Hay un sabio principio para la práctica política de todas las izquierdas en la noción de "tejer la vida en libertad".

Las tres vertientes presentadas no constituyen un modelo aditivo sino de múltiples articulaciones. No son paradigmas que se reemplazan nítidamente unos a otros. Queda clara, sin embargo, la necesidad de que la izquierda y el autonomismo - y el humanodevengan Tierra. El humano "post-humano" - aquel "humano" que emerja del final del antropocentrismo - tendrá que aprender de nuevo a existir como ser vivo en comunidades de humanos y no-humanos, en el único mundo que verdaderamente compartimos que es el planeta. La re-comunalización de la vida y la re-localización de las economías y la producción de los alimentos en la medida de lo posible - principios claves de los activismos y diseños para la transición - se convierten en principios apropiados para la práctica teórico-política del presente. De hecho ya encontramos entramados potentes del pensamiento de izquierda, autonómico y de la Tierra en los

\footnotetext{
${ }^{17}$ En el Norte Global, por ejemplo, la noción de decrecimiento apunta a la necesidad de vivir diferente, más allá de "consumir menos". Algunos teóricos y activistas hablan de "occidentes" o "modernidades alternativas" y no dominantes dentro de Europa mismo. Esta importante noción, sin embargo, no debe obviar la consideración de los impactos históricamente sedimentados de las modernidades dominantes — sistema-mundo moderno/colonial一.

${ }^{18}$ Tramas y Mingas para el Buen Vivir, Popayán, 21 y 22 de octubre de 2015.
} 
encuentros inter-epistémicos tales como las Tramas y Mingas para el Buen Vivir en Popayán, o en eventos como el Encuentro "Pensamiento Crítico Frente a la Hidra Capitalista”, convocado por el EZLN y celebrado en el CIDECI-Unitierra, San Cristóbal de Las Casas en mayo de 2015.

Muchas, si no la mayoría, de estas experiencias comunalitarias y autónomas en defensa de la Tierra son inevitablemente debilitadas por los contextos antagónicos en los que se llevan a cabo, a pesar de su compromiso con las transformaciones. Debe mencionarse que, en su búsqueda de autonomía, algunas recaen en el desarrollismo, otras son subvertidas desde dentro por sus propios líderes, otras reinscriben antiguas formas de opresión o crean otras nuevas y no es raro que las movilizaciones decaigan bajo el increíble peso de las presiones del momento o debido a la represión abierta. Los antagonismos son inherentes a toda práctica social. Esto no descalifica por completo las acciones de las "comunidades realmente existentes" ni debe condenarlas a la categoría residual de ilusorias, localistas o románticas. En esto yace la esperanza; al fin y al cabo: "la esperanza no es la certeza de que algo pasará, sino de que algo tiene sentido, pase lo que pase" (G. Esteva).

Aquellos que aún insistan en la vía del desarrollo y la modernidad son o suicidas, o al menos ecocidas, y sin duda históricamente anacrónicos. Por el contrario, no son románticos ni "infantiles" aquellos que defienden el lugar, el territorio y la Tierra; constituyen la avanzada del pensamiento pues están en sintonía con la Tierra y la justicia y entienden la problemática central de nuestra coyuntura histórica, las transiciones hacia otros modelos de vida, hacia un pluriverso de mundos. No podemos imaginar y construir el postcapitalismo - y el postconflicto- con las categorías y experiencias que crearon el conflicto - particularmente el desarrollo y el crecimiento económico-. Saltar al Buen Vivir sin completar la fase de industrialización y modernización es menos romántico que completarla, ya sea por la vía de la izquierda o de la derecha. "No podemos construir lo nuestro con lo mismo [...] lo posible ya se hizo, ahora vamos por lo imposible" (Activistas indígenas, campesinos y afrodescendientes, Tramas y Mingas para el Buen Vivir, Popayán, 2014).

¿Podremos atrevernos a afirmar que hoy en día Abya Yala/Afro/Latinoamérica presenta al mundo, en la complejidad de su pensamiento crítico en las tres vertientes tan esquemáticamente resumidas, un modelo diferente de pensar, de mundo y de vida? En esto - y a pesar de todas las tensiones y contradicciones entre las vertientes y al interior de cada una de ellas - radicaría "la diferencia latinoamericana" para la primera mitad del siglo XXI. Algo que sí podemos decir con certeza, con la gran Mercedes Sosa, es que pueblos, colectivos, movimientos, artistas e intelectuales caminan la palabra "por la cintura cósmica del sur" en "la región más vegetal del tiempo y de la luz" que es el hermoso continente que habitamos. Gracias a la vida, que nos ha dado tanto... 


\section{Referencias bibliográficas}

Botero, Patricia (coord.) (2015). Resistencias. Relatos del sentipensamiento que caminan la palabra. Colombia: Colectivos, movimientos sociales y comunidades en resistencia desde Colombia: Universidad de Manizales.

Botero, Patricia y Alicia Itatí Palermo (coord.) (2013). La utopía no está adelante: Generaciones, resistencias, e institucionalidad emergentes. Buenos Aires: CLACSO/CINDE.

Castro Gómez, Santiago (1996). Crítica de la razón latinoamericana. Barcelona: Puvill Libros.

Fals Borda, Orlando (1970). Ciencia propia y colonialismo intelectual. México: Nuestro Tiempo.

Freire, Paulo (1970). Pedagogía del oprimido. México: Siglo XXI.

Gudynas, Eduardo (2015). "La derecha y la izquierda no entienden a la naturaleza". En La Razón, 23 de agosto. Bolivia. Disponible en: http:/www.la-razon.com/suplementos/ animal_politico/Eduardo-Gudynas-izquierda-entienden-naturaleza_0_2330167108. html.

Gutiérrez Aguilar, Raquel (2011). "Pistas reflexivas para orientarnos en una turbulenta época de peligro”. En Raquel Gutiérrez A. (coord.). Palabras para tejernos, resistir y transformar en la época que estamos viviendo. Oaxaca: Pez en el Árbol.

Maturana, Humberto y Gerda Verden-Zöller (1993). Amor y juego. Fundamentos olvidados de lo humano. Desde el patriarcado a la democracia. Santiago: J.C Sáez Editores.

Quijano V., Olver (2012). Ecosimías. Visiones y prácticas de diferencia económico/cultural en contextos de multiplicidad. Quito: Universidad Andina Simón Bolívar.

Sader, Emir (2015). "La crisis del pensamiento crítico latinoamericano". En Agencia Latinoamericana de Información. Disponible en: http://www.alainet.org/es/ articulo/173375\#sthash.LVxjxa53.dpuf.

Von Werlhof, Claudia (2015). Madre Tierra o muerte! Reflexiones para una teoría crítica del patriarcado. Oaxaca: El Rebozo. 


\section{Mirar los horizontes. Reflexiones finales}

Los trabajos incluidos en esta obra constituyen una pequeña muestra de la amplitud y la complejidad de las tensiones y crisis de la democracia liberal, como régimen y como modelo ideológico. Lejos de anclarse en una apreciación desencantada, esta obra registra diversas vertientes de esas tensiones y crisis pero también prácticas y acciones políticas que en su ejercicio autogestionario de lo político, desde escalas socio-espaciales micro, rechazan, cuestionan, defienden y construyen lo propio, resignificando así la democracia. Ambas realidades, desde la impronta teórica o descriptiva, son objeto de la mirada críticaanalítica en cada uno de los textos. Representan aportes relevantes al universo de la democracia y lo democrático, elementos que en estas líneas finales buscamos registrar desde las dos interrogantes anticipadas en la introducción.

Respecto a la primera: ipuede la democracia liberal seguir sosteniéndose con procesos electorales disociados de una sociedad que vive la cotidianidad de la pobreza y de las grandes desigualdades en ingreso y estatus, como expresiones fácticas de la incompatibilidad entre democracia y capitalismo?, los textos de la primera parte develan que la naturaleza de la política del mundo capitalista, devenida en la predominante democracia representativa, entraña en sí misma la disociación entre la política y la sociedad, visible en las "crisis" recurrentes, que no son más que los desenlaces y tensiones socio-temporales entre representación y política, entre el ideal y el logro. Para decirlo sintéticamente: los trabajos de la primera parte de esta obra reflexionan sobre la desarticulación de origen entre la democracia representativa, expresada en las urnas electorales y el parlamento, y las aspiraciones de igualdad y justicia social a la que está compelida, con mayor urgencia, la democracia en una geografía como la que trata esta obra.

No obstante esta condición contradictoria, los autores que participan en esta obra, más que "normalizarla", la someten a observación y reflexión minuciosa, comprendiendo que ha sido profundizada como parte de un nuevo proyecto de dominio hegemónico 
global. En tal sentido, existe la comprensión de que el modelo de democracia que hoy observamos en fase de crisis, tuvo como momento de formación hegemónica — hace más de cuarenta años - la crisis internacional de 1973, cuando un grupo de especialistas, intelectuales funcionales y dirigentes de Estado y de los grandes corporativos trasnacionales, conocido como la Comisión Trilateral, planteó la necesidad de restablecer un conjunto de normas para una gobernabilidad global que delineara el comportamiento de los gobiernos nacionales del norte y el sur, alineados y no alineados al régimen geopolítico este-oeste.

A diferencia de lo que hoy prima en el debate académico-político en torno a la también denominada crisis democrática - fundamentada en su intrínseco deterioro-, en aquel momento el riesgo se focalizaba en los "excesos de democracia" en el mundo. Es decir, la expansión irrefrenable de valores y demandas ligadas a la libertad democrática que atentaban contra la gobernabilidad de la sociedad de mercado emergente (Ranciére, 2007).

Los fundamentos ideológicos de este sentido instrumental de crisis aún prevalecen en el orden internacional, e intentan reducir el torrente de la ampliación y democratización misma de la democracia, así como legitimar intervenciones políticas y armadas de países y organismos internacionales que se autodefinen como "democráticos" en espacios que han "diagnosticado" no ser tales. No obstante, el sentido de crisis en el debate contemporáneo apunta al corazón mismo de la democracia tal como ha sido formulada, monopolizada e impuesta luego como modelo de gobierno dominante: democracia como esquema procedimental mínimo en su dimensión institucional: parlamento, administración estatal, sistema de partidos plurales, separación de poderes, procedimientos electorales y jurídicos, etcétera.

Este modelo se enfrenta a un deterioro y descomposición a tal punto que se ha vuelto atentatorio de sí mismo lo que, paradójicamente, es una condición para su propia reproducción. Ante el dominio de este modelo hegemónico de gobierno y su inherente reproducción bajo diversas formas de crisis, el desafío consiste en reconocer la riqueza de los análisis situados históricamente y desde los específicos contextos de México y los países de Centroamérica tratados en esta obra. La concatenación local-nacional-regional de los casos de estudio permite reconocer las genealogías y contradicciones, así como una propia forma de tejer el sentido de crisis y perplejidad con el que las sociedades de esta región enfrentan, padecen o se apropian de la idea, la práctica y el sentido de la democracia para impugnarla o resignificarla.

Vista en el anterior sentido, la democracia representa "una promesa y un problema a la vez" (Rosanvallon, 2007). Promesa en tanto régimen que abriga la posibilidad de futuros mejores para la sociedad, y problema en el sentido de que la realidad no consuma a cabalidad las expectativas de mejoría de la sociedad, e incluso las contiene y hasta las subvierte. 
Las respuestas de los autores de la segunda parte de este libro son precisas eilustrativas al coincidir en que la democracia liberal reducida a elecciones se sostiene por los juegos de poder entre partidos, gobernantes e intereses geopolíticos, y no por los modos de actuación y organización política de la población votante que con la emisión del sufragio pudieran incidir para mover las condiciones ancestrales de pobreza y desigualdad.

La contundencia de los hechos que se registran en esta segunda parte del libro, aunque afianza el sentido de crisis de la democracia, son también expresiones de los temasproblemas irresueltos o en tensión en los regímenes democráticos de estas regiones. Hacen explicito el alcance - limitado - de la propuesta democrática en su versión liberalparlamentaria, y muestran que como regímenes tampoco cumplen tareas elementales de gobierno.

No obstante, y en su sentido más positivo, los materiales analizados refrendan también la tesis de la "incompletitud" de la democracia, del proyecto inacabado que representa y de la imposibilidad de fundamento último que la define, al punto que desborda el dominio institucional. Enlazan así con la segunda vertiente desarrollada en el libro aludida en el subtítulo y enunciado como resignificación; teórica y empíricamente conceptualizada como "democracias otras". Afrontan como hechos sociales la segunda pregunta, adelantada en la introducción: ipueden los proyectos y experiencias políticas "otras" en nombre del derecho a la vida constituirse en el campo político de subjetivaciones capaces de sustraerse del paradigma liberal-democrático y de instituir desde su multiplicidad, heterogeniedad e impredecibilidad, un nuevo paradigma democrático? La respuesta común es afirmativa, no obstante, los autores de la tercera parte, con excepción del primero, parecerían modular un pensamiento que refrenda la incompletud de la democracia.

Expresiones de democracia directa o desde abajo, e incluso el renombramiento de la acción política — como la concepción de demoeleuthería - , buscan condensar la capacidad de innovación con sentido transformador de la política; remitir a los sujetos que con su acción antagonista resignifican y revitalizan la democracia a partir de un conjunto de prácticas alternativas, dando lugar a la tensión entre lo instituido y la potencia de lo constituyente, que en este libro tiene expresiones de alteridad. En ese sentido, esta redefinición de las posibilidades de acción (Castro-Gómez, 2015) desestructura la intención monopólica de las élites políticas, económicas e intelectuales sobre la democracia para devolverla al terreno de lo contingente, y en esa medida darle el valor de susceptibilidad y de ser resignificada políticamente.

En esa línea, las expresiones de democracia directa o desde abajo representan el sentido más esperanzador de la democracia como ideal, no sólo porque potencializa el nodo conceptual: "poder del pueblo", sino porque profundizan valores que hoy asumimos que le son inherentes, como el de la legitimidad. Y aunque esperanzadora, no se la debe idealizar y situar como expresión última y autentica de lo democrático; debe por tanto 
registrarse como sistema que activa formas de autogobierno que revitalizan acciones sociales que son eminentemente políticas.

Igualmente relevante es reconocer que estas expresiones "demodiversas" amplían el debate teórico-metodológico en torno a las posibilidades de lo democrático. El análisis de estas experiencias desancla del esquema institucional la noción de actor político, para virarlahacialaconfiguración delossujetos políticosmásalládelosespaciosinstitucionales. La tercera parte de este libro focaliza formas de organización y acción política que desbordan el ámbito político institucional, resaltando paralelamente el complejo proceso de construcción de subjetividades políticas en clave socio-antropológica.

Son estos sujetos antagonistas o litigantes que, desde los márgenes de la institucionalidad, no sólo cuestionan no estar incluidos en el reparto político "ya existente", sino que demandan un cambio radical en el reparto mismo. Con su acción testimonian lo que la democracia liberal parlamentaria ha buscado domeñar y relegar: el antagonismo y la convivencia de la diversidad en el ejercicio de lo democrático.

Desde esta concepción y práctica, la dimensión de lo posible, situada en este libro como un debate abierto, representa, por un lado, una expresión contrahegemónica de la democracia, entendida como resistencia e impugnación, como un contrapoder que subvierte y asume a la democracia como una forma de poder político que (auto)organiza lo social (Álvarez, en este libro), apropiándose de los valores democráticos que derivan de la desconfianza expresada en el intento por velar, regular y buscar los medios que permitan un buen gobierno a través de diversos poderes de "control", formas de "obstrucción" y la puesta a prueba a través del "juicio" que diseñan los divergentes sectores de una sociedad (Rosanvallon, 2007: 24).

Por otro lado, representa una resustancialización mediante la ampliación del canon democrático: la redistribución y el ejercicio de poderes inclusivos, comunitarios y participativos; la reinvención de la ciudadanía desde formatos plurales y la capacidad de sustituir las relaciones de poder por formas de autoridad compartida, institucionalizadas en procesos que devienen de la capacidad de incidencia real y heterogénea en las gramáticas sociales, culturales y legales: estatutos legales y constituciones (Santos, 2003; 2006).

La posibilidad implica la recuperación de lo político como un escenario latente, que instituye alteridades para el ejercicio y el trazo de horizontes alternativos de lo democrático, prescindiendo, incluso, de laestructuraprocedimental y suinstitucionalidad resguardada bajo la forma Estado, e instituyendo formatos autónomos desde abajo (Alonso y Alonso, en este libro), desde escalas, actores y subjetividades alternativas que redefinen los formatos para autorrepresentarse (Leyva y Köhler, en este libro).

Las interrogantes, sin embargo, siguen siendo contundentes: icómo interpretar las líneas de fuga y los límites para tal potencia de lo posible en la región del sur sureste de México y en los países de Centroamérica?, iqué cualidades y subjetividades políticas pueden re-significar el sentido y la apropiación de lo democrático en nuestros dolidos 
contextos de atrofia y violencia estructural?, ¿qué horizontes podrán constituir un giro profundo ante una crisis que se reproduce a sí misma?

La riqueza de los enfoques, experiencias y perspectivas para pensar las democracias en México y Centroamérica, en un momento de profundas turbulencias en toda América Latina, deja claro que la compleja agenda social, política y económica que atraviesan las realidades de nuestra región -minería y extractivismo, reprimarización de la economía, transmigración, integración regional, criminalización de poderes, aseguramiento geopolítico, procesos destituyentes y golpes de Estado, autonomías no estatales, crisis de los gobiernos progresistas, etcétera, son dimensiones que desbordan, pero que también redirigen el sentido del debate sobre lo democrático en nuestras regiones. Las democracias posibles, por ello, conllevan tantas perturbaciones como esperanzas.

\author{
María del Carmen García Aguilar \\ Jesús Solís Cruz \\ Pablo Uc
}

\title{
Referencias bibliográficas
}

Castro-Gómez, Santiago (2015). Revoluciones sin sujetos. Slavoj Zizek y la crítica del historicismo posmoderno. México: Akal, Interpares.

Crozier, Michel, Samuel Huntington y Joji Watanuki (1975). The Crisis of Democracy: Report on the Governability of Democracies to the Trilateral Commission. Nueva York: New York University Press.

Rosanvallon, Pierre (2007). La contrademocracia. La política en la era de la desconfianza. Buenos Aires: Manantial.

Santos, Boaventura de Sousa (2003). Renovar la teoría crítica y reinventar la emancipación social. Buenos Aires: CLACSO.

Santos, Boaventura de Sousa (2006). Democratizar la democracia. Los caminos de la democracia participativa. México: FCE. 


\section{Semblanza de los colaboradores}

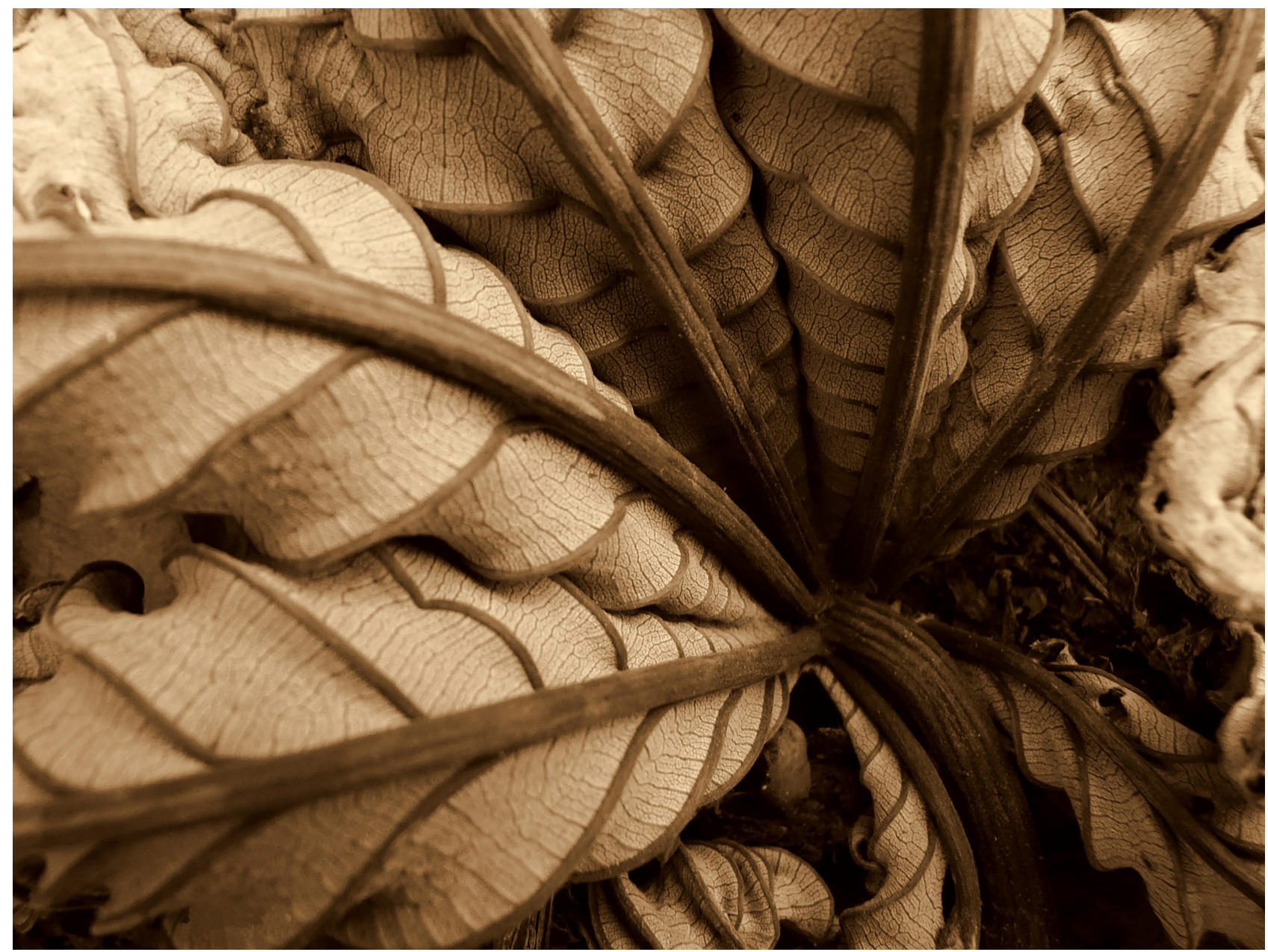


Laura Álvarez Garro. Doctora en Humanidades con énfasis en filosofía moral y política por la Universidad Autónoma Metropolitana, Unidad Iztapalapa (UAM-I), y maestra en Ciencias Sociales por la Facultad Latinoamericana de Ciencias Sociales (FLACSO). Actualmente se desempeña como docente en la Escuela de Filosofía, en la Maestría en Teoría Psicoanalítica y en el Posgrado Centroamericano de Ciencias Políticas, todos de la Universidad de Costa Rica (UCR), y como investigadora en el Centro de Investigaciones Históricas de América Central (CIHAC) de la misma universidad. Es miembro activo del Grupo de Trabajo América Latina: Gobiernos, Movimientos y Persistencias del Consejo Latinoamericano de Ciencias Sociales (CLACSO). Sus temas de interés son la teoría política contemporánea, el psicoanálisis lacaniano y la historia conceptual, con particular énfasis en el estudio de la democracia y los movimientos sociales.

María del Carmen García Aguilar. Socióloga por la UNAM, maestra en desarrollo rural y doctora en Ciencias Sociales por la UAM-Xochimilco, es miembro del SNI nivel II, y tiene el reconocimiento de Profesor con Perfil Deseable PROMEP. Desde 1995 es investigadora-docente del Centro de Estudios Superiores de México y Centroamérica de la Universidad de Ciencias y Artes de Chiapas (CESMECA-UNICACH). Su experiencia en la investigación social es amplia. Ha abordado temas como sociología del mundo rural, movimientos sociales, democracia y migraciones internas e internacionales, cuya problematización entraña las dimensiones del poder y los antagonismos del orden instituido. Es profesora de la Maestría y el Doctorado en Ciencias Sociales y Humanísticas del CESMECA-UNICACH.

Pablo Uc. Investigador social y escritor mexicano. Licenciado en Ciencias Políticas y Estudios Internacionales y Maestro en Ciencias Sociales y Humanísticas. Sus líneas de investigaciónsecentraneneldesenvolvimientohistóricodelageopolíticalatinoamericana, los movimientos sociales en Abya Yala y la historia política de las democracias y los movimientos populares en México y Centroamérica. Es investigador en el Observatorio de las Democracias: Sur de México y Centroamérica del CESMECA-UNICACH y del Consejo Latinoamericano de Ciencias Sociales (CLACSO). 
Daniel Villafuerte Solís. Doctor en Ciencias Sociales por la Universidad Autónoma Metropolitana. Actualmente es investigador titular del Centro de Estudios Superiores de México y Centroamérica de la Universidad de Ciencias y Artes de Chiapas (CESMECAUNICACH=. Es miembro del Sistema Nacional de Investigadores del Consejo Nacional de Ciencia y Tecnología, nivel III e investigador emérito por el Consejo de Ciencia y Tecnología del Estado de Chiapas. Es miembro de la Red Internacional de Migración y Desarrollo y del consejo editorial de las revistas Estudios Fronterizos (Universidad Autónoma de Baja California), LiminaR. Estudios Sociales y Humanísticos (Centro de Estudios Superiores de México y Centroamérica); y Línea Imaginaria (Pedagógico de Rubio, Venezuela).

Jahir Dabroy. Doctorando en Administración y Políticas Públicas por el Instituto Nacional de Administración Pública (INAP) y maestro en Políticas Públicas por la Universidad Autónoma Metropolitana (UAM). Investigador en temas sociopolíticos de Guatemala y la región latinoamericana. Docente de las maestrías en Análisis Estratégico, Seguridad y Geopolítica en la Universidad de San Carlos, en Gestión Pública y Liderazgo de la Escuela de Gobierno (Cayalá), y de las carreras de Ciencia Política y Relaciones Internacionales en la Universidad y San Carlos y la Universidad Rafael Landívar en Guatemala.

Andrés León. Doctor en Antropología por la Universidad de la Ciudad de Nueva York (CUNY) y maestro en Ciencias Políticas por la Universidad de Costa Rica. Actualmente es profesor de las escuelas de ciencias políticas y antropología, así como investigador del Centro de Investigaciones y Estudios Políticos (CIEP), de la Universidad de Costa Rica (UCR).

Carlos Mauricio Hernández. Doctorando en Ciencias Sociales y Humanísticas en el Centro de Estudios Superiores de México y Centroamérica de la Universidad de Ciencias y Artes de Chiapas (CESMECA-UNICACH). Sus temas de investigación versan sobre filosofía de la religión en Feuerbach, mesianismo político en El Salvador (2004-2009) y Estado y democracia en Ignacio Ellacuría. Coautor del libro Regreso a la vida. Historia de víctimas y victimarios (2014).

Manuel Martínez Espinoza. Politólogo. Se ha interesado en temas de teoría política, ciudadanía y políticas públicas y ha estudiado los casos de las elecciones vecinales en la ciudad de México, las Juntas de Buen Gobierno del movimiento zapatista, la cooperación al desarrollo en Chiapas y Guatemala, los sistemas de protección social y la minería en América Latina. Actualmente es Catedrático CONACYT asignado al Centro de Estudios Superiores de Méxicoy Centroamérica de la Universidad de Cienciasy Artes (CESMECA-UNICACH) e investiga la participación ciudadana en las políticas sociales en el sureste de México. 
Juan Mora Heredia. Profesor-investigador del Departamento de Sociología de la Universidad Autónoma Metropolitana-Azcapotzalco (UAM-Azcapotzalco). Maestro en Sociología Política por el Instituto Dr. José María Luis Mora, México.

Margarita Jiménez Badillo. Doctora en Ciencia Política y de la Administración por la Universidad de Salamanca, España. Es profesora-investigadora del Instituto Internacional de Estudios Políticos Avanzados de la Universidad Autónoma de Guerrero. Nivel l del SNI-CONACyT.

Jesús Solís Cruz. Doctoren Antropología Social por El Colegio de Michoacán. Especialista en Antropología Política, rama desde la cual ha incursionado en temas de Estado nacional, ciudadanía, movimientos sociales, mediación política y derechos etnoculturales. Es profesor titular en los programas de Maestría y Doctorado en Ciencias Sociales y Humanísticas, respectivamente, del Centro de Estudios Superiores de México y Centroamérica de la Universidad de Ciencias y Artes de Chiapas (CESMECAUNICACH). En el Observatorio de las Democracias ha desarrollado investigación en temas de calidad de democracia y procesos electorales en Chiapas. Es autor del libro Ser ciudadano. Ser indio. Luchas políticas y formación del Estado en Nurío y Tiríndaro, Michoacán (COLMICH/UNICACH, 2012), así como de artículos en revistas especializadas y libros.

Efraín Eric Poot Capetillo. Maestro en Antropología Social por El Colegio de Michoacán. Centro de Investigaciones Regionales “Dr. Hideyo Noguchi” de la Universidad Autónoma de Yucatán. Sus temas de especialización son: elecciones, partidos políticos, movimientos sociales, calidad de la democracia.

Carlos Alonso Reynoso. Doctor en Ciencias de la Salud Pública y profesor del Centro Universitario de Ciencias Sociales en la Universidad de Guadalajara. Es miembro del Sistema Nacional de Investigación. Ha publicado tres libros acerca de movimientos emergentes en México.

Jorge Alonso Sánchez. Doctor en Antropología y profesor investigador emérito en el CIESAS Occidente. Es miembro de la Academia Mexicana de Ciencias y también ha sido nombrado investigador nacional emérito por el CONACYT. Es coautor con Carlos Alonso de los libros: En busca de la libertad de los de abajo: la demoeleuthería (2015) y Una fuerte indignación que se convirtió en movimiento: Ayotzinapa, (2015)

Xochitl Leyva Solano. Trabajadora del campo de las ciencias sociales. Profesorainvestigadora en CIESAS Sureste, Chiapas, México. Ha trabajado en temas de antropología política, el poder, los movimientos y las redes anti y alter. Forma parte de las siguientes redes: http://jkopkutik.org/sjalelkibeltik/y www.encuentroredtoschiapas.jkopkutik.org. 
Axel Köhler. Antropólogo visual. Investigador-docente del Centro de Estudios Superiores de México y Centroamérica de la Universidad de Ciencias y Artes de Chiapas (CESMECA-UNICACH). Miembro y cofundador del Proyecto Videoastas Indígenas de la Frontera Sur (PVIFS), de la Red de Artistas, Comunicadores Comunitarios y Antropólog@s de Chiapas (RACCACH) y de la Red Trasnacional Otros Saberes (RETOS). Formapartedelas siguientes redes:http://jkopkutik.org/sjalelkibeltik/ywww. encuentroredtoschiapas.jkopkutik.org.

Arturo Escobar. Profesor de antropología en la Universidad de Carolina del Norte en Chapel Hill e investigador asociado del Grupo Cultura/Memoria/Nación de la Universidad del Valle en Cali, Colombia. Sus intereses principales son la ecología política, el diseño ontológico, la antropología del desarrollo, los movimientos sociales y la tecnociencia. Entre sus libros más conocidos se encuentran: La invención del desarrollo (1996), Territorios de diferencia: lugar, movimiento, vida, redes (2010), Una minga para el postdesarrollo (2013) y Sentipensar con la Tierra. Nuevas lecturas sobre desarrollo, territorio y diferencia (2014).

Ayün Mutsábiri. Fotógrafa chileno-latinoamericana. En 2005 participó en el seminario La Fotografía como Medio de Subjetivización, en la Casa de la Cultura de Temuco, Chile. Coordinó y participó en exposiciones individuales y colectivas tales como: "Golpe de Tierra", (2006), "Sin zapatos y a contracorriente" (2010 y 2012), "Intersticios olvidados" (2014), "Visiones en tiempo presente" (2016) y en el Festival Tragameluz (2014). De 2007 a 2009 colaboró en el registro fotográfico del proyecto: Guía Interpretativa Ecocultural Pewenche. Participó en el Encuentro Latinoamericano de Arte para la Transformación Social (2010) y en el Colectivo Viaje de la Serpiente (de Chile a México). Sus referencias virtuales son: https://www.behance.net/mutsabiri y http://aventanabierta.jimdo.com. 
DEMOCRACIAS POSIBLES:

CRISIS Y RESIGNIFICACIÓN. SUR DE MÉXICO Y CENTROAMÉRICA se terminó de imprimir en los talleres de

Ediciones Navarra, Van Ostade No. 7,

Col. Alfonso XIII. México, D.F., en el mes de septiembre de 2016, en tiro de 1000 ejemplares. 